\title{
LOS ORÍGENES ADOLESCENTES DEL SELFIE Y SU REPRESENTACIÓN EN EL ARTE Y EN LOS MEDIOS DE MASAS
}

TESIS DOCTORAL

Presentada por:

Javier Gayet Valls

Dirigida por:

Dra. Paula Santiago Martín de Madrid Dr. David Pérez Rodrigo

Valencia, Julio de 2018

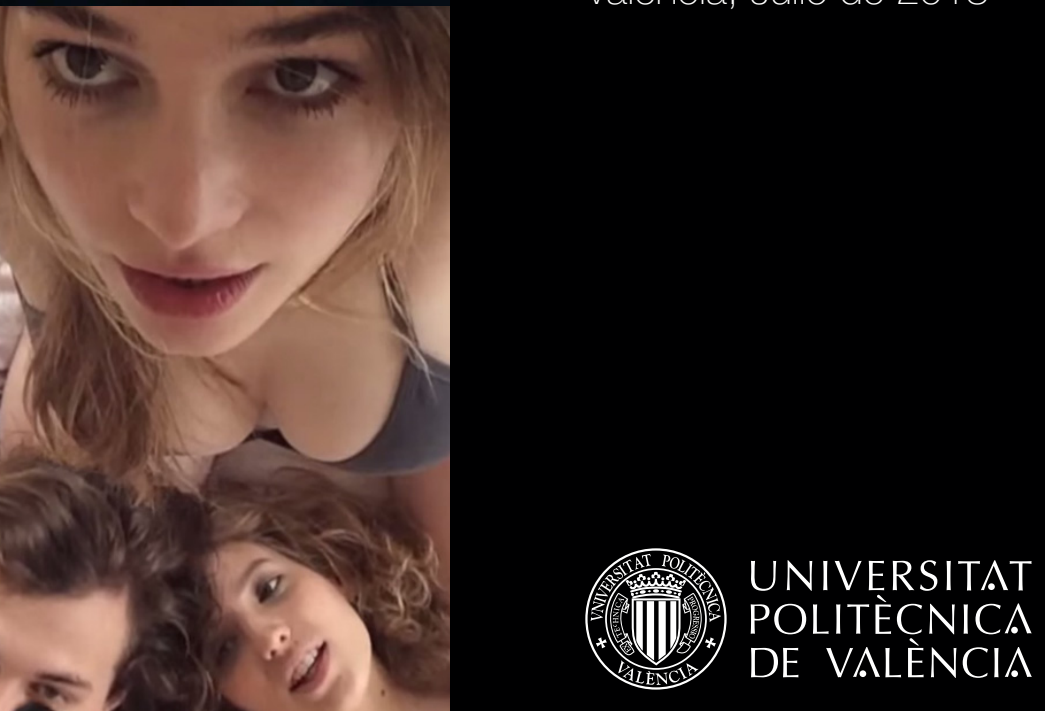




\title{
UNIVERSITAT POLITÈCNICA DE VALÈNCIA
}

Programa de doctorado: Arte, Producción e Investigación

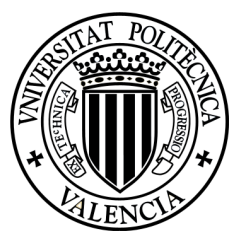

TESIS DOCTORAL

\section{LOS ORÍGENES ADOLESCENTES DEL SELFIE Y SU REPRESENTACIÓN EN EL ARTE Y EN LOS MEDIOS DE MASAS}

\author{
PRESENTADA POR \\ Javier Gayet Valls
}

DIRECTORES

Dra. Paula Santiago Martín de Madrid

Dr. David Pérez Rodrigo

Valencia, Julio 2018 

A mis yayos, Vicenta y Paco.

Os recuerdo cada día. 


\section{RESUMEN}

Estamos viviendo un principio de siglo en el que las reglas del juego han cambiado en lo que a fotografía y producción fotográfica se refiere, debido en parte a la democratización de los actuales dispositivos electrónico-digitales de captura fotográfica y al desarrollo de Internet como espacio expositivo o de publicación. Asimismo, la proliferación de novedosas y diferentes formas de autorretrato dentro del medio cibernético-virtual, nos plantea nuevos paradigmas formales, conceptuales y definitorios vinculados a la historia de la imagen y a la teoría del arte.

El self shot, definido como autorretrato fotografiado con un dispositivo digital para su posterior (o instantánea) publicación en la red de manera voluntaria o involuntaria, y sus diferentes tipologías, como el selfie o el mirrorpic, no son en absoluto un hecho aislado o un género puntual y arbitrario. Son cientos de miles las fotografías que se producen y publican diariamente en todo el mundo, siguiendo las premisas y normas que el propio fenómeno dicta: fotografías sujetas a unos cánones compositivos, estéticos y formales que concluyen en una inabordable imaginería de rostros y cuerpos autorrepresentados.

Actualmente, este tipo de imágenes se han convertido en algo cultural, fomentando la propia transformación evolutiva del medio fotográfico (e incluso sirviendo, con su marcada iconicidad, como marco referencial para diversas representaciones en ámbitos ajenos: el arte, el entretenimiento audiovisual o la publicidad). No obstante, su génesis no fue tan popular, sino el fruto de una creación experimental e íntima vinculada a autoras adolescentes que, encerradas en sus cuartos de baño, se autofografiaban con una cámara compacta en la mano 
a través de su reflejo en el espejo y sin saber que estaban desarrollando unos protocolos conductuales que heredarían una década más tarde una gran multitud de grupos poblacionales de diferentes edades que se extienden por nuestras sociedades contemporáneas.

La presente Tesis Doctoral aborda todos estos fenómenos e intenta vincularlos al hecho artístico y a cómo el mismo ha influido (y se ha visto, a su vez, influido) por los mass-media.

Palabras clave: adolescentes, autorretrato, cuerpo, dispositivos electrónicos, erotismo, espejo, fotografía, fotografía digital, imagen, Internet, mirrorpic, postfotografía, redes sociales, selfie, self shot, smartphone, vida privada. 


\section{RESUM}

Estem vivint un principi de segle en el qual les regles del joc han canviat pel que fa a fotografia i producció fotogràfica a causa, en part, de la democratització dels actuals dispositius electrònic-digitals de captura fotogràfica i al desenvolupament d'Internet com a espai expositiu o de publicació. Així mateix, la proliferació de noves i diferents formes d'autoretrat dins del medi cibernètic-virtual, ens planteja nous paradigmes formals, conceptuals i definitoris vinculats a la història de la imatge i a la teoria de l'art.

El self shot, definit com a autoretrat fotografiat amb un dispositiu digital per a la seua posterior (o instantània) publicació en la xarxa de manera voluntària o involuntària, i les seues diferents tipologies, com el selfie o el mirrorpic no són en absolut un fet aïllat o un gènere puntual i arbitrari. Són centenars de milers les fotografies que es produeixen i publiquen diàriament arreu del món seguint les premisses i normes que el propi fenomen dicta: fotografies subjectes a uns cànons compositius, estètics $\mathrm{i}$ formals que conclouen en una inabordable imatgeria de rostres i cossos autorrepresentats.

Actualment, aquest tipus d'imatges s'han convertit en un fet cultural, fomentant la pròpia transformació evolutiva del medi fotogràfic (i fins i tot servint, amb la seua marcada iconicidad, com a marc referencial per a diverses representacions en àmbits aliens: l'art, l'entreteniment audiovisual o la publicitat). No obstant açò, el seu gènesi no va ser tan popular, sinó el fruit d'una creació experimental i íntima vinculada a autores adolescents que, tancades en les seues cambres de bany, s'autofotografiaven amb una càmera compacta a la mà a través del seu reflex en l'espill, i sense saber que estaven desenvolupant uns protocols 
conductuals que heretarien una dècada més tard una gran multitud de grups poblacionals de diferents edats que s'estenen per les nostres societats contemporànies.

La present Tesi Doctoral aborda tots aquests fenòmens i intenta vincular-los al fet artístic i a com el mateix ha influït (i s'ha vist, al seu torn, influït) pels massmedia.

Paraules clau: adolescents, autoretrat, cos, dispositius electrònics, erotisme, espill, fotografia, fotografia digital, imatge, Internet, mirrorpic, postfotografia, xarxes socials, selfie, self shot, smartphone, vida privada. 


\section{ABSTRACT}

We are living at the beginning of a century in which the rules of the game have changed in terms of photography and photographic production. This is due, in part, to the democratisation of the current electronic-digital photographic capture devices and the internet's development as a space for exhibiting and publishing photos. Likewise, the proliferation of different, never-before-seen forms of self-portraits within the cybernetic-virtual medium presents us with new conceptual, formal and defining paradigms that are linked to the history of the image and the theory of art.

The self shot, defined as a self-portrait photographed with a digital device for its subsequent (or instantaneous) voluntary or involuntary publication on the web, and its different typologies, such as the selfie or the mirror pic, is by no means an isolated event or a limited and arbitrary genre. Every day, hundreds of thousands of photographs are produced and published around the world, adhering to the premises and rules that the phenomenon itself dictates: photographs subject to compositional, aesthetic and formal norms that end with an overwhelming amount of imagery of self-represented bodies and faces.

Currently, these types of images have become cultural by nature, advancing the photographic medium's unique evolutionary transformation (and even serving, with its marked iconicity, as a framework of reference for various representations in other areas: art, audio-visual entertainment or advertising). However, its origin was not so mainstream. In contrast, it was the result of an experimental and intimate creation tied to adolescent authors who, locked in their bathrooms, would photograph themselves with a compact camera in hand through their 
reflection in the mirror and without knowing that they were developing behavioural protocols that would be inherited a decade later by a vast number of population groups of different ages, that would then spread all throughout our contemporary societies.

This Dissertation addresses all of these phenomena and tries to relate them to the artistic context and how this context has influenced (and has, in turn, been influenced by) mass media.

Key words: adolescents, self-portrait, body, electronic devices, eroticism, mirror, photography, digital photography, image, Internet, mirrorpic, postphoto, social networks, selfie, self shot, smartphone, private life. 


\section{ÍNDICE}

\section{LA ERA DEL FILM}

2.1. Breves apuntes acerca del autorretrato antes de la llegada de la fotografía.

2.2. Aproximación a la irrupción de la fotografía y a su democratización entre las masas.

2.3. Autorretratos fotográficos realizados por aficionados antes de la llegada de la fotografía digital.

\section{Capítulo 3.}

EL SELF SHOT: AUTORRETRATOS DIGITALES

PUBLICADOS EN LA RED

3.1. Self shot. Definición y acotación terminológica. 
3.1.1. Tipologías del autorretrato digital publicado en la red $y$ 76 modos de visión.

3.1.1.1. El mirrorpic o autorretrato digital de espejo. 93

3.1.1.2. El selfie primitivo. 95

3.1.1.3. El selfie.

3.1.1.4. Otros tipos de self shots no clasificados.

100

3.1.2. Algunos apuntes aclaratorios.

101

3.2. Breve historia del autorretrato digital publicado en la red.

104

3.2.1. Fase de desarrollo del self shot (2004-2010).

108

3.2.2. Fase de consolidación formal del self shot y de expansión del selfie (2010-2014).

3.2.3. Fase de popularización del self shot (2014-hasta la actualidad).

3.3. El self shot como objeto fotográfico.

3.3.1. El espejo como elemento conformador del mirrorpic y el mito de Narciso.

3.3.2. La pantalla-espejo como superficie constructora del selfie.

3.3.3. La dictadura de la herramienta y su relación con las nuevas perspectivas compositivas.

3.4. El self shot como concepto fotográfico.

3.4.1. La mirada postfotográfica.

3.4.2. Una aproximación desde la semiótica y la retórica. 174

3.4.3. El referente etnográfico y sociológico.

SEGUNDA PARTE:

DEUS EX MACHINA

\section{Capítulo 4.}

\section{EL SENSOR DE IMAGEN ELECTROMAGNÉTICO}

4.1. Principios, origen y desarrollo del sensor electromagnético de imagen fotográfica.

4.1.1. Fundamentos técnicos del sensor de imagen. 
4.1.2. Origen del sensor de imagen y su integración con la cámara fotográfica.

4.1.3. Evolución de la cámara fotográfica digital antes de la

llegada del smartphone.

4.2. La adaptación del fotógrafo de película argéntica a la fotografía digital. Diferencias y convergencias.

4.3. El smartphone y su importancia fotográfica en torno al selfie.

4.3.1. El sensor delantero del smartphone y el uso de la pantalla-espejo.

4.3.2. Selfie apps.

\section{Capítulo 5.}

\section{LA PANTALLA INDISCRETA DEL ADOLESCENTE}

5.1. La mujer adolescente y su relación con la fotografía.

5.1.1. Fotografía adolescente documental.

5.1.2. La desprofesionalización del fotógrafo de portfolios y la visión de la moda por parte de las adolescentes.

258

5.1.2.1. El alcance y el control de la belleza en manos de las adolescentes.

5.1.3. La influencia de la fotografía de moda en el autorretrato adolescente.

5.2. El espacio propio y privado convertido en escenario público.

278

5.2.1. La pantalla indiscreta.

285

5.2.1.1. JenniCam: una vida en directo.

5.2.1.2. El voyeur y "la vecinita de al lado".

5.3. Del autorretrato a la fama.

5.3.1. Identidad e influencia.

5.4. El tratamiento del desnudo mediante el selfie y otros autorretratos publicados en la red.

5.4.1. The Celebgate Scandal.

5.4.2. El suicidio de Amanda Todd.

5.4.3. Otros riesgos en torno a la práctica del selfie. 
Capítulo 6. EL CIBERESPACIO: UNA GALERÍA VISUAL INFINITA EN LA RED GLOBAL

6.1. Breves apuntes sobre la historia de la computación.

6.2. Aproximación al recorrido operado por Internet.

6.2.1. Orígenes de Internet.

6.2.2. Tim Berners-Lee inventa la Web.

6.2.3. Algunos apuntes acerca del hipertexto.

364

6.2.4. Los navegadores web y las primeras interacciones

366 sociales en el ciberespacio.

6.2.5. La Web 2.o y la institucionalización del Internet social.

371

6.2.6. Internet hoy.

375

6.2.7. Un nuevo medio de comunicación de masas.

379

6.3. Redes sociales: nuevas sociedades y galerías globales.

6.3.1. Definiciones, catalogación y algunos conceptos asociados a las redes sociales.

6.3.1.1. El \#hashtag.

6.3.2. Principales redes sociales en las que son notorias las autofotos y otros medios de exhibición y distribución del selfie.

6.3.2.1. MySpace.

6.3.2.2. Los blogs y el desarrollo de Blogger.

404

6.3.2.3. Los fotoblogs: Fotolog.

6.3.2.4. Redes sociales basadas en la imagen: Flickr, Tumblr y Pinterest.

6.3.2.5. Facebook.

6.3.2.6. La desaparecida Tuenti.

6.3.2.7. Plataformas y perfiles para relaciones y encuentros.

6.3.2.8. Twitter.

6.3.2.9. Instagram y su importancia postfotográfica. aplicaciones de mensajería instantánea WhatsApp, SnapChat y Messenger. 
TERCERA PARTE:

DE DIARIOS Y OTRAS ARTES

\section{Capítulo 7.}

\section{LA MUSEIFICACIÓN DEL SELFIE}

7.1. El selfie utilizado como objeto artístico.

7.1.1. La autorrepresentación terapéutica de Cristina Núñez.

7.1.2. Tete de Alencar: Cinderella Flash.

7.1.3. Los reflectogramas de Joan Fontcuberta.

458

7.1.4. Self-timer Stories.

7.1.5. Lucía del Carmen Luque Rodríguez.

7.2. Selfies representados mediante las Bellas Artes.

464

7.2.1. Juan Francisco Casas y sus selfies realizados con bolígrafo.

7.2.2. La certeza de uno mismo en Begoña Riera.

466

7.2.3. Una escultura bajo el agua.

7.2.4. El selfie pintado.

7.3. El selfie acumulado y utilizado como proyecto artístico.

7.3.1. Selfiecity.

7.3.2. The Adaption to my Generation.

7.3.3. El yo frente al espejo.

7.3.4. En torno a la cara.

7.3.5. Exposición Avatares.

7.4. El selfie como simulación o herramienta museística.

7.4.1. Face to Facebook.

7.4.2. Selfies realizados en el museo.

7.4.3. Selfies permitidos en el museo.

7.5. El selfie representado en otras artes. 
Capítulo 8. EL SELF SHOT PUBLICADO EN FORMATO LIBRO

8.1. Los diarios digitales de Natacha Merritt. 488

8.2. Sasha Grey: Neü Sex. 493

8.3. Las modelos autorretratadas de Uwe Ommer. 496

8.4. Selfish, por Kim Kardashian. 499

Capítulo 9.

LA PRESENCIA Y EL USO DEL SELFIE EN LA PUBLICIDAD

503 Y EN OTROS MEDIOS DE MASAS

9.1. La utilización del selfie y del mirrorpic en campañas de publicidad y como estrategia de marketing.

9.1.1. El selfie como objeto fotográfico en sí mismo trasladado

506 o simulado.

9.1.2. El selfie como representación de su acto y práctica.

520

9.1.3. La autofoto como invitación para el desarrollo de una campaña de marketing.

9.1.4. La publicidad engañosa basada en la apropiación del autorretrato ajeno.

9.2. La presencia del selfie en el cine y en las series televisivas.

9.3. El selfie como marco argumental en los shows televisivos, en los programas de radio y en la música.

9.4. El uso del selfie en los videojuegos.

9.5. Infografías, memes y chistes gráficos relacionados con el selfie.

9.6. El selfie vendido a través de otros soportes. 


\section{BIBLIOGRAFÍA}

Libros.

575

Tesis doctorales y trabajos de investigación.

593

Artículos en revistas y prensa periódica.

595

Catálogos y fotolibros.

607

Filmografía.

608

Artículos online.

611

Páginas web y recursos obtenidos en sitios de Internet.

626 

Su padre ha vuelto de trabajar antes de lo previsto, su hermano -aire a efebo francés, trece años de incipiente sexualidad-ha salido con su grupo de criaturas de extrarradio; su madre descansa a oscuras en la habitación contigua, migrañas -dice-; hay algo de fin del mundo en el ambiente, algo de despedida que probablemente no llegue. El barrio residencial no esconde secretos, el barrio de concentración $-y$ dormitorio y secuencia estival interminable- junto a la interestatal, viejos conocidos, aquí y allá un halo de era buen chico y también de viejas apoyadas en el marco de la ventana, siempre esas mujeres y también ese extraño efecto de oasis que refleja un paraíso sobre el asfalto. La intimidad de su habitación no es suficiente, el cuarto de baño es la promesa de un escenario más adecuado, cierra el pestillo y solo queda ese after shave de su padre que no se molesta en retirar, tampoco los cepillos de dientes, ni la toalla que es un recuerdo de cuando podía andar desnuda junto a su hermano pequeño. Se desprende de todo menos de la ropa interior, la compró hace un par de semanas, su prenda inferior preferida, tan breve como una forma reconocible en una nube, se cubre con un brazo el pecho, la mirada ha sido ensayada frente al espejo decenas de veces. Un burdo chasquido digital que imita un obturador. Una instantánea. Un nuevo paisaje de piel y azulejos blancos. 


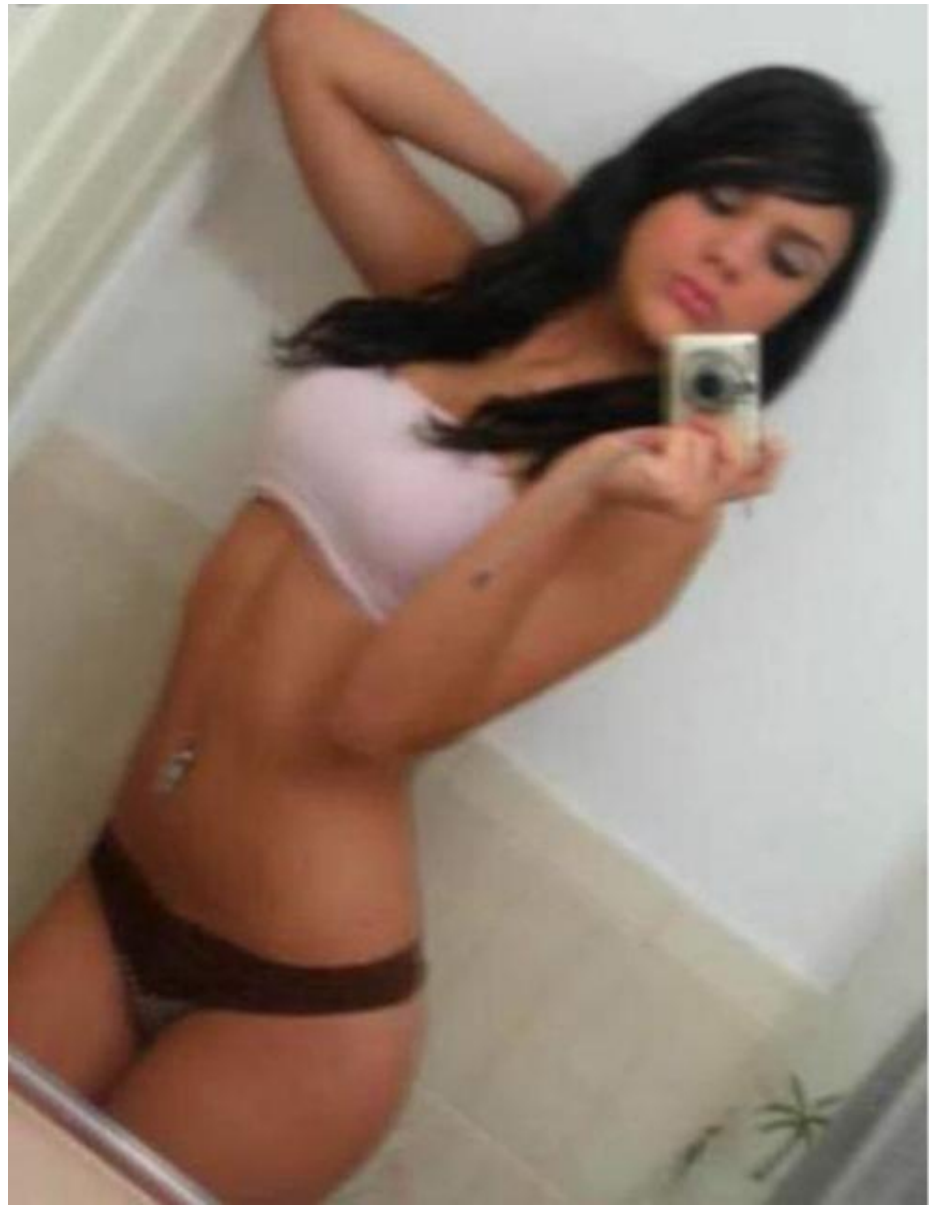




\section{INTRODUCCIÓN}

Dime lo que ves, $\mathrm{y}$ te diré para qué vives y cómo piensas.

RÉGIS DEBRAY, Vida y muerte de la imagen, 1992.

Comenzamos a investigar en 2009 la tímida y relativamente reciente aparición de un tipo de imagen fotográfico-digital exhibida en el territorio de Internet, y que por aquel entonces había sido bautizada como self shot por la comunidad de usuarios de la red. Nos motivó escoger este (por aquel entonces poco visible) objeto fotográfico como tema de estudio no solo por sus posibilidades y por su complejidad, sino también por la relación íntima y representativa en relación con los nuevos retos a los que se estaba (y se está) enfrentando la fotografía en los primeros años de nuestro nuevo milenio. A finales de 2012 publicamos el trabajo fin de máster Del espejo al sensor. Cuerpos publicados en la red global: El self shot adolescente $y$ otros autorretratos postfotográficos, trabajo al que siguió una serie de ponencias en diversos congresos y publicaciones que también fueron una antesala, a modo de prólogo, para establecer algunos de los pilares estructurales que cimentarían esta Tesis Doctoral. 
Basándonos en el material redactado por el anonimato colectivo de Internet, definimos al self shot como un autorretrato fotográfico-digital publicado en la red de manera voluntaria o involuntaria. Una actividad que era practicada por aquel entonces, y casi en exclusiva, por jóvenes adolescentes, en su mayoría mujeres. El dispositivo de captura digital (democratizado por cultura y coste) se convirtió en la herramienta fundamental para el desarrollo de este objeto fotográfico. Dicho dispositivo aparecía en ocasiones reflejado en un espejo y compartiendo protagonismo con la modelo que, íntima y eróticamente, se autorretrataba encerrada en su cuarto de baño. En otras ocasiones, esta autofoto era un novedoso ejercicio de encuadre, dictaminado por la longitud del brazo sustentador de la cámara que apuntaba, sin ningún tipo de control visual, hacia el rostro. Posteriormente, estas imágenes eran publicadas de manera indirecta $\mathrm{o}$ autopublicadas por sus autoras en Internet a través de fotoblogs y redes sociales. Asimismo, podían ser compartidas por correo electrónico, multiplicándose y convirtiéndose en públicas aunque partieran, en ocasiones, de lo privado. De este modo, se añadían a un imaginario popular que poco a poco se convirtió en global, fijando una iconografía reconocible y un modelo a seguir.

La herencia de este tipo de imágenes producidas desde hace años por el colectivo adolescente, se hace patente en el (recientemente mediático) selfie contemporáneo (que también hemos definido, junto con el autorretrato de tipo mirrorpic, como dos tipologías de self shots con características particulares y únicas), una práctica fotográfica que se ha extendido de manera masiva por todo tipo de población a lo largo del globo. Ahora bien, cabe señalar que su crecimiento entre las masas de casi cualquier condición poblacional no ha sido solo debido al contagio icónico de estos autorretratos producidos durante la década pasada tras la llegada de las comunidades propiciadas por una Web 2.0 participativa, una democratización de las cámaras digitales compactas y una emancipación fotográfica de los adolescentes. Su crecimiento y desarrollo también ha sido fruto de la evolución de los smartphones (que unificaron herramienta de captura fotográfica y dispositivo de publicación conectado a la 
red), de la consolidación de la popular app de microblogging basada en la imagen denominada Instagram y de la explosión mediática del término selfie que se desató, de manera exponencial, a principios de 2014 tras la 86ª edición de la ceremonia de los Premios Oscar, en Estados Unidos. El famoso "Selfie de los Oscar” realizado por Bradley Cooper y tuiteado por la presentadora de la gala Ellen DeGeneres se convirtió en el tuit con mayor impacto de la historia. No obstante, esta popularización masiva del término y su uso había comenzado meses antes, durante 2013, momento en el que, entre otros acontecimientos, la palabra selfie se convirtió en la palabra del año para el Diccionario Oxford de la lengua inglesa, tras una investigación de idioma que reveló que la frecuencia de la palabra selfie en el idioma inglés había aumentado en un $17.000 \%$ durante el año anterior.

Sin embargo, y pese al desarrollo tecnológico y social y al estallido mediático que ha animado a cualquier público a realizar masivamente este tipo de prácticas fotográficas, nuestra investigación se ha centrado de manera particular en estudiar los orígenes de este fenómeno y su impacto icónico en otros ámbitos. Fenómeno que ha sido fruto de la creatividad y del atrevimiento de un colectivo de mujeres adolescentes: las primeras selfshooters. Ellas acuñaron durante la década pasada un modelo que poco a poco se hizo visible. Rompieron la primera capa de hielo, luego pasó todo lo demás.

Y es precisamente el hecho de que se haya generado en algo más de una década una inmensa y descontrolada producción de autorretratos (que abarcan desde escenas casuales y divertidas, hasta íntimos desnudos capturados frente al espejo de un cuarto de baño cerrado con pestillo) lo que ha posibilitado la creación de una fuerte iconografía e, incluso, un simbolismo en torno a estas prácticas productoras de lo que podemos considerar como objetos fotográficos plenamente contemporáneos. Debido a este reconocimiento, dicha iconografía ha servido como influencia o como marco referencial para generar discursos o estrategias mediante su aprovechamiento en medios externos al propio, tales 
como puedan ser el arte, la publicidad y el marketing. La expansión del fenómeno también ha justificado el desarollo y la adaptación de la industria fotográfica actual hacia unas prácticas cada vez más extendidas y que, a su vez, habían sido fruto de los avances desarrollados en las herramientas realizadoras de fotografías digitales durante sus primeros años de implantación popular.

Aunque el fenómeno del self shot es relativamente reciente, ya han transcurrido suficientes años para poder entenderlo como un proceso que evoluciona, que se clasifica en tipos, que es fruto de una época y que se puede analizar desde planteamientos artísticos y científicos.

Ello hace que podamos enfrentarnos al recorrido de esta relativamente novedosa práctica, enfocándola desde un punto de vista interdisciplinar en el que intervenga la historia, la teoría del arte y de la fotografía, la semiótica, la sociología y los medios de comunicación de masas, planteando además las siguientes dos hipótesis:

1. ¿Podemos entender el self shot (autorretrato fotográfico-digital publicado en la red de manera voluntaria o involuntaria) y sus variantes (selfie, mirrorpic...) como un fenómeno fotográfico, masivo e icónico, siendo en sus orígenes el producto de una emancipación fotográfica por parte de los y las adolescentes autorretratados gracias a sus novedosos dispositivos de captura digital y a la influencia de la fácil plataforma de publicación personal que ha supuesto ser Internet y mediante la cual acuñaron y popularizaron una práctica actualmente extendida entre la mayoría de grupos poblacionales de nuestras sociedades modernas?

2. ¿Ha alcanzado el selfie (y el resto de self shots) una iconicidad y una popularidad suficientemente notoria como para poder ejercer, mediante el uso de su imagen cultural, una fuerte influencia como marco referencial en el ámbito del 
arte, de la publicidad, del cine y de otros medios de masas ajenos a la propia naturaleza del mismo?

Partiendo de estas dos cuestiones, nos vemos obligados a desarrollar en profundidad nuestro principal objeto de estudio (el autorretrato fotográficodigital publicado en la red) y algunos de los ámbitos transversales que lo conforman, marcando los siguientes objetivos:

- Describir desde perspectivas diferenciadas el origen y la actual consolidación del fenómeno del self shot, estableciendo una definición, acotando sus tipologías y modos (mirrorpic, selfie...) y rastreando su aparición y desarrollo en el tiempo, así como sus precedentes. Ello nos va a llevar a efectuar todas las aclaraciones pertinentes que establezcan los conceptos que vamos a tratar en este estudio.

- Vincular los orígenes de esta actualmente extendida práctica fotográfica con el desarrollo de los nuevos dispositivos de captura fotográfica digitales, con la evolución de la red como superficie de publicación personal y de consulta global, y con la consecuente emancipación fotográfica que, a su vez, ha adquirido el colectivo adolescente de las sociedades desarrolladas y globalizadas, principalmente desde mediados de la década pasada.

- Asociar dicho fenómeno con la cada vez más generalizada autopublicación voluntaria (y en ocasiones involuntaria) que sus autoras y autores (en sus albores, mujeres y hombres adolescentes $\mathrm{y}$, actualmente, muchos grupos poblacionales) hacen de estas imágenes en la red, entendiendo ambos gestos (acción fotográfica y publicación) como prácticas unidas e indivisibles que suponen un protocolo que se ha popularizado, naturalizado y consolidado en el transcurso de la última década. 
- Establecer un marco histórico-técnico que describa los últimos avances contemporáneos en la esfera de la fotografía digital a través de las tipologías de sus dispositivos de captura fotográfica (basados en el sensor electrónico), además de estudiar la evolución que Internet y sus redes sociales (principal escenario de publicación del self shot) han experimentado estos últimos años.

- Investigar de manera transversal acerca de la viabilidad de nuevos paradigmas teóricos o conceptuales vinculados a la fotografía contemporánea (o postfotografía) en cuanto a este tipo de prácticas.

- Analizar formalmente las estructuras compositivas de este tipo de objetos fotográficos que son nuestro principal tema de investigación (selfies y mirrorpics), asociando estos resultados no solo a la visión y voluntad de sus autoras, sino también a los protocolos de encuadre y uso fotográfico que plantean los nuevos dispositivos de captura de imagen.

- Visibilizar la problemática que pueden acarrear cierto número de malas prácticas en la red relacionadas con este tipo de actividad fotográfica y que pueden llegar a suponer un grave problema para los colectivos más jóvenes de nuestras sociedades.

- Rastrear una serie de ejemplos que demuestren la influencia de la iconografía del selfie y/o del mirrorpic aplicada como marco referencial, simulación o traslado en medios externos al propio, tales como las artes plásticas, la publicidad, el marketing, el cine, las series televisivas, las publicaciones impresas y los videojuegos.

En cuanto a la metodología que utilizaremos para intentar alcanzar estos objetivos, queda fundamentada en:

- Una recopilación de fuentes bibliográficas que aborda temas de diversa índole; algunas anteriores al surgimiento de nuestro objeto de estudio, pero que 
nos han servido, o bien para realizar contextos históricos previos, o bien para interpretar y/o actualizar algunas teorías asociables al self shot y a su contexto. Otra buena cantidad de las fuentes bibliográficas recopiladas han sido desarrolladas a partir del surgimiento de nuestro objeto de estudio, de ahí que sus temas tratados tengan una implicación directa o transversal con algunos de nuestros desarrollos o (afortunadamente, y al contrario que nos ocurrió cuando, hace años, comenzamos investigar sobre este tema) que lleguen a manejar, incluso, como tema principal de su exposición el objeto selfie. Esta amplia recopilación temática se relaciona con cuestiones que tienen que ver con la historia y la teoría de la fotografía y del autorretrato, con los medios de masas, con la postfotografía y con los nuevos dispositivos de captura digital, con las prácticas y la psicología del adolescente contemporáneo, con la red, la Web, sus redes sociales y el uso que hacen los usuarios de ellas, y con cuestiones relacionadas con el arte y con la publicidad. Asimismo, deseamos completar este recorrido con aportaciones derivadas de la semiótica, de la retórica, de la etnografía o de la sociología, así como del ámbito del derecho y de la censura. Ello nos ha llevado a efectuar una selección de lecturas centradas, entre otros, en los siguientes autores (que citamos alfabéticamente): Roland Barthes, John Berger, Erika Bornay, Pierre Bourdieu, José Luis Brea, Manuel Castells, Régis Debray, Guy Debord, Umberto Eco, Joan Fontcuberta, Cynthia Freeland, Gisèle Freund, Román Gubern, Jacques Lacan, Martin Lister, Javier Marzal, Michel Melot, Lynda Nead, John Pultz, Susan Sontag, Marie-Loup Sougez, Remedios Zafra y Santos Zunzunegui. También otra serie de autores y autoras más recientes y concretamente especializados en algunos capítulos fundamentales de nuestro objeto de estudio nos han ayudado a, esta vez sí, justificar académicamente la existencia de este. Algunos de estos han sido: Elisenda Ardèvol, Alejandra Borero, Begonya Enguix, Edgar Gómez-Cruz, Amparo Lasén o Suanny Londoño.

- Con independencia de esa primera recopilación de fuentes y, en un segundo momento, se ha efectuado una ampliación a publicaciones en revistas 
especializadas, catálogos y filmografía. Esta labor se ha visto complementada con la búsqueda de fuentes documentales y visuales que guardan relación con el self shot, a través de la red (el ciberespacio donde se desarrolla nuestro objeto de estudio y sus variantes) y mediante páginas web, foros, redes y aplicaciones.

- En los casos que lo han requerido hemos empleado el método de análisis de imagen fotográfica planteado por el profesor y catedrático de Comunicación Audiovisual Javier Marzal en su libro Cómo se lee una fotografía. Este método, de origen semiótico, es el utilizado dentro del área de Comunicación Audiovisual de la Universitat Jaume I (disponible en: <www.analisisfotografia.uji.es>)

- A lo largo de todos los años que llevamos investigando este fenómeno hemos ido capturando y archivando multitud de self shots encontrados tanto en redes sociales, foros, blogs y diversos espacios de la red que los cobijan o que fueron sus espacios originales de publicación. También hemos realizado un rastreo de autorretratos fotográfico-digitales que fueron publicados por adolescentes en los pocos años de recorrido que nuestro objeto de estudio realizó desde sus orígenes hasta llegar al año 2009, momento en el que empezamos a trabajar con ellos. Esta extensa recopilación nos ha proporcionado la oportunidad de evaluar hoy en día unos registros en ocasiones difíciles de volver a encontrar en 2018, dada la naturaleza volátil de Internet y la habitual destrucción de contenidos a la que generalmente se ve sometido, calificando estos objetos (a menudo enterrados) como fósiles de la red.

- Finalmente, otra de nuestras metodologías recopilatorias ha tenido que ver con un trabajo de campo desarrollado durante nuestros casuales quehaceres cotidianos, mediante registros fotográficos (realizados con nuestro smartphone) de todos aquellos ejemplos que nos hemos encontrado en las calles de nuestra ciudad (Valencia) relacionados con lo que el noveno capítulo de esta Tesis Doctoral aborda: el selfie representado o utilizado en publicidad y campañas de marketing. Así, estas fotografías callejeras y apuntes fotográficos rápidos, 
utilizados como algunas de las imágenes del capítulo citado, nos han ayudado a intentar evidenciar parte de nuestra segunda hipótesis también en nuestro territorio.

En función a lo señalado, nuestro trabajo se articula en torno a un capítulo introductorio (en el que estamos), ocho capítulos que constituyen la base estructural de la investigación (divididos a su vez en tres partes que agrupan de una manera estilística u organizativa las diferentes áreas del recorrido) y un último capítulo con las conclusiones a las que hemos llegado tras finalizar el desarrollo de nuestro estudio.

La primera parte, EL AUTORRETRATO EN EL ESPEJO, agrupa los capítulos 2 y 3.

En el capítulo 2, titulado AUTORRETRATOS FOTOGRÁFICOS DURANTE LA ERA DEL FILM, analizamos brevemente el recorrido del género del autorretrato a través de la historia del arte en occidente, así como las prácticas en torno al autorretrato realizadas por fotógrafos y, sobre todo, por las masas populares o por los aficionados durante la democratización de la fotografía a lo largo del siglo XX.

En el capítulo 3, EL SELF SHOT: AUTORRETRATOS DIGITALES PUBLICADOS EN LA RED, definimos algunas cuestiones terminológicas, efectuando también diversas aclaraciones vinculadas a nuestro objeto de estudio. También establecemos sus tipologías y sus modos de creación. Además, realizamos un recorrido histórico desde sus orígenes, a principios del siglo XXI, hasta nuestros días. Si desarrollamos su historia, tampoco dejamos atrás su teoría, analizándolo como objeto fotográfico y como concepto fotográfico.

La segunda parte, titulada DEUS EX MACHINA, agrupa los capítulos 4, 5 y 6. 
El capítulo 4, EL SENSOR DE IMAGEN ELECTROMAGNÉTICO, se halla dedicado al nuevo dispositivo de captura fotográfica digital, así como a las propiedades que recibe del sensor electrónico que alberga en su interior. El capítulo posibilita analizar la evolución de este tipo de tecnología que ha cambiado las bases y los planteamientos de la fotografía y de su relación con la sociedad del siglo XXI. Abordamos, por ello, el empleo de los smartphones como máquinas fotográficas y de publicación, y los nuevos usos y prácticas que ofrecen estos aparatos.

En el siguiente capítulo 5, LA PANTALLA INDISCRETA DEL ADOLESCENTE, abordamos la cuestión del adolescente contemporáneo y su relación con la fotografía. Nos centramos en ejemplos que atestiguan su emancipación fotográfica, utilizando algunas imágenes que muestran visualmente esta cuestión. A su vez, abordamos el espacio privado en donde acostumbran a ser realizados los autorretratos digitales y de cómo estos se convierten en públicos tras las prácticas exhibicionistas que profesan los adolescentes. El capítulo concluye abordando un tema delicado: el desnudo en la red, sus reivindicaciones y también sus peligros, visibilizando los problemas a los que se puede enfrentar el adolescente y el menor en lo que a difusión de la imagen propia y acoso se refiere.

El capítulo 6, EL CIBERESPACIO: UNA GALERÍA VISUAL INFINITA EN LA RED GLOBAL, cierra esta trilogía integrada por el adolescente, la cámara digital e Internet: los ingredientes que constituyen la condición sine qua non para la conformación de los self shots. En el epígrafe planteamos el desarrollo de la Web y de las redes sociales contemporáneas, en tanto que soportes de visionado y superficies de publicación de los autorretratos digitales.

La tercera y última parte, titulada DE DIARIOS Y OTRAS ARTES, agrupa los capítulos 7, 8 y 9. 
El capítulo 7, LA MUSEIFICACIÓN DEL SELFIE, se encuentra dedicado al estudio de artistas, colectivos artísticos o instituciones artísticas que de una $u$ otra manera han utilizado la iconografía del self shot y sus variantes (entre ellas el selfie), como objetos artísticos, como representaciones mediante el uso de las Bellas Artes, como proyectos artísticos, simulaciones o herramientas museísticas.

El capítulo 8, EL SELF SHOT PUBLICADO EN FORMATO LIBRO, también desplaza a nuestro objeto de estudio de su soporte natural hacia otro que le es ajeno, mostrando a una serie de selfshooters que han pasado de exponer en las pantallas a hacerlo sobre el soporte papel mediante publicaciones físicas.

Por último, el capítulo 9, LA PRESENCIA Y EL USO DEL SELFIE EN LA PUBLICIDAD Y EN OTROS MEDIOS DE MASAS, pretende englobar también una cantidad de ejemplos que ilustran cómo la marcada iconografía que nuestro objeto de estudio ha forjado a lo largo de más de una década de desarrollo cultural es capaz no solo de influir o vertebrar el marco referencial de diferentes campañas de publicidad y marketing, sino también, ejercer una presión en otras áreas de los medios de masas contemporáneos como el cine, las series televisivas o los videojuegos.

Para finalizar, nuestro trabajo se cierra con un capítulo 10 dedicado a las CONCLUSIONES.

$$
* * *
$$

Vamos a comenzar sin más dilación nuestra exposición, no sin antes expresar aquí unos agradecimientos de manera personal.

Existe una infinidad de personas que ha hecho posible la realización de este trabajo y que, sin su desinteresada colaboración y benevolente apoyo, hubiera sido imposible llevarlo a cabo. No solo les estoy profundamente agradecido, sino que también me siento endeudado con todas ellas y ellos. 
Las primeras personas a las que quiero agradecer su ayuda y confianza, son mis tutores, mentores y amigos David Pérez y Paula Santiago, directores de esta investigación. Ellos me apoyaron en todo momento, desde los difíciles comienzos, hasta las últimas correcciones. Acudí a ellos hace años con un puñado de ideas inconexas y un objeto de estudio aparentemente banal, extraño y sin demasiado interés académico $\mathrm{y}$, sin cuestionarlo en ningún momento, me acogieron bajo su tutela ofreciendo energías y herramientas para para poder desarrollarlo a través de estas páginas. Su acertada guía en la búsqueda bibliográfica solo fue superada por las largas y agradables conversaciones, generalmente debates, que hemos tenido en tantas ocasiones sobre este tema que finalmente ha resultado ser candente, atractivo y azarosamente oportuno. Toda esta ayuda que me han ofrecido David y Paula, junto con sus demasiadas horas de dedicación, ha sido algo que nunca podré olvidar.

Asimismo, agradezco a otros profesores y técnicos de la Facultad de Bellas Artes de San Carlos su contribución y esfuerzos en mi enseñanza y en mi desarrollo como alumno, además de la ayuda que, de una u otra manera, me han prestado en este proyecto. La lista de profesionales sería casi interminable como para mostrarla aquí, pero quiero hacer especial mención y mostrar también mi agradecimiento a Nuria Rodríguez, a Chema López, a Laura Silvestre, a Francesc Vera, a Geles Mit, a Juan Canales, a Ana Teresa Ortega, a Enrique Tormo, a Idoia Calabuig, a Josep Frasquet, a Chema de Luelmo, a David Heras, a Pep Benlloch, a Juan Peiró, a José Luis Cueto, a Rodrigo Pérez y por supuesto también a Luis Armand por todo su apoyo e interés.

Agradezco de igual manera todos los esfuerzos que ha puesto en mi instrucción a la Universitat Politècnica de València y a aquellos que la hacen funcionar. Doy fe, con total convicción, de que la Universidad pública funciona.

También doy las gracias a todas mis amigas y amigos, compañeros de estudios y de correrías, que me han acompañado y ayudado estos años 
universitarios, de máster y doctorado. A mis amigas y amigos más cercanos, gracias por sus visitas inesperadas, ayuda en las lecturas, préstamos de libros, contestación a llamadas de auxilio, consejos, apoyo moral y también por sus cuestionamientos y por la infinita paciencia que han demostrado durante estos años de forzoso abandono por mi parte.

Deseo, asimismo, mostrar mi gratitud a mi escasa lista de familiares por su apoyo incondicional y ayuda desde que tengo uso de razón. Mi madre y mi hermano saben lo importantes que son para mí y lamento durante estos años, haberlos de alguna manera desatendido. Esta gratitud quiero, a su vez, extenderla a los que no podrán ver finalizado el transcurso de esta aventura, pero que tanto me siguen ayudando desde la lejanía: mis queridos yayos Paco y Vicenta, a los que he dedicado esta Tesis Doctoral.

Y si tengo que agradecer a alguien el lujo que supone hoy en día la posibilidad de realizar una empresa de esta envergadura, ella es, sin duda, mi amada esposa y compañera Alicia, por la paciencia infinita que ha demostrado durante todos estos años y por haberme ayudado (y sufrido) más que nadie. La vida a tu lado se me hace más fácil, y hacer estas cosas, tienen si estás tú, todos los sentidos. Y por supuesto las dos personitas más importantes de mi vida: mis hijos Pau y Samuel, que sin aún entender estas letras negras que diariamente han robado parte del tiempo de nuestros juegos, no han dudado, sin embargo, en sentarse sobre mis rodillas, modelando plastilina o realizando algún dibujo, pacientes y en silencio, mientras yo redactaba todas estas páginas. Vuestra compañía, así como sentir esos pequeños latidos ha sido y será siempre mi motor.

Muchas otras personas han contribuido también de manera directa en este trabajo con sus aportaciones materiales. 
A todos los autores de los libros, tesis y artículos que he leído y que conforman la bibliografía que es, a su vez, el núcleo de este trabajo. Gracias por ese fundamental e imprescindible soporte.

Agradezco a Edu Reptil los versos que compuso para embellecer con palabras la antesala de estas páginas. No hay mejor poesía que la suya para describir un self shot. Muchas gracias a todas y a todos los que han aportado sus imágenes (o su imagen) a este escrito. También a las fantásticas autorretratistas de mi entorno y que tanto admiro, gracias a Isabel, Dana, Marisol, Blanki, Maribel y Lorena, no solo por prestarme vuestras fotografías para poder ilustrar lo que es un bello selfie, sino también por realizarlos diariamente y seguir haciéndolo. Confieso que me siguen encantando.

Y, por supuesto, gracias al resto de selfshooters, conocidas y anónimas, distribuidas por el mundo y por la red. Sois las protagonistas de este trabajo y vuestras fotografías son ejercicios maravillosos. Hacen de este mundo un lugar más bello. Por último, agradezco a la chica, primera imagen de la portada, que se autorretratara aquel preciso día, hace más de diez años. Que hiciera clic en ese instante, con esa inclinación y de esa manera. Esa imagen, que guardo desde entonces y que apareció azarosamente en Google Imágenes mientras buscaba modelos de cámaras compactas, es la que siempre utilizo como ejemplo en ponencias y publicaciones. Es para mí, la encarnación icónica del self shot. Ha sido una de mis fuentes de inspiración y nunca podré darle las gracias. Porque nunca conoceré su nombre... 


\section{PRIMERA PARTE: EL AUTORRETRATO EN EL ESPEJO}





\title{
2. AUTORRETRATOS FOTOGRÁFICOS DURANTE LA ERA DEL FILM
}

\author{
Cuando abro la cartera \\ para enseñar el carné \\ para pagar algo \\ o para consultar el horario de trenes
}

te miro.

JOHN BERGER, Y nuestros rostros, mi vida, breves como fotos, 1986.

Es probable que pueda resultar innecesario comenzar este estudio con un capítulo que aborde (aunque sea de manera fugaz) el tratamiento del autorretrato fotográfico durante su etapa argéntica o predigital. Dado que nuestro objeto de estudio (el self shot y sus variantes, entre ellas el selfie), es fruto indisociable de la era digital y que, por lo tanto, no tiene cabida antes de la llegada de esta nueva tecnología medial fotográfica que se produce durante los últimos años del siglo pasado, podría pensarse que la aproximación que vamos a efectuar a lo largo de las sucesivas páginas resulta un tanto fuera de lugar o es poco significativa.

Sin embargo, y bajo nuestro punto de vista, establecer algunos apuntes acerca del autorretrato como objeto artístico y fotográfico en etapas anteriores al surgimiento de nuestro principal tema de estudio, así como analizar el 
tratamiento que han dado las masas a la producción de su propia imagen y a la relación que, a su vez, han tenido estas en torno a unos procesos fotográficos que poco a poco se han ido democratizando y haciendo extensibles a lo largo del siglo $\mathrm{XX}$, pueden ser aproximaciones pertinentes a unas prácticas predecesoras que van a asentar las bases de un movimiento espontáneo y de carácter bastante popular.

Este movimiento al que aludimos se desarrollará a principios del siglo XXI y quedará constatado (como veremos) en la conjunción de tres ejes: fotografía digital, adolescente emancipado fotográficamente y red global como herramienta de difusión (Internet), una conjunción que generará, así, ese self shot o autorretrato digital publicado en la red que vertebrará, como objeto principal de estudio, el resto de capítulos de este trabajo.

\subsection{Breves apuntes acerca del autorretrato antes de la llegada de la fotografía.}

El retrato humano y por ende, el autorretrato, es algo tan antiguo como la propia imagen, o como el arte abordado desde su historia. Y que el pueblo haga lo posible por adueñarse de estas imágenes ${ }^{1}$, también es algo implícito a la relación que este ha tenido con el arte desde tiempos pretéritos. Los intentos de apropiación de las imágenes por parte de las masas pueden ser de diversa índole: un deseo de figurar en el mundo de lo imaginario y por lo tanto de lo eterno y trascendental, un ánimo de posesión física de la propia imagen, o de la de otro, como si de la posesión de lo real se tratara; o un uso y disfrute de la imagen

1 MELOT, Michel, Breve historia de la imagen, Madrid, Siruela, 2010, pág. 51. 
dentro de los protocolos culturales de entendimiento y traducción del mundo que rodea a este indivíduo, así como de lo concerniente a sus ritos, espiritualidades y supersticiones. En todo caso, la producción del retrato y del autorretrato parecerá aliviar estos deseos y pasiones individuales y grupales, ya que tenemos referencias vivas que nos han llegado como huellas de un mundo antiguo desde las primeras pinturas rupestres de todas las culturas del globo.

En pintura o en cualquier tipo de arte realizado durante la historia humana, el retrato queda definido de maneras similares: por ejemplo, como "una representación exacta, o que procura serlo, de una persona real, existente o que haya existido"2, o de una manera más sintética, como "la prepresentación de un sujeto"3. En este mismo sentido el autorretrato, que no es más que una representación en forma de retrato que el artista realiza de sí mismo ${ }^{4}$, al igual que sucede en otras artes, puede haber sufrido transformaciones definitorias según la época en la que el mismo se realice. Por ejemplo, Sandra Escohotado apunta que:

\footnotetext{
"Un autorretrato clásico tiene que adecuarse a una imitación fiel del modelo elegido, con unos rasgos fácilmente diferenciadores para un ser único. Sin embargo, bajo la consideración humanista, en un autorretrato la imitación fiel no es un requisito indispensable. [...] en el arte moderno, los artistas han profundizado en la desfiguración intencionada, apartándose de la realidad para conseguir una expresión más ligada al espíritu o al alma, es decir, para expresar mejor el carácter espiritual de la persona. En el plano formal también hay una definición que uniría ambas consideraciones del autorretrato, la clásica y la contemporánea, como una representación de la propia figura humana”.
}

2 BAILI, Jean-Christophe, La llamada muda, Madrid, Akal, 2001, pág. 10.

3 MARTÍNEZ-ARTERO, Rosa, El retrato del sujeto en el retrato, Barcelona, Montesinos, 2004, pág. 11.

4 ESCOHOTADO, Sandra, Autorretrato, arte y mujer, Madrid, Universidad Complutense de Madrid, 2005, pág. 23.

5 Ídem. 
Por lo tanto en un autorretrato, parece que el único requerimiento requerido, es el que parte de la representación figurativa o simbólica del cuerpo humano de la persona que realiza dicha representación.

Durante el desarrollo de la cultura occidental europea tras la Edad Media, el autorretrato solo era privilegio de los que oficialmente eran considerados como "hacedores de imágenes". Estos eran artesanos y artistas que, escapando de la constante tarea de representar seres antropomorfos ajenos a sí mismos, divinos o humanos, se autorrepresentaban en algún lugar de sus obras por medio del autorretrato. Mediante este pequeño gesto únicamente se pretendía dejar, en la mayoría de ocasiones, una firma o un testimonio menor que iba a quedar camuflado dentro de una gran escena. Sin embargo, a partir del Renacimiento y sobre todo con la llegada de la modernidad, cuando el artista se reconoce como una figura de prestigio, los autorretratos se convierten casi en una obligación. El artista autorrepresentado pasa a ser el centro de la obra, generalmente dispuesto en soledad, de modo que el autorretrato pictórico se convierte en un género per se. No obstante, el deseo por parte de las masas de ser retratadas, así como la capacidad que estas tendrían para realizar ese acto de manera autónoma mediante el autorretrato, no confluiría, por lo menos de una manera totalmente institucionalizada, hasta la democratización de la fotografía a finales del siglo XIX.

Pero antes de acercanos a esta confluencia, debemos repasar brevemente algunas cuestiones relacionadas con el autorretrato prefotográfico que amplíen la información dispuesta en el párrafo anterior.

Los primeros retratos bidimensionales conocidos $^{6}$ son los llamados retratos de El Fayum (Imagen 2.1), realizados entre los siglos I y IV después de Cristo en los alrededores de la provincia romanizada de Egipto del mismo 
nombre (El Fayum). Estos retratos fueron pintados con encáustica y temple sobre lienzos y tablas ${ }^{7}$, cubriendo parte del rostro en el enfardelado de las momias. Estos trabajos representaban de una manera fidedigna e identitaria a una parte privilegiada de la población, ya que el objetivo de los mismos era que los difuntos pudiesen ser identificados en el transcurso hacia la otra vida ${ }^{8}$. Sin embargo, y en referencia no al retrato sino al autorretrato del artista, podemos decir que una de las primeras muestras bidimensionales fechadas es la realizada por Jean Fouquet (Imagen 2.2) en $1450^{9}$.

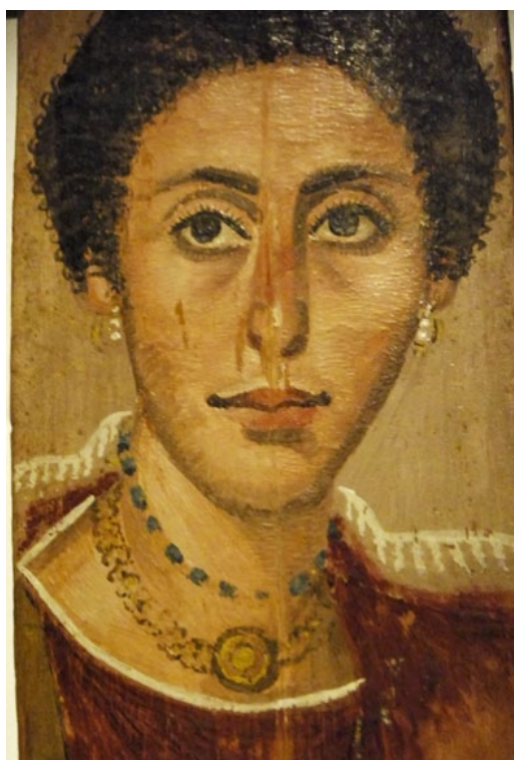

Imagen 2.1: Autor desconocido, Retrato de una mujer, 200 d. C.

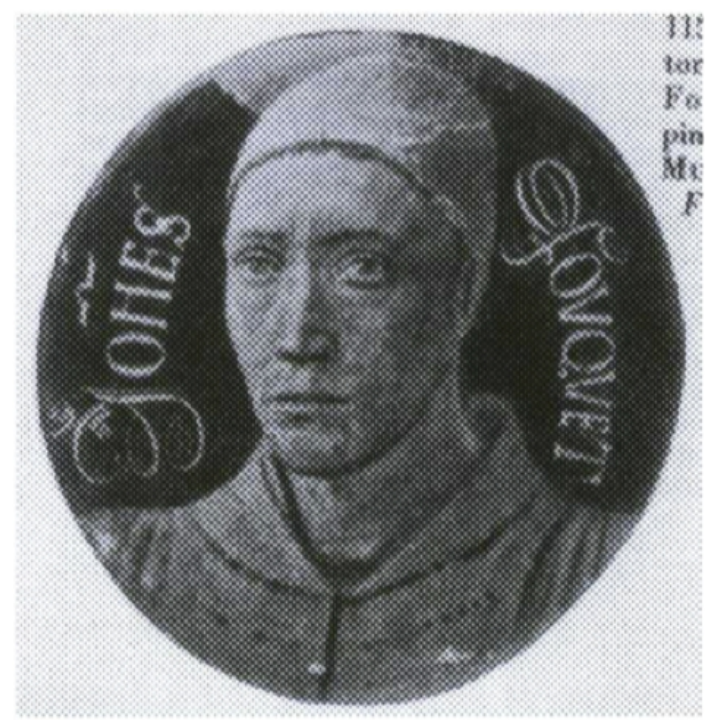

Imagen 2.2: Jean Fouquet, Autorretrato, 1950.

7 Ibídem, pág. 29.

8 De hecho, este intento de registro fidedigno en un esfuerzo por el reconocimiento podría considerarse como uno de los antecedentes conceptuales del retrato fotográfico, aunque sea de manera transversal. CRISÓSTOMO, Mamen, "Interfaces. Retratos de El Fayum", 2011, disponible en: <http://egiptologia. com/interfaces-retratos-de-el-fayum/> [Fecha de consulta: 10 de julio de 2017].

ESCOHOTADO, Sandra, op. cit., pág. 29. 
De hecho, el autorretrato del artista comenzó a institucionalizarse como firma oculta en la obra durante la Edad Media. Y ello a pesar de que ya existían precedentes puntuales en la escultura, como el autorretrato que realizó Fidias en el escudo de Atenea del Partenón, osadía que pagó con una condena temporal, pero que aún puede verse en uno de los museos de Moscú. No obstante, podemos generalizar que "ya a la altura del siglo XVI, los artistas empiezan a incluirse cada vez más dentro del marco, físicamente en sus obras"10, aunque podamos encontrar, como ya hemos sugerido, ejemplos característicos durante la Edad Media (pensemos en las catedrales de Santiago de Compostela y de Praga, donde los arquitectos grababan imágenes de sí mismos en lugares poco visibles ${ }^{11}$, motivados por la necesidad de autoafirmación que durante esta época sufrían unos pintores y escultores que eran vistos como artesanos ${ }^{12}$, muy por debajo del papel asumido por músicos o poetas en la escala social ${ }^{13}$ ).

Así pues, el autorretrato camuflado como firma del artista quedará fuertemente institucionalizado como ejercicio a lo largo del siglo XVI, como ponen de relieve las obras de Lorenzo Ghiberti (Imagen 2.3) o de Jan Van Eyck (Imagen 2.4). Paulatinamente, a lo largo de los siguientes siglos se convertirá el autorretrato en un género autónomo en sí mismo, adquiriendo una enorme presencia en el transcurso de la historia del arte. De este modo, serán muchos los artistas que recurrirán al autorretrato por distintas motivaciones: "desde un

1o MORENO, Dana, "Selfies, breve historia del autorretrato", en ArtyHum. Revista digital de artes y humanidades, $\mathrm{n}^{\circ} 3,2014$, pág. 144.

11 IVY, Jeanne, "The Exploration of Self: What Artists Find When They Search in the Mirror. The SelfPortrait as a Signature", 2011, disponible en: <http://userpages.umbc.edu/ ivy/selfportrait/ signat.html $>$ [Fecha de consulta: 1 de julio de 2017].

12 De hecho, los retratistas no se consideraron como verdaderos artistas hasta bien avanzado el siglo XVI, momento en el cual, curiosamente, se elevó su categoría por encima de otros géneros, después del religioso y el histórico. CID, Carlos, “Algunas reflexiones sobre el autorretrato”, en Liño. Revista anual de historia del arte, $\mathrm{n}^{\mathrm{O}} 5,1985$, pág. 179.

13 COLORADO, Óscar, “Autorretrato y fotografía”, 2013, disponible en: <https://oscarenfotos.com/ 2013/o8/11/autorretrato-y-fotografia/> [Fecha de consulta: 25 de julio de 2017]. 
análisis del alma y la expresión de su propio yo, a considerarlo únicamente como objeto de estudio en el marco de la anatomía humana" ${ }^{14}$.

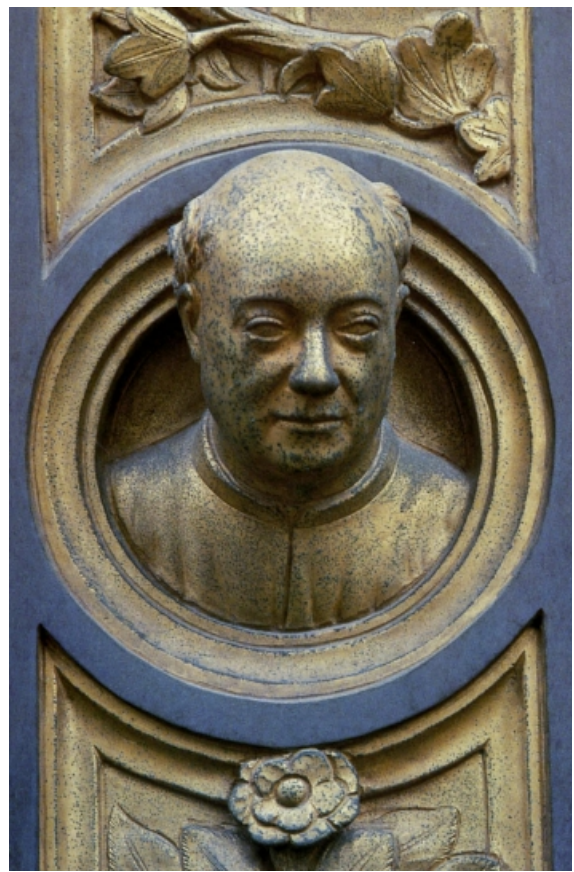

Imagen 2.3: Lorenzo Ghiberti, baptisterio en la Catedral de Florencia, 1401. El escultor realizó su autorretrato en un lugar discreto, en una de las puertas del citado baptisterio $^{15}$.

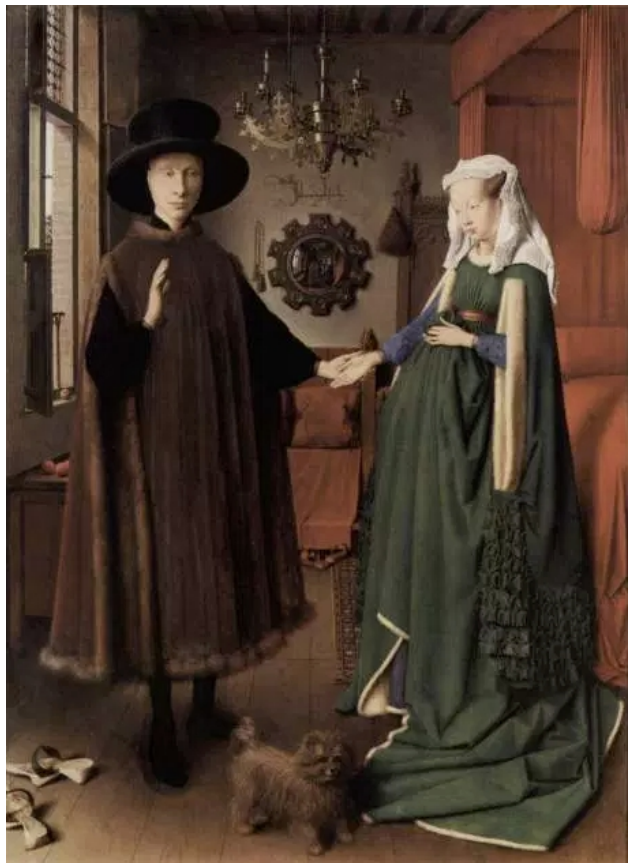

Imagen 2.4: Jan Van Eyck, $E l$ matrimonio Arnolfini, 1434. El pintor se autorretrató diminutamente en el espejo que gobierna el fondo y el centro de la composición de esta pintura ${ }^{16}$.

Los siglos XV y XVI colocarán en Europa al hombre como centro del mundo, de ahí que la pintura y la representación del hombre (cada vez más extendida y perfeccionada a nivel realista) otorgará a los gremios de pintores una

14 ROMERO, Irene, "Autorretratos. El cuerpo como campo de batalla en la fotografía femenina del s. XX”, en HUM 736. Papeles de cultura contemporánea, $\mathrm{n}^{0}$ 15, 2012, pág. 39.

15 COLORADO, Óscar, op. cit., s/n.

16 ESCOHOTADO, Sandra, op. cit., pág. 36. 
presencia notoria, elevando la figura de maestro de taller hasta los altares del artista. Durante las expansiones monárquicas y el desarrollo de los imperios y las cortes del siglo XVII, los pintores gozarán de gran fama, y estos, poseedores de ciertas libertades, no dudarán en seguir reivindicando el autorretrato pictórico como una obligación de pleno derecho, cuestión que lo convertirá en un género autónomo con las mismas bases que las del retrato (con la salvedad de que el artista se representará a sí mismo). Durante esta época:

"[...] el autorretrato y la autorrepresentación expresan, bajo diversos aspectos, una ruptura social e histórica del artista en relación a su entorno. Al exhibir y dar protagonismo a su rostro, el artista se afirma, afianzando su estatuto en pro de una cierta independencia económica y social (en el sentido de una autonomía creciente frente al mecenas). De alguna forma, ese rostro cuya visibilidad se pone ahora de manifiesto, osa mostrar deseo en alcanzar la aceptación de su subjetividad singular y un lugar indiscutible en el mundo. [...] Hasta el siglo XVIII, esta ruptura sacrifica parcialmente el apoyo de la corporación, de los principales clientes (especialmente la iglesia y la nobleza) y del público. De hecho, ese fenómeno coincide con una transformación más profunda en el seno del individuo y de la sociedad europea, e incluso en la relación de ese individuo en la sociedad occidental. [...] Las transformaciones sociales (grupo) son el reflejo de un nuevo comportamiento (individual). En el caso del medio artístico, deja de haber una norma estética uniforme, tras el (lento) fin de estructuras corporativas como gremios o guildas, la academia y el fin de la primacía de los Salones como forma de consagración de una carrera artística. A partir del siglo XIX, la diversidad de formatos de presentación del trabajo contribuye a modificar los niveles de producción y recepción de las obras. Ese cambio progresivo está también en la base de una creciente libertad artística, sinónimo de una afirmación de la libertad individual e intelectual más allá de las leyes del grupo social al que pertenece el artista: el movimiento Romántico enaltece la singularidad" ${ }^{\prime 17}$.

17 GALLIS, María I., Autorretrato y autorrepresentación: territorio de experimentación y cambio de paradigma en el siglo $X X$, Valencia, Universitat Politècnica de València, 2011, pág. 315. 
Pese a la irrupción de las vanguardias en las esferas artísticas de comienzos del siglo XX, el género del autorretrato (en algunas ocasiones de manera central o reiterativa) continuará ostentando una destacada presencia en la producción de los artistas. Sin embargo, no será hasta este momento, y no por el devenir de la pintura sino por la popularidad y democratización de la fotografía, cuando el autorretrato (en este caso fotográfico) pasará a convertirse también en un privilegio de las masas.

Estas masas, al igual que sucedía en el siglo XIX, seguían mostrando un ávido deseo por lograr una representación pictórica o fotográfica. Curiosamente, estas búsquedas fueron primero una moda entre las clases pudientes, y los caricaturistas, dibujantes ambulantes y estudios de fotografía callejeros se encargaron de que cualquiera con un puñado de monedas pudiera tener su propia representación bidimensional.

No obstante, con esta masificación de la fotografía, la autonomía que significaba el hecho de que cada individuo pudiera autorrepresentarse, iba a traer consigo que el autorretrato dejara de ser un ejercicio privilegiado y único de los artistas. Ejercicio que, durante los siglos pasados, había quedado inmortalizado en obras de pintores de tanto prestigio y reputación como Velázquez (Imagen 2.5), Rembrandt (Imagen 2.6), Van Gogh (Imagen 2.7) o Frida Kahlo (Imagen 2.8). 


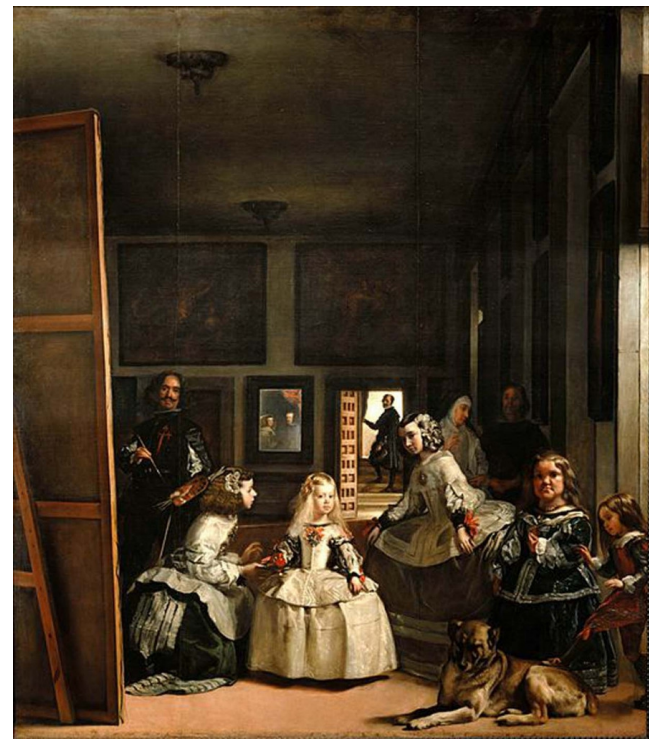

Imagen 2.5: Diego Rodríguez de Silva y Velázquez, Las Meninas o La familia de Felipe IV, 1656.

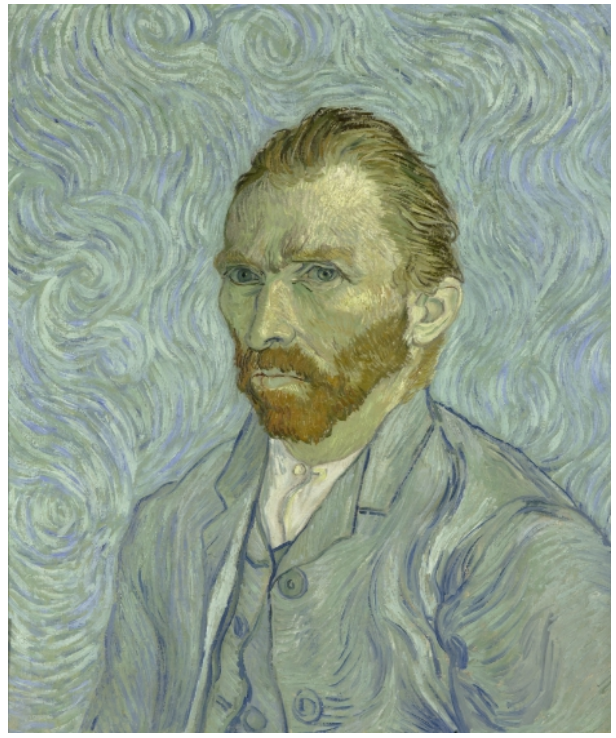

Imagen 2.7: Vincent van Gogh, Autorretrato, 1889.

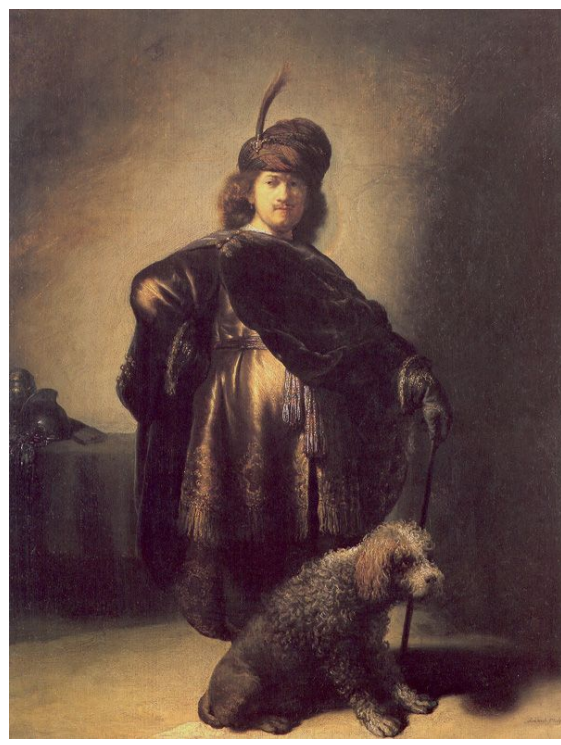

Imagen 2.6: Rembrandt Harmenszoon van Rijn, Autorretrato con atuendo oriental, 1631.

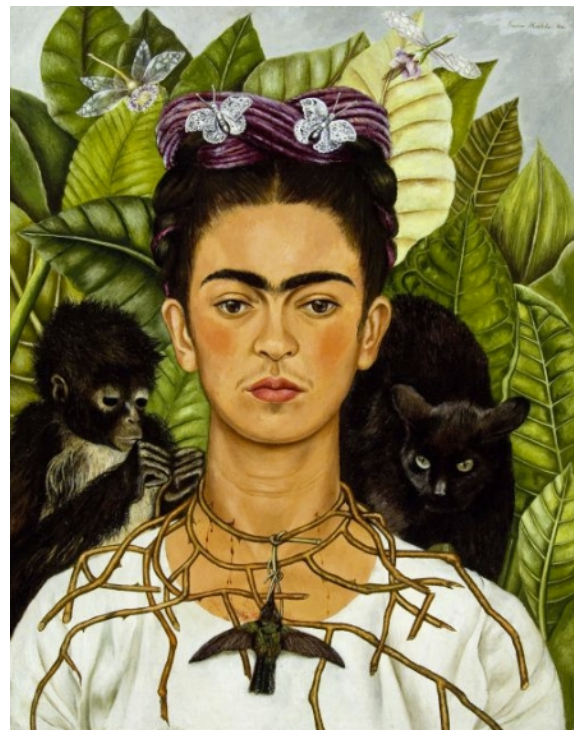

Imagen 2.8: Frida Kahlo, Autorretrato con collar de espinas, 1940. 
Ahora bien, pese a la irrupción e institucionalización de la fotografía como principal herramienta para la producción de imágenes en las sociedades modernas (también en el ámbito del retrato y del autorretrato), la pintura continuará abordando este último género a lo largo del siglo XX. De hecho, el autorretrato pictórico resultará en esta época de gran utilidad en los procesos de investigación artística por parte de los pintores de la vanguardia y de la postmodernidad ${ }^{18}$, tanto en los procesos plásticos como en los fotográficos, continuando la progresiva consolidación que este género (también tímidamente popularizado entre las masas gracias a la democratización de la fotografía durante el siglo pasado) iría ostentando a lo largo de los años:

"Al final del día mucho se puede elucubrar sobre el autorretrato, sus funciones, etapas y caminos. Tal vez hay un único punto de acuerdo claro: ineludiblemente todo autorretrato refleja la manera en la que su autor quiere ser visto por el mundo"19.

\subsection{Aproximación a la irrupción de la fotografía y a su democratización entre las masas.}

La invención, desarrollo, popularización, democratización e institucionalización de la fotografía supone una serie de hitos tan importantes en relación a la extensión y al crecimiento de la imagen ${ }^{20}$ solo comparable a lo que la invención de la imprenta había supuesto siglos antes para la difusión de la

18 GENARO, Noemí, El autorretrato fotográfico como herramienta educativa, Granada, Universidad de Granada, 2013, pág. 22. COLORADO, Óscar, op. cit., s/n. expresión icónica. ZUNZUNEGUI, Santos, Pensar la imagen, Madrid, Cátedra, 2010, pág. 131. 
palabra escrita ${ }^{21}$. Su apropiación por parte de las masas también sería, en cierta medida, inevitable.

"En su origen, la fotografía fue el resultado de la convergencia de la cámara oscura (óptica) y las emulsiones sensibles a la luz (química)”22, de hecho, "la fotografía se asienta en una serie de principios ópticos conocidos, al menos, desde Aristóteles”. En este sentido, cabe recordar que uno de sus componentes básicos, la cámara oscura, "se encuentra perfectamente descrito en los textos de Al-Hazan (siglo XI)" llegando a convertirse durante "el siglo XVI (véanse los casos de Leonardo o Giacomo della Porta) en aliado insustituible de los pintores y dibujantes". A su vez, "la inclusión de unas lentes en el orificio que permitía la entrada de la luz en la cámara oscura" posibilitaba "concentrar los rayos de luz y producía una imagen de mayor nitidez" ${ }^{23}$. También guardan relación con el desarrollo de las ópticas las llamadas "linternas mágicas" del siglo XVI ${ }^{24}$. En lo que se refiere al conocimiento de la acción luminosa sobre ciertas superficies sensibles, hemos encontrado también algunos ejemplos de notable antigüedad respecto a la invención de la fotografía:

“Alberto el Grande (1139-1238) conocía el nitrato de plata y en 1694 el alemán Wilhelm Homberg presentó un informe en la Real Academia de Ciencias de París donde describía el ennegrecimiento de los huesos de buey que habían sido impregnados de ácido nítrico en una solución de plata” ${ }^{25}$.

BREA, José Luis, Las tres eras de la imagen, Madrid, Akal, 2010, pág. 37.

SÁNCHEZ-VIGIL, Juan Miguel, El documento fotográfico. Historia, usos, aplicaciones, Gijón, Trea, 2006, pág. 29.

ZUNZUNEGUI, Santos, op. cit., pág. 131.

RAMÍREZ, José Antonio, Medios de masas e historia del arte, Madrid, Cátedra, 1976, pág. 65. 
Un siglo más tarde, Thomas Wedgwood y John Herschel marcarán el camino hacia la fijación y reproducción de las imágenes obtenidas en la cámara oscura, mediante reacciones químicas en superficies debidamente preparadas ${ }^{26}$.

En 1826 el francés Nicéphore Niépce reunirá todos estos elementos en una brillante conjunción que, tras una década de experimentación, le transformarán en el "principal inventor" de la fotografía ${ }^{27}$. Dado que la luz solar es la que produce la imagen, llamó al proceso heliografía. El término fotografía, sin embargo, podemos atribuirlo a Hercules Florence, quien "en 1832 obtuvo fotografías y realizó copias por contacto y en sus notas denominó al proceso photographie, mucho antes de que Henri Fox Talbot utilizara la palabra photography" ${ }^{28}$.

Muy poco tiempo después, en 1837, el también francés Louis-JacquesMandé Daguerre inventó un tipo de cámara fotográfica, aplicando todos los descubrimientos de Niépce. Dos años después de la muerte de este, Daguerre descubrió que una imagen casi invisible (o latente) podría hacerse aparecer (o revelarse) con vapor de mercurio, reduciéndose así el tiempo de exposición de ocho horas como mínimo a veinte o treinta minutos. Pero no fue hasta mayo de 1837 cuando encontró un medio para fijar las imágenes con una solución de sal común ${ }^{29}$. Desarrolló así la primera placa fotográfica: el daguerrotipo, que se publicitó como el "espejo que recuerda". El primer sistema que comercializó a partir de 1839 tuvo un enorme éxito hasta 1855. "Los daguerrotipos daban una visión muy precisa y fueron tratados como objetos preciosos. Los retratos fueron

26 ZUNZUNEGUI, Santos, op. cit., pág. 131.

27 BATCHEN, Geoffrey, Arder en deseos. La concepción de la fotografía, Barcelona, Gustavo Gili, 2004, pág. 30.

28 SÁNCHEZ-VIGIL, Juan Miguel, op. cit., pág. 31.

29 GERNSHEIM, Alison y GERNSHEIM, Helmut, Historia gráfica de la fotografía, Barcelona, Omega, 1967, pág. 22. 
muy apreciados y se multiplicaron con rápidez" ${ }^{30}$. Daguerre fue, por lo tanto, quien disfrutó del honor y de los beneficios económicos de ser el primero en anunciar su procedimiento ante el público, inicialmente en la Académie des Sciences, el 7 de enero de 1839, y cinco meses después en la Chambre des Députés:

“Todos ustedes saben, y algunos de ustedes, caballeros, puede que hayan tenido ya la oportunidad de convencerse de que, después de quince años de difícil y perseverante trabajo, el señor Daguerre ha descubierto al fin un procedimiento para fijar los distintos objetos reflejados en una cámara oscura [...] El método del señor Daguerre es de su propia invención, y se diferencia del de su predecesor tanto en su procedimiento como en sus efectos" ${ }^{31}$.

Casi simultáneamente a las experiencias de Niépce y de Daguerre tuvieron lugar los trabajos de William Henry Fox Talbot, un matemático y filólogo británico a quien muchos atribuyen realmente la paternidad de la fotografía.

"Desde el punto de vista de los resultados inmediatos los trabajos de Talbot son menos brillantes que los de Daguerre pero este descubrimento y el de la imagen latente, efectuado en septiembre de 1840, van a traer consecuencias de más largo alcance: el negativo permite repetir la misma imagen cuantas veces se desee; la imagen latente (con la que se reduce el tiempo de exposición), y la utilización del papel hacen factible abaratar la fotografía" ${ }^{2}$.

Sin embargo, la cámara inventada por Fox Talbot en 1839 si que fue técnicamente superior a la de Daguerre.

COLLE, Raymond, "La revolución de la fonofotografía. Teléfonos con cámara y redes sociales", en Revista mediterránea de momunicación, $\mathrm{n}^{0}$ 4, 2013, págs. 7-9.

RAMÍREZ, José Antonio, op. cit., pág. 70. 
“Tan solo 30 años después de su invención, como un artilugio de lujo para la élite, la fotografía ya estaba siendo utilizada en los archivos policiales, en los informes de guerra, en los reconocimientos militares, en la pornografía, en la documentación enciclopédica, en los álbumes familiares, en postales, en los estudios antropológicos [...], en ciertos sondeos [...], efectos estéticos, periodismo y retrato formal" ${ }^{33}$.

La historia de la fotografía, y su desarrollo hasta llegar a nuestra era electrónico-digital, fue también la historia de sus soportes. Durante el siglo XIX y desde su invención, estos fueron de lo más variopinto ${ }^{34}$. La llegada de la película y el papel, más propios del siglo $\mathrm{XX}$, es lo que permitiría, finalmente, su ágil democratización entre las masas, así como el surgimiento de la fotografía de aficionado, y su integración en la casi totalidad de las facetas de la vida de multitud de sociedades, convirtiendo la misma en el primer objeto postindustrial $^{35}$.

Es probable que uno de los episodios que más aceleró esta sorpresiva democratización de un objeto que había sido complejo, científico y exlusivo hasta principios del siglo XX fuese la presentación por parte de George Eastman de la cámara Kodak número 1, en 1888. El lema para su promoción fue memorable a la vez que preciso, en un intento de resumir las virtudes que suponía eliminar la mayoría de trabas técnicas en la toma fotográfica para acercar esta a las masas: "Usted apriete el botón, nosotros hacemos el resto" ${ }^{36}$.

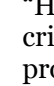

prog progresivamente sustituidos por el poliéster para evitar los efectos de su composición química. [...] Los soportes y emulsiones desarrollados durante el siglo XIX fueron daguerrotipos (Louis-Jacques Daguerre, 1839), dibujos fotogénicos, calotipos y papel salado (Henri Fox Talbot, 1839, 1841, 1850), vidrio a la albúmina (Niépce de Saint Victor, 1847), papel a la albúmina (Blanquart-Evrard, 1850), colodión húmedo (Scott Archer, 1851), ambrotipo (Cutting, 1852), ferrotipo (Hamilton Smith, 1856), placa seca de gelatina (Leach Maddox, 1871), papeles al colodiocloruro de plata (Simpson, 1885), papeles al gelatinocloruro de plata (Abney, 1882), papel al gelatinobromuro de plata (Mawdsley, 1874), película de nitrato de celulosa (1880) y acetato de celulosa (1920). Se aplicaron después los soportes plásticos durante todo el siglo XX”. SÁNCHEZ-VIGIL, Juan Miguel, op. cit., págs. 25-26.

FLUSSER, Vilém, Una filosofía de la fotografía, Madrid, Síntesis, 2001, pág. 49.

SÁNCHEZ-VIGIL, Juan Miguel, op. cit., pág. 37. 
Este acto, y la extensa popularidad que adquirieron las cámaras Kodak y otros sucedáneos en las primeras décadas del siglo XX, fue lo que democratizó el hacer fotográfico por parte del gran público. No obstante, la adquisición de fotografías y el ansia de obtener el registro fotográfico o de imagen de la propia persona por parte de las masas también fue un hecho que se había popularizado décadas atrás. $\mathrm{Al}$ respecto, la moda de los perfiles y las siluetas (Imagen 2.9), por ejemplo, constituyó un popular ejercicio de registro mediante el retrato perfilado y recortado en un papel negro acharolado, principalmente practicado entre clases pudientes y después entre las populares de la sociedad francesa y británica.

En relación a esta técnica cada vez más extendida, Gilles-Louis Chrétien inventó en 1786 el physionotrace (fisionotrazo), combinando la sombra, una plancha de cobre y el aguatinta, un artilugio que actuó como precursor de la fotografía ${ }^{37}$.

También, una vez inventada la fotografía, y a los pocos años de su perfeccionamiento, el despliegue de estudios fotográficos a pie de calle acercó a las clases pudientes y también al resto de ciudadanos la posibilidad de obtener una copia de su persona representada en una imagen mediante el ejercicio del retrato fotográfico ${ }^{38}$.

A mediados del siglo XIX, la posibilidad de la instantánea que suponía el nuevo procedimiento del colodión húmedo, unido al coste muy inferior en relación al daguerrotipo y al advenimiento de la imagen multiplicable, iban a abrir el paso definitivo al retrato fotográfico ${ }^{39}$, alcanzando este a todas las capas de la sociedad y democratizando su adquisición sobre todo mediante el objeto 
"tarjeta de visita”40 (Imagen 2.10), que también se popularizó rápidamente entre las masas $^{41}$, concediendo al cuerpo una vida distinta a la de su presencia física puntual $^{42}$.

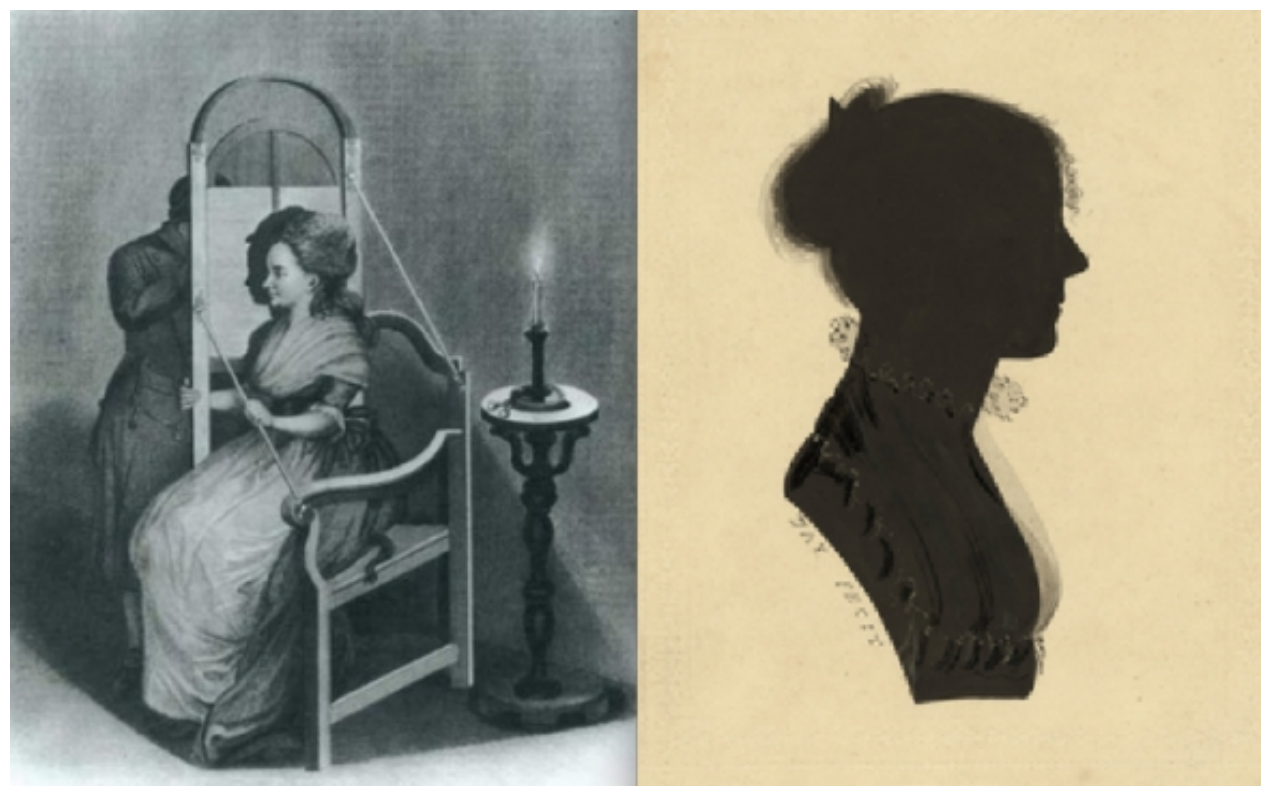

Imagen 2.9: Escenificación y ejemplo del desarrollo de una silueta en el siglo XVIII.

40 "Patentada en 1854 por el fotógrafo francés André A. E. Disdéri, su proceso de fabricación incluía una cámara de varias lentes y una película que se desplazaba para producir de seis a doce copias en papel de albúmina a partir de una sola placa negativa de vidrio. Medían 2,5 por 3,5 pulgadas y se montaban en cartulina gruesa. Los fotógrafos ahora podían hacer hasta doce copias de una sola vez, el precio de los retratos bajó notoriamente y estos se situaron al alcance de la mayoría de la gente. De hecho, la tarjeta de visita fue una de las mercaderías comercializada con mayor amplitud en el siglo XIX y ayudó a definir y a registrar a las «masas» como una entidad”. PULTZ, John, La fotografía y el cuerpo, Madrid, Akal, 2003, pág. 16.

En estos años, además, "el retrato se vulgariza lo suficiente para permitir al proletariado la posesión de su propia imagen”. RAMÍREZ, José Antonio, op. cit., pág. 82.

PULTZ, John, op. cit., pág. 17. 

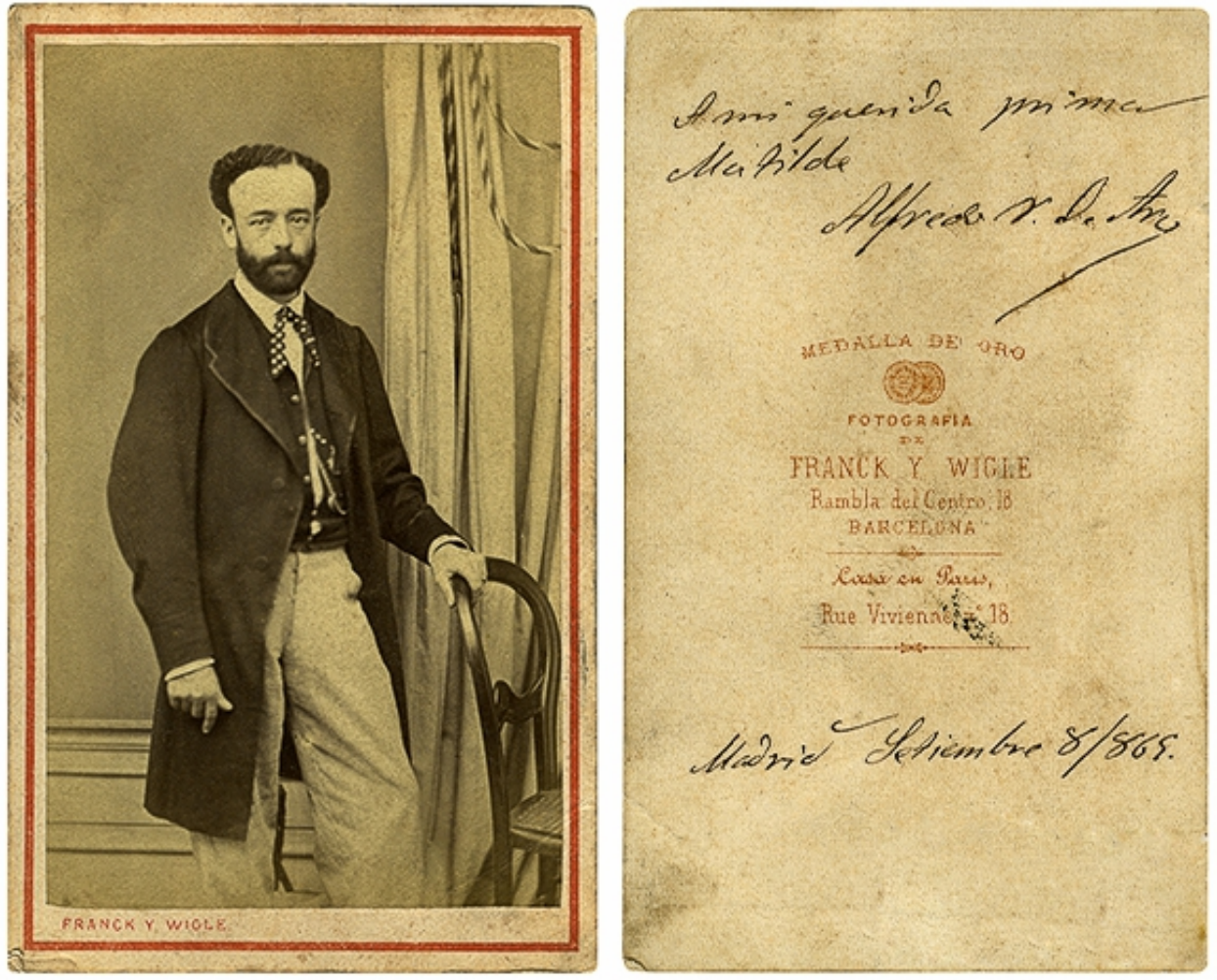

Imagen 2.10: Ejemplo de tarjeta de visita (anverso y reverso) de 1865 realizada por el estudio fotográfico de Barcelona Franck y Wigle. "La masificación de las cartes de visite hizo hablar a los sociólogos del arte de una democratización de la imagen” 43 .

\section{Pero volvamos al detonante que unificó fotografía y masas, un hecho que} se produjo no mediante el consumo del producto fotográfico ${ }^{44}$, sino a través de la

43 FONTCUBERTA, Joan (Ed.), Estética fotográfica: una selección de textos, Barcelona, Gustavo Gili, 2003, pág. 23.

44 Recordemos que, hasta entonces, dicho producto dependía de los estudios fotográficos. Este privilegio en la producción de retratos pronto estaría en manos de todos: "El retrato fue la base de la fotografía en sus inicios y con las galerías nació una nueva industria que reactivó la economía al generar puestos de trabajo. En 1849 se hicieron más de cien mil daguerrotipos en París, y a mediados del siglo XIX, gracias al modelo carte de visite inventado por Disdèri, los retratos fotográficos inundaron todos los foros sociales. En 1861 Londres contaba con 200 estudios, un año después se produjeron en Gran Bretaña más de cinco millones de fotografías y en las galerías de prestigio trabajaban más de cincuenta empleados de media. En Estados Unidos funcionaban 72.00o estudios en el año 1878, con una producción de tres millones de retratos tan solo en Nueva York”. SÁNCHEZ-VIGIL, Juan Miguel, op. cit., págs. 84-85. 
autogestión en la producción fotográfica protagonizada por las cámaras Kodak. Ya hemos señalado que la primera cámara comercializada con intención de ser masiva fue la cámara de cien vistas de Kodak, lanzada en 1888:

\begin{abstract}
“Costaba 25 dólares y una vez tomadas las fotos, debía enviarse por correo la cámara completa a la fábrica de Kodak en Estados Unidos, en donde ellos, por 10 dólares, sacaban el rollo, revelaban las fotos y las devolvían junto con la cámara, de nuevo cargada para otras cien vistas. De esta forma, los usuarios se liberaban del sucio proceso del laboratorio" ${ }^{45}$.
\end{abstract}

Parece que los cuatro pilares del negocio de Kodak fueron centrarse en el cliente, producir en masa a bajo costo, tener una distribución mundial y disponer de una publicidad amplia y agresiva; cuatro pilares que hoy en día podríamos atribuir también a las empresas distribuidoras de los millones de contenidos audiovisuales que Internet genera en plataformas como, por ejemplo, Youtube o Netflix. "El dominio de Kodak en la industria de la fotografía se extendió a lo largo del siglo XX, manteniéndose a la cabeza en ventas y proporcionando a sus clientes diversas opciones para guardar sus recuerdos" ${ }^{* 6}$.

La fotografía se iba a convertir así en una tecnología de consumo, adquiriendo una nueva dimensión social en un entorno que estaría a lo largo del siglo marcado por una serie de cambios tecnológicos y sociales como fueron la aparición del automóvil o el desarrollo del turismo.

\footnotetext{
"La fotografía era un producto tecnológico simple y fiable, y a la postre deseable, al que podían acceder amplias capas de la población, especialmente las familias de clase media, como instrumento para captar y guardar aquellos acontecimientos domésticos y de ocio más significativos" ${ }^{47}$.
}

45 MORENO, Adriana Marcela, "Fotografía amateur: la construcción cultural de un rol", en Comunicación, $\mathrm{n}^{0} 34,2016$, pág. 31.

46 Ídem.

47 MIRA, Enric, "Tras la crisis de la cultura Kodak. Un análisis de la funcionalidad de la fotografía personal en la Web 2.0", en Historia y comunicación social, vol. 19, $\mathrm{n}^{\circ} 2$ (Ejemplar dedicado a: La 
Así, en el discurso que introdujo Kodak, la fotografía ya no era técnica, artística e intelectual, sino que pasó a ser una actividad que todos debíamos y podíamos practicar: todos podíamos ser fotógrafos. "En su publicidad, Kodak hizo mucho énfasis en incluir a las mujeres y promover en ellas la fotografía como una actividad legítima y necesaria" ${ }^{48}$.

Durante las primeras décadas del siglo $\mathrm{XX}$, las cámaras seguirían reduciendo su tamaño y su coste, aumentando también la facilidad para revelar los rollos de película (primero en blanco y negro, posteriormente en color ${ }^{49}$ ) y materializar económicamente las imágenes en papel.

"Gracias a los avances tecnológicos para la simplificación de estas máquinas, que en muchos casos se hicieron portátiles, fue posible para más personas tener acceso a actividades en un principio destinadas solo a los profesionales. Este proceso de reducción de costos y tamaños, que permite el uso de los aparatos para producir imágenes por un mayor número de personas, puede rastrearse claramente en la historia de la fotografía" ${ }^{\circ}$.

Ya en 1925 era común encontrar en los periódicos algunos anuncios destinados a elogiar algún nuevo aparato fotográfico, como por ejemplo el de la cámara Ermanox:

comunicación en la profesión y en la universidad de hoy), 2014, pág. 747.

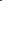

"En 1914 Kodak puso a la venta la película l

(a) penta la película Eastman Portrait con soporte plástico que sustituiría definitivamente al cristal, aunque los profesionales continuaron usando el vidrio hasta la década de los treinta. En esta década nació la fotografía documental, con antecedentes a finales del siglo XIX, y se desvaneció al término de la Segunda Guerra Mundial cuando sus principios fueron absorbidos por el fotoperiodismo". Asimismo, cabe señalar que "la investigación en color continuó su desarrollo tras la interrupción de la Primera Guerra Mundial, y en 1927 salió al mercado la primera película pancromática sensible a todos los colores. En 1935, ya con las nuevas cámaras de 35 milímetros en pleno apogeo (Leica y Conta), se presentó la película Kodachrome para cine inventada por Leopold Mannes y Leopold Godowsky, promocionada por la Eastman Kodak Company”. SÁNCHEZ-VIGIL, Juan Miguel, op. cit., pág. 45. 
"Fotografías de noche y de interior sin flash. Saque fotos usted mismo en el teatro durante la representación. Exposiciones de corta duración o instantáneas. Con la cámara Ermanox, pequeña, de fácil manejo y poco visible" ${ }^{51}$.

El fenómeno del consumo masivo de las tecnologías de la imagen se irá desarrollando en las siguientes décadas y a lo largo del siglo XX con la renovación constante del mercado a través de innovaciones técnicas que atendían a una demanda de usuarios en crecimiento. La fotografía en color, la Polaroid de revelado instantáneo ${ }^{52}$ o las cámaras de cine de película de $8 \mathrm{~mm}$ son algunos ejemplos de hitos tecnológicos relacionados con la fotografía, cuyo destino final fue la obligada inclusión de cada uno de estos productos en cada hogar de clase media de las sociedades más modernas ${ }^{53}$.

En 1963, Kodak volvía a sorprender con una nueva gama de aparatos: la Instamatic (Imagen 2.11).

"La mayor parte de los aficionados para quienes la foto no es ante todo más que un medio de conservar un recuerdo en imágenes, tanto si se trata de familiares o amigos como de lugares visitados adoptaron esos aparatos, fáciles de manipular y baratos" ${ }^{54}$.

Podemos afirmar que en la década de los años 60 y 70 del siglo pasado la fotografía de aficionado o familiar ya se encontraba fuertemente institucionalizada, como práctica de ocio y de conservación de instantes vividos, cuando se presentó el proceso Polaroid patentado por el físico Edwin Robert Land en la ciudad de Boston (Massachussetts), mediante el cual se incluía en una cámara especial una cápsula para revelado inmediato del negativo, con la que se producía una copia positiva en blanco y negro. "Este método revolucionó los campos en los que era necesario realizar pruebas (publicidad, propaganda, moda, etcétera). Un año más tarde, Land presentó la Model 95 Land Camera, comercializada en la década de los cincuenta, y en 1954 se realizaron las primeras pruebas en color que dieron lugar al método Polacolor, lanzado en 1963 y posteriormente en 1975 con el nombre de Polaroid”. SÁNCHEZ-VIGIL, Juan Miguel, op. cit., pág. 50.

FREUND, Gisèle, op. cit., pág. 178. 
gracias a lo fácil que resultaba su uso por parte del gran público. En la década de 1960 más de dos tercios de los fotógrafos eran aficionados que practicaban la fotografía eventualmente, en reuniones familiares o de amigos, bien durante las vacaciones o durante los viajes turísticos. En los años 1970 la fotografía familiar dictaba la principal producción de una industria que no daba abasto ${ }^{55}$.

"Existe una estrecha relación entre la presencia de niños en el hogar y la posesión de una cámara y que esta suele ser propiedad indivisa del grupo familiar, vemos que la práctica fotográfica existe $-\mathrm{y}$ subsiste- en la mayoría de los casos, por su función familiar o, mejor dicho, por la función que le atribuye el grupo familiar, como pueda ser solemnizar y eternizar los grandes momentos de la vida y de la familia, y reforzar, en suma, la integración del grupo reafirmando el sentimiento que tiene de sí mismo y de su unidad" ${ }^{6}$.

El acto fotográfico en estas circunstancias se escenificaba como un acto solemne, reservado a ocasiones privilegiadas ${ }^{57}$, una práctica familiar puramente ritual $^{58}$ que sustituía la incertidumbre fugaz de las impresiones subjetivas por la certeza definitiva de una imagen objetiva, una imagen cuyo objeto producido, la fotografía en papel, era almacenada en un álbum familiar, como si fuera un trofeo ${ }^{59}$.

"La fotografía ha jugado un papel estratégico en la unión de la familia, el consumo y el ocio en la esfera privada [...] un lugar excepcional para la articulación de la identidad. Concretamente, la fotografía ha sido capaz de transmitir la experiencia privada, desde

"En 1972 se calculaban solo en Norteamérica más de 42 millones de aficionados que habían tirado la increíble cantidad de más de 5 mil millones de fotos. En Francia, la cifra de aparatos fotográficos en activo era el mismo año de 10 millones de unidades, es decir, que un francés de cada cinco y medio es fotógrafo". Ídem. BOURDIEU, Pierre, Un arte medio, Barcelona, Gustavo Gili, 2003, pág. 57.

FONTCUBERTA, Joan, La cámara de Pandora. La fotografi@ después de la fotografía, Barcelona, Gustavo Gili, 2010, pág. 28. GÓMEZ-CRUZ, Edgar y ARDÈVOL, Elisenda, "Cuerpo privado, imagen pública: el autorretrato en la práctica de la fotografía digital”, en Revista de dialectología y tradiciones populares, vol. $67, \mathrm{n}^{0} 1$, 2012, pág. 184. 
el plano de lo cotidiano e insignificante a un mundo de imágenes y momentos idealizados alrededor de los cuales se pueden formar identidades significativas. En mi opinión, este desplazamiento de lo cotidiano a lo trascendente ha estado históricamente ligado a la noción del tiempo libre, sobre todo a lo largo del último siglo"6o.

Así pues, la fotografía de turistas ${ }^{61}$ (Imagen 2.12), compuesta por un grupo frente a un monumento o nada más bajar del avión, y realizada directamente por un miembro de la expedición, o mediante un trípode, o por un extraño al que se le solicita la toma, acabará conviertiéndose en un cliché icónico antes de la llegada de la fotografía digital, al igual que sucederá con la reconocida iconografía del selfie (como veremos a lo largo de los siguientes capítulos). También el álbum familiar, receptáculo que guardará estas fotos grupales de turistas junto con retratos e instantáneas (imágenes de ritos de continuación familiar como las bodas) será el objeto común en todo hogar, en el que la relación entre las fotografías y la memoria fundirá la identidad individual y la colectiva en un tiempo narrativo familiar ${ }^{62}$.

"El álbum familiar expresa la verdad del recuerdo social. [...] Las imágenes del pasado, guardadas en un orden cronológico, el «orden de las razones» de la memoria social, evocan y transmiten el recuerdo de sucesos que merecen ser conservados porque el grupo ve un factor de unificación en los monumentos de su unidad pasada o, lo que viene a ser lo mismo, porque toma de su pasado la confirmación de su

LISTER, Martin (Comp.), La imagen fotográfica en la cultura digital, Barcelona, Paidós Ibérica, 1997. págs. $178-179$.

61 En relación a la fotografías realizadas por los turistas, al igual que en todas las fotografías grupales, dice Bourdieu: "En la mayor parte de las fotografías de grupo, los sujetos se presentan apretados unos junto a los otros (siempre en el centro de la imagen) y, a menudo, abrazados. Las miradas convergen hacia el objetivo de modo que toda la imagen indica lo que es su centro ausente. Cuando se trata de una pareja, los sujetos se cogen por la cintura en una pose completamente convencional”. BOURDIEU, Pierre, op. cit., pág. 143. Se trata de uno de esos momentos en los que se forjaba la institucionalización del acto de posar que, a su vez, es definido por Barthes así: "Entonces, cuando me siento observado por el objetivo, todo cambia: me constituyo en el acto de "posar», me fabrico instantáneamente otro cuerpo, me transformo por adelantado en imagen”. BARTHES, Roland, La cámara lúcida, Barcelona, Paidós Ibérica, 2009, pág. 31. 
unidad presente. Por ello, nada es más decoroso, más tranquilizante y edificante que un álbum de familia" ${ }^{3}$.

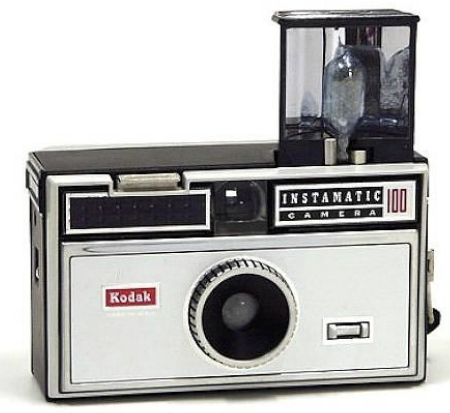

Imagen 2.11: Kodak modelo Instamatic de 1963.

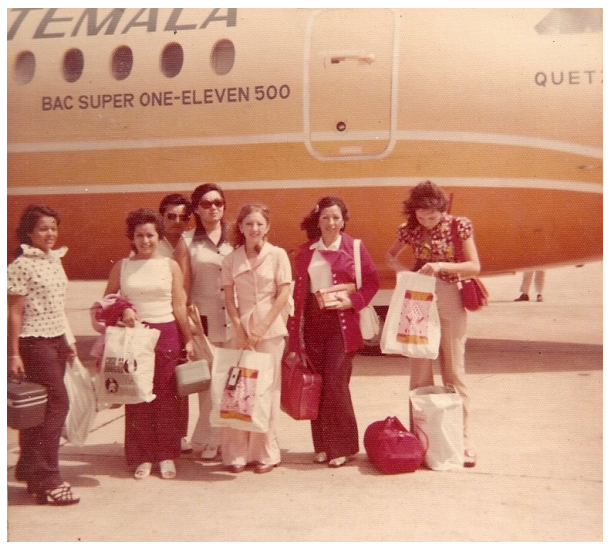

Imagen 2.12: Foto de turistas realizada durante la década de los años 1960.

La instantánea y el álbum familiar, elaborados sin recurrir a los estudios fotográficos callejeros (que seguirán existiendo, pero en una proporción menor respecto a décadas anteriores), tendrán que ver con un naciente DIY (Do It Yourself - Hazlo tú mismo) para la fotografía, que irá acentuándose hasta los años noventa del siglo pasado, poco antes de la llegada de la tecnología digital a las esferas de lo fotográfico ${ }^{64}$. "Repasando el álbum tenemos la sensación de que las fotografías fueron tomadas para que la realidad fuese pasado" ${ }^{65}$. Respecto a los que ya no están presentes en el mundo de los vivos, la fotografía contenida en estos álbumes ya no será elegida como una representación del desaparecido, sino como un verdadero sustituto de su ausencia, teniendo en cuenta su conjunto de 
imágenes. "Es como si una parte de la sustancia del desaparecido se hubiera conservado por arte de magia en su imagen" ${ }^{\circ 6}$.

Durante su auge, los álbumes harán del mundo un lugar donde el cuerpo de la famlia, los amigos, las celebridades o los personajes políticos parecerán iguales. Esta inclusión democrática tenía sin embargo sus límites: los álbumes no incluían a la gente marginada o excluida de la vida de la propia clase media, como los pobres y los enfermos ${ }^{67}$.

En los años 80 y 90 del siglo pasado, por tanto, la fotografía familiar, turística, amateur y de aficionado (grupos generalmente superpuestos en una única actitud), se consideraba ya el eje principal de la producción fotográfica mundial en cuanto a volumen de creación. Asimismo, sus prácticas, se encontraban arraigadas en una amplia clase media (y también en otros estratos superiores e inferiores económicamente hablando). Estas prácticas, fruto de la progresiva democratización de un proceso científico y mecánico complejo como era la máquina fotográfica y la película química, fácilmente utilizable ahora por parte de un gran público que por fin podía adueñarse no solo de la imagen sino de la capacidad de producirla ${ }^{68}$, allanó el camino hacia el escenario que pronto irrumpiría (como veremos transversalmente en sucesivos capítulos) en la escena fotográfica amateur: la fotografía digital también adoptada en el hogar.

No obstante, aunque la fotografía digital integrada en el hogar trajo una extensa serie de libertades para los usuarios amateurs que registraban de manera autónoma los acontecimientos de su entorno, la privacidad aún no sería del todo plena (como ocurriría con la fotografía digital desde los primeros años de nuestro siglo XXI) mientras no se eliminara el intermediario del laboratorio

66 TISSERON, Serge, El misterio de la cámara lúcida. Fotografía e inconsciente, Salamanca, Ediciones Universidad de Salamanca, 2000, pág. 60.

67 PULTZ, John, op. cit., pág. 18. 
con sus trabajadores ajenos a esas familias, unos trabajadores que eran los encargados de revelar las películas y ampliarlas en papel mediante su propia manufactura o el manejo de máquinas (ambos ejercicios en ningún caso ajenos a la intromisión o al cotilleo). Sin embargo, sí que existieron modelos de cámara que aportaron esta plena libertad y privacidad propias de la tecnología digital como fueron (y volvemos a nombrarlas) las cámaras Polaroid. "El éxito inicial de la Polaroid se había fundamentado en un factor técnico obvio: la reducción de espera entre el momento de la toma y el momento de su plasmación visible" ${ }^{69}$. Efectivamente, las cámaras Polaroid introdujeron en el ámbito de la fotografía doméstica o privada este carácter lúdico o discreto que tan bien ha sabido heredar la fotografía digital. De la misma manera, era ese sistema intantáneo el que garantizaba, a su vez, la privacidad, adecuándose por tanto a cualquier situación de intimidad ${ }^{70}$.

"[...] las cámaras digitales terminaron sentenciando lo que tenía que haber sido la edad de oro de Polaroid, [...] No se trataba solo de la instantaneidad, sino también de otros factores tales como costes más reducidos, formatos menores, pesos más livianos, imágenes fáciles de transmitir y compartir. Desde luego estos factores técnicos tenían una gran importancia en el cambio de hábitos de los consumidores"71.

Debido a ello, entendemos que, no solo la cámara Polaroid, sino todas las imbricaciones aludidas entre fotografía y masas, imbricaciones que anteriormente habían contribuido a formar parte del carácter emancipatorio del siglo XX en el ámbito privado o grupal mediante la autogestión fotográfica (hechos que continuaban aliviando los deseos de posesión de la imagen propia que tanta importancia habían asumido en siglos precedentes), debido a ello, repetimos, todos estos hechos asumirán el papel de padrinos perfectos, como veremos en los siguientes capítulos de este estudio, para la fácil adopción de la 
fotografía digital a principios del actual siglo XXI en casi la totalidad de hogares de nuestras sociedades más desarrolladas, así como para su uso en las esferas privadas e íntimas por parte de los adolescentes habitantes de dichos hogares.

\subsection{Autorretratos fotográficos realizados por aficionados antes de la llegada de la fotografía digital.}

El autorretrato fotográfico no fue algo excesivamente popular entre las masas durante el siglo XX. Aquel individuo deseoso de ser representado en una fotografía siempre optó, o bien por el estudio fotográfico ${ }^{72}$, o bien por la ayuda de algún familiar o persona presente en el espacio en el que surgiera tal deseo. Es cierto, sin embargo, que la práctica del autorretrato fotográfico fue más prolífica entre artistas, investigadores de la imagen y fotógrafos de profesión:

\footnotetext{
"Es el autorretrato, a partir de la aparición de la fotografía, el que hace que el artista, en este caso el fotógrafo, comience a ver la cámara fotográfica como un medio recurrente para el estudio del Yo, de aquello que se vislumbra más allá de la propia apariencia física. En el caso de las artistas, la fotografía se convierte desde su inicio en vehículo de liberación y autoafirmación, en constante desarrollo, demostrando su evolución en el tiempo a través de sus obras"73.
}

Existe una buena cantidad de artistas que, casi desde los orígenes de la fotografías y hasta bien entrados los años 1990, optaron por el autorretrato fotográfico como medio de expresión, de extensión del discurso personal o de exploración del yo. Un posible despliegue y análisis profundo en torno a estas fi-

72 GERNSHEIM, Alison y GERNSHEIM, Helmut, op. cit., pág. 8.

73 ROMERO, Irene, op. cit., pág. 39. 
guras excede los objetivos e intenciones de este estudio, centrado básicamente en el autorretrato actual practicado por las masas populares. No obstante, nos gustaría destacar brevemente cuatro figuras de técnicos o artistas para nosotros relevantes en la historia del autorretrato fotográfico.

El primero del que tenemos constancia se trata de un autorretrato realizado por Nadar en 1865 a bordo del globo aerostático Le Géant que él mismo había construido ${ }^{74}$ (Imagen 2.13). Pese a estos tímidos inicios, los artistas fotógrafos destacarán por medio de sus autorretratos durante la segunda mitad del siglo XX, bajo figuras como la joven Francesca Woodman, que de 1972 a 1980 creó más de 10.000 negativos de los cuales produjo unas 800 ampliaciones, dejando una impronta singular en sus autorretratos deambulantes entre la ausencia y la presencia ${ }^{75}$ (Imagen 2.14); o como la conocida Cindy Sherman, que se dio a conocer poco después en la década de 1980 con la serie Fotogramas sin título, en la que se representó a sí misma en una diversidad de poses y situaciones, siendo irreconocible de una escena a otra debido a sus cambios de maquillaje, peinado, pose y expresión facial en una evocación de escenas de viejos melodramas y películas de misterio de Hollywood ${ }^{76}$ (Imagen 2.15), escenas en las que utilizaba la escritura autobiográfica como un comentario alegórico a la identidad femenina ${ }^{77}$.

Por último, entre las obras del fotógrafo y teórico Jeff Wall deseamos destacar un complicado autorretrato (a nivel formal) en el que, por medio de un espejo, artista, modelo y cámara realizadora de la toma son presentados de manera compleja y equilibrada dentro de un cuadro-ventana en el que se compensan equilibradamente las figuras, se juega con el orden perspectivo

\footnotetext{
74 CID, Carlos, op. cit., pág. 201.

75 COLORADO, Óscar, op. cit., s/n.

76 FREELAND, Cynthia, Pero ¿esto es arte? Una introducción a la teoría del arte, Madrid, Cátedra, 2004, pág. 152.

77 GUASCH, Anna M., Autobiografías visuales, Madrid, Siruela, 2009, pág. 21.
} 
renacentista y se crea una compleja red mediante la dirección de las miradas ${ }^{78}$ (Imagen 2.16).

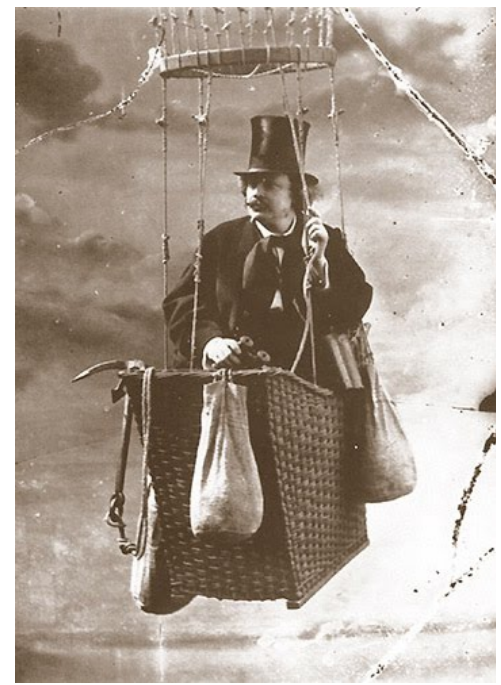

Imagen 2.13: Nadar, Autorretrato en globo, 1865.

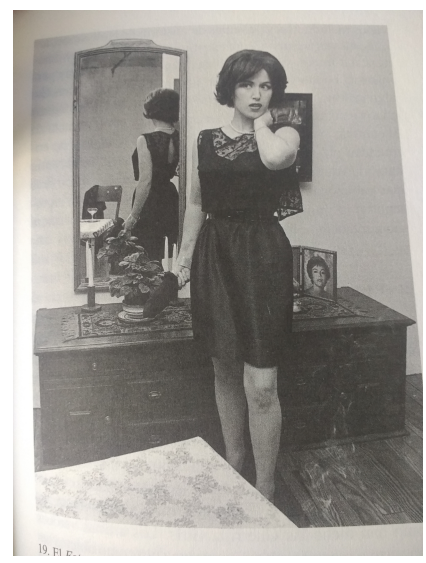

Imagen 2.15: Cindy Sherman, Fotograma sin título \#14, 1978.

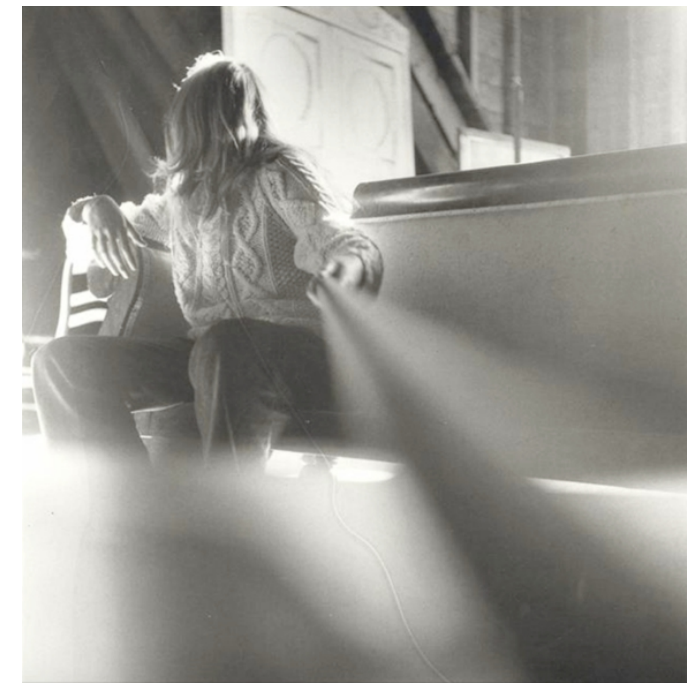

Imagen 2.14: Francesca Woodman, Self Portrait at Thirteen, 1972.

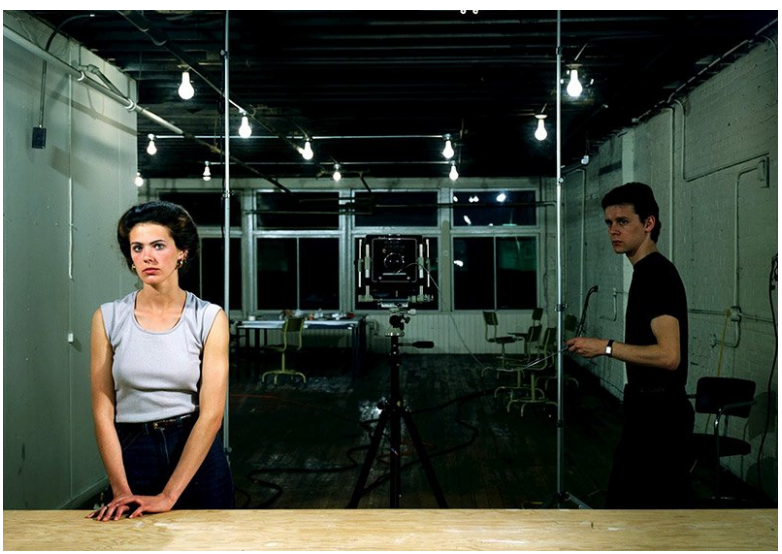

Imagen 2.16: Jeff Wall, Retrato para mujeres, 1979. Barcelona, Gustavo Gili, 2004, pág. 47. 
Pese a que, como hemos comentado, estos ejemplos de autorretrato abundan en la historia de la fotografía de una manera razonable si los enfocamos en sus esferas más artísticas, también hemos encontrado del lado de la práctica amateur, familiar o de aficionados otros tantos ejemplos más escondidos y que, sin embargo, tienen para nosotros una importancia mucho más justificada, dada la conexión que pueden tener (en todo caso como precedente puntual) respecto al objeto de estudio de este trabajo: el autorretrato fotográfico digital publicado en la red.

Para encontrar un primer ejemplo de este tipo de autorretratos realizados de manera privada o casual nos tenemos que remontar a 1839. Trece años después de que Nicéphore Niépce realizara la que es considerada como la primera fotografía conocida en la historia ${ }^{79}$, el empresario industrial estadounidense Robert Cornelius realizó el también más antiguo autorretrato conocido (Imagen 2.17) colocándose frente a su cámara y utilizando un rudimentario mecanismo de disparo remoto ${ }^{80}$.

$\mathrm{Al}$ margen de este ejemplo, la práctica del autorretrato fotográfico entre las masas no será algo que abundará en el siglo XIX por los motivos anteriormente expuestos. Sin embargo, a partir de la segunda década del siglo XX empezamos a encontrar ejemplos de todo tipo. En 1914, con Europa a punto de ser consumida por una larga y cruenta guerra y ante la proximidad de una revolución en su país, la duquesa Anastasia Nikolàyevna Románova de Rusia colocaba una Kodak Brownie frente al espejo de su habitación y se disponía, sin saberlo, a ser la primera adolescente (que tengamos constancia) en registrar su propia imagen en el espejo de su espacio privado (Imagen 2.18). Tenía trece $a_{n}{ }^{81}$. Este ejemplo, pese a su caracter anecdótico, no deja de ser un curioso

SOUGEZ, Marie-Loup, op. cit., pág. 37.

COLORADO, Óscar, op. cit., s/n.

CEBALLOS, Noel, "Breve historia cultural del selfie", 2014, disponible en: <http://www.revistagq. 
guiño al tipo de imágenes que las y los adolescentes realizarían de manera relativamente coincidente en sus habitaciones un siglo después con sus cámaras compactas digitales y smartphones. Anastasia le envió esta foto realizada a una amiga mediante el correo postal, acompañada de una carta en la que escribió: "He tomado esta foto de mí misma mirándome al espejo. Fue muy difícil, ya que mis manos estaban temblando" 82 .

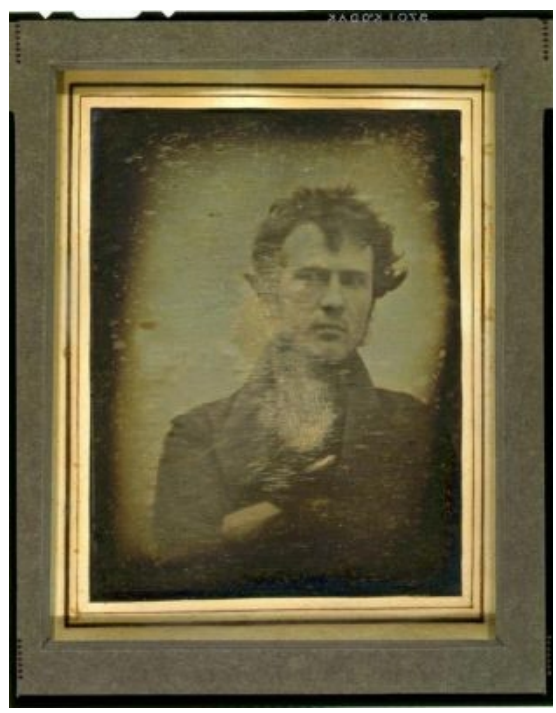

Imagen 2.17: Robert Cornelius, Autorretrato, 1839.

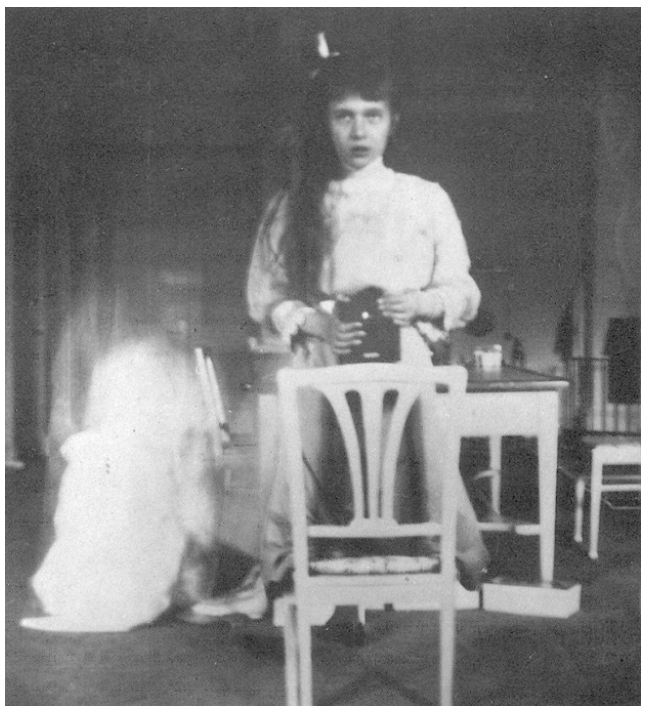

Imagen 2.18: Anastasia Nikolàyevna Románova, Autorretrato, 1914.

Cuatro años más tarde, el australiano Thomas Baker, realizaba un ejercicio de igual naturaleza (Imagen 2.19). Su autorretrato fue tomado en la soledad íntima de una habitación, sentado en la cama o en una silla y frente al espejo del tocador. Algunos de sus objetos personales reposaban sobre una mesa dispuesta entre el modelo y el espejo que refleja su imagen. Protagonistas en la

com/noticias/tecnologia/articulos/breve-historia-cultural-del-selfie/19701> [Fecha de consulta: 22 de julio de 2017].

82 Ídem. 
escena, y dentro de ese juego de planos que presenta esta imagen, se encuentran el fotógrafo y su cámara, que descansa sobre un trípode para evitar la trepidación en la toma. Con la mano sobre el dispositivo y accionando el disparador, Thomas posa con solemnidad ${ }^{83}$. En sus ojos no podemos distinguir si está mirando hacia la lente reflejada, y por tanto, hacia sus futuros espectadores o, si por contra, mira su propia figura en el espejo. Por otro lado, también hemos encontrado el ejemplo anónimo realizado en la siguiente década, durante los años 20 del siglo pasado (Imagen 2.20).

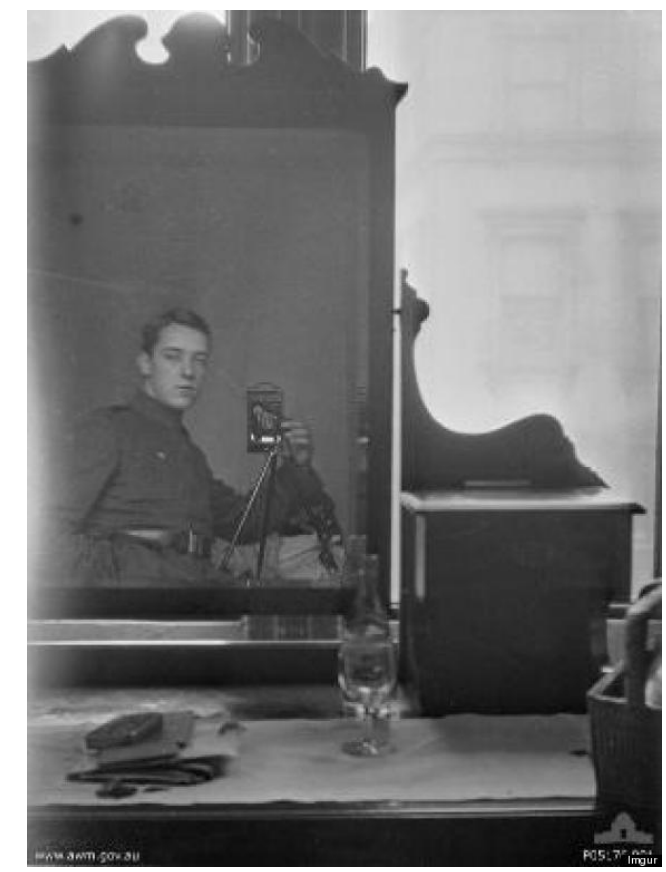

Imagen 2.19: Thomas Baker, Autorretrato, 1918.

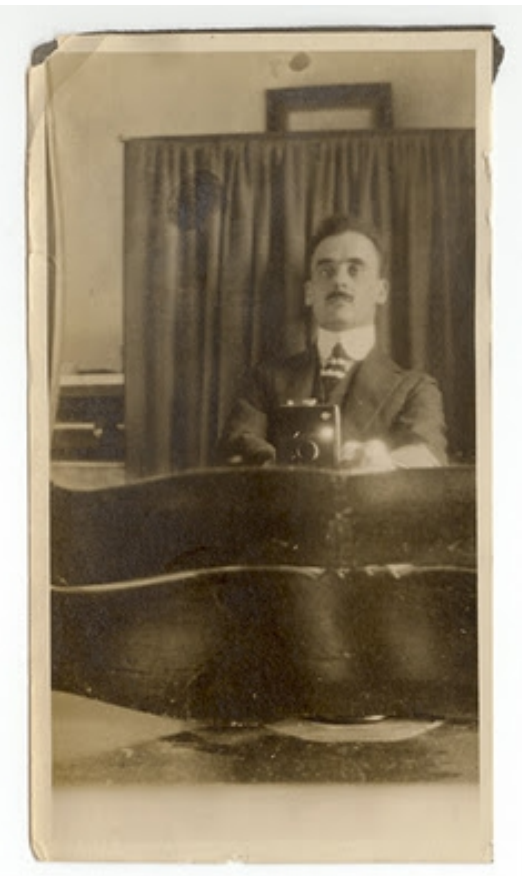

Imagen 2.20: Anónimo, Autorretrato, en torno a 1925.

83 También con los protocolos de ese ejercicio reflexivo y consciente que supone el autorretratarse: "Con el autorretrato fotográfico, el autor está implicado conscientemente en la construcción de la imagen. Se convierte en sujeto activo de la imagen, y, a la vez, en objeto. Prepara el escenario, el posicionamiento de la cámara, y, gracias al disparador automático, por último, se coloca delante de eesta. Tanto en el proceso como en la planificación o selección de la imagen, decide su carácter, qué mensaje pretende transmitir, controla el proceso”. GENARO, Noemí, op. cit., pág. 271. 
A principios de los años 50 del siglo XX la fotografía amateur ya se encontraba completamente democratizada e integrada entre las masas de las sociedades modernas capitalistas ${ }^{84}$. Existía una cámara en prácticamente cada hogar y sus usos e intenciones oscilaban entre lo lúdico y lo reverencial, tal y como hemos recogido en el punto anterior. Son en estos años de la década de 1950 cuando, dado el creciente número de usuarios aficionados, más empiezan a proliferar los autorretratos populares en Europa y Estados Unidos (Imágenes 2.21 y 2.22).

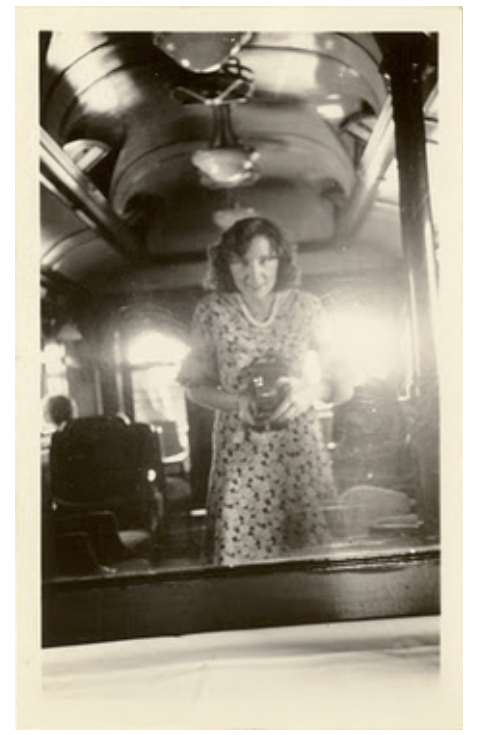

Imagen 2.21: Autorretrato realizado mediante el reflejo en un espejo por una aficionada en 1952.

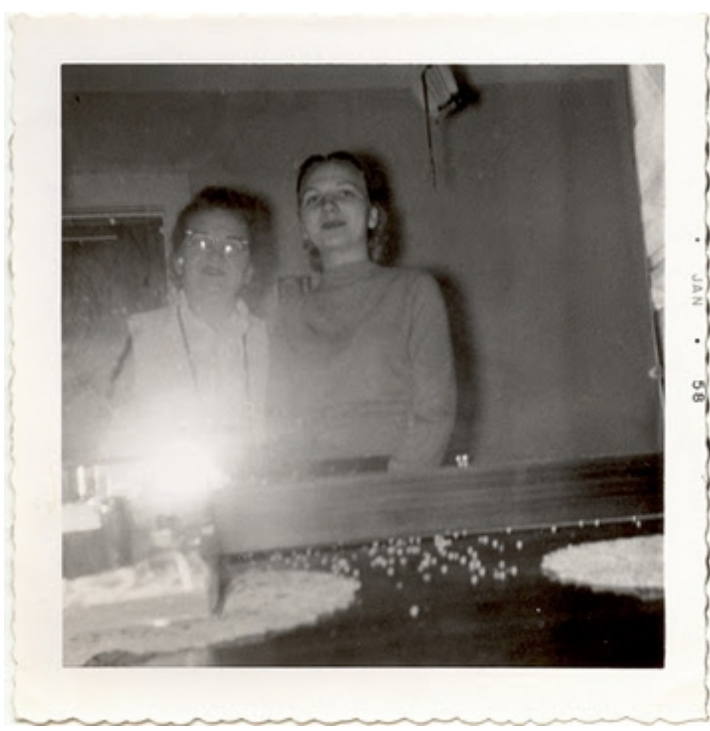

Imagen 2.22: Autorretrato realizado de la misma manera por una aficionada junto con una compañera. La fotografía se encuentra fechada en 1958.

También en esta época encontramos ejemplos de autorretratos algo más relevantes, como los realizados por Vivian Maier (Imagen 2.23). Esta mujer que $a$ priori podría ser considerada como una aficionada a la fotografía alcanzó 
notoriedad durante las décadas posteriores a su actividad gracias a una gran producción de fotografía callejera que realizó desde los años 1950 de manera personal. Vivian también produjo una gran cantidad de autorretratos, a menudo reflejos en las ventanas. Era una persona muy reservada que escondía sus fotografías con privacidad y discrección. Debido a eso:

“[...] su trabajo, que representa la vida urbana de Nueva York y Chicago en la segunda mitad del siglo XX, fue descubierto en 2007 y presentado al público por John Maloof, que fue curador de su trabajo y realizador de un documental sobre Vivian Maier, Buscando a Vivian Maier, que fue nominado al Oscar al Mejor Documental en 2015. La fama de Maier como una de las fotógrafas callejeras más famosas de Estados Unidos, desafortunadamente solo se hizo póstuma" ${ }^{85}$.

También a finales de la citada década de mediadios del siglo XX se realizó un autorretrato el autodenominado "fotógrafo popular" Bob Willoughby (junto con la actriz estadounidense e icono de la nouvelle vague francesa Jean Severg, durante la filmación de la película Saint Joan en 1957) (Imagen 2.24).

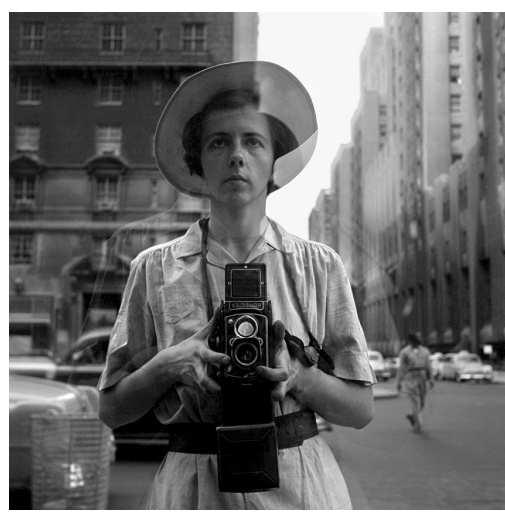

Imagen 2.23: Vivian Maier, Autorretrato, 1953.

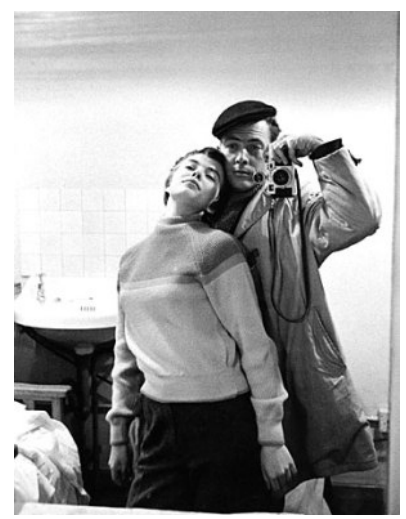

Imagen 2.24: Bob Willoughby, Autorretrato junto a Jean Severg, 1957.

85 TJINTJELAAR, Joel, “Top 10 Self Portraits by Famous Artists - and Not Only Photographers”, 2014, disponible en: <http://www.bwvision.com/top-10-self-portraits/> [Fecha de consulta: 20 de julio de $2017]$. 
Con todo, también en la década de los años 1960 continuamos constatando ejemplos de autogestión de la representación de la imagen propia mediante el autorretrato fotográfico amateur o casero, mayoritariamente entre adultos (Imagen 2.25) y en ocasiones entre jóvenes (Imagen 2.26), hecho que contrastará con los orígenes del autorretrato digital que, como veremos en el siguiente capítulo y sucesivos, estará casi totalmente protagonizado por el colectivo adolescente ${ }^{86}$.

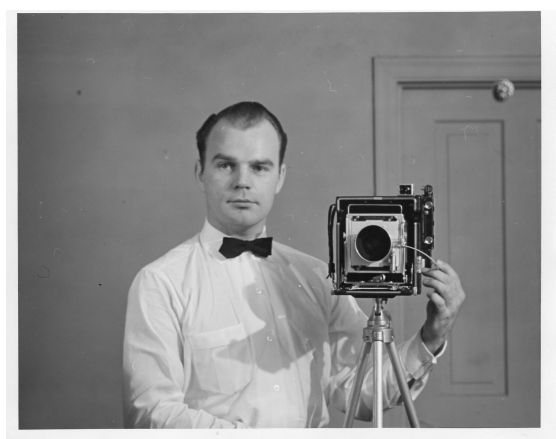

Imagen 2.25: Anónimo, Autorretrato, 1963.

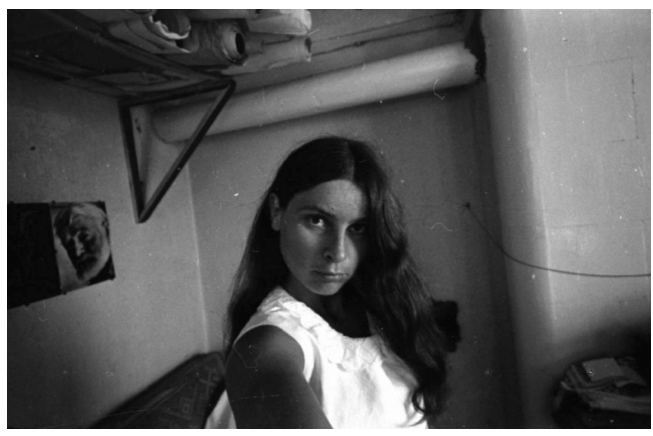

Imagen 2.26: Zenta Dzividzinska, Autorretrato, 1966.

Con la aparición de la fotografía en color y, como hemos visto, las ventajas de realizar este tipo de ejercicios con cámaras de revelado instantáneo y privado como fueron las populares cámaras Polaroid (Imagen 2.27), el autorretrato fotográfico realizado por las masas seguirá creciendo hasta finales de los años 1990, momento en el que la fotografía química cederá su legado y protagonismo a una incipiente y nueva tecnología fotográfica digital que, como veremos a continuación, cambiará drásticamente (en la mayoría de ámbitos aunque no en todos) la relación de las masas con todos los tipos de actitudes

86 TIFENTALE, Alise, "Why Every Self-portrait is Not a Selfie, but Every Selfie is a Photograph", 2016, disponible en: <http://www.alisetifentale.net/research-blog-at/2016/3/9/why-every-self-portrait-isnot-a-selfie-but-every-selfie-is-a-photograph > [Fecha de consulta: 22 de julio de 2017]. 
fotográficas, circunstancia que será especialmente explotada por los más jóvenes en las esferas íntimas mediante la exploración y publicación del yo generado con estas herramientas.

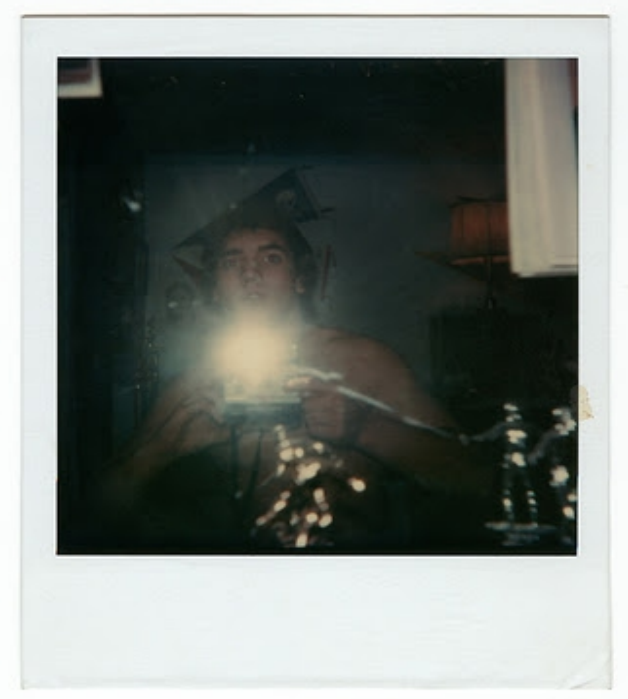

Imagen 2.27: Autorretrato fotográfico realizado mediante el reflejo en un espejo por un joven mediante una cámara Polaroid durante la última década del siglo pasado. 


\section{EL SELF SHOT: AUTORRETRATOS DIGITALES PUBLICADOS EN LA RED}

Un instante más y Alicia había pasado a través

del cristal y saltaba con ligereza dentro del cuarto del espejo.

LEWIS CARROLL, A través del espejo y lo que Alicia encontró allí, 1871.

A mediados de la década pasada nos asomamos en nuestras pantallas por un agujero dirigido hacia la red global, y las vimos allí. Abundaban, estaban por todas partes, y pudimos empezar a considerarlas como fotografías contemporáneas. Su marcada iconografía, fruto de los referentes y de la cultura visual de sus protagonistas, de su ingenio emancipado y de las pautas compositivas que invitaban a practicar los nuevos dispositivos de captura fotográfica digital, se podía aprenciar a simple vista. Por otro lado, su tendencia masiva, popular y finalmente institucionalizada ha podido resultar comprensible teniendo en cuenta su soporte altamente perceptible y global. Hablamos de los self shots: los autorretratos digitales publicados en la red, que surgieron como fruto de una práctica que sus autoras, generalmente jóvenes mujeres adolescentes, visibilizaron mediante su repetición. Unos autorretratos, a su vez, que a lo largo de más de diez años se han popularizado como ejercicio lúdico, 
testimonial, adictivo, erótico... y como objeto fotográfico, hasta propiciar la instaurada práctica del selfie y de toda la imaginería que ha generado (y ello junto con el beneficio industrial que ha producido).

No obstante, antes de analizar este fenómeno que es nuestro objeto de estudio conviene establecer ciertas pautas, nomenclaturas, definiciones y aclaraciones que nos ayuden a acotar un hecho que aún no tiene establecidas demasiadas bases teóricas por tratarse de una actividad relativamente reciente. Los términos que usaremos asociados a estas prácticas están construidos a partir de la jerga propia del que es su medio: Internet.

\subsection{Self shot. Definición y acotación terminológica.}

Basándonos en el material redactado desde el anonimato colectivo de Internet, el término self shot (utilizado principalmente durante los albores de la práctica que constituye nuestro objeto de estudio) quedaría definido como un "autorretrato fotográfico-digital publicado en la red de manera voluntaria o involuntaria”. Como podemos constatar en el gráfico que hemos diseñado (Imagen 3.1) y en el punto 3.1.1, este objeto fotográfico catalogable queda subdividido en diferentes subtipos: mirrorpic, selfie primitivo, selfie y otros tipos de self shots. Estas terminologías y subtipos atienden, no solo a una diferencia en el propio objeto-autorretrato-digital a nivel formal y situacional, sino también a la transformación sufrida, debido al paso de los años, en los tipos de máquinas fotográficas utilizados desde principios del siglo XXI hasta nuestros días. Además, debemos de ser conscientes en todo momento que estos términos no configuran ni tampoco responden a un dogma en ningún diccionario avalado por las academias, puesto que, salvo en casos contados (como veremos), sus 
nomenclaturas no han atravesado las puertas del ciberespacio. Asimismo, el uso que hemos dado a los términos que catalogan y diferencian estos tipos de prácticas públicas a través del ejercicio del autorretrato, están inspirados por la jerga de la red que, a su vez, los apunta o remite (casi siempre de manera coincidente a nuestra catalogación) a comentarios de espacios web y a buscadores de imágenes.

Por último, no debemos descuidar un importante aspecto en referencia a la apropiación de esta terminología poco ortodoxa que, en algunas ocasiones, está sometida a mutaciones y puede comportarse de manera líquida. Esta circunstancia ha quedado evidenciada mediante nuestras observaciones, por ejemplo, en el hecho de que, de unos años a esta parte, el término selfie se ha popularizado en demasía, mientras que el término self shot ha quedado en desuso. Dicho acontecimiento se refleja en la jerga preponderante en la red y en los textos académicos, además de en el lenguaje popular, que tan pronto olvida lo viejo como adopta lo nuevo. Estaríamos por tanto ante una colonización e invasión por parte del objeto (subtipo) anidado, hacia el estado-conjunto general que lo acoge $e^{1}$ : hoy en día se empieza a utilizar el término selfie para definir casi cualquier tipo de autorretrato fotográfico, cuando en realidad, y como veremos en las definiciones, atiende a un tipo muy concreto de autorretrato digital publicado en la red que viene determinado principalmente por el tipo de pantalla-espejo del smartphone que lo hace posible. Pese a esta aparente colonización del término que, tememos, en un futuro acabe copando todo el tipo fotográfico aquí estudiado, nosotros seguiremos a lo largo de estas páginas atendiendo a las definiciones seguidamente acotadas, puesto que pensamos que, no solo son más fieles a las nomenclaturas que históricamente han recibido estos

1 Esta colonización terminológica podría recordarnos a otras tantas en la historia, como la utilización que hacemos del término teléfono o teléfono móvil para referirnos a un dispositivo (smartphone) que hace las veces de cualquier tipo de gadget (agenda, calculadora, reloj, alarma, publicador, navegador, videoconsola, red, linterna...) además de teléfono, y que este uso (el que permite hacer llamadas telefónicas) ha quedado como una función secundaria o terciaria del aparato. 
objetos antes y durante los años de desarrollo de nuestras investigaciones, sino que también nos serán especialmente útiles para organizar estas tipologías y adaptarlas a sus máquinas y actitudes conformadoras.

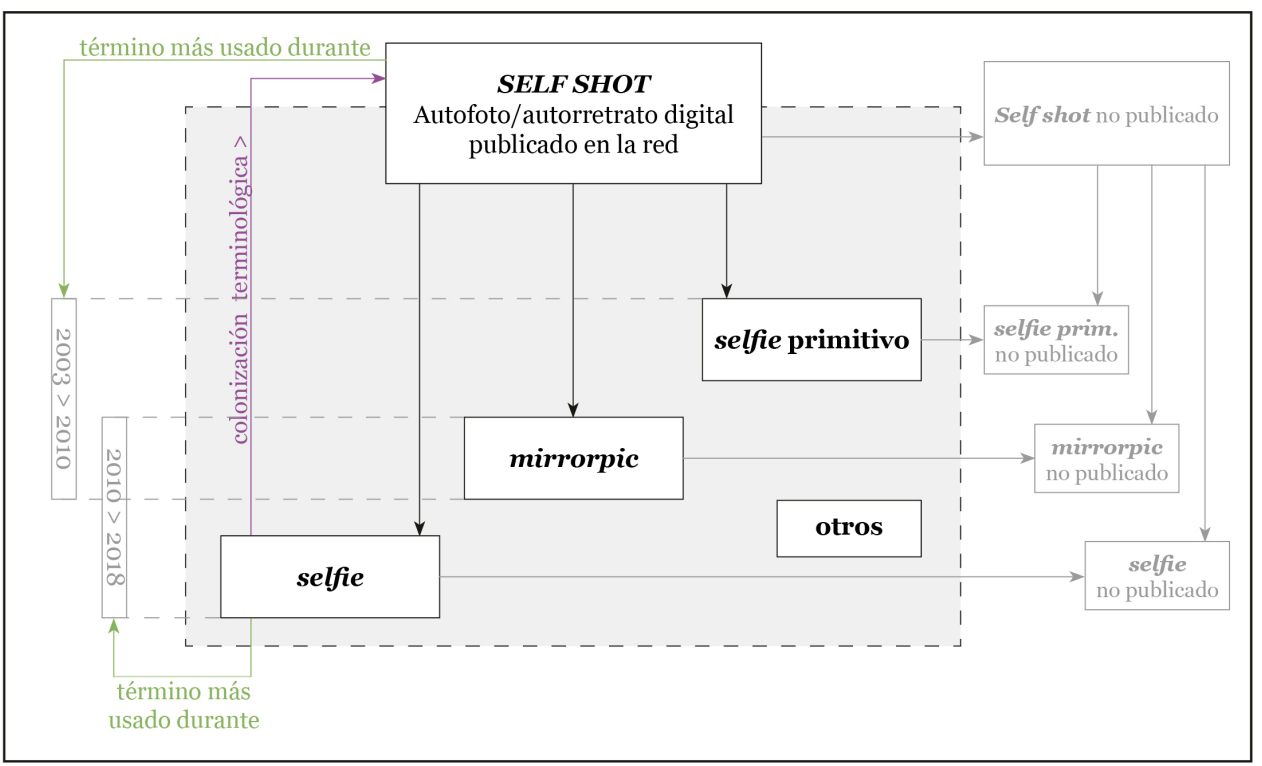

Imagen 3.1: Gráfico terminológico y conceptual que muestra todas las variantes de nuestro objeto fotográfico de estudio, sus grados de relación y una acotación cronológica que podría servir de guía aproximada (aunque no exclusiva) de usos. Lo utilizaremos como apoyo visual también durante el punto 3.1.1.

\subsubsection{Tipologías del autorretrato digital publicado en la red y modos de visión.}

Un autodisparo, autofoto o autorretrato digital publicado en la red, que también llamaremos self shot a lo largo de este estudio (remitiendo al término 
original utilizado en el ciberespacio por sus anónimas masas, sobre todo durante los primeros años de su desarrollo), es un tipo de fotografía contemporánea. Si "el inventario comenzó en 1839 y desde entonces se ha fotografiado casi todo $[\ldots]^{2}$," el self shot se podría concebir como un nuevo objeto fotográfico que incrementa ese inventario del que hablaba Susan Sontag.

Lo hemos definido antes como autorretrato digital publicado en la red de manera voluntaria o involuntaria. Inevitablemente esto nos lleva a aceptar, que pueden existir self shots que no son publicados, ya que, o bien se quedan permanentemente en sus dispositivos o en unidades de almacenamiento de datos digitales sin que nadie más salvo sus autores puedan verlos, o bien son eliminados antes de hacerse públicos. Dado que estos últimos ejemplos no tienen ni tanta importancia ni tanta notoriedad para nosotros o para los espectadores y estudiosos de este fenómeno fotográfico, los definiremos como self shots no publicados (como podemos volver a consultar en la imagen 3.1), dejándolos fuera de nuestra clasificación y abordaje.

Este término anglosajón, pese a ser ampliamente utilizado en las redes y en las comunidades de la Web durante la década pasada, no ha tenido un impacto en los diccionarios oficiales, tal como su sucedáneo, el mucho más popular selfie. No obstante, podemos completar nuestra definición personal (basada, como hemos dicho, en años de observación y clasificación) con algunas definciones que hemos encontrado en volúmenes virtuales menos oficiales que los diccionarios convencionales. Así, el Urban Dictionary, disponible online, definió el self shot en 2010 de la siguiente manera: "Fotografía que los myspacers $^{3}$ que se toman de ellos mismos con la vaga esperanza de que se vean medio decentes con la cantidad correcta de luz y el ángulo correcto. [...] A

2 SONTAG, Susan, Sobre la fotografía, Barcelona, Debolsillo, 2008, pág. 13.

3 Como veremos en el capítulo 6, MySpace fue una de las primeras redes sociales y también la primera en la que se comenzaron a ver este tipo de imágenes. 
menudo son editadas con Photoshop [...]"4. En este mismo diccionario encontramos la definición de la persona que practica el autorretrato digital publicado en la red, a la que se bautiza como selfshooter: "Usualmente una mujer adolescente que se practica autofotografías para publicarlas online" ${ }^{\text {. }}$

Por otro lado, la versión inglesa de la enciclopedia online construida por los usuarios del ciberespacio, Wikipedia, da una definición más formal de este fenómeno fotográfico, aunque debemos puntualizar que el título del artículo ha cambiado de "Self shot" en 2011 (durante los primeros años de nuestra investigación) a "Selfie" en 2018 (actualmente), sin que aparentemente se hayan modificado demasiado sus contenidos salvo para incluir nuevos eventos relacionados con los años que nos separan de aquella primera entrada. Esto evidenciaría el hecho que anteriormente hemos comentado: el término secundario está colonizando y asumiendo las propiedades del principal. Igualmente, en dicho medio la definición queda redactada como:

"El selfie es un autorretrato fotográfico, habitualmente tomado con un smartphone que debe de sosternerse con la mano o con un palo-selfie. Los selfies a menudo se comparten en servicios de redes sociales como Facebook, Instagram y SnapChat. [...] generalmente se refiere a las fotografías de autorretrato tomadas con la cámara sostenida con los brazos extendidos o apuntando a un espejo, a diferencia de las tomadas con el disparador automático o el control remoto" ${ }^{6}$.

Esta misma enciclopedia popular da una definición ligeramente diferente en su versión española, apuntando a la "Autofoto" como título:

4 Disponible en: <https://www.urbandictionary.com/define.php?term=Selfshot $>$ [Fecha de consulta: 12 de enero de 2018].

5 Disponible en: <https://www.urbandictionary.com/define.php?term=Self\%20Shooter > [Fecha de consulta: 12 de enero de 2018].

6 VV. AA., "Selfie", 2018, disponible en: <en.m.wikipedia.org/wiki/Selfie> [Fecha de consulta: 12 de enero de 2018]. 
"Una autofoto, [...] o selfi (también conocida con las voces inglesas selfie o selfy) es un autorretrato realizado con una cámara fotográfica, generalmente una cámara digital o un teléfono móvil. Se trata de una práctica muy asociada a las redes sociales, ya que es común subir este tipo de autorretratos a dichas plataformas"7.

A partir de ahora, el resto de definiciones que mostramos y que hemos encontrado tanto en diccionarios como en otras publicaciones y estudios, apuntan, o bien al término selfie (dada su reciente publicación y a la relación que esta proximidad temporal guardaría con la ya mencionada colonización del término del subgrupo en lo relativo al grupo principal), o bien a términos asociables al viejo término self shot (como autofoto).

Pese a que en ningún diccionario de nuestra lengua aparece algún término relacionado con nuestro objeto de estudio, encontramos en el diccionario de la lengua inglesa de Oxford (English Oxford Dictionary) una definición informal de selfie incorporada a finales de 2013:

"A photograph that one has taken of oneself, typically one taken with a smartphone or webcam and shared via social media"8.

En la traducción: "Una fotografía que uno ha tomado de sí mismo, generalmente mediante un smartphone o una webcam y compartida a través de las redes sociales".

Por otro lado, recientes estudios como el de Mercè Galán definen este tipo de objeto fotográfico como "la suma de un autorretrato tomado con un dispositivo móvil+software+una red social conectada a Internet”, autorretratos, además, que se suben "a diario a la red y significan distintas cosas, teniendo en

7 VV. AA., “Autofoto”, 2018, disponible en: <https://es.wikipedia.org/wiki/Autofoto> [Fecha de consulta: 12 de enero de 2018].

8 Disponible en: <https://en.oxforddictionaries.com/definition/selfie> [Fecha de consulta: 21 de enero de 2018]. 
cuenta el contexto y las amistades a las que se dirigen"9. También Diego Basile y Joaquín Linne amplían esta definición, puntualizando algunos aspectos detallados de esta práctica y asociándola como práctica mayoritariamente adolescente, muchas veces en relación con el espejo:

"Este tipo de fotos son centrales en la configuración identitaria y en la sociabilidad cotidiana de los adolescentes contemporáneos, tanto de sectores medios como de sectores populares. Publicadas en muchos casos como imágenes de portada en el propio perfil, suelen ser de tono intimista, tomadas en el propio hogar, en la habitación o el baño. Permiten al adolescente experimentar con la autopresentación y la imagen propia. A su vez, esta práctica funciona como una extensión y socialización de la tradicionalmente íntima relación con el espejo"10.

Una puntualización adicional de Manuel Canga permite fijar las condiciones que deben establecerse para que el autorretrato digital publicado en la red (self shot y sus vertientes) pueda ser considerado como tal, puesto que incide en el hecho de que debe estar realizado por la mano del autor, el cual desempeña a su vez la función de modelo, tratándose siempre de un autorretrato explícito que introduce la mirada del espectador en el interior de la imagen para convertirlo en testigo de una escena irrepetible ${ }^{11}$.

Para finalizar, un artículo online de Alise Tifentale titulado "¿Por qué cada autorretrato no es un selfie, pero cada selfie es una fotografía?” nos puede ayudar a aislar el término selfie, no solo del resto de autorretratos realizados antes de la llegada de la fotografía digital y la red, sino también del resto de autofotos realizadas antes de la llegada del smartphone y del desarrollo de las

9 GALÁN, Mercè, "El posicionamiento subjetivo del \#selfie”, en Asparkia. Investigació feminista, nº 27, 2016, pág. 32.

10 BASILE, Diego y LINNE, Joaquín, "Performances de autopresentación a través de fotografías digitales. El caso de los adolescentes de sectores populares en Facebook”, en Cuadernos.Info, n ${ }^{\circ} 35$ (Ejemplar dedicado a: Comunicación y educación), 2014, pág. 212.

11 CANGA, Manuel, "Introducción al fenómeno del selfie: valoración y perspectivas de análisis”, en Fotocinema. Revista científica de cine y fotografía, nº 10, 2015, pág. 402. 
lentes delanteras que permiten la fotografía mediante el uso de la pantalla-espejo que veremos más adelante:

"Estas consideraciones pueden servir, en parte, como una respuesta para aquellos que tienden a aplicar el término selfie retroactivamente a los autorretratos fotográficos realizados antes de 2010. Aunque hay muchos autorretratos en la historia de la fotografía que se parecen a los selfies (autorretratos en los espejos, autorretratos realizados mientras se sujeta la cámara con el brazo extendido, etc.), estas imágenes no son selfies porque no son productos de la cámara en red, no se hicieron con una cámara del teléfono inteligente y no se compartieron en las redes sociales [...]" ${ }^{12}$.

Lo apuntado nos lleva a focalizar nuestra atención en otro eje que nos puede ayudar a establecer una definición del self shot por medio del apoyo visual: Google Images, es decir, del buscador de imágenes del que es actualmente el mayor motor de búsqueda de la red, un buscador que posee casi una autoridad exclusiva.

Por fortuna conservamos una captura de pantalla que realizamos en algún momento de 2013 (antes de la total popularización del término selfie), momento en el que hicimos una búsqueda del término self shot, mediante esta conocida herramienta, con el objetivo de realizar una de nuestras primeras investigaciones (Imagen 3.2).

12 TIFENTALE, Alise, "Why Every Self-portrait is Not a Selfie, but Every Selfie is a Photograph", 2016, disponible en: <http://www.alisetifentale.net/research-blog-at/2016/3/9/why-every-self-portrait-isnot-a-selfie-but-every-selfie-is-a-photograph $>$ [Fecha de consulta: 22 de julio de 2017]. 


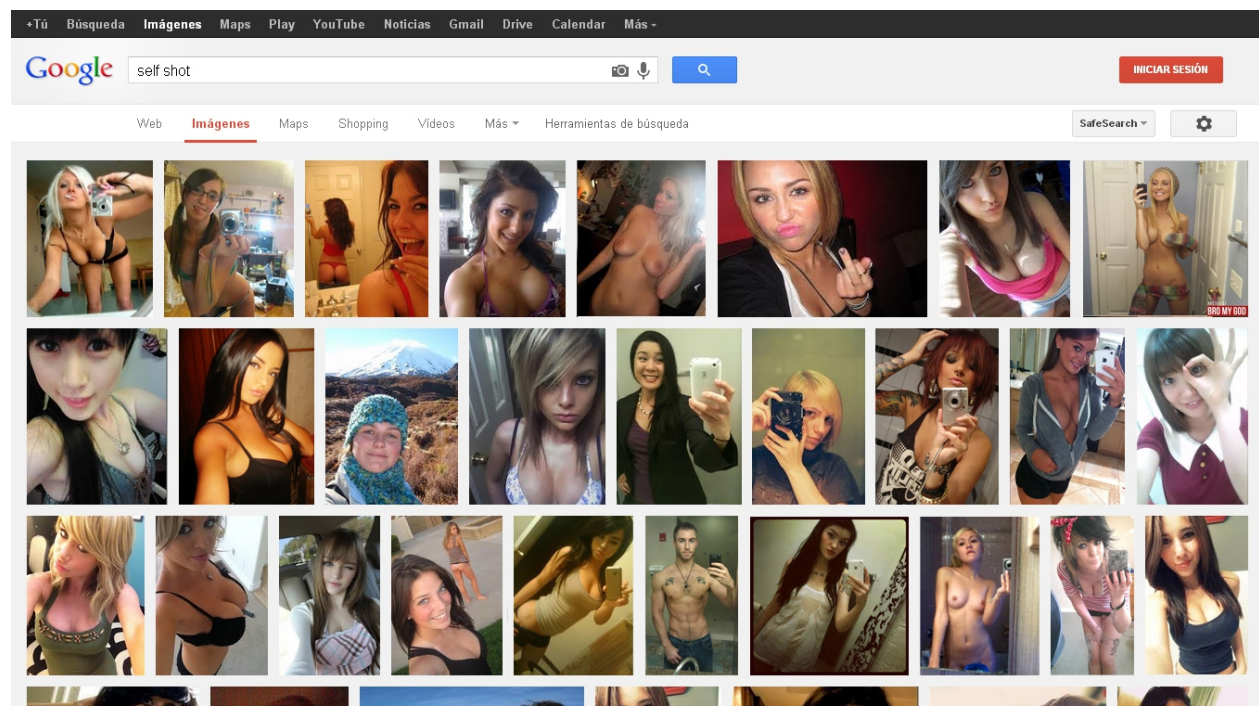

Imagen 3.2: Captura de pantalla que muestra un rastreo del término self shot en el buscador de imágenes de Google Inc. La captura fue realizada en 2013.

Esa captura de pantalla única e irrecuperable por la propia naturaleza cambiante y modelable del posicionamiento de objetos en la red (y que funciona como aquel fósil que ayuda a desentrañar algunos detalles de una civilización perdida y no recuperable) nos muestra lo que suponía el término buscado (self shot) en aquellos años en los que esta palabra era más popular que la modalidad bautizada como selfie.

Aunque veintisiete ejemplos aparentemente aleatorios ${ }^{13}$ no deben servir de apoyo para establecer pautas generales, esta muestra sí que puede aproximarse al resto de resultados que podemos encontrar en este listado de imágenes. En dicha agrupación de 2013 encontramos una selección de

13 Aparentemente, pese a que el posicionamiento de los contenidos de los buscadores puede parecer democrático y objetivo, no hay que olvidar que no estaría condicionado a mostrar equidad o corrección, puesto que su conformación se encuentra delimitada por los usuarios que la han construido y constituido. Estaríamos, por tanto, ante un posicionamiento subjetivo, fruto de una sociedad patriarcal mayoritariamente gestionada por hombres blancos heterosexuales. 
autorretratos digitales publicados voluntariamente por sus autoras, salvo unos pocos que muestran desnudos más explícitos y que podrían haber sido colocados en la red a traición (como veremos en el capítulo 5). La gran mayoría de ejemplos son autorretratos realizados por mujeres jóvenes y adolescentes, encontrando tan solo un ejemplo de género masculino.

Estos ejercicios de autoafirmación y muestra del yo ${ }^{14}$, casi siempre quedan envueltos por actitudes de seducción, de divertimento o de testimonio. A su vez, algunas fotografías parecen concebidas para su muestra pública y otras para el ámbito privado o personal.

Como vamos a ir viendo en los siguientes puntos, encontramos casi todos los subtipos de autorretrato digital publicado en la red, y debemos destacar que los dispositivos de captura fotográfica reflejados en los espejos de los self shots de tipo mirrorpic muestran un todavía dominio de las cámaras compactas y semiprofesionales, frente a un uso del smartphone como cámara publicadora que iba en aumento, pero que aún no había desplazado completamente a las cámaras fotográficas digitales durante aquel principio de década ${ }^{15}$.

Por otro lado, un nuevo rastreo del mismo término (self shot) realizado durante 2018 también mediante el motor de búsqueda de imágenes de Google ${ }^{16}$

14 En relación a estas definiciones, el yo queda también definido como elemento conformador del autorretrato digital publicado en la red: "Los usos confesionales de Internet parecen encajarse en esta definición: serían manifestaciones renovadas de los viejos géneros autobiográficos. El yo que habla y se muestra incansablemente en la Web suele ser triple: es al mismo tiempo autor, narrador y personaje. Pero además no deja de ser una ficción, ya que, a pesar de su contundente autoevidencia, el estatuto del yo siempre es frágil". SIBILIA, Paula, La intimidad como espectáculo, Buenos Aires, Fondo de Cultura Económica, 2008, pág. 37. Asimismo, "la proyección del self a través de los dispositivos fotográficos [...] se establece a partir de una «triple deixis» de la primera persona: yoaquí-ahora". BROULLÓN-LOZANO, Manuel A., "Por una semiótica del selfie en la cultura visual digital”, en Fotocinema. Revista científica de cine y fotografía, nº 11, 2015, pág. 222.

15 Asumimos que este muestreo de 2013 contiene fotografías de dicho año, pero también anteriores. Es probable que las fotografías mostradas mayoritariamente se realizaran entre 2009 y 2013, viendo el tipo de dispositivos usados, aunque no podemos tener garantías de su fecha de realización exacta por tratarse de imágenes digitales demasiado alejadas de sus originales primigenios que sí que conservarían los metadatos que podrían darnos dicha información.

16 Volvemos a utilizar el popular motor de búsqueda de imágenes de Google Inc., disponible desde 
sigue mostrándonos resultados similares reflejados en fotografías que a su vez son diferentes a las mostradas hace cinco años (Imagen 3.3). Esta comparación podría poner de manifiesto de manera visual y contrastada el siguiente hecho: la iconografía del autorretrato digital publicado en la red (pese a sus leves transformaciones debido a los cambios en los elementos que lo hacen posible) sigue un patrón formal, es decir, una similar línea compositiva y estética.

En este sentido, continúa tratándose de un ejercicio de autorrepresentación generalmente femenino que se encuentra relacionado con el divertimento, con el registro autobiográfico, con la búsqueda de la belleza ${ }^{17} \mathrm{y}$, en algunos casos, con la seducción, el erotismo y el desnudo. Sin embargo, lo que sobre todo pone de manifiesto el self shot es que alude a una práctica común ${ }^{18}$, una práctica que prosigue en la actualidad.

cualquier navegador o aplicación para la navegación web, y que como hemos visto es capaz de buscar y mostrar, ordenando de manera temporal, cualquier imagen disponible en la red. Estas imágenes, que acostumbran a estar asociadas a una o más palabras (con las que podemos encontrarlas), se ordenarán de arriba a abajo siguiendo diversos criterios. Uno de ellos es el cronológico, es decir, el de la novedad, cuestión que debemos tener en cuenta y que pone de relieve el carácter cambiante y vivo de estas muestras. Por ejemplo, las imágenes que ofreció el rastreo de la palabra self shot el 13 de julio de 2013 (Imagen 3.2) no son las mismas imágenes que muestra la búsqueda realizada a día de hoy (Imagen 3.3). No obstante, la mayoría de estas imágenes, protagonistas en el pasado, seguirán presentes en algún lugar de la casi infinita maraña visual que nos ofrece el buscador.

17 Respecto a la belleza o lo bello en la fotografía, dice Susan Sontag: "La cámara ha tenido tanto éxito en su función de embellecer el mundo, que las fotografías, más que el mundo, se han convertido en la medida de lo bello". SONTAG, Susan, op. cit., pág. 89. Estos objetos, además de bellos, puede que sean en el futuro, los que definirán una época.

18 Una búsqueda hecha en el motor de Google con la palabra self shot mostraba en la ya citada fecha del 13 de julio de 2013 una cantidad aproximada de 331.00o.ooo de resultados. Es curioso ver cómo ese número ha descendido drásticamente a 32.00o.0oo de resultados si también sumamos sus dos variantes (con y sin separación) tras una nueva búsqueda realizada a principios de 2018. Es posible que este hecho se deba al desuso que ha sufrido este término en pos de la colonización por parte de su variante selfie, que a día de hoy muestra la desorbitante cifra de 983.000.00o de resultados. 


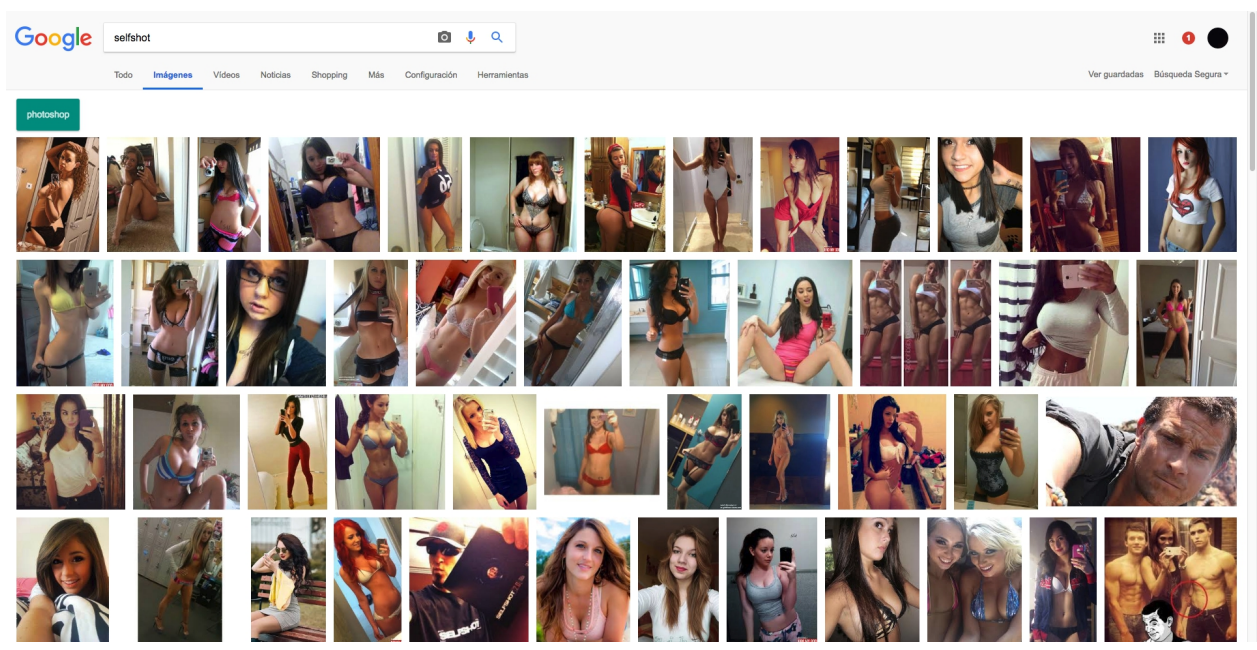

Imagen 3.3: Captura de pantalla que muestra un rastreo del término self shot en el buscador de imágenes de Google Inc. La captura se llevó a cabo a principios de 2018.

Para finalizar este apartado en el que analizamos e intentamos precisar el concepto terminológico mediante la visión de imágenes con las que los usuarios han definido y clasificado este objeto en la red, hemos querido también mostrar una búsqueda de imágenes realizada a día de hoy, principios de 2018, mediante la introducción del recientemente utilizadísimo término selfie (Imagen 3.4). Revisando y comparando esta búsqueda con las anteriores podemos comprobar cómo, en este caso, la aparición de imágenes se divide, por un lado en la muestra de selfies auténticos (subtipo que definiremos más adelante) y, por otra, en una serie de imágenes, asociadas generalmente a campañas publicitarias de carácter promocional, que lo que muestran (mediante una escenificación artificial) es el acto de ejecutar un selfie más que un selfie en sí mismo en tanto que objeto fotográfico. Este hecho puede poner de manifiesto cómo este término tan utilizado hoy en día se ha convertido en un cliché o en una imagen culturalmente aceptada y conocida debido a la rápida masificación de su práctica. 


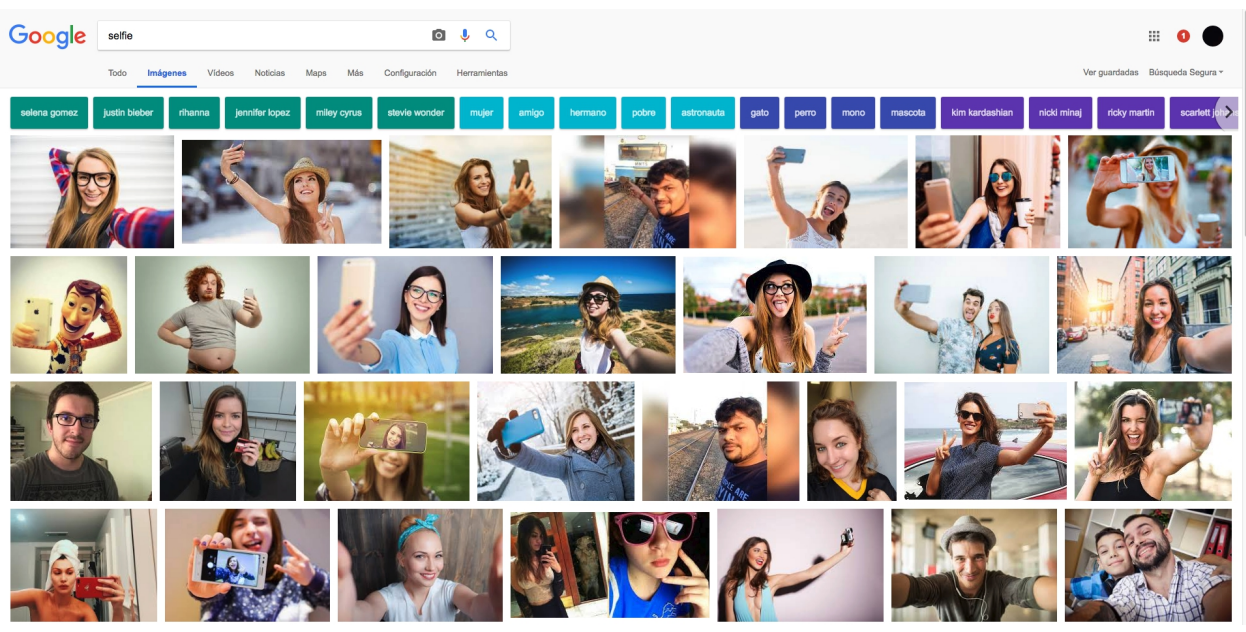

Imagen 3.4: Captura de pantalla que muestra un rastreo del término selfie en el buscador de imágenes de Google Inc. Captura efectuada a principios de 2018.

En resumen, pese a los cambios en las tendencias terminológicas, a lo largo de este estudio utilizaremos el término autorretrato digital publicado en la red para referirnos a nuestro objeto de estudio de manera general, englobando todos sus subtipos formales. También utilizaremos lo que consideramos que pueden tratarse como sinónimos acortados de este largo término. Nos referimos a nociones como self shot, autodisparo o autofoto. De igual manera usaremos los términos mirrorpic, selfie primitivo, selfie u otro tipo de self shot no clasificado para referirnos a los subtipos formales que nuestro objeto de estudio global ha tenido a lo largo de su cambiante recorrido ${ }^{19}$.

No obstante, y antes de entrar en la definición de estos subtipos, abordaremos a continuación, mediante un pequeño inciso, la también acotación terminológica $^{20}$ de cuatro técnicas de encuadre y visionado durante el ejercicio

19 De esta manera, cualquier selfie sería un tipo de autorretrato digital publicado en la red o self shot, pero no todos los tipos de autorretratos digitales publicados en la red o self shots son selfies, puesto que hay otras tipologías formales y conceptuales, como pudimos ver en el gráfico expuesto al principio de este punto (Imagen 3.1).

20 Acotación terminológica de nomenclatura propia que proponemos como utilidad para resolver de 
del self shot que nos ayudarán a entender sus subtipos por la relación directa que guardan con estas técnicas.

1) Visión directa por visor (Imágenes 3.5 y 3.6). Este tipo de visionado durante el encuadre, la composición y la realización de la toma fotográfica sería prácticamente exclusivo de la era de las máquinas analógicas o de película fotoquímica (a excepción de las cámaras réflex digitales y de medio formato digitales que lo han conservado).

Su técnica consiste en que el fotógrafo observa aquello que va a fotografiar por medio del visor de la cámara: un vidrio que muestra de manera real (puesto que lo que se ve es la realidad a través de este mismo vidrio) lo que capta la lente y, por tanto, lo que quedará atrapado una vez dicho fotógrafo pulse el disparador de la cámara. Las diversas maneras con las que este vidrio se alinea (de manera exacta o aproximada) con la lente son llevadas a cabo mediante un espejo-pentaprisma (cámaras réflex y de paso universal), mediante un visor telemétrico (cámaras compactas) o mediante un vidrio esmerilado (cámaras de gran formato $)^{21}$.

Este tipo de visionado obliga al fotógrafo a acercar su ojo a la máquina y a alinearlo con ella, ejercicio dictaminado por la naturaleza física de la máquina y que ha dejado su marca formal en la mayoría de fotografías del siglo XX.

manera más óptima y concisa el desarrollo de este estudio.

21 Se puede consultar esta información de manera más detallada en: ADAMS, Ansel, La cámara, Madrid, Omnicón, 2002. 


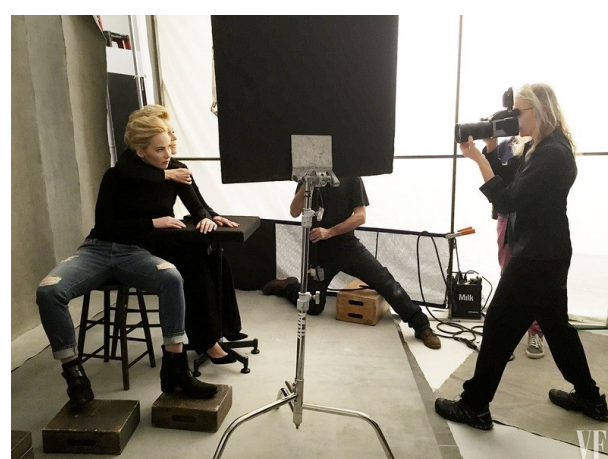

Imagen 3.5: La fotógrafa Annie Leibovitz realizando un retrato por medio de la visión directa por visor. Fotografía de Rachel DeLoache Williams, 2016.

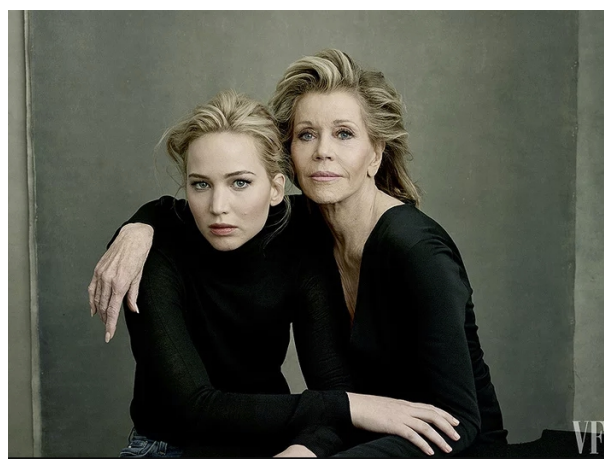

Imagen 3.6: Ejemplo de fotografía resultante del tipo de visión descrito en la Imagen 3.5. Annie Leibovitz, Jane Fonda y Jennifer Lawrence para Vanity Fair, 2016.

2) Visión directa por pantalla (Imágenes 3.7 y 3.8). Este relativamente novedoso tipo de visionado durante el encuadre, la composición y la realización de la toma fotográfica es exclusivo de la tecnología digital de las cámaras y dispositivos fotográficos comenzados a desarrollar durante los últimos años del siglo pasado. Cada uno de estos dispositivos, sobre todo las cámaras digitales compactas pero también los smartphones, poseen una pantalla de cristal líquido (LCD) o similar que transmite a tiempo real y como si de un vídeo se tratara (mientras la cámara esté activada), lo que ve la lente de dicha máquina. Aunque esta pantalla podría colocarse en cualquier lugar del dispositivo (debido a la no necesaria alineación con la lente, dado que se trata de una señal electrónica de vídeo que replica lo que ve la lente de manera remota), la lógica y la costumbre del acto de la captura fotográfica clásica hacen que su posición predilecta sea la parte posterior de la lente (del cuerpo de la cámara), emitiendo la imagen vista por ella de manera opuesta a sí misma (es decir, si la cámara apunta hacia lo que tiene delante la lente, la pantalla LCD, emite en dirección contraria hacia donde esta se dirige, o sea, hacia nosotros, siempre y cuando fotografiemos algo que se sitúe frente a nuestra mirada y con la cámara sujeta con las manos). Este acto de visión se asemejaría al realizado por las cámaras fotográficas analógicas de no ser 
por la siguiente diferencia: al no tratarse de un visor de la realidad por medio de un recorrido físico de vidrios y vacíos que atraviesa el propio aparato, sino de un ingenio que transmite una imagen de vídeo de la realidad tomada por la lente mediante una pantalla visible desde diversos ángulos, esto nos va a posibilitar novedosas maneras de componer, ya que podemos disociar el eje-lente del ejeojo, es decir, separar el dispositivo hasta la máxima distancia que nos permita el brazo en cualquier eje (vertical, horizontal o profundo) respecto a nuestros ojos, sin perder por ello el contacto con lo que la cámara está registrando.

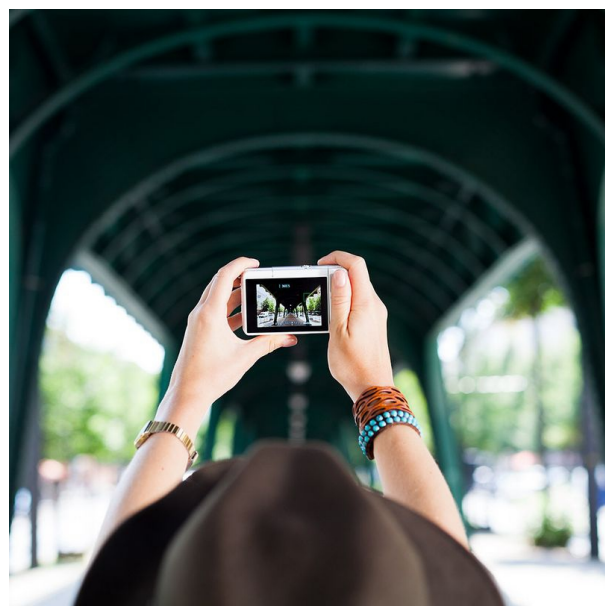

Imagen 3.7: Una persona realizando una fotografía por medio de la visión directa por pantalla, hecho que le permite separar el visor de su ojo.

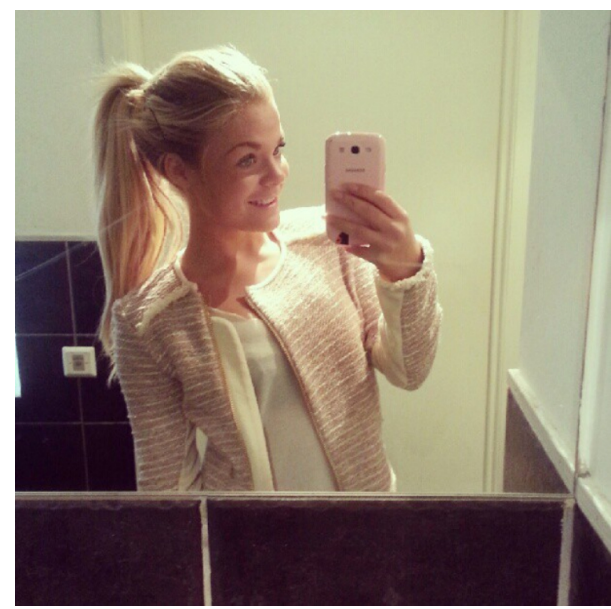

Imagen 3.8: Ejemplo de fotografía resultante del tipo de visión planteada en la Imagen 3.7. La única manera de hacerse un autorretrato utilizando la visión directa por pantalla consiste en fotografiar nuestro reflejo apuntando a la superficie reflectante (mirrorpic). Afinaremos el encuadre mirando la pantalla. En este tipo de self shot se ven los límites del espejo y el reflejo del dispositivo siempre queda también plasmado en la fotografía. 
3) Visión indirecta (Imágenes 3.9 y 3.10). Este tipo de visionado por parte del fotógrafo durante el encuadre, la composición y la realización de la toma fotográfica fue relativamente utilizado antes de la llegada de la fotografía digital (como divertimento o experimentación) y extensamente practicado en esta nueva era de la fotografía por las selfshooters, justo antes de la incorporación de las pantallas LCD abatibles y/o el desarrollo de las lentes frontales de los smartphones, que inauguraron la visión directa por pantalla-espejo junto con nuevas formas de componer $\mathrm{y}$, a su vez, nuevos productos fotográficos en lo concerniente a puntos de vista y construcciones formales.

Por lo tanto, durante una pequeña franja de tiempo, quizá un lustro en el transcurso de la década pasada, si queríamos autorretratarnos con aquellas máquinas solo teníamos dos opciones: o bien utilizar la anteriormente mencionada visión directa por pantalla, mientras encuadrábamos nuestro reflejo en el espejo de, por ejemplo, un cuarto de baño (fotografiar nuestra propia imagen), o bien girar la cámara hacia nosotros mismos para realizar una fotografía a ciegas con la que teníamos que acertar el encuadre y, a continuación, luego comprobar (tantas veces como quisiéramos, dada la gratuidad e instantaneidad de las pruebas fotográfico-digitales) si la toma de nuestro autorretrato era la correcta o no.

Esta manera de fotografiar a ciegas conlleva girar la cámara hacia nosotros y dejar de ver lo que muestra la pantalla LCD, ya que esta queda situada en oposición a nuestros ojos, dando lugar a la visión indirecta que hemos definido y descrito en este punto. 


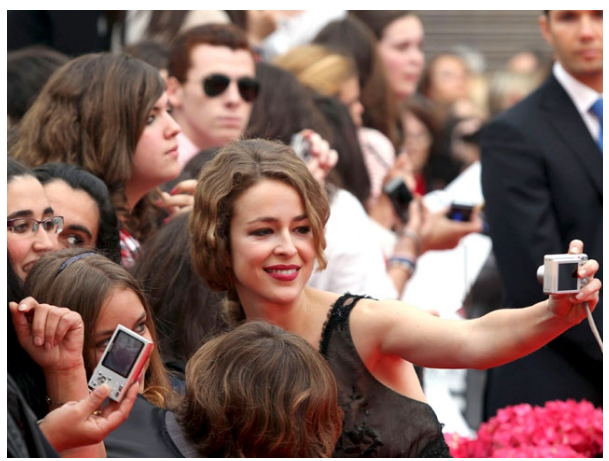

Imagen 3.9: La acrtiz Silvia Abascal practicando un selfie primitivo junto a sus fans con la cámara compacta de uno de estos durante el Festival de cine de Málaga en 2010, utilizando la visión indirecta para realizar el encuadre, puesto que este tipo de cámaras de finales de la década pasada carecían de pantalla abatible.

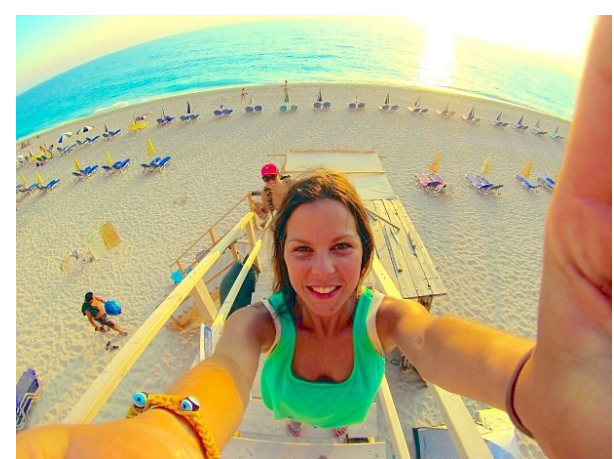

Imagen 3.10: Ejemplo de fotografía resultante del tipo de visión analizado en la Imagen 3.9. Autofoto de tipo selfie primitivo realizado por la usuaria @danabargielowski y publicado en Instagram en 2012. Este autorretrato digital publicado en la red ha sido realizado con una cámara deportiva Go Pro (las deformaciones de la imagen son su inconfundible sello), cámara que también carece de pantalla abatible.

4) Visión directa por pantalla-espejo (Imágenes 3.11 y 3.12). Este último tipo de visionado durante el encuadre, la composición y la realización de la toma fotográfica vuelve a ser exclusivo de la era de las máquinas digitales, tal y como lo es también la visión directa por pantalla. Este tipo de visionado vendría a compensar la problemática que supone la anteriormente analizada visión indirecta en el buen hacer del autorretrato fotográfico. De hecho, la visión directa por pantalla-espejo ha sido crucial para el desarrollo compositivo y reconocible del selfie, configurándose por medio de los nuevos dispositivos que han permitido este tipo de visión: las cámaras fotográficas digitales con pantalla LCD abatible $180^{\circ}$ y los smartphones con lente frontal. Así pues, no solo con las cámaras cada vez más extendidas que permiten desplegar su pantalla hasta colocarla de manera paralela junto a la lente (emitiendo su imagen en la misma dirección hacia donde la lente de la cámara apunta), sino también con los smartphones con lente frontal (siendo esta lente de carácter secundario respecto 
a su lente principal trasera, aunque se coloca también paralela al eje de emisión de la pantalla), podemos realizar el mismo tipo de ejercicio: vernos reflejados como si la pantalla fuera un pequeño espejo de mano y, a la vez, fotografiarnos. Esto se produce porque este tipo de nuevas tecnologías, mira y emite lo que captan, dirigiéndolo hacia un mismo punto y desde un mismo plano. Hay que señalar que, mediante este tipo de visión, no estamos fotografiando un reflejo, ya que no existe espejo que lo produzca. La cámara sigue fotografiando lo que ve, que es nuestro rostro (o nuestro cuerpo si conseguimos alejar lo suficiente la cámara y alzarla en busca del ángulo adecuado). Sin embargo, lo que miramos es una pantalla LCD alineada a una lente que nos apunta y que muestra lo que esta ve. Por tanto, esta pantalla se comporta como ese espejo de mano del que hablábamos, dado que con solo apretar un botón la máquina hace una fotografía capturando nuestro retrato. Resulta evidente afirmar que esta nueva manera de fotografiar y encuadrar ha modificado el modo no solo de enfrentarnos a nuestro rostro y registrarlo, sino que también, como veremos, ha producido un nuevo objeto fotográfico a nivel formal reflejado en millones de autorretratos.

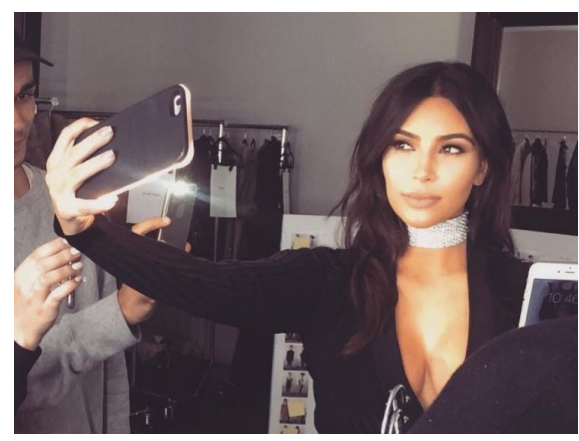

Imagen 3.11: La celebridad estadounidense Kim Kardashian realizándose un selfie tras las bambalinas de un desfile de moda mediante la visión directa por pantalla-espejo. Gracias a este tipo de visión la autorretratista puede ajustar el encuadre y el gesto puesto que está viento su rostro a tiempo real por medio de una simulación de reflejo en la pantalla LCD del dispositivo y ello gracias a la cámara secundaria situada sobre esta misma pantalla.

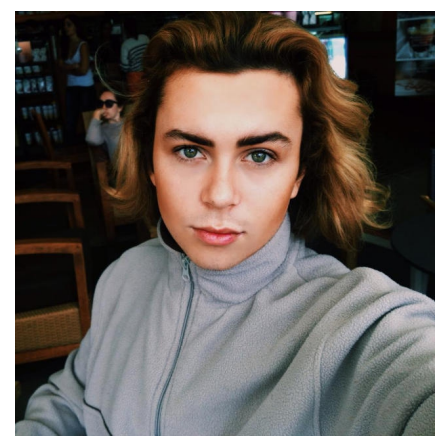

Imagen 3.12: Ejemplo de fotografía resultante del tipo de visión utilizado en la imagen 3.11. Un selfie del usuario @kurtcoleman publicado en Instagram en 2014 y realizado con un smartphone. Se observa en este tipo de autorretratos un gesto más controlado y un encuadre más frontal que en los selfies primitivos. 
Teniendo en cuenta lo señalado, pasaremos ahora a definir los cuatro tipos de autorretratos digitales publicados en la red que han sido producidos por estos tipos de visión mediante sus correspondientes dispositivos.

\subsubsection{El mirrorpic o autorretrato digital de espejo.}

Utilizaremos durante todo este estudio el término mirrorpic (o autorretrato digital de espejo) para referirnos a un tipo concreto de autorretrato digital publicado en la red que definimos aquí como una variante del self shot en el que la persona que se autorretrata lo hace fotografiando con cualquier tipo de dispositivo de captura fotográfico-digital (cámara compacta digital, cámara réflex digital, smartphone, tablet...) su propio reflejo especular que emana de una superficie-espejo hacia la que apunta con el dispositivo que, como norma general, saldrá asimismo representado en la propia fotografía, junto con la representación del propio autor o autora (Imagen 3.13) ${ }^{22}$. El fotógrafo y teórico Joan Fontcuberta detectó la masiva producción de este tipo de imágenes a principios de nuestra década y las acuñó con un término castellanizado: reflectogramas ${ }^{23}$. Cabe decir que el autorretrato digital publicado en la red de tipo mirrorpic siempre se realiza utilizando la visión directa por pantalla.

Si hacemos una búsqueda sencilla en el motor de imágenes de Google Inc. introduciendo el bloque de palabras self shot mirror pic podremos hacernos una idea de la interminable muestra de este tipo de fotografías, muy delimitadas a la imagen confirma la unión corpórea entre el enunciador y el dispositivo fotográfico, el cual aparecerá incluido también en la composición”. BROULLÓN-LOZANO, Manuel A., op. cit., pág. 227.

Algo que, como veremos en el capítulo 7, conforma la base de alguno de sus proyectos expositivos. 
nivel formal y que, tras su repetida práctica durante más de diez años, se han convertido en un referente cultural e icónico reconocible y masivamente imitado. Pese a que en las muestras de los buscadores abunda el autorretrato íntimo, erótico, de autocontemplación del propio cuerpo y/o de imaginería adolescente, podemos constatar tras búsquedas en redes sociales y otras superficies de soporte online que este tipo de autorretrato se practica también con otras intencionalidades y en diferentes franjas de edad. Pese a que esta práctica todavía producida (Imagen 3.14) ha decrecido, su auge se alcanzó a finales de la década pasada, cuando aún no se habían desarrollado las pantallas-espejo.

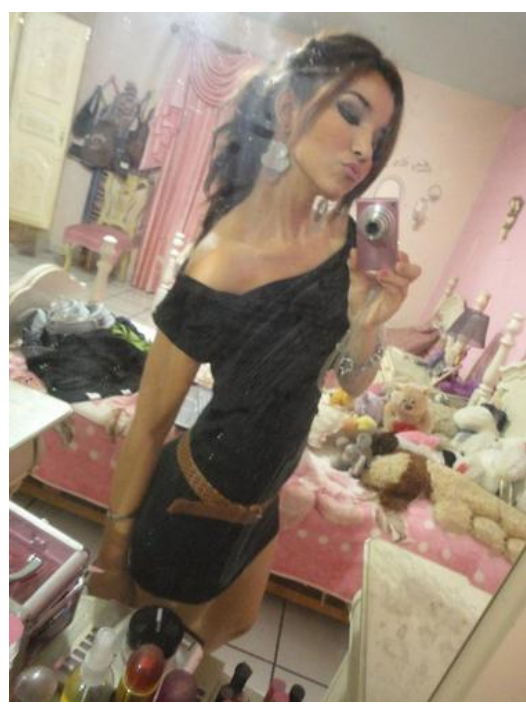

Imagen 3.13: Mirrorpic anónimo realizado en torno a 2010 con una cámara compacta (se ve reflejada), representativa de aquella época. La imagen recoge el autorretrato de una chica adolescente en su habitación. Los límites y la suciedad del espejo puntualizan su presencia en la composición.

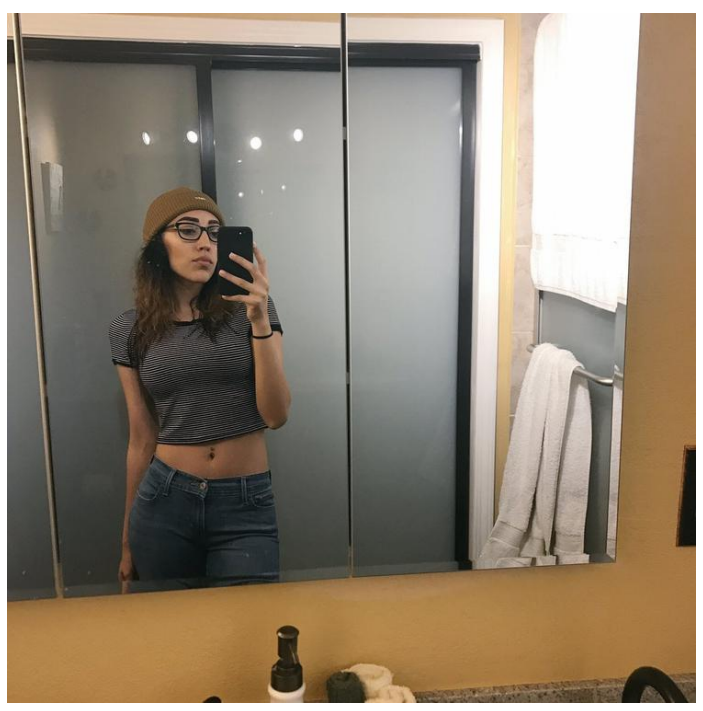

Imagen 3.14: Mirrorpic anónimo realizado en torno a 2016 con un smartphone (también se ve reflejado) contemporáneo. La autorretratada es una joven reflejada en el espejo de un cuarto de baño. Al igual que en el ejemplo anterior, estas autorretratistas se han servido de la visión directa por pantalla. 


\subsubsection{El selfie primitivo.}

Utilizaremos también durante todo este estudio el término selfie primitivo (o proto-selfie) (Imagen 3.15) para referirnos a un tipo concreto de autorretrato digital publicado en la red que definimos aquí como una variante del self shot en el que la persona autorretratada gira el dispositivo dirigiendo su lente principal hacia su rostro o rostro-cuerpo mediante un disparo a ciegas (Imagen 3.16) sin hacer uso de ningún tipo de pantalla, es decir, utilizando la visión indirecta. Este subtipo de self shot fue muy común durante los albores de esta nueva forma y moda fotográfica (a lo largo de la década pasada), ya que eran muy pocos los dispositivos digitales de captura fotográfica que incluían pantallas desplegables, dado que aún no se habían desarrollado los smartphones ni sus lentes frontales. Pese a que las diferencias entre un selfie y un selfie primitivo pueden ser a veces sutiles si solo evaluamos el contenido de las fotografías, en muchas ocasiones resulta evidente, no solo por la fecha de realización que pondría de manifiesto el tipo de tecnología, sino también por el encuadre, la actitud o la mirada de la persona autorretratada (una mirada ligeramente desviada apuntaría a un selfie realizado con una pantalla-espejo, también ligeramente desplazada respecto a la lente, sin embargo una mirada directa es más propia de un selfie primitivo). La calidad en la imagen también podría constituir una evidencia de lo señalado, puesto que, como veremos en el capítulo 4, la fotografía digital no ha dejado de perfeccionarse desde su invención. Como hemos señalado al definir la visión indirecta, totalmente asociada a este tipo de autorretratos, la gratuidad e instantaneidad es una propiedad de la tecnología fotográfico-digital que permite la permanente prueba-error tan fundamental para el desarrollo de este tipo de ejercicios realizados a ciegas. Al margen de que este modo de este autorretrato es casi exclusivo de una época en la que no existían las pantallas-espejo, se puede seguir observando de manera puntual y como excepción la práctica del selfie primitivo con dispositivos con los que no 
haría falta hacerlos (Imagen 3.17), cuestión que podría derivar del hecho de que las lentes traseras de la pantalla de los smartphones suelen ofrecer una mayor calidad que las lentes frontales.

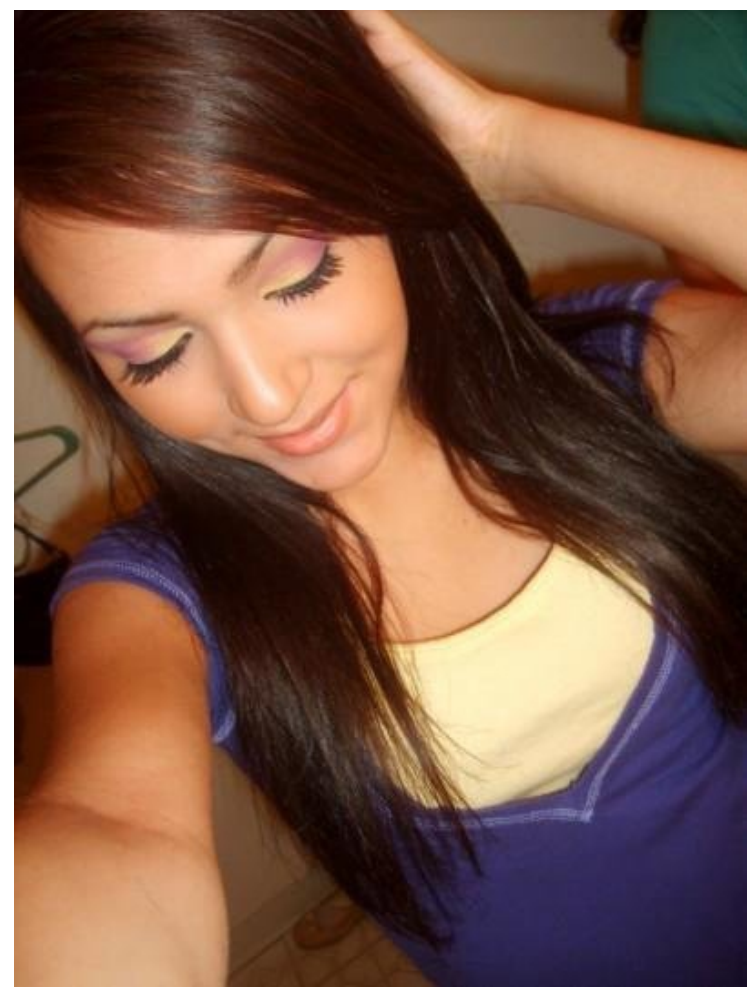

Imagen 3.15: Anónimo autorretrato digital publicado en la red en torno a 2010 y de tipo selfie primitivo, en el que la autorretratista ha tenido que fotografiarse girando la cámara para apuntar con la lente hacia su rostro y cuerpo. 


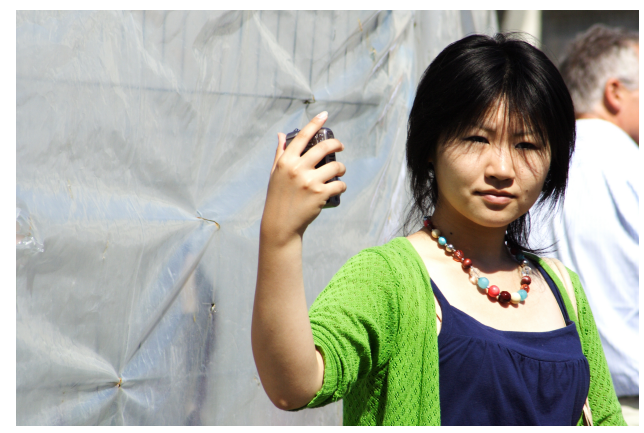

Imagen 3.16: Fotografía de contexto tomada por nosotros en 2007 en la que se muestra a una turista realizándose un selfie primitivo en la ciudad de Praga.

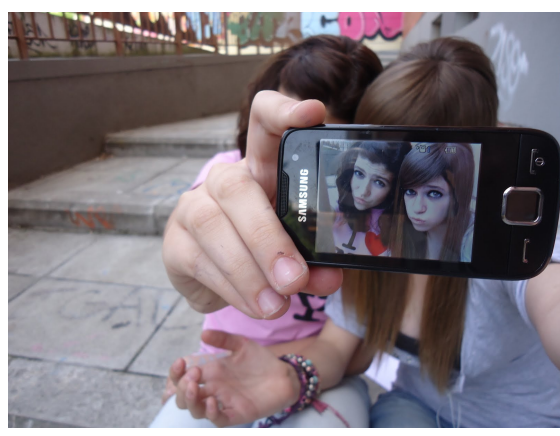

Imagen 3.17: Fotografía de contexto. Dos adolescentes realizándose un selfie primitivo (sin necesidad, puesto que su smartphone posee lente frontal).

\subsubsection{El selfie.}

Vamos a utilizar también durante todo este estudio el término selfie $e^{24}$ no para englobar todo el fenómeno del autorretrato digital publicado en la red, como parece que está sucediendo durante estos años con la colonización efectuada por este término (como hemos repasado anteriormente), sino para referirnos a un tipo concreto de autorretrato digital que definimos aquí como una variante del self shot en el que la persona que se autorretrata lo hace por medio de una pantalla-espejo, ya sea la desplegable de una cámara fotográfica, la del monitor de una computadora que incorpore una webcam o, generalmente, la de un

24 Pese a que la grafía selfi, (plural selfis), es una adaptación adecuada al español de la forma inglesa selfie (de self, «auto» o «a sí mismo»), término que "se utiliza con mucha frecuencia en los medios de comunicación en español, en ejemplos como «Todos se apuntaron a la selfie de la presentadora» $\mathrm{o}$ «En agosto, un selfie en el que se mostraba al papa Francisco en compañía de un grupo de jóvenes dio la vuelta a la red»" VV. AA., "Selfi, adaptación al español de selfie", 2014, disponible en: <https://www.fundeu.es/recomendacion/selfi-adaptacion-al-espanol-de-selfie/> [Fecha de consulta: 12 de julio de 2015]. Con independencia de que también se ha utilizado el término selfy, en este estudio nos ceñiremos a utilizar el vocablo selfie para singular y su lógico plural también inglés selfies. 
smartphone con lente frontal ${ }^{25}$. Esta pantalla hace las veces de espejo de mano y produce un efecto reflejo con el que la o el autorretratista puede componer a tiempo real el encuadre fotográfico, así como afinar el gesto deseado (Imagen 3.18).

Como se puede imaginar, este subtipo de autorretrato se hace servir de la visión directa por pantalla-espejo propia de este tipo de dispositivos, que, en cierta medida, ha invitado a desarrollar un tipo de estructura compositiva y formal en estas fotografías, así como a mostrar un tipo de gestos más propios de las distancias íntimas (Imágenes 3.19 y 3.20) que de las distancias sociales más vinculadas a las autofotos de tipo mirrorpic en las que, como norma aceptada, la lente está mucho más alejada del cuerpo de la modelo.

Este subtipo de autofoto, el selfie, es el más practicado hoy en día frente a sus otros competidores, y su predominio ha crecido de manera exponencial desde que comenzara a crecer un tipo de dispositivo (el smartphone con lente frontal) que hoy casi la totalidad de las poblaciones de los países desarrollados lleva en sus bolsillos. A este hecho hay que añadir que este propio smartphone que, por sus atributos, fomenta la autofotografía, es además una herramienta publicadora siempre conectada al ciberespacio, herramienta desde la que se puede terminar de manera instantánea este ciclo de autorretrato fotográfico publicado en la red sin necesidad de utilizar una plataforma auxiliar de publicación (la computadora), tal como ocurría con las cámaras compactas propias de la década pasada. cámara de fotos, el fotógrafo y el objeto fotográfico, de manera que, girando sobre sí mismo, el dispositivo tecnológico pasa a ser un espejo en el que se reflejan tanto el retratista como el retratado". BROULLÓN-LOZANO, Manuel A., op. cit., pág. 216. 


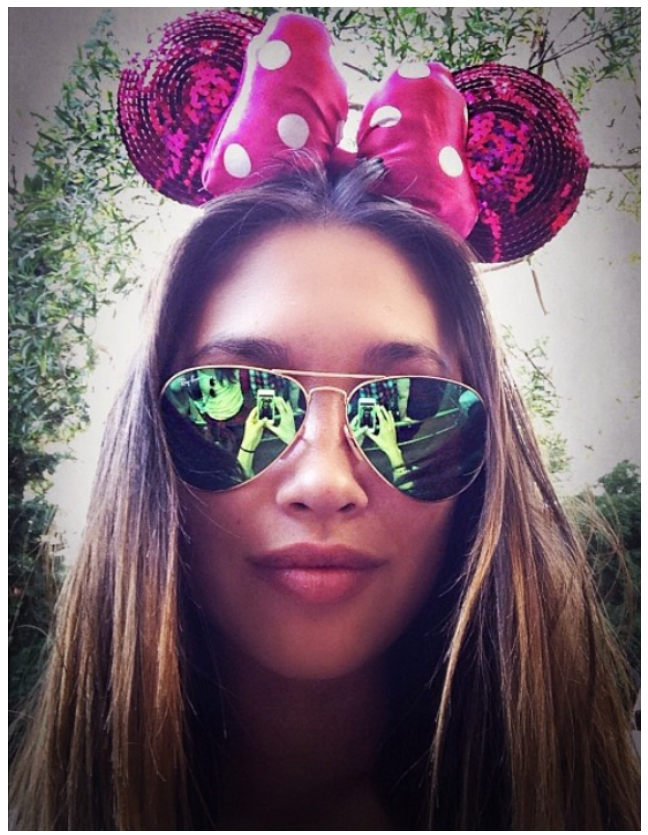

Imagen 3.18: Selfie realizado y publicado en Instagram en algún momento de 2015 por la modelo Jocelyn Chew. Puede verse reflejado en sus gafas el dispositivo con pantalla-espejo (su smartphone) con el que se practicó este autorretrato.

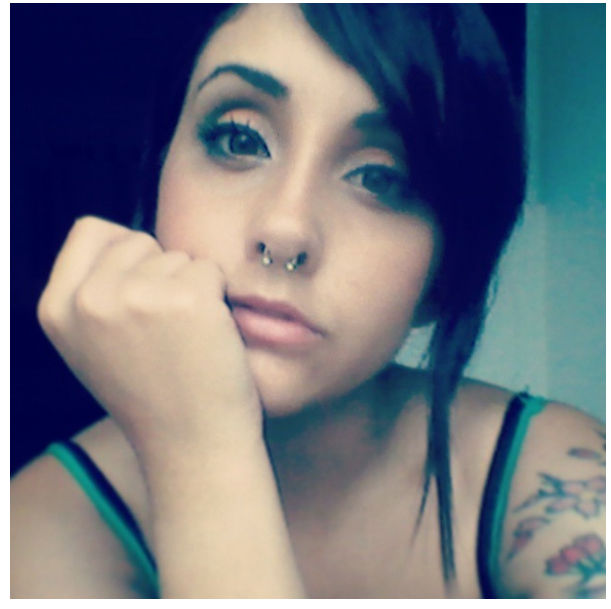

Imagen 3.19: Selfie realizado por Lorena Erre en 2013.

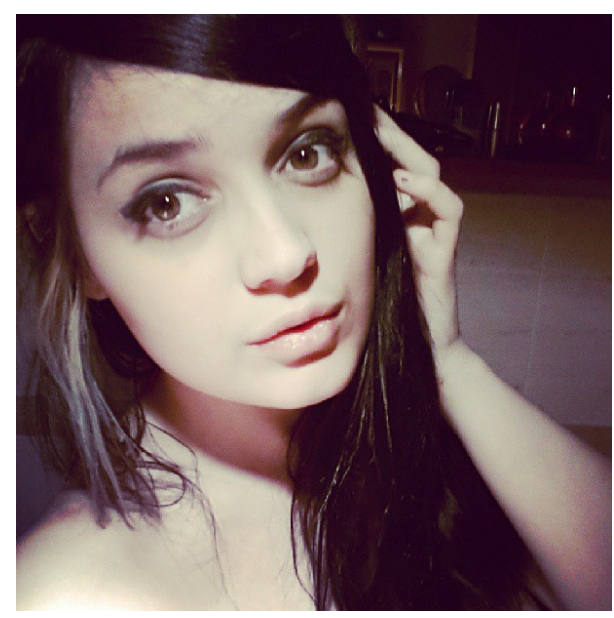

Imagen 3.20: Selfie realizado por Blanki Blue en 2012. 


\subsubsection{Otros tipos de self shots no clasificados.}

Por último, vamos a utilizar de manera muy puntual en el desarrollo de este estudio el término otro tipo de self shot no clasificado para referirnos a un tipo concreto de autorretrato digital publicado en la red raramente utilizado, pero valorable bajo nuestro punto de vista, que definimos aquí como una variante del self shot en el que la persona autorretratada hace una combinación de dos o más metologías propias del mirrorpic, del selfie primitivo y/o del selfie (Imágenes 3.21 y 3.22). En relación a esta tipología, tan solo destacar que, además de poseer escasos ejemplos, los mismos constituyen modalidades con un plus de complejidad que derivan de ejercicios de captura todavía más creativos, llegando en algunas ocasiones a combinar varios dispositivos fotográficos para realizar la toma mediante el uso de varias lentes y sensores.

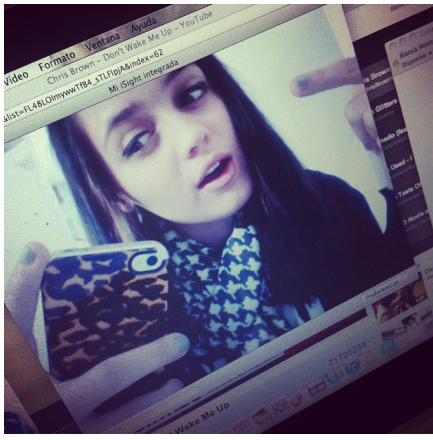

Imagen 3.21: Fotografía realizada por Blanki Blue en 2013. Se trata de un self shot con una razonable dosis de complejidad: un autorretrato que representa la propia imagen de Blanki, que a su vez es presentada sobre una pantalla que hace las veces de espejo gracias a su webcam. Se trata, por ello, de un reflejo simulado que captura con su smartphone: una fotografía imposible de realizar sin la combinación de dos lentes en dispositivos separados y enfrentados.

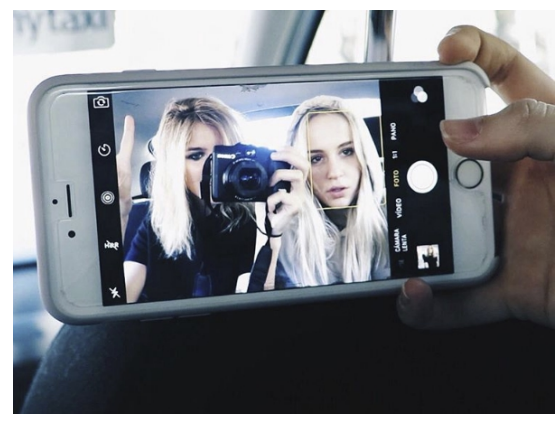

Imagen 3.22: Otro tipo de autorretrato similar al anterior realizado en 2017 y publicado en Instagram por la usuaria @irimatic. En él vemos un ejercicio similar al anterior, aunque en lugar de ser una fotografía realizada por un smarthone a la pantalla-espejo que una webcam produce sobre el monitor de una computadora, es, en este caso, una fotografía realizada con una cámara fotográfico-digital a la pantalla-espejo que una lente frontal produce sobre la pantalla de un smartphone. 


\subsubsection{Algunos apuntes aclaratorios.}

Antes de empezar a desarrollar el resto de puntos y capítulos que seguirán haciendo referencia a nuestro objeto fotográfico de estudio (fruto de los desarrollos durante la década pasada de la figura del adolescente emancipado fotográficamente, de la cámara digital popularizada por cultura y coste y de la red como espacio de publicación instantáneo en el ciberespacio), consideramos oportuno añadir algunas breves aclaraciones que nos parecen pertinentes.

La primera de ellas responde a nuestro deseo de puntualizar que la gran mayoría de las imágenes estudiadas en este trabajo (o que sirven como ejemplo para su desarrollo) presentan mujeres. Hemos intentado, pues, mantener la proporción cuantitativa que asumen en su producción, dado que nos enfrentamos a un fenómeno realizado mayoritariamente por mujeres ${ }^{26}$ jóvenes $^{27}$ (Imagen 3.23), especialmente en sus primeras fases cronológicas. Así pues, pese a que veremos figuras masculinas a lo largo de las siguientes páginas (Imagen 3.24), su proporción será sustancialmente menor a la protagonizada por chicas

26 El estudio realizado por Selfimetric asegura que las mujeres se hacen autofotos en un porcentaje mucho mayor que los hombres, en algunos casos, como en el de la ciudad de Moscú, llegan a representar hasta el $82 \%$ de este tipo de fotos. ALPAÑÉS, Enrique, "Muerte por «selfie»: la realidad que esconden los números", 2016, disponible en: <https://elpais.com/elpais/ 2016/02/04/tentaciones/ 1454589530_250716.html> [Fecha de consulta: 20 de abril de 2017]. Asimismo, "la aparición de tendencias mundiales y que son apropiadas corporalmente por los jóvenes (especialmente las mujeres), generan comportamientos y actitudes que transforman las construcciones identitarias del sujeto". BORERO OSORIO, Alejandra y LONDOÑO GUTIÉRREZ, Suanny, "Mujer Selfie, construcción de un discurso femenino adolescente mediado por el consumo de la imagen", en $V$ Encuentro Internacional de Investigadores en Publicidad (RELAIP), Alicante, 2016, pág. 127.

27 La web de periodismo de datos Priceonomics ha evaluado y calculado que el $30 \%$ de los selfies que hay en la red están hechos por personas de entre 18 y 24 años. ALPAÑÉS, Enrique, Ídem. No obstante, el porcentaje es igual o mayor (según qué medio lo evalúe) en el caso de los menores de edad. Muchos estudios coinciden también con estos datos, asegurando que desde la década pasada la práctica del self shot ha sido realizada principalmente por gente joven: GÓMEZ-CRUZ, Edgar y ARDĖVOL, Elisenda, "Cuerpo privado, imagen pública: el autorretrato en la práctica de la fotografía digital", en Revista de dialectología y tradiciones populares, vol. $67, \mathrm{n}^{0} 1$, 2012, pág. 188 . No obstante, como veremos, esa proporción acabará balanceándose hacia gran parte del público postadolescente y adulto a lo largo de nuestra década con la popularización de la práctica y la epidemia de nuevos dispositivos que invitan a la práctica del selfie. 
adolescentes. Tal y como hemos comentado anteriormente, somos conscientes del posicionamiento subjetivo que distribuye una gran parte de este tipo de imágenes en la red en según qué superficies de publicación (o reedición), dadas las estructuras patriarcales y machistas que pueden seguir operando mayoritariamente en algunos sectores del ciberespacio ${ }^{28}$. No obstante, también deseamos reseñar la gran cantidad de espacios personales existentes en los que la mujer no solo ha gozado de una total libertad, control y voluntad creativa, sino donde también ha dominado la manufactura de los grandes hitos que han reconfigurado una gran parcela de la imagen fotográfica contemporánea practicada en gran medida por las masas. A esto sumamos, asimismo, que un intento objetivo de analizar por nuestra parte aquello que hemos constatado durante estos años de investigación en la cotidianeidad de la calle y en escenarios sociales, podría poner de manifiesto que este tipo de prácticas del autorretrato digital publicado en la red, junto con todos sus poderosos estatutos, ha estado y está mayoritariamente en las manos de las jóvenes mujeres de las sociedades desarrolladas $^{29}$. Por pura lógica, y pese a que las recomendaciones de uso de la lengua española no hayan dado todavía ese paso, también utilizaremos en muchas ocasiones durante este estudio pronombres y/o artículos femeninos (las

28 “[...] la escasa participación de las mujeres en la sociedad de la información, tanto en las fases de diseño de las tecnologías como en la producción de contenidos, no es tenida en cuenta, ni son analizadas debidamente las consecuencias que esto tiene para las características que definen a la actual Internet. Es una realidad que las brechas digitales existen, y ello no tiene que ver ni con el miedo a las tecnologías ni con la ignorancia o la incapacidad de acceso. Si bien la ciencia moderna surge con la exclusión de las mujeres y el exterminio de algunas de las formas en las que se expresaba un conocimiento que les era propio, a lo largo de la historia se ha dado un proceso lento y gradual de incorporación femenina a las actividades científicas y tecnológicas [...] la equidad de acceso al territorio digital entre varones y mujeres aún es una meta a alcanzar". BONAVITTA, Paola; CAMACHO, Jeli E. y DE GARAY, Jimena, "Mujeres, feminismos y redes sociales. Acceso, censura y potencialización”, en Question, vol. 1, nº 48, 2015, pág. 35.

$\mathrm{Al}$ respecto, cabe señalar que hay algunos estudios que apuntan a un uso diferenciado del ciberespacio por según que sexo: “[...] en internet se hallan de nuevo diferencias entre los dos géneros como ocurre con el resto de tecnologías. Para los chicos el atractivo principal corresponde al ocio lúdico, principalmente los videojuegos, mientras que para las chicas el atractivo principal se centra en el ocio comunicativo a través de conversaciones por chat, Messenger o correo electrónico. [...] los chicos prefieren descargar juegos y videoclips, mientras que las chicas se inclinan más por el chat y los mensajes instantáneos”. VÁZQUEZ, María F., La cultura visual en la adolescencia, Sevilla, Universidad de Sevilla, 2015, pág. 30. 
modelos, las autorretratistas, las selfshooters...) para referirnos a un conjunto de mujeres y hombres cuya proporción es favorable hacia estas.

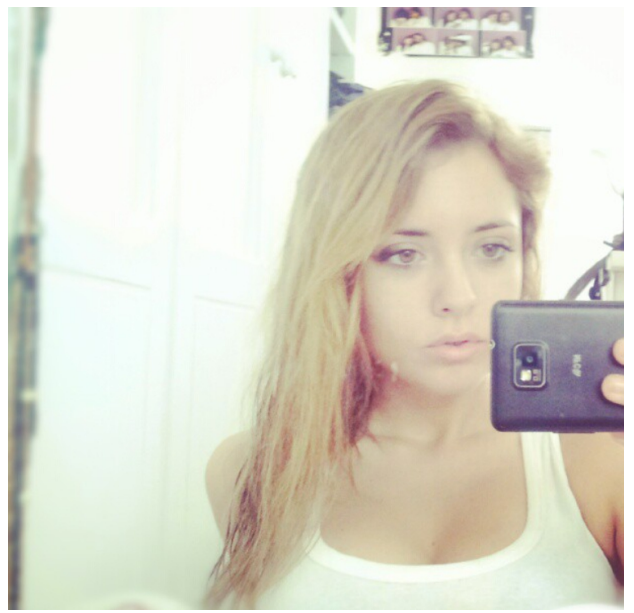

Imagen 3.24: Autofoto de tipo mirrorpic realizada y publicada por @_isabeltormo en Instagram en 2012.

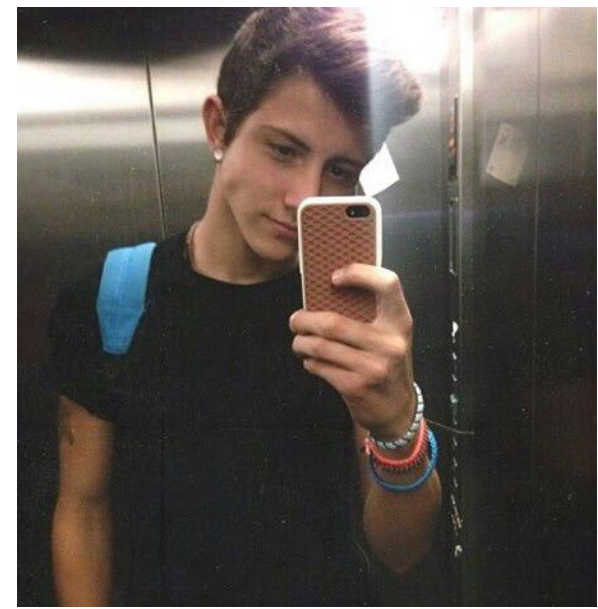

Imagen 3.25: Otro ejemplo de autorretrato digital publicado en la red realizado, en esta ocasión, por un hombre joven.

Respecto a la edad de las modelos, se trata de un tema complejo de averiguar en fotografías anónimas, cuando además, están realizadas generalmente por adolescentes y postadolescentes. De momento ningún lector de imágenes artificial es capaz de averiguar la edad de la persona representada en una imagen mediante la lectura y reconocimiento de los píxeles que la forman.

No obstante, en muchas ocasiones es fácil realizar un rastreo para averiguar la edad de la modelo representada, siempre y cuando confiemos en la fecha de nacimiento que aporta como dato en sus redes sociales de publicación y cruzando esa fecha con los metadatos EXIF del archivo JPG estudiado o con los datos de publicación en dicha red que, generalmente, suponen instantaneidad 
respecto a la toma (sobre todo si se ha realizado con la cámara de un smartphone).

Visto esto, debemos puntualizar que se ha tenido especial cuidado en la elección de estas fotografías (pese a ser públicas y de libre consulta en la Web) y, en muchas ocasiones, se ha obtenido el consentimiento de la modelo. Asimismo tenemos la garantía de que todos los cuerpos desnudos que aparecen en estas páginas pertenecen a mujeres mayores de edad. Remarcamos esta circunstancia, dado que nos vemos en la obligación moral de ser cuidadosos con estas cuestiones que, tal como veremos en el capítulo 5, son de gran importancia social, puesto que pueden acarrear problemas al ya de por sí frágil colectivo adolescente.

\subsection{Breve historia del autorretrato digital publicado en la red.}

Para conseguir abordar de una manera más ordenada este breve recorrido por lo que podemos considerar una historia del self shot desde sus orígenes hasta nuestros días, hemos considerado oportuno dividir este transcurso en tres etapas que, además, consideramos bien diferenciadas debido a los cambios producidos en las prácticas en torno a este tipo de autorretrato, así como a la actitud y franjas de edad de sus autoras, y a las drásticas transformaciones que han afectado a las herramientas conformadoras y publicadoras, unos hechos que, por tanto, también han transformado este propio objeto fotográfico dándole además una visibilidad cada vez mayor. 
Dividimos, pues, este camino en tres etapas (Imagen 3.26):

- Una primera etapa que llamaremos fase de desarrollo del self shot. Esta fase comprenderá desde los primeros autorretratos digitales publicados por parte del colectivo adolescente en las primeras redes sociales como MySpace, Fotolog o Metroflog (años 2004, 2005 y 2006), hasta la llegada de los primeros smartphones con cámara frontal ${ }^{30}$ y la popularización de la red social fotográfica Instagram (año 2010).

- Una segunda etapa que denominaremos fase de consolidación formal del self shot y de expansión del selfie. Este periodo abarca desde la llegada de los primeros smartphones con cámara frontal y la popularización de la red social fotográfica Instagram (año 2010), hasta la viralización tanto del término como de su metología práctica gracias no solo al nombramiento como palabra del año por parte de The Oxford English Dictionary (finales de 2013), sino también al impacto mediático del selfie de la $86^{\mathrm{a}}$ ceremonia de los Premios Oscar, mejor conocido como el "Selfie de los Oscar" (marzo de 2014).

- La tercera y última etapa la definiremos como la de la fase de popularización del self shot. Esta fase se extiende desde la viralización tanto del término como de su metología práctica gracias al nombramiento como palabra del año por parte de The Oxford English Dictionary (finales de 2013) y al impacto mediático del selfie de la 86 ${ }^{\mathrm{a}}$ ceremonia de los Premios Oscar (marzo de 2014), hasta el día de hoy.

30 No confundir con la cámara trasera o principal de la que ya disponían desde su invención al igual que muchos tipos de teléfonos celulares. 


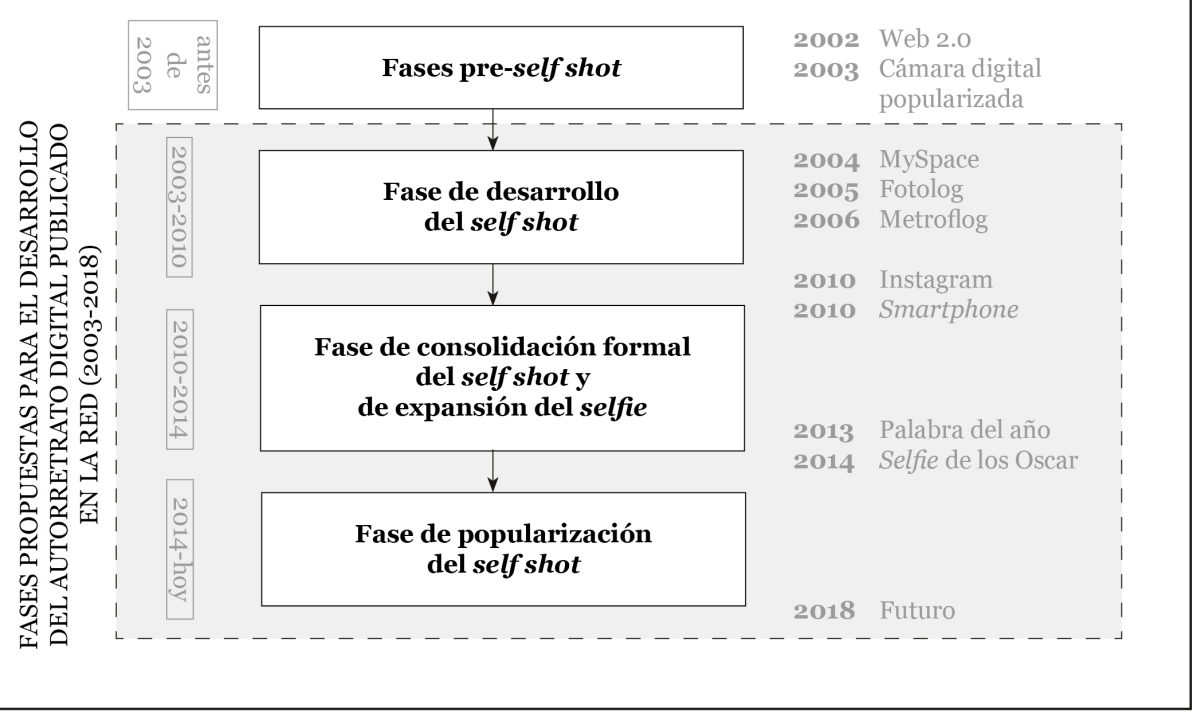

Imagen 3.26: Gráfico cronológico que muestra las tres fases propuestas para el desarrollo del autorretrato digital publicado en la red.

Cabe señalar que estas fronteras cronológicas no son rotundas, sino que podrían quedar desdibujadas durante los meses de sus fechas de relevo. En cualquier caso, los momentos que hemos destacado no conllevan cambios drásticos, sino transiciones diluidas y no bruscas, aunque generadoras de fases e instantes diferenciados.

No obstante, antes de andentrarnos en la primera fase de las que hemos mencionado, es necesario recordar que en el "adueñamiento de las imágenes por parte de las masas" ${ }^{11}$, podemos hablar de un proto-self shot que, si bien se realizaba con algunos de sus paradigmas constructivos y formales, todavía no alcanzaba el grado de "objeto voluntaria o involuntariamente publicado", por lo que quedaba reservado para la esfera privada, encerrado en las cámaras y en las 
computadoras, formando parte de un divertimento experimental (Imagen 3.27) relacionado con la ya creciente rutina de registrarlo todo ${ }^{32}$, o con el juego sexual e identitario de la autorrepresentación. Respecto a esto último, veremos expuesto en el capítulo 8 el ejemplo de Natacha Merritt (Imagen 3.28) como uno de los ejemplos más representativos de este proto-self shot erótico o autorretrato digital no publicado en la red.

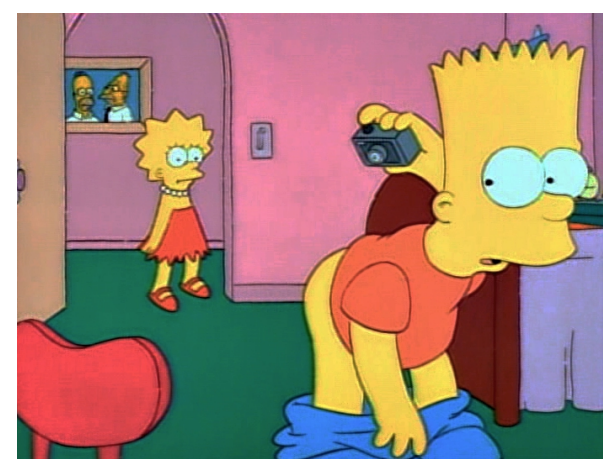

Imagen 3.27: El personaje animado Bart Simpson realizándose una autofoto de sus posaderas desnudas con una cámara digital compacta, siendo sorprendido por su hermana en un episodio de la serie Los Simpson

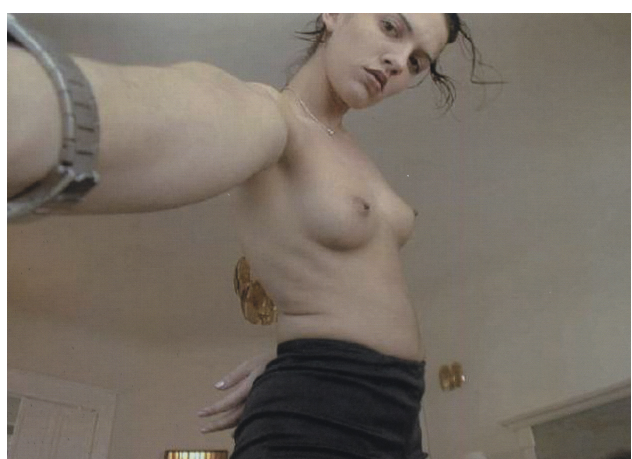

Imagen 3.28: Uno de los autorretratos digitales no publicados en la red (pero sí en soporte libro) de Natacha Merritt, que volveremos a ver en el capítulo 8 cuando repasemos su obra. A nuestro entender debe de ser considerado como un protoself shot.

Algo que se habría incrementado en demasía con la llegada de la fotografía digital y sus posibilidades. FONTCUBERTA, Joan, La cámara de Pandora. La fotografi@ después de la fotografía, Barcelona, Gustavo Gili, 2010, pág. 30. Este hecho, a su vez, marcaba una nueva ceremonialidad que no era más que la progresión de aquellas prácticas rituales y estereotipadas propias de la fotografía argéntica en manos de las masas. Pensemos, por ejemplo, en el cliché al que respondían las fotografías en grupo realizadas por los turistas delante del monumento de turno. BOURDIEU, Pierre, Un arte medio, Barcelona, Gustavo Gili, 2003, pág. 79. 


\subsubsection{Fase de desarrollo del self shot (2004-2010).}

Aunque en los capítulos 4, 5 y 6 analizaremos de manera más desglosada y detallada cómo el objeto fotográfico acotado como autorretrato digital publicado en la red o self shot, al igual que todas sus variantes, ha sido posible, hemos de partir ahora de un hecho: el fenómeno que estudiamos surge como consecuencia de la conjunción de tres factores:

- La existencia de un adolescente emancipado fotográficamente ${ }^{33}$, autodidacta de este medio y con grandes necesidades de experimentación física, identitaria y compositiva a través del autorretrato, ejercicio habitual a principios de nuestro siglo XXI.

- El surgimiento de un dispositivo de captura fotográfico-digital ya democratizado ${ }^{34}$ en 2004 cultural y económicamente, lo que suponía, al menos, uno o dos aparatos capturadores de imágenes digitales en cada hogar de las sociedades desarrolladas ${ }^{35}$.

Como veremos más adelante, en "los años finales del siglo XX la característica ha sido la implantación de las nuevas tecnologías y la aplicación de la fotografía digital a todos los campos. Pero su influencia no es solo material o mecánica, sino mental [...], y los jóvenes creadores consideran la fotografía digital como un medio más en su experimentación”. SÁNCHEZ-VIGIL, Juan Miguel, El documento fotográfico. Historia, usos, aplicaciones, Gijón, Trea, 2006, págs. 52-53.

34 De hecho, datos de 2005 nos arrojan unas cifras que demuestran lo populares que ya eran en los hogares las tecnologías relacionadas con los ordenadores, cámaras y conexiones a Internet, elementos fundamentales para el desarrollo de nuestro objeto de estudio: "Si se atiende a las cifras proporcionadas por un informe realizado por AdEsE en [...] 2005, cifras que han debido elevarse considerablemente en la actualidad, se puede esbozar una idea aproximada de la relevancia que las nuevas tecnologías tienen en España. Según el informe en estas fechas más de la mitad de los hogares españoles disponía de ordenador, y de ellos el 64\% tenía acceso a Internet. El 12\% contaba con ordenadores portátiles. El 80\% de los hogares tenía teléfonos móviles”. VÁZQUEZ, María F., op. cit., pág. 17.

35 Ya que, como también veremos, el "medio fotográfico ha conocido una profunda transformación en los últimos quince años, como consecuencia de la introducción de las tecnologías digitales en el campo de la fotografía. En efecto, a finales de los ochenta y principios de los noventa del pasado siglo, las tecnologías digitales hicieron su aparición en el campo del tratamiento digital de las imágenes fotográficas; pocos años después, ya empezada la primera década del siglo XXI, irrumpieron con fuerza los dispositivos de captura de imagen basados en la tecnología digital". MARZAL, Javier, "La 
- Y, como tercer y último factor, la disponibilidad de un lugar virtual de exhibición online, generador de un ciberespacio que los jóvenes construirán a su antojo, como usuarios poseedores de un control total del soporte Internet gracias a la implementación de la Web 2.0 en torno a 2002 y la llegada de las primeras redes sociales hacia 2004.

Así pues, a lo largo de la pasada década, fueron los adolescentes los que cimentaron las bases (con sus prácticas del autorretrato íntimo visibilizado) de un tipo de imagen fotográfica muy reconocible, sobre todo en los años finales de esta fase, dada la ingente cantidad de estas imágenes que fueron realizadas por todo el globo.

Estos autorretratos inundaron después el ciberespacio y mostraron a sus jóvenes creadoras en sus habitaciones y cuartos de baño, generalmente en el ámbito privado del hogar (Imágenes 3.29, 3.30, 3.31 y 3.32), generando un elemento fotográfico que sería "eminentemente local en su producción, aunque [...] global en su recepción" ${ }^{36}$. La llegada del smartphone como "cámara de fotos siempre en el bolsillo", así como la consolidación cultural del self shot en las redes sociales, llevará este ejercicio a cualquier ámbito público, pero es en torno al material producido durante esta primera década del siglo XXI donde más autorretratos de interior hemos encontrado.

muerte de la fotografía: la revolución digital y la crisis de identidad del medio fotográfico", en Revista de Occidente, $\mathrm{n}^{0}$ 328, 2008, pág. 68.

36 PÉREZ, Johanna, "Fotografía en tiempos de darwinismo tecnológico", en Aularia. Revista digital de comunicación, vol. 4, $\mathrm{n}^{0}$ 1, 2015, pág. 13. 


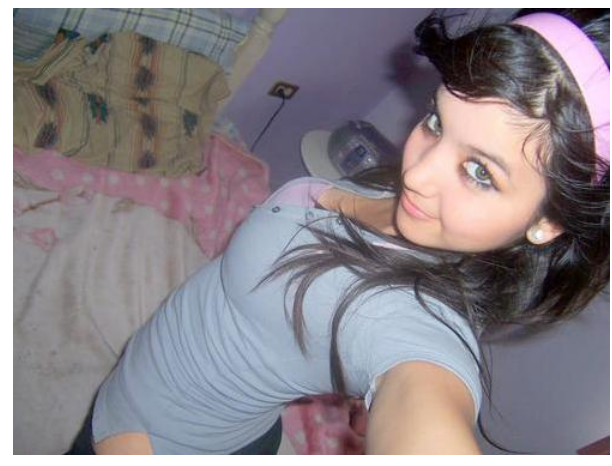

Imagen 3.29: Selfie primitivo realizado por Mónica Liseth Murillo en 2007 y publicado por ella misma en su cuenta de la red social Metroflog. Repasaremos en el capítulo 5 la figura de esta adolescente y su sorprendente caso de popularidad espontánea a través de un espacio propio en red, uno de los primeros en surgir durante esta nueva era del autorretrato.

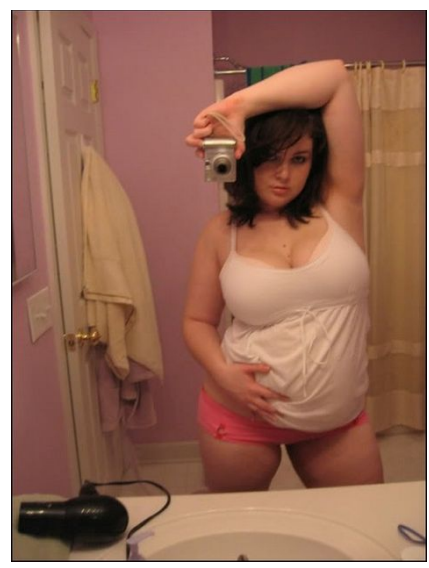

Imagen 3.31: Autorretrato digital publicado en la red de tipo mirrorpic. Uno de los muchos cuerpos reflejados en los espejos de los cuartos de baño que veremos a lo largo de este estudio y que empezaron a difundirse durante la etapa temporal que aquí tratamos.

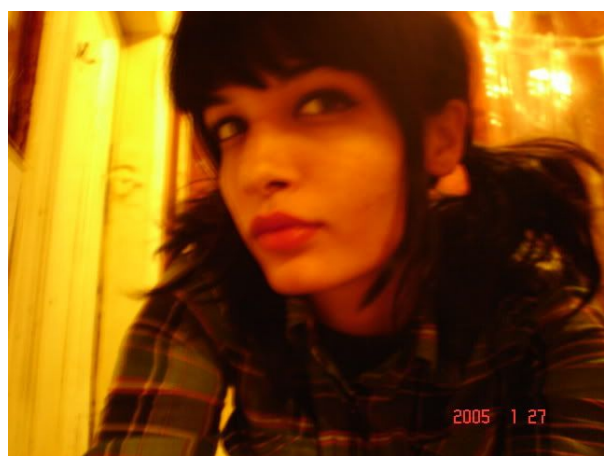

Imagen 3.30: Selfie primitivo de Melissa Eve realizado con una cámara compacta en 2005. Uno de los autorretratos digitales publicados en la red más antiguos que hemos encontrado.

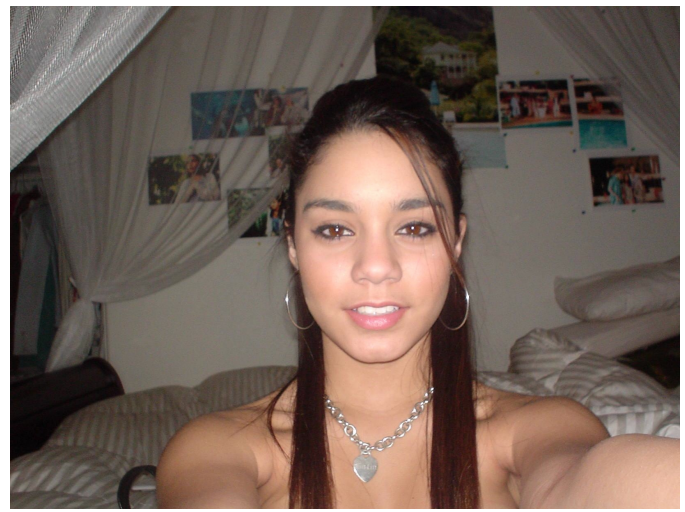

Imagen 3.32: Autorretrato digital publicado en la red de manera no voluntaria tras la primera filtración de fotografías íntimas de su autora, la actriz estadounidense Vanessa Hudgens, en 2007. 
De este modo, tomarse autorretratos y posteriormente publicarlos ${ }^{37} \mathrm{o}$ compartirlos pasaría a convertirse a lo largo de esta década en una práctica generaliza en la vida cotidiana de cualquier adolescente del globo que tuviera acceso a estas tecnologías:

"Los autorretratos cada vez se integran más como parte de la cotidianeidad y ya no resulta extraño ver a alguien tomarse una foto con el brazo extendido y en Internet pueden contarse por millares las imágenes en las que aparece una o más personas tomándose una foto frente a un espejo, práctica que, sobre todo, parece aún mucho más común entre los jóvenes” ${ }^{38}$.

La propagación de esta imagen y su continua repetición y visibilidad, además, la iba a dotar en estos años de una narrativa propia en las redes sociales $^{39}$, transformando una imagen privada y reservada en un elemento público reconocible.

"Antiguamente las fotos eran reservadas al círculo familiar. Ahora quedan a disposición de todos los internautas. Quizás pueda compararse este cambio a la revolución que originó la imprenta, poniendo poco a poco a disposición de todos los textos antes reservados a eruditos. Por cierto, es imposible visualizar aún las consecuencias culturales futuras. La misma tecnología ha demostrado evolucionar en forma imprevisible" ${ }^{40}$.

37 Hay que tener en cuenta que, durante esta primera fase de desarrollo del self shot, las publicaciones no son instantáneas, pues la distancia entre el dispositivo de captura y la computadora publicadora todavía no se ha reducido hasta la inexistencia, como en el caso de los actuales smartphones. LISTER, Martin, “¿Demasiadas fotografías? La fotografía como contenido generado por el usuario", en adComunica. Revista científica de estrategias, tendencias e innovación en comunicación, $\mathrm{n}^{\circ} 2$ (Ejemplar dedicado a: Nuevas tendencias e hibridaciones de los discursos audiovisuales en la cultura digital contemporánea), 2011, págs. 33-34. Este transcurso de tiempo indeterminado entre la toma y la publicación también es propio (aunque no exclusivo) de esta primera fase temporal del autorretrato digital publicado en la red. GÓMEZ-CRUZ, Edgar y ARDÈVOL, Elisenda, op. cit., pág. 191. LEONARDO, Norberto, "Del mito del Narciso a la selfie. Una arqueología de los cuerpos codificados", en Palabra clave, vol. 18, $\mathrm{n}^{\circ}$ 3, 2015, pág. 676.

40 COLLE, Raymond, "La revolución de la fonofotografía. Teléfonos con cámara y redes sociales", en Revista mediterránea de comunicación, $\mathrm{n}^{\circ} 4,2013$, pág. 32. 
Así pues, esta práctica realizada por el colectivo adolescente devendrá uno de esos elementos propios con el que la fotografía digital buscará su lugar en el mundo de las imágenes, no solo mediante una producción desmesurada respecto a su química predecesora ${ }^{41}$, sino también a través de tiempos, objetos y procesos conjugados con distintas prácticas novedosas que legitiman el hecho de que estamos ante un medio heredero del anterior, pero con nuevas posibilidades ${ }^{42}$, cuestión que permitiría alejar su práctica de todos esos vaticinios con los que muchos teóricos ${ }^{43}$ han apuntado a una posible muerte de la fotografía ${ }^{44}$ al incidir en la diferenciación, incluso desde sus tímidos albores, entre las eras analógica y digital ${ }^{45}$.

No obstante, sea como sea, esta democratización fue creando una dependencia en sus usuarios a lo largo de la década pasada. Hace veinte años, en los inicios del desarrollo de la tecnología digital aplicada a la fotografía, ya se pensaba que la fotografía desempeñaba un papel capital y que apenas existía

41 "Hoy se toman cerca de 1000 millones de fotografías al día y se hacen más fotos en dos minutos que las que se hicieron en todo el siglo XIX". COLLE, Raymond, op. cit., pág. 6.

RABADÁN, Ángel V., "Selfie y la impronta visual: el autorretrato 3.o. Representación, presentación, corporealización”, en Icono14, vol. 14, $\mathrm{n}^{\circ}$ 2, (Ejemplar dedicado a: Digital Economy and its Impact in the Media), 2016, pág. 31.

Entre ellos: BELTING, Hans, Antropología de la imagen, Buenos Aires, Katz Ediciones, 2007; MIRZOEFF, Nicholas, Una introducción a la cultura visual, Barcelona, Paidós, 2003; MITCHELL, William J., The Reconfigured Eye. Visual Thruth in the Post-Photographic Era, Cambridge, Massachussets, MIT Press, 1992 y RITCHIN, Fred, After Photography, Nueva York, Norton \& Company, 2008.

"La opinión crítica mayoritaria, que empezó a forjarse a finales de los años ochenta y cobró impulso con la creciente disponibilidad de esas nuevas tecnologías, se puso de parte de quienes habían intentado que nos resignáramos a la «muerte de la fotografía», ya que creían que el estatus privilegiado del medio como árbitro de la verdad y patrón de la realidad había quedado fatalmente socavado con los procesos de creación de imágenes por ordenador". GREEN, David (Ed.), ¿Qué ha sido de la fotografía?, Barcelona, Gustavo Gili, 2007, pág. 49. En todo caso, y como dice Joan Fontcuberta: "La fotografía electrónica [...] no constituye una simple transformación de la fotografía fotoquímica sino que introduce toda una nueva categoría de imágenes que ya hay que considerar "posfotográficas». La pregunta de si la fotografía digital es todavía fotografía, no tiene respuesta concluyente". FONTCUBERTA, Joan, op. cit., págs. 60-61. Abordaremos mejor este tema a lo largo del capítulo 4 dedicado al dispositivo de captura fotográfico-digital.

"[...] hay que distinguir entre la información transmitida por la fotografía canónica y la transmitida por la imagen fotónica. Al mismo tiempo, hay que distinguir la recepción analógica de la recepción cibernética”. SCHAEFFER, Jean-Marie, La imagen precaria. Del dispositivo fotográfico, Madrid, Cátedra, 1990, pág. 56. 
actividad humana que no la utilizara de uno u otro modo. Se había vuelto indispensable tanto para la ciencia como para la industria y había sido el punto de arranque de los mass media ${ }^{46}$.

Durante esta fase del desarrollo del self shot, esa dependencia y práctica de la fotografía, más que diaria, se convirtió en instantánea, extendiéndose a muchísimas más actividades humanas (prácticamente a todas), hasta convertirnos en una sociedad fotográfica a través de lo digital. Esta explosión, a su vez, fue tan rápida como sorpresiva:

"La irrupción de las nuevas tecnologías de la imagen, y más concretamente de la fotografía digital, no ha hecho sino complicar aún más e introducir mayor confusión, al menos aparentemente, en la propia concepción del medio fotográfico y de la llamada sociedad digital. [...] la aparición de las nuevas tecnologías de la imagen no solo supone un cambio en los modos de construir y crear las imágenes, sino sobre todo se cree que estos cambios están relacionados con los modos de conocer y de interrelacionarnos con el mundo. [...] solemos olvidar que la imagen fotográfica, aunque sea actualmente un objetivo de la tecnología digital, es ante todo un objeto cultural" ${ }^{47}$.

Como hemos visto, la suma de estos motivos (y algunos otros) propició que el adolescente se apropiara de la práctica fotográfica durante aquella fase. El hecho de disponer en cada hogar de ese medio de autorrepresentación gratuito (que eran las cámaras digitales asequibles, las webcams de las computadoras o los celulares con cámaras de baja calidad), junto con, quizá, la energía, el tiempo libre o el aburrimiento propios de esas edades, sería lo que fomentó esa tentación de representar, compartir y publicar el propio cuerpo autorretratado:

"Sin embargo, la más extrema digitalización y fracticidad de su representación no se produce en un momento de crisis de su imagen real. Hoy lo corporal parece

46 FREUND, Gisèle, La fotografía como documento social, Barcelona, Gustavo Gili, 1998, pág. 8.

47 MARZAL, Javier, op. cit., pág. 87. 
revalorizarse como símbolo de una época de fuerte estetización donde prima la apariencia y la satisfacción urgente de las demandas del cuerpo. Como si el cuerpo temeroso de su plena digitalización se entregara al mundo para reivindicarse antes de ser neutralizado y reducido a su imagen, lo inmaterial, el no-cuerpo" 48 .

Fuimos de esta manera testigos de cómo "las fotos que los adolescentes intercambian de modo compulsivo" iban a recorrer "un amplio espectro de códigos de relación, desde simples gestos salutatorios [...] hasta expresiones más sofisticadas que traducen afecto, simpatía, cordialidad, encanto o seducción" ${ }^{49} \mathrm{y}$, pese a que durante estos años estuviéramos enfrentándonos al nacimiento de unos nuevos objetos fotográficos aparentemente azarosos y cargados de banalidad, el impacto mediático y la consolidación icónica que iban a recibir en el futuro, podrían haber puesto de manifiesto que, en realidad, tal y como había sucedido con las fotografías de aficionados durante décadas pasadas, también estas imágenes eran capaces de llegar a alcanzar, en según qué casos, una auténtica calidad estética y ser ejemplos de prácticas fotográficas más complejas y valorables:

"La fotografía ingenua o comercial o meramente utilitaria no difiere en condición de la fotografía como la practican los profesionales más talentosos: hay imágenes obtenidas por aficionados anónimos que resultan tan interesantes, y formalmente tan complejas y representativas de los poderes propios de la fotografía, como las de un Stieglitz o un Evans" ${ }^{\circ}$.

Si analizamos las imágenes producidas durante aquel lustro (la segunda mitad de la década que inauguraría el siglo XXI), que pudimos en su día recopilar y hoy en día ampliar mediante un rescate entre los restos que subyacen por un ciberespacio casi olvidado, descubrimos cómo, bajo todos aquellos autorretratos

ZAFRA, Remedios, Un cuarto propio conectado. (Ciber)espacio y (auto)gestión del yo, Madrid, Fórcola ediciones, 2010, pág. 83. 
de espejo de cuarto de baño, estaban enterrados una serie de referentes e intenciones basadas en los cánones que la imagen publicitaria y erótica (objetos presentes en nuestro contexto histórico) invitaban a imitar ${ }^{51}$. Este hecho referencial (causa del bombardeo mediante el cual los mass media asediaban la mirada de los jóvenes a través de la imagen de lo corporal) modelaría, junto con la manufactura del selfshooter y de su máquina, estos autorretratos digitales que tarde o temprano saltarían a la red (Imágenes 3.33 y 3.34):

“[...] los modelos y cánones [...] representan un ideal (perfección) de referencia para un grupo social. Estos cánones particularmente marcados en los imaginarios visuales de Occidente, pueden cuestionarse desde innumerables prismas críticos, pero sin embargo siguen estando hoy en día muy presentes en la publicidad y en los medios y me atrevería a precisar que especialmente fortalecidos en la imagen fija" ${ }^{52}$.

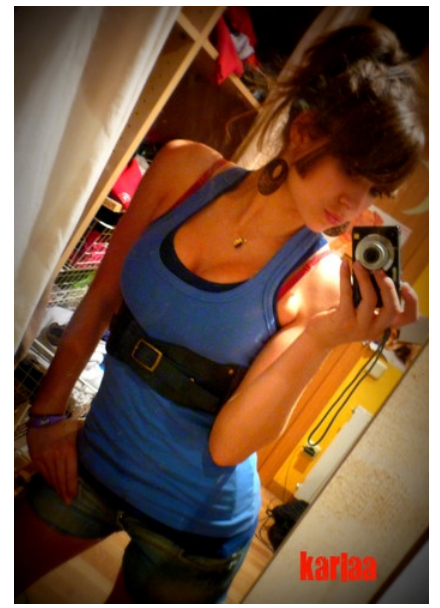

Imagen 3.35: Mirrorpic realizado por la usuaria Carla Lerín y publicado en Fotolog en 2009 por ella misma. $\mathrm{Su}$ referencia apunta a una parcela de la fotografía publicitaria.

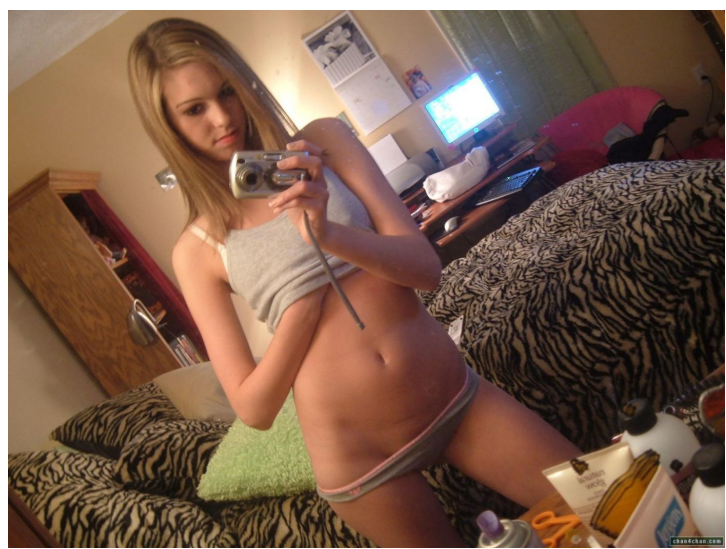

Imagen 3.35: Mirrorpic anónimo encontrado en la red y fechado en torno a 2008. Su referencia apunta a una parcela de la fotografía erótica o sensual.

51 A partir de aquí, veremos esta imitación y referencialidad repetidas hasta nuestros días en este tipo de autorretratos. Estas pautas serán repasadas con una mayor extensión y análisis en los capítulos 5 y 6 .

ZAFRA, Remedios, op. cit., pág. 87. 
De este modo, podemos concluir que terminaba la década: con el final del desarrollo creciente de un tipo de imagen fotográfica que había sido producida por las personas jóvenes mediante sus dispositivos digitales caseros, unas imágenes que serían publicadas de manera voluntaria en las primeras redes sociales y espacios personales de exhibición icónica, como Fotolog (Imagen 3.35) o MySpace, o de manera involuntaria en diferentes foros y rincones oscuros del ciberespacio. Tras este primer momento surgirá ahora una nueva fase en la que esta práctica comenzará a consolidarse, considerándose un cliché aceptado como práctica regular, lo que impulsará su extensión a mayores franjas de edad, cambiando sus estructuras formales y pautas de actitud en la creación y publicación (gracias al desarrollo de nuevos y diferentes dispositivos de captura) y también por medio de nuevas y diferentes superficies de exhibición.

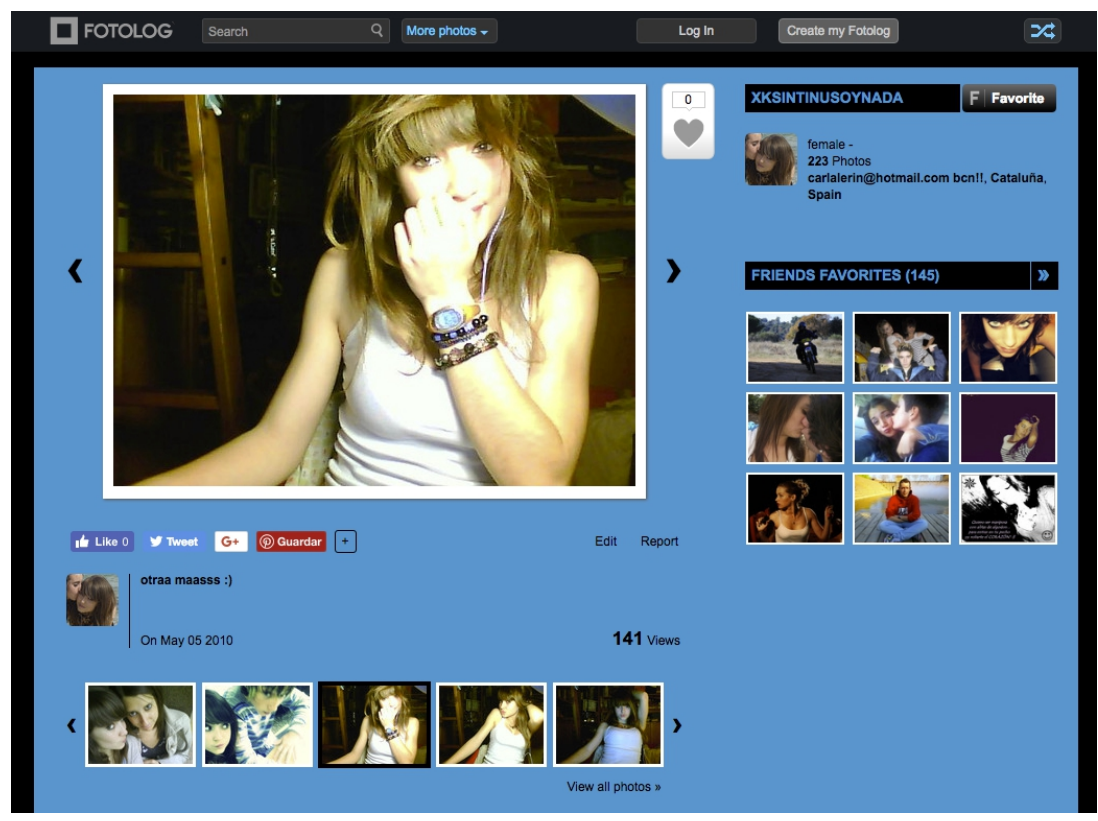

Imagen 3.35: Otro autorretrato digital publicado en la red realizado por Carla Lerín, uno de los pocos que se realizaban en aquella época utilizando la visión directa por pantalla-espejo gracias a la webcam de la computadora de su habitación. Efectivamente, puede considerarse un selfie y además podemos verlo insertado en su contexto: la red social de imagen fotográfica Fotolog. 


\subsubsection{Fase de consolidación formal del self shot y de expansión del selfie (2010-2014).}

Efectuaremos a continuación un breve recorrido por esta segunda fase que, si bien presenta unas cotas cronológicas algo más cortas respecto a las de su etapa predecesora, también supondrá, ya no una ascensión, sino una importante transformación y consolidación de las formas compositivas y protocolarias del autorretrato digital publicado en la red. Asimismo, una nueva tipología poco practicada con anterioridad asumirá el protagonismo en la mayoría de self shots a lo largo de estos años: las nuevas formas del selfie. Finalmente, aunque la visibilidad de la práctica no alcanzará a la totalidad de las masas, sí que será realizada por franjas poblacionales más diversas y la imagen cultural de este objeto fotográfico se expandirá por las praderas del ciberespacio hacia tierras más amplias y de uso común.

Bajo nuestro punto de vista, los factores más importantes causantes de todos estos tipos de transformación, consolidación y expansión de nuevos objetos formales serán tres: 1. La rápida democratización de los nuevos dispositivos de captura fotográfica que, a su vez, también tendrán la capacidad de ser una herramienta de publicación en la red siempre en el bolsillo: los smartphones ${ }^{53}$. 2 . El desarrollo de las lentes frontales en estos mismos smartphones, inicialmente como lente secundaria para realizar videollamadas y no como cámara fotográfica secundaria (rol que, azarosamente, sí que acabarán asumiendo), lo que propiciará la expansión de la autofoto mediante la visión directa por pantallaespejo, es decir, a través del selfie. 3. El surgimiento de una nueva generación de redes sociales, mucho más abiertas a círculos públicos y con un mayor grado de

53 Todo lo referente a los dispositivos digitales de captura fotográfica, incluidos los smartphones, será tratado a lo largo del siguiente capítulo. 
censura en según que casos. Desde la no tan usada por adolescentes pero si líder en cuanto a número de usuarios registrados Facebook, hasta la importante identitaria y fotográficamente hablando Instagram ${ }^{54}$.

Siempre bajo el punto de vista de nuestras observaciones a lo largo de aquellos años, nos gustaría señalar que durante esta fase se observa un incremento de los self shots fuera del hogar, quizá debido a esta capacidad del smartphone de ser simultáneamente computadora contectada a Internet y cámara fotográfica, todo de bolsillo, con ese extra de movilidad que otorga poder disfrutar de una conexión a la red sin necesidad de estar en un domicilio.

Otro factor determinante cabría vincularlo a una cierta pérdida de vergüenza en lo relativo a la visivilidad del gesto de hacerse un selfie, hecho que alcanzará unas elevadas cotas de naturalidad durante estos años, siendo una práctica cada vez más común ${ }^{55}$. En la esfera pública de Internet y de sus redes empezaremos a ver cambios en las formas de estos objetos fotográficos, sutiles en según qué ejemplos y drásticos en según qué otros. Ahora bien, en cualquiera de ambos casos, generando siempre nuevas estructuras fotográficas por las causas ya comentadas en torno a la transformación de los medios fácticos. Así, por ejemplo, pese a encontrar construcciones compositivas de cámara picada hacia el eje decreciente cabeza-cuerpo-pies, un mayor control en el encuadre y desvío de la mirada apuntaría a la sustitución del selfie primitivo por un selfie (Imagen 3.36), que a su vez, y como veremos (Imagen 3.40), evolucionará hacia encuadres

Estas y muchas otras redes sociales utilizadas a lo largo de estos quince años serán analizadas en profundidad en el capítulo 6 .

"Si paseamos por la calle de cualquier ciudad es fácil encontrarse con un grupo de gente tomando fotografías. A veces, como es habitual en las grandes ciudades, capturando los elementos más significativos y de interés turístico; otras veces vemos que simplemente hacen fotos en grupo. Alejan la cámara estirando el brazo todo lo que pueden para encuadrarse, a veces con ángulos picados y haciendo muecas. [...] Mientras, alguien en su casa improvisa un autorretrato haciendo una fotografía al reflejo del espejo sin descuidar que se vean detalles de su casa o al contrario, cuidando a la perfección hasta el más mínimo detalle para que todo sea perfecto". CALDEVILLA, David, "Las redes sociales. Tipología, uso y consumo de las redes 2.0 en la sociedad digital actual”, en Documentación de las ciencias de la información, $\mathrm{n}^{0}$ 33, 2010, págs. 79-80. 
más frontales y próximos al rostro, bajo formas más propias del retrato. Por otro lado, la aplicación de los primeros filtros de estética retrofotográfica que permitía (y permite) añadir a la red social Instagram las fotografías publicadas (Imagen 3.37), también supondrá una huella y marca perfectamente reconocible en esta fase de principios de nuestra década.

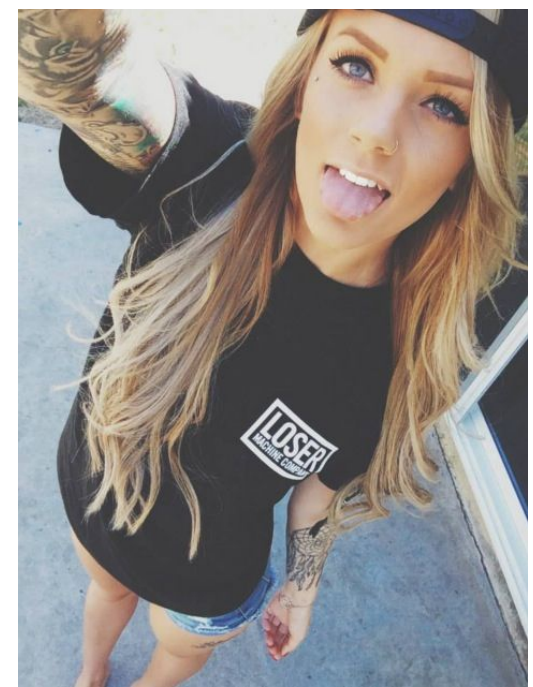

Imagen 3.36: Selfie anónimo encontrado en la red, en torno a 2014. El formato, el desvío de los ojos y el filtro aplicado apunta a un autorretrato hecho con un smartphone durante esta década, aunque su resultado sea más propio de la pasada.

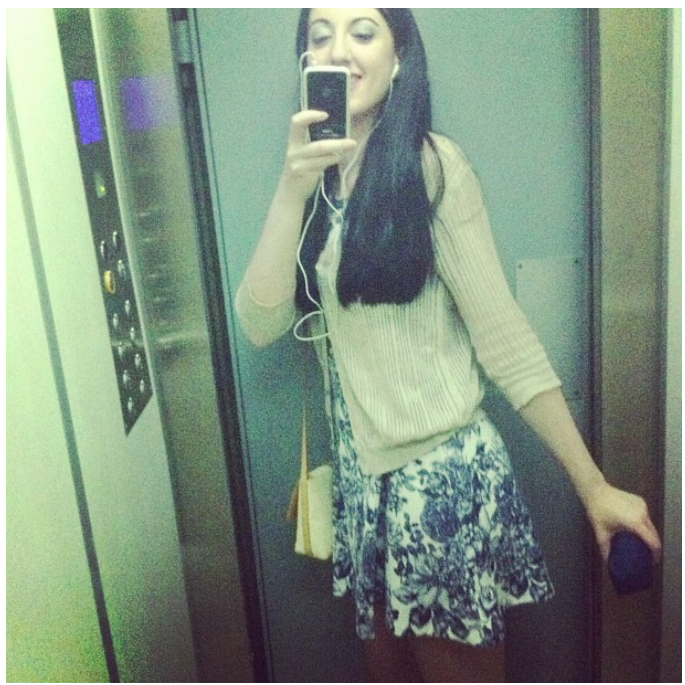

Imagen 3.37: Self shot de tipo mirrorpic realizado contra el espejo de un ascensor y publicado por Marisol Salanova en su cuenta de Instagram durante 2012.

Como hemos comentado anteriormente, los cambios de etapa no suponen un corte dramático ni tampoco un abandono de las viejas prácticas. Seguiremos viendo en estos años una producción (quizá no tan desmesurada y menos descontrolada en cuanto a la voluntad de publicación) de autorretratos ante espejos ubicados en lugares privados del hogar. No obstante, este tipo de imágenes se va a volver más visible por voluntad directa de sus autoras y autores, 
siendo publicadas habitualmente en la plataforma que por aquel entonces significaba la red social fotográfica Instagram, siempre con unos baremos de muestra del cuerpo adecuados, no solo al atrevimiento lógico de las autorretratistas en su exhibición pública, sino también hacia las normas de censura de estas redes sociales ${ }^{56}$.

Estas nuevas imágenes pseudoeróticas serán realizadas en lugares públicos, como playas o piscinas, aunque generalmente seguirán asociadas a interiores. La autoafirmación de la belleza mediante la muestra de unas partes más o menos prohibidas del físico, nos dará las evidencias del desarrollo de un incremento del culto al cuerpo y de su customización por medio del tatuaje y/o del fitness (Imágenes 3.38 y 3.39). Asimismo, en estos ligeramente variados mirrorpics se puede observar no solo la presencia de la nueva herramienta fotográfica reflejada en los espejos (el smartphone), sino un ligero detrimento del ángulo fotográfico y, cómo no, los inconfundibles filtros de la red social que en su mayor parte acogerá estos autorretratos digitales voluntariamente publicados.

También las edades de las y los modelos ampliarán (que no sustituirán, ya que estas prácticas siguen todavía dominadas por los adolescentes ${ }^{57}$ ) sus cotas hacia jóvenes que rondan la veintena, pudiendo ser estos los mismos adolescentes que diez años antes habían comenzado a coquetear con estos modelos de autorretrato, de ahí que podamos afirmar que la exportación de esta práctica a edades más avanzadas todavía resulta tímida y no masiva.

\footnotetext{
56 Que como veremos en profundidad a lo largo de los sucesivos capítulos de este estudio, censuran en cuestión de segundos cualquier fotografía que incluya genitales (femeninos o masculinos) y/o pezones (femeninos), ajustándose a una cultura de la censura más propia del país que desarrolló estas redes sociales: Estados Unidos. 


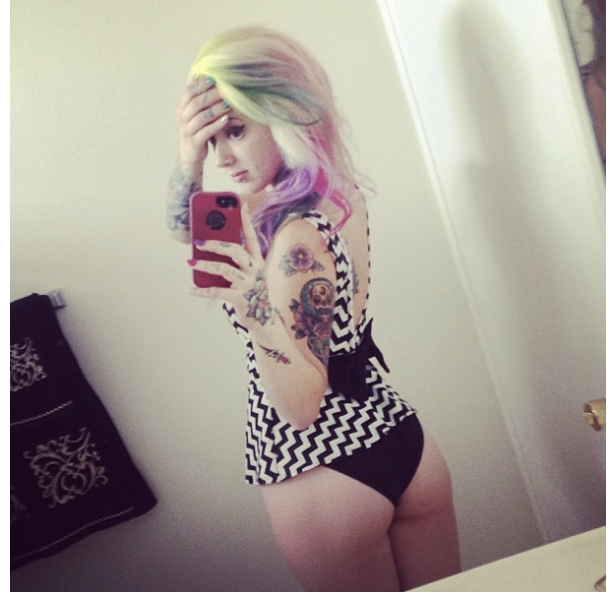

Imagen 3.38: Mirrorpic publicado en Instagram en 2012. Se trata de un autorretrato realizado por una modelo de SuicideGirls.

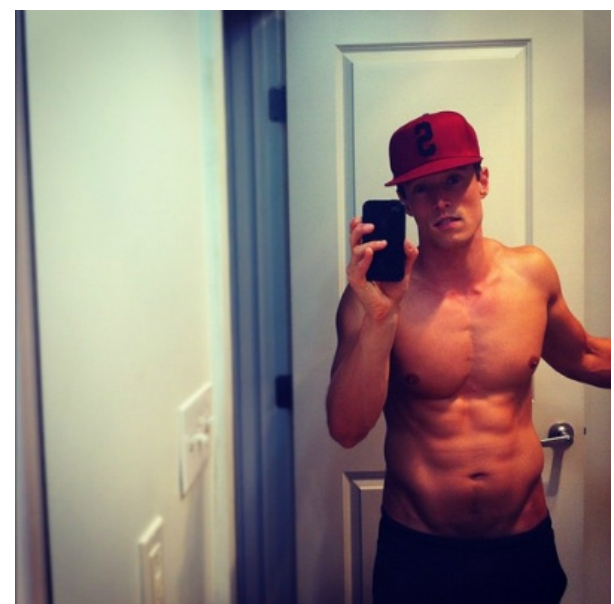

Imagen 3.39: El mismo tipo de autorretrato con escenario y actitudes similares, realizado por un joven durante 2013 y publicado en el mismo medio.

$\mathrm{Al}$ margen de estos filtros, marcos y cambios de escenarios y/o actitudes, hemos podido observar también un rápido cambio en el modelo compositivo y constitutivo del rostro en los selfies bajo su imparable expansión como subtipo del autorretrato digital publicado en la red. Este nuevo modelo irá progresivamente abandonando la foto en picado para construir la representación de las caras bajo unas perspectivas más próximas y frontales, aunque siempre con una ligera inclinación superior (Imagen 3.40). Las nuevas lentes secundarias de los smartphones, la posibilidad de encuadrar y observarse a tiempo real mediante la ya mencionada pantalla-espejo (que a su vez invitará a la aproximación del dispositivo, ya que lente y pantalla irán unidas, y dicha pantalla se observará mejor de cerca que de lejos, así como el auge de la propaganda de la belleza propia mediante construcciones más próximas al rostro que al cuerpo en las nuevas redes sociales, serán tres elementos clave para entender ese cambio de modelo formal que sufrió el self shot a principios de esta década, hecho que 
llevará a la ejecución de encuadres más cerrados y próximos que ciertamente pueden recordarnos al retrato fotográfico clásico.

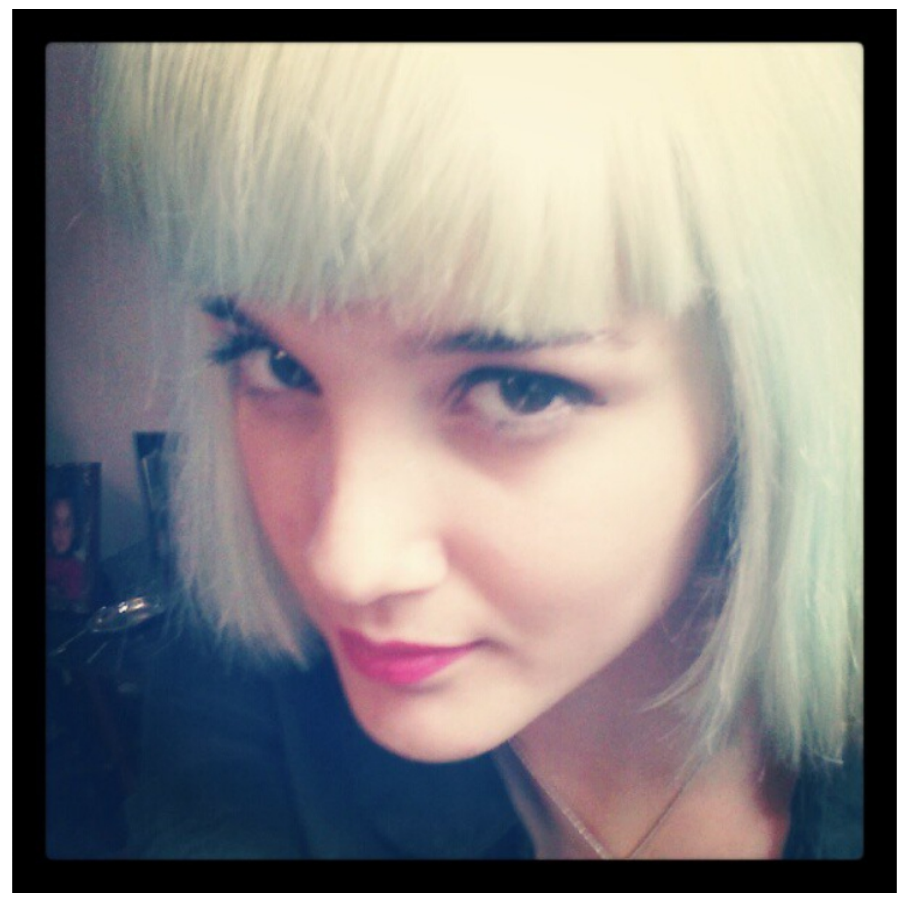

Imagen 3.39: Selfie realizado por la usuaria @munsury y publicado en Instagram en 2012. Un ejemplo del acercamiento al encuadre del rostro que irá experimentando poco a poco este subtipo de autorretrato digital publicado en la red.

Tal y como estamos viendo, y como expondremos más adelante, el formato cuadrado se impondrá en este tipo de autorretratos, ya que será de obligatorio uso en su principal red social publicadora (Imágenes 3.40 y 3.41). Las autorretratistas tendrán, pues, que adaptarse a esta nueva proporcionalidad entre los lados (1/1), alejada de los clásicos dos tercios (2/3) de las cámaras réflex o de los tres cuartos (3/4) o cuatro quintos (4/5) de las cámaras compactas, teléfonos celulares y webcams. En paralelo, podremos constatar en la siguiente 
fase cómo, una vez Instagram permita el formato libre, habrá un abandono de este formato cuadrado, al igual que sucederá con el uso de filtros tras años de saturación.

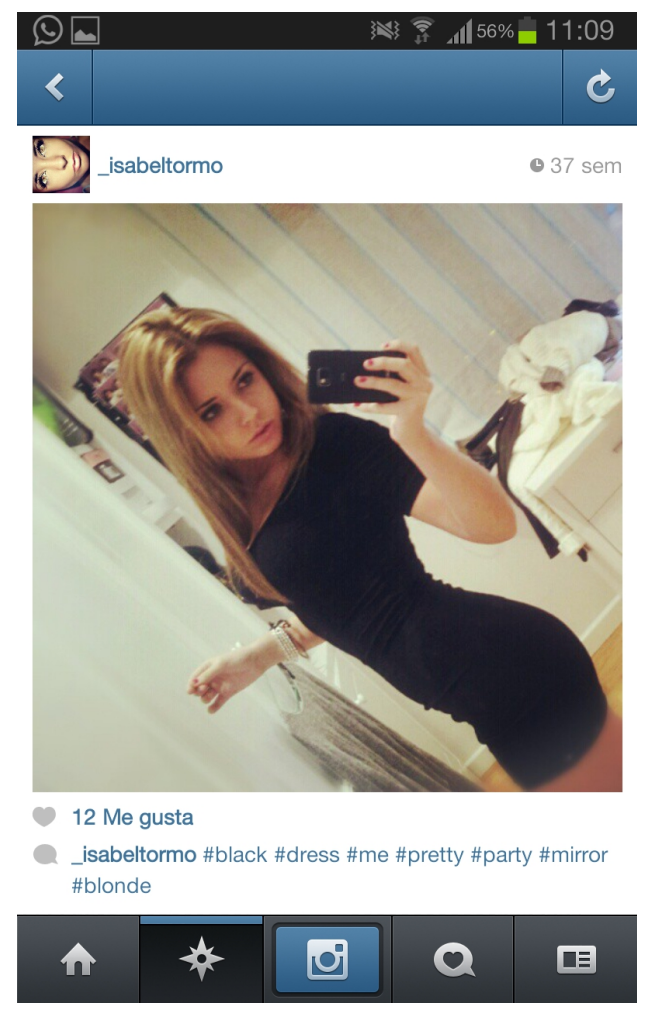

Imagen 3.40: Autorretrato de tipo mirrorpic publicado por la usuaria @_isabeltormo en Instagram en algún momento de 2012. Una composición muy controlada en diagonal ayudaría a incluir el cuerpo entero dentro del formato cuadrado. Hemos introducido tanto en esta imagen como en la siguiente la captura completa de pantalla de smartphone que rodea a la fotografía y que es la interfaz de su soporte publicador en diferentes versiones de su evolución.

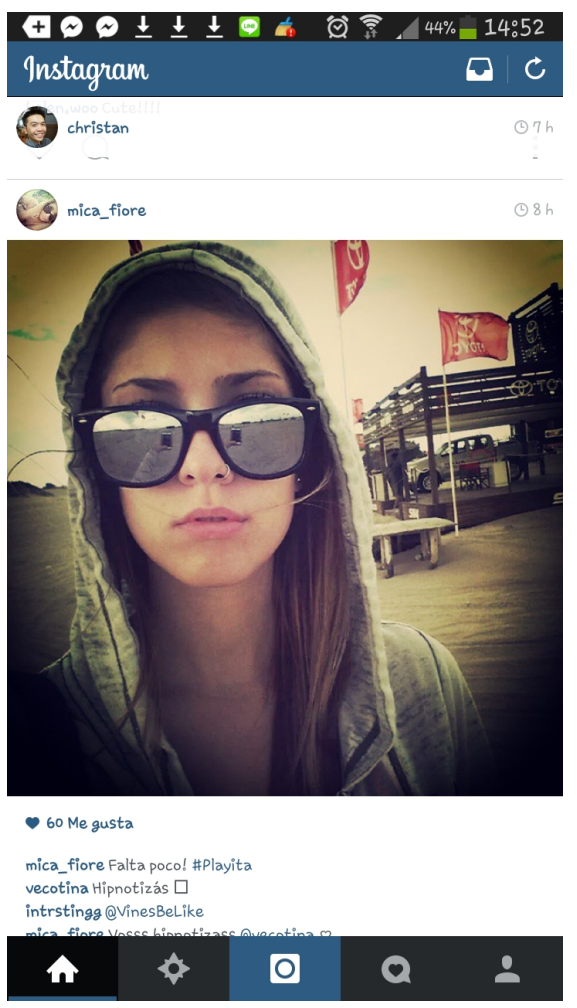

Imagen 3.41: Otro selfie publicado en esta ocasión por la usuaria argentina @mica_fiore en 2013. En el presente caso volvemos a ver el smartphone, herramienta capturadora y publicadora, representado en un reflejo (los vidrios de sus gafas de sol). 
Pese a que, como hemos comentado, Instagram ostentará el primer puesto entre las redes de producción y publicación de nuestros objetos de estudio entre los más jóvenes, también Facebook y Twitter jugarán un papel crucial durante estos años como plataformas para la difusión de la identidad del yo virtual de los jóvenes (y no tan jóvenes), siendo la segunda una red social también muy dada a mostrar self shots de todo tipo (Imagen 3.42), incluidos los acumulados en las recopilaciones de autofotos eróticas publicadas generalmente de manera involuntaria y que se encuentran en esta red $^{58}$, hecho que viene propiaciado por las bajas cotas de censura que aplica dicha plataforma de microblogging.
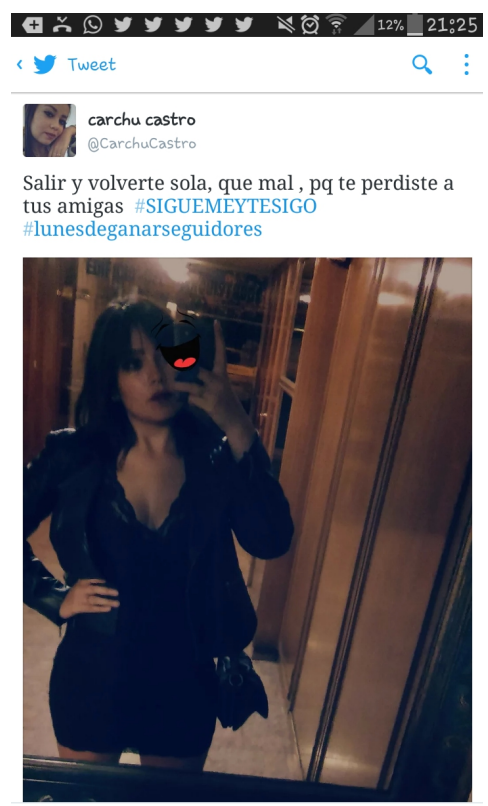

Imagen 3.42: Autorretrato digital publicado en la red social de microblogging Twitter, previamente editado desde el mismo smartphone de la usuaria @CarchuCastro. 
Para finalizar esta fase, y en relación a la popularidad del término y ejercicio del autorretrato digital publicado en la red, cabe apuntar que en el transcurso de los dos últimos años de la misma (2013 y 2014) no será extraño ver la práctica de este acto tanto en lugares públicos, como de la mano de notorias celebridades (Imágenes 4.43 y 4.44) y personajes de la escena mediática. Pese a ello, todavía no se convertirá en un objeto popular de común conocimiento por la casi totalidad de las masas, hecho que si ocurrirá tras el acontecer de varios eventos que ubicaremos en la tercera fase temporal de nuestro objeto de estudio.

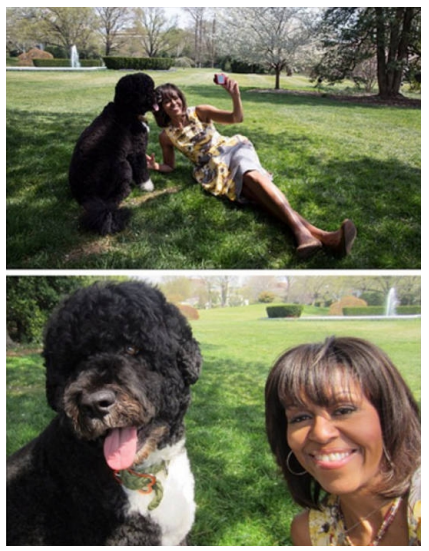

Imagen 3.43: En este collage publicado por Michelle Obama el 11 de abril de 2013 en su cuenta de Instagram se puede ver, arriba, a la protagonista durante el acto de practicarse un self shot (fotografía de Chuck Kennedy) junto a su mascota en los jardines de la Casa Blanca. Abajo, el selfie primitivo resultante ${ }^{59}$.

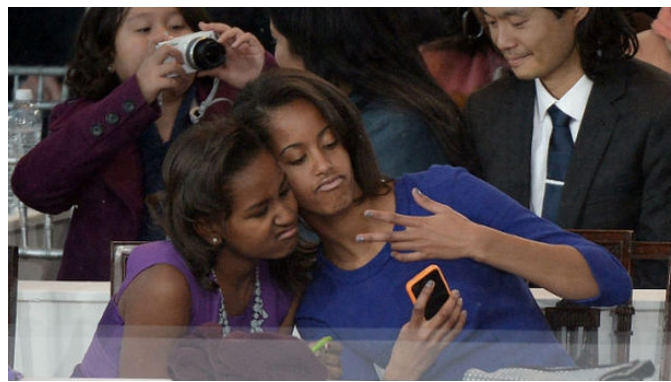

Imagen 3.44: Las hijas de la anterior protagonista, Sasha y Malia Obama, también realizándose un selfie durante la ceremonia de toma de posesión de su padre como presidente de Estados Unidos el 21 de enero de 2013 en Washington ${ }^{60}$.

59 Imagen disponible en el artículo online. Véase VV. AA., "Michelle Obama llega a los 50 años: razones para una celebración (FOTOS)", 2014, disponible en: <https://www.huffingtonpost.com/2014/01/o6/ michelle-obama-cumpleanos-50_n_454996o.html?utm_hp_ref=voces $>$ [Fecha de consulta: 10 de enero de 2017].

60 VV. AA., "Barack Obama compte sur le service secret pour impressionner les prétendants de ses filles", 2014, disponible en: <https://www.2ominutes.fr/insolite/1266323-20131221-20131221-barackobama-compte-service-secret-impressionner-pretendants-filles $>$ [Fecha de consulta: 10 de enero de 2017]. 


\subsubsection{Fase de popularización del self shot (2014-hasta la actualidad).}

Alcanzamos ahora la última fase que nos ha llevado hasta la actualidad y que hemos definido como la fase de popularización del autorretrato digital publicado en la red, sobre todo en lo que concierne a uno de sus subtipos: el selfie.

La principal característica de esta etapa, como su nombre indica, ha sido la explosión mediática que este mismo término, selfie (junto con la imagen cultural tanto de su forma como de su práctica), sufrió de manera exponencial tras el acontecimiento de la 86 ${ }^{\mathrm{a}}$ edición de los Premios Oscar ${ }^{61}$ en Estados Unidos a principios de 2014, evento en el que se produjo el famoso "Selfie de los Oscar" ${ }^{\prime 2}$. Este autorretrato digital y grupal, automáticamente publicado en la red tras su realización en directo bajo millones de miradas alrededor de todo el mundo, fue realizado por Bradley Cooper y tuiteado por la presentadora de la gala Ellen DeGeneres. Esta imagen fotográfica asociada a una entrada de este microblog se convirtió en el tuit $t^{63}$ con mayor impacto de la historia (Imágenes $3.45,3.46$ y 3.47). No obstante, otra serie de acontecimientos en torno a este acontecimiento también iban a servir de plataforma para la popularidad de este fenómeno entre las masas. Nos referimos, en concreto, al suceso ocurrido tres meses antes, a finales de 2013, en el que, como ya hemos visto, la palabra selfie llegará a convertirse en la palabra del año para el diccionario de la lengua inglesa www.huffingtonpost.es/2015/o1/21/historia-selfie_n_6517496.html $>$ [Fecha de consulta: 22 de julio de 2017]. 
de Oxford $^{64}$, tras una investigación realizada por sus editores que reveló que la frecuencia de la palabra selfie en el idioma inglés había aumentado en un 17.000\% durante ese año ${ }^{65}$.

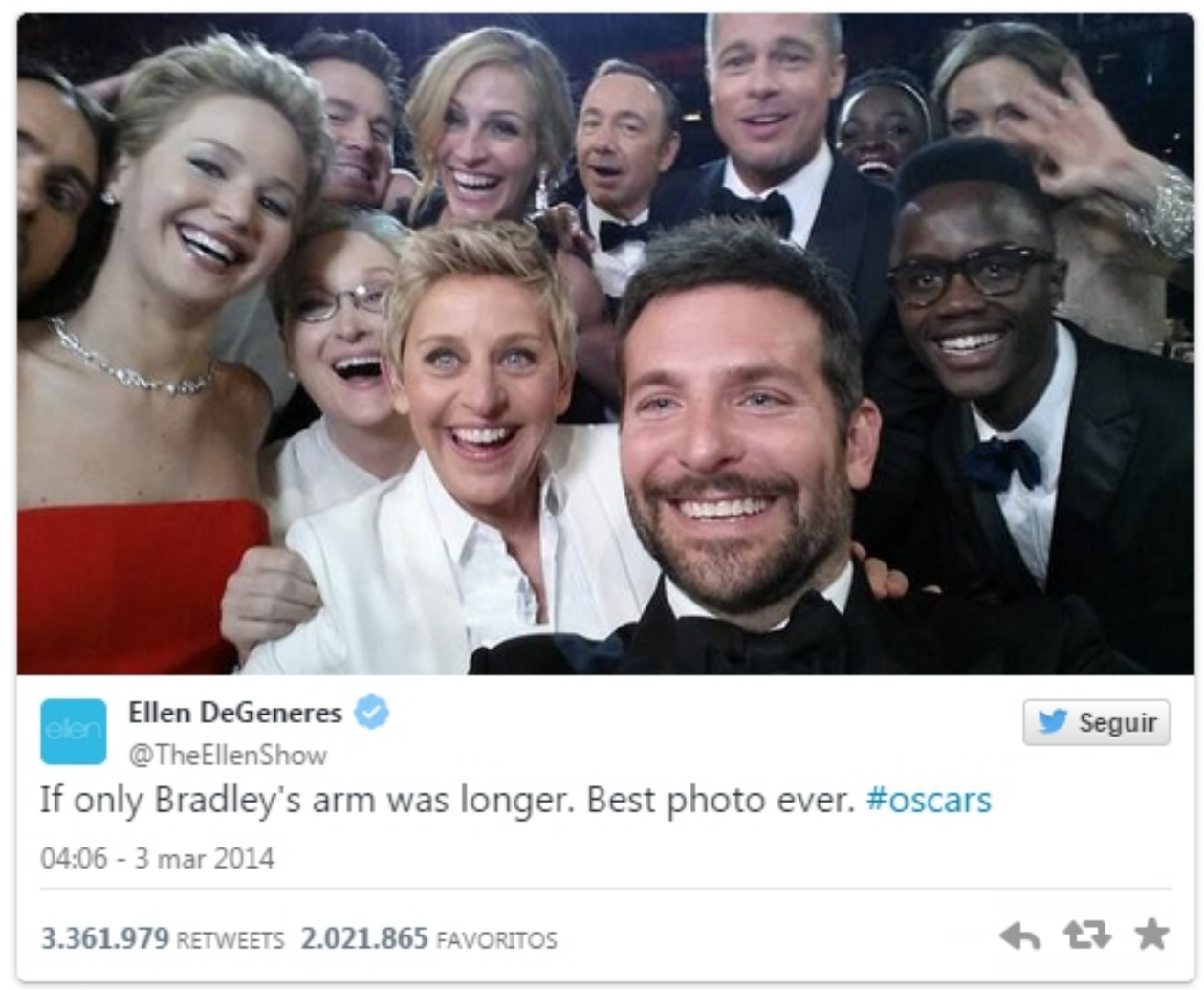

Imagen 3.45: El "Selfie de los Oscar". Esta imagen recoge la publicación original de la misma sobre el soporte de su tuit, en la cuenta de Ellen DeGeneres. Bradley Cooper hizo este autorretrato en 2014 desde el smartphone de la presentadora, dispositivo con el cual se publicaría instantáneamente la imagen en la red social Twitter. Podemos leer en la traducción del contenido del tuit: "Si solo el brazo de Bradley fuera más largo. La mejor foto que he visto. \#oscars". La publicación de manera casi inmediata superó los tres millones de retuits, viralizándose a velocidad de vértigo por todo el planeta.

65 Noticia en castellano en: <http://mexico.cnn.com/salud/2013/11/19/selfie-se-convierte-en-lapalabra-en-ingles-del-ano-para-oxford $>$ [Fecha de consulta: 24 de julio de 2016]. 


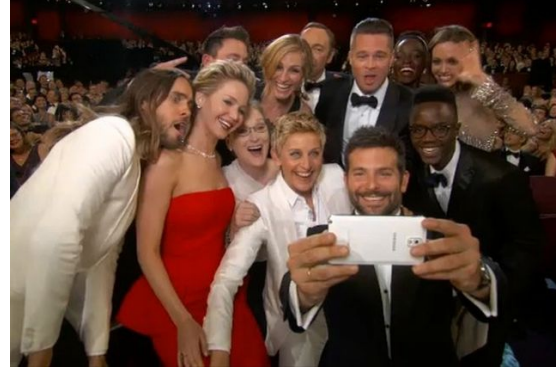

Imagen 3.46: Una foto realizada en la gala al elenco de la autofoto, durante el mismo momento en la que esta se realizaba.

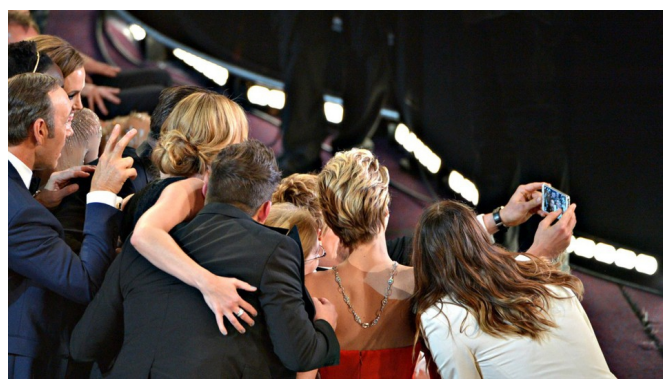

Imagen 3.47: Mismo acto recogido en la foto anterior, pero desde otro punto de vista.

Como hemos visto, el "Selfie de los Oscar" popularizó y mediatizó tanto el término como el acto o la práctica de este tipo de ejercicio fotográfico, de ahí que la gran mayoría de las sociedades y estratos poblacionales del globo fueron conocedores de una práctica que, si bien llevaba años en desarrollo y consolidación, su notoriedad solo quedaba circunscrita a los propios canales de comunicación e imagen que suponían ser sus soportes, lugar donde los jóvenes compartían esta subclase de fotografías.

No obstante, tanto el diccionario de la lengua inglesa de Oxford como el "Selfie de los Oscar" solo se encargaron de impulsar un término a nivel mediático que ya había estado creciendo de manera exponencial desde comienzos de la década ${ }^{66}$ y cuya percepción ya había sido detectada por otros ${ }^{67}$. Sin embargo, este acto tan visible ideado por Ellen DeGeneres o por los asesores encargados de

66 De hecho, y como veremos con más profundidad en el capítulo 6, fue la usuaria de Instagram Jennie Lee la primera en acuñar durante 2011 el término \#selfie por medio de un hashtag, apoyándose en un término que tímidamente se había extendido por el ciberespacio desde mediados de la década anterior. ALPAÑES, Enrique, op. cit., s/n.

67 Por ejemplo, a finales de 2012, la revista Time también incluyó selfie en su lista de palabras del año, y a mediados de 2013, Samsung hizo públicos los datos de su última encuesta: "Alrededor del 30\% de las fotos hechas por personas entre 18 y 24 años son autorretratos". CEBALLOS, Noel, "Breve historia cultural del selfie", 2014, disponible en: <http://www.revistagq.com/noticias/tecnologia/articulos/ breve-historia-cultural-del-selfie/19701> [Fecha de consulta: 22 de julio de 2017]. 
estructurar los contenidos de la gala de los Oscar de 2014 fue verdaderamente el responsable (y no otro) de desatar un aluvión de noticias ${ }^{68}$ relacionado con esta práctica recién descubierta por muchos adultos gracias a su único canal de consulta: la televisión.

Entre todas estas noticias televisivas y también de medios digitales que, primero anunciaron y describieron, y con posterioridad consolidaron y buscaron hechos insólitos y sensacionalistas en torno a un fenómeno que parecía haber alcanzado altas cotas de agotamiento (en todos los sentidos), destacamos ${ }^{69}$ alguna de las muchas que tratarían este propio acto $\mathrm{u}$ objeto fotográfico como apoyo para dar una noticia todavía mayor ${ }^{70}$, o las que analizarían algún hecho cuyo propio protagonista sería un selfie ${ }^{71}$.

68 En realidad el tratamiento del selfie como práctica y forma (pero sobre todo como práctica) se viralizaría en noticieros y programas de variedades de todo el mundo televisivo. Hemos sido también testigos de que, en nuestro país, este boom duraría por lo menos desde 2014 a 2016.

69 Dejando al margen las puramente descriptivas del fenómeno, que rozan la casi infinidad.

70 Como aquel selfie que se viralizó en 2016 y que representaba a las dos deportistas pertenecientes a paises técnicamente enfrentados por una pausada guerra. La representación de la práctica del selfie (Imagen 3.48) "de dos jugadoras de voleibol playa que se convirtió en una de las imágenes de las Olimpiadas de Río. La imagen de Lee Eun-ju, de Corea del Sur, y Hong Un-jong, de Corea del Norte, durante un descanso mientras se entrenaban para las competencias de gimnasia, fue percibida como un ejemplo del espíritu deportivo que promueven las Olimpiadas". Redacción BBC Mundo, "El selfie que unió a Corea del Norte y Corea del Sur en las Olimpiadas de Río 2016”, 2016, disponible en: $<$ http://www.bbc.com/mundo/noticias-america-latina-37014947> [Fecha de consulta: 10 de agosto de 2016].

71 Como la noticia de 2017 de carácter kafkiano que nos presentó a un mono protagonista de un selfie (Imagen 3.49) que, aunque suene tautológico, había sido realizado por él mismo gracias a la orquestación de un fotógrafo, representante para el simio de un mundo incomprensible que, sin embargo, estaría dispuesto a desplegar los mecanismos que asignan la autoría de una obra a según qué fotógrafo (mono o humano). "Naruto apretó un botón, se sacó una foto y la justicia comenzó a trabajar. ¿De quién eran los derechos de imagen? ¿Del simio o del fotógrafo? Ahora, seis años después de que este mono se sacara un selfie con la cámara de un fotógrafo británico, el caso no ha tenido que ser zanjado por la vía legal. El fotógrafo David Slater y la organización Personas por el Trato Ético de los Animales (PETA, por sus siglas en inglés), que reclamaba los derechos de Naruto, han llegado a un acuerdo: el fotógrafo donará el $25 \%$ de los futuros ingresos generados por la foto a organizaciones que protejan a Naruto y los demás macacos crestados de Indonesia. «PETA y David Slater están de acuerdo en que este caso plantea cuestiones innovadoras sobre la expansión de los derechos legales para los animales, un objetivo que ambos apoyan y por el que seguirán trabajando»". VV. AA., "Llegan a un acuerdo por los derechos de imagen de un selfie hecho por un mono", 2017, disponible en: <https://www.2ominutos.es/noticia/3132849/o/acuerdo-derechos-selfie-mono/> [Fecha de consulta: 20 de julio de 2017]. 


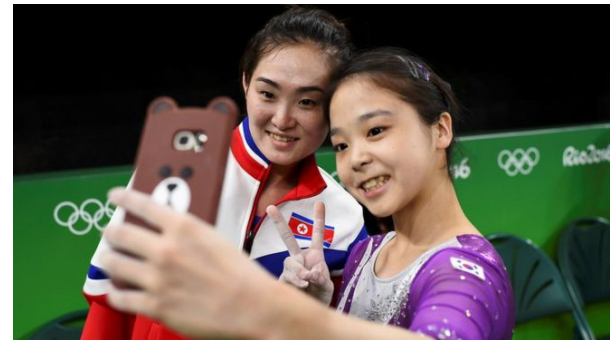

Imagen 3.48: El selfie de las dos Coreas, durante las Olimpiadas de Río en 2016.

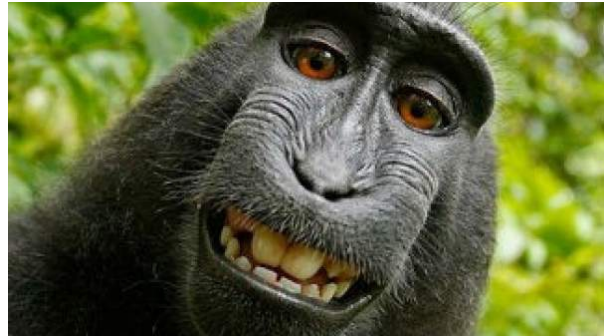

Imagen 3.49: El selfie del mono Naruto.

A lo largo de los años de esta etapa, también será notorio el acto de hacerse un selfie por la visibilidad que seguirán aportando en torno a él una innumerable cantidad de celebridades (Imagen 3.50), además de poderosos mandatarios como Barack Obama o el Papa Francisco ${ }^{72}$, cuyos autorretratos digitales publicados en la red alcanzarán rápidamente una viralización mediática tras sus ejecuciones.

Asimismo, será durante esta etapa (en octubre de 2014) cuando se producirá la filtración de fotografías íntimas de celebridades, caso también apodado como Celebgate, hecho que consistió en la apropiación y difusión por parte de hackers de mirrorpics y selfies eróticos (muchos, desnudos) de conocidas actrices, cantantes y modelos (Imagen 5.51), que sufrirían la sustracción de este material sensible directamente desde su lugar de almacenamiento en la nube $^{73}$.

72 VV. AA., “Ahora que están de moda: breve historia de las fotos selfie”, 2014, disponible en: <https:// www.sopitas.com/301149-ahora-que-estan-de-moda-breve-historia-de-las-fotos-selfie/> [Fecha de consulta: 20 de julio de 2017].

73 Veremos detenidamente este notorio acontecimiento (que afectó a más de un centenar de celebridades, cuyos autorretratos íntimos fueron sustraídos y publicados) durante el capítulo 5 . 


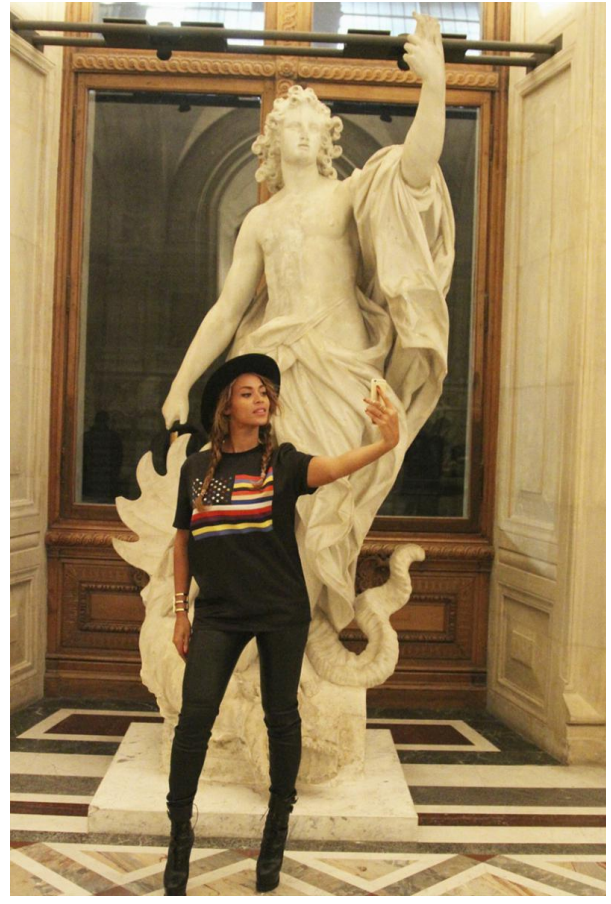

Imagen 3.50: Beyoncé realizándose un selfie frente a la escultura de Apolo y la serpiente pitón del Museo del Louvre en París, durante el mes de octubre de $2014^{74}$. En la imagen observamos cómo la conocida cantante imita de manera irónica la pose de la estatua, curiosamente coincidente con la forma popular de tomarse un selfie.

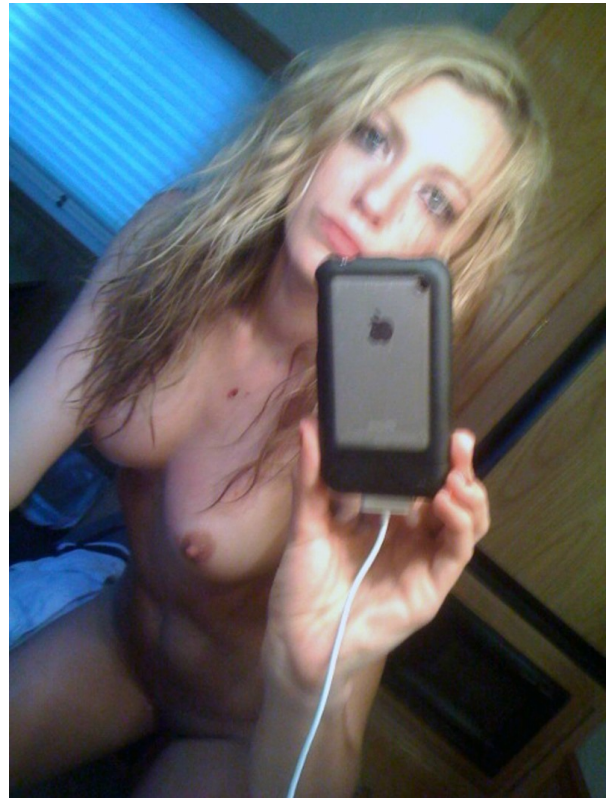

Imagen 3.51: Uno de los self shots de tipo mirrorpic filtrados durante el Celebgate, autoría de la actriz y modelo estadounidense Blake Libely. En el mismo se autorretrata desnuda frente a un espejo con una intencionalidad privada (pese a su involuntaria publicación tras el robo).

En fechas recientes, el aluvión de noticias en los medios también ha sido una de las múltiples causas por las que la tendencia de realizarse self shots en casi cualquier circunstancia se ha convertido en una tendencia compulsiva, casi obligada en cualquier situación. Algunos estudios ${ }^{75}$ han apuntado a la creación de

74 CANTÓN, Eva, “Beyoncé, «selfie» VIP con La Gioconda”, 2014, disponible en: <https:// www.elperiodico.com/es/gente/20141014/beyonce-selfie-vip-con-la-gioconda-3601638> [Fecha de consulta: 8 de enero de 2017].

75 BALAKRISHNAN, Janarthanan y GRIFFITHS, Mark D., “An Exploratory Study of «Selfitis» and the Development of the Selfitis Behavior Scale", en International Journal of Mental Health and 
un término, el de selfitis, que si bien no ha sido catalogado como patología por las autoridades psiquiátricas de las instituciones nombradas, sí que queda descrito como práctica preocupante en las sociedades contemporáneas y, en ocasiones, como actividad totalmente disociada de la realidad. Al respecto, podemos encontrarnos con ejemplos de jóvenes que prefieren salir bien en un autorretrato antes que registrar un acontecimiento extraordinario (Imagen 3.52). O también ejemplos de transeúntes y turistas que se practican irreverentes selfies $^{76}$ en situaciones para nada apropiadas (Imagen 3.53), banalizando hechos que pueden ser tildados de serios o preocupantes.

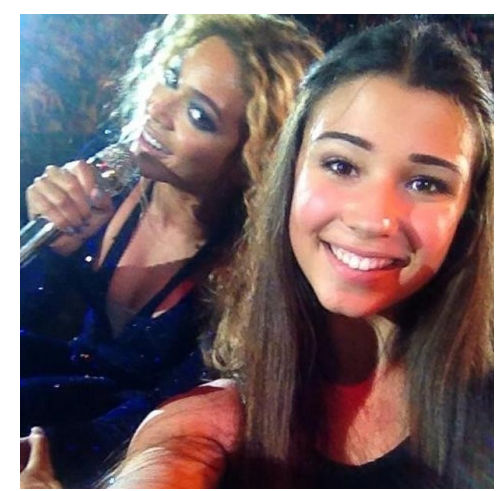

Imagen 3.52: Un selfie realizado por una joven durante un concierto de Beyoncé a principios de la fase que aquí tratamos. Cuando la estrella se le acerca, la protagonista del autorretrato prefiere colocar a la estrella como atrezzo en la composición de su autofoto.

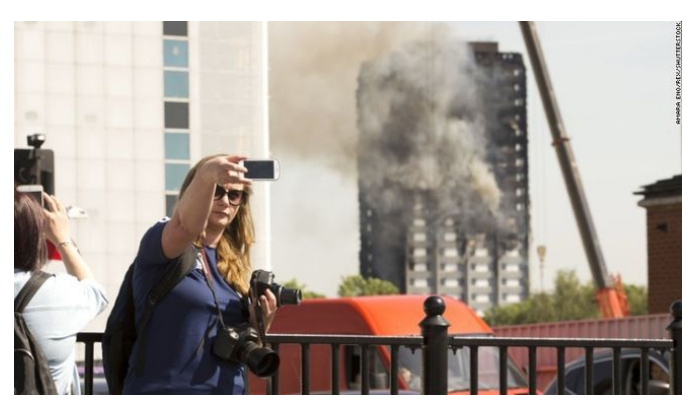

Imagen 3.53: Una turista realizándose un selfie primitivo junto a la Grenfell Tower de Londres durante su incendio en junio de 2017.

Pese a todo ello, en nuestros días, tanto los productos fotográficos que genera la práctica del autorretrato digital publicado en la red, como la propia

Addiction, 2017, págs. 1-15.

76 PAYO, Alberto, "Las víctimas de la Torre Grenfell piden que paren los selfies: «Es una tragedia, no una atracción turística»", 2017, disponible en: <http://www.elmundo.es/f5/comparte/2017/06/23/ 594cdoc5468aeb1a248b45fd.html> [Fecha de consulta: 24 de julio de 2017]. 
acción de hacerse un selfie en sí misma (su gesto metodológico), se ha convertido no solo en un objeto y pose reconocible, sino también en un producto cultural. Como veremos en los capítulos 7, 8 y 9, podríamos considerar que nos encontramos en una era post-self shot debido a la gran cantidad de productos artísticos, literarios, televisivos y publicitarios que utilizan el selfie, ya sea como representación, ya sea como presentación para transmitir o comunicar un mensaje, utilizando una referencialidad tan conocida por el público general. Por otro lado, el selfie se ha convertido en un sustitutivo de la fotografía grupal que practicaban los turistas durante el siglo pasado con la cámara en poder de un trípode o de un desconocido (Imagen 3.54). Además, el acto de hacerse un selfie se practica en cualquier tipo de situación con total naturalidad y es reconocible hasta para el inesperado participante secundario (Imagen 3.55), y es una práctica que se constituye como un valor, incluso, en las esferas más mediáticas (Imagen 3.56), siendo difícil no ser partícipe directa o indirectamente en este nuevo "encuadre".

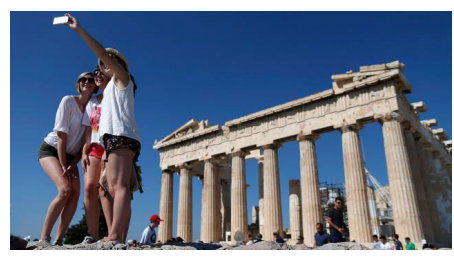

Imagen 3.54: Grupo de turistas realizándose un selfie frente al Partenón de Atenas.

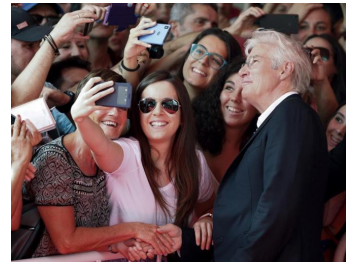

Imagen 3.55:

Richard Gere acercándose a unas fans que se quieren autorretratar con él.

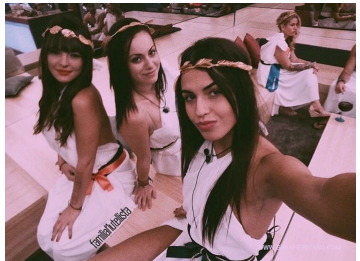

Imagen 3.56: Un selfie que fue realizado por una de las concursantes de la edición española del programa televisivo Gran Hermano en su edición de 2015.

La globalización, este artefacto económico, tecnológico, político, social y sobre todo cultural que ha conectado a las diferentes sociedades a lo largo del 
globo siendo, en parte, expansión y sincretismo de la cultura occidental, también ha sido responsable de la rápida exportación de este producto gracias a que su habitáculo es una etérea y deslocalizada red global: Internet. Así pues, su práctica no es exclusiva de un territorio, sino de cualquier lugar donde puedan llegar las tecnologías conformadoras de iconicidad (Imágenes 3.57 y 3.58).

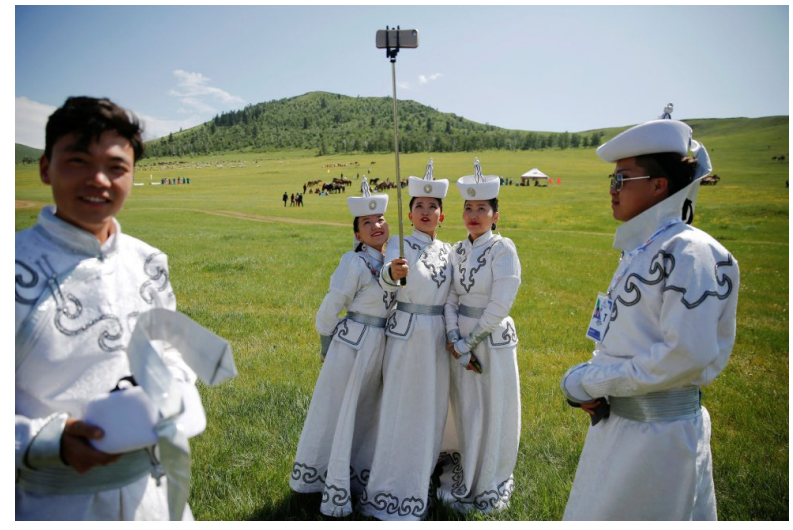

Imagen 3.57: Tres jóvenes autorretratándose mediante un palo-selfie durante unas festividades en Mongolia.

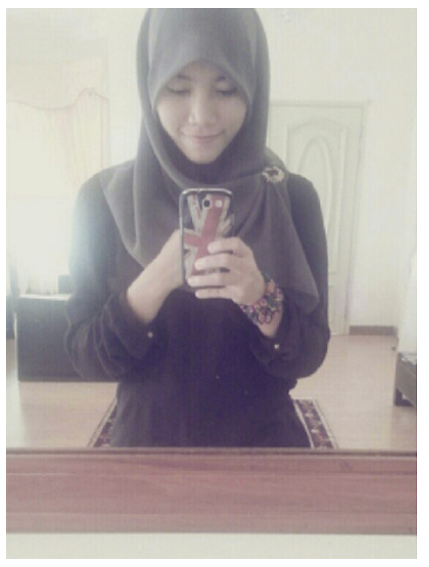

Imagen 3.58: Un mirrorpic de la usuaria indonesia@amalstella publicado en Instagram en 2014.

Junto a ello, va a ser también durante esta etapa, a partir de 2014, cuando el término selfie asumirá paulatinamente la nomenclatura primordial, dejando de considerarse un subtipo particular y ejerciendo esa colonización terminológica de la que hablábamos antes en el punto 3.1.1. De hecho, es fácil constatar en situaciones cotidianas cómo el uso lingüístico del selfie está anulando, incluso, términos como los de retrato o fotografía, llegándose a escuchar frases mal planteadas como "Déjame que te haga un selfie".

En torno a esta moda cada vez más creciente, se ha creado una fuerte demanda y, a su vez, los mercados se han empleado a fondo, o bien para 
satisfacer dicha demanda mediante una suculenta oferta de productos relacionados con el selfie, o bien para crear necesidades antes inexistentes en relación a este tipo de ejercicio y a sus productos fotográficos asociados. Así, por ejemplo, no son pocos los smartphones de última generación que ofrecen mejoras técnicas para realizar selfies de mayor calidad, no solo presentando lentes principales giratorias o lentes frontales con mejores ópticas y resoluciones, sino aportando buenos flashes frontales para iluminar correctamente nuestros rostros en condiciones de luz adversas o para compensar los autorretratos realizados a contraluz. Es el caso, entre otros ${ }^{77}$, del smartphone de manufactura china Gionee S6s con Selfie Flash incorporado (Imagen 3.59).

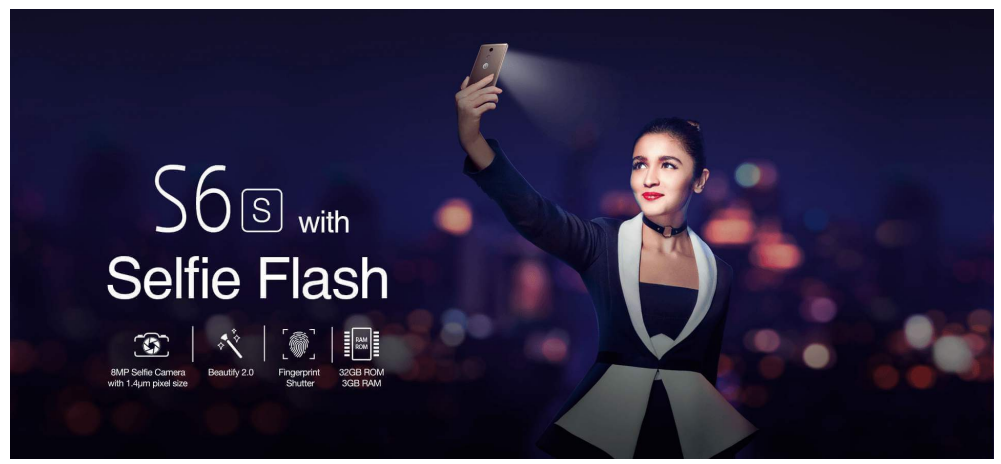

Imagen 3.59: Cuña gráfica publicitaria del smartphone Gionee S6s, presumiendo de su Selfie Flash.

Pero pensamos que, sin duda, el accesorio o gadget que más ha influenciado, no solo la práctica pública del selfie, sino un nuevo cambio en sus estructuras compositivas fotográficamente hablando ha sido el palo-selfie (selfie stick en inglés). Un tipo de accesorio que se ha puesto muy de moda en la fase que estamos aquí tratando, empezando a utilizarse de manera masiva en torno a 2014. El palo-selfie (Imágenes 3.60 y 3.61) puede ser entendido como una

77 Repasaremos los modelos de dispositivos fotográficos que más han influenciado en el devenir de los self shots y que, a su vez, les han ido dando forma con el paso de los años durante el siguiente capítulo. 
prolongación del brazo que sujeta el smartphone mientras se realizan este tipo de autorretratos, así pues, en lugar de alejar el dispositivo de captura fotográfica y su pantalla-espejo a una distancia tan lejana como el contacto que nuestra propia anatomía permita, el palo-selfie incrementa esta distancia metro y medio más gracias a un palo extensible y rematado por una especie de sustentor donde reposa el smartphone. Un disparador en el extremo del palo que hace las veces de empuñadura permite hacer un clic igualmente que lo hace un dedo, salvo por el hecho de que el gesto viaja en realidad por un cable o mecanismo a lo largo del palo hasta llegar al dispositivo fotografico que, tras recibir la señal, realizará el disparo. El palo-selfie se pliega sobre sí mismo hasta ocupar un reducido tamaño, siendo también muy ligero, dado el habitual poco peso en gramos del objeto que está destinado a sostener, ergonomía que conviene a este accesorio en un portable adicional a los habituales, fácil de transportar y ya imprescindible para cualquier turista o asistente a un evento. Ha sido tal la plaga de lugares públicos y eventos privados que se han visto invadidos por este artilugio que se pueden encontrar prohibiciones expresas ${ }^{78}$ al uso de este accesorio tanto en museos, como en zoológicos y parques (Imágenes 3.62 y 3.63).

Respecto a su huella, está hoy en día presente en los selfies producidos por este accesorio, que si bien no son mayoritarios, poseen una inconfundible firma en su construcción formal: el usuario o usuarios autorretratados quedan más centrados en el encuadre de la imagen, su tamaño es más reducido y el fondo o paisaje vuelve a adquirir el mismo protagonismo que ostentaba en las fotografías tradicionales de contexto o escenario. A su vez, en la mayoría de ocasiones el propio palo aparece en la imagen como si del brazo de la selfshooter se tratara.

78 VV. AA., "Lugares a los que no podrás llevarte tu palo de selfies", 2015, disponible en: <https://verne. elpais.com/verne/2015/03/31/articulo/1427814695_994335.html> [Fecha de consulta: 1 de noviembre de 2017]. 


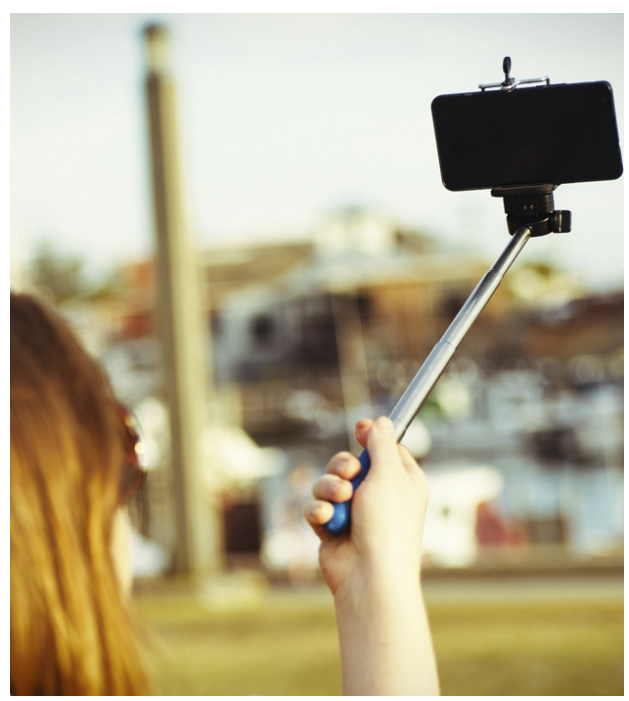

Imagen 3.60: Palo-selfie.

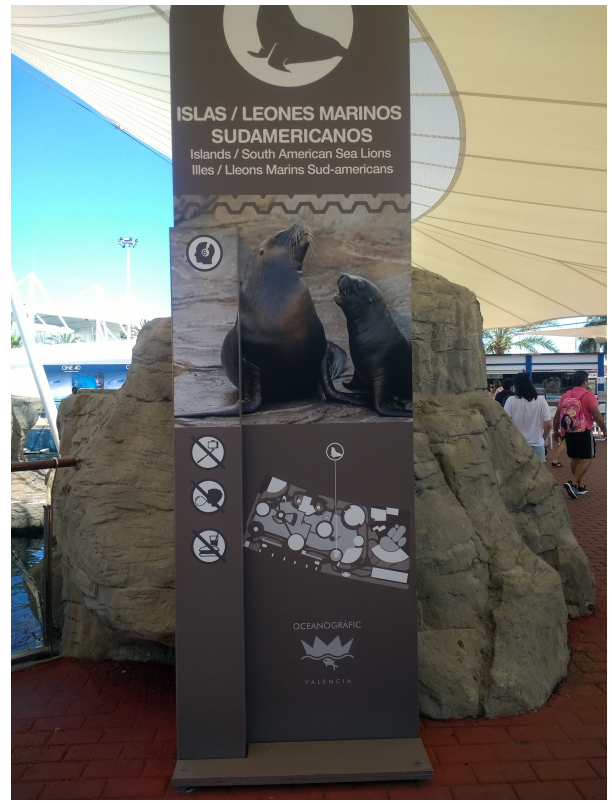

Imagen 3.62: Una de las prohibiciones en el parque marino Oceanogràfic de Valencia: la relativa al uso del palo-selfie.

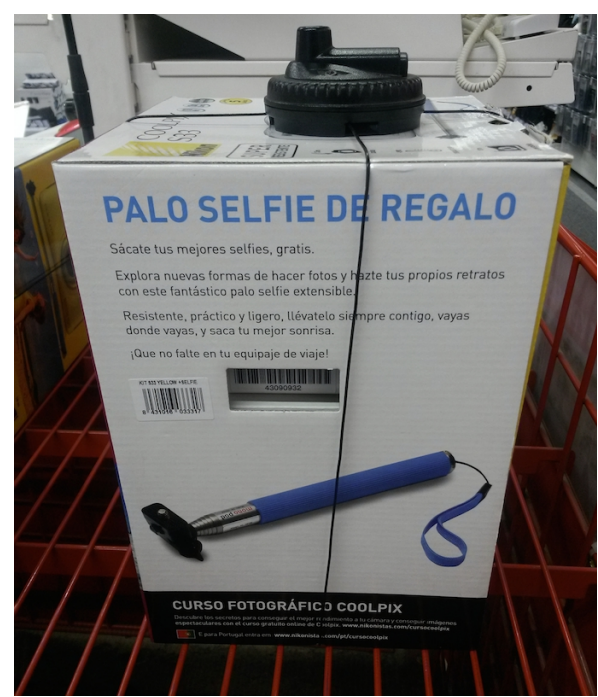

Imagen 3.61: Oferta ofrecida con la compra de la cámara Nikon Coolpix S33: un palo-selfie de regalo.

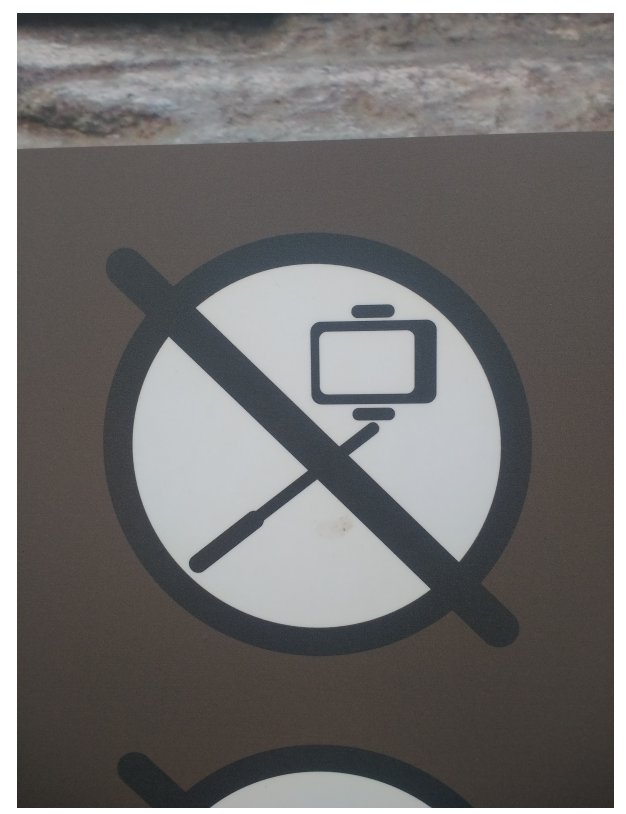

Imagen 3.63: Detalle de la anterior imagen. 
Recientemente, un último accesorio, aunque no tan popular como el anterior, pero si con cierta notoriedad y uso (sobre todo entre aquellos deportistas de riesgo y exploradores gustosos de publicar sus proezas en primera persona), ha entrado en escena como el más novedoso gadget diseñado para mejorar (o refrescar) la ya institucionalizada realización de selfies: se trata del SelfFlying Drone (Imágenes 3.64 y 3.65), una diminuta nave no tripulada (dron), generalmente de cuatro hélices y controlable desde el propio smartphone que integra una cámara también remota para poder practicarse selfies en cualquier circunstancia e, incluso, de manera autónoma en los prototipos más novedosos (gracias al seguimiento mediante un detector de rostro) sin necesidad de usar la extensión del brazo o del palo-selfie.

Actualmente, existe mucha oferta en el mercado de este tipo de drones que realizan selfies ${ }^{79}$ bajo la producción de diferentes marcas y con precios similares a los adquiridos por los teléfonos inteligentes.

Al igual que el anterior gadget, esta nueva herramienta vuelve a ser responsable de cambios sustanciales y coautorías en las obras producidas, no obstante, su impacto cultural como producto no será, de momento, tan trascendental como el originado por el palo-selfie, dada la todavía escasez de su uso. <http://www.expansion.com/directivos/estilo-vida/tendencias/2016/o5/01/57262fc546163f8c458b4 5c6.html> [Fecha de consulta: 20 de julio de 2017]. 


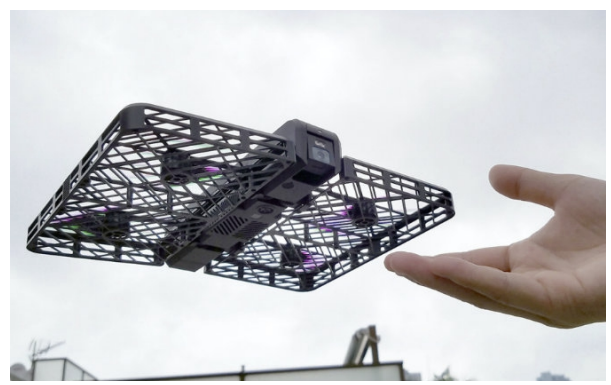

Imagen 3.64: Self-Flying Drone de la marca Hover y modelo Poooo17 plegable.

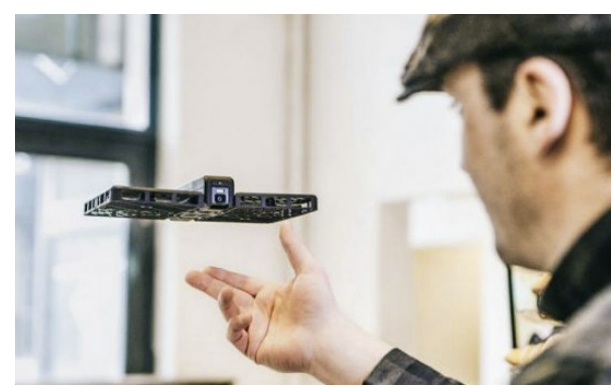

Imagen 3.65: El instrumento señalado en la imagen precedente cuenta con control de gestos. Ello le permite escanear y reconocer a su dueño y tomarle, mediante control de voz, autorretratos.

Para finalizar el recorrido por este periodo, queremos apuntar que, si bien las formas fotográficas y las prácticas asociadas al autorretrato digital publicado en la red no han variado demasiado respecto al rápido cambio y consolidación que sufrieron durante la fase anterior (tras, como hemos visto, los impactos producidos por la integración de las lentes frontales y pantallas espejo en los smartphones y sus nuevas perspectivas compositivas, generadas al mismo tiempo que Instagram se convertía en la primera e indiscutible plataforma de publicación del selfie), sí que existen algunos elementos clave que han producido leves adaptaciones y modificaciones en estos últimos años. Por un lado, el self shot ha encontrado nuevas vías para compartir entre dos personas su intimidad mediante canales de mensajería instantánea entre smartphones. Nos referimos a las nuevas aplicaciones de WhatsApp, SnapChat, LINE y Telegram. A su vez, por medio de funcionalidades similares (denominadas estados), los self shots también son capaces de hacerse públicos entre nuestro grupo de contactos de una manera más directa que las proporcionadas por redes sociales más complejas como Facebook o Twitter. Asimismo, hemos observado que, si bien nuestro objeto de estudio, como práctica y como imagen producida, era un ejercicio casi exclusivo de las esferas adolescentes de las sociedades desarrolladas 
durante sus primeros años de surgimiento, este objeto ha ido contagiando su esencia paulatinamente no solo a todas las sociedades, sino a cualquier franja de edad (Imagen 3.66), siendo hoy día una práctica general directamente influenciada por los planteamientos que en su día hicieron nuestros atrevidos jóvenes. Además, con la mejora de los dispositivos fotográficos y sus componentes, durante estos años nos enfrentamos a unas imágenes más nítidas y definidas, capaces de gestionar mejor la luz y de iluminar al sujeto de una manera más existosa. No obstante, una deceleración fácilmente observable en un objeto fotográfico que presenta cada vez menos cambios y más asentamiento formal, podría darnos una pista acerca de si nos encontramos realmente al final de un camino.

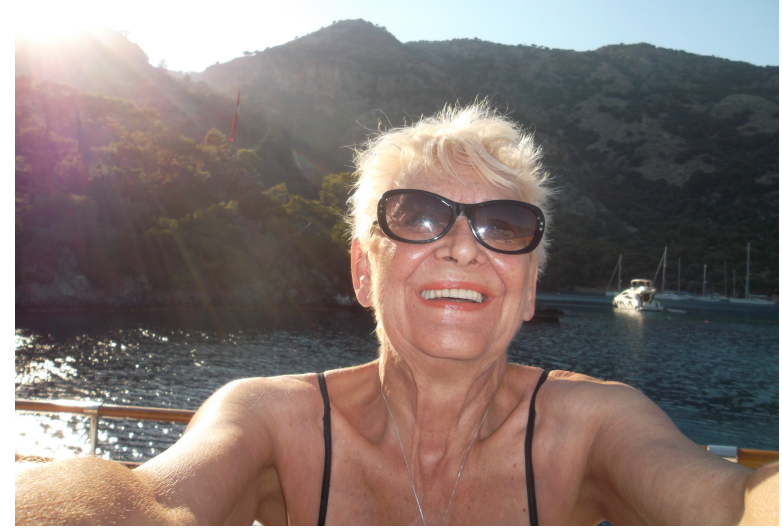

Imagen 3.66: Selfie realizado por una persona jubilada en un contexto vacacional.

En este sentido, el futuro del selfie y del resto de autorretratos digitales publicados en la red se presenta incierto y difícil de vaticinar bajo las oscuras brumas del futuro. Podría quedar como un objeto fotográfico antiguo, o una práctica obsoleta y criticada ante tantos años de saturación y ruido, siendo tan exótica como un daguerrotipo o como alguien fumando en pipa por la vía pública. Puede que el reconocimiento facial personal que ya practican nuestras 
nuevas máquinas mediante sus lecturas y simulación de interpretación (para bien o para $\mathrm{mal}^{80}$ ) conviertan nuestros autorretratos en condición sine qua non durante los trámites tecno-burocráticos. O quizá el self shot derive hacia una práctica cada vez más extentida hasta convertirse en un todo obligado cuya negación solo genere parias del sistema, tal y como podemos ver en el terrorífico episodio Nosedive ${ }^{81}$ (Caída en picado) de la serie de televisión británica Black Mirror de corte fantástico-futurista (aunque muy crítica con las nuevas tecnologías y las posibles oscuridades donde podrían sumergirnos como especie). En dicho episodio, a través de la imagen propia publicada (Imágenes 3.67 y 3.68) y de la gestión de nuestra identidad en las redes, se crea una nueva casta social extendida y obligada, autogestionada y evaluada por sus usuarios, hasta quedar convertida en un nuevo poder.

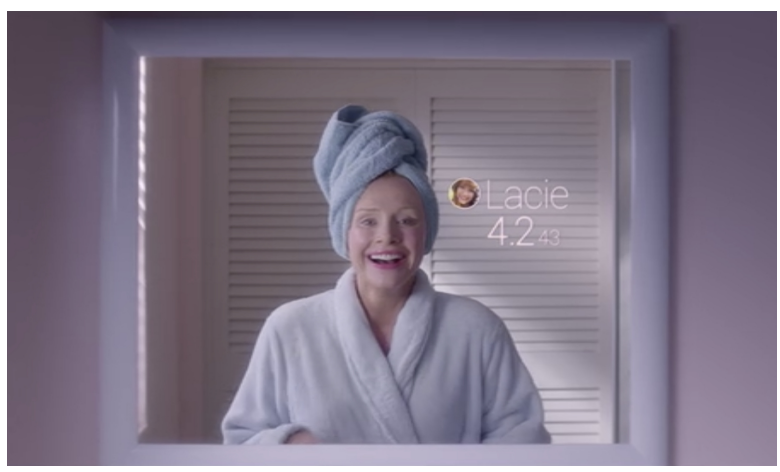

Imagen 3.67: Mirrorpic alternativo (sin cámara reflejada) realizado por la protagonista del capítulo "Nosedive" de la serie británica Black Mirror. La citada serie se desarrolla en un escenario futurista en el que la herramienta fotográfica y publicadora reside insertada en una lentilla del ojo, desde donde se fotografía y consulta.

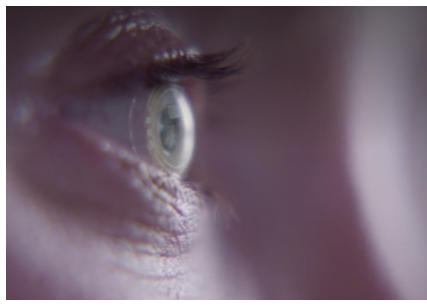

Imagen 3.68: Detalle de la lentilla con propiedades de cámara fotográfica digital y demás funciones propias del smartphone.

8 L LIZANA, José Alberto, “Apple reconoce en qué fotos sales en sujetador desde iOS 10”, 2017, disponible en: <https://apple5x1.com/ios-10-sujetador/> [Fecha de consulta: 1 de noviembre de 2017].

81 BORG, Laurie; BROOKER, Charlie; HOGAN, Ian; JONES, Annabel y PHILIPS, Angela (Productores), WRIGHT, Joe (Director), Nosedive (Caída en picado) [Episodio de la serie televisiva Black Mirror], Reino Unido, Netflix UK / House of Tomorrow, 2016. 


\subsection{El self shot como objeto fotográfico.}

En el desarrollo de las siguientes páginas vamos a partir de la premisa de que el autorretrato digital publicado en la red es un objeto fotográfico, es decir, una fotografía. Esta afirmación, tal vez poco cautelosa, es un atajo rápido que nos será de utilidad para simplificar nuestros próximos argumentos. No obstante, no hemos encontrado ningún dato concluyente que afirme que la fotografía digital es tan fotográfica como la fotografía química. Más adelante veremos que, a pesar de que muchos lo ponen en duda, otros intentan establecer una delgada línea que separe ambas tecnologías, aproximándolas hasta el punto de casi solaparlas. Partiremos, pues, de la idea de que la fotografía digital, es decir, el soporte del self shot aquí analizado, pese a sus grandes diferencias respecto a su tecnología predecesora del siglo $\mathrm{XX}$, tiene también tantas similitudes y resultados visualmente parecidos (pese a que su modus operandi sea totalmente diferente), que por lo menos a nivel formal, en tanto que objeto o imagen visual, puede recibir aquí un tratamiento similar al del análisis fotográfico tradicional.

De hecho, para comenzar, podemos tener la seguridad de otorgar al self shot el valor de imagen, ya que nuestro objeto de estudio posee esos tres hechos irreductibles que, ciñéndonos a parámetros clásicos, lo etiquetan como tal: "una selección de la realidad, unos elementos configurantes, y una sintaxis, entendida esta como una manifestación de orden" ${ }^{82}$. Se trataría, pues, de una imagen técnica generada por un aparato ${ }^{83}$ bajo, generalmente, el mando de una o un autor. Asimismo, ya hemos visto cómo mediante esta práctica podríamos apuntar que el pueblo se apropia de la manera de crear imágenes y de sus herramientas conformadoras. Escribía John Berger que "lo visible siempre ha sido y sigue

82 VILLAFAÑE, Justo, Introducción a la teoría de la imagen, Madrid, Pirámide, 1988, pág. 30.

83 FLUSSER, Vilém, Una filosofía de la fotografía, Madrid, Síntesis, 2001, pág. 23. 
siendo la principal fuente humana de información sobre el mundo" ${ }^{4}$. Ciertamente, a lo largo de este apartado 3.3 vamos a poder analizar la construcción compositiva, estructural y formal de varios tipos diferentes de autorretratos digitales publicados en la red partiendo de esta idea de imagen visible reconocible, y entendiendo que el significado de las imágenes, también las supuestamente fotográficas, está en su superficie ${ }^{85}$. No hay que olvidar que un selfie es una imagen controlada e idealizada ${ }^{86}$, generalmente mediante un reflejo. Para desarrollar mejor esta idea, podemos adentrarnos en los engaños y falsas realidades que confieren dos de los elementos conformadores de este reflejo, fundamentales en el desarrollo del self shot: el espejo, en el caso de los mirrorpics, y la pantalla-espejo en el caso de los selfies.

\subsubsection{El espejo como elemento conformador del mirrorpic y el mito de Narciso.}

"El rol psicológico del espejo emerge en un sistema conceptual iniciado en la Antigüedad, para fundar un razonamiento analógico y para servir a un pensamiento simbólico. La imagen extraña, oscura y brillante de los espejos antiguos, ligados a su modelo por un vínculo impalpable de semejanza, es considerada, en principio, el reflejo de una realidad sobrenatural" ${ }^{87}$.

84 BERGER, John, Y nuestros rostros, mi vida, breves como fotos, Madrid, Hermann Blume, 1986, pág. 52.

85 FLUSSER, Vilém, op. cit., pág. 11. CRESPO, Gloria, "Rineke Dijkstra: «Un selfie es una imagen idealizada, un cliché»", 2017, disponible en: <https://elpais.com/cultura/2017/10/19/babelia/1508412110_560353.html?por=mosaico> [Fecha de consulta: 19 de diciembre de 2017].

MELCHIOR-BONNET, Sabine, Historia del espejo, Buenos Aires, Edhasa, 2014, pág. 403. 
A medida que, a través de los siglos de la edad moderna el individuo va definiendo su existencia histórica y corporal, el espejo va a ofrecerle el medio de acotar sus límites, de distinguirse ${ }^{88}$. Así pues, el espejo se verá perfeccionado como objeto gracias a los progresos técnicos del vidrio, también desarrollado durante esta misma edad moderna, mejorando la tecnología del espejo y, hasta nuestros días, transformado en la ventana nítida que cuelga en nuestras habitaciones y cuartos de baño. De este modo, el espejo ha quedado configurado como un instrumento de adaptabilidad social, proporcionando al hombre y a la mujer, no solo la libertad de una conversación solitaria, sino una representación de sí mismo, una puesta en escena, un disfraz ${ }^{89}$.

"Todos los juegos, todas las ilusiones son posibles, pues el espejo transparente hace olvidar su pantalla. El hombre es quien manipula el espacio y disfruta de su poder" ${ }^{90}$.

El espejo siempre se nos presenta como una especie de prodigio en donde la realidad y la ilusión se codean y confunden, como un jeroglífico de la verdad y también de la falsedad ${ }^{91}$; lugar en donde la autorretratista, como Alicia, puede perderse entre innumerables realidades asimétricas hasta encontrar y decidir, entre una de ellas, el propósito que registrar y compartir:

"El mundo del Espejo, en el que penetra la valiente y sensata Alicia, evitando quedar apresada en la imagen del espejo, no es el lugar del reverso simétrico, de la antimateria, ni la imagen invertida en el espejo del mundo del que ella procede. Es el mundo del discurso y de la asimetría, cuyas reglas arbitrarias se esfuerzan por apartar al sujeto, Alicia, de toda posibilidad de identificación naturalista. Aunque en su andadura Alicia se despoje de una cierta seguridad autosuficiente y santurrona, todavía continúa haciendo preguntas y deseando saber sensatamente, ¿quién ha

88 Ídem.

89 Ibídem, pág. 404.

9o Ídem.

91 BALTRUSAITIS, Jurgis, El espejo. Ensayo sobre una leyenda científica, Madrid, Miraguano / Polifemo, 1988, pág. 281. 
soñado todo? Por muy inextricablemente ligados que estén Alicia y el Rey Rojo en los sueños y en el universo discursivo del otro, no son uno y el mismo; y la pregunta de Alicia esta planteada, como debe ser, no con visos metafísicos, sino prácticos"92.

Si bien la pantalla-espejo se configura como parte de la herramienta del selfie, el espejo físico quedará a su vez constituido como un complemento externo a la herramienta conformadora del mirrorpic que, sin embargo, está adscrito de manera indisociable a este tipo de imagen fotográfica. ¿Es pues el mirrorpic la imagen de un reflejo, o la imagen de un objeto que contiene un reflejo? En ocasiones, la presencia o no del marco de este espejo (Imágenes 3.69 y 3.70) podría marcar la diferencia en cuanto a la profundidad de los planos de la imagen y ubicar el punto de vista del espectador sin necesariamente resolver esta pregunta conceptual. Respecto a si la imagen reflejada es un signo, Umberto Eco apunta a que, en un espejo:

“[...] percepción, pensamiento, conciencia de la propia subjetividad, experiencia especular, semiosis, aparecen como momentos de un nudo inextricable, como puntos de una circunferencia a la que parece arduo asignar un punto inicial”93.

Respecto al espejo en la relación del proceso del mirrorpic publicado, Ana Maqueda señala:

\footnotetext{
"Ante el retrato, como ante el espejo, se suscita la impresión de que hay dos espacios, a uno y otro lado, interior y exterior, la confrontación con otro rostro, con otro cuerpo semejante al propio. En realidad, nos enfrentamos a algo esencialmente distinto, una imagen, un objeto, no un sujeto. El receptor, recibe en el móvil, menor que un palmo de su mano, la imagen retrato-espejo en segundos. Estas imágenes se exponen a la colectividad sin necesidad de ser exhibidas en una galería, ni de ser instaladas o trasladadas sobre un soporte. En la inmediatez de la comunicación y la instantánea digital, el consumo visual de estas imágenes es automático. Tal fugacidad permite una
}

DE LAURENTIS, Teresa, Alicia ya no, Madrid, Cátedra, 1992, pág. 10. ECO, Umberto, De los espejos y otros ensayos, Barcelona, Lumen, 200o, pág. 11. 
ojeada rápida, suficiente para que un alertado cerebro, las procese. Con semejante inmediatez han sido concebidas y realizadas, en la inconsciencia de lo espontáneo o en lo espontáneo de la inconsciencia”94.

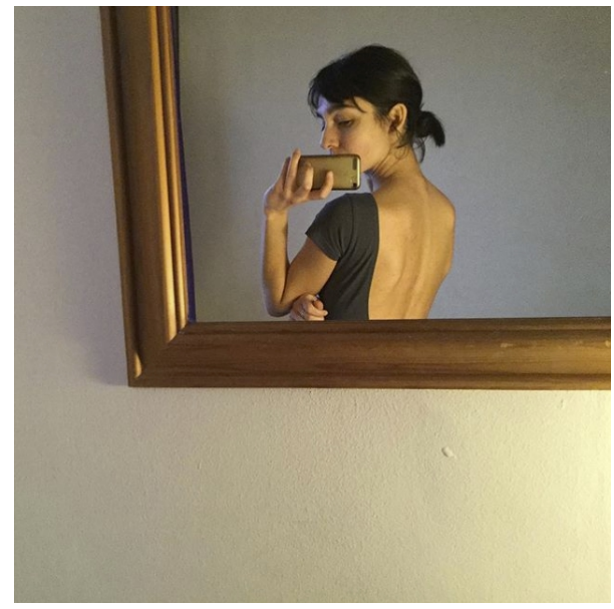

Imagen 3.69: Mirrorpic publicado por la usuaria@nnannea en Instagram en 2018. La presencia en el encuadre de algunos de los límites del espejo, incluye a este objeto en el contexto.

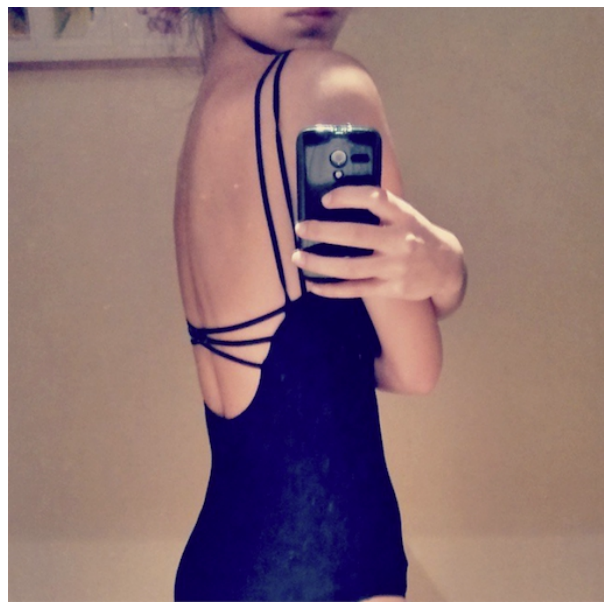

Imagen 3.70: Otro mirrorpic publicado también por la usuaria @nnannea en Instagram en 2014. Al sacar fuera del encuadre los marcos del espejo, se pierde el contexto del objeto quedando solo presente el del reflejo.

Mediante estas estrategias en relación con el espejo, al igual que el artista autobiográfico ${ }^{95}$, el selfshooter conformaría su yo virtual mediante la observación y publicación de su propia realidad reflejada:

"Mirarse en el espejo, al igual que ser visto por la sociedad, sería el medio de construir e identificar el yo. La formación del yo quedaría representada por un proceso consecutivo: del sujeto al objeto (primero soy un sujeto y después me convierto en un Metáforas de la multitud. III Congreso internacional estética y política, Valencia, 2015, pág. 99. 
objeto), lo cual, aplicado al campo autobiográfico, permitiría que cada uno se vea a sí mismo como cualquier otro" ${ }^{96}$.

Entendemos, pues, que el autorretrato y el espejo guardan una relación íntima, y que ambos se han desarrollado de manera paralela a lo largo de la historia $^{97}$. En los espejos el autorretratista se mira a sí mismo, cara a cara. Mientras este lo observa, sus facciones se vuelven hacia sí en un diálogo recíproco. No obstante, si el sujeto desaparece del frontal del espejo, este también queda despojado de su reflejo ${ }^{98}$. Sin embargo:

"Imaginemos que disponemos de un espejo congelante. La imagen reflejada se congela en la superficie, aun cuando el objeto desaparezca. Por fin hemos instituido una relación de ausencia entre antecedente y consecuente. No obstante, no habremos eliminado el vínculo causal entre referente originario e imagen. Un paso adelante, entonces, pero mínimo. Espejo congelante es la placa fotográfica”99.

De esta manera, actualizando un poco más estos comentarios de Eco, efectivamente el mirrorpic compartido es el envío de un reflejo en diferido. Es la captación de mi yo reflejado, capturado como instante mediante el sensor electrónico y escrito como imagen fija sobre un archivo digital visualizable en una pantalla (la de nuestra cámara) y destinado a volar a continuación por el ciberespacio hasta llegar, por medio de otras pantallas, a los ojos del o de los destinatarios. El mirrorpic es nuestro reflejo, congelado, capturado y enviado, de nosotros a vosotros.

Otro hecho característico de los autorretratos de espejo, y que se ha convertido en una curiosa firma inconfundible de los mirrorpics, es la

96 LACAN, Jacques, "El estadio del espejo como formador de la función del yo [je] tal como se nos revela en la experiencia psicoanalítica”, en Escritos, vol. 1, México D.F., Siglo XXI, 2009, pág. 10.

97 CID, Carlos, "Algunas reflexiones sobre el autorretrato", en Liño. Revista anual de historia del arte, $\mathrm{n}^{\mathrm{O}}$ 5, 1985, pág. 183.

98 ECO, Umberto, op. cit., pág. 22.

99 Ibídem, pág. 36. 
generalmente diagonalidad de la modelo y su contexto frente a una rectitud ideal de los cuatro lados del dispositivo reflejado, paralelo a los cuatro lados del cuadro de la imagen. Este hecho sucede solo en los casos en los que la autorretratista inclina pocos o muchos grados el smartphone o cámara fotográfica respecto al plano del suelo donde reposan sus pies. Esta diagonal forzada puede parecer un artificio innecesario para representar un cuerpo imaginado desde la rectitud vertical, que espera ser observado por otro ser que entienda la perpendicularidad respecto al suelo como la constante racional de la figura observada. No obstante, una buena mayoría de autorretratos digitales publicados en la red que representan a estas y estos jóvenes reflejados en los espejos de sus cuartos de baño y de sus dormitorios ostentan algún tipo de diagonalidad. Quizá la facilidad y libertad que otorga componer mediante la visión directa por pantalla (que definíamos en el punto 3.1.1 de este capítulo) invite, entre la multitud de posibilidades vistas, a inclinar la cámara. $\mathrm{Y}$ ello tal vez se realice para generar dinamismo, o con la intención de incluir la máxima envergadura corporal, dado que generando una diagonal entre los vértices opuestos del cuadro de la fotografía, siempre se encontrará más superficie que respecto a una de sus alturas perpendiculares.

En todo caso, y como apuntábamos, puede resultar curioso este hecho tan constante en los mirrorpics: el de un mundo inclinado, y un dispositivo como único elemento paralelo a los límites de la imagen, algo que siempre ocurrirá ya que el sensor electrónico de imagen que habita en el interior del aparato, también es paralelo a los lados del dispositivo contenedor, y es este sensor el que conforma una imagen digital de píxeles alineados en cuadrícula paralela a los límites de la propia imagen creada (Imágenes 3.71 y 3.72). Con esta racionalidad y rectitud, parecería que la herramienta es la única verdadera protagonista dentro del espejo, ante un mundo irreal que incluiría, entre sus diagonales, a la modelo también representada (que quedaría a expensas de la máquina fotográfica, no solo a nivel fáctico, sino también a nivel conceptual) 


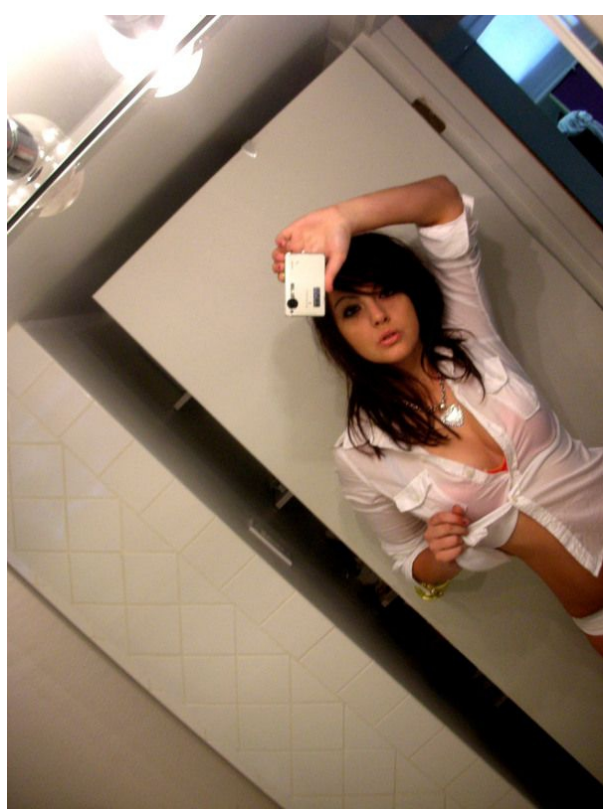

Imagen 3·71: Mirrorpic anónimo de 2009.

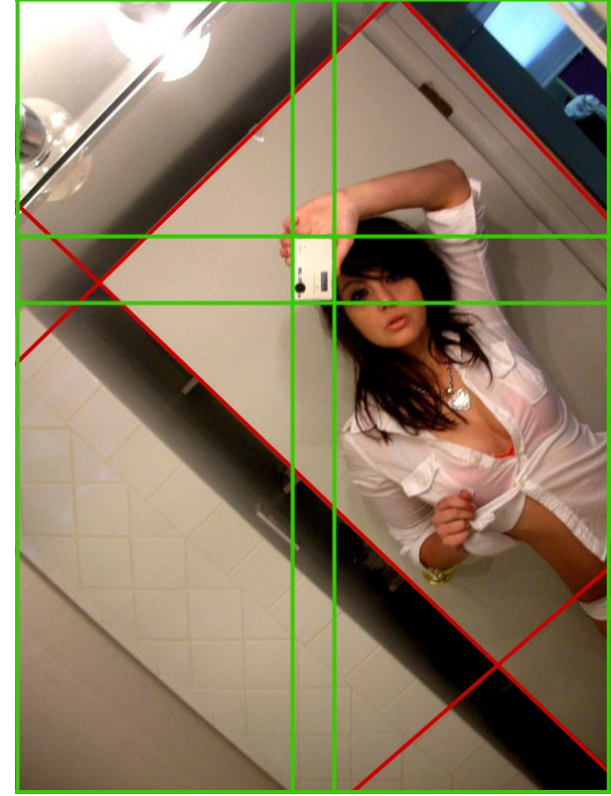

Imagen 3.72: Mediante un esquema de líneas aplicadas sobre la imagen anterior, podemos ver, gracias a las diagonales rojas, la inclinación real del dispositivo frente a la perpendicularidad humana respecto al plano del suelo. Por medio de las líneas verdes observamos cómo los lados del dispositivo reflejado siempre son paralelos a las líneas de los límites del cuadro de la imagen, también en verde.

Observando, pues, los mirrorpics adolescentes de los primeros años de la conformación del self shot y también los mirrorpics más actuales que inundan Instagram (ambos revisados a lo largo de este estudio con multitud de ejemplos), podemos comprobar tras analizar los gestos, las poses y las miradas de sus protagonistas (y también en relación al mito tan relacionado con el reflejo especular), el gran carácter narcisista que poseen sus autoras y autores, algo que queda reflejado en la lectura simbólica del objeto fotográfico mediante la observación del sujeto autorrepresentado. 
Es, pues, el mito de Narciso otro elemento fundador de la imagen ilusionista $^{100}$. En el mito griego, el bello Narciso vio su imagen reflejada en la superficie del agua y se enamoró de sí mismo. Esto tiene tal importancia para el autorretrato que, de existir entonces, Narciso habría trazado el suyo propio ${ }^{101}$.

"Inclinado sobre su manantial, Narciso apaga su sed: su imagen ya no es otra, es su propia superficie quien lo absorbe, quien lo seduce de tal modo que solo puede acercarse sin pasar nunca más allá, pues ya no hay más allá como tampoco hay distancia reflexiva entre Narciso y su imagen. El espejo del agua no es una superficie de reflexión, sino una superficie de absorción” ${ }^{102}$.

$\mathrm{Al}$ margen de esta vanidad frente al espejo que nos puede dar una imagen referencial de narcisismo representado, existe también una relación directa con esta actitud mediante las identidades virtuales expuestas en la red por medio del autorretrato $^{103}$, como veremos a lo largo de los capítulos 5 y 6 . Desde esta perspectiva, podemos apuntar que los adolescentes, mediante el uso de la Web 2.0 y sus subproductos generados (las redes sociales), han creado un culto al narcisismo ${ }^{104}$, mucho más aceptado socialmente de lo que ha sido en épocas pasadas, debido en parte a la popularidad de estas nuevas autorrepresentaciones fotográficas.

100 MELOT, Michel, op. cit., p. 30.

101 "Hevelack Ellis introdujo en Psicología el término narcisismo para definir un amor desviado hacia la propia imagen. Freud aplicó en Psiquiatría la «neurosis narcisista» a la psicosis, y sobre todo a la esquizofrenia en que el enfermo se desprende del mundo y concentra en sí toda la líbido que normalmente se proyecta sobre los objetos externos”. CID, Carlos, op. cit., págs. 188-189.

102 BAUDRILLARD, Jean, De la seducción, Madrid, Cátedra, 1998, p. 67.

103 CALDEVILLA, David, op. cit., págs. 81-82.

104 NAVARIDAS, Fermín y SANTIAGO, Raúl, "La Web 2.o en escena”, en Pixel-Bit. Revista de medios y educación, $\mathrm{n}^{0}$ 41, 2012, pág. 28. Añadamos, a su vez, que las "redes sociales y apps como Instagram son un foco de atención debido a su relación con el narcicismo presente en nuestra cultura posmoderna”. COLORADO, Óscar, “Autorretrato y fotografía”, 2013, disponible en: <https://oscarenfotos.com/ 2013/o8/11/autorretrato-y-fotografia/> [Fecha de consulta: 25 de julio de 2017]. Y en relación a esto, apuntamos que "[...] un selfie siempre es un ejercicio de vanidad, por la sencilla razón de que un selfie existe para ser compartido con los demás”. CEBALLOS, Noel, op. cit., $\mathrm{s} / \mathrm{n}$. 
"Tomando como clave la concepción preliminar y deíctica del selfie (yo/nosotros, aquí y ahora; frente a vosotros/ellos, ahí/allá y antes/después) cabría preguntar si ese control de la autorrepresentación a partir del discurso fotográfico digital podría ser considerado como un logro en lo que se refiere a la libre construcción del self, la autopercepción del sí mismo ante el espejo y ante la sociedad. Recuérdese que la soberbia de Narciso consiste en su conquista de la posición privilegiada en la estructura social, hasta entonces reservada a los dioses. Por tanto, pasa de ser vigilado (objeto de la mirada de otros más poderosos, panopticon) a convertirse en libre elector (sujeto observador ante la sociedad, y objeto que concita y sintetiza las miradas de otros en algún aspecto o condición, synopticon)”105.

Pero estas nuevas (en algunos casos) formas construidas sobre la imagen fotográfica a través del autorretrato frente a un espejo y en un contexto íntimo (o no), y que hemos revisado a lo largo de este punto, no serán los únicos ejemplos formales característicos de una era en la que, debido a numerosos cambios técnicos, económicos, sociales y metodológicos, han surgido estos nuevos ejemplos fotográficos relacionados con un reflejo. También, como hemos visto anteriormente, la pantalla-espejo de los smartphones actuará como espejo de mano sobre el que reflejar el rostro y parte del cuerpo, haciendo las veces de superficie constructora de otro tipo de self shot poseedor de diferentes cualidades compositivas y formales: el selfie, también objeto fotográfico fruto de otro tipo de reflejo eletrónico-lumínico.

\subsubsection{La pantalla-espejo como superficie constructora del selfie.}

Como hemos señalado antes, la aparición de los nuevos dispositivos de captura digital ha generado una gran cantidad de nuevas formas y actitudes en cuanto a la realización de fotografías, no solo de autorretratos. Durante los 
registros de imagen clásicos, tanto en la fotografía como en el cine, la búsqueda del punto de vista del realizador de la imagen, construida desde su eje ojo-visorlente y desde su posición erguida, evidenciaba la presencia de este en algún lugar fuera de las paredes del plano o encuadre. Uno de los motivos de esta estrategia compositiva comúnmente utilizada era la de colocar al espectador en la escena, simulando su presencia entre los miembros del elenco o tras las cortinas de la ventana, haciéndole partícipe o voyeur. Un mítico director de cine estadounidense como Howard Haws decía respecto a su propia manera de componer el encuadre de la imagen: "Trato de contar mis historias exactamente como vosotros las veríais, de la forma más simple, colocando la cámara a la altura de los ojos"106. Esta presencia del espectador (de sus ojos y de su cuerpo) en la escena puede ser también llevada a cabo de una manera totalmente vertiginosa y sensitiva, como en la cinta cinematográfica Salvar al soldado Ryan ${ }^{107}$, dirigida por Steven Spielberg en 1998, director que utiliza todo tipo de técnicas durante la primera escena (el desembarco de Normandía realizado por los aliados durante la Segunda Guerra Mundial) para convertir al espectador en uno más de los soldados.

Sin embargo, este tipo de encuadres y puntos de vista realizados siempre desde un supuesto ojo humano y que evidencian la presencia del espectador humano en la escena, darán paso con la llegada del dispositivo doméstico de grabación o, más recientemente, del dispositivo digital de captura, a la presencia ya no del humano, sino de la propia máquina captadora como protagonista de la escena desde su cuarta pared. Así pues, el espectador observando estas nuevas obras (de la misma manera que viendo un selfie o un mirrorpic), ya no es consciente de una presencia humana que mira la escena desde algún lugar fuera

106 TRUEBA, Fernando, "Howard Hawks o la escritura invisible”, en El País [edición impresa del jueves 5 de enero de 1978].

107 BRYCE, Ian; GORDON, Mark; LEVINSOHN, Gary y SPIELBERG, Steven (Productores), SPIELBERG, Steven (Director), Saving Private Ryan (Salvar al soldado Ryan) [Cinta cinematográfica], Estados Unidos, DreamWorks SKG / Paramount Pictures / Amblin Entertainment, 1998. 
de esta, sino de la presencia de un dispositivo de captura de imagen que registra la escena, evidenciado mediante el acto del self por las manos de quien está tomando la imagen. Bajo estas pautas encontramos el ejemplo de la película de 1999 El proyecto de la bruja de Blair ${ }^{108}$, realizada bajo los protocolos del falso documental o del metraje encontrado. En la misma sus escenas principales están rodadas con cámaras domésticas, siendo la manufactura y presencia de estas evidente, sobre todo en los momentos en los que los protagonistas apuntan a sus propios rostros con estas máquinas (Imagen 3.73).

Por otro lado, encontramos el film de 2014 Chronicle $^{109}$ de corte similar al precedente, pero más actualizado en cuanto a dispositivos de captura, ya que cada escena del metraje está realizada o simulada desde cualquier tipo de aparato contemporáneo de captura (videocámaras digitales, smartphones, tablets o cámaras de videovigilancia), siendo la invitación al espectador de detectar la presencia de estas (puesta de relieve a partir de los propios puntos de vista generados desde las ópticas) un hecho destacable en cada toma (Imagen 3.74).

Este versus estre las maneras de encuadrar la realidad que hacían los fotógrafos clásicos frente a los modos que tiene el autorretratista digital de encuadrar la realidad que rodea a su yo, es fruto también de la diferencia entre ambas actitudes: así pues el fotógrafo tradicional pone el punto de vista en el eje de cómo él ve el mundo y el selfshooter lo pone en el eje de cómo el mundo quiere que lo vea.

108 COWIE, Robin y HALE, Gregg (Productores), MYRICK, Daniel y SÁNCHEZ, Eduardo (Directores), The Blair Witch Project (El proyecto de la bruja de Blair) [Cinta cinematográfica], Estados Unidos, Artisan Entertainment / Haxan Films, 1999.

109 DAVIS, John y SCHROEDER, Adam (Productores), TRANK, Josh (Director), Chronicle (Chronicle) [Cinta cinematográfica], Estados Unidos, 2oth Century Fox, 2014. 


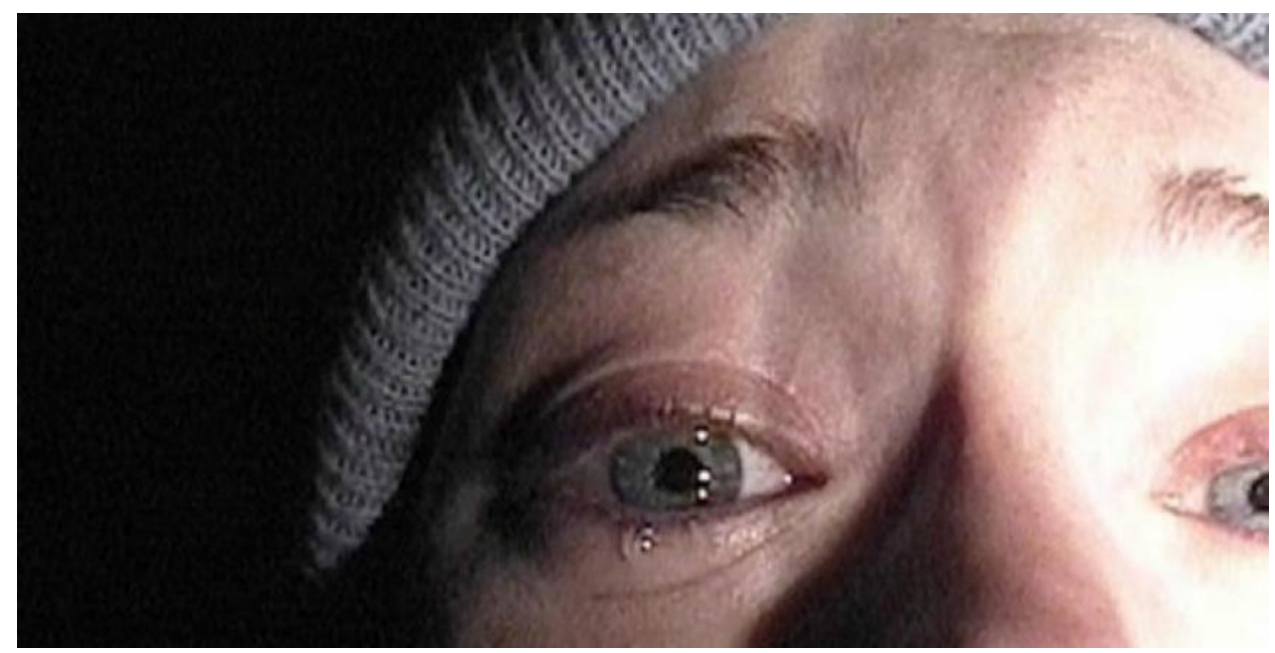

Imagen 3.73: Fotograma de la película de 1999 The Blair Witch Project que muestra parte del rostro de una joven que se autoencuadra con una cámara doméstica de los años 1990 mientras se graba.

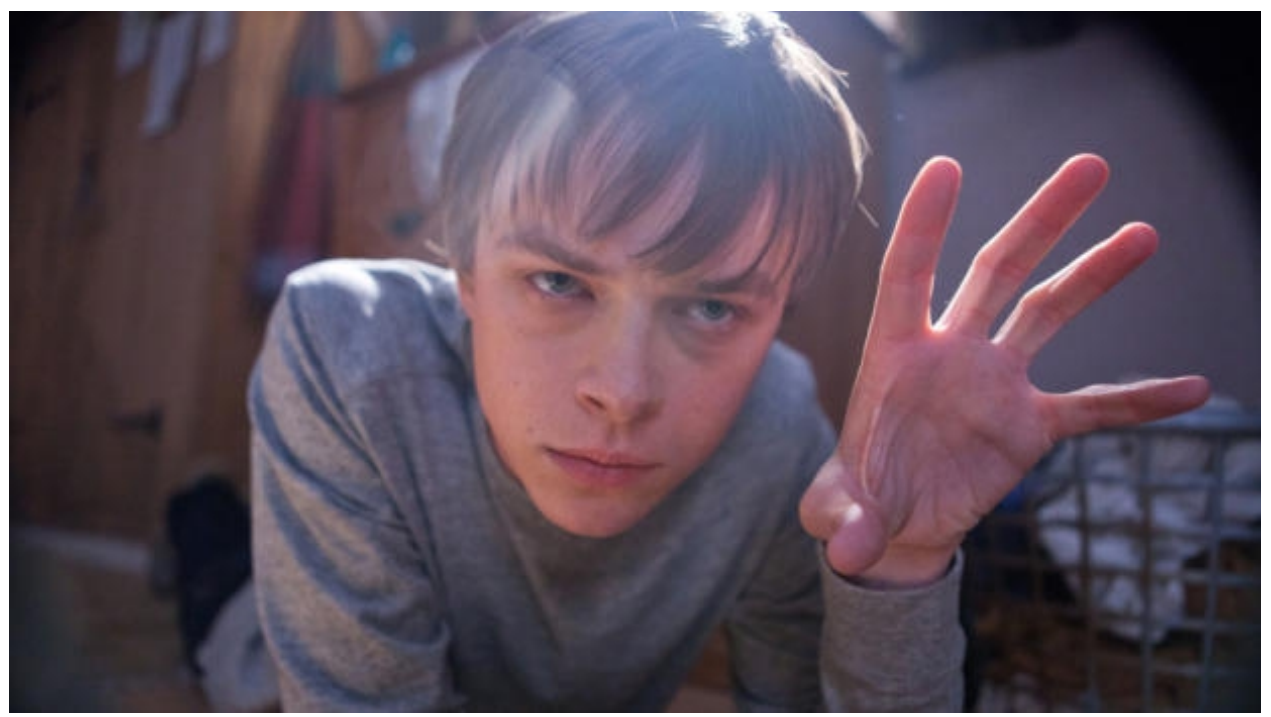

Imagen 3.74: Fotograma de la película de ciencia ficción de 2014 (rodada también bajo las premisas del metraje encontrado) Chronicle. En la misma, uno de sus tres protagonistas se autorregistra utilizando (mediante telequinesis) un dispositivo de captura digital que maneja desde el suelo, construyendo su imagen con la deformación propia de los selfies. 
El selfie, como elemento fotográfico, también ha sufrido estas nuevas estructuras compositivas que tanto lo caracterizan. Ya hemos visto cómo en sus formas más primitivas en las que todavía se realizaban los autodisparos a ciegas, la tendencia era buscar (intuir) un punto de vista cenital levantando el brazo con el dispositivo girado hacia el rostro. De esta manera, además del rostro (generalmente la única opción para encuadrar dada la corta longitud del brazo respecto al cuerpo y a la óptica del dispositivo) también podíamos introducir dentro del cuadro de la imagen el cuerpo y los pies. A su vez, este tipo de encuadre generaba unas distorsiones de desproporción que pronto se establecerían como algo más común de ver y, por tanto, algo más aceptable compositivamente hablando. Veremos en el capítulo 5 que estas nuevas formas compositivas propias de esta era y de sus dispositivos pueden llegar a embellecer el rostro por encima de sus posibilidades, aproximándolo a cánones introducidos por la dictadura de la moda y de los medios de comunicación. Así pues, estas distorsiones propias del selfie primitivo agrandarán los ojos y los pómulos, escondiendo las orejas, eliminando la papada y generando un tronco más esbelto y delgado. También en el selfie desarrollado a partir de la llegada de la pantallaespejo (que, como repasábamos en el punto 3.1.1, supone el efecto espejo de mano proporcionado por la lente frontal pegada a la pantalla que apunta hacia nosotros) se producen nuevos cambios en los modelos compositivos y estructurales de las imágenes de autorretrato producidas bajo estas nuevas pautas. La capacidad de vernos a tiempo real mientras nos fotografiamos, como en un espejo, nos permite jugar con el encuadre y con los puntos de vista de una manera más exitosa y controlada (Imágenes 3.75 y 3.76). Sin embargo, aunque estos protocolos parecen ser compartidos por el mirrorpic de cuarto de baño o de superficie reflectante en el ámbito público, su producto fotográfico es diferente, ya que la distancia entre sujeto y reflejo también lo es: frente a la pantalla-espejo nos miramos cara a cara, como al ponernos delante de un espejo de pared, pero la diferencia radica en el hecho de que al enfrentarnos a nuestro reflejo proyectado desde la palma de nuestra mano ya no estamos frente a un alter que 
nos observa a través de una distacia social (como en una conversación), es decir, ya no somos un cuerpo al otro lado del marco del espejo. Ahora nuestro otro yo es alguien que nos mira desde la distancia íntima, muy cerca del rostro, como lo hace un amante. Somos (o son) un rostro mirando a otro rostro.

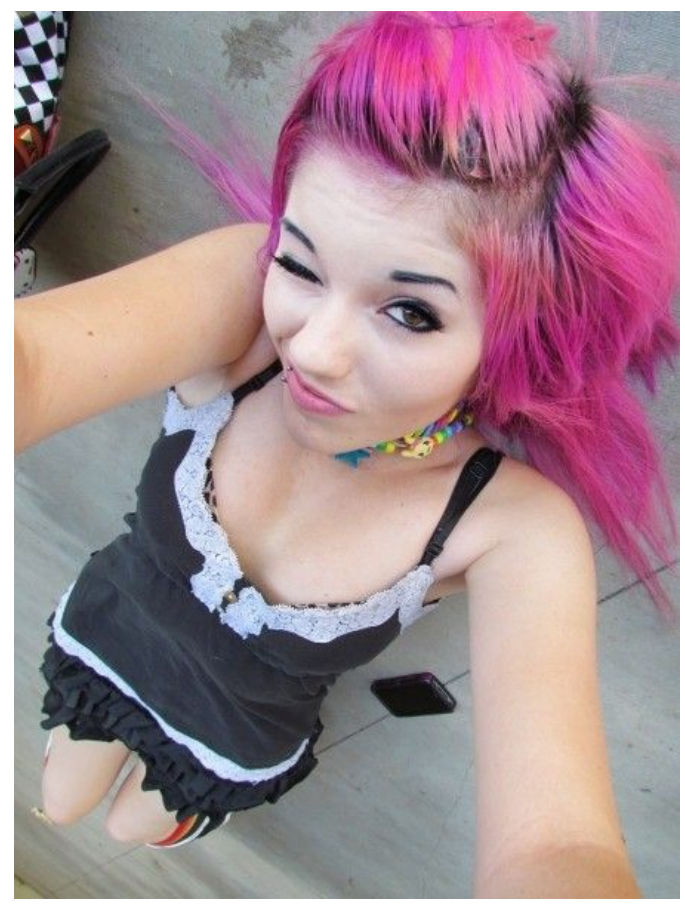

Imagen 3.75: Selfie de Leda Bunny publicado en Facebook en 2013. El encuadre, como podemos ver, desde una cámara que se evidencia en el extremo de unos brazos que salen del cuadro (afinado mediante la pantalla-espejo), nos procura un punto de vista totalmente novedoso: la cámara invertida para enderezar una figura que realmente está tumbada en el suelo y que crea la ilusión de frontalidad cenital. En detrimento de ello, las deformaciones caracuerpo-piernas son una constante en este tipo de imágenes.

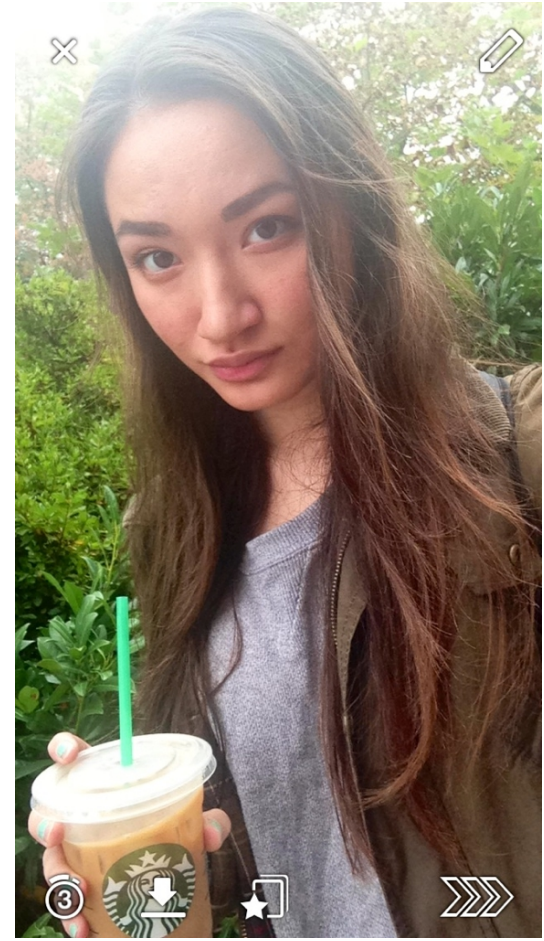

Imagen 3.76: Selfie anónimo compartido vía SnapChat en 2013 y encontrado en el buscador de imágenes de Google Inc. Como vimos, en esta nueva era de las pantallas-espejo el retrato se vuelve más próximo gracias al apoyo (o la tentativa) que proporciona el pequeño reflejo, buscando la frontalidad o, como en este caso, un plano ligeramente contrapicado. 
Cabe apuntar que, mientras el espejo de pared nos ofrece una imagen casi real, muy similar a la observable en el mundo físico tridimensional, la pantallaespejo, por contra, podría ofrecernos un producto especular de menor calidad, hecho que intervendría sobre el producto fotográfico generado mediante su uso. ¿Qué otra cosa puede esperarse de una superficie que no reflecta sino de manera simulada, emitiendo (en lugar de reflectando) una traducción en luz emitida mediante una pantalla y que es fruto de una realidad captada a tiempo real por la lente frontal a modo de vídeo rebotado? ¿Cómo podemos esperar que esa rejilla de micropuntos emisores de luz puedan competir con la pulida superficie de un espejo moderno? Ciertamente, la compresión de millones de puntos lumínicos es tal que, a efectos prácticos, el resultado es el mismo para nuestra percepción. La pantalla-espejo, pese a tratarse de una superficie no reflectante pero sí emisora, cumple su perfecto cometido como espejo de bolsillo.

Pero para realizar su trampa, su ilusión, la pantalla-espejo debe de realizar un truco final. Los ingenieros y programadores ya se han encargado de ello. $\mathrm{Y}$ es que esta pantalla simplemente no puede mostrar lo que su lente y sensor adjuntos graban, lo que van a fotografiar (Imagen 3.77), puesto que nuestro cerebro no sería capaz de asumir una imagen no invertida como reflejo. Para simular esa inversión, idéntica a la que hace el reflejo especular del espejo, el procesador del dispositivo y su software integrado producirán la magia del volteo horizontal ${ }^{110}$, la derecha será izquierda y la izquierda derecha, y debido a ello ya podremos disponer de nuestro reflejo (similar al que ofrece un espejo, Imagen 3.78) en la palma de nuestra mano o en el extremo distal de nuestro palo-selfie.

110 Como en los espejos: "[...] nosotros y la habitación aparecemos invertidos de izquierda a derecha. Como el cuerpo no es absolutamente simétrico y la izquierda-derecha son esenciales para la percepción e influyen en la expresión, la figura que apreciamos es la contraria de la que ven los demás”. CID, Carlos, op. cit., pág. 8. 


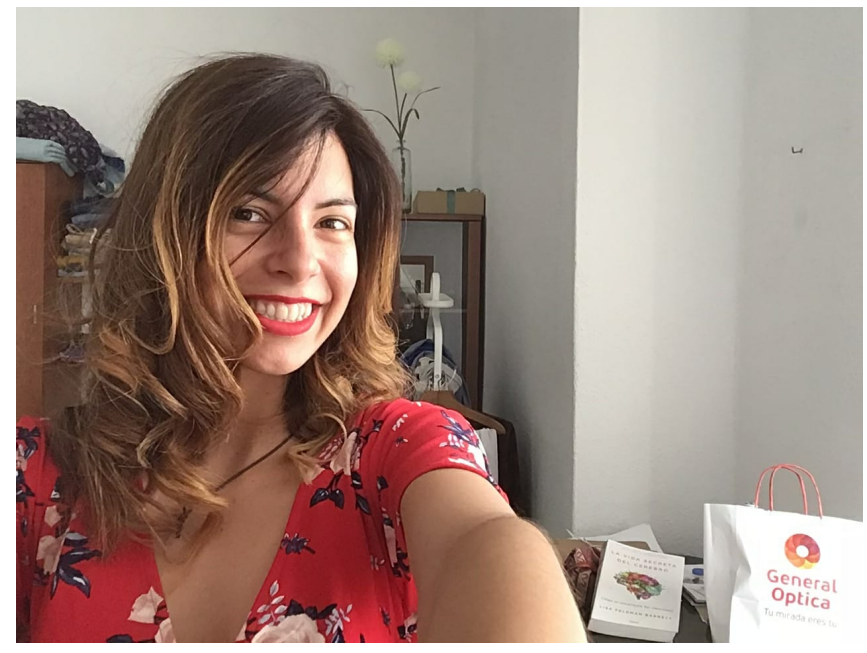

Imagen 3.77: Selfie realizado y publicado en la red por la usuaria@maribelagud en 2018. Aquí, el objeto fotográfico producido, aparece con la lateralidad correcta.

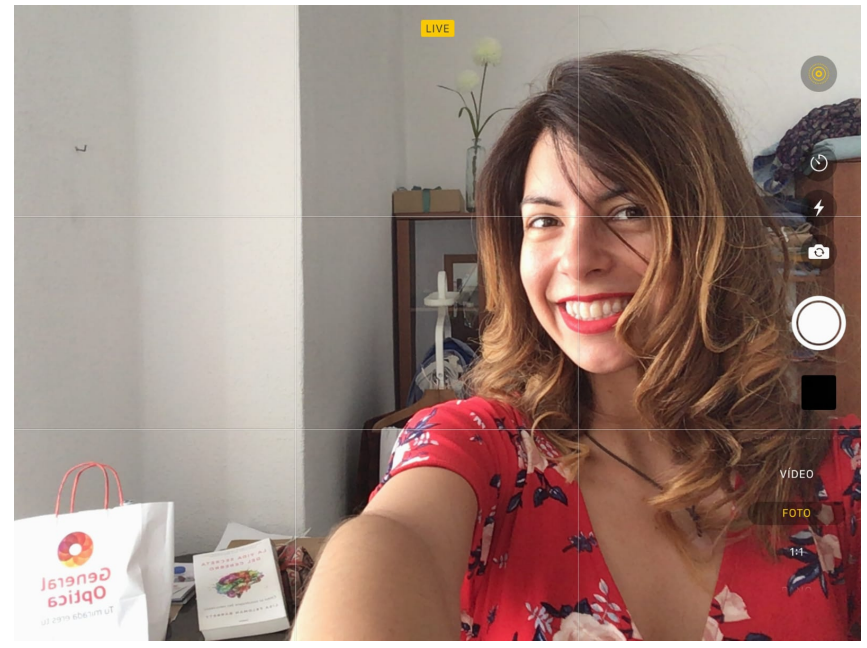

Imagen 3.78: Captura de pantalla de lo que está viendo la usuaria en la superficie virtualmente reflectante de su dispositivo en el mismo instante en el que se realiza el autorretrato. 
No obstante, y hablando de espejos y reflejos, siempre tendremos en cuenta la distinción que efectúa Eco respecto a la cámara oscura, hecho que justifica por qué este volteo no se produce también de manera vertical. Recordemos que ello se debe a que se parte de un entendimiento cultural de la imagen reflejada que deriva de una antropomorfización de los haces de luz rebotados:

\footnotetext{
"Si reducimos el fenómeno especular a un puro esquema abstracto, advertimos que no se producen fenómenos del tipo de la cámara oscura (fig. 1) [Imagen 3.79], sino fenómenos en los que ningún rayo se cruza (fig. 2) [Imagen 3.80]. Solo si antropomorfizamos lo que en el esquema corresponde al objeto real, adquiere este conciencia de una derecha y una izquierda y las compara con el objeto que se refleja en la superficie y con el objeto virtual que aparece más allá de la superficie -pero siempre partiendo del cálculo ilusorio de lo que serían derecha e izquierda si ese objeto, en lugar de reflejo, fuera real" ${ }^{111}$.
}

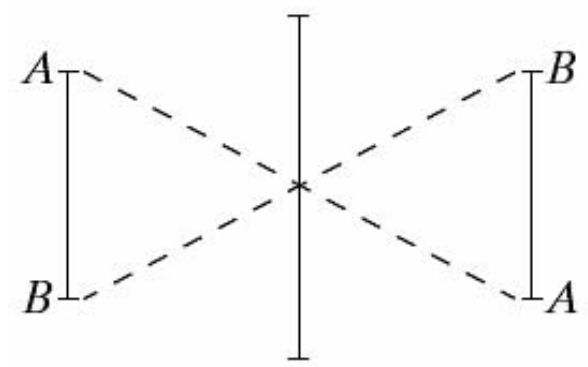

Imagen 3.79: Esquema extraído del estudio De los espejos y otros ensayos de Umberto Eco, en relación a la cámara oscura.

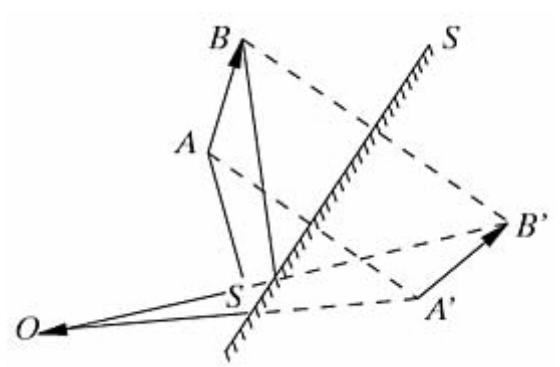

Imagen 3.80: Esquema presente en el citado estudio de Umberto Eco en relación al reflejo especular. 
Para finalizar, es un hecho también destacable de los selfies la generalmente desviación de la mirada hacia el vértice y no hacia el espectador del autorretrato. Esto es causado por la posición de la óptica receptora ligeramente desplazada de la pantalla-espejo emisora del reflejo. La autorretratista tendría así dos opciones: una, mirar su reflejo durante la composición y también durante el disparo, lo que provocaría esta desviación de la mirada que ocurre en la mayoría de los selfies que podemos encontrar; y dos, mirar su reflejo durante la composición, pero dirigir su mirada hacia la lente durante el disparo, lo cual haría que el autorretrato resultante "observara directamente a quien lo está mirando".

\subsubsection{La dictadura de la herramienta y su relación con las nuevas perspectivas compositivas.}

$\mathrm{Si}$ reparamos en lo acontecido durante estos años (cuestiones que estamos repasando a lo largo de este capítulo) y continuamos analizando todas estas nuevas formas fotográficas como objetos poseedores de perspectivas compositivas y formales alternativas que son construidas en su bidimensionalidad de una manera relativamente novedosa, podríamos apuntar que sus ejecutores, los y las autorretratistas, han sido totalmente responsables de estas derivas y transformaciones, siguiendo sus propias pautas de creatividad y experimentación. Pero, a pesar de ello y a pesar también de las innumerables referencias aportadas por el bombardeo mediático propio de una sociedad de imágenes, espectáculo y representación, otros factores externos a su propio control y albedrío podrían ser también corresponsables de la construcción de estas formas. En este sentido, se puede afirmar que es probable que el principal factor de la estructura formal de los self shots derive de la propia herramienta: la 
máquina fotográfica o dispositivo de captura digital, junto con sus elementos (sensores, ópticas, software, etc.). De este modo, y como en tantas otras ocasiones ha sucedido a lo largo de la historia del arte, la herramienta del artista sería coautora de la propia obra de arte, conformando un tándem con el artista.

\begin{abstract}
"A la luz de estos planteamientos lo que parece constatable es que a día de hoy la red y los teléfonos móviles con cámaras implementadas han alterado significativamente las formas de obtención, manipulación y difusión de las fotografías, abriendo un nuevo espacio en el ejercicio de una nueva experiencia fotográfica. El selfie tiene mucho que enseñarnos sobre el papel omnipresente de la fotografía en la vida cotidiana, pues la estructura temporal de la imagen fotográfica es desafiada” ${ }^{112}$.
\end{abstract}

Las nuevas perspectivas compositivas creadas así de esta manera, serían capaces de generar estas nuevas formas en las que, como también a lo largo de la historia del arte, la perspectiva como forma simbólica ${ }^{113}$ volverá a dar otro giro en su forma de ser dispuesta frente al espectador, generando estas extrañas deformaciones que, si bien a priori pueden resultar irreales, con el paso del tiempo devienen habituales ${ }^{114}$ :

"Conviene no perder de vista que, a lo largo de los siglos, han existido múltiples artificios destinados a producir una representación icónica que una cultura dada

112 RABADÁN, Ángel V., op. cit., págs. 39-40.

${ }_{113}$ "Desde este punto de vista la perspectiva queda claramente situada como un método de representación que aspira -pero difiere sustancialmente a la vez- a representar de forma eficiente la profundidad del mundo real, a través de la producción de un «display» bidimensional capaz de generar una imagen retínica lo más comparable posible al «display» tridimensional formado por el tema objeto del mensaje visual". ZUNZUNEGUI, Santos, Pensar la imagen, Madrid, Cátedra, 2010, pág. 45. En relación a esta importante cuestión de la perspectiva como forma en la imagen y no como realidad, el fundamental ensayo de Panofsky: PANOFSKY, Erwin, La perspectiva como forma simbólica, Barcelona, Tusquets, 1999. Entendemos pues que, pese a sus posteriores roturas y deformaciones aquí tratadas, la fotografía sería la "heredera lógica de la perspectiva". RAMÍREZ, José Antonio, Medios de masas e historia del arte, Madrid, Cátedra, 1976, pág. 165. Al fin y al cabo, "fueron los pintores los que inventaron la fotografía”. BARTHES, Roland, La cámara lúcida, Barcelona, Paidós Ibérica, 2009, pág. 94.

114 SCHAEFFER, Jean-Marie, op. cit., pág. 8. 
considerase adecuada en relación a su sistema de organización del sentido (contenido)" ${ }^{115}$.

También José Luis Brea apunta a esta adaptabilidad, puntualizando que:

"Variarán, además, el conjunto global de las reglas que ordenan los modos del representar, del producir imágenes, tanto como las del contemplarlas o el extraer de ellas valor de simbolicidad: el ámbito mismo de la visualidad, en su conjunto, el espacio lógico de la totalidad de los actos de ver. Para todo ello, la aparición del ojo técnico resulta fundamental. Él, la máquina de ver y producir técnicamente las imágenes de ese ver [...], traerá modificaciones que acabarán por prefigurar un orden de la visión radicalmente diferenciado" ${ }^{116}$.

Todos estos cambios que requieren sus acompasadas adaptabilidades, como hemos comentado al principio de este punto, serían en parte fruto y voluntad de esa máquina coautora de la obra, que dejaría su huella impresa en la pieza, como si formara parte de las voces de la conciencia de la autorretratista. Esta circunstancia, por ejemplo, ha inundado los noticieros de la televisión con vídeos realizados en formato vertical por buenos ciudadanos que se ocupan de grabarlo todo. Esta vigilante obediencia, sin embargo, obliga a una edición en horizontal (con añadidos laterales en negro o con imágenes desenfocadas), intervención que ha de realizarse para compensar el efecto derivado de este modo de grabación vertical que permite el smartphone ${ }^{117}$. Así, la presunta (aunque no obligada) verticalidad implícita en la toma, dada la ergonomía del dispositivo capturador, junto con su propia miniaturización, son ejemplos de cómo el dispositivo procura cambios e impone sentencias sobre el supuesto libre

115 ZUNZUNEGUI, Santos, op. cit., pág. 48.

116 BREA, José Luis, Las tres eras de la imagen, Madrid, Akal, 2010, pág. 37.

117 VV. AA., "La batalla del vídeo vertical: 90 grados que están haciendo que nos perdamos una parte del mundo", 2017, disponible en: <https://lgmobile.xataka.com/la-batalla-del-video-vertical-90-gradosestan-nos-perdamos-una-parte-del-mundo/> [Fecha de consulta: 9 de octubre de 2017]. 
albedrío del fotógrafo ${ }^{118}$, así como sobre el de cualquier artista a lo largo de la historia del arte:

"Los avances científicos siempre han tenido repercusiones inmediatas sobre los resultados artísticos: la herramienta ha condicionado al artista de tal manera que, aunque para muchos sea duro de asumir, desde el acceso a ciertos minerales para conseguir colores únicos por parte de los pintores pre-industriales (anteriores a la síntesis química de los colores), hasta el uso del vídeo en los rodajes cinematográficos, el paralelismo avances tecnológicos/evolución artística se puede trazar en una línea de tiempo casi perfecta” ${ }^{119}$.

Esta idea en torno a la dictadura del dispositivo apuntada hacia nuestro objeto de estudio podría, sin embargo, no ser una tiranía totalitaria aunque sí severa. En palabras de David Caldevilla (en uno de los estudios más pioneros que hemos encontrado sobre el autorretrato digital publicado en la red y sobre su relación con la Web 2.0, difundido en 2010):

\begin{abstract}
"Resulta imposible saber quién realizó el primer autorretrato desde un ángulo picado y cuáles eran sus motivaciones para haberlo tomado así y no de otro modo. Posiblemente lo que no sabía es que ese tipo de fotos con el paso del tiempo se iban a convertir en un fenómeno imitado por muchísima gente. ¿Por qué se hace la gente fotos desde un ángulo picado? Posiblemente muchos de los usuarios asiduos a las redes sociales conozcan la respuesta: para parecer más delgados. La composición y los sistemas de representación se han convertido en dos piezas fundamentales para construir las identidades virtuales y elegir qué parte de lo real vamos a compartir y cómo vamos a representarlo. Es cierto que mucha gente sigue realizando fotografías sin tener en cuenta los efectos ópticos o sin aplicar retoques digitales para posteriormente compartirlas en las redes sociales, pero también se ha generado paralelamente un discurso donde determinados recursos y modos de representación
\end{abstract}

\footnotetext{
118 MARTÍNEZ, Diego, Miniaturización y democratización de las cámaras cinematográficas y de vídeo digital, Gandía, Universitat Politècnica de València, 2016, pág. 92.

119 CASTILLO POMEDA, José M. "La composición en los tiempos del selfie", en Espéculo. Revista de estudios literarios, $\mathrm{n}^{\mathrm{o}} 54$ (Ejemplar dedicado a: Narrar en la era digital), 2015, pág. 128.
} 
se han convertido en una moda y han ido generado un discurso estético bastante interesante" ${ }^{120}$.

Es probable que estos dos conceptos contrapuestos convivan creando un equilibro que se retraolimenta en este tipo de creaciones, combinando la autoría de la máquina y la del autor. Bajo nuestra opinión, el primer protocolo podría pesar más que el segundo, no obstante, esto no quita valor ni a la adaptación de un usuario o usuaria que se apropia y modela sus tecnologías ${ }^{121}$, ni a la creatividad expresa en muchas de las imágenes generadas por los y las selfshooters aquí mostradas (Imagen 3.81).

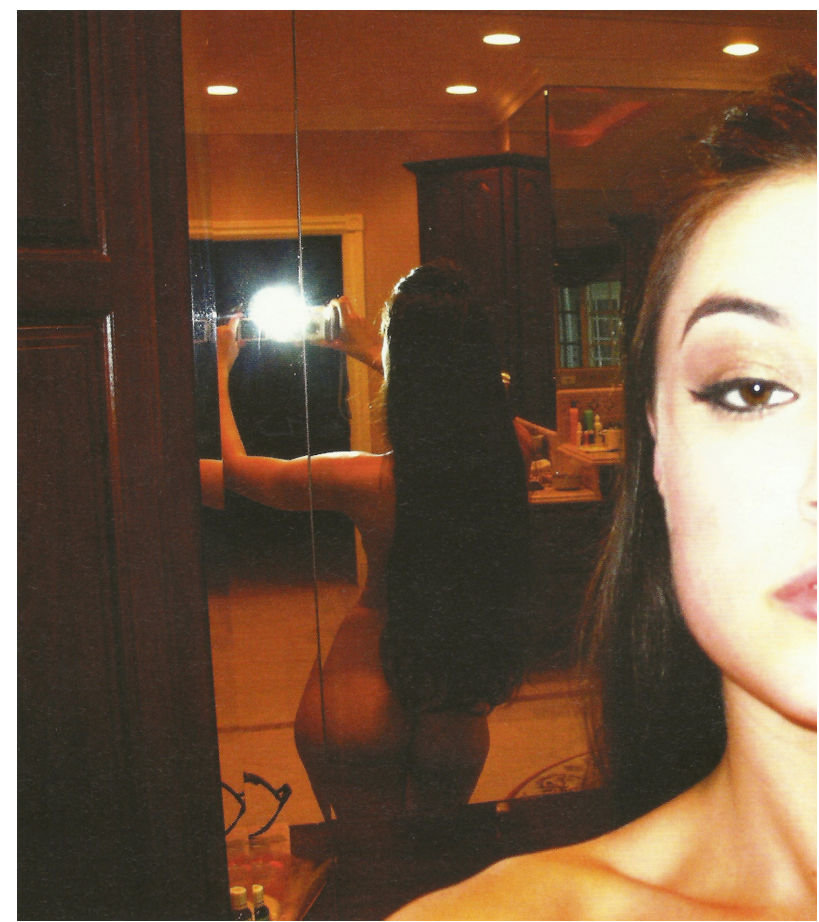

Imagen 3.81: Autorretrato realizado por Sasha Grey en 2010. La imagen será publicada en su libro Neü Sex (que analizaremos en el capítulo 8).

120 CALDEVILLA, David, op. cit., pág. 83.

121 GATES, Bill, Camino al futuro, Madrid, McGraw-Hill, 1997, pág. 7. 


\subsection{El self shot como concepto fotográfico.}

De la misma manera con la que acabamos de elaborar un análisis en torno a nuestro objeto de estudio desde el punto de vista formal o físico, partiendo de la premisa de que podría tratarse de un objeto fotográfico, podemos igualmente establecer diferentes aproximaciones mediante un conjunto de aspectos conceptuales relacionados con la fotografía que permitirían dotar a este objeto de un estatuto fotográfico con teoría propia.

Dicho de otra manera: pasaremos a tratar en este último punto del capítulo 3 los aspectos más teóricos y conceptuales del self shot, habiendo dejado cerrado en el subcapítulo anterior los aspectos más técnicos y formales de su cuerpo fotográfico.

\subsubsection{La mirada postfotográfica.}

En tanto que el self shot y sus variantes son objetos exclusivamente fotográfico-digitales, no solo hijos de las doctrinas de esta nueva era electrónica de la fotografía, sino quizá también uno de sus mayores abanderados, podemos catalogarlos como un objeto postfotográfico, una de las etiquetas más extendidas para definir la fotografía del siglo XXI por autores como Joan Fontcuberta:

\footnotetext{
"En efecto, la fotografía ha sobrepasado el año 2000 con una sensación de crisis de identidad. El vertiginoso cambio tecnológico al que asistimos, así como el contexto político y económico que lo propician, ha trastocado la génesis y la naturaleza de la imagen fotográfica hasta un grado tal que se legitiman todas las incertidumbres sobre su estatus actual. Permanece el gesto del fotógrafo y permanecen también las
} 
apariencias de la imagen final como producto icónico, pero el recorrido entre uno y otra discurre hoy por un paisaje irreconocible. Algunas voces autorizadas -como la de Cartier-Bresson- se obcecan en clamar que la fotografía no ha cambiado desde sus orígenes, salvo en la técnica, que es lo que menos nos interesa. Lo que es una forma de decir: tranquilos, no pasa nada. Pero lo cierto es que sí pasa. Lo importante no es saber si el bueno de Henri encontrará repuestos para su Leica o si alguien seguirá revelando sus rollos de blanco y negro. Lo importante serían cuestiones de otro tipo [...] La fotografía ha modificado el protocolo con la industria, con la ciencia, con la publicidad, con el periodismo, con la comunicación, con el arte, con la vida cotidiana... Todo el fundamento ético y estético ha sido subvertido. Decididamente, el paisaje se ha vuelto irreconocible, tan irreconocible que algunos, los más radicales, hablan de la muerte de la fotografía, y otros, más comedidos, introducen una nueva categoría, necesariamente ambigua: la postfotografía (una curiosa denominación que es muy cercana a otra: la posthistoria). $\mathrm{Y}$ a poco que reflexionemos percibiremos que esas nuevas tecnologías constituyen las causas más visibles de un cambio, pero no son ni mucho menos las únicas ni tan siquiera las más decisivas. La dramática metamorfosis del grano de plata al píxel no representa más que una pantalla que eclipsa la evolución operada en todo el marco que proporcionaba un encaje cultural, instrumental e histórico de la fotografía”" ${ }^{122}$.

Ya hemos visto cómo las prácticas en torno a la fotografía digital están transformando el campo cultural de la fotografía ${ }^{123}$ y cómo su generalización ha tenido consecuencias importantes en lo que se refiere al estatuto de la imagen fotográfica en la cultura visual contemporánea ${ }^{124}$.

Con la llegada de esta nueva era, la fotografia se ha vuelto, si se nos permite la expresión, más narrativa y su tiempo de exposición se ha expandido más allá del instante abstracto de la captura. El tiempo expandido del inconsciente óptico fotográfico se convierte en un tiempo concentrado de narración, y la vocación de narrar (de dar cuenta de la experiencia, ahogada en

\footnotetext{
122 FONTCUBERTA, Joan (Ed.), Fotografía. Crisis de historia, Barcelona, Actar, 2002, págs. 9-11.

123 RABADÁN, Ángel V., op. cit., pág. 30.

124 MARZAL, Javier, op. cit., pág. 93.
} 
las nuevas sociedades bajo el paradigma de la información) "encuentra en este tiempo-ahora expandido del instante fotográfico la ocasión de relatarse como invocación, también, de un tiempo pleno" ${ }^{125}$.

Estas prácticas postfotográficas son causa directa de que, en el actual panorama de convergencia de medios, la fotografía haya dejado de ser un medio autónomo.

\begin{abstract}
"Las acciones que conforman la práctica común de la fotografía ya no quedan reducidas al uso de la cámara como dispositivo único y separado ni el acto de tomar fotografías es el momento central en la creación de significados de las imágenes fotográficas. Asistimos a [la...] era postcámara donde la cámara fotográfica ha quedado absorbida en otros dispositivos como teléfonos móviles, tablets e incluso complementos de vestir como las Google Glass. Siguiendo esta línea, [...] la fotografía se ha convertido en algo ambiental no solo por la proliferación de imágenes que se esparcen sin restricción por dominios públicos y privados -ubicuidad como everywhere - sino también, y sobre todo, porque la fotografía es cada vez más inseparable de los logros e innovaciones asociadas con el fenómeno de la ubicuidad de los dispositivos informáticos, y de las mismas tecnologías de la comunicación, en casi todo tipo de objetos y dispositivos. [...] en un entorno de convergencia medial, la fotografía ha traspasado el ámbito estricto de los llamados nuevos medios y de sus remediaciones [...], para implicarse con la racionalidad que subyace al sistema de la tecnociencia y la reordenación de la vida que tiene lugar bajo su amparo" ${ }^{126}$.
\end{abstract}

Por su parte, el ya citado Brea sostiene que, en un mundo postfotográfico, las fotografías han dejado atrás su física corpórea para devenir entidades fantasmales:

125 BREA, José Luis, La era postmedia. Acción comunicativa, prácticas (post)artísticas y dispositivos neomediales, Salamanca, Centro de Arte de Salamanca, 2002, págs. 19-20.

126 MIRA, Enric, “Tras la crisis de la cultura Kodak. Un análisis de la funcionalidad de la fotografía personal en la Web 2.0”, en Historia y comunicación social, vol. 19, $\mathrm{n}^{\circ} 2$ (Ejemplar dedicado a: La comunicación en la profesión y en la universidad de hoy), 2014, pág. 749. 
"Fantasmización. En buena medida, las electrónicas poseen la cualidad de las imágenes mentales, puro fantasma. Aparecen en lugares -de los que inmediatamente se esfuman-. Son espectros, puros espectros, ajenos a todo principio de realidad. Si, al decir lacaniano, lo real es lo que vuelve, las imágenes electrónicas carecen de toda realidad, por falta de la menor voluntad de retorno. Ellas son del orden de lo que no vuelve, de lo que, digamos, no recorre el mundo «para quedarse». Faltas de recursividad, de constancia, de sostenibilidad, su ser es leve y efímero, puramente transitorio. [...] Como las imágenes mentales -las imágenes de nuestro pensamiento-, las electrónicas solo están en el mundo yéndose, desapareciendo. Por momentos están, pero siempre dejando de hacerlo. Como lo espectral, su ser es el de las apariciones $-\mathrm{y}$, como ellas, se apresuran rápido a abandonar la escena en que comparecen-. Son, al mismo tiempo, (des)apariciones [...], la imagen digital no está presente en el mundo. Desaparece como una transición que no queda en el sitio sino que es como un fantasma, aparece y desaparece" ${ }^{127}$.

Este carácter fantasmagórico propio de los nuevos objetos fotográficos es, a su vez, una metáfora del proceso de desmaterialización que ha sufrido este cambio de era. Hoy las fotografías son datos visuales en estado puro, contenido sin materia física, imagen sin cuerpo.

Como estamos viendo, esta condición inmaterial de la fotografía abre perspectivas magníficas para la difusión y la interacción colectiva ${ }^{128}$. Por otro lado, su conservación sí que plantea un reto, ya que si bien las fotografías clásicas eran (casi) eternas en su soporte papel, necesitando luz ambiente para ser contempladas pero no energía para ser mantenidas, las nuevas fotografías

127 BREA, José Luis, Las tres eras..., op. cit., pág. 67.

128 FONTCUBERTA, Joan, La cámara de..., op. cit., págs. 64-65. 
electrónicas son efímeras en su soporte pantalla ${ }^{129}$, y pese a no necesitar luz ambiente para ser vistas, necesitan energía constante para ser retroiluminadas.

Pese a todo, la lectura que hacemos de la física visual de la imagen podría seguir siendo la misma en ambos mundos, el verdadero cambio, como hemos visto, reside en todo lo demás, y esta desmaterialización de la física objetual, nos llevaría también a plantear el concepto de original y copia en estos nuevos productos postfotográficos.

No es que la imagen fotográfica producida con medios químicos no fuera copiable, pero existía un original en tanto en cuanto la imagen latente era generada en una única gelatina de plata $\mathrm{y}$, una vez allí y tras su nacimiento $\mathrm{y}$ revelado, generalmente solo producía una copia sobre su medio final: el papel. Además, esta imagen física era estéril e incapaz de generar nuevas copias, y si queríamos producir otra imagen casi idéntica teníamos que volver a la fuente (la película) para materializarla de nuevo.

Sin embargo, una fotografía digital, a nivel conceptual, existe siempre como copia y nunca como original, en tanto que se trata de un texto escrito invariable (concepto) y no de una escultura molecularmente inimitable (objeto).

129 En tanto que la mayoría de fotografías digitales no salen de las múltiples pantallas que las acogen, salvo una pequeña cantidad que (bajo técnicas de impresión) alcanzarán el estatuto de fotografíaspapel. "Una de las principales consecuencias que ha tenido la aparición de las cámaras digitales fotográficas ha sido la espectacular bajada de impresiones fotográficas, un proceso que ha sido y está siendo vivido de forma dramática por los fabricantes de productos fotoquímicos para el revelado de películas y positivado de copias, y por los laboratorios fotográficos. En efecto, el consumidor ha ido almacenando durante años fotografías en su ordenador, y apenas ha impreso imágenes, ni siquiera con sus equipos domésticos". SOLER, María, Las empresas de fotografía ante la era digital. El caso de la Comunidad Valenciana, Madrid, Ediciones de las Ciencias Sociales, 2007, pág. 59. Este ejercicio quedará, pues, como condición adicional, en lugar de como condición única de reproducción visual: "Definitivamente ya no podemos suponer que la imagen fija impresa fotográfica es la forma arquetípica de la fotografía, sino una de las muchas realizaciones posibles de una serie de aparatos tecnológicos y prácticas configuradas alrededor de la producción del campo visual. La fotografía, por lo tanto, ya no tiene (si es que alguna vez la tuvo) ninguna estabilidad ontológica”. GREEN, David (Ed.), op. cit., pág. 8. 
De hecho, su propio nacimiento ya escenifica una rápida clonación: fotografiar con cualquier dispositivo exige pronto rápidas copias, incluso de manera pasiva si las realizamos con un smartphone, que generalmente de manera automática crea clones en la nube para guardar las copias de seguridad. Compartir, publicar, enviar... los ejercicios que, también de manera casi inevitable acompañan al hecho fotográfico digital, crearían nuevos clones en servidores y dispositivos ajenos, sin contar con una posible viralización de la imagen, que elevaría a millones la copia de la misma en pocos minutos. ¿Dónde queda entonces el original?

Nos enfrentamos, por ello, a "una ontología clónica, innumeral, para la que ya no existen los singulares. [...] cada una de ellas es un cualsea que, siendo un uno entre muchos, es al mismo tiempo la totalidad posible de la serie vertida infinitas veces" ${ }^{\prime 30}$.

Esta circunstancia, inevitablemente, nos lleva, por un lado, a la clonación automática y, por otro, a la viralización o pandemia en ocasiones de una imagen que se convierte pronto (aunque sea durante un fugaz instante) en icono efímero. La red puede ser así soporte para la cacofonía visual de una misma imagen que residiría como pulso, como horda, pudiendo asediar desde innumerables frentes los ojos ávidos de su consumo (Imagen 3.82).

130 BREA, José Luis, Las tres eras..., op. cit., págs. 75-76. 


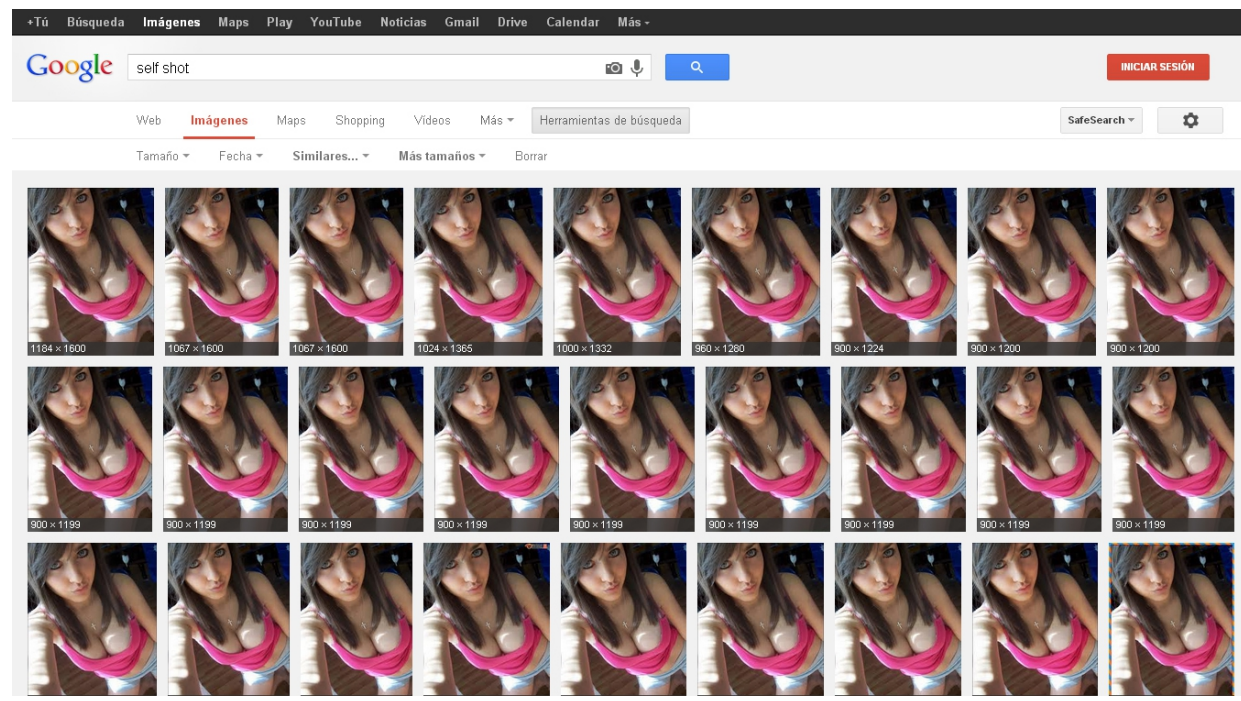

Imagen 3.82: Un ejemplo visual a través de una captura de pantalla de los resultados mostrados por el buscador de imágenes de Google Inc., tras introducir esta fotografía de Jaime Laycock. El buscador es capaz de encontrar por toda la red otras copias (en todas sus variables de tamaño en píxeles) de esta imagen. Tras una búsqueda realizada el 17 de julio de 2015, se filtraron miles de copias idénticas, localizadas en infinidad de sitios de Internet. Millares de clones de la fotografía primigenia, que sumados a la cantidad de copias que, con total seguridad, se encuentran almacenadas de manera local en una miriada de computadoras personales, ejemplifican la naturaleza rizomática y pandémica de algunas de las fotografías digitales que se publican en la red.

Por otro lado, al no haber un soporte estandarizado para la visualización vía pantalla de estas imágenes digitales clónicas, se produce "una incertidumbre sobre cómo se ven las imágenes en diferentes entornos". Ello hace "que las manifestaciones estéticas de una fotografía [sean] múltiples y siempre condicionadas a la tecnología de representación y visualización de las imágenes" ${ }^{131}$.

131 IGLESIAS, David, La fotografia digital en los archivos. Qué es y cómo se trata, Gijón, Trea, 2008, pág. 16. 
Frente a esta cacofonía visual y aluvión de imágenes que generan una hipervisualidad, es normal ver una copia rizomática en torno a la misma figura icónica, según hemos visto en los ejemplos que ilustran nuestro objeto de estudio. Ya decía Walter Benjamin que, al igual que durante la historia, la copia de la imagen ha sido una constante, en una era en la que la reproductibilidad técnica es facilmente viable, esto se puede manifestar con una intensidad creciente $^{132}$, y mucho más hoy en día, donde la generación de la copia ya es un hecho pasivo por parte de los dispositivos de captura fotográfica. También otro autor cuyas teorías quedan fuera de esta era como puede ser René Berger, habla de:

"[...] lo múltiple que tiene como propio, no solo la falta de referencia a un original, sino además la abolición de la idea de que puede haber original, pues dado que cada ejemplar comporta, en su singularidad, una referencia a los demás ejemplares, unicidad y multiplicidad dejan de oponerse, del mismo modo que «creación» y «reproducción» dejan de ser antinómicas”"133.

Curiosamente, esta afirmación que procede de una era fotográfica, podemos aplicarla, sin problema alguno, a la nueva etapa postfotográfica.

Dejando de lado los conceptos de original y copia, nos enfrentamos una vez más a esta hipervisualidad propia de la postfotografía, una hipervisualidad que no es algo nuevo, ya que las imágenes se han multiplicado cuantitativamente a lo largo de la totalidad del siglo pasado de manera constante y progresivamente creciente $^{134}$. Sin embargo, a partir del surgimiento de la nueva fotografía, este crecimiento progresivo generará una vertiginosa curva de explosión exponencial, que alcanzará sus mayores cotas con la llegada de la Web 2.0 y, posteriormente, con la implantación de las redes sociales y los canales comunicacionales de los

\footnotetext{
132 BENJAMIN, Walter, Sobre la fotografía, Valencia, Pre-Textos, 2004, pág. 93.

133 BERGER, René, Arte y comunicación, Barcelona, Gustavo Gili, 1979, pág. 17.

134 AUMONT, Jacques, La imagen, Barcelona, Paidós, 1992, pág. 333.
} 
smartphones (tal y como veremos en mayor profundidad durante los capítulos 4 y 6). Este hecho nos lleva a entender las imágenes como "habitantes obsesivos de todos los lugares, potencialmente. Ellas siempre están en todas partes, siempre han tenido ese don -el de la ubicuidad-" ${ }^{135}$. A su vez, la hipervisualidad del mundo, que convierte a la imagen audiovisual en un constante directo, ha puesto en jaque, incluso, al modelo historiográfico que permite conservar su legado ${ }^{136}$.

\begin{abstract}
"Hemos alcanzado la hipervisualidad, donde una imagen es reproducible en millones de espacios diferentes a la vez y donde un fenómeno cotidiano y/o social (una circunstancia determinada y circunscrita en un espacio y un tiempo determinado y condicional) es representado de múltiples formas, a través de múltiples «ojos sociales enculturizados» cada uno de ellos de maneras muy diferentes [...]. Hipervisualidad, «por la cuestión de la densidad de imágenes por metro cuadrado o por metro cúbico, tanto en el espacio global de la ciudad como en el espacio personal y centrípeto de la organización del mundo que nos rodea»"137.
\end{abstract}

Es de esperar que esta hipervisualidad a la que estamos aludiendo implique un riesgo de deterioro de la propia imagen fotográfica hasta el punto de convertirla, como venimos sugiriendo, en otra cosa. De esta manera:

\begin{abstract}
"[...] los riesgos de una sociedad basada en imágenes y progresivamente vaciada de contenidos son notables y la cuestión no estriba tanto en debatir si una sociedad eminentemente icónica es más o menos culta, más o menos inteligente que las predecesoras, sino en prevenirla contra esos peligros que esconde el envoltorio de la golosina audiovisual" ${ }^{138}$.
\end{abstract} encuentro interdisciplinar", en Fotocinema. Revista científica de cine y fotografía, no 10 (Ejemplar dedicado a: Miradas convergentes: la fotografía y sus interpretaciones en humanidades y ciencias sociales), 2015, pág. 20.

137 RABADÁN, Ángel V., op. cit., pág. 31.

138 RÓDENAS, Gabriel, “Capturar es compartir. Filosofía, redes sociales y fotografía 2.o”, en Enrahonar. An International Journal of Theoretical and Practical Reason, $\mathrm{n}^{\mathrm{O}} 5 \mathrm{O}$ (Ejemplar dedicado a: Estética de las imágenes), pág. 70. 
Estos riesgos podrían apuntar hacia uno de los principales males de la postfotografía: la gestión cualitativa mediante el visionado de la imagen ante tal aluvión de productos generados:

"La capacidad humana de análisis y síntesis de los millones de imágenes creadas en el día a día se ha visto rebasada en forma significativa. Parte del análisis se enfoca a algunos de los problemas que se enfrentarán y la manera en que deberá penetrarse en el análisis cuantitativo y cualitativo de ese alud de imágenes" ${ }^{\prime 39}$.

Será entonces razonable pensar que, pese al esfuerzo entendible ante tal alud de imágenes, el ojo sigue haciendo gala de la discriminación visual que siempre lo ha caracterizado ${ }^{140}$, ejercicio más que necesario frente a esta realidad social prácticamente construida en torno al consumo de la imagen postfotográfica.

"Como una lluvia constante, densa y pertinaz -acaso como aquella lluvia de Blade Runner que anticipaba su reino-, miles de imágenes descargan en todo momento, en toda dirección, en todo lugar, sobre el mundo que habitamos"141.

\subsubsection{Una aproximación desde la semiótica y la retórica.}

Si continuamos con la premisa de que el self shot y sus variantes pueden ser analizados como objetos fotográficos, desarrollaremos ahora un pequeño

139 MONROY, Rebeca, "Nuevos retos para los fotohistoriadores de la fotografía analógica a la digital”, en Iztapalapa. Revista de ciencias sociales y humanidades, $\mathrm{n}^{0} 78$ (Ejemplar dedicado a: Imágenes y cultura digital), 2015, pág. 16.

140 BREA, José Luis, Las tres eras..., op. cit., pág. 69.

141 Ibídem, pág. 92. 
recorrido por algunas de sus facetas que, al igual que la fotografía clásica, también contemplan conceptos relacionados con la semiótica, con la retórica y con teorías convergentes a estas disciplinas tan fértiles en el ámbito de la imagen:

\begin{abstract}
"La nueva realidad social de la fotografía implica también para los investigadores la necesidad de abordarla ya no solo como medio de representación (lo que muestra), sino considerando las formas en que es creada y utilizada. Esto significa que la semiótica de este tipo de mensaje ha de ser considerada también de otra forma, asociándose con una perspectiva antropológica [...], y teniendo en cuenta que su significado, en el momento de la toma, puede cambiar radicalmente en el momento de su observación, en otro lugar y otro momento" ${ }^{142}$.
\end{abstract}

Así, igualmente el discurso fotográfico digital, que incluiría subproductos como el self shot, podría también adecuarse a un análisis que sitúe dicho discurso en el interior de un determinado conjunto de prácticas significantes, dejando de lado todo intento de ver en aquel un puro mecanismo del que el mundo se serviría para hablarse en una operación tautológica. Este ejercicio, apunta Santos Zunzunegui, etiquetado como una semiótica de la fotografía ${ }^{143}$, parte de un artículo publicado por Roland Barthes en 1961 titulado "El mensaje fotográfico" ${ }^{144}$.

142 COLLE, Raymond, op. cit., pág. 52.

143 ZUNZUNEGUI, Santos, op. cit., pág. 137.

144 BARTHES, Roland, "Le message photographique", en Communications, 1. "Barthes no vacilaba en afirmar que siendo el contenido de la fotografía lo real literal, la escena en sí, ello se debe a que en el tránsito entre realidad e imagen se da una reducción de proporciones, de perspectiva, de color, pero no una transformación. La fotografía se definiría, pues, por su perfección analógica que la constituye en mensaje sin código, estrictamente constituido por el nivel de la denotación. El propio Barthes advertiría que esa especie de «objetividad fotográfica» solo existe finalmente en el nivel del mito, pues el mensaje absolutamente analógico se ve contaminado por una serie de procedimientos de modificación de lo real (o lo que parece ser lo mismo para Barthes, del mensaje denotador, como el trucaje y la pose o de manipulación propiamente fotográfica: fotogenia, esteticismo, sintaxis). Con todo, su posición central [...] consiste en afirmar la identidad tautológica entre significante y significado fotográfico, lo que supone que para leer ese nivel primario de la imagen no hace falta otro saber que el relacionado con nuestra percepción. De tal manera que Barthes ve la especificidad semiótica de la fotografía en la evaluación final del segundo de los términos de la tradicional trilogía del significante, significado y referente. [...] la fotografía, como todo signo icónico, no reproduce objetos sino marcas semánticas, es decir, elementos de la forma del contenido que están vehiculados en el plano de la expresión en virtud de marcas convencionales”. ZUNZUNEGUI, Santos, op. cit., pág. 138. 
En nuestra actualidad, frente al aluvión de fotos que inundan las redes sociales, cubriendo casi todas las facetas y contextos creativos en los que se mueve hoy en día la fotografía popular, ¿habría perdido esta parte de su carácter? Berger comenta sobre la fotografía realizada durante el siglo pasado por las masas (unificando memorabilidad y banalidad) lo siguiente:

"Las fotografías testimonian una elección humana en una situación determinada. Una fotografía es el resultado de la decisión del fotógrafo de que merece la pena registrar que ese acontecimiento o ese objeto se han visto. Si todo lo que existe se fotografiara continuamente, las fotografías carecerían de sentido. Las fotografías no celebran ni el acontecimiento ni la facultad de la visión en sí. Son un mensaje acerca del acontecimiento que registran. La urgencia de este mensaje no depende enteramente de la urgencia del acontecimiento, pero tampoco es completamente independiente de este. En su forma más sencilla, el mensaje decodificado significa: He decidido que merece la pena registrar lo que estoy viendo" ${ }^{145}$.

Debemos preguntarnos si este nuevo tipo de imágenes fotográficas está, como vemos, continuando un legado semiológico y elevándolo a otra dimensión, o simplemente haciendo tabula rasa frente a un escenario en el que ya no existiría la interpretación de la representación, sino una presentación del directo constante. La interpretación de las imágenes generalmente se sitúa en el centro del debate semiológico, que acaba preguntándose lo que ocurre con estas cuando pasan por el filtro de la lectura y de la interpretación, un filtro que en nuestro caso, se vincula con la intención del espectador del autorretrato fotográfico ${ }^{146}$. Además, se ha de tener en cuenta, lógicamente, que al igual "que hay distintos tipos de imágenes, hay, inevitablemente, distintos tipos de interpretaciones. Ningún mensaje, sea cual sea, puede pretender una interpretación unívoca” ${ }^{147}$.

145 BERGER, John, Sobre las propiedades del retrato fotográfico, Barcelona, Gustavo Gili, 2006, pág. 9.

146 JOLY, Martine, La interpretación de la imagen entre memoria, estereotipo y seducción, Barcelona, Paidós, 2003, pág. 12.

147 Ibídem, pág. 14. 
En este sentido, y en relación a nuestro objeto de estudio, son unos pocos los autores, como Manuel A. Broullón-Lozano, que han apuntado hacia una supuesta semiótica del selfie en nuestra cultura visual digital, apostando por ese legado heredado de la fotografía clásica que hemos comentado anteriormente y que podría establecer una tipología cultural semiótica en torno a la estructura del ver y del ser visto a través de este objeto fotográfico propio de la Web 2.0 ${ }^{148}$.

También Norberto Leonardo apunta a una semiología personal en las redes sociales virtuales por medio del uso de la fotografía:

"La imagen seduce, cuenta con ese halo de encantamiento propio de la publicidad, la televisión y el cine. La imagen es un territorio que mediante la pose, el encuadre, la utilería, la vestimenta, la escenografía y el retoque digital se convierte en gobernable. La imagen digital es un espacio donde los jóvenes se sienten seguros, quien más quien menos tiene una imagen en donde se gusta a sí mismo y la presenta ante los demás en esa copresencia virtual de las redes sociales. Cada uno en su perfil se expone irremediablemente: cede ante los demás mostrándose - no puede no hacerlo-, pero tiene la libertad dentro de la red de elegir el modo de hacerlo. [...] De ahí que se creen las más diversas formas comunicacionales y dinámicas de exposición en las redes sociales virtuales" ${ }^{149}$.

Estas ideas nos llevan a pensar cómo hoy los usuarios de las redes sociales basadas en la imagen fotográfica toman parte de un espacio comunicativo donde no hay un significado único, sino múltiples significados, y donde los autores nacen simultáneamente con sus publicaciones. De este modo, el autor "no es reemplazado por otro que precede o transciende su trabajo". Ello hace que "la acción de tomar fotos ya no [consista] en grabar o representar algo, sino en lo que la pragmática denomina un acto performativo" ${ }^{150}$.

148 BROULLÓN-LOZANO, Manuel A., op. cit., pág. 215.

149 LEONARDO, Norberto, op. cit., pág. 684.

150 GIRALDO, Diana y RUEDA, Rocío. "La imagen de perfil en Facebook. Identidad y representación en esta red social”, en Folios. Revista de la facultad de humanidades, n 43, 2016, pág. 122. 
Dicho con unas palabras similares, y apuntando exclusivamente a la semiótica de los autorretratos digitales que hacen las veces de fotografía de perfil en las redes sociales, nos parecen muy oportunas las palabras de Emetrio Díez, de María M. Perelló y de Max Römer expuestas en su precoz estudio de 2012 en donde analizan semióticamente este tipo de imágenes de perfiles, muchas de ellas, self shots:

"La forma del signo y su funcionalidad obedecen a una necesidad, un lenguaje y un contexto específico en el sentido de que ese signo construye, y como un código (legisigno) para que alguien sustituya al usuario por su foto (discencia) con el fin de que se le vea bajo una determinada etiqueta social (símbolo), y en los casos en los que no se produce esta funcionalidad, la duda que produce el no reconocer al usuario, genera una aproximación del signo desde el ámbito remático, lo que se solventa creemos y nos aventuramos a hipotetizar, con el contexto general del perfil, las publicaciones de ese sujeto y, por qué no decirlo, de sus propios círculos de amistad. Por otro lado, como hallazgo colateral, podemos corroborar que el uso de la red social [...] tiene como propósito en sus usuarios el intercambiar sus imágenes como propias, como una terceridad indispensable para el manejo del sexo, edad y raza, así como para la creación de perfiles de identidad que por su relación semiótica den tanto de sí, como una relación social de persona a persona" ${ }^{151}$.

Vistas estas aproximaciones podemos pensar que la imagen fotográfica digital puede tener multitud de convergencias y paralelismos con su antecesora también en lo referente a la semiótica, siendo esta igualmente y de manera esencial (pero no exclusiva) un signo de recepción. Sería, por tanto, imposible de comprender plenamente en el marco de una semiología que definiera el signo del autorretrato fotográfico digital publicado en la red desde el punto de vista de su emisión quedando como uno de sus aspectos secundarios. Al respecto, se ha de recordar que "la imagen fotográfica considerada en sí no es un mensaje" 152.

\footnotetext{
151 DÍEZ, Emeterio; PERELLÓ, María M. y RÖMER, Max, "Análisis semiótico de la fotografía de perfil de jóvenes en Tuenti”, en Estudios sobre el mensaje periodístico, $\mathrm{n}^{0}$ 18, 2012, pág. 817.

152 SCHAEFFER, Jean-Marie, op. cit., pág. 8.
} 
Por otra parte, y en relación a la emisión y a la recepción de nuestro objeto fotográfico de estudio, vemos que sí que ha habido un cambio trascendental en esta línea de relación comunicacional entre los actores (emisor y receptor), que si bien en la pasada era de la fotografía respondía generalmente a una relación unidireccional ${ }^{153}$, en este nuevo escenario digital asentado en el anidamiento de la imagen fotográfica en el contexto del ciberespacio, vemos cómo dicha relación comunicacional se vuelve recíproca entre unos actores que son, al mismo tiempo, creadores de contenido y receptores del mismo ${ }^{154}$.

El selfie, tan utilizado hoy en día como herramienta discursiva en las plataformas que lo enmarcan y alojan, podría estar conectado mediante su repetición diaria por parte de cualquier autor o autora en una cadena o secuencia narrativa (a modo de diario) con cierto aire de relato que simule, de cara al exterior público, una vida más o menos cierta o idílica. Al igual que ocurría con algunas facetas de la fotografía argéntica, encontraríamos un sentido de lectura mediante esta conexión temporal y secuencial. Todo esto, no de una manera exclusiva pero sí relacional, nos lleva a plantearnos una retórica del selfie:

"La retórica del selfie se basa por tanto en una enunciación demostrativa en primera persona: yo demuestro, por la evidencia de la imagen, que estoy aquí haciendo tal cosa; y por eso tengo que aparecer necesariamente en primer plano. Por ello el selfie se basa en la afirmación de la individualidad, cuando no del ego. Entonces también está asociado a unas ciertas construcciones de la belleza masculina y femenina en enunciados fotográficos de carácter denotativo del desnudo (socialmente considerado decente cuando incluye el busto y las piernas de la mujer y el torso del hombre) en lugares asociados a la consecución de esa belleza, especialmente gimnasios y tiendas

153 McQUAIL, Denis, Introducción a la teoría de la comunicación de masas, Barcelona, Paidós, 1985, pág. 41.

154 RUIZ, Sonia, Del blog al microblog. El devenir del receptor en generador y emisor de contenidos en la Web 2.o, Málaga, Universidad de Málaga, 2009, pág. 383. 
de ropa. La estrategia de promoción individual pasa 1) por una espectacularización de la cotidianeidad y 2) por una exaltación del cuerpo" ${ }^{155}$.

En este sentido, podría ser oportuno desglosar la práctica del selfie en tres aspectos interesantes: "presentación (del cuerpo y del yo), representación (para uno mismo y para los demás) y corporealización o encarnación (embodiment), esto es configuración e inscripción de los cuerpos" ${ }^{156}$. No obstante, representación y presentación quedan confundidos mediante el ejercicio de publicación en la red a tiempo real.

Con todo, dejaremos de lado la capacidad de directo real que tienen algunas redes sociales y aplicaciones de la publicación y gestión del yo mediante la autoimagen por no tratarse de un objeto puramente fotográfico, sino de un traslado de la realidad a modo de vídeo o de directo televisivo. No obstante, un selfie publicado al mismo tiempo que se realiza y que es consultado (con su respectivofeedback) en pocos segundos, podría estar más cerca de la presentación performativa que de la representación fotográfica, sin perder completamente ninguno de estos dos aspectos. De esta manera, el autorretrato digital publicado en la red a tiempo real sería un "estoy aquí" en lugar del propio "estuve aquí" más común (por sus propios e indisiciables artificios técnicos) a la fotografía argéntica.

En todo caso, no nos encontraríamos ante la caída de un reino, sino frente al surgimiento de un birreinato, al fin y al cabo, la fotografía (pensamos), por su propio carácter de instante pasado, sería incapaz de perder su naturaleza representativa en pos de un nuevo cuerpo exclusivamente presentado. Retomando las palabras del citado Zunzunegui en relación a esta faceta propia de lo fotográfico:

155 BROULLÓN-LOZANO, Manuel A., op. cit., pág. 227.

156 GALÁN, Mercè, op. cit., pág. 32. 
"Curiosamente, el instante fotográfico no puede confundirse con el instante vivido. Y ello porque el fotógrafo trabaja en futuro anterior. Cuando se toma una foto, el presente ya es pasado aunque aún espera al fotógrafo el momento del revelado de la imagen, lo que lleva a aquel a vivir el presente de su experiencia como el pasado de un futuro" 157 .

Pese a tener también, pues, ese carácter representativo que pretende la recuperación de instantes pasados ${ }^{158}$, formalizados a través de huellas de lo que ha sucedido ${ }^{159}$, nuestro objeto de estudio fotográfico no diría exclusivamente lo que ya no es, en pos de lo que ha sido ${ }^{160}$, sino más bien y de manera simultánea (pese a actuar como una paradoja que aceptamos) tanto lo que ha sido como lo que está siendo:

"Que las imágenes a través de la red sean cada vez más inmediatas y transitorias, puro
reflejo de experiencias efímeras, se ha señalado en ocasiones como una amenaza para
la memoria que descansaba en la materialidad y durabilidad de las fotografías
analógicas. En Instagram o en Flickr el usuario no capta sino su vida cotidiana,
ampliando indefinidamente el dominio de lo fotografiable hasta quedar
indeterminado y disuelto en el universo de lo fugaz, lo mundano y banal. Como cada
instantánea es rápidamente sustituida por otra en un flujo imparable de imágenes, la
función documental de las imágenes sobre eventos pasados se antoja irrelevante [...].
Son imágenes concebidas como reflejo de una inmediatez vivencial [...] y sometidas a
una recepción igualmente urgente y desechable. El efecto comunicativo prima sobre el
conmemorativo, lo transitorio se impone a lo durable. Mientras Roland Barthes [...]
planteaba que cada fotografía era una forma de ça-a-été que señalaba no sólo la
historia del sujeto representado sino también su mortalidad, esta representación
fotográfica sin peso de las imágenes en red sería una forma de je-suis-là, un modo de

157 ZUNZUNEGUI, Santos, op. cit., pág. 135.

158 SÁNCHEZ-VIGIL, Juan Miguel, op. cit., pág. 13.

159 BERGER, John, Mirar, Barcelona, Gustavo Gili, 2008, pág. 62.

160 BARTHES, Roland, op. cit., pág. 98. 
decir yo estoy aquí que no haría referencia tanto a un pasado vivido como a la afirmación de un presente hueco"161.

Como veremos en los sucesivos capítulos, la fotografía digital en general, y el self shot en particular, continúan difundiendo la cultura visual contemporánea. Si bien de la era del nitrato de plata a la era de lo numérico la imagen fotográfica se ha impuesto de distintas maneras en el proceso de difusión (como reproducción, estándar, modelo, referente, mensaje...), y el carácter visual implícito en ella ha designado a la vez lo figurativo y lo visible reinvistiendo, entre otras cosas, la cultura y la comunicación, podríamos decir que dicha difusión ha pasado a convertirse en el propio modelo de la creación ${ }^{162}$.

No obstante, lo figurativo y visual presentado o representado en nuestro objeto de estudio no tiene por qué estar ligado con nuestra realidad (o verdad) fuera de la pantalla. Veremos durante el capítulo 5 de manera más precisa y particular y en relación al self shot cómo el objeto fotográfico no tiene por qué testimoniar o mantener una relación de verdad con el acontecimiento o fragmento de la realidad que presenta. Sin embargo, comentaremos aquí brevemente algunos aspectos más generales aplicables a la fotografía digital y a sus géneros que están también íntimamente relacionados con esa disociación entre fotografía y verdad.

Apunta Michel Melot en su Breve historia de la imagen que no hay fotografía sin realidad $^{163}$ y que la fotografía, como imagen, estaría siempre a mitad de camino entre el modelo imaginario y la realidad ${ }^{164}$. Pese a que la fotografía no tiene porque mostrar algo necesariamente verdadero, sí que debe

\footnotetext{
161 MIRA, Enric, op. cit., págs. 151-152.

162 ARBAÏZAR, Philippe y PICAUDÉ, Valérie (Eds.), La confusión de los géneros en fotografía, Barcelona, Gustavo Gili, 2004, pág. 11.

163 MELOT, Michel. op. cit., pág, 71.

164 Ibídem, pág. 15.
} 
de proporcionar una respresentación lo suficientemente precisa y fiel para permitir el reconocimiento ${ }^{165}$, y aunque la fotografía tenga la deslucida reputación de ser la más realista, y por ende la más heredera de las artes miméticas ${ }^{166}$, esto jamás implicaría a la fotografía como objeto narrador de una verdad absoluta.

Visto desde el lado del discurso, la imagen aparece como cargada de una función de prueba empírica: "Lo que os digo es verdadero, ya que lo muestra la imagen"167. Pero, en realidad, cualquier aserción referencial en la fotografía tiene tendencia a ser aceptada, ya sea verídica o no. El discurso se presenta como si fuese obligado por la imagen a decir la verdad, mientras que la coacción efectiva que la imagen es capaz de ejercer sobre él es únicamente del orden de la compatibilidad. Ya conocemos la razón de esta débil coacción: "el testimonio confiere a la imagen una función indicial que transciende ampliamente su materialización icónica, y que solo puede desempeñar si un saber lateral capaz de saturarla toma el relevo" ${ }^{168}$. Asimismo, señala Berger:

\footnotetext{
"Una fotografía es efectiva cuando el momento registrado contiene una medida de verdad que es aplicable en general y que revela lo ausente igual que lo que está presente en ella. La naturaleza de esta medida de verdad y la manera para apreciarla varían enormemente. Puede ser por una expresión, una acción, una yuxtaposición, una ambigüedad visual y una configuración. Esta verdad nunca es independiente del espectador. Para el hombre que lleva en la cartera una fotografía de su novia tomada en un fotomatón, la medida de verdad de una fotografía impersonal seguirá dependiendo de las categorías generales arraigadas en la conciencia del espectador" ${ }^{169}$.
}

\footnotetext{
165 BOURDIEU, Pierre, op. cit., pág. 60.

166 SONTAG, Susan, op. cit., pág. 57.

167 SCHAEFFER, Jean-Marie, op. cit., pág. 104.

168 Ídem.

169 BERGER, John, Sobre las propiedades..., op. cit., pág. 14.
} 
Uno de los estudios más completos en torno a fotografía y verdad es, a nuestro parecer, El beso de Judas de Joan Fontcuberta. En dicho texto el autor pone de manifiesto que en nuestro mundo contemporáneo las apariencias han sustituido a la realidad y que, pese a ello, la fotografía (una tecnología históricamente al servicio de la verdad) sigue ejerciendo una función de mecanismo ortopédico de la conciencia moderna en el sentido de que la cámara no miente y de que toda fotografía es una evidencia. Si bien la historia de la fotografía puede ser contemplada como un diálogo entre la voluntad de acercarnos a lo real y las dificultades para hacerlo ${ }^{170}$, y que la fotografía ha sido entendida durante mucho tiempo como la manera en que la naturaleza se representaba a sí misma ${ }^{171}$, Fontcuberta será especialmente crítico con esta creencia, cuestionando la supuesta veracidad de la cámara y a su objeto fotográfico producido.

Así pues, y partiendo de esta premisa, una crítica de la noción de verosimilitud o de realismo en el objeto fotográfico nos conduciría desde una idea de la fotografía como espejo de lo real, pasando por la de una transformación de lo real, hasta, por fin, llegar a la idea de fotografía como huella o sombra oblicua de lo real ${ }^{172}$. Todo esto tendrá, como veremos, relación directa con el self shot, dado que lo que se plantea con ello es de qué manera más o menos veraz quedará representado el cuerpo reconstruido por medio del autorretrato digital en las pantallas de sus espectadores.

"En la actualidad son escasas las voces dispuestas a poner en duda la idea de que el cuerpo -en cualquiera de sus acepciones- responde a un constructo elaborado social y culturalmente. De igual manera, son también pocos quienes rechazan el hecho de que la fotografía sea capaz de reproducir no ya con fidelidad mimética, sino con una

\footnotetext{
170 FONTCUBERTA, Joan, El beso de Judas. Fotografía y verdad, Barcelona, Gustavo Gili, 2009, pág. 12.

171 Ibídem, pág. 26.

172 DURAND, Régis, El tiempo de la imagen. Ensayo sobre las condiciones de una historia de las formas fotográficas, Salamanca, Universidad de Salamanca, 1998, pág. 52.
} 
elevada dosis de rigor documental ese consenso que denominamos realidad. Cuerpo y fotografía, en tanto que procesos de producción textual, constituyen complejas elaboraciones discursivas que actúan no como meras presencias significantes despojadas de significados, sino como representaciones codificadas -a la par que codificadoras- dotadas de un plural carácter simbólico, económico, cultural, político, sexual, etc. Esta pluralidad trae consigo que abordar una cuestión como la presente conlleve, desde un primer momento, tener que asumir el inevitable sesgo ideológico mediante el que se define cualquiera de los términos utilizados. Así, nociones como las de cuerpo o sexualidad, lejos de designar una realidad imparcialmente establecida y objetiva, contribuyen desde su pretendida asepsia descriptiva o normativa a establecer la realidad de una idea -que es idea sobre una realidad- a través de la cual se delimita un determinado y preciso orden que varía en función de épocas y culturas" ${ }^{173}$.

De esta manera, durante el siglo XXI la nueva fotografía digital ha sido todavía más expuesta que su antecesora a la sentencia de la duda o de la mentira, dada la facilidad del retoque y de la alteración que presenta el propio medio electrónico con ayuda del software, hecho que alejaría aun más a estos nuevos objetos fotográficos de la vérité (fiel testimonio del mundo real tangible y visible), atestiguando que "la producción de imágenes digitales sigue siendo un proceso abiertamente de ficción" ${ }^{174}$. Sin embargo, y como veremos durante el capítulo 5, los mayores ardides, manipulaciones y elaboraciones ficcionales ${ }^{175}$ que los y las autorretratistas digitales hacen (o se dejan hacer por la máquina) no tendrán tanto que ver con el software informático como con cuestiones puramente fotográficas, como son el encuadre o la óptica del dispositivo de captura.

173 PÉREZ, David, La certeza vulnerable. Cuerpo y fotografia en el siglo XXI, Barcelona, Gustavo Gili, 2004, págs. 9-10.

174 BATCHEN, Geoffrey, Arder en deseos. La concepción de la fotografía, Barcelona, Gustavo Gili, 2004, pág. 210.

175 PALAO, José Antonio, La profecía de la imagen-mundo para una genealogía del paradigma informativo, Valencia, Ediciones de la Filmoteca / Instituto Valenciano de Cinematografía Ricardo Muñoz Suay, 2004, pág. 39. 
Según podremos analizar, esta manipulación no solo en la fotografía singular, sino en el relato secuencial de los muros, biografías o stories de las redes sociales dará pie a un cuerpo fotográfico basado en el conjunto y no en la unidad, pese a poder ser percibido como documento fidedigno, ya que no será definido en términos exclusivamente demostrativos o de sinceridad, sino como simulacro o bien de transparencia o bien de complicidad con el destinatario. De este modo, "el problema del self se convierte en el de la imaginería de la primera persona, la construcción de una puesta en imagen (cuando no en escena) del yo, del aquí y del ahora" ${ }^{176}$, siendo generalmente esta puesta en escena idílica, puesto que quedará concebida como un escaparate similar al de los antiguos álbumes familiares (que veíamos en el capítulo anterior), recogiendo siempre hechos agradables $^{177}$ y evitando plasmar las también presentes en el mundo real (que no en el socio virtual) miserias de la vida.

\subsubsection{El referente etnográfico y sociológico.}

"El selfie y la tecnología que lo genera, es una herramienta de comunicación a través de la imagen hasta ahora con una influencia nunca vista, gracias a la democratización y facilidad de su uso" ${ }^{178}$. Desde esta perspectiva, realizar este tipo de fotografías podría ser entendido como una manera de contribuir a construir nuestra realidad: autorrepresentarnos y autopublicarnos genera una marca autoetnográfica mediante la que se afirma el hecho de que estamos ahí

\footnotetext{
176 BROULLÓN-LOZANO, Manuel A., op. cit., pág. 222.

177 SÁNCHEZ-VIGIL, Juan Miguel, op. cit., pág. 82.

178 GALÁN, Mercè, op. cit., pág. 34.
} 
cuando las cosas están sucediendo: "Hacer que tu causa tenga una imagen es una batalla fundamental, un elemento de lucha, de contestación y de resistencia” ${ }^{179}$.

Esta marca etnográfica que generaría la práctica en torno a nuestro objeto de estudio a través de un uso de la red, fenómeno que Robert V. Kozinets ha catalogado como netnografía ${ }^{180}$, seguiría perfectamente el legado que la fotografía ha supuesto para las sociedades en tanto que acto de necesidad:

"La práctica fotográfica, sometida a las reglas sociales, investida de funciones sociales y vivida como «necesidad», se explica por lo que es su consecuencia, es decir, por las satisfacciones psicológicas que procura" ${ }^{181}$.

Así, esta práctica social realizada a lo largo de todo el globo queda ligada a una serie de procedimientos que involucran desde decisiones emocionales, cálculos y estrategias de diverso tipo, hasta control en las puestas en escena, capturas fotográficas de imagen, revisiones y habilidades de publicación y visibilidad. Se trata, por tanto, de "un ritual digital de paso, el cual celebra la presencia y la exposición del sujeto en la red social” ${ }^{182}$.

Si podemos considerar el autorretrato digital publicado en la red como una forma cultural cuyos referentes provienen del campo artístico y de los mass media, y si vinculamos el mismo con procesos de autoconocimiento y de experimentación personal, podemos afirmar también que con la popularización de las tecnologías digitales de la imagen, el self shot parece haberse integrado en la vida cotidiana de muchas personas, con distintas funciones y usos,

\footnotetext{
179 FONTCUBERTA, Joan, La cámara de..., op. cit., pág. 39.

180 COZINESS, Robert V., Netnography: Doing Ethnographic Research Online, Thousand Oaks, SAGE Publications, 2010, pág. 24.

181 BOURDIEU, Pierre, op. cit., pág. 53.

182 GIRALDO, Diana y RUEDA, Rocío, op. cit., pág. 133.
} 
conformándose como una práctica sociológica específica de la fotografía $\operatorname{digital}^{183}$ :

"[...] el selfie, no sólo [supone] la presentación de la persona en los contextos sociales de interacción, sino también [se configura] como práctica socio-técnica creativa, lúdica o auto-reflexiva sobre sí, el cuerpo y la identidad personal a través del dispositivo móvil. Esta práctica de autorretrato, vinculada generalmente a la narrativa cotidiana personal pasa a ser, a través de Internet, una práctica pública que puede tener una amplia audiencia. En este sentido, podría entenderse también como una nueva forma cultural de presentación social de sí, que conllevaría un trabajo de performación de la identidad personal de un modo relacional, ya sea como una actuación pública del yo o como resultado de una práctica performativa sobre el propio cuerpo" ${ }^{184}$.

Ya hemos visto durante el capítulo 2 cómo la expansión de la fotografía argéntica llevó, entre otras cosas, al desarrollo de dos tipos de prácticas populares en las sociedades modernas: la fotografía familiar asociada al ámbito hogareño y la fotografía de vacaciones y viajes. A finales del siglo pasado, la fotografía doméstica, o bien tomaba la forma de "entretenimiento familiar", o bien formaba parte de este ${ }^{185}$. Pese a que, como vimos, la fotografía había jugado un papel estratégico en la unión de la familia, el consumo y el ocio en la esfera privada, dando fruto a un lugar excepcional para la articulación de la identidad (mediante un desplazamiento de lo cotidiano a lo trascendente tras una ampliación del tiempo libre de las sociedades a lo largo del último siglo ${ }^{186}$ ), actualmente se puede constatar una transformación en los sustratos de estas prácticas sociales o familiares en torno a la fotografía doméstica. Y es que tras el relativo aislamiento de las familias en pos de una parcelación del ocio

183 GÓMEZ-CRUZ, Edgar y ARDÈVOL, Elisenda, op. cit., pág. 203.

184 RABADÁN, Ángel V., op. cit., pág. 26.

185 SLATER, Don, "La fotografía doméstica y la cultura digital", en LISTER, Martin (Comp.), La imagen fotográfica en la cultura digital, Barcelona, Paidós Ibérica, 1997, pág. 175.

186 Ibídem, págs. 178-179. 
dependiente de las pantallas móviles y no estáticas en el hogar (cuestión que cabe unir a los fenómenos tratados en este estudio acerca de las estrategias de autorrepresentación fotográfica y de autopublicación en las redes sociales), el surgimiento de este tipo de herramientas habría causado una transformación del álbum familiar, quedando concebido de manera más individualista, aunque públicamente más exhibido.

Así, la cámara digital se habría convertido en una herramienta de representación todavía más activa y masiva, siendo un vehículo para documentar las condiciones propias (de vida, trabajo y socialidad), para crear representaciones alternativas de uno mismo (alternativas de sexo, clase, grupo de edad, raza, etc.) y para ganar poder sobre la imagen personal ${ }^{187}$. Como hemos visto, estas nuevas herramientas tanto de captura como de orden, clasificación y exhibición (en este caso electrónico-virtual y no en formato libro o papel) han cambiado la naturaleza del álbum familiar transformándolo en un álbum individual o grupal en el ámbito social ${ }^{188}$. De esta manera, y frente a una continuada democratización, no solo del consumo audiovisual sino también de la

187 GÓMEZ-CRUZ, Edgar y ARDÈVOL, Elisenda, op. cit., pág. 183.

188 En palabras textuales de Raymond Colle, que en 2013 apuntaba al concepto de fonografía abordando el acto fotográfico desde esta nueva herramienta que veremos en el próximo capítulo y que Colle asociaba a los álbumes virtuales que en la nube han sustituido a los álbumes físicos, además de aportar gran cantidad de datos acerca de esta explosión productiva que ha alcanzado la fotografía popular desde la integración de la tecnología digital en las cámaras y soportes de publicación: "La difusión de la fotografía digital dio pie a la creación de sitios web para publicarlas (anticipando el sistema, hoy más generalizado, de archivo en la «nube», es decir en servidores externos destinados al almacenamiento de datos). Así, Picasa fue creada en 2002 por Lifescape y es propiedad de Google desde el año 2004. Flickr, lanzado en febrero de 2004 por Ludicorp y adquirido por Yahoo! en 2005, albergaba más de tres mil millones de imágenes en noviembre de 2008. Pero Facebook les hizo rápidamente la competencia y, en agosto de 2011, alojaba ya unos 140 mil millones de fotos, pasando del billón (un millón de millones) de páginas vistas en un mes [...]. Entre los 3,5 trillones de fotos que existen alrededor del planeta (solo en servicios de acceso público -no solo internet-) desde la primera imagen tomada por Joseph Niépce en 1826, el 4\% pertenecía así a la red social Facebook [...]. Y no se ha de olvidar que han surgido otros servicios de alojamiento de fotografías como Pinterest, mientras Instagram (con 27 millones de usuarios en marzo 2012) fue adquirido por Facebook, sumándose a la colección propia de esta red social y llegando de este modo a 100 millones de usuarios mensuales en febrero 2013. En el mundo, setecientos millones de teléfonos tienen hoy una cámara fotográfica. El $67 \%$ de los poseedores tomaría fotos al menos una vez por semana y el $54 \%$, además, las enviarían por este medio a terceros. El $83 \%$ de ellos también utilizarían su ordenador con un programa para editarlas [...]. Hoy se toman cerca de 1.000 millones de fotografías al día y se hacen más fotos en dos minutos que las que se hicieron en todo el siglo XIX”. COLLE, Raymond, op. cit., pág. 52. 
propia producción audiovisual ${ }^{189}$, asistimos a una noosfera o espacio donde se desarrolla la inteligencia colectiva en una especia de álbum-mundo ${ }^{190}$. No obstante, no debemos olvidar que la sociedad hipervisual en la que vivimos, inundados por imágenes y estímulos visuales, solo ha sido posible por su herencia fotográfica y por la densidad icónica que desde el siglo XIX ha ido adquiriendo, una densidad que se ha multiplicado posteriormente por el fotograbado y, en estos momentos, por el desarrollo de las tecnologías digitales ${ }^{191}$.

Para finalizar podemos preguntarnos: ¿̇en qué estado queda la memoria frente a este escenario de hipervisualidad (casi más presentada que representada) y de producción y publicación constante de nuestros rostros y los de nuestros conocidos en un casi directo siempre consultable y siempre permanente en el ciberespacio? La fotografía tradicionalmente se ha considerado una memoria protésica exterior a nuestros pensamientos que dejaba constancia de un acontecimiento pasado y recordable en una futura visualización o consulta $^{192}$. De hecho, antes de la llegada de la tecnología digital y la seguridad (o no) en relación a cantidad de copias y conservación en la nube que esto aporta, las viejas fotografías familiares se guardaban como un tesoro ${ }^{193}$. Este carácter de la fotografía argéntica de trazo único de algo que siempre se escabulle ${ }^{194}$, pero que complementa nuestra memoria, podría quedar desterrado como una creencia olvidada o como el culto a un dios de una civilización perdida. Y es que ante el aluvión de instantáneas creadas y publicadas casi a todas horas por los mayormente jóvenes, pero también adultos en nuestras sociedades, la memoria recuerda poco, convirtiéndose en volátil ${ }^{195}$. Frente a la fugacidad o al consumo de

\footnotetext{
189 RÓDENAS, Gabriel, op. cit., pág. 61.

190 Ibídem, pág. 66.

191 RIEGO, Bernardo, op. cit., pág. 20.

192 BERGER, John, Mirar, op. cit., pág. 56.

193 SÁNCHEZ-VIGIL, Juan Miguel, op. cit., pág. 82.

194 DURAND, Régis, op. cit., pág. 11.

195 BREA, José Luis, Las tres eras..., op. cit., pág. 79.
} 
usar y tirar propio de la nueva era de la fotografía, esta quedaría desvinculada del hecho memorable, o, en el caso de conservar dicho valor, necesitaríamos una vida entera para recordar dicha vida, como si todos estuviéramos condenados a ser Funes el memorioso ${ }^{196}$.

Tras desplegar a lo largo de este capítulo una suerte de facetas relacionadas con la definición, la acotación tipológica, la historia, el análisis fotográfico y la teoría conceptual del self shot y de sus sucedáneos, pasaremos en la siguiente parte del presente estudio a analizar de manera más exhaustiva y profunda los tres elementos principales que, bajo nuestro punto de vista, han sido fundamentales e intrínsecos a nuestro objeto de estudio, constituyendo la condición sine qua non para su conformación: hablamos del democratizado dispositivo electrónico-digital de captura fotográfica, del adolescente emancipado fotográficamente, y de la red como superficie global de exhibición pública de lo fotografiado.

196 En referencia al cuento de Borges del mismo nombre, disponible en: BORGES, Jorge Luis, Ficciones. Madrid, Alianza, 1997, pág. 122. 
Los orígenes adolescentes del selfie y su representación en el arte y en los medios de masas

$-192-$ 


\section{SEGUNDA PARTE:}

\section{DEUS EX MACHINA}





\section{EL SENSOR DE IMAGEN ELECTROMAGNÉTICO}

Mi madre me regaló mi primera cámara.

Me fotografié el rabo.

TERRY RICHARDSON, Terryworld, 2004.

El desarrollo del autorretrato digital publicado en la red como práctica cada vez más insistente e institucionalizada entre las masas, hasta devenir en lo que hoy conocemos como selfie, podría entenderse como algo más que un acto vulgar o baladí: ha sido, bajo nuestro punto de vista, el responsable del surgimiento de una serie de oportunidades para nuevos desarrollos de la fotografía tras un recorrido histórico que la ha ido transformando a lo largo de casi dos siglos. Después de un revolucionario proceso que, a finales del siglo pasado, sacudió profundamente todos los estratos de la fotografía (tras la sustitución de su soporte argéntico por un novedoso soporte electrónico), los profesionales y aficionados tuvieron que acostumbrarse a las nuevas reglas, protocolos, tiempos, coyunturas e imágenes que nos trajo la fotografía digital. No obstante, pese a esta reconstrucción conceptual y técnica del producto fotográfico y de su soporte hacedor (el sensor electromagnético), no se planteó durante los primeros años de la rápida popularización de la nueva fotografía ningún cambio sustancial en el resto de la máquina fotográfica (lente y cuerpo). Así pues, pese a que se sustituyó la película fotosensible (que se esculpía como respuesta al 
estímulo de la luz) por un sensor electrónico (que en lugar de esculpir generaba un acto de escritura), el laboratorio de revelado-ampliación por una computadora con software de edición y el papel por la (casi siempre) pantalla de cristal líquido, las cámaras compactas de viaje; las cámaras réflex profesionales y el resto de formatos universales solo sufrieron cambios en la "parte de atrás". Los cuerpos y los ojos de las nuevas cámaras, hechas a imagen y semejanza de sus predecesoras ahora clásicas, eran como unos replicantes que, desconocedores de su naturaleza androide, se comportaban como humanos porque pensaban que lo eran.

De este modo, los fotógrafos sostenían la nueva cámara de igual manera, la guardaban en la misma bolsa y bandolera, apuntaban y encuadraban con las mismas actitudes y poses, y veían a través del visor y de la pantalla ese fragmento del mundo y del tiempo que deseaban capturar tal y como lo hacían los usuarios de las máquinas predecesoras. Tuvieron que entrar en escena tres elementos: 1. el teléfono celular con cámara incorporada (que luego serían smartphones conectados a la red) y las pequeñas cámaras de bajo coste, 2. el adolescente emancipado como fotógrafo amateur, y 3. las nuevas plataformas sociales, soporte de fotografías y producto del desarrollo de la Web 2.o, para que también un cambio sustancial se produjera en el acto fotográfico y, sobre todo, en el desarrollo de la máquina a nivel de ingeniería: la industria de la fotografía volvía a rodar a todo tren y, en menos de diez años produjo lo que tenemos hoy en día: más ojos-máquina en nuestro poder que ojos humanos en nuestra cara, y concebidos de una manera muy distinta. Así, esta trilogía de actores (sensor electrónico pequeño, adolescente emancipado fotográficamente y Web social como galería global) ha aparecido para dar un nuevo giro a la práctica fotográfica de las masas por medio del autorretrato digital publicado en red y su posterior evolución hacia el selfie popular. Como un trío de dioses, esta transformación ha descendido hasta entrar en la escena fotográfica para ocasionar un sorprendente giro de guion dejando boqueabierto (o decepcionado) al espectador. Es lo que tiene: Deus ex machina. 
Empezaremos abordando en este capítulo el primer ingrediente que ha hecho posible el desarrollo y la proliferación del autorretrato digital publicado en red o self shot. Este factor ha sido (y es) el dispositivo electrónico de captura fotográfica (casi siempre de bolsillo): un dispositivo que genera archivos digitales que acabarán formándose como imágenes fotográficas gracias a su sensor de imagen, generalmente $\mathrm{CMOS}$ o $\mathrm{CCD}^{1}$, unas imágenes (archivos de datos) que no son más que ceros y unos escritos de manera lineal y que reposan sobre soportes de naturaleza magnética (tarjetas de memoria, discos duros y servidores que en su conjunto crean Internet...). Dichos datos pueden ser traducidos e interpretados, y se muestran transformados y agrupados en píxeles de colores sobre una cuadrícula regular siempre que sean visualizados sobre superficies de monitorización (pantallas, tabletas, smartphones, televisiones...) conectados a dichos soportes magnéticos.

El resultado del mosaico (Imagen 4.1) que crean esos píxeles ${ }^{2}$ es una fotografía, interpretada como las de toda la vida: una imagen que nuestro cerebro lee y comprende. Para nuestra mente, esa imagen es algo que representa una porción de la realidad, un instante que existió en forma de materia que desprendía luz y que se coló por una lente, fijándose (escribiéndose) sobre un soporte sensible.

Sensores, píxeles, chips... Ciertamente esta implementación de las tecnologías digitales presenta un vertiginoso giro respecto a su pasado analógico

1 Las cámaras digitales incorporan los sensores CCD (Charged Couples Devices), dispositivos de carga acoplada que hacen la función de la película donde se forma la imagen, y, en cuanto a los dispositivos de memoria (sustitutos de la película), se emplean tarjetas Compact Flash o Smart Media con capacidad de almacenamiento variable que evoluciona constantemente. SÁNCHEZ-VIGIL, Juan Miguel, El documento fotográfico. Historia, usos, aplicaciones, Gijón, Trea, 2006, pág. 28.

2 El píxel o pixel (acrónimo del inglés picture element, "elemento de imagen") es la menor unidad homogénea en color que forma parte de una imagen digital, ya sea esta una fotografía, un fotograma de vídeo o un gráfico. VV. AA., "Píxel", 2018, disponible en: <https://es.wikipedia.org/wiki/Píxel> [Fecha de consulta: 3 de enero de 2018]. 
y ha supuesto drásticos cambios en las formas de comunicación, socialización, gestión y creatividad en las sociedades occidentales ${ }^{3}$.

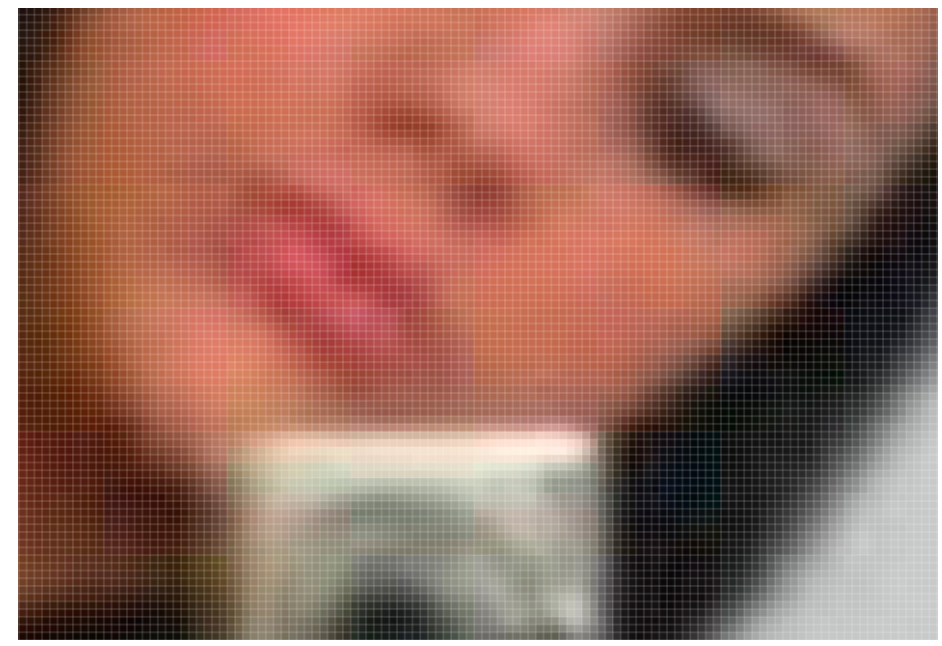

Imagen 4.1: Detalle que muestra una cantidad de píxeles de colores sobre su rejilla cuadriculada.

Pero, pese a este cambio drástico de tecnología, ¿por qué la gente continúa fotografiando? Esta pregunta ha sido el leitmotiv de múltiples estudios ${ }^{4}$ y puede abordarse desde innumerables prismas críticos.

"El hecho de tomar fotografías, de conservarlas o de mirarlas puede aportar satisfacciones en cinco campos: «la protección contra el paso del tiempo, la comunicación con los demás y la expresión de sentimientos, la realización de uno mismo, el prestigio social, la distracción o la evasión»"5. cualitativo en un grupo de estudiantes ourensanos/as sobre el fenómeno del sexting", en Revista de estudios e investigación en psicología y educación, $\mathrm{n}^{0}$ 13, 2015, pág. 58.

4 MARZAL, Javier, Cómo se lee una fotografía, Madrid, Cátedra, 2007, pág. 87. 
Paso a paso, hemos llegado a un momento en el que la gente fotografía más (y posiblemente mejor) que nunca. Fotografiamos compulsivamente y, como hemos apuntado, la industria tecnológica se ha adaptado a esta necesidad, facilitando el acceso de la fotografía a las masas e invitando a desarrollar sus cualidades técnicas, estéticas y de visualización. Así pues, necesidad y herramienta evolucionan cogidas de la mano. Se retroalimentan. Debido a esto, la industria crece, innova y genera dividendos, y el usuario queda satisfecho y saciado (de momento).

"La práctica fotográfica, sometida a las reglas sociales, investida de funciones sociales y vivida como «necesidad», se explica por lo que es su consecuencia, es decir, por las satisfacciones psicológicas que procura" ${ }^{\prime}$.

Este matrimonio entre las masas y la cámara fotográfica, que pudiera parecer de conveniencia hace un siglo, está cada vez más enamorado. Mucho más tras el giro radical que supuso la sustitución de la fotografía argéntica por la fotografía electrónica. Pero los esfuerzos de la industria por satisfacer al público general ${ }^{7}$, reflejados en la evolución de los dispositivos digitales (generando máquinas que minimizan el conocimiento técnico y producen fácilmente una imagen bella), pueden parecer, a priori, degradantes para el estadio de la creatividad. Esa democratización y simplificación del acto de fotografiar podría acarrear consecuencias nocivas que acabarían poniendo a la máquina y a sus decisiones por delante del libre albedrío del complacido fotógrafo.

6 Ibídem, pág. 53.

7 Y es que, desde el nacimiento de la Kodak Pocket desarrollada por George Eastman que en 1895 se popularizó entre las masas bajo el lema: "Usted apriete el botón, nosotros haremos el resto", la industria no ha dejado de perfeccionar sus cámaras para que toda fotografía realizada con ellas desde la más absoluta ignorancia técnica, sea una toma perfecta. SÁNCHEZ, Nieves, Evolución de la fotografía a través de la obra de Lewis Carroll: Alicia en el país de las maravillas y a través del espejo, Madrid, Universidad Complutense de Madrid, 2004. 
"Desde el punto de vista técnico, ya nadie puede fallar una foto. Esa es una de las razones del inmenso atractivo de la foto entre las masas"

No obstante, la delegación en la máquina y la confianza plena en la correcta ejecución del sensor electrónico y de su software integrado, no tiene por qué entenderse como algo negativo que deslegitime a lo fotográfico en nuestro objeto de estudio. Las y los autorretratistas, al liberarse de un conocimiento técnico que, de ser obligado, hubiera distraído su interés por la fotografía como herramienta de expresión, tendrían vía libre para sus creaciones, concentrando su atención en otros valores. Centrarán, pues, su interés y habilidad únicamente en lo que podemos considerar como fundamental en una fotografía: algo que de forma telegráfica y orientativa podríamos resumir en "el qué por encima del cómo", en "la idea por encima de la técnica".

Así, la composición y el encuadre, el gesto y la pose de la figura, el erotismo y la escenificación de sus referencias visuales serán voluntades inteligentes, conscientes y trabajadas que se hallarán por encima de las decisiones del sensor y de su procesador.

“[...] uno de los argumentos principales de la defensa de la fotografía ha sido la insistencia en que la captación de imágenes procede sobre todo de la localización de un temperamento, y solo secundariamente de una máquina”.

Y de no ser así, el fotógrafo siempre puede establecer un pacto con la cámara moderna para generar, entre ambos, construcciones estéticas nuevas (Imagen 4.2) o revisadas.

8 FREUND, Gisèle, La fotografía como documento social, Barcelona, Gustavo Gili, 2008, pág. 182.

9 SONTAG, Susan, Sobre la fotografía, Barcelona, Debolsillo, 2008, pág. 118. 


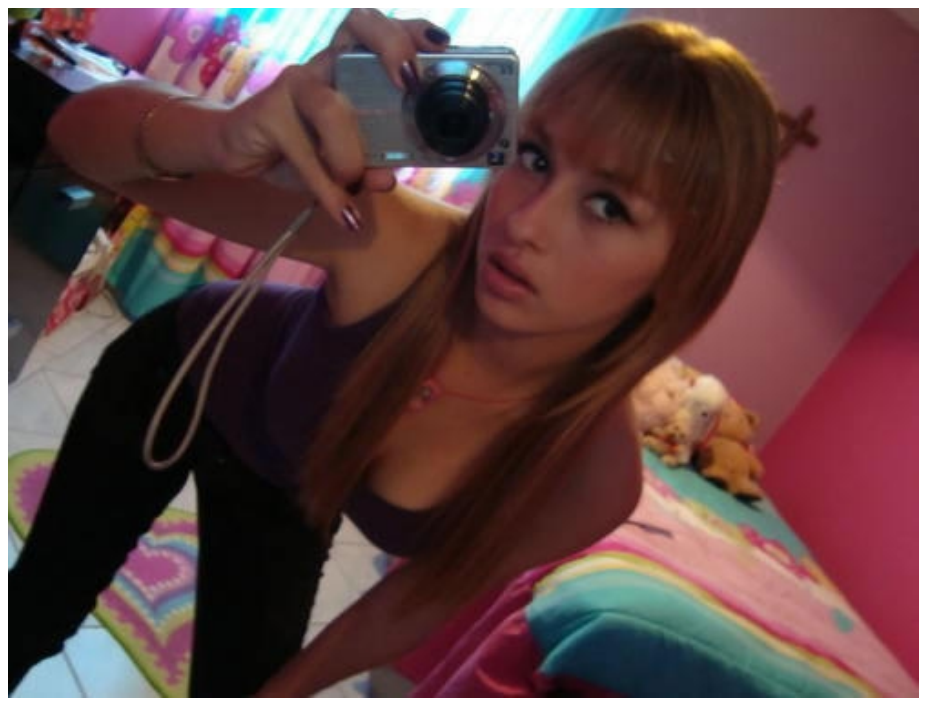

Imagen 4.2: Autorretrato digital publicado en red anónimo y de tipo mirrorpic, realizado aproximadamente entre 2007 y 2009. Un ejemplo de la intervención del software integrado en la cámara sobre la captura. El color ha sido saturado y el contraluz de la ventana compensado. La representación de la fotógrafa presenta una deformación mano-cabeza-cuerpo, dada la aproximación de la lente al espejo y el punto de vista diagonal.

Como decimos, son varios los factores que influyen y posibilitan la generación y expansión del selfie y del resto de autofotos, pero es el sensor electrónico (reflejado contra el espejo, otro artefacto tecnológico que revisamos durante el capítulo anterior), el núcleo y corazón de la nueva fotografía digital que ha sustituido a la fotografía química. Es este sensor el poseedor de propiedades y naturalezas que están marcando los nuevos usos que se le da a la fotografía y que, asimismo, están estipulando las nuevas formas de la imagen que, en la mayoría de ocasiones, no dejan de ser protocolos clásicos adaptados por una nueva generación de fotógrafas y fotógrafos. Describir y desarrollar los atributos propios de este pequeño sensor electrónico será, por tanto, algo primordial para entender en su totalidad el fenómeno que aquí nos ocupa. En su breve recorrido por la historia de la imagen, Melot apunta un interesante comentario en torno a esta cuestión: 
"Un tejido de imágenes envuelve nuestro mundo desde que entramos en lo que Régis Debray denomina la videosfera, esta era en la que la imagen es más fácil de producir que un discurso. Las imágenes nos devoran, nos acosan. Estamos sumergidos, inmersos en la imagen. Las pantallas integradas en los teléfonos móviles han cambiado el uso de la fotografía y las cámaras de vigilancia funcionan sin reflexionar. Las imágenes son consumidas in situ o transmitidas sin demora, demasiado numerosas para merecer ser conservadas, tan numerosas que pronto no habrá ningún acto ni gesto nuestro que no haya constituido el objeto de una imagen, como antaño de una simple palabra" ${ }^{10}$.

Adentrémonos ahora, pues, en las estrañas de cobalto y silicio de los sensores electrónicos de imagen y captura fotográfica, no sin perder la perspectiva de que, tanto aquí como en otras partes de este estudio, también dedicadas al análisis tecnológico podrían suponer un problema, ya que nuestros puntos de vista particulares podrían verse ampliamente rebasados con el paso del tiempo, y nuestras conclusiones quedar pronto obsoletas también por causa de la celeridad y complejidad de los cambios que se están produciendo en la globalizada cultura contemporánea en torno al ámbito de las nuevas tecnologías ${ }^{11}$.

\subsection{Principios, origen y desarrollo del sensor electromagnético de imagen fotográfica.}

El sensor electrónico (o sensor de imagen) es el corazón del dispositivo de captura digital (Imagen 4.3). Es el objeto físico y electrónico que permite, tanto

10 MELOT, Michel, Breve historia de la imagen, Madrid, Siruela, 2010, pág. 91.

CARRILlO, Jesús, Arte en la red, Madrid, Cátedra, 2004, pág. 9. 
en las cámaras fotográficas digitales, como en los smartphones con lente integrada, capturar la imagen y generar su latencia digital en un soporte de memoria conectado a él. El sensor es, en definitiva, el sustituto de la vieja película fotosensible utilizada por las cámaras analógicas en la pasada era de la fotografía. El principal cambio estaría focalizado, por lo tanto, en esa "parte de atrás" de la que hablábamos antes. Jeff Wall nos aportó en 2007 un ilustrativo párrafo en torno a esta cuestión de las partes delantera y trasera de la máquina fotográfica y qué transformaciones había sufrido (y parecía que iba a seguir sufriendo) en esta nueva era:

\begin{abstract}
"Las fotografías son el resultado de una combinación o una colaboración entre la parte delantera y la parte posterior de la cámara. La parte delantera está compuesta por la lente y el obturador, y la posterior por la película o por otra superficie o sistema de registro. La parte posterior ha sufrido una constante y rápida evolución justo desde el inicio de la fotografía hasta nuestros días, cuando ya existen elementos para cámaras digitales que empiezan a ser de amplio uso. Me imagino que este frenético ritmo de cambio continuará por mucho tiempo, dado el número de potenciales superficies de registro y procesos que parecen coexistir. La parte delantera de la cámara ha sufrido menos cambios paro ha avanzado lentamente hacia cierta perfección que, por supuesto, todavía no ha alcanzado. Las lentes han cambiado mucho desde los inicios de la fotografía, pero, a pesar de ello, no han sido esencialmente repensadas o reinventadas como sí ha sucedido con los elementos posteriores de las cámaras. [...] La parte posterior de la cámara es la parte agitada, históricamente más inmediata, impaciente por capturar lo que fluye lentamente de la abertura de la parte delantera”" ${ }^{\prime 2}$.
\end{abstract}

Por tanto vemos que, si bien "la imagen no ha cesado de perfeccionarse en ningún momento" ${ }^{13}$, las herramientas y tecnologías que son capaces de producirla tampoco han dejado de evolucionar y de mejorar con el paso de los años.

12 WALL, Jeff, Fotografía e inteligencia líquida, Barcelona, Gustavo Gili, 2007, págs. 23-25.

13 MELOT, Michel, op. cit., pág. 78. 


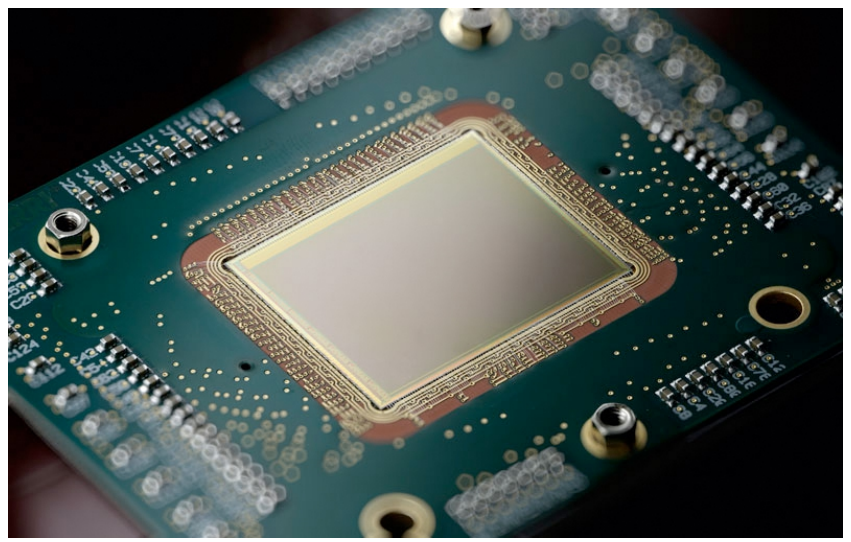

Imagen 4.3: El sofisticado sensor electrónico de la cámara de cine Arri Alexa.

En las dos últimas décadas, hemos asumido progresivamente la tecnología digital en prácticamente todos los usos de la fotografía, y las anteriores tecnologías de captura fotográfica que utilizaban la química y la plata como ingredientes, han quedado trasladadas a usos más artísticos y minoritarios. Es cierto que algunas modas y apuestas del mercado han intentado (y conseguido) aproximar los protocolos analógicos propios de la fotografía del siglo $\mathrm{XX}$ a nuestros días, pero han sido ejercicios puntuales y escasos, exigidos $\mathrm{y}$ valorados por solo unos pocos ${ }^{14}$. Pretender recuperar esos procesos de la fotografía clásica para satisfacer a la totalidad de las masas como antaño se hacía, supone una batalla perdida. Hoy la fotografía popular es digital... con todos los cambios de paradigma que ello conlleva:

Hablamos, entre otros ejemplos, de la recuperación de la lomografía, que desde principios del siglo XXI hasta la fecha vuelve a estar de moda entre grupos reducidos de aficionados viviendo una segunda edad de oro. Hoy en día se siguen produciendo en fábricas, de manera regular, una respetable cantidad de cámaras de plástico que utilizan como soporte de captura la película fotográfica usada en épocas previas a la aparición de la tecnología digital. 
"La fotografía electrónica [...] no constituye una simple transformación de la fotografía fotoquímica sino que introduce toda una nueva categoría de imágenes que ya hay que considerar "posfotográficas». La pregunta de si la fotografía digital es todavía fotografía, no tiene respuesta concluyente. [...] lo que confiere una identidad peculiar a la fotografía digital es la transustancialidad de su estructura íntima: la sustitución del grano químico por los bits de información”"15.

Ahora bien, no podemos olvidar que la aficionada o aficionado que se ha apropiado de la tecnología, exige estas mejoras aplicadas al sensor electrónico y a la máquina que lo contiene. Hoy las fotos producidas son más nítidas, pueden hacerse con menos luz, tienen más resolución y detalle. Y los aparatos son más portátiles, más fáciles de manejar a nivel técnico. Pero si las exigencias de los compradores han transformado el mercado, las competencias e innovaciones de este mismo mercado (en pos de la seducción de sus clientes) también han cambiado los hábitos y los usos de la fotografía al mismo tiempo que la construcción de las imágenes que la máquina produce:

\begin{abstract}
"Cada momento histórico presencia el nacimiento de unos particulares modos de expresión artística, que corresponden al carácter político, a las maneras de pensar y a los gustos de la época. El gusto [...] se forma en función de unas condiciones de vida muy definidas que caracterizan la estructura social [...]. Así ocurre que cada sociedad produce unas formas definidas de expresión artística que, en gran medida, nacen de sus exigencias y de sus tradiciones, reflejándolas a su vez"16.
\end{abstract}

Desde esta perspectiva, no se puede explicar el fenómeno del autorretrato digital publicado en la red ni de su específico selfie sin tener en cuenta la máquina tecnológica que lo genera. Tampoco debemos ignorar las propiedades que este dispositivo ha ido desarrollando hasta la actualidad ni las transformaciones que ha generado en las formas y en los contenidos de sus

\footnotetext{
15 FONTCUBERTA, Joan, La cámara de Pandora. La fotografi@ después de la fotografía, Barcelona, Gustavo Gili, 2010, págs. 60-61.

16 FREUND, Gisèle, op. cit., pág. 7.
} 
imágenes fotográficas producidas. Así pues, el sensor electrónico define y estaría íntimamente ligado a la imagen fotográfica digital que produce. Por eso, estudiar los principios y la evolución del sensor de imagen electrónico nos puede ayudar a analizar el tipo de imágenes que se han ido generando (paralelamente con dicho sensor) desde hace más de veinte años.

\subsubsection{Fundamentos técnicos del sensor de imagen.}

El sensor de imagen es la superficie sensible a la luz que, dentro de una cámara electrónica, tanto de vídeo como de fotografía estática ${ }^{17}$, detecta y captura la información que compone la imagen. Esto se logra al convertir la atenuación de las ondas de luz (cuando estas atraviesan o son reflejadas por cuerpos) en señales de naturaleza eléctrica. Las ondas capturadas por el sensor pueden ser luz u otro tipo de radiación electromagnética ${ }^{18}$.

Este chip está formado por millones ${ }^{19}$ de componentes sensibles a la luz (fotodiodos o fototransistores). Esos millones de celdas están generalmente a oscuras, y tan pronto como se las expone a la luz, capturan las ondas proyectadas webcams, videoporteros, equipos médicos o equipos de visión nocturna. PÉREZ, Mario, "Tipos y características de los sensores de cámaras de fotos", 2018, disponible en: <https://www.blogdel fotografo.com/tipos-caracteristicas-ventajas-sensores-camaras-fotos/> [Fecha de consulta: 29 de enero de 2018].

VV. AA., "Sensor de imagen", 2011, disponible en: <https://es.wikipedia.org/wiki/Sensor_de_ imagen> [Fecha de consulta: 29 de enero de 2018]. de imprimir (o visualizar) fotos a tamaños más grandes con pérdidas de calidad menores. Ídem. 
de un objetivo componiendo (escribiendo) la imagen digital ${ }^{20}$ sobre una extensión de almacenamiento de datos ${ }^{21}$.

Respecto a la tecnología de los sensores, existen actualmente muchas modalidades. Aunque las más extendidas han sido durante muchos años el sensor CCD (Charged Couple Device) y el SuperCCD. Actualmente el más distribuido comercialmente, debido a su menor consumo de energía y coste de fabricación ${ }^{22}$, es el sensor $\mathrm{CMOS}^{23}$.

Casi todos los sensores tienen la misma construcción física y funcionamiento, por lo menos en rasgos generales: son superficies semiconductoras, un chip sobre el que reposa una malla muy empaquetada de electrodos de polisilicio. Al impactar los fotones sobre el silicio se producen electrones generados que pueden guardarse de forma temporal. Periódicamente se lee el contenido de cada una de esas millones de células haciendo que los electrones se desplacen físicamente desde la posición donde se originaron (en la superficie del chip), hacia el amplificador de señal. Con ello se genera una corriente eléctrica que será proporcional al número de fotones que llegaron a dicho fotodiodo. Dicho de otra manera:

“Cada fotodiodo está conectado a dos polos encargados de medir el voltaje. Cuando un fotón pasa por el filtro de color, libera electrones en el sustrato de silicio. Una carga eléctrica aplicada a los polos reúne estos electrones, el sistema mide su cantidad y luego la anota en formato digital" 24 .

20 "Finalmente, el fichero informático que almacena ese patrón puede ser representado en una pantalla (o impreso en papel fotográfico realizando ciertos procesos) de modo que nuestros ojos lo perciban como una imagen; una sucesión continua de imágenes pasando por la pantalla a alta velocidad es percibida por el ojo como un vídeo". Ídem.

21 PÉREZ, Mario, op. cit., s/n.

22 SOLER, María, Las empresas de fotografía ante la era digital. El caso de la Comunidad Valenciana, Madrid, Ediciones de las Ciencias Sociales, 2007.

23 Ídem.

24 COLLE, Raymond, "La revolución de la fonofotografía. Teléfonos con cámara y redes sociales", en Revista mediterránea de comunicación. Colección mundo digital, $\mathrm{n}^{\circ}$ 4, 2013, págs. 12-13. 
Para coordinar los periodos de almacenamiento (tiempo de exposición) y vaciado del fotodiodo (lectura del píxel) debe existir una fuente eléctrica externa que marque el ritmo de almacenamiento-lectura: el reloj del sistema. La forma y amplitud de reloj son críticas en la operación de lectura del contenido de los píxeles ${ }^{25}$.

Hoy en día, casi la totalidad de los sensores comercializados son de tecnología CMOS. A diferencia de los caros y casi obsoletos CCD, estos no reciben el nombre por cómo funcionan, sino por el tipo de proceso de fabricación que siguen: semiconductor complementario de óxido metálico (complementary metal-oxide-semiconductor), que es la misma tecnología que se usa para fabricar cualquier tipo de microchip hoy en día. La principal diferencia que vemos aquí con respecto al CCD es que dentro de cada fotodiodo está incluida la electrónica que convierte esa carga de electrones, que se crea cuando incide luz sobre el sensor, en una señal de voltaje analógico. Voltaje que será después convertido por uno o varios conversores A/D en una señal digital (unos y ceros) ${ }^{26}$.

En las siguientes dos imágenes podemos ver dos esquemas. Uno simula la ampliación de un minúsculo corte frontal del sensor (Imagen 4.4) en el que se puede apreciar la rejilla de células individuales que, tras unas microlentes, y antes de llegar a los fotodiodos, contienen unos filtros con los colores rojo, verde y azul $(R G B)$ distribuidos regularmente en una cantidad de 1:2:1 y que son los causantes de, combinándose por cercanía con distintas intensidades, simular el espectro completo de color para los espacios $s R G B$ o Adobe RGB. El otro esquema (Imagen 4.5) presenta un corte vertical con el que podemos visualizar todas las capas del sensor. Photonic_en/Review/ccd1.htm> [Fecha de consulta: 29 de enero de 2018]. en: <http://dgpfotografia.com/2015/06/24/evolucion-de-los-sensores-digitales-en-fotografia-de-ccda-cmos/> [Fecha de consulta: 29 de enero de 2018]. 


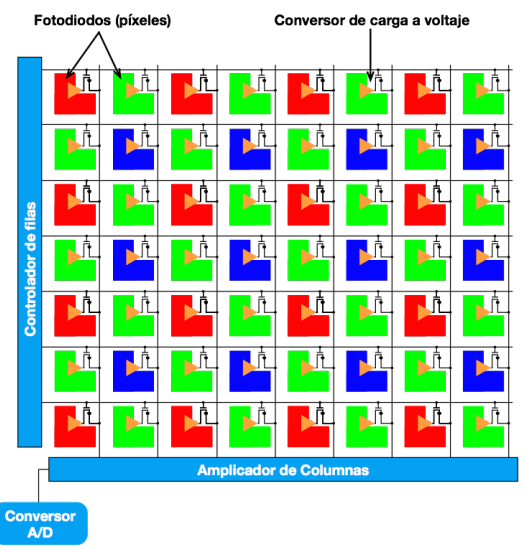

Imagen 4.4: Corte frontal del sensor CMOS. Fuente: David García (ver nota al pie, pág. 208).

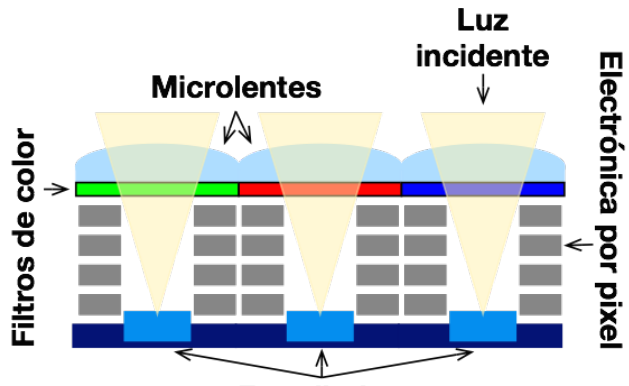

Fotodiodos

Imagen 4.5: Corte vertical del sensor CMOS. Fuente: David García (ver nota al pie, pág. 208).

Respecto a los tipos de archivo digital codificado en mapa de bits (cuadrículas formadas por píxeles) que genera el sensor de imagen una vez la cámara fotográfica digital realiza una toma, encontramos los formatos identificados como PICT (imágenes para animación o edición en vídeo), que podemos dividir básicamente en archivos tipo JPG (archivo de imagen comprimido), tipo TIFF (archivo de imagen no comprimido) ${ }^{27}$ y tipo RAW (archivo de imagen en bruto que contiene la totalidad de los datos de la imagen tal y como ha sido captada y de la que, mediante el uso de cierto tipo de software, obtendremos copias en TIFF o en JPG) ${ }^{28}$. El formato RAW será característico de las cámaras réflex y profesionales.

27 SÁNCHEZ-VIGIL. Juan Miguel, op. cit., págs. 27-28.

28 VV. AA., "Raw (formato)", 2018, disponible en: <https://es.wikipedia.org/wiki/Raw_(formato)> [Fecha de consulta: 3 de enero de 2018]. 
Sin embargo, la capacidad de compresión, ligereza, operatividad y estandarización del tipo de archivo JPG (o JPEG), lo convertirán en el favorito, no solo de las cámaras más populares y de los smartphones, sino también de Internet, siendo el tipo de imagen que más abunda en los servidores y el que más vemos cuando navegamos por la Web. El formato JPG fue desarrollado por el Join Photographic Experts Group (JPEG) para imagen fija. Las especificaciones técnicas de la versión 1.02 fueron publicadas en 1992. Utiliza el color $Y c b C r$ que proviene de la conversión de los valores $R G B$. En la descompresión se convierte de nuevo en $R G B$. Para escala de grises utiliza únicamente el componente luminancia $Y$. Es muy ligero debido a su alto índice de compresión basado en varios protocolos, sin embargo, esto conlleva una pérdida de calidad que puede ser asumible si tenemos en cuenta para qué se destina generalmente este archivo de imagen ${ }^{29}$. Así pues, podemos aventurarnos a decir que más del $99 \%$ de los selfies del ciberespacio y del resto de autorretratos publicados en la red son archivos de tipo JPG.

\subsubsection{Origen del sensor de imagen y su integración con la cámara fotográfica.}

Cuando los visionarios modernos, desde los escritores Julio Verne y H. G. Wells hasta los guionistas de Star Trek, imaginaban el futuro de la humanidad, lo hacían describiendo una absoluta tecnologización de la vida ${ }^{30}$. Y así está siendo tras el desarrollo de muchos ingenios desarrollados, sobre todo, en las últimas dos décadas del siglo XX y durante la primera del XXI.

IGLESIAS, David, La fotografía digital en los archivos. Qué es y cómo se trata, Gijón, Trea, 2008, págs. 42-44.

30 CARRILLO, Jesús, op. cit., pág. 15. 
La invención y el desarrollo del sensor de imagen a principios de los años setenta del siglo pasado ha sido una de las causas, en muchos ámbitos y aplicaciones, de parte de esta modernización de la que hoy gozamos (o sufrimos). El artilugio había sido predicho, muchas décadas antes, por el mismísimo Alexander Graham Bell, inventor de la telefonía: el profesor Bell estaba convencido de que en un futuro cercano sería posible ver por telegrafía, de manera que dos personas que hablaran por teléfono podrían al mismo tiempo verse las caras. Ampliando esta idea, también sería factible transmitir fotografías por medio de la electricidad ${ }^{31}$.

Dio en el clavo. Pero no sería hasta finales de 1969, cuando los inventores Willard Boyle y George Smith (Imagen 4.6) desarrollaron en los Laboratorios Bell su dispositivo de carga acoplada (CCD). En aquellos años, las sociedades occidentales habían dejado de competir por el petróleo como principal fuente de desarrollo de las sociedades y había empezado la carrera por el microchip y los microprocesadores ${ }^{32}$. Pronto, componentes como el flúor, el sicilio y el cobalto serían los más demandados por las fábricas. Esta deriva, entre muchas otras, propiciaría la caída de la Unión Soviética y el "fin de la bipolaridad USA-URSS" 33 . Nuestra contemporánea sociedad de la tecnología se iba a inventar durante la década de los setenta en los laboratorios y en los garajes de Estados Unidos. Así

31 LISTER, Martin (Comp.), La imagen fotográfica en la cultura digital, Barcelona, Paidós Ibérica, 1997, pág. 225.

32 Respecto al término micro cabe decir que la electrónica no ha dejado de miniaturizarse desde el desarrollo de los primeros diodos a principios del siglo XX. A partir de los años 1970 la miniaturización y compactación de los transistores fue en aumento. En 1971 la compañía Intel lanzó el primer microprocesador: un circuito integrado especialmente construido para efectuar las operaciones básicas ya señaladas por Charles Babbage (como veremos en el desarrollo de la computación en el primer apartado del capítulo 6). Esta era la última clave necesaria para el desarrollo de aparatos económicos de posible venta masiva. "La miniaturización ha progresado tanto que hemos pasado de un procesador conteniendo 2.300 transistores en 1971) a 55 millones de transistores en el chip en el año 2002, funcionando en forma 20.000 veces más rápida. En 2005 ya se superaban los 200 millones de transistores en el chip. Pero desde este año los fabricantes han decidido no proseguir en la carrera por aumentar el tamaño y la velocidad (lo cual provoca mayor calor, que cuesta disipar) sino buscar otras soluciones, como incluir dos o más procesadores en un mismo chip, de ahí los «múltiples núcleos» que ofrecen los aparatos de hoy”. COLLE, Raymond, op. cit., pág. 36.

BOURRIAUD, Nicolas, Radicante, Buenos Aires, Adriana Hidalgo, 2009, pág. 219. 
pues, Willard Boyle y George Smith desarrollarán el dispositivo que acabará siendo el padre primigenio de todos los sensores electrónicos contemporáneos de captura de imagen que se encuentran no solo en cámaras digitales y smartphones, sino también en cámaras de vídeo,webcams, cámaras de vigilancia y demás aparatos de registro de imagen.

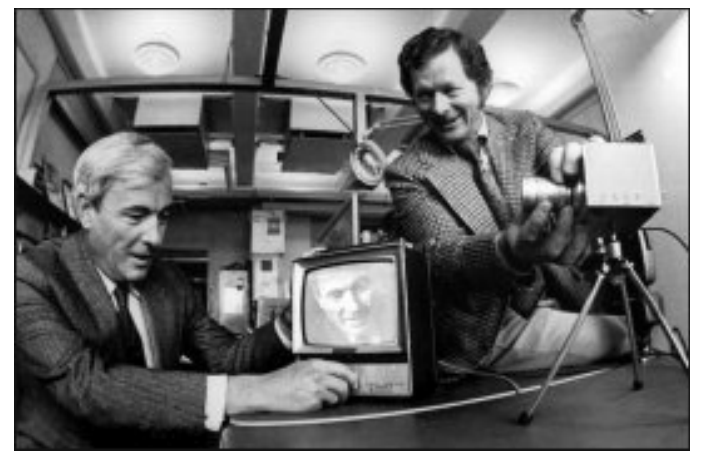

Imagen 4.6: Willard Boyle (izquierda) y George Smith, inventores del CCD, en los laboratorios Bell.

Curiosamente, al igual que ocurre con muchos inventos notorios, los propósitos de uso de sus fundadores iban por otros derroteros. La intención original de Boyle y Smith era la de crear un nuevo tipo de memoria de semiconductores para computadoras que pudiera estar asociado a una cámara para usos de video-portería. En 1970, cámara y sensor se encontraban ya unidos, y cinco años más tarde, esa visión a tiempo real tenía suficiente definición como para poder presentarse en pantallas de televisión ${ }^{34}$. 2014, disponible en: <http://www.historyofinformation.com/expanded.php?id=1103> [Fecha de consulta: 12 de enero de 2018]. 
Sin embargo, hasta 1986 no se establecerá la relación entre el sensor electrónico y la fotografía ${ }^{35}$. Anteriormente, Kodak había desarrollado el primer sensor integrado en una cámara de fotos, capaz de producir imágenes digitales.

\footnotetext{
"Era un prototipo que tenía el tamaño de una tostadora, de $4 \mathrm{~kg}$ de peso, y generaba una imagen de 0.01 megapíxeles, necesitando 23 segundos para guardar una fotografía en blanco y negro en una cinta de casete y otros tantos en recuperarla" ${ }^{36}$.
}

Con posterioridad, otras marcas comenzaron a desarrollar también sus primeras cámaras para competir desde la industria en este nuevo mercado digital. A finales de ese mismo año 1986, Canon será la primera marca en comercializar una cámara de naturaleza electrónica: la Canon RC-701 (Imagen 4.7) con un sensor que producía 180.000 píxeles totales (o,2 megapíxeles) y que costaba la friolera de 27.000 dólares.

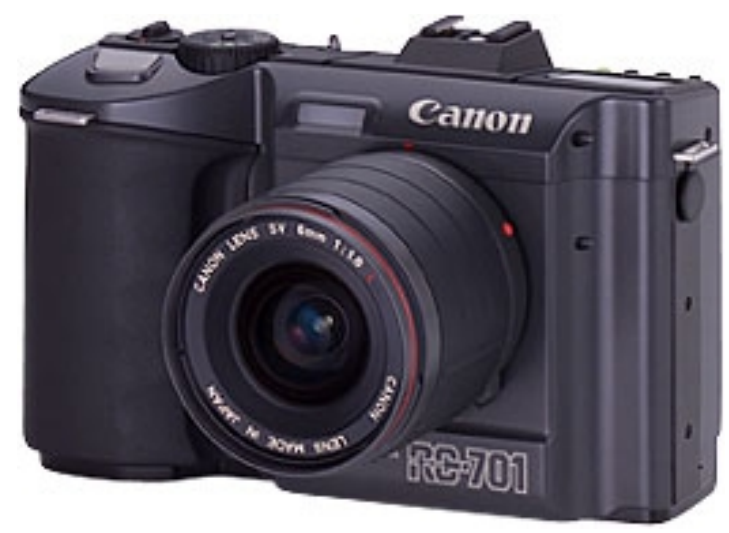

Imagen 4.7: La Canon RC-701 (RC: Realtime Camera). El sistema completo de la primera cámara digital en ser comercializada.

Unos años antes, en 1981, Sony Corporation había creado una cámara que bautizó como Mavica. El sensor de esta cámara era muy parecido al contemporáneo, con la excepción de que capturaba la toma con dos chips diferentes (luminancia y color) en lugar de con uno solo. Sin embargo, Mavica no puede considerarse la primera cámara digital de la historia, ya que en realidad, se trataba de una cámara de vídeo primitiva con una lente sencilla que también era capaz de congelar la imagen grabada en movimiento.

COLLE, Raymond, op. cit., pág. 33 . 
Desde esta primera cámara comercializada hasta las que se pueden adquirir hoy en día, cientos de nuevos sensores electrónicos han evolucionado y se han adaptado a las exigencias del mercado de la mano de otras diferentes marcas: Minolta, Olympus, Toshiba, Nikon... Los primeros esfuerzos estuvieron en el lado de la producción y del abaratamiento de costes. La primera cámara Kodak profesional con tecnología digital a la venta se inició en 1991, mientras la primera cámara digital que funcionaba con conexión a un PC fue la Apple Quicktake 100, en 1994. La primera cámara fotográfica para aficionados, con una pantalla de cristal líquido en la parte posterior, fue la Casio QV-10 de 1995 (Imagen 4.8), y la primera cámara fotográfica en utilizar tarjetas de memoria CompactFlash fue la Kodak DC-25 (Imagen 4.9) en 1996. En 1997 aparecieron las primeras cámaras fotográficas de un megapíxel y en 1999 las primeras reflex (DSLR), con más de 2 megapíxeles ${ }^{37}$.

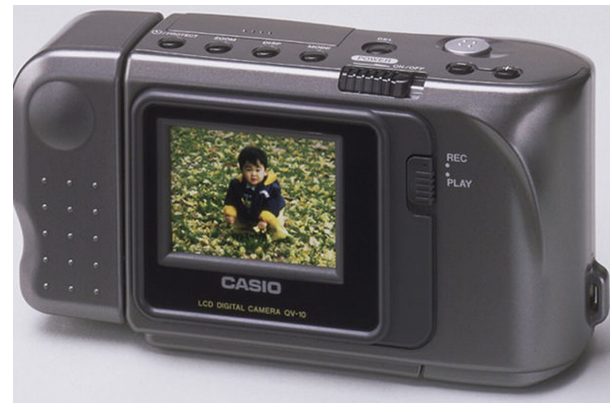

Imagen 4.8: Casio QV-10 (1995), la primera cámara digital con pantalla de cristal líquido en la parte posterior.

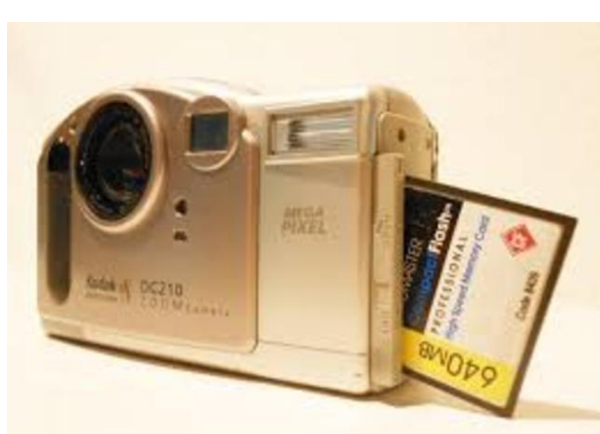

Imagen 4.9: Kodak DC-25 (1996), la primera cámara digital con almacenamiento por tarjeta de memoria.

La carrera en la popularidad del dispositivo había comenzado y, muy pronto, todo ser humano habitante de un país desarrollado tendría una cámara de fotos digital en casa (o en el bolsillo). No se escatimó en la mejora mecánica de 
la máquina: modelos más pequeños y portátiles, procesadores más rápidos, baterías más duraderas, mejores sistemas de almacenamiento de los archivos... Poco tiempo después, las ansias de mejora del sensor se centraron en el incremento de la resolución y del tamaño de los archivos que era capaz de generar, así como en la relativamente reciente "guerra de los megapíxeles", en la que cada fabricante prometía tamaños de impresión sobre papel cada vez mayores $^{38}$. Hasta la llegada de los smartphones y la mejora de las cámaras incluidas en estos, habrá un desarrollo muy rápido de las cámaras compactas digitales y réflex digitales.

\subsubsection{Evolución de la cámara fotográfica digital antes de la llegada del smartphone.}

Las cámaras digitales comenzaron a comercializarse en Estados Unidos de forma masiva entre el público a finales de la década de 1990. Sin embargo, en el mercado español la nueva era digital se producirá con cierto retraso: “en el año 2001 tan sólo un 10\% de las cámaras vendidas eran digitales” ${ }^{39}$. Como sucedía con la fotografía analógica o fotoquímica, también en la fotografía digital se puede distinguir principalmente entre cámaras para el segmento de la fotografía de consumo y cámaras digitales para el segmento profesional ${ }^{40}$. Así, cámaras de

38 Antes de la existencia de Internet y de la democratización de las pantallas como soporte de visualización de imágenes, no se concebía otro destino final de la foto digital que no fuera su impresión o materialización sobre papel, tal y como ocurría con la fotografía de film. Hoy en día, en la era de la nube y de la deslocalización física del archivo digital, en esta época en la que la tableta y el smartphone se usan como soporte visual, pocas fotografías llegan al papel; pero ha existido un largo periodo intermedio entre ambas etapas en el que los fabricantes ofrecían facilidades y mejoras constantes en la reproducción de la imagen sobre formato físico/papel.

Ibídem, pág. 55. 
bolsillo y de viaje evolucionarán con los mismos esfuerzos que las cámaras réflex o las cámaras telemétricas en lo que a la nueva tecnología digital se refiere.

Donde más esfuerzos dedicó la industria fue al crecimiento y mejora de los sensores de tamaño grande, que se adaptaron a la máquina que tradicionalmente había sido la abanderada del fotoperiodismo y de la fotografía documental: la cámara réflex. La réflex digital (Imagen 4.10) imitaba a su vieja homóloga analógica. La misma calidad de imagen, las mismas lentes intercambiables, la misma filosofía a la hora de visualizar y disparar... A su vez, presentaba las mismas mejoras que cualquier cámara digital: gratuidad en el disparo, intentos de captura infinitos, revisión instantánea, prueba y error, gestión rápida de la imagen fotográfica... Esto, además de beneficiar a los profesionales de lo fotográfico y a la industria de la imagen, también popularizó aún más a la cámara réflex entre los fotoaficionados.

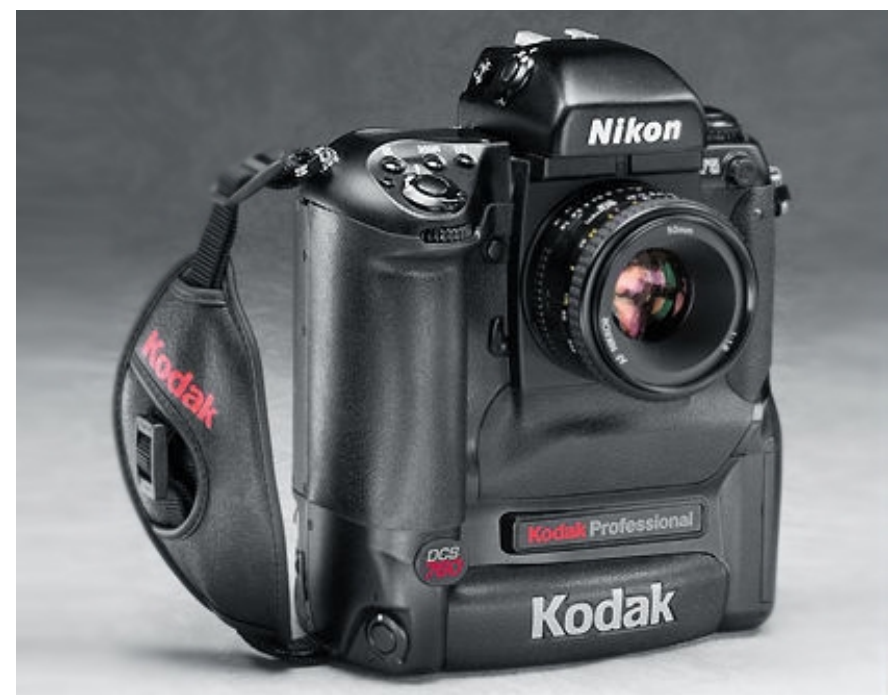

Imagen 4.10: La Kodak Professional Digital Camera System o DCS 100, con tecnología Nikon, fue la primera cámara réflex digital que se comercializó. Desde entonces, este tipo de cámara no dejará de mejorar en prestaciones y en modelos adaptados a diferentes tipos de público y bolsillos. Hoy en día, incluso, comparte sus funciones de cámara fotográfica con la posibilidad de grabación de vídeo. 
Por otro lado, las cámaras compactas e híbridas también se extendieron entre toda esa nueva raza de usuarios de la fotografía digital. Permitían fotografiar cualquier cosa, ser transportadas a cualquier sitio, ser compañeras de viaje, y cambiaron los modos de encuadrar y componer gracias a su ausencia de visor (que había sido sustituido por una pantalla de cristal líquido que hacía las veces de nuevo visor disociado del eje de la lente). Ahora los fotógrafos podían alejar las cámaras de sus caras. Estos nuevos objetos modificaron las estrategias compositivas de la escena (y sus resultados formales en la fotografía), ofreciendo novedosas perspectivas que fueron (y son) consecuencia de disparar desde la mano en lugar de disparar desde el ojo (Imagen 4.11).

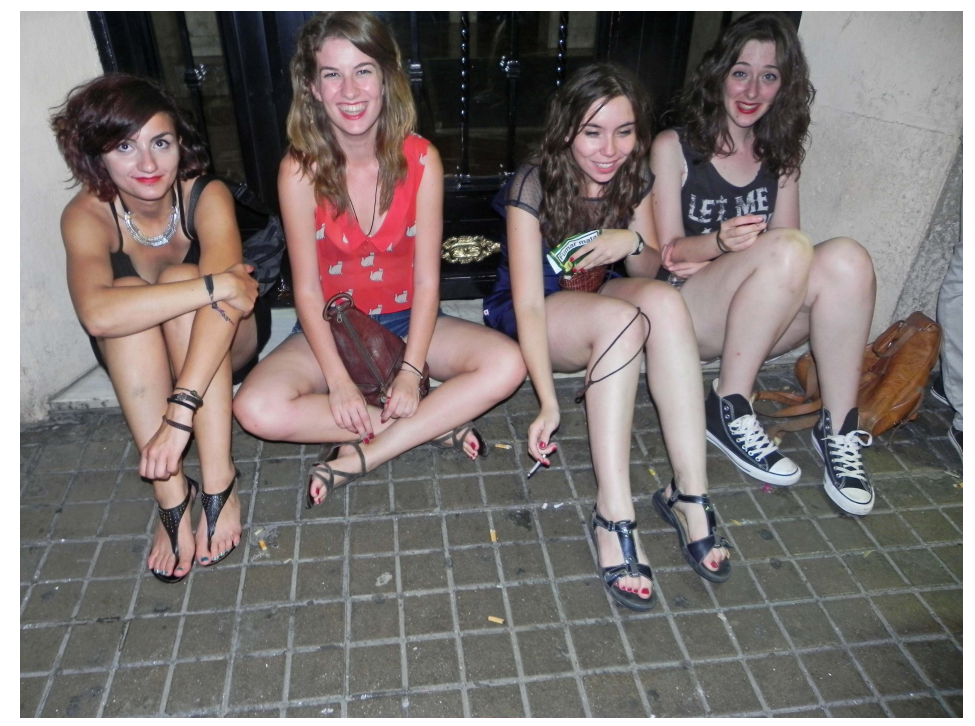

Imagen 4.11: Luis Armand, Claudia y Las Chinoises, 2012. Esta fotografía ejemplifica la separación física entre el ojo del fotógrafo y el visor de su máquina, un hecho generalizado entre muchos fotógrafos contemporáneos. La imagen, además de ofrecer una perspectiva más cercana al suelo, delata de otra manera la posición de la cámara: mediante las miradas de sus protagonistas. Vemos como dos de las chicas miran (posan) hacia la lente, sin embargo, la chica de la izquierda dirige su mirada en otra dirección: mira hacia los ojos del fotógrafo ${ }^{41}$. 
Consideramos este hecho como uno de los puntos clave para entender la construcción formal del selfie y del resto de autorretratos digitales publicados en la red: como hemos visto en el capítulo anterior, la aparición de pantallas visualizadoras separadas del visor que nos invitan a retirar la cámara del ojo, así como las pantallas desplegables (Imagen 4.12), las cámaras-espejo o los palosselfie, han generado nuevos puntos de vista, nuevos encuadres y nuevas estrategias compositivas (Imagen 4.13) por parte de los usuarios y usuarias a la hora de realizar sus fotografías. Esto justificaría, como vimos, que la herramienta (la cámara) es coautora de la fotografía realizada, y que esta no es exclusivamente fruto (aunque si parte) del total libre albedrío del hacedor de la misma, por lo que las imágenes no le serían totalmente propias, al igual que ha ocurrido tantas otras veces a lo largo de la historia del arte en relación a la herramienta y al artista.

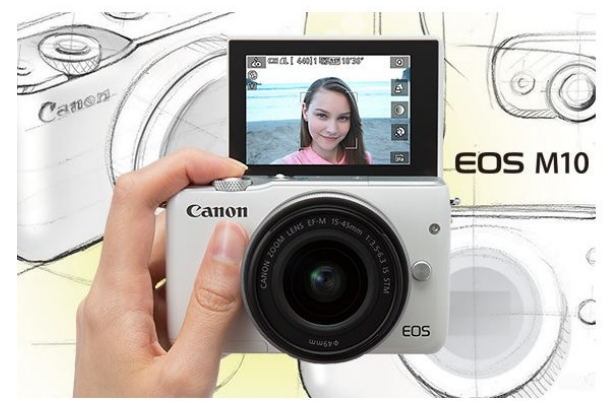

Imagen 4.12: Cámara compacta Canon EOS M10. Dispone, como muchos otros modelos, de una pantalla desplegable 180 grados que hace las veces de visor.

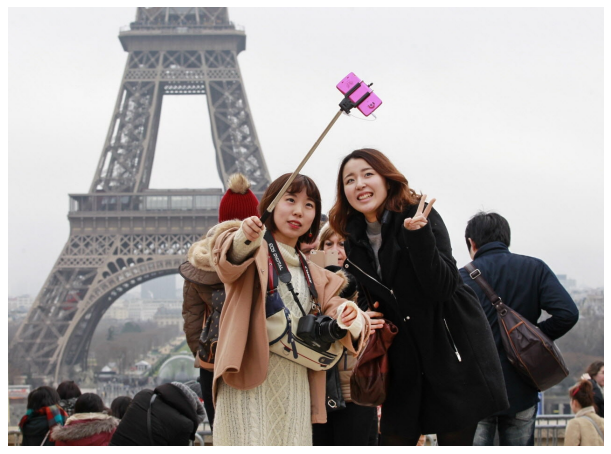

Imagen 4.13: Turistas asiáticas realizándose una autofoto con uno de los encuadres característicos al que nos fuerza el palo-selfie.

que denuncia su presencia, manifiesta el grado primero, el más evidente, de esa modificación que la aparición de la cámara ha producido. Es decir, "la presencia de la cámara modifica la naturalidad de la escena, aunque crea otra naturalidad”. BECEYRO, Raúl, Ensayos sobre fotografía, Buenos Aires, Paidós, 2003, pág. 42. 
De este modo, tal y como hemos visto, si el sensor creció para adaptarse a las grandes cámaras históricas de 35 milímetros y de medio formato, también se redujo para encajar no solo en el interior de cámaras compactas cada vez más pequeñas, manejables, ligeras y baratas, sino también en muchos otros dispositivos que, hasta entonces, no disponían de la propiedad de captura de imagen: computadoras (ahora con webcams integradas, videoconsolas (Imagen 4.14), teléfonos móviles (celulares), tabletas digitales...

Durante estos últimos años, el desarrollo del sensor electrónico se ha concentrado en su adaptación a uno de los más relevantes y recientes inventos: el smartphone (Imagen 4.15). Concebido como un teléfono-computador portátil con aplicaciones y conexión a Internet, este terminal ha acabado por asumir el rol de cámara de fotos, conectada 24 horas a la red, y con las posibilidades de publicación instantánea que esto supone: otra nueva transformación de los usos de la fotografía de masas.

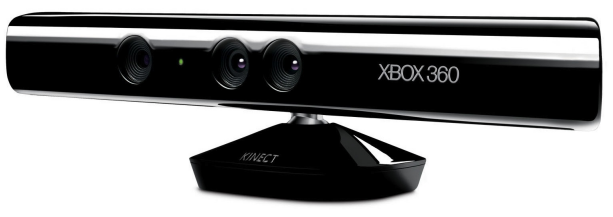

Imagen 4.14: Kinect es un dispositivo diseñado por Microsoft Corporation para su uso doméstico en la esfera del videojuego, y que posee dos cámaras paralelas que interpretan el espacio tridimensional donde se encuentra el sujeto, permitiendo a este, con su movimiento, interactuar con la videoconsola.

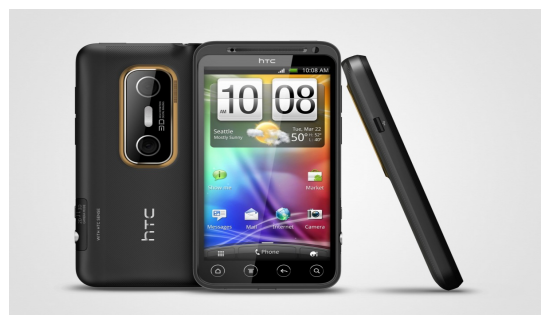

Imagen 4.15: Smartphone HTC Evo 3D. Uno de los primeros teléfonos inteligentes en incluir doble lente fotográfica en su parte trasera para conseguir un efecto $3 \mathrm{D}$ en las fotografías obtenidas. 
Este es el momento en el que nos encontramos. Las marcas siguen desarrollando sensores electrónicos cada vez mejores y más adaptados a sus cámaras y propósitos. La imagen digital se necesita, y también sus máquinas generadoras. El usuario pide y la industria desarrolla; la industria inventa, y el aficionado se maravilla, adquiere y se adapta. El invento está ya diluido en la sociedad, en sus acontecimientos y haceres. Es parte de su política y de su economía.

No es de extrañar, por tanto, que toda la tecnología aplicada al sensor electrónico continúe desarrollándose por la industria, como siempre ha hecho, y que lo haga, además, cada vez más rápido:

\footnotetext{
"En la actualidad, dominada por la tecnoestructura cuyo objetivo persigue la creación incesante de nuevas necesidades, el desarrollo de la industria fotográfica es uno de los más rápidos entre el de todas las industrias. La imagen responde a la necesidad cada vez más urgente en el hombre de dar una expresión a su individualidad. [...] Hacer fotos se le antoja como una exteriorización de sus sentimientos, una especie de creación. Así se explica el creciente número de fotógrafos aficionados que hoy se cifra por cientos de millones y que tiende a incrementarse cada vez más” ${ }^{42}$.
}

Es necesario adentrarnos en el desarrollo del smartphone como máquina fotográfica heredera de la cámara compacta de aficionado para comprender mejor el fenómeno del selfie a través de su máquina hacedora. Pero antes de abandonar estos comentarios en torno a las cámaras fotográficas digitales basadas en sus anteriores análogas analógicas, efectuaremos unos breves apuntes sobre el cambio que supuso para el fotógrafo de película química la llegada de la fotografía digital.

FREUND, Gisèle, op. cit., págs. 8-9. 


\subsection{La adaptación del fotógrafo de película argéntica a la fotografía digital. Diferencias y convergencias.}

El cambio que supuso la llegada de la captación de imágenes fijas (y en movimiento) basada en dispositivos y soportes de captura fotográfica fundamentados en una tecnología electrónico-digital, produjo una ruptura respecto a los soportes fílmicos y procesos químicos en los que se había sustentado la fotografía desde sus orígenes. Como es de suponer, esto ha causado profundos cambios en los haceres de profesionales del sector y aficionados, ha tambaleado a la industria fotográfica (naciendo nuevas fábricas y muriendo antiguas) e, incluso, ha puesto en duda si la fotografía digital continúa siendo fotografía o, por el contrario, es otra cosa...

\footnotetext{
"Podemos identificar ciertos momentos históricos en los cuales la súbita cristalización de una nueva tecnología (como, por ejemplo, la imprenta, la fotografía o la informática) proporciona el núcleo de nuevas formas de práctica social y cultural y marca el inicio de una nueva era de exploración artística. Los últimos años treinta del siglo XIX -la época de Daguerre y Talbot- fue uno de esos momentos. Y el inicio de los noventa del XX será recordado como otro de ellos: la época en la que la imagen digital procesada por ordenador comenzó a reemplazar a la imagen fijada sobre emulsión fotográfica basada en plata... Desde el momento de su sesquicentenario en 1989 la fotografía estaba muerta -o más precisamente, radical y permanentemente desplazada... como lo estuvo la pintura ciento cincuenta años antes-" ${ }^{43}$.
}

Como hemos visto, el cambio de los protocolos técnicos de la fotografía digital es absolutamente diferente a los que presentaba (y aún presenta, aunque de manera minoritaria) la fotografía química. Por un lado, las emulsiones fotográficas eran y son fotosensibles, esto es, son sensibles a la luz: tras ser 43 BATCHEN, Geoffrey, Arder en deseos. La concepción de la fotografía, Barcelona, Gustavo Gili, 2004,
pág. 206. 
expuestas a esta, los haluros de plata son convertidos en plata metálica a través de un complejo proceso químico y esa suma de millones de haluros transformados de manera latente y luego ampliados en papel desde la película, crea la ilusión de la imagen. Ahora, los dispositivos electrónicos son los materiales fotosensibles, responsables de realizar la transformación de la luz en electricidad, de manera proporcional a la iluminación de la escena ${ }^{44}$, tal y como hemos visto en el desarrollo del sensor electrónico.

El cambio salta a la vista, y como en otras épocas de la historia en las que surgen modelos nuevos de hacer las cosas, apocalípticos e integrados dan su opinión al respecto ${ }^{45}$. Por ejemplo, en el año 1936 fue Walter Benjamin quien se interesó por reflexionar acerca de una problemática consciente de época: el surgimiento del cine y la fotografía. En su citadísimo ensayo La obra de arte en la época de su reproductibilidad técnica ${ }^{46}$, Benjamin sostenía que, ante la posibilidad de ser reproducidas, las obras de arte pierden su aura, su "aquí y ahora”. En este sentido -y alejado de las posturas apocalípticas de Theodor Adorno y Max Horkheimer en Dialéctica de la Ilustración ${ }^{47}$ - no ve en ello una devastación cultural, sino un cambio en los esquemas de "percepción sensorial" (nuevos sensorium $^{48}$ ).

Sin embargo, otros teóricos de la imagen más contemporáneos se aventuran a decir que en ciertos aspectos nos enfrentamos a la muerte de la fotografía con la transformación de lo analógico a lo digital, pero, como en la ficción cinematográfica, el cadáver se queda y se reanima, por un misterioso

SOLER, María, op. cit., pág. 55 .

En referencia al clásico ensayo de Umberto Eco: ECO, Umberto, Apocalípticos e integrados ante la
cultura de masas, Barcelona, Lumen, 1968 . Incluido en: BENJAMIN, Walter, Sobre la fotografía, Valencia, Pre-Textos, 2004.

Véase: ADORNO, Theodor W. y HORKHEIMER, Max, Dialéctica de la Ilustración, Madrid, Akal, 2007.

LEONARDO, Norberto, "Del mito del Narciso a la selfie. Una arqueología de los cuerpos codificados",
en Palabra clave, vol. $18, \mathrm{n}^{\circ} 3,2015$, pág. 683 . 
nuevo proceso, para habitar la tierra como un zombie... La digitalización ha sido un proceso que canibaliza y regurgita las imágenes fotográficas, permitiendo la producción de simulaciones sobre simulaciones... La fotografía, dicen, pierde su especial posición estética y se convierte en simple información visual, y una vez que la información queda recogida exclusivamente mediante sensores de imagen fijos, como sucede con el vídeo, la fotografía tradicional basada en película y papel podría desaparecer como tecnología y como estética vinculada a un medio específico: "El final de la fotografía no es el final de algo que se asemeja a la fotografía, sino el final de algo que puede considerarse como estable"49.

Sin embargo, y pese a esto, podemos aproximarnos a la idea de que la imagen fotográfica argéntica y la imagen fotográfica digital comparten una cierta base común ${ }^{50}$. También pensamos que la segunda intentó desarrollarse a imagen y semejanza de la primera y que, además, comparten muchas de las características que, por lo menos a nivel formal, experimentamos al contemplar una fotografía. Es probable que parte de las diferencias estén en las oportunidades, en las prácticas, en los usos y en las magnitudes más que en las formas, aunque estas últimas también, como hemos visto, presentan evidentes cambios estructurales.

Desde el punto de vista del consumidor de imágenes fotográficas, la tecnología digital resulta invisible, transparente, en el sentido de que no vemos digitalmente. Sin poner en duda que se trata de tecnologías que están transformando nuestra relación con los objetos de la cultura y sus usos sociales, para creadores y espectadores, conviene tomar la distancia necesaria para comprender que, en lo esencial, no varía su naturaleza profunda. En este sentido, 
"las fotografías no son [...] menos «ciertas» con respecto a la apariencia de las cosas del mundo que las imágenes digitales" ${ }^{11}$.

Uno de los mayores cambios y diferencias que ha suscitado la imagen digital frente a su predecesora imagen física es la sobreacumulación, magnitud e incluso cacofonía visual. El ritmo de producción, circulación y consumo de imágenes ha sido muy rápido desde su desarrollo a principios de los años noventa del siglo pasado y continúa aumentando de forma exponencial con el paso de los años ${ }^{52}$. Esto, irremediablemente, ha producido cambios en la vida cotidiana de las sociedades usuarias de la fotografía.

"La fotografía como práctica popular, ha pasado de ser una práctica ritual, que se realiza en momentos y contextos específicos, como testimonio y objeto de memoria eventos familiares, celebraciones, viajes-, a una costumbre cotidiana que puede darse en cualquier momento del día e independientemente de la ocasión. Todo se ha convertido en fotografiable. Pero los cambios no se han dado sólo en el terreno de los contextos de producción y de los objetos fotográficos, sino también en lo que hace referencia a los contextos de circulación y exhibición de las imágenes, concretamente en su utilización como objetos de sociabilidad”53.

Por tanto el rol y la función de la fotografía digital podrían haber cambiado las prácticas que efectuamos mediante ella en nuestra cultura. La fotografía digital parece tener tiempos, objetos y procesos diferentes de los que propicia la fotografía analógica o argéntica. Entre ellos, uno de los más comunes y extendidos es nuestro objeto de estudio: el autorretrato digital adolescente publicado en la red. Los autorretratos cada vez se integran más como parte de la cotidianeidad y ya no resulta extraño ver a alguien tomarse una foto con el brazo

Ibídem., pág. 93 .

MARTIN, Lister (Comp.), op. cit., pág. 13.

GÓMEZ-CRUZ, Edgar y ARDÈVOL, Elisenda, "Cuerpo privado, imagen pública: el autorretrato en la práctica de la fotografía digital”, en Revista de dialectología y tradiciones populares, vol. $67, \mathrm{n}^{\circ} 1$, 2012, pág. 184 . 
extendido en cualquier lugar y situación ${ }^{54}$. Y no solo eso, estos cambios entre los dos modelos también resultan apreciables en la documentalidad social (hecha ahora por esa misma sociedad presente), en el fotoperiodismo e incluso en la vigilancia y control de las sociedades.

Podríamos concluir diciendo que, al igual que muchos otros, no nos atrevemos a afirmar si la fotografía ha muerto tras la llegada de la nueva era digital que ha sustituido a la argéntica. ¿Es una imagen digital producida por un dispositivo fotográfico de captura digital una fotografía en sí misma? Personalmente somos incapaces de ofrecer de manera rotunda una respuesta, no obstante, sí que apuntaremos que, entre ambos mundos, y en referencia a la fotografía digital (sea cadáver, zombie, cuerpo reencarnado o dios resucitado), existen por un lado importantes continuidades culturales de uso ${ }^{55}$, y por otro se presentan importantes mutaciones y nuevas prácticas tanto de producción como de consumo. "Esto no significa que vayan a dejar de realizarse imágenes fotográficas, pero indica la posibilidad de una decisiva transformación de su significado y su valor, y por tanto de su significación de ahora en adelante" ${ }^{6}$.

\subsection{El smartphone y su importancia fotográfica en torno al selfie.}

Ya hemos visto que el desarrollo del sensor electrónico como nueva superficie de captura fotográfica no ha supuesto del todo una ruptura del medio 
fotográfico, sino más bien una transición ${ }^{57}$. Pero la fotografía, si es que podemos seguir llamándola así, se ha desarrollado por otros caminos y métodos novedosos gracias, entre otras cosas, al desarrollo del smartphone como nueva máquina fotográfica, sin que esto suponga un abandono completo del propio medio.

"La pulverización de las imágenes en puntos elementales, accesibles y manipulables ha permitido esta volatilidad, esta maleabilidad y esta multitud. Pero la naturaleza de la imagen no ha cambiado. La digitalización no ha hecho perder a la imagen su naturaleza analógica: solo la técnica de reproducción es «digitalizada»o «vectorizada»" 58 .

La popularización y el uso del smartphone con propósitos fotográficos supone la segunda gran revolución dentro de la era de la imagen digital. Si bien la democratización de la máquina digital había cambiado los hábitos fotográficos de la sociedad hacia otros más dinámicos y vigorosos (gracias a las réflex y a las cámaras compactas de sensor electrónico), los teléfonos inteligentes despertaron aún más el deseo, la necesidad y, finalmente, el hábito de publicar la imagen propia. Si el primer grupo de dispositivos permitía la captación y visualización instantánea de la imagen, esta segunda familia de aparatos, además, posibilitaba el intercambio y la publicación inmediata de la fotografía, reduciendo a cero el lapso de tiempo que había anteriormente entre la realización de la toma y la publicación de la misma, ya que, gracias al smartphone podemos dar a nuestra imagen fotográfica recién realizada, una salida a la red global casi inmediata.

"Ya no existen hechos desprovistos de imágenes ni la documentación y transmisión del documento gráfico son fases indisociadas del mismo suceso" ${ }^{59}$.

Puesto que "[...] la fotografía digital ha asumido las antiguas aplicaciones de la fotografía tradicional". FONTCUBERTA, Joan, op. cit., pág. 12.

58 MELOT, Michel, op. cit., pág. 94.

FONTCUBERTA, Joan, op. cit., pág. 28. 
Aunque antes de la llegada del smartphone ya existían otros teléfonos celulares $^{60}$ y agendas electrónicas con conexión a Internet ${ }^{61}$, y aunque la implantación de la cámara fotográfica digital en dispositivos telefónicos unos años antes había convertido a estos teléfonos portátiles en pequeñas cámaras $\operatorname{compactas}^{62}$, no fue hasta la llegada del iPhone (desarrollado por Apple Inc. y comercializado en 2007) el momento en el que el que se acuñó el concepto y el uso del smartphone dentro de los países desarrollados y globalizados ${ }^{63}$. En menos de un año de la salida del iPhone, en Japón y en Corea ya se utilizaban más los smartphones que las computadoras para conectarse a Internet, y a principios de nuestra década ${ }^{64}$, esta práctica se iba a dar en todas las sociedades tecnológicas del planeta $^{65}$.

Durante los primeros años del uso y desarrollo de estos dispositivos móviles con cámaras integradas, la calidad de las imágenes resultantes era algo pobre comparándola con la que producía el resto de cámaras. Hoy muchos consideran encantadora la estética povera de estos primeros aparatos que son propias de una época terminada que no volverá, pero en la que se desarrolló un registro estético para muchos aceptado e incluso institucionalizado:

\footnotetext{
"Desde el punto de vista de la recepción, es cierto que la fotografía digital ha traído consigo, en determinados contextos, una modificación de los hábitos de consumo del espectador que, en tanto que usuario habitual de cámaras digitales de baja resolución,
}

6o La consultora InfoTrends CAP Ventures Inc. estimó que en 2004, tres años antes de la llegada del smartphone, se vendieron 175 millones de teléfonos móviles con cámara. SOLER, María, op. cit., pág. 66.

61 Como el iPaq, comercializado por Hewlett-Packard Company, y que atendía a usos relativamente exclusivos. Las propiedades del iPaq fueron heredadas por los teléfonos Blackberry al inicio de la era de los smartphones. Podemos poner como ejemplo el mítico Nokia N95 y su cámara de cinco megapíxeles integrada. COLLE, Raymond, op. cit., pág. 18.

64 "Según el Banco Mundial, el 75\% de la población mundial tenía teléfono móvil a mediados de 2012 y el número de abonados globales «pronto» será superior al de la población mundial. [...] de los 1.780 millones de teléfonos celulares vendidos en 2012, el 83\% tenía cámara fotográfica”. Ibídem, pág. 17.

65 PISANI, Francis y PIOTET, Dominique, La alquimia de las multitudes. Cómo la Web está cambiando el mundo, Barcelona, Paidós, 2008, pág. 97. 
se ha acostumbrado a tolerar mejor este tipo de imágenes (es paradigmático el caso de la fotografía integrada en el teléfono móvil, cuya baja calidad es muy evidente, por el momento)" ${ }^{\prime 66}$.

Hoy, y tras el desarrollo y mejora constante de este invento por parte de otras marcas dentro de la competencia lógica del mercado ${ }^{67}$, el smartphone se concibe realmente como una cámara de fotos ${ }^{68}$ gestionada por una minicomputadora y conectada al mundo a través de las señales inalámbricas que nos rodean (Wi-Fiy redes $4 \mathrm{G}$ ). Asimismo, es capaz de publicar contenidos en espacios virtuales y de intercambiar datos e imágenes mediante los servicios de mensajería también comunes entre smartphones de distintas marcas. No es de extrañar que, desde 2015, el uso y la valoración fotográfica respecto al smartphone superara a la del resto de cámaras del mercado ${ }^{69}$, incluso compitiendo (y casi alcanzando) con las cámaras reflex y de vídeo a nivel cualitativo ${ }^{70}$.

Todas estas propiedades se suman a la portabilidad continua que le confiere su pequeño tamaño y su carácter aún telefónico (nos acompaña día y

MARZAL, Javier, op. cit., pág. 91. intereses de los operadores móviles en todo el mundo, publica anualmente un informe sobre la economía de la industria móvil. En el informe del año 2014, muestra cómo el ecosistema móvil ha tenido un profundo impacto en las economías nacionales de todo el mundo, particularmente en las áreas de creación de empleo y crecimiento económico. En cuanto a cifras relacionadas con el crecimiento económico, el informe muestra que la industria móvil en 2014 generó el 3,8\% del Producto Interior Bruto mundial (PIB mundial), un total de 3 trillones de dólares en términos de valor añadido a la economía global”. SOCUÉLLAMOS, Anna, Análisis de posicionamiento de las marcas en el sector tecnológico de los smartphones, Valencia, Universitat Politècnica de València, 2015, págs. 2529.

68 En julio de 2013 llegaba a Europa el Samsung Galaxy S4 Zoom, desarrollado por la empresa surcoreana líder en telecomunicaciones Samsung Group. Con su lente avanzada poseedora del primer zoom óptico que funciona en un smartphone, y su sensor electrónico capaz de generar fotografía de 16 millones de píxeles, este terminal híbrido representó la verdadera fusión entre smartphone y cámara compacta. No obstante, a partir de 2016 encontramos en cualquier smartphone de gama alta cámaras que pueden llegar a aportar mayor calidad que muchas cámaras físicas profesionales.

69 ROSSIGNOL, Joe, "iPhone Remains Flickr's Most Popular Camera in 2015 Ahead of Canon, Nikon and Samsung", 2015, disponible en: <https://www.macrumors.com/2015/12/o3/flickr-iphone-mostpopular-camera-2015/> [Fecha de consulta: 3 de enero de 2017].

70 MARTÍNEZ, Diego, Miniaturización y democratización de las cámaras cinematográficas y de vídeo digital, Gandía, Universitat Politècnica de València, 2016, pág. 93. 
noche, en nuestros bolsillos y mesitas de noche $\left.{ }^{71}\right)$. Si tenemos también en cuenta la aceptación y el uso que se da al smartphone por parte de prácticamente todos los estratos de la sociedad, incluido los adolescentes ${ }^{72}$, no nos debe extrañar que esta nueva máquina fotográfica se haya encargado de acelerar aún más todos esos cambios que la fotografía ha experimentado en su transformación tras el advenimiento de la era digital ${ }^{73}$, respondiendo así "a un mundo acelerado, a la supremacía de la velocidad vertiginosa y a los requerimientos de la inmediatez y globalidad"74.

Las previsiones para el futuro solo son una prolongación de las cifras que han crecido de manera imparable a lo largo de esta década: en 2020, un 63\% de la población mundial podría estar suscrita a algún operador móvil ${ }^{75}$. Hoy por hoy, las pantallas de las computadoras, y también de los smartphones, se han convertido en las superficies que más miramos. El ensimismamiento en las pantallas de los smartphones, incluso cuando caminamos, podría ser solo un avance de lo que nos puede plantear un futuro rodeado de superficies luminosas transmisoras de imágenes e información aplicadas a casi cualquier ámbito de la vida:

"Que ella, la ciudad, es la constelación de las mil pantallas a través de las que el sujeto se apropia de un escenario en el que pueda llegar a advenir lo que podríamos llamar

71 CUESTA, Ubaldo y GASPAR, Sandra, "Análisis motivacional del uso del smartphone entre jóvenes: una investigación cualitativa”, en Historia y comunicación social, vol. 18, nº 2, 2013, págs. 436-437.

72 "El móvil ha pasado de ser un artículo de lujo a una herramienta esencial de la comunicación. Es sinónimo de símbolo personal y esta seña de identidad define, en muchos casos, la personalidad de los jóvenes, siendo ellos los principales impulsores de esta tecnología. [...] los jóvenes utilizan de forma generalizada el móvil por encima de otras tecnologías, preferencia que se debe al carácter privado de este frente al uso compartido y familiar del resto de las nuevas tecnologías". VÁZQUEZ, María F., La cultura visual en la adolescencia, Sevilla, Universidad de Sevilla, 2015, págs. 34-35.

73 Transformación que se refleja, entre otras cosas, en el hecho de registrar y compartir (publicar) compulsivamente casi cualquier actividad humana. "Hoy tomar una foto ya no implica tanto un registro de un acontecimiento como una parte sustancial del mismo acontecimiento. Acontecimiento y registro fotográfico se funden”. FONTCUBERTA, Joan, op. cit., pág. 28. 
una vida psíquica: ella sólo se tiene en lo común, en ese territorio virtual en el que las imágenes del deseo se entrecruzan, se retroproyectan, en una pantalla interpuesta en la que sólo somos como reflejo y fantasmagoría añadida a la percepción de la representación especular de los otros, y la reciprocidad que en esos trazados tales reflejos de otredad se reenvían -entre sí, y en algún lugar de sus rebotes febrilestambién hacia nosotros"76.

Y finalmente, mientras escribimos estas líneas, el futuro de la fotografía asociada al smartphone sigue prometiendo mejoras e innovaciones: las más inmediatas y ya disponibles son la fotografía computacional, el reconocimiento de imagen y la inteligencia artificial (AI) asociada al acto fotográfico. Respecto a la fotografía computacional, se puede señalar que la misma se basa en la aparición de los modos avanzados con doble cámara en smartphones, tecnología que poseen los modelos de gama alta más recientes de 2017 y 2018. De hecho, algunos afirman que podría ser el mayor hito de la fotografía móvil en mucho tiempo ${ }^{77}$.

Habíamos pasado por momentos clave como el aumento del tamaño de los sensores y de su resolución, pero la llegada de los modos HDR o la inclusión de los estabilizadores ópticos (relevantes en la construcción del modelo actual de fotografía compuational), podría ponernos en las manos una máquina diminuta capaz de alcanzar los resultados de las réflex más voluminosas y profesionales aunque sea de manera falsa o artificial. Y es que las cámaras con dos y tres lentes (Imagen 4.16) y con diferentes sensores y ópticas en su parte trasera, son capaces de combinar hasta tres fotografías tomadas desde lugares diferentes y con protocolos distintos para unirlas en una metafotografía que nos podría mostrar unas estructuras compositivas e ilusorias en la imagen fotográfica que se hallaría

77 SABÁN, Antonio, "El modo retrato después de la doble cámara", 2017, disponible en: <https:// hipertextual.com/2017/10/doble-camara-modo-retrato $>$ [Fecha de consulta: 2 de diciembre de 2017]. 
dotada de una calidad y firmeza muy superiores a la que nos ofrecen las lentes de los smartphones convencionales.

Por otro lado, no conocemos demasiado de la inteligencia artificial asociada al smartphone fotográfico, ya que, en los momentos en los que finalizábamos esta investigación, este concepto era solo un anuncio sin demasiadas pistas como parte de la estrategia comercial de la marca de móviles china Huawei, que a finales de marzo de 2018 desvelará su próximo smartphone Huawei P20 y sobre el que todavía se guarda un total hermetismo.

Algunos rumores apuntan a una triple lente y un triple sensor en la parte trasera y con un software integrado que lo dotará de inteligencia artificial. Su enigmático anuncio (Imagen 4.17) presenta el siguiente eslogan: "El renacimiento de la fotografíA se acerca”.

Tampoco sabemos si esa supuesta inteligencia ayudará al fotógrafo a construir de una manera más fácil y cualitativa el cuerpo de la imagen o, por el contrario, será una herramienta que podrá ayudarle a gestionar a nivel de volumen la cantidad de fotos que pueda realizar. En todo caso, estemos tranquilos por lo futurista o apocalíptico que pueda sonar este concepto. Entendemos que el uso de la inteligencia artificial como reclamo publicitario no deja de ser eso, un reclamo.

Sin duda, estas nuevas cámaras fotográficas y dispositivos presentarán mejoras espectaculares y harán más fácil (o más difícil) la vida al fotógrafo gracias a nuevas tecnologías de computación y programación, pero las máquinas, de momento, no han alcanzado un entendimiento semántico de los datos que manejan... (de momento), por ello, la llegada de HAL 9000 de 2001, una odisea en el espacio (y su ansia por destruirnos) tendrá que esperar. 


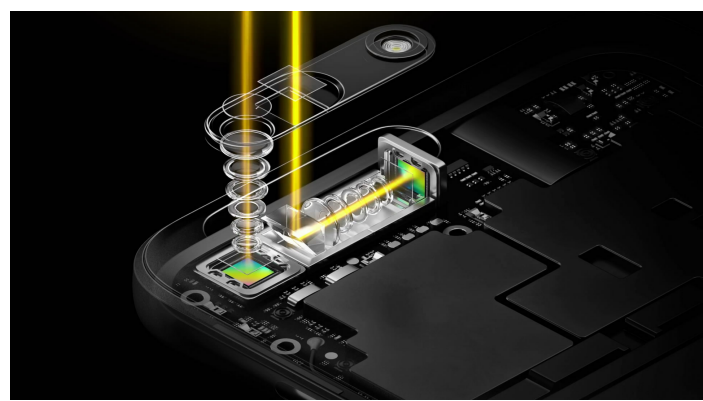

Imagen 4.16: Esquema de la ingeniería interna que presenta la doble cámara (cámara dual) trasera que, con una doble lente, una estándar y otra teleobjetivo (la cual consigue profundidad con un ángulo de 90 grados), es capaz de generar imágenes similares a las de una cámara réflex por medio de la combinatoria de las dos imágenes generadas mediante fotografía computacional ${ }^{78}$.

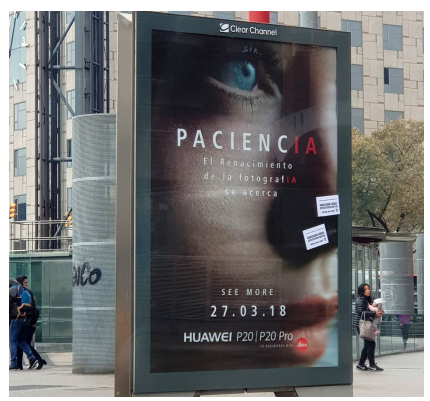

Imagen 4.17: Todavía hoy no tenemos más noticias del esperado Huawei P20 salvo algún rumor disperso y este enigmático anuncio que promete su estreno a finales de marzo de 2018. Será el primero en contar con tres lentes traseras y dos delanteras, que operarán con una supuesta inteligencia artificial.

\subsubsection{El sensor delantero del smartphone y el uso de la pantalla-espejo.}

Pese a esta nueva aparición de las multilentes traseras y delanteras, durante casi diez años la mayoría de smartphones ha contenido dos lentes y dos sensores electrónicos asociados a cada una de estas lentes. En la parte posterior (o anterior ${ }^{79}$ ) del dispositivo continúa estando la lente principal (Imagen 4.18), la smartphones. Muchos usuarios piensan que, de esta forma, las imágenes capturadas tendrán una mayor calidad, pero lo cierto es que no siempre es así. La mayoría de sistemas de doble cámara están destinadas a realizar fotografías con diferentes efectos, como el modo gran angular del LG G6. En cambio, otras, como la del Huawei P10, combinan dos sensores diferentes con el fin de obtener resultados con un mayor nivel de detalle, gracias a la posibilidad de utilizar los datos de dos capturas para crear una sola imagen". COLLADO, Christian, "Así funciona la cámara de fotos de tu smartphone", 2017, disponible en: <https://andro4all.com/2017/o5/camara-smartphone-comofunciona $>$ [Fecha de consulta: 10 de agosto de 2017].

Definir cuál es la parte anterior y cuál la posterior en un smartphone puede resultar algo 
que le otorga los mejores atributos de cámara fotográfica y posibilita sus funciones como tal. Pero en la parte delantera, sobre la pantalla, se encuentra una lente mucho más pequeña unida a un sensor diminuto de menor resolución. Esta cámara secundaria fue concebida exclusivamente para realizar videollamadas $^{80}$ (Imagen 4.19), pero también se le dotó con la capacidad para realizar fotografías ${ }^{81}$.

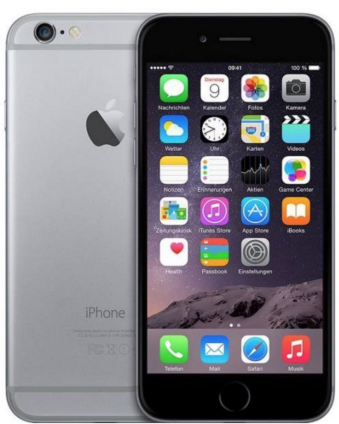

Imagen 4.18: Lente trasera principal (parte superior izquierda) y lente delantera secundaria (arriba de la pantalla en la parte derecha) del Iphone 6 de 2014.

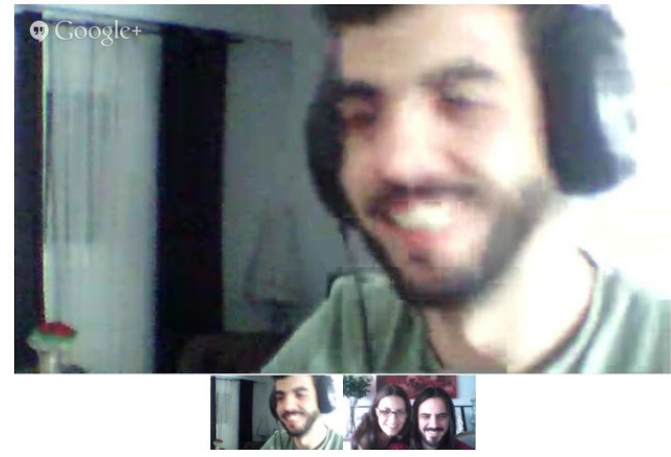

Imagen 4.19: Ejemplo de videollamada a través del servicio Hangouts de Google Inc. Disponible para smartphones o, como en este caso, para computadoras domésticas.

Esta decisión de la industria aparentemente baladí y con poco interés práctico (dada su menor resolución frente a la lente principal), ha sido crucial

conceptualmente complejo dado que se trata de un objeto híbrido que une dos máquinas en una sola: si consideramos al smartphone como un teléfono o tableta pequeña, su parte anterior será la pantalla (lo que nos permite interactuar con él) y su parte posterior será el otro lado, la tapa de la batería. Pero como precisamente en esa tapa se encuentra la lente principal, si lo consideramos cámara de fotos su lateralidad quedará invertida: su parte anterior será donde se encuentre la lente que apuntamos hacia la escena durante el ejercicio de captura fotográfica, mientras que su parte posterior será la pantalla donde previsualizamos esa misma escena.

8 Videoconferencia o videollamada es la comunicación simultánea bidireccional de audio y vídeo, que permite mantener reuniones con grupos de personas situadas en lugares alejados entre sí.

81 Aunque debido al diminuto tamaño del sensor secundario, estas imágenes tendrían menor calidad y resolución que las producidas por su hermana mayor. De manera estándar, en la actualidad, podemos estar hablando de cinco megapíxeles útiles frente a los doce o dieciséis que suele producir el sensor principal. 
para el desarrollo y perfeccionamiento del selfie: el autorretrato de rostro reflejado en pantalla.

Una vez más, los usos prácticos dados a una invención marchan por caminos distintos a los imaginados por sus inventores ${ }^{82}$. La creatividad, divertimento y experimentación generalmente adolescente y mayoritariamente femenina, ha desarrollado toda esta productiva imaginería de rostros (autorretratos) capturados de manera próxima e íntima y encajados con un visor que hace las veces de espejo (Imagen 4.20).

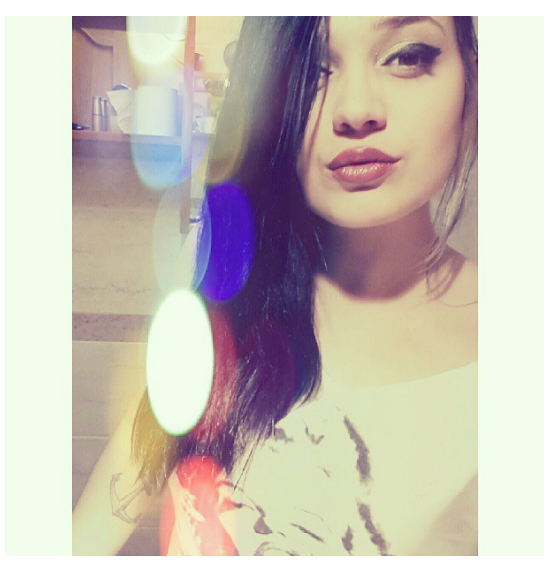

\begin{abstract}
Imagen 4.20: Autorretrato realizado por la usuaria Blanki Blue mediante el uso de la lente delantera y la pantalla espejo. Fue publicado en Instagram durante 2013.
\end{abstract}

82 No obstante, este nuevo uso práctico dado a la cámara secundaria se ha desarrollado como opción adicional, sin disminuir el objetivo original de la lente secundaria. Sigue habiendo costumbre de realizar intercambios de imagen a tiempo real con los smartphones, tal y como se han realizado anteriormente con las webcams de los computadores domésticos. Esos estudios íntimos de presentación del cuerpo estableciendo discursos comunicativos en la distancia a través de la imagen, quedarían fuera de nuestro objeto de estudio, pero merece la pena citarlos aunque no se trate de fotografías: "No olvidemos que en la red los espacios de presentación y representación del cuerpo «convergen» cada vez más y que los dispositivos online permiten más solapamiento entre lo real y lo virtual. De manera que la complejidad de este desmontaje vendría dada porque la presentación y la representación no están garantizadas allí donde habitamos mediados por una pantalla, y allí donde todos producimos imágenes. El increíble poder colectivo de la Red y de esta convergencia apuntaría a que derruir determinados cánones, o subvertirlos al menos, es cada vez más posible”. ZAFRA, Remedios, Un cuarto propio conectado. (Ciber)espacio y (auto)gestión del yo, Madrid, Fórcola ediciones, 2010, pág. 90. 
Ya hemos visto en el capítulo 3 cómo el desarrollo y la disposición estructural de estas nuevas herramientas ha permitido desarrollar (o ha obligado a hacerlo) nuevas estrategias compositivas, encuadres y construcciones del rostro mediante el autorretrato. No incidiremos más en esta cuestión ni hasta qué punto el autor o autora de un autorretrato está utilizando su libre albedrío en la construcción de la imagen o si es la herramienta la que, con sus protocolos fijados, decide esto. No obstante, hay una nueva serie de herramientas adicionales en torno a la fotografía realizada con smartphones que actúa como extensión de este y que también interviene de manera directa sobre su producto fotográfico. Nos parece pertinente desarrollarlo en este lugar, pues su habitar es exclusivo del propio smartphone: hablamos de las selfie apps, aplicaciones de teléfono móvil inteligente para la creación y la postproducción de selfies.

\subsubsection{Selfie apps.}

Las apps son aplicaciones informáticas diseñadas para ser ejecutadas en teléfonos inteligentes, tabletas y otros dispositivos móviles. Las mismas permiten al usuario o usuaria efectuar una tarea concreta de cualquier tipo (profesional, de ocio, educativa, de acceso a servicios, etc.), facilitando las gestiones o actividades a desarrollar. Por lo general, se encuentran disponibles a través de plataformas de distribución, controladas por las compañías propietarias de los sistemas operativos móviles como Android, iOS, BlackBerry OS, Windows Phone, entre otros. Existen aplicaciones móviles gratuitas y otras de pago, donde en promedio el 20\% o el $30 \%$ del coste de la aplicación se destina al distribuidor y el resto es 
para el desarrollador. El término app se volvió popular rápidamente, tanto que en 2010 fue listada como la palabra del año de la American Dialect Society ${ }^{83}$.

Hoy en día existen apps para casi todo, y, por supuesto, muchas de las aplicaciones que instalamos en nuestros smartphones sirven para alterar o perfeccionar el propio software de la cámara de fotos del mismo. Muchas de estas apps fotográficas utilizan el selfie como reclamo y/o están diseñadas especialmente para convertirse en un valor añadido, directamente aplicado a unos supuestos mejores selfies que podríamos obtener con esa misma cámara de nuestro smartphone.

Entre las muchas aplicaciones de este tipo queremos destacar cuatro de las más descargadas ${ }^{84}$ : Sweet Selfie (Imagen 4.21), la app para mejorar selfies más utilizada, permite aplicar filtros y mejorar la luz de los autorretratos, algo similar a lo que hace BestMe Selfie Camera (Imagen 4.22). Por otro lado, Selfie Studio (Imagen 4.23), con una actitud más asiática, nos permite añadir pegatinas o stickers a nuestros autorretratos, así como cambiar los colores y las iluminaciones de estos. Además, convierte la pantalla en una fuente de iluminación potente para poder alumbrarnos el rostro mientras lo fotografiamos. Por último una de las apps pioneras en la intervención sobre los selfies, es la llamada B612 (Imagen 4.24), disponible en la aplicación de mensajería asiática LINE $^{85}$.

83 VV. AA., "Aplicación móvil”, 2018, disponible en: <https://es.wikipedia.org/wiki/Aplicación_móvil> [Fecha de consulta: 12 de enero de 2018].

84 Algunas, como Sweet Selfie, con más de 100 millones de descargas en todo el mundo.

85 Datos obtenidos de: GAURAV, Adip, “Android Smartphone Me Selfie Lene Ke Liye Top Best Apps”, 2016, disponible en: <https://www.futuretricks.in/top-best-selfie-expert-apps-for-android > [Fecha de consulta: 10 de agosto de 2017], y de SMITH, Josh, "13 Best Selfie Apps for 2018”, 2017, disponible en: $<$ https://www.gottabemobile.com/best-selfie-apps/?gbmsl=10> [Fecha de consulta: 2 de enero de 2018]. 


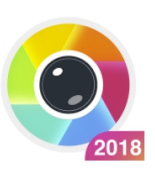

Sweet Selfie - Mejor cámara selfie belleza

Ufoto Fotografia

1. PEGI3

Contiene anurcios - Ofrece compras en la aplicación
- Esta aplicación es compatible con tu dispositivo.

$$
\text { 田 A }
$$

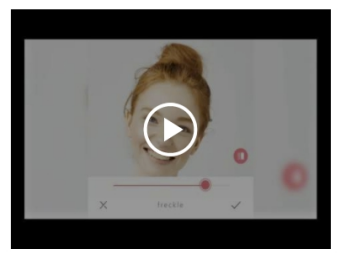

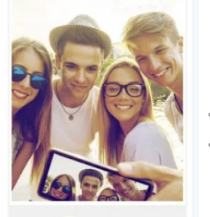

(2) Selfie

Imagen 4.21: Sweet Selfie. Pantalla de descarga de la aplicación.
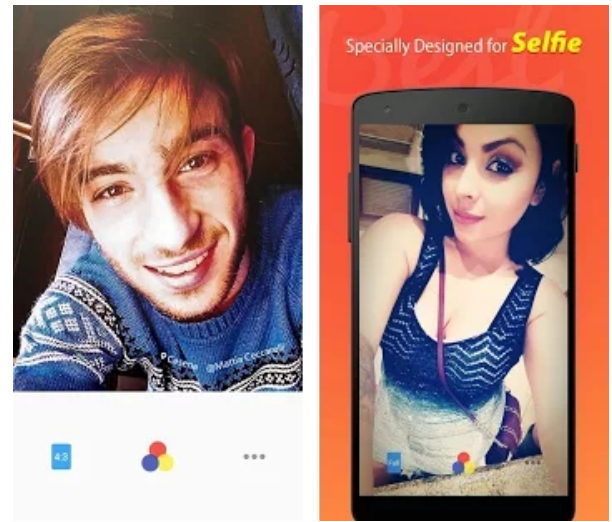

Imagen 4.22: BestMe Selfie Camera, especialmente diseñado para los selfies, reza la publicidad online.

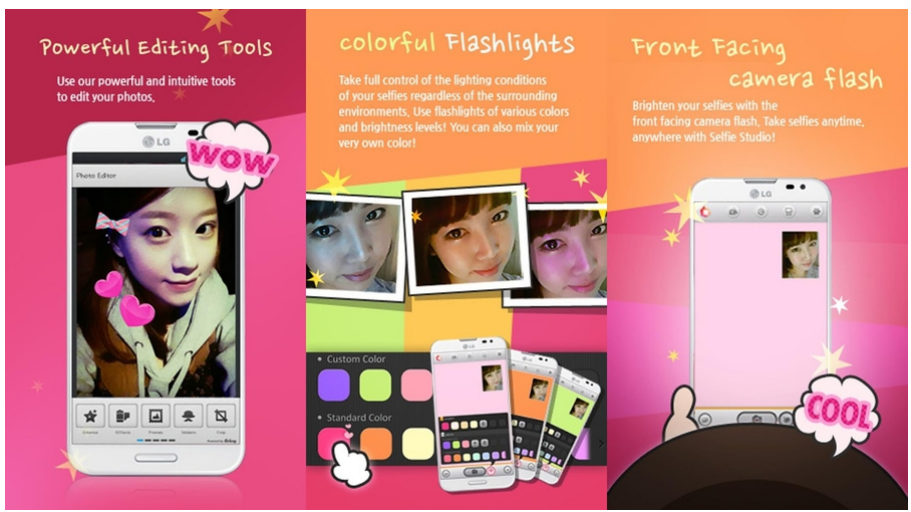

Imagen 4.23: Opciones de la aplicación Selfie Studio.

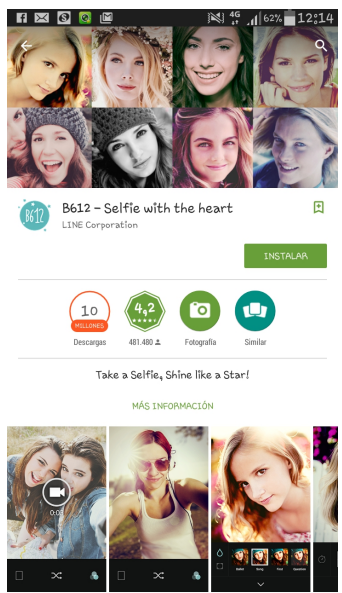

Imagen 4.24:

Pantalla de descarga de la app B612. 
Los orígenes adolescentes del selfie y su representación en el arte y en los medios de masas 


\section{LA PANTALLA INDISCRETA DEL ADOLESCENTE}

Deseo creer con todo mi corazón (iy cuán sinceramente nadie puede saberlo más que yo!) que un ser exterior e invisible se interesa por mi destino; pero ¿̇cómo hacer para creerlo?

CHARLES BAUDELAIRE, Carta a su madre (Libro de los pasajes), 1861.

Podemos aventurarnos a decir que el adolescente (en especial la mujer adolescente) ha sido una figura imprescindible en la conformación de los autorretratos digitales publicados en la red (o self shots) durante los últimos diez años, hasta el punto de que su influencia, como hemos visto, no solo ha repercutido en la aceptación y práctica del selfie por parte de todos los estratos poblacionales sino también actuando como marco referencial para una nueva imaginería en la publicidad y otros medios de comunicación. Después de establecer como primer ingrediente del fenómeno del selfie al sensor electrónico propio de los dispositivos digitales de captura fotográfica, abordaremos ahora la figura del adolescente emancipado fotográficamente como segundo factor conformador, ya que es la fotógrafa creadora y la modelo representada quien desempeña el papel protagonista (Imagen 5.1).

Remedios Zafra sintetiza en un párrafo muy preciso esta amalgama que supone la superposición de la adolescente, la imagen propia compartida, el 
espacio privado, la red pública y el desarrollo de la identidad a través de ideas propias e imágenes:

"Aquí te dejo mi diario, mi opinión, mi juicio de las cosas, mi selección del mundo, mis imágenes, mi red. Evité candados y escondites que conocieras porque quiero facilitarte las cosas. Mañana volveré (si acaso hubiera mañana) y te contaré más. Dime algo para saber que me has leído. No por nada, solo por sentir que existo y que en algo tiene sentido que (te) escriba".

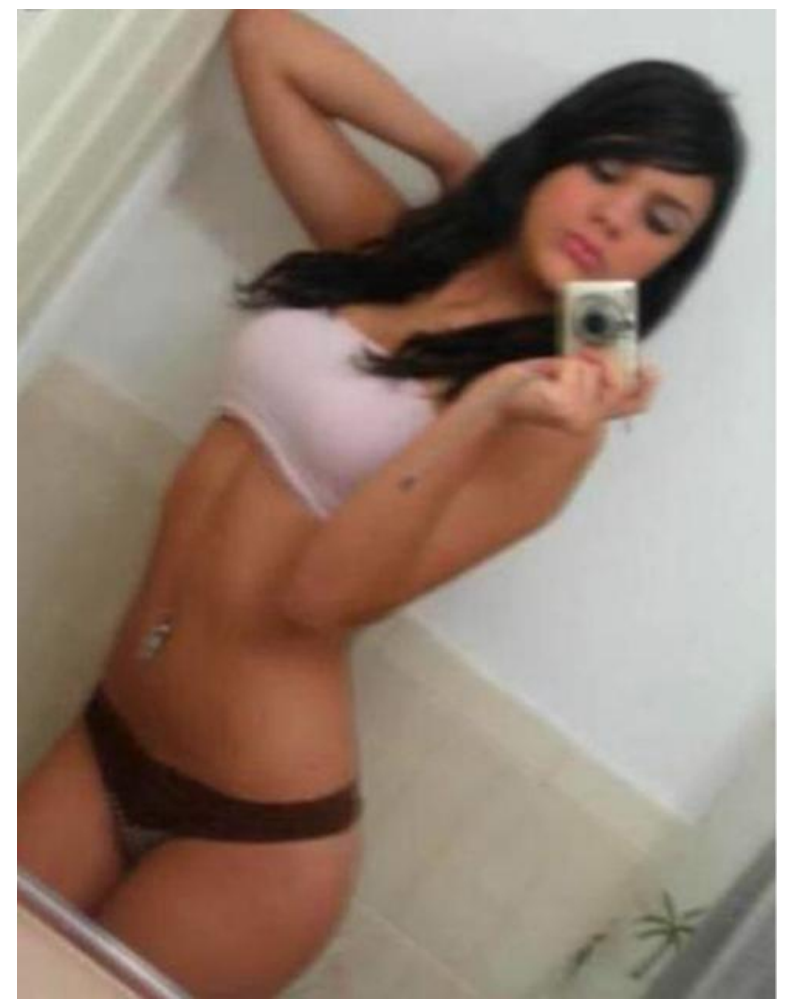

Imagen 5.1: Self shot anónimo de tipo mirrorpic, uno de los primeros con los que nos topamos mientras desarrollábamos una de nuestras primeras investigaciones en 2010.

1 ZAFRA, Remedios, Un cuarto propio conectado. (Ciber)espacio y (auto)gestión del yo, Madrid, Fórcola ediciones, 2010, pág. 82. 
La adolescencia se ha transformado en una etapa generadora de imágenes y en productora de autorretratos que son resultado no solo de la propia condición social del joven y del desarrollo de la máquina fotográfica moderna, sino también del auge del ciberespacio y del correspondiente flujo de imágenes que la red procura y solicita, dado que esta se ha convertido en uno de los engranajes que hace posible el desarrollo de la cultura visual contemporánea (Imagen 3.2).

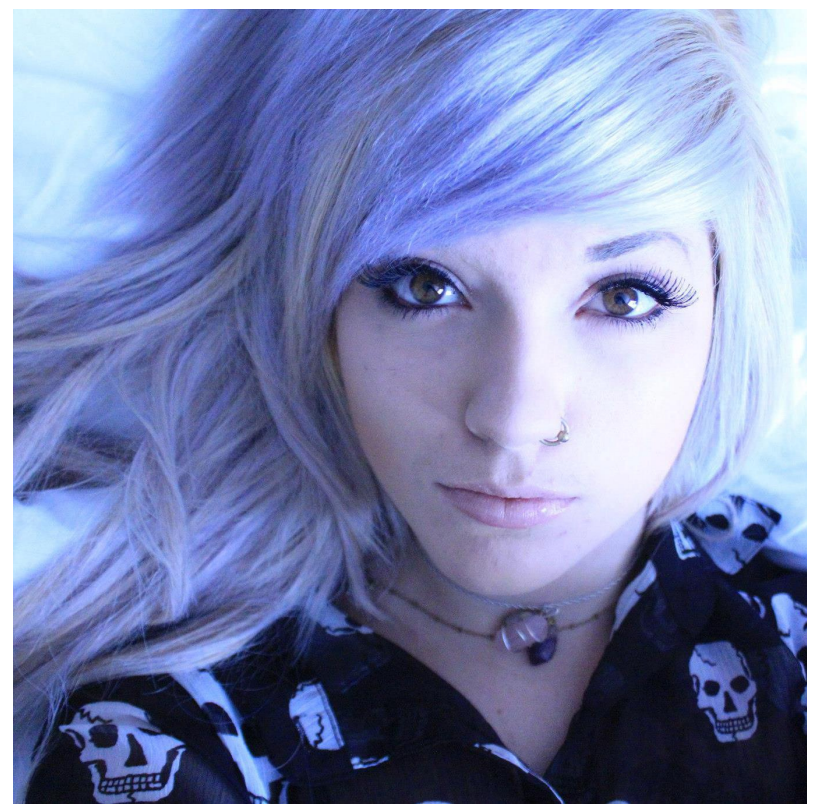

Imagen 5.2: Autorretrato realizado por Leda Bunny en 2012.

Tanto los adolescentes que hace diez años comenzaron esta andanza compartiendo sus self shots en Metroflog y enviando sus autorretratos íntimos por correo electrónico o por chat como también los adolescentes que hoy en día exhiben sus selfies en Instagram, pertenecen a la llamada Generación Z. Esta generación, nacidos entre 1994 y 2010, fueron los primeros bebés que crecieron paralelos al desarrollo y al uso de Internet, aprendiendo a interactuar con otros en el plano físico y en el virtual de forma casi simultánea. "Hay estudios que 
afirman que los niños $\mathrm{Z}$ aprenden a manejar tabletas antes que hablar. Para ellos, los datos son parte de su alimento"'.

Los adolescentes pertenecientes a la Generación $\mathrm{Z}$ también han sido llamados "nativos digitales", que al contrario que sus antecesores, los "inmigrantes digitales", no han conocido un mundo sin Internet y "para ellos la red es un espacio de desarrollo tan natural como el mundo real” ${ }^{3}$. La expresión nativos digitales (digital natives) fue acuñada por el escritor y conferenciante en educación Mark Prensky ${ }^{4}$, aunque también es utilizado el término de early adopters (adoptadores tempranos) para definir a aquellos que serían los primeros en apropiarse de la Web y familiarizarse con esta durante los últimos años de la década de los noventa ${ }^{5}$.

La apropiación de la Web (y posteriormente de la red completa, así como muchas de las tecnologías que la circundan) que han hecho los adolescentes a lo largo de estos últimos años, no solo se ha llevado a cabo como espectadores o como consultores, sino también y principalmente como creadores de contenidos, algo que, en otros medios anteriores, siempre había sido privilegio de los adultos.

Así pues, estos cambios producidos por las nuevas formas de relación social de intercambio de la cultura entre los adolescentes (también en parte del público adulto) han hecho surgir la figura del productor de contenidos (produser). "Las diferencias clásicas entre los que producen y los que consumen se han extinguido en estas plataformas neomediales" ${ }^{6}$. El produser vendría a ser

2 SARTORIO, Guillem, "Pegados al móvil: así es la vida de tu hijo adolescente", 2016, disponible en: <http://www.elmundo.es/papel/historias/2016/11/27/58381e3622601db6198b4678.html> [Fecha de consulta: 2 de julio de 2017].

3 RUIZ, Sonia, Del blog al microblog. El devenir del receptor en generador y emisor de contenidos en la Web 2.o, Málaga, Universidad de Málaga, 2009, pág. 51.

4 PISANI, Francis y PIOTET, Dominique, La alquimia de las multitudes. Cómo la Web está cambiando el mundo, Barcelona, Paidós, 2008, pág. 31.

5 Ibídem, pág. 38.

6 ROBLES, Elena, Tumblr: estudios estéticos sobre la plataforma web Tumblr. Construcción de la 
concretamente "un usuario activo y productivo de contenido creado, modificado, desarrollado y compartido por una comunidad virtual"7, y, respecto al pasado, esto establecería un cambio entre, por un lado, la concepción de consumir como usuario, y por otro, la de usar las tecnologías y su respectiva arquitectura y recursos para producir contenidos que otros consumen. No obstante, los usos de los que únicamente cumplen esta función consumidora tienen también un "efecto agregado en la evolución del sistema".

La apropiación de la Web por los jóvenes ha resultado decisiva desde finales de la década pasada:

\begin{abstract}
"La Web permite que los jóvenes empleen esta herramienta como quieran, y les ayuda a construir su identidad en relación con los demás al margen de cualquier mecanismo institucional tradicional. Las herramientas como Facebook, MySpace o los blogs les permiten hacerlo, pues son plataformas abiertas, modificables y con reglas flexibles. [...] Crear, publicar y modificar su perfil en un sitio de red social les permite ajustar su identidad en relación con los demás con pequeños retoques. Crear un blog, o escribir comentarios en los de los amigos, implica construir su opinión, afirmarse, decir lo que uno piensa y enfrentarse a otros".
\end{abstract}

Históricamente, la gente, las instituciones, las empresas y la sociedad en general, han transformado la tecnología (cualquier tecnología) apropiándosela, modificándola y experimentando con ella. También, como vemos, los jóvenes hacen lo mismo en relación a Internet:

"La historia de la tecnología demuestra claramente que la contribución de los usuarios es crucial en la producción, ya que la adaptan a sus propios usos y valores y, en último término, transforman la propia tecnología [...] los nuevos usos de la tecnología, así

identidad a través de la creación colectiva, Valencia, Universitat Politècnica de València, 2014, pág. 16.

7 Ídem.

8 CASTELLS, Manuel, La galaxia Internet, Barcelona, Debolsillo, 2003.

9 PISANI, Francis y PIOTET, Dominique, op. cit., págs. 42-43. 
como las modificaciones efectuadas en dicha tecnología, son transmitidos de vuelta al mundo entero, en tiempo real. [...] Esta es la razón por la que Internet creció y sigue creciendo, a un ritmo sin precedentes" ${ }^{10}$.

Y para que Internet haya crecido gracias al uso y a la producción de sus usuarios han debido de cumplirse tres condiciones: en primer lugar, la arquitectura en red ha de ser de carácter abierto, descentralizado, distribuido y multidireccional en su interactividad; en segundo lugar, todos los protocolos de comunicación y sus desarrollos también deben ser abiertos, distribuirse libremente y ser susceptibles de modificación; y en tercer lugar, las instituciones que gestionan la red han tenido que construirse de acuerdo con los principios de transparencia y cooperación que son inherentes a Internet desde sus orígenes ${ }^{11}$ (como veremos, más adelante, en el siguiente capítulo).

Una apropiación y gestión de Internet por parte de la comunidad adolescente ha generado irremediablemente un ciberespacio adolescente donde estos se desenvuelven diariamente como parte de sus prácticas creativas y relacionales. Así pues, los medios digitales proveerían hoy a las generaciones jóvenes una cantidad de recursos simbólicos para expresarse ellos mismos y construir sus propias identidades. "Este grupo poblacional está viviendo con mayor intensidad los medios digitales como una manera de responder a las necesidades expresivas y a las exploraciones identitarias que caracterizan nuestra vida social moderna"12.

Como veremos en el capítulo siguiente, la "tecnología discreta" con la que los programadores han desarrollado las interfaces de los sistemas operativos y de las aplicaciones web y móvil para su fácil uso, sobre todo desde la llegada de la

CASTELLS, Manuel, op. cit., pág. 18.

Ibídem, pág. 43. esta red social”, en Folios. Revista de la facultad de humanidades, n $^{\circ}$ 43, 2016, pág. 123. 
Web 2.0 ${ }^{13}$, han hecho posible que los estudiantes de instituto de la década pasada vieran los ordenadores como superficies para jugar y relacionarse, más que como máquinas rígidas con las que programar ${ }^{14}$.

Ese tipo de interfaces, llamadas user friendly (amigables para el usuario), podría haber facilitado esa integración, democratización y apropiación fácil y rápida por parte del público joven, que ejercería pronto, como veremos en el siguiente apartado, una emancipación respecto a las nuevas tecnologías (fotografía digital incluida). Respecto a esa interfaz de las pantallas del ordenador que empezó tal recorrido hace casi dos décadas, cabe señalar que quedó definida esencialmente por ser a la vez interfaz (una membrana entre el usuario y unos fenómenos y acontecimientos que ocurren en algún lugar más allá de la pantalla) y panel de control (lo que permite ejercer operaciones sobre tales procesos) ${ }^{15}$ :

\begin{abstract}
"Baudrillard señalaba la naturaleza de la pantalla como interfaz, membrana comunicacional que nos seduce y absorbe con su promesa de proyección infinita del yo a través de sus redes. Como el espejo de Alicia en el País de las Maravillas, el interfaz no nos devolvería nunca una imagen estable de nosotros mismos, sino que nos invitaría a traspasar el umbral de miles de mundos sucesivos, mundos virtuales que el usuario cruzaría uno tras otro en una travesía sin fin. La aparente inocencia y transparencia de los interfaces, cada vez más user friendly, para él no sería tanto el síntoma de la humanización del ordenador como el de la progresiva actualización de su soberanía como modelo de articulación de la subjetividad”"
\end{abstract}

Por otro lado, y respecto a la utilización que dan los adolescentes a la red después de, como hemos visto, estas facilidades que ha producido tal

13 PISANI, Francis y PIOTET, Dominique, op. cit., pág. 153.

14 TURKLE, Sherry, La vida en la pantalla: la construcción de la identidad en la era de Internet, Barcelona, Paidós, 1997, pág. 77.

15 CARRILLO, Jesús, Arte en la red, Madrid, Cátedra, 2004, pág. 69.

16 Ibídem, pág. 73 . 
emancipación, debemos apuntar que los principales usos no empezaron siendo académicos, sino más bien de ocio, relación social y consumo de material audiovisual ${ }^{17}$. Y aunque el interés por la Web como herramienta para el desarrollo personal en el ámbito relacional fue rápidamente utilizado por el colectivo adolescente, pronto los adultos también empezarían a emular estas prácticas $^{18}$.

Una cantidad de datos estadísticos recopilados desde 2012 pueden reflejar la realidad de la apropiación y uso que los adolescentes habían dado a este nuevo escenario desde el desarrollo de la Web 2.0 y el surgimiento de los chats, blogs y otras plataformas comunicaciones y de las redes sociales. El porcentaje de jóvenes que utilizaban Internet no dejó de crecer la década pasada: había pasado de un 51\% en 2003 a un 70\% en 2007 y a un 96,3\% en 2010, según, entre otras fuentes, el $\mathrm{INE}^{19}$. La cantidad y frecuencia de uso de la Generación Z fue mucho mayor en comparación con las generaciones precedentes. Para ellos la red fue (y en parte también continúa siendo hoy con datos todavía más pormenorizados) un medio que les facilitaba: diversión $(79,7 \%)$, productos culturales (el 85\% descarga filmes y música; el 53,4\% busca viajes y entradas), formación (el 67,3\%, aprendizaje; el 89,6\%, información), oportunidades de trabajo $(58,5 \%)$ y, en referencia a nuestro objeto de estudio, relaciones sociales (80\% relacionarse; $30 \%$ contactar) (INE, 2010) ${ }^{20}$. Dos años después, tras la salida de la red social favorita de los adolescentes (Instagram), y durante un momento que podemos considerar álgido en la institucionalización de las redes sociales como principal ámbito relacional en el ciberespacio, el mismo Instituto Nacional de Estadística elevó a 91,2\% la cifra de menores (de diez a quince años)

VÁZQUEZ, María F., La cultura visual en la adolescencia, Sevilla, Universidad de Sevilla, 2015, pág. 29.

PISANI, Francis y PIOTET, Dominique, op. cit., págs. 43-44.

Instituto Nacional de Estadística (España).

DÍEZ, Emeterio; PERELLÓ, María M. y RÖMER, Max, “Análisis semiótico de la fotografía de perfil de jóvenes en Tuenti”, en Estudios sobre el mensaje periodístico, $\mathrm{n}^{\circ}$ 18, 2012, pág. 814. 
que accedían habitualmente a Internet, elevándose este porcentaje con la edad hasta alcanzar el 96,5\% a los quince años (esto los ha situado en el segundo lugar en cuanto a usuarios de la red, después de los jóvenes de dieciséis a veinticuatro años). Este grupo etario de menores adolescentes también conforma el colectivo principal de uso diario de las redes sociales en España, con un 85,9\% que navegaron con mucha frecuencia por este tipo de aplicaciones ${ }^{21}$. Estas redes sociales constituyen lo que más les atrae del medio, sobre todo a las niñas, que se inician de forma más temprana que los niños y son más asiduas a ellas ${ }^{22}$.

Así pues, durante todos esos años y hasta llegar a la actualidad, se ha ido gestando una auténtica comunidad-red de adolescentes emancipados tecnológicamente hablando y que han conformado (como vemos en la construcción del autorretrato digital publicado, erótico o no, entre muchas otras cosas) una auténtica conciencia colectiva de imaginería visual y de protocolos y prácticas sociales institucionalizadas. Esta inteligencia e imaginación colectiva propia del espacio cibernético y virtual de Internet, consolida un nuevo tipo de inteligencia caracterizada por el conjunto de miembros que participan y colaboran de manera directa e indirecta en el ciberespacio ${ }^{23}$. En estas prácticas realizadas por los nativos digitales vemos como:

\begin{abstract}
“[...] lo real y lo virtual no son territorios opuestos, por el contrario cada vez tienen más zonas de solapamiento, donde lo público y lo privado se acoplan, se comparten en una intimidad semipública que forma parte de la vida cotidiana, donde las relaciones sociales ejercen un discurso normativo de represión y disciplina sobre los cuerpos" ${ }^{24}$.
\end{abstract}

21 CATALINA, Beatriz; GARCÍA, Antonio y LÓPEZ DE AYALA, María C., "Los riesgos de los adolescentes en Internet”, en Revista latina de comunicación social, nº 69, 2014, pág. 463.

22 VÁZQUEZ, María F., op. cit., pág. 103.

23 LÉVY, Pierre, Qu'est-ce que le virtuel?, París, La Découverte, 1995, pág. 35.

24 GALÁN, Mercè, "El posicionamiento subjetivo del \#selfie", en Asparkia. Investigació feminista, no 27 , 2016, pág. 39. 
Precisamente esta confusión e hibridación entre lo público y lo privado mediante la exhibición del propio cuerpo en el escenario panóptico de la red es lo que repasaremos a lo largo de las siguientes páginas. También veremos cómo la construcción y publicación del yo del adolescente por medio de sus selfies y demás autorretratos ha sido posible, asimismo, gracias a su capacidad de dominio y experimentanción sobre el medio fotográfico para ellos disponible.

\subsection{La mujer adolescente y su relación con la fotografía.}

Hoy en día el adolescente se nutre de la imagen gracias a las nuevas tecnologías. Las pantallas de sus smartphones y de las computadoras alojadas en sus habitaciones se han convertido en ventanas por las que ver y entender el mundo (su mundo) a través de fotografías y palabras. Esto les ha dotado de una nueva cultura visual de la que, tal como hemos visto antes, también son partícipes como productores. El desarrollo popular de Internet ha fomentado, aún más si cabe, el fluir de esas imágenes. Ahora la red es el mayor de los mass media y, como casi todos ellos, está basado en la imagen. Imágenes que nos han atrapado en una espiral de contemplación:

"La necesidad de confirmar la realidad y dilatar la experiencia mediante fotografías es un consumismo estético al que hoy todos son adictos. Las sociedades industriales transforman a sus ciudadanos en yonkis a las imágenes; es la forma más irresistible de contaminación mental”25.

Además de este consumo patológico de imágenes de terceros, sigue creciendo la obsesión por ser fotografíado que ha existido siempre en los países 
industrializados ${ }^{26}$, aunque sea por medio de la autofotografía. De este modo, nuestra sociedad se ha transformado en productora de imágenes, en especial la gente joven, convertida en la más prolífica y compulsiva de todos los segmentos sociales.

La fotografía, combinada con las redes sociales (espacios de publicación) confiere al adolescente además de esa realidad, una identidad y una categoría. Este binomio convierte al autorretrato del adolescente en una imagen-fetiche que actúa a través de una suerte de magia simpática, es decir, me fotografío, por lo tanto, existo: quien mira mi autorretrato me está espiando, quien lo comenta me está reconociendo, quien lo almacena me está poseyendo y quien lo ignora me está matando.

Podemos de esta manera constatar que si la democratización de la red, también entre los más jóvenes, los ha llevado a convertirse en auténticos entendidos de la imagen contemporánea (sobre todo en lo que concierne al retrato publicitario ${ }^{27}$ ), la también democratización de los dispositivos de captura digital (las nuevas cámaras fotográficas) ha convertido a las y a los adolescentes en fotógrafos contemporáneos gracias a estas prácticas tempranas, experimentales y constantes, cuya iconicidad tanto se está extendiendo (Imagen 5.3 y 5.4$)$.

26 "La gente de los países industrializados procuran hacerse fotografiar porque sienten que son imágenes, que las fotografías les confieren realidad”. Ibídem, pág. 157.

27 El retrato en la imagen publicitaria contemporánea que atiende hoy en día a modelos de representación humana (también generalmente femenina) combina, entre otras cosas, las formas clásicas de representación de la mujer en la historia del arte, junto con la fotografía moderna más seductora y erótica: "Este tipo de retrato ha determinado fuertemente el carácter de la fotografía publicitaria, no sólo de la moda, joyas, perfumes o cine; en realidad todo tipo de mercancía y servicio ha recurrido en uno u otro momento a un tipo de retrato en el que se potencia la elegancia, la gracia o el sex appeal del modelo". EGUIZÁBAL, Raúl, Fotografía publicitaria, Madrid, Cátedra, 2006, pág. 113 . 


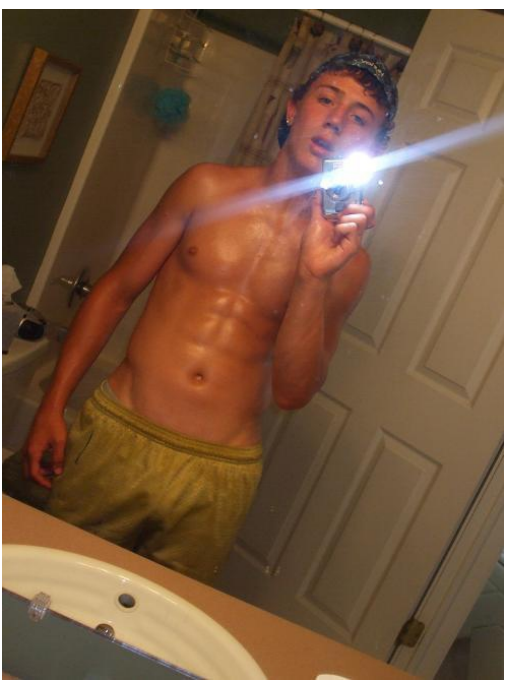

Imagen 5.3: Autorretrato de tipo mirrorpic, habitual entre adolescentes desde mediados de la década pasada. Entre los minoritariamente masculinos, este. La cámara compacta Coolpix de 2007 y el flash automático podrían indicar la época aproximada, antes de 2010.

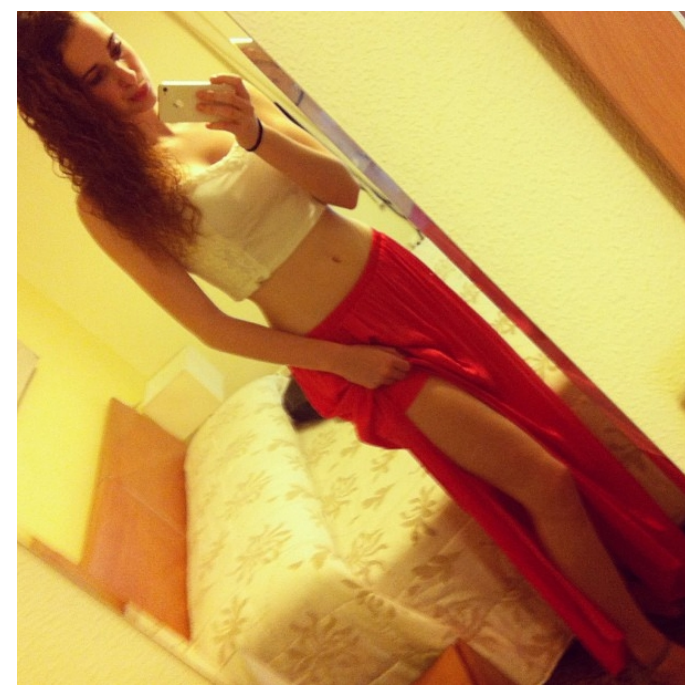

Imagen 5.4: Algo más elegante, este mirrorpic cedido por Natalia. El dispositivo de captura empleado, un smartphone de 2013 ubica el año aproximado en el que se realizó esta imagen.

Como venimos apuntando, la democratización del dispositivo fotográfico ha tenido mucho que ver en la emancipación fotográfica del adolescente. Pese a que la fotografía ha tenido un uso exclusivo a lo largo de su historia, su democratización y utilización por parte de las masas ha seguido un recorrido paulatino a lo largo del siglo XX. No obstante, el desarrollo de la fotografía digital que veíamos durante el capítulo anterior ha llevado, durante la década, pasada a una cámara digital en cada hogar y, asimismo, a varias cámaras por individuo gracias a su bajo coste de compra en relación a sus máquinas predecesoras ${ }^{28}$. La facilidad con la que un adolescente ha podido hacerse, en su ámbito cotidiano, 
con un dispositivo fotográfico de captura digital, revisión instantánea y, a veces, publicación directa ha sido fundamental para que este pudiera desarrollar su laboratorio de creación fotográfica en torno a su propio cuerpo. Esta democratización de la fotografía se habría dado básicamente entre mujeres ${ }^{29} \mathrm{y}$ adolescentes $^{30}$.

\begin{abstract}
"Durante los últimos años, con la masificación de las tecnologías de la información y la comunicación se han desarrollado nuevas prácticas en la mayoría de los ámbitos sociales. Entre ellas, en las últimas décadas se produjo a nivel global una ampliación del acceso a la fotografía. Este fenómeno se dio en tres dimensiones: por sector social, dado que con la masificación de las cámaras digitales los sectores populares pueden acceder a sus propios equipos; por segmentos etarios, ya que los adolescentes utilizan cotidianamente sus cámaras; y por género, desde que la práctica fotográfica ya no es solo masculina sino que una gran parte de las mujeres posee su cámara” ${ }^{31}$.
\end{abstract}

La complejidad del medio fotográfico se ha mitigado paulatinamente gracias a los automatismos que las cámaras digitales más económicas y los smartphones han ido incluyendo en su perfeccionamiento tecnológico. Apuntar y hacer clic sería más que suficiente, no obstante, hacer una fotografía es mucho más que eso y en sus mejores creaciones los adolescentes también han estado a la altura. El lenguaje fotográfico resulta un lenguaje cercano y fácil de comprender y utilizar para ellos, siendo desarrolladores de una simbología y de una sintaxis vinculadas a su generación ${ }^{32}$. Así, la apropiación del autorretrato digital

29 Puesto que las mujeres adolescentes serían mayoría en la práctica y publicación de self shots. VÁZQUEZ, María F., op. cit., pág. 109.

3o Colectivo que, pese a que vive "distintas experiencias según sector social, género y área de residencia geográfica" podría verse igualado por la democratización y abaratamiento de los dispositivos, al generar una serie de imágenes constantemente "replicadas" que no apuntan sino a un cuerpo común representado. BASILE, Diego y LINNE, Joaquín, "Performances de autopresentación a través de fotografías digitales. El caso de los adolescentes de sectores populares en Facebook", en Cuadernos.Info, $\mathrm{n}^{0} 35$ (Ejemplar dedicado a: Comunicación y educación), 2014, pág. 210. Ídem.

MARTÍNEZ, Silvia, "Fotografiarse, retratarse, expresarse. Fotografía y expresión de lo personal en adolescentes", en Arteterapia. Papeles de arteterapia y educación artística para la inclusión social, $\mathrm{n}^{0} 6,2011$, pág. 283. 
publicado en red, insistimos, podría considerarse una práctica mayoritariamente adolescente $^{33}$, siendo los jóvenes, pensamos, los que habrían influido sobre los adultos contagiando su propia imagen spameada durante años. Y pese a que se ha dicho que los adolescentes no tienen demasiada cultura visual ${ }^{34}$, probablemente posean mucha de la cultura visual que ellos mismos, en parte gracias a los dictámenes de sus herramientas de captura fotográfica, han inventado, producido y distribuido. En este sentido, la fotografía podría tratarse como un "fenómeno cultural, que es carente de identidad propia como medio y que genera productos culturales reflejo de la sociedad que los produce y utiliza como medio" 35 .

Como podría ser de esperar, la emancipación fotográfica de la mujer adolescente fue principalmente despertada por la curiosidad, experimentación y también la facilidad que le dio tener un dispositivo fotográfico de captura digital al alcance de la mano. Lo acabamos de repasar, el hecho de que el consumidor pudiera comprar de manera tan económica una cámara fotográfica digital (generalmente compacta ${ }^{36}$, Imagen 5.5) en cualquier tipo de comercio, grandes superficies, cadenas de tiendas de informática o cadenas de tiendas de electrodomésticos durante la década pasada, hizo que cada hogar dispusiera de por lo menos una de ellas ${ }^{37}$, muchas veces propiedad de la misma adolescente.

GÓMEZ-CRUZ, Edgar y ARDÈVOL, Elisenda, "Cuerpo privado, imagen pública: el autorretrato en la práctica de la fotografía digital”, en Revista de dialectología y tradiciones populares, vol. $67, \mathrm{n}^{0} 1$, 2012, págs. 183-184. Posiblemente, en relación a la cultura visual clásica (para ellos) y anterior a la consolidación del ciberespacio. CANGA, Manuel, "Introducción al fenómeno del selfie: valoración y perspectivas de análisis", en Fotocinema. Revista científica de cine y fotografía, n ${ }^{0}$ 10, 2015, págs. 386-387. MARZAL, Javier, Cómo se lee una fotografía, Madrid, Cátedra, 2007, pág. 43.

El consumidor buscaba sobre todo que las cámaras ocuparan poco espacio, que pesaran poco, y que la relación calidad-precio fuera razonable. Un elemento muy valorado, asimismo, era y sigue siendo la sencillez de manejo, también para el colectivo adolescente. SOLER, María, Las empresas de fotografía ante la era digital. El caso de la Comunidad Valenciana, Madrid, Ediciones de las Ciencias Sociales, 2007, pág. 56.

Ibídem, pág. 55. 
Por otro lado, las cámaras digitales incorporadas en los teléfonos móviles ${ }^{38}$ generaron un rápido crecimiento de los mercados para el consumo y la producción de imágenes ${ }^{39}$, siendo además muy discretos. No obstante, pese a utilizar herramientas de uso sencillo, estas han generado nuevas maneras de entender la imagen y el empleo que han hecho de ellas los adolescentes ha tambaleado y derruido los muros que separaban la vida privada de la pública.

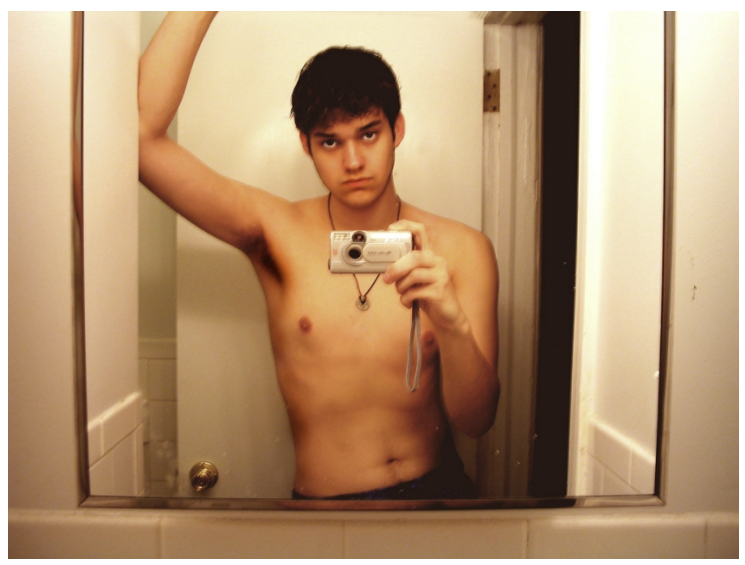

Imagen 5.5: Autorretrato digital publicado en la red realizado con una cámara compacta.

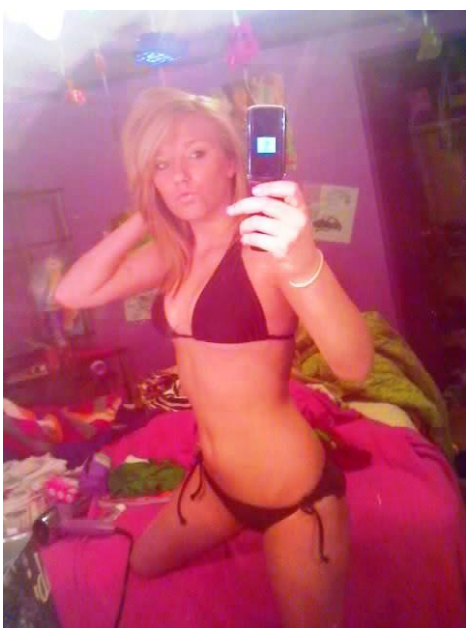

Imagen 5.6: Mismo ejercicio, también un autorretrato contra un espejo, realizado con un teléfono celular con cámara.

Es normal pensar que el adolescente acabe autorretratándose en la intimidad, para luego editar y exhibir dichas fotos bien sea en los espacios comunes de la red social $^{40}$, bien sea para compartir de manera privada esas

Los teléfonos móviles (celulares) con cámara incorporada fueron los predecesores de los smartphones, y muy característicos en manos de los adolescentes que se autofotografiaban frente al espejo del cuarto de baño entre 2003 y 2007 (Imagen 5.6).

MORENO, Adriana M., "Fotografía amateur: la construcción cultural de un rol", en Comunicación, n ${ }^{\circ}$ 34, 2016, pág. 32.

BASILE, Diego y LINNE, Joaquín, op. cit., pág. 201. 
imágenes con su compañero o compañaera sentimental ${ }^{41}$. Explorar, encontrar el mejor punto de vista ${ }^{42}$ y registrar su cuerpo en torno a unas pautas establecidas por la moda, el erotismo publicitario o, incluso, la pornografía sería un acto natural del entorno propio de nuestra sociedad de la imagen, de la representación y del espectáculo. La fotografía tiene ese poder, el de recrear una imagen cultural. No obstante, el hecho de autorretratarse evita el contacto con otro fotógrafo (pues el fotógrafo es uno mismo) y queda, por tanto, exenta esa relación de poder y de sumisión que existe generalmente entre fotógrafo $\mathrm{y}$ fotografiado ${ }^{43}$. Así pues, con su actividad fotográfica (sea o no azarosa), el adolescente abarca dos géneros propios de este medio: la fotografía documental y la fotografía de moda.

\subsubsection{Fotografía adolescente documental.}

En las esferas más públicas, el adolescente (con su cámara siempre en el bolsillo) se ha transformado en un documentalista de la vida joven en la sociedad contemporánea, gracias, no solo a esta facilidad de registro que proporciona la nueva máquina fotográfica, sino también a la publicación y exhibición de estos registros en las redes sociales (Imagen 5.7). Se ha creado así, de manera inopinada y gracias a caprichosas fotografías, una ingente cantidad de

Que se hagan públicas o no con posterioridad y de manera forzosa será algo que veremos más adelante. intimidad como espectáculo, Buenos Aires, Fondo de Cultura Económica, 2008, pág. 14. fotográfico, Valencia, Universitat Politècnica de València, 2015, pág. 23. 
documentos ${ }^{44}$ que recordarán en el futuro de qué manera se desenvolvían los jóvenes de principios del siglo XXI en su ajetreada vida social (Imagen 5.8).

\begin{abstract}
"Hoy quienes más fotos hacen ya no son los adultos, sino los jóvenes y los adolescentes. Y las fotos que hacen no se conciben como «documentos», sino como «divertimentos», como explosiones vitales de autoafirmación [...] Constituyen la mejor plasmación de las imágenes-kleenex: usar y tirar. Producimos tanto como consumimos: somos tanto homo photográphicus como llanos foto-adictos, cuantas más fotos mejor, nada puede saciar nuestra sed de imágenes, el soma de la posmodernidad" 45 .
\end{abstract}

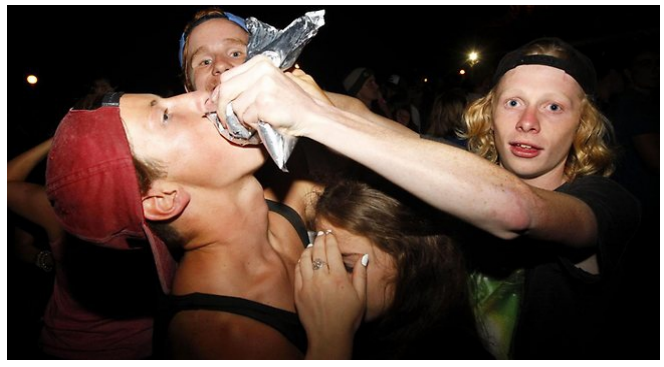

Imagen 5.7: Fotografía realizada por adolescentes en su propio ámbito relacional en torno a 2012.

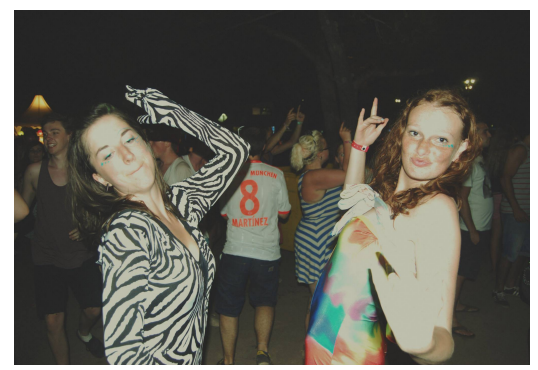

Imagen 5.8: Una imagen similar a la precedente, realizada hacia 2015.

A pesar de lo señalado, sí que podemos concebir estos divertimentos como documentos, aunque se trate de documentos pasivos. Y es que desde la era de la fotografía química, momento en el que se desarrolló la fotografía entre los

44 Y con documento fotográfico nos referimos al género histórico de la fotografía que asumió el fotógrafo documentalista durante su desarrollo, haciéndonos ver, mediante su relato fotográfico, una parcela oculta de la realidad que era fruto de su análisis proyectual. Pero en ese sentido también, "cualquier fotografía adquiere valor documental en cuanto que ilustra acerca de algún hecho, es decir, que informa, transmite o sugiere conocimientos. El ilustrador o documentalista fotográfico en su labor profesional necesita del documento para justificar, completar o contrastar la información textual o verbal”. SÁNCHEZ-VIGIL, Juan Miguel, El documento fotográfico. Historia, usos, aplicaciones, Gijón, Trea, 2006, pág. 14.

FONTCUBERTA, Joan, La cámara de Pandora. La fotografi@ después de la fotografía, Barcelona, Gustavo Gili, 2010, pág. 29. 
después denominados fotoaficionados ${ }^{46}$, el volumen de fotografías no ha dejado de aumentar gracias a este tipo de documentos sociales:

"Los libros de fotografías forman pilas cada vez más altas, calculando el pasado perdido (de allí la promoción de la fotografía de aficionados), tomando la temperatura del presente. Las fotografías procuran historia instantánea, sociología instantánea, participación instantánea" ${ }^{37}$.

Sin embargo, en nuestra actualidad digital, el número de fotografías realizadas se sigue incrementando exponencialmente. Por ello, el número de documentos fotográficos realizados casi por inercia de mano de los adolescentes abarca prácticamente casi cualquier acontecimiento que ocurra.

En cierta medida, este tipo de tendencias y usos que el adolescente da a la fotografía puede llegar a desplazar a los que hasta el momento eran profesionales y expertos en la materia. Por ejemplo, el fotógrafo documentalista Jouko Lehtola $^{48}$, que durante los años 1990 realizó multitud de fotografías que mostraban las reuniones, fiestas y quehaceres adolescentes de la época (Imagen 5.9), quedaría hoy diluido entre tanto fotógrafo adolescente. Lo que antaño mediante la fotografía de Lehtola era un ojo privilegiado capaz de mostrar al mundo un reino oculto en la noche adolescente, hoy carecería de dicho privilegio pues ese reino es documentado por muchos y, además, publicado en tiempo real para cualquiera que desee verlo.

Que también, poco a poco, podrían ir adquiriendo el papel de documentalistas pasivos. MONROY, Rebeca, "Nuevos retos para los fotohistoriadores de la fotografía analógica a la digital", en Iztapalapa. Revista de ciencias sociales y humanidades, $\mathrm{n}^{\mathrm{0}} 78$ (Ejemplar dedicado a: Imágenes y cultura digital), 2015, pág. 18. cultura, $\mathrm{n}^{\mathrm{0}} 4$ (Ejemplar dedicado a: Un mundo adolescente), 2001. 


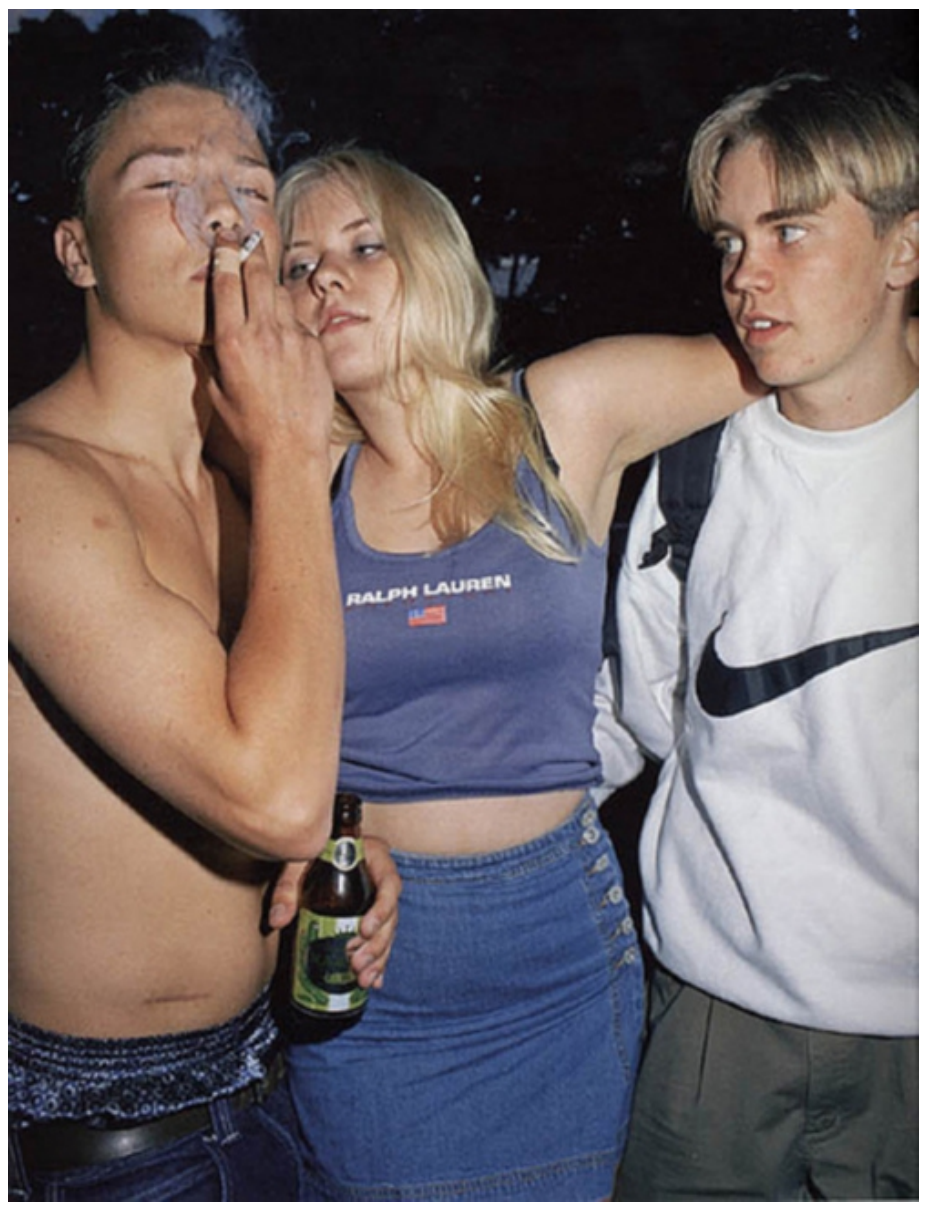

Imagen 5.9: Jouko Lehtola, First freedom, 1995.

Ahora bien, si con esta emancipación fotográfica los y las adolescentes pueden llegar a asumir el rol del fotógrafo documental en nuestra contemporaneidad $^{49}$, algo parecido puede ocurrir con la fotografía de moda y

Pese a que el sociólogo Don Slater afirma que la fotografía familiar (en nuestro caso, la variante de amistad adolescente) no es documental ni en su finalidad ni en sus modos, sino que "se trata de imágenes sentimentales que pretenden convertir en trascendentes las emociones de los momentos y de las personas sacándolas de lo cotidiano". SLATER, Don, "La fotografía doméstica y la cultura digital", en LISTER, Martin (comp.), La imagen fotográfica en la cultura digital, Barcelona, Paidós, 1995, pág. 180. Sin embargo Juan Miguel Sánchez-Vigil, al igual que nosotros, piensa que esto podría ser falso: "Evidentemente, nada tiene que ver el sentimentalismo con el documento; la fotografía familiar no es periodística, pero sí es fuente de ilustración y, por consiguiente, un fondo documental interesante. La 
erótica debido a la creciente y unificada producción de nuestras autorretratistas: su supuesto amateurismo, valorado por muchos, podría formar parte de un nuevo paradigma de lo erótico en la fotografía, y marcar nuevas tendencias dentro de la fotografía de moda industrial y/o la dedicada a la imagen publicitaria.

\subsubsection{La desprofesionalización del fotógrafo de portfolios y la visión de la moda por parte de las adolescentes.}

Hemos visto que el adolescente puede asumir la función de documentalista cuando se encuentra en situaciones sociales con otros miembros de sus colectivos. Pero cuando las autorretratistas se encuentran en esferas más privadas, se convierten en expertas del erotismo, de la seducción y de la simulación de la imagen inspirada en la moda publicitaria (generalmente tiránica $\left.{ }^{50}\right)$.

La manufactura amateur propia de los primeros self shots, solía producir fotografías pobres en cuanto a nitidez, foco y limpieza debido a la precariedad de las lentes de los celulares y cámaras compactas. Estas carencias podrían ser propias de alguien no profesional, poseedor de un equipo asequible y limitado. Esto es algo que siempre se le ha criticado al fotógrafo aficionado desde que hizo su aparición en el siglo XX:

particular foto de recuerdo es la memoria de un tiempo en el documento universal del hombre". SÁNCHEZ-VIGIL, Juan Miguel, op. cit., pág. 26.

"La popularidad estaría ganada al cumplir con formas estipuladas de belleza, generalmente tiranizadas por la moda. Hay jóvenes que hablan sobre este aspecto bajo la noción de construcción de personaje y profundizan acerca de las imposiciones sociales y las apropiaciones de mandatos de deber estéticos". LEONARDO, Norberto, "Del mito del Narciso a la selfie. Una arqueología de los cuerpos codificados", en Palabra clave, vol. 18, nº 3, 2015, pág. 693. 
"La imagen se ha desvalorizado desde que cientos de millones de aficionados aprietan el disparador cada día, sin que importe que en la mayoría de casos sigue existiendo una gran diferencia entre la calidad de la foto del aficionado y la del profesional" ${ }^{51}$.

Sin embargo, la aparición de smartphones fotográficos de alta gama, la modernización y mejora de las cámaras réflex y compactas (incluso las de bajo coste), sumado a la extensa cultura visual y a la experiencia tras horas de experimentación que poseen nuestras autorretratistas contemporáneas, las alejan de aquel torpe fotógrafo aficionado del siglo pasado. Es cierto que parte del mérito es de la máquina, puesto que se delega mucho en ella. Sin embargo, otras muchas cuestiones que tienen que ver no solo con la técnica sino con lo narrativo y/o con la manera de construir una imagen, son resueltas con presteza. Los selfies y resto de autorretratos digitales publicados en la red siempre nacen por voluntad propia de estas jóvenes buscadoras de belleza, y su calidad puede estar al margen de la buena o mala praxis del dispositivo.

\begin{abstract}
"Pero ya resulta claro que no existe un conflicto inherente entre el uso mecánico o ingenuo de la cámara y la belleza formal de orden muy elevado, ningún tipo de fotografías en las cuales semejante belleza no pudiera estar presente: una instantánea funcional sin pretensiones puede ser visualmente tan interesante, elocuente y bella como las fotografías artísticas más aclamadas" ${ }^{2}$.
\end{abstract}

La democratización y progresiva economización del dispositivo digital es uno de los factores que ha procurado que el adolescente contemporáneo posea mayores dotes para la fotografía respecto a sus jóvenes predecesores del siglo pasado. Como hemos visto anteriormente, durante esas décadas, la proliferación de la fotografía entre los aficionados, había permitido que hubiera una cámara de fotos en cada hogar para inmortalizar los acontecimientos importantes del grupo familiar:

51 FREUND, Gisèle, La fotografía como documento social, Barcelona, Gustavo Gili, 1998, pág. 158. 
“[...] existe una estrecha relación entre la presencia de niños en el hogar y la posesión de una cámara y que esta suele ser propiedad indivisa del grupo familiar, vemos que la práctica fotográfica existe - y subsiste- en la mayoría de los casos, por su función familiar o, mejor dicho, por la función que le atribuye el grupo familiar, como pueda ser solemnizar y eternizar los grandes momentos de la vida y de la familia, y reforzar, en suma, la integración del grupo reafirmando el sentimiento que tiene de sí mismo y de su unidad"53.

Sin embargo, en nuestros días, el número de dispositivos de captura fotográfica que existe en cada hogar, acostumbra a ser superior al número de sus habitantes: un único adolescente puede hacer fotografías con las dos lentes de su smartphone, con la webcam de su computadora portátil, con su barata cámara compacta y, en el caso de tener, también con su tablet, videoconsola de bolsillo o cámara réflex.

La cámara réflex, de hecho, se ha convertido en una herramienta popular entre algunos jóvenes, y aunque esta tendencia empieza a cambiar debido a los grandes avances acontecidos en el campo de la fotografía a través de smartphones cada vez más perfeccionados, muchas adolescentes siguen usando este tipo de cámaras para ejercer la fotografía, y también sus autorretratos reflejados, en este caso, de mejor calidad. Es curioso, sin embargo, ver actualmente este tipo de máquinas (cámaras fotográficas complejas asociadas durante décadas al fotógrafo profesional que, tras años de oficio, desarrollaba las habilidades para manejarlas) en manos de los y las jóvenes adolescentes. La sustitución de la película química por un sensor electrónico que procura la captura digital, unida a la compresión y ligereza, así como a la evolución de los nuevos modelos y al abaratamiento de estas cámaras réflex, las ha convertido en herramientas más populares aún entre los fotoaficionados, y por supuesto, también entre las adolescentes. Ellas las utilizan para hacerse estupendos 
autorretratos (Imagen 5.10) que presentan, además de muchos de los principios formales del self shot, mejor resolución óptica y calidad técnica en la imagen respecto a sus alternativos autorretratos hechos con cámaras compactas o smartphones.

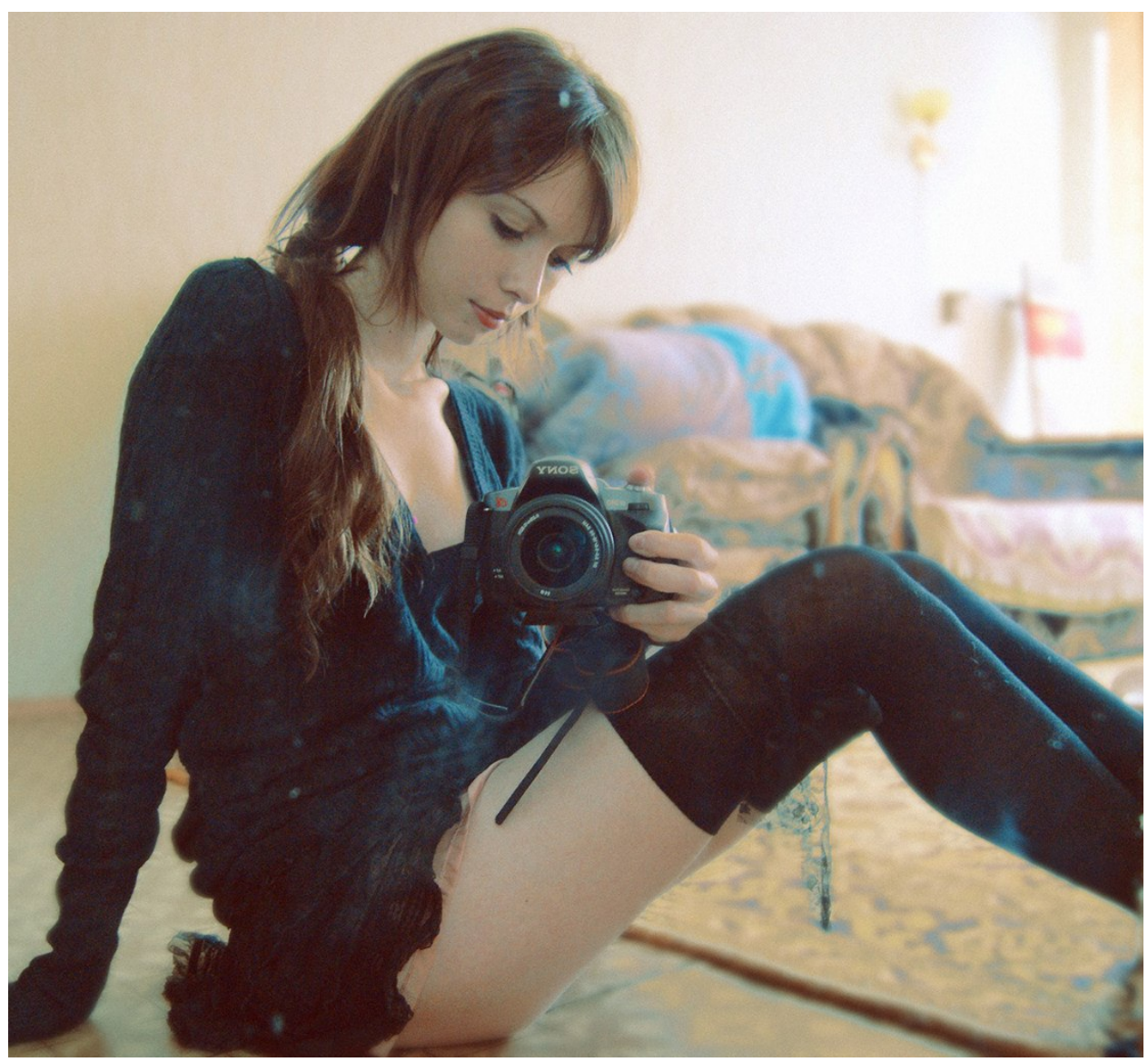

Imagen 5.10: Autorretrato digital publicado en la red de tipo mirrorpic (fotografía de un espejo encuadrando el reflejo especular del autorretratado), realizado por una adolescente anónima entre 2009 y 2013. Fuente: GUEK, "A Relic from Back Before Instagram Turned the Self-shot Portrait into Kitschy Garbage”, 2013, disponible en: $<$ https://imgur.com/gallery/33TIoB1> [Fecha de consulta: 3 de marzo de 2018].

No obstante, y como podemos observar en este mirrorpic, algunas selfshooters usuarias de cámaras réflex pueden preferir dejarla sobre la mesa y 
autorretratarse con su smartphone (Imagen 5.11). Puede que esto suponga un sacrificio en la calidad técnica y en la finura de la imagen, pero pocos pueden resistirse a autorretratarse y publicar ese mismo autorretrato segundos después de realizar la toma (y con un sencillo gesto), gracias a una cámara que permite hacer ambas cosas sin tener que esperar los largos lapsos de tiempo que existen (por el momento) entre la realización de una fotografía con una cámara réflex y su posterior publicación:

"Ya no existen hechos desprovistos de imágenes ni la documentación y transmisión del documento gráfico son fases indisociadas del mismo suceso" ${ }^{54}$.

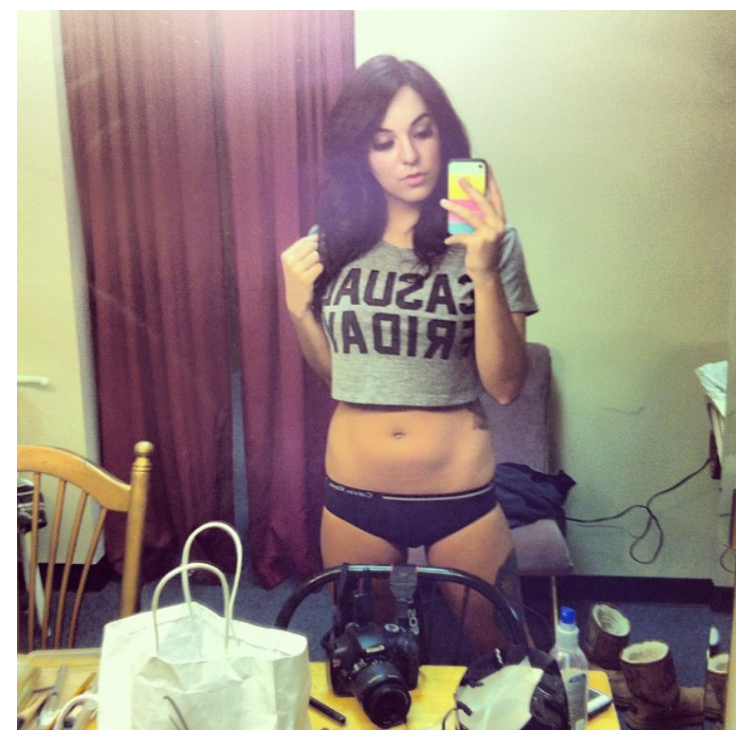

Imagen 5.11: Autorretrato realizado por la modelo Stephanie Marazzo con su smartphone en 2012.

FONTCUBERTA, Joan, op. cit., pág. 28. 


\subsubsection{El alcance y el control de la belleza en manos de las adolescentes.}

La fotografía digital, como vamos a repasar ahora, ha transformando no solo el campo cultural de la fotografía (por ejemplo, difuminando la división entre la práctica profesional, amateur y casera), sino "la misma forma en que la gente se fotografía y utiliza las fotografías" ${ }^{55}$.

Así pues, con réflex en mano, vemos adolescentes simular (y asumir) algunas funciones del fotógrafo de moda publicitaria ante otras adolescentes que interpretan, a su vez, el papel de modelos (Imagen 5.12). La actitud y el protocolo constatados en esta imagen puede recordarnos a los habitualmente observados en las sesiones de los fotógrafos más profesionales (Imagen 5.13).

Los resultados de estas sesiones adolescentes aparentemente amateurs, aunque modestos, podrían competir en forma, actitud y resultados con los obtenidos por sus homólogos fotógrafos de la industria de la imagen. De hecho, la fotografía de estudio ya había empezado una etapa crepuscular tras la democratización del uso de la cámara réflex y con el fotomatón, "invento diabólico donde la ausencia del fotógrafo permitió al modelo desinhibirse" ${ }^{56}$.

55 GÓMEZ-CRUZ, Edgar y ARDÈVOL, Elisenda, op. cit., pág. 184. 


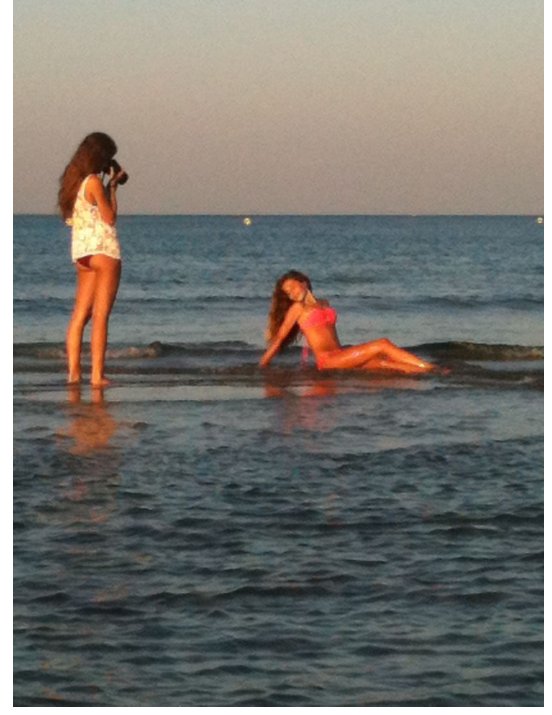

Imagen 5.12: Adolescentes fotografiándose en la playa, 2013. Autora: Alicia Antón.

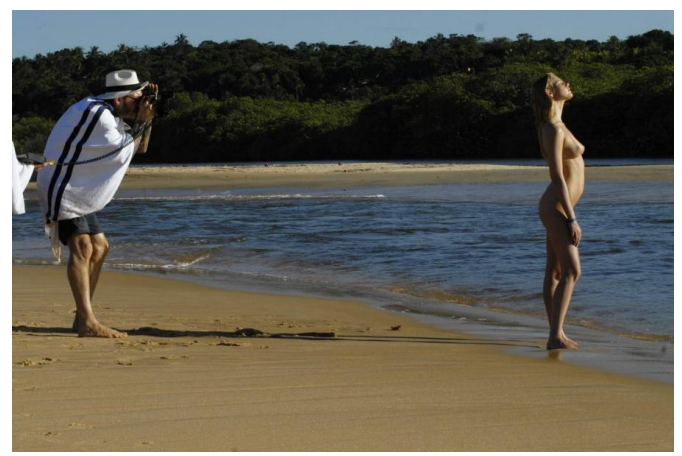

Imagen 5.13: Instantánea anónima de Terry Richardson realizando fotografías para el calendario Pirelli, 2010.

A su vez, esta sorpresa cualitativa también puede producirse si comparamos algunos de los autorretratos realizados por estas jóvenes creadoras frente a otras imágenes efectuadas por fotógrafos profesionales y en las que ellas también son protagonistas. En Instagram encontramos multitud de ejemplos que verifican visualmente esta cuestión. Mostramos dos de ellos.

En el primero podemos ver a la usuaria @violetta1996, una adolescente siberiana que reside en la ciudad de Krasnoyarsk. No sabemos por qué Violetta contrató los servicios de un fotógrafo profesional (Imagen 5.14). Puede que únicamente para sentirse modelo por un día, ya que, aunque las imágenes que obtuvo el fotógrafo profesional son correctas, no ensombrecen, ni siquiera mejoran, la calidad, la autenticidad y la belleza de los propios autorretratos de Violetta (Imagen 5.15) realizados cotidianamente para el contento de sus seguidores. 


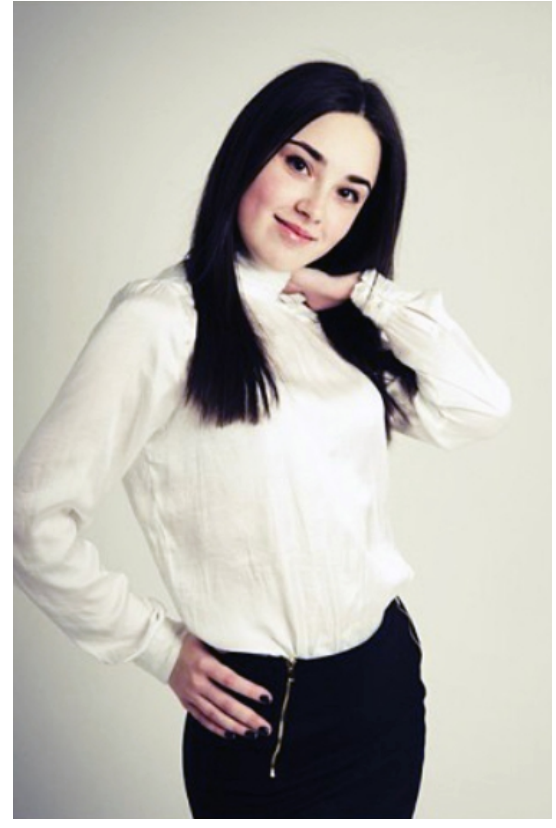

Imagen 5.14: Fotos de la usuaria de Instagram @violetta1996 realizadas en un estudio fotográfico profesional: Umbrella Photoroom, en Krasnoyarsk (Rusia).
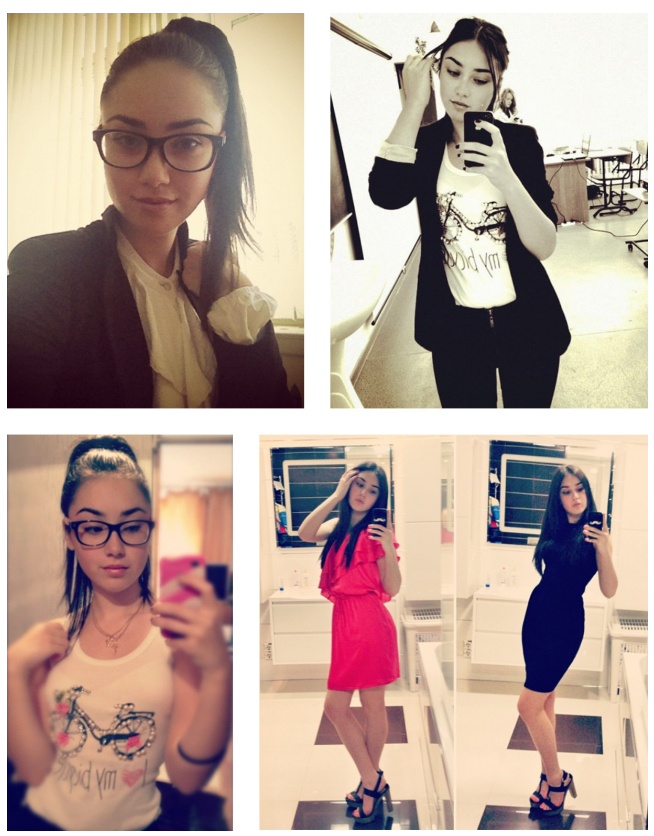

Imagen 5.15: Autorretratos de @violetta1996 publicados en Instagram entre 2012 y 2013.

Algo parecido ocurre con la usuaria @_isabeltormo, un ejemplo mucho más cercano geográficamente hablando. Isabel es otro claro ejemplo de la autorretratista que supera con sus selfies y mirrorpics al fotógrafo profesional. Ella posa, frente a su cámara, con seguridad, serenidad y seducción. Las imágenes que crea son finos retratos en los que emplea un sencillo pero correcto uso de la luz, un encuadre preciso y una búsqueda constante de la belleza contemporánea (Imagen 5.16). Ella sabe sacarse más partido que el fotógrafo de estudio que intentó retratarla ${ }^{57}$ (Imagen 5.17). 

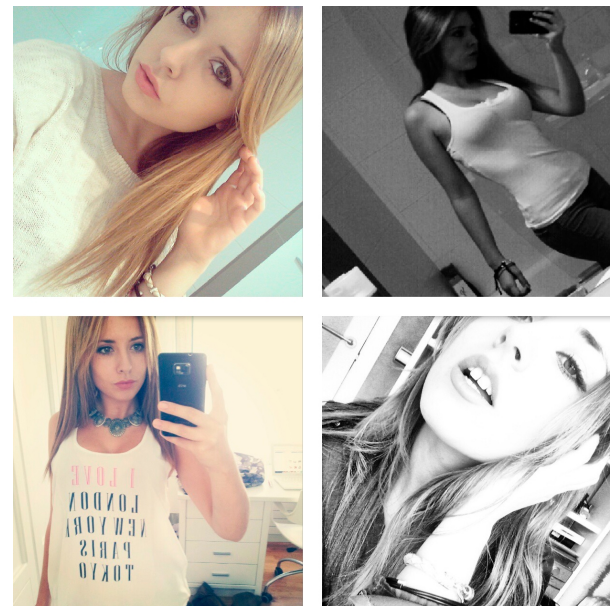

Imagen 5.16: Autorretratos de @_isabeltormo publicados en Instagram entre 2012 y 2013.

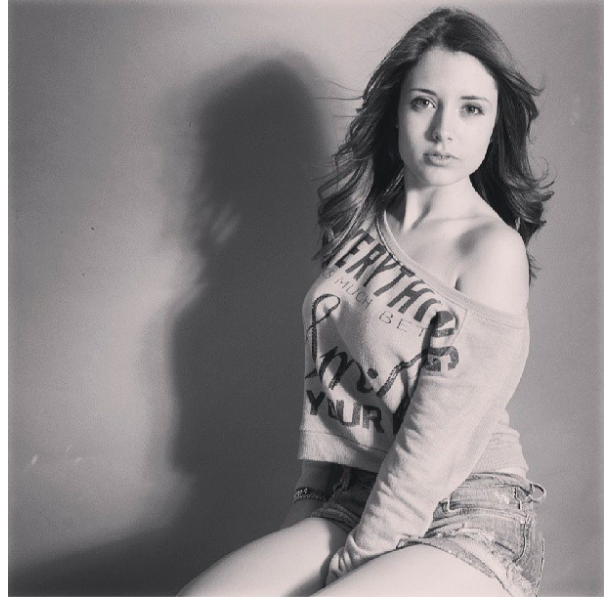

Imagen 5.17: Un retrato de la misma usuaria realizado en un estudio fotográfico.

En el caso concreto del selfie más actual, y para finalizar esta comparativa entre las fotografías realizadas por un fotógrafo de una joven frente a las autofotos registradas por esta, traeremos también a colación el proyecto artístico e investigador de María Cereijo, en el que compara y evalúa las fotografías tomadas por ella misma de su modelo (Imagen 5.18), y las que esta misma modelo se ha practicado en sus ejercicios de autorretrato (Imagen 5.19 y 5.20). Cereijo opina:

"En nuestro proyecto pudimos observar que en la mayor parte de los casos hay una diferencia notable entre la foto que tomamos nosotros a la modelo, y la que el individuo hizo para sí mismo. «El pudor es un lastre» dice Alberto García Alix en una de sus múltiples entrevistas, no puede haber mejor muestra de ello que la diferencia corporal adoptada en las dos fotos. Quizás el motivo sea que las fotografiadas no podrán manipular la fotografía que se le saca como suelen hacer con las propias: no se

un ultraje, sino porque temen la reprobación de la cámara. Quieren la imagen idealizada: una fotografía donde salgan mejor que nunca”. SONTAG, Susan, op. cit., pág. 90. Y esto es lo que consiguen, añadimos nosotros, mediante la práctica del selfie. 
trata solamente de decir yo existo sino de yo existo y controlo la manera en la que me ven"58.

Evidentemente, tras lo que hemos descrito con anterioridad, no podemos ahora no estar de acuerdo con lo apuntado por Cereijo. La soledad y tranquilidad de la que goza la autorretratista, así como su instantánea capacidad de pruebaerror (gracias a la tecnología digital), y el pleno conocimiento de su cuerpo tras una vida de análisis y estudio frente al espejo, la dota de la capacidad de realizar unas fotografías más naturales y controladas que las que podría tomar de ella un segundo actor.

No obstante, añadimos, que el principal control de la belleza y el aumento del atractivo que muestra la imagen autorregistrada frente a la más profesional se debe, sin duda, a la manufactura de la herramienta: unas lentes más angulares ${ }^{59}$, como las que son propias de las máquinas hacedoras de selfies, otorgarían al rostro unos atributos institucionalizados y definidos como bellos en el mundo real de nuestra contemporaneidad (y no en el de la respresentación), y ello mediante los recursos que ofrecen ojos y labios más grandes (aportanto exotismo) y mandíbula y contorno de la cara más estrechos (aportando delgadez).

Por supuesto, encontrar estos ángulos también exige habilidad por parte de la autoretratada, pero estamos, sobre todo, ante una intervención propia de la máquina, tal y como hemos planteado en el capítulo 3 .

59 Las pequeñas ópticas ligeramente angulares y propias de las lentes delanteras de los smartphones y concebidas para el desarrollo del selfie crean esta deformación del rostro que ya se ha fijado como imagen cultural y "correcta” de una cara. La duda es si se desarrollaron así para cumplir este cometido, para cumplir otros generando el propio como un encuentro colateral, o simplemente imitaron la manufactura de aquellas cámaras compactas (también angulares) que tenían que ser giradas mediante un disparo a ciegas para generar los primeros selfies primitivos. 


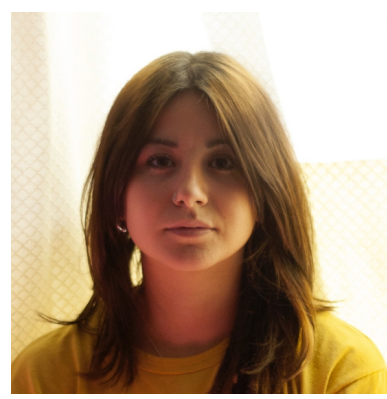

Imagen 5.18: María Cereijo, Helena, 2015.

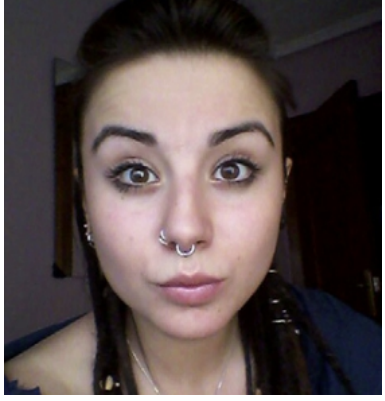

Imagen 5.19: Selfie para el proyecto "El yo frente a la cámara".

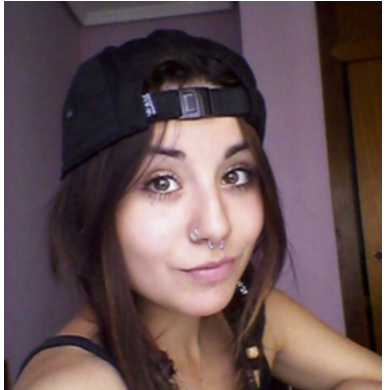

Imagen 5.20: Selfie para el proyecto "El yo frente a la cámara".

Viendo estos tres ejemplos, podríamos tener la tentacion de preguntarnos qué interpretación de la belleza (totalmente controlada por la autorretratista en sus selfies, y fuera de su control en sus books profesionales) es la verdadera, o mejor dicho, la que más se aproxima a la realidad de su referente. Sin duda nos atrevemos a afirmar, por la experiencia personal que hemos tenido al conocer en persona a muchas de las selfshooters que seguíamos en las redes durante el transcurso de esta investigación, que un retrato realizado por una réflex profesional es más fiel a la belleza real de la modelo y que, sin embargo, el atractivo que aporta un selfie realizado con los protocolos aquí vistos siempre es superior al que apreciamos en la realidad ${ }^{60}$. Tendríamos por supuesto siempre en cuenta, como hemos visto en el capítulo 3 , lo incompatible que es la verdad con la fotografia:

"Toda fotografía es una ficción que se presenta como verdadera. Contra lo que nos han inculcado, contra lo que solemos pensar, la fotografía miente siempre, miente por instinto, miente porque su naturaleza no le permite hacer otra cosa. Pero lo

6o Otros autores también apuntan a la subjetivización que proporciona el selfie: "Mediante la práctica del selfie la toma fotográfica es inseparable de la presencia corporal, lo cual hace de la imagen un espacio de enunciación subjetiva. [...] toda representación «es la simbolización de un referente, real o imaginario, mediante unas configuraciones artificiales [...], que lo sustituyen en el plano de la significación y le otorgan una potencialidad comunicativa»". RABADÁN, Ángel V., "Selfie y la impronta visual: el autorretrato 3.0 representación, presentación, corporealización", en Icono14, vol. 14, $\mathrm{n}^{\mathrm{O}} 2$ (Ejemplar dedicado a: Digital Economy and its Impact in the Media), 2016, pág. 35. 
importante no es esa mentira inevitable. Lo importante es cómo la usa el fotógrafo, a qué intenciones sirve. Lo importante, en suma, es el control ejercido por el fotógrafo para imponer una dirección ética a su mentira. El buen fotógrafo es el que miente bien la verdad"61.

Serían, por tanto, las y los autores del selfie (adolescentes, jóvenes o adultos), unos perfectos (y perfeccionistas) mentirosos ${ }^{62}$ aprovechando esta propiedad inherente de la fotografía ${ }^{63}$ que se convierte en una especie de certificado para el espectador. Y esta actuación aparentemente desleal no tendría mayor trascendencia si la comparamos con la histórica tendencia humana de mostrar la mejor versión de uno mismo por medio de la alteración de nuestra propia realidad ${ }^{64}$ : con la ropa $y$ accesorios, con el maquillaje, e incluso últimamente con la cirugía, extremo al que han llegado muchos individuos coetáneos de esta sociedad de las apariencias. Por ello mismo, este perfeccionamiento del yo, sería un acto predecible si tenemos en cuenta que no solo se trata de hedonismo visual frente a un espejo fotográfico-digital que genera un producto para nuestra propia contemplación, sino también el hecho de que ese producto será exportado a un escaparate público-virtual ${ }^{65}$ en el que miles de ojos lo juzgarán sin necesariamente tener que situarse, a posteriori, frente al

61 FONTCUBERTA, Joan, El beso de Judas. Fotografia y verdad, Barcelona, Gustavo Gili, 2009, pág. 15.

62 Porque "no ha sido hasta el advenimiento de las tecnologías digitales cuando no solo los especialistas, sino también los profanos, el gran público en definitiva, han descubierto la inevitable manipulación que opera en el proceso de toda imagen fotográfica”. FONTCUBERTA, Joan, La cámara de Pandora..., op. cit., pág. 10.

63 Ya que "sin duda, la fuerza de la fotografía tiene que ver con la manera en que nos coloca ante una duplicación de las apariencias liberada de las distorsiones que introduce la imagen manual. Es lo que Roland Barthes ha llamado el certificado de presencia que extiende la imagen fotográfica, el hecho de que su referente deje de ser (como era el caso de la pintura) algo facultativamente real para convertirse en algo necesariamente real”. ZUNZUNEGUI, Santos, Pensar la imagen, Madrid, Cátedra, 2010, pág. 132.

64 SÁNCHEZ-VIGIL, Juan Miguel, op. cit., pág. 83.

$65 \mathrm{Y}$ esto es consecuencia de que "la vida en la pantalla hace que sea muy fácil presentarnos como alguien diferente al que somos en la vida real”. TURKLE, Sherry, op. cit., pág. 287. De hecho, las fotografías de perfil que encontramos en las redes sociales se parecen a la publicidad: "quieren vendernos algo y, aunque no mienten, tampoco dicen toda la verdad". FAERMAN, Juan, Faceboom. El nuevo fenómeno de masas Facebook, Barcelona, Alienta, 2010, pág. 59. 
referente original en el mundo real. Al fin y al cabo, "la estrategia de la seducción es la de la ilusión”66.

"Como rezaba un grupo en Facebook: «Nadie es tan guapo como en su foto de perfil ni $\tan$ feo como en el DNI»"67.

Ya hemos visto que esta superación formal por parte del amateurismo de las autorretratistas digitales (frente a la pretendida profesionalidad que existe en torno a la fotografía de belleza ${ }^{68}$ ) depende del escenario privado e íntimo en el que se cocinaron estas prácticas y de las derivas de las ópticas de sus máquinas conformadoras. Las selfshooters, además, son devoradoras de la imagen cultural contemporánea, la consumen más que nadie a través de la red y de otros mass media. Sería lógico pensar, por tanto, que también ellas son las creadoras y las causantes de esta propia imagen contemporánea, compartiendo esta labor con fotógrafos profesionales cada vez menos solicitados en cuestiones de books y portfolios personales ante tanta autorretratista emancipada.

De hecho, esta emancipación fotográfica por parte de las adolescentes contemporáneas puede recordarnos a la emancipación intelectual que desarrollaron los alumnos del "maestro ignorante", antiguo relato que da título a una de las obras de Jacques Rancière ${ }^{69}$. Solo que en este caso no hablaríamos de alumnos capaces de aprender sin la necesidad de adquirir la información a través de los conocimientos de un maestro, sino de adolescentes capaces de desarrollar la belleza de sus propias imágenes fotográficas, sin la necesidad de hacerlo mediante los servicios y habilidades de un "fotógrafo profesional inútil”.

66 BAUDRILLARD, Jean, De la seducción, Madrid, Cátedra, 1998, pág. 69.

67 CALDEVILLA, David, "Las redes sociales. Tipología, uso y consumo de las redes 2.o en la sociedad digital actual”, en Documentación de las ciencias de la información, nº 33, 2010, pág. 83.

68 Lo que durante estos últimos años ha estado aportando una sensación de crisis a los profesionales frente a los amateurs; es decir, ha sido "un sismo que hizo mella en las definiciones y características otorgadas a quienes se dedican a estas actividades”. MORENO, Adriana M., op. cit., pág. 32.

69 RANCIÈRE, Jacques, El maestro ignorante. Cinco lecciones sobre la emancipación intelectual, Barcelona, Laertes, 2003. 


\title{
5.1.3. La influencia de la fotografía de moda en el autorretrato adolescente.
}

Asumiendo que en las redes sociales las identidades son configuradas, en numerosos casos, como "identidades de escaparate", podríamos apuntar que los y las adolescentes acaban por hacer un trabajo parecido al de los publicistas, que ritualizan lo que ya está ritualizado, es decir:

\begin{abstract}
"[...] que toman las manifestaciones de género que compartimos socialmente y las reconfiguran, exagerándolas. En sus autopresentaciones buscan poses brillantes y, para ello, toman como referente la publicidad y las representaciones de hombres y mujeres de otros formatos audiovisuales, reproduciendo y remodelando algunos estereotipos de género"’o.
\end{abstract}

Por lo tanto, la construcción propia de imágenes fijas mediante fotografía digital por parte de los que comenzaron la andadura de los autorretratos (y también los que les han imitado) sigue operando con fuerza mediante estos modelos de perfección. "Las imágenes buscan parecérseles. Es decir, buscan el ideal representado" ${ }^{11}$. Así pues, "nuestros álbumes fotográficos online serían en ese sentido no solo una auto-representación sino la representación de las ideas o valores a los que apuntan esas imágenes, especialmente las imágenes posadas"72.

Esta redundancia eterna que los autorretratos adolescentes han mostrado imitando a la moda podría ser algo inevitable teniendo en cuenta que son los hijos nacidos en la "civilización del cliché" a la que apunta Zunzunegui:

70 ARAUNA, Núria; MARTÍNEZ, Inmaculada J. y TORTAJADA, Iolanda "Estereotipos publicitarios y representaciones de género en las redes sociales”, en Comunicar. Revista científica iberoamericana de comunicación y educación, $\mathrm{n}^{\mathrm{0}}$ 41, 2013, pág. 178.

71 ZAFRA, Remedios, op. cit., pág. 88.

72 Ídem. 
“[...] nuestra autodenominada «civilización de la imagen», [es] sobre todo una «civilización del cliché». Y esto puede explicarse en un doble sentido. Por un lado, porque la inflación icónica se edifica sobre la redundancia. Por otro, en un sentido más complejo, por el hecho de que el Poder constituido mantiene muchas veces un interés cierto en la ocultación, distorsión o manipulación de ciertas imágenes de tal manera que estas casi dejan de ser un medio de revelar la realidad para convertirse en una forma de ocultarla"73.

También durante nuestra década, y como en las anteriores, la fotografía de moda sigue siendo, el campo más productivo para el retrato glamour. "Al igual que la de los estudios cinematográficos, está íntimamente emparentada con la fotografía publicitaria"74. Esta imagen cultural tan fuerte y asentada, tan atractiva para el público joven, tiene un fácil consumo por su parte: la presencia de la imagen en nuestra sociedad contemporánea ya era invasiva antes de la llegada de Internet. En este sentido, el desarrollo de la red y de las pantallas durante estas dos décadas, así como la facilidad con la que los adolescentes la consumen, no ha hecho sino agravar la presencia de estos iconos de divismo, narcisismo y seducción ante los ojos de cualquier espectador activo o pasivo. El adolescente autorretratista "capta el mundo tal como lo ve, es decir, de acuerdo con la lógica de una visión del mundo que toma sus categorías y sus cánones de las artes del pasado"75. Mediante este ejercicio de traducción, el joven podría seguir sintiendo las satisfacciones que, también según Bourdieu cualquier fotógrafo siente. Nos referimos a cuestiones como la necesidad de protección contra el paso del tiempo, la comunicación con los demás, la expresión de sentimientos, la realización de uno mismo, el prestigio social, la distracción o la evasión ${ }^{76}$. 


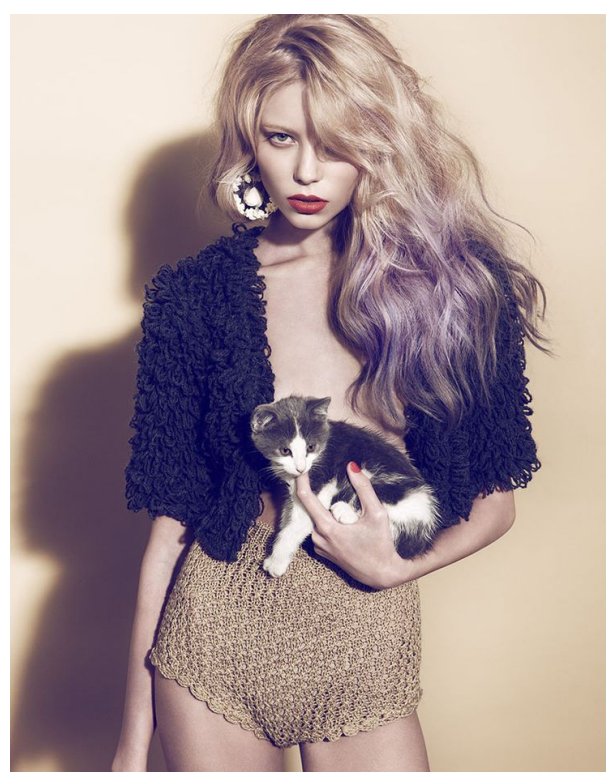

Imagen 5.21: Retrato para una campaña publicitaria de moda, 2014.

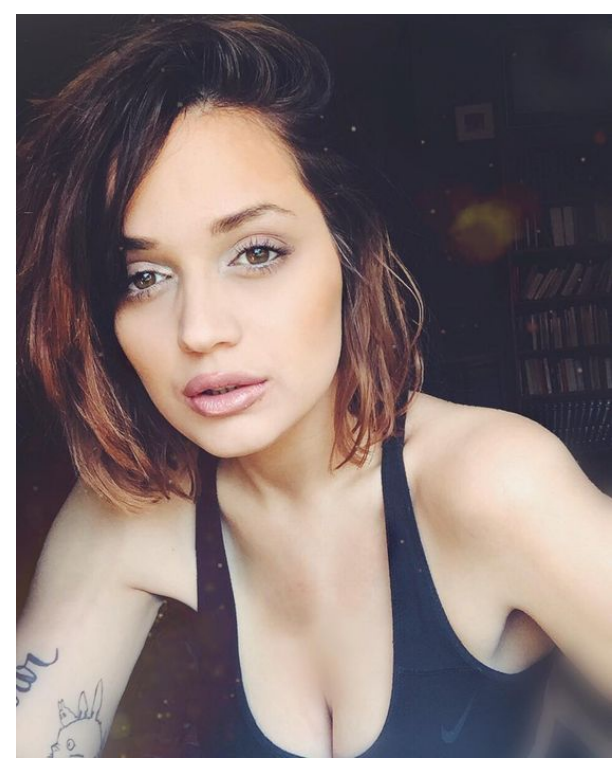

Imagen 5.22: Autorretrato de Blanki Blue realizado por medio de una webcam en su habitación y publicado en Instagram durante 2015 .

Aunque históricamente, tanto en la moda, en el cine y en la publicidad la construcción fotográfica se ha constituido en torno a la mujer, en los últimos años hemos asistido, no solo casi al mismo tratamiento en lo concerniente a la figura del hombre ${ }^{77}$, sino en ocasiones, a un cambio de roles que ha llevado a una imagen más andrógina para representar ambos sexos ${ }^{78}$.

No obstante, como ya hemos señalado, el desarrollo del autorretrato fotográfico digital por parte de la comunidad juvenil y adulta, sobre todo el EGUIZÁBAL, Raúl, op. cit., pág. 115.

78 "Según la cual existe una preferencia manifiesta hacia el físico ideal del género opuesto que sigue los cánones físicos propuestos culturalmente. Específicamente los chicos de hoy día eligen una imagen mucho más delgada de lo normal como cuerpo ideal femenino, y lo mismo ocurre con las chicas, que se decantan por un cuerpo más marcado y fuerte de lo que los chicos de su edad presentan; de modo que la apariencia ideal para cualquiera de los géneros parece ser reforzada por las preferencias del sexo opuesto". VÁZQUEZ, María F., op. cit., pág. 42. 
basado en las actitudes y referentes de la fotografía de moda, es mayoritariamente femenino. $\mathrm{Y}$ respecto a estos referentes encontramos en el selfie y resto de self shots todo un abanico de actitudes en la representación que también les son propios: desde la visión de la mujer como muñeca (Imágenes 5.21 y 5.22), acorde a la cultura que la ha colocado tradicionalmente en una posición de sumisión y pasividad ${ }^{79}$, hasta el icono de la femme fatale (Imágenes 5.23 y 5.24), que se había extendido como un mito a través de la literatura, el celuloide y también la fotografía publicitaria a lo largo del siglo $\mathrm{XX}^{80}$.

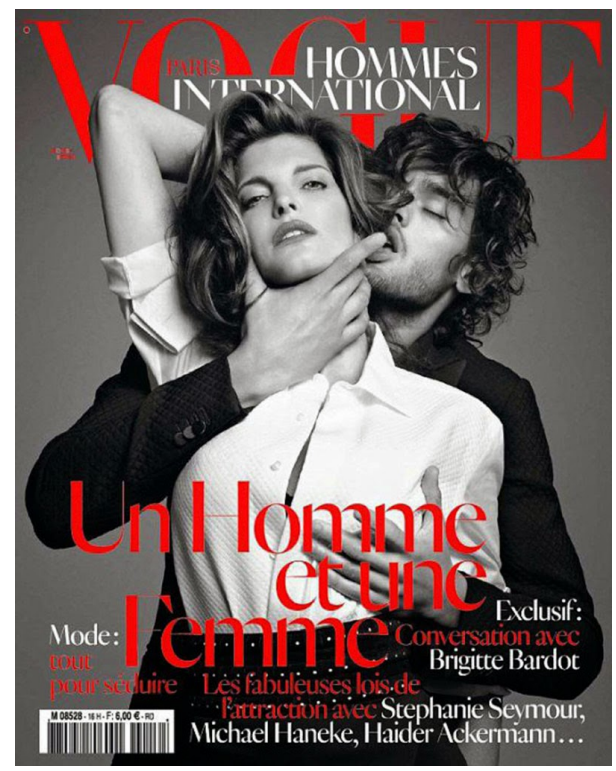

Imagen 5.23: Sumisión en la fotografía de moda.

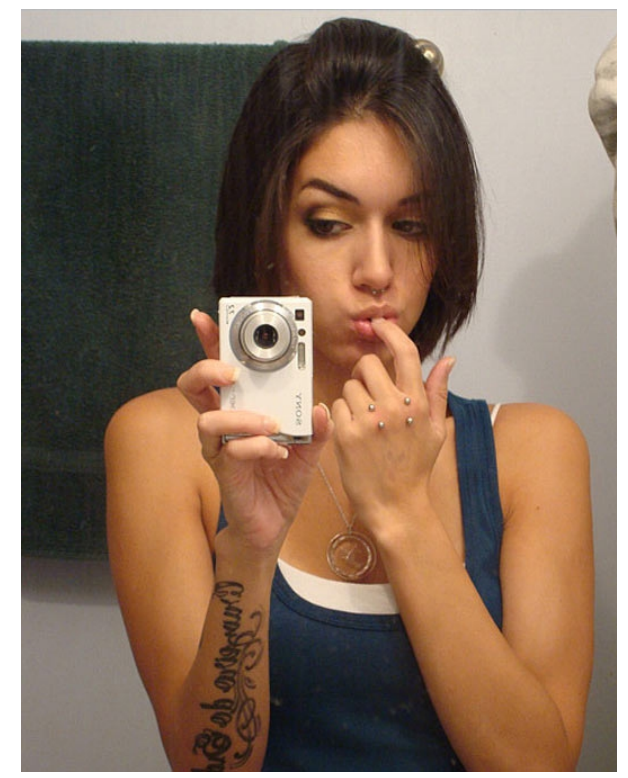

Imagen 5.24: Inocencia y sumisión en el self shot.

79 Ibídem, pág. 199.

8o BORNAY, Erika, Las hijas de Lilith, Madrid, Cátedra, 2005, pág. 22. 


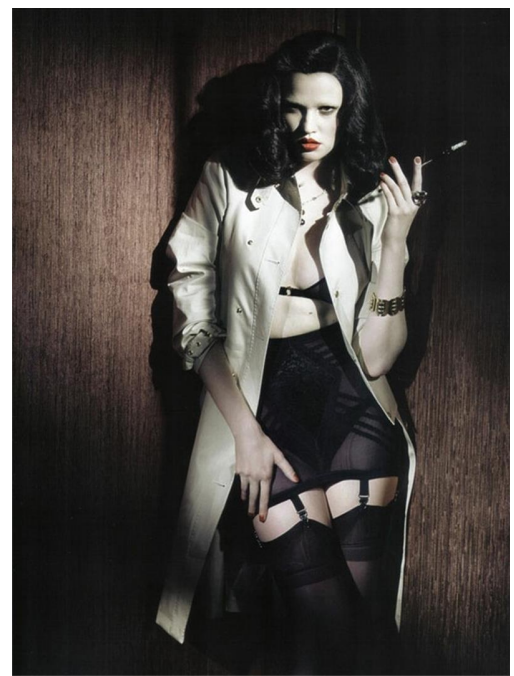

Imagen 5.25: Autoridad y dureza en la fotografía de moda mediante la representación de la femme fatale.

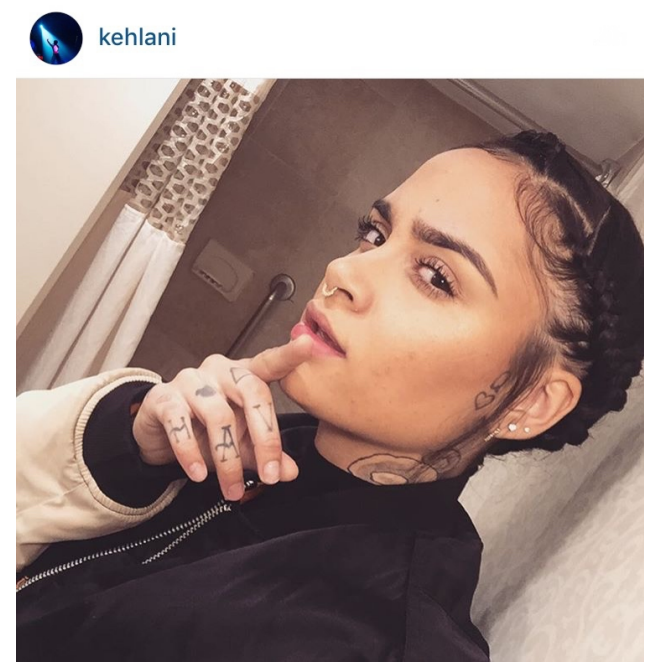

Imagen 5.26: Autoridad y dureza en el selfie.

Por tanto, muchas de las identidades corporales que se venden como ideales suelen venir definidas de antemano, envasadas y ya dispuestas para el público desde las industrias de consumo, justamente a través de las imágenes de la publicidad. De manera que la autorretratista se identifica con una imagen corporal que queda constituida en gran parte a partir de este repertorio disponible que proviene del ámbito mediático, en especial de la imagen publicitaria como referente a imitar ${ }^{81}$.

No obstante, y como veremos más adelante, no todo son lindezas frente a un escenario que puede desencadenar grandes problemas sociales y de salud pública: la institucionalización de la tiranía de la belleza en torno a objetivos imposibles de representación. $\mathrm{Y}$ es que en un momento en el que la persecución de la belleza corporal está propiciando la aparición de nuevas epidemias sociales

81 GÓMEZ-CRUZ, Edgar y ARDÈVOL, Elisenda, op. cit., pág. 188. 
(como los trastornos de alimentación o los comportamientos compulsivos relacionados con la autoproyección), los medios de difusión podrían contribuir a consolidar la "tiranía de las apariencias" por medio de la tecnología y sus agendas: en una sociedad en la que solo lo que se observa tiene importancia, la tecnología mediática podría haber potenciado el lenguaje visual frente al oral, transformándonos en animales videntes con un modelo plástico de entender el mundo y con un concepto del hombre en el que el físico (lo que se ve) adquiriría un valor casi absoluto. De esta manera, la técnica habría extendido el interés por la imagen personal al hacer que gran parte de los ciudadanos mantengan una interacción privada con los cánones de belleza corporal existentes en los mass media $^{82}$. En este aprendizaje implícito hacia el canon, la red, de momento, no parece haber sido capaz de poner plenamente en cuestión soluciones para mitigar los males transversales de esta tiranía de la belleza y de la representación.

"De dicho aprendizaje se deduce con frecuencia la sobredimensión dada a la identificación con un modelo y, como consecuencia, la insatisfacción que deriva no solo en su ocultación y reclusión en los ángulos muertos de la cámara, sino en la perpetuación de una frivolísima dictadura estética"83.

En todo caso, y pese a esto, la búsqueda incansable de la belleza y de su representación (o presentación) por medio del selfie y del resto de autorretratos que practican los jóvenes, parece haberse convertido en el leitmotiv del escaparate visual que protagonizan las redes sociales. Pero ¿qué podemos considerar como bello en referencia al retrato y a la representación del cuerpo? Según Umberto Eco:

“«Bello» (al igual que «gracioso», «bonito», o bien «sublime», «maravilloso», «soberbio» y expresiones similares) es un adjetivo que utilizamos a menudo para

82 MARTíN, Marta, "La tiranía de la apariencia en la sociedad de las representaciones", en Revista latina de comunicación social, $\mathrm{n}^{0}$ 50, 2002, pág. 35 .

83 ZAFRA, Remedios, op. cit., pág. 89. 
calificar una cosa que nos gusta. En este sentido, parece que ser bello equivale a ser bueno y, de hecho, en distintas épocas históricas se ha establecido un estrecho vínculo entre lo Bello y lo Bueno. Pero si juzgamos a partir de nuestra experiencia cotidiana, tendemos a considerar bueno aquello que no solo nos gusta, sino que además querríamos poseer" ${ }^{84}$.

Tampoco podemos olvidar que la belleza nunca ha sido algo absoluto e inmutable, y que se adapta a distintos rostros según la época histórica y la ubicación geográfica ${ }^{85}$. Por lo tanto, el selfie podría tener su propio código de belleza que lo retroalimenta hacia una replicancia casi infinita y que, a su vez, se habría basado (como estamos viendo) en la copia sistemática de los modelos impuestos por la fotografía publicitaria y la representación de la diva y del divo en el resto de medios de comunicación de masas.

Se genera con esta imitación del referente de la diva en la publicidad una carrera hacia la saturación de las imágenes de esta misma versión de diva en las redes sociales, que ofrece mediante su aparición en estos espacios públicos una continuidad de instantes de su propia vida ${ }^{86}$ :

“[...] el divismo se presenta como un fenómeno de profundo interés para la semiótica visual, construido sobre parejas de oposiciones como las de público/privado, notoriedad/anonimato y sobre todo ser/aparentar, que en un contexto visual es declinable según la dicotomía secreto/transparencia. Esta estrategia vinculada al régimen de lo visible está en la base del mecanismo de representación del divismo desde sus primeras manifestaciones, que se remontan a finales del siglo XIX" ${ }^{87}$.

Esta visibilidad de la intimidad que, como estamos viendo, ha reducido a membrana la separación entre el espacio privado de la habitación y el espacio

\footnotetext{
84 ECO, Umberto, Historia de la belleza, Barcelona, Lumen, 2004, pág. 8.

85 Ibídem, pág. 13.

86 MATTEI, María M., "El divismo en tiempos de \#Instagram”, en CIC. Cuadernos de información y comunicación, $\mathrm{n}^{\mathrm{O}} 20$ (Ejemplar dedicado a: Ídolos e iconos en la semiosfera mediática), 2015, pág. 96.

87 Ibídem, pág. 97.
} 
público del ciberespacio será nuestro marco argumental durante las siguientes páginas.

\subsection{El espacio propio y privado convertido en escenario público.}

Hoy en día los límites de la adolescencia se han modificado tras los cambios que han ido sufriendo las sociedades occidentales en cuestiones como la familia, el trabajo, los estudios y la juventud. La emancipación adolescente comienza de manera más temprana y su actividad se desarrolla más allá de la veintena. En un texto de 2011, Luz Sánchez-Mellado señalaba al respecto:

"Los niños quieren dejar de serlo. Los adultos no se ven como tales. La infancia se acorta. La adolescencia se estira. La juventud se eterniza. Las fronteras entre edades se difuminan. Las nuevas tecnologías, la crisis económica, el aumento de la esperanza vital y el hedonista estilo de vida moderno redefinen las etapas de la existencia. Cada cual diseña su ciclo biográfico como quiere. O como puede" 88 .

Acotar la adolescencia contemporánea puede resultar complicado, pero podemos definirla en este trabajo, siquiera sea vagamente, como esa edad intermedia entre la niñez y la madurez, etapa que está principalmente asociada a la permanencia del individuo bajo la tutela y techo del hogar materno y paterno.

La distinción entre lo público y lo privado tiene una larga historia en el pensamiento social y político occidental, aunque esta amplia distinción entre lo 
público y lo privado no ha sido nunca rígida ni ha quedado bien definida en el desarrollo histórico de las sociedades modernas ${ }^{89}$. La vida privada en el hogar ha cambiado mucho durante las últimas décadas ${ }^{90}, \mathrm{y}$ su interés por parte del observador externo es algo que se empezaría a gestar a finales del siglo XIX ${ }^{91}$. Dicha privacidad deseada ha quedado totalmente entremezclada con el panorama público gracias a los últimos desarrollos tecnológicos:

\begin{abstract}
"La reconstitución de lo público y lo privado como esferas de información y contenido simbólico cada vez más separadas de los escenarios físicos y más entramadas con las tecnologías de comunicación en desarrollo y los flujos de información, han creado una situación muy fluida en la cual los límites entre lo público y lo privado se desdibujan y cambian constantemente, y en la cual los límites que sí existen en cualquier momento se vuelven porosos, discutibles y sujetos a negociación y resistencia”92.
\end{abstract}

Así pues, las características específicas de Internet como medio de comunicación propicia que muchas de las imágenes personales y familiares sean subidas a plataformas abiertas de libre compartición.

\begin{abstract}
"Aunque en muchos casos se suben a estas plataformas fotografías personales para ser compartidas por un grupo de amigos o familiares, lo cierto es que estas plataformas proporcionan la opción de que puedan hacerse públicas, y generalmente, por comodidad, suelen mantenerse en abierto, aunque sean para uso privado. ¿Hasta
\end{abstract}

89 THOMPSON, John B., Los media y la modernidad: una teoría de los medios de comunicación, Barcelona, Paidós, 1998, pág. 163.

90 Véase: VV. AA., Historia de la vida privada. De la Primera Guerra Mundial a nuestros días. Vol. V, Barcelona, Círculo de Lectores, 1993.

91 Y es que "[...] es posible detectar las raíces de este gusto por lo real ya en el siglo XIX. Una disposición que no se plasma solamente en la ficción, como las novelas realistas y naturalistas que se convirtieron en uno de los grandes vicios de la época, sino también en el periodismo sensacionalista que floreció en aquellos tiempos y que los lectores devoraban en tabloides y folletines. E inclusive en los museos de cera y otros espectáculos de la vida moderna que se ofrecían en las calles de las ciudades y apelaban al realismo como un ingrediente fundamental de su éxito. De esta forma, inclusive, se asentó el terreno para el surgimiento del cine, cuyas manifestaciones ancestrales eran promovidas con ganchos publicitarios del tipo: no son imitaciones ni trompe l'oeil, son reales”. SIBILIA, Paula, op. cit., pág. 222.

92 THOMPSON, John B., "Los límites cambiantes de la vida pública y la privada", en Comunicación y sociedad, $\mathrm{n}^{\circ} 15,2011$, pág. 34 . 
qué punto estas imágenes caseras son «públicas»? ¿Cómo se define lo público y lo privado en Internet?"93.

Claramente estas distinciones aplicadas en torno al espacio privado y a la fotografía durante el siglo XX quedan rotas. Por ejemplo, Barthes decía que "la «vida privada» no es más que esa zona del espacio, del tiempo, en la que no soy una imagen, un objeto" 94 , sin embargo en la era del selfie, la vida privada (en ocasiones auténtica, en otras falseada) queda registrada y publicada, por tanto, en ella somos también imagen y objeto. A su vez, cuando Bourdieu habla de la aparición de la práctica doméstica de la fotografía coincide con una diferenciación más precisa de lo que pertenece al orden público y al privado: “[...] estamos condenados a distinguir entre las imágenes reservadas a la contemplación familiar y las imágenes que pueden enseñarse a los «extraños»" 95 , sin embargo con esta porosidad entre lo público y lo privado que generan las prácticas contemporáneas en torno a la fotografía y su publicación forzosa en las redes sociales y demás plataformas públicas, esa distinción a la que apuntaba Bourdieu quedará totalmente fracturada.

Así, en la actualidad, la mujer adolescente tiene reivindicados y ganados dos espacios dentro de ese hogar. Estos espacios están perfectamente vinculados a la creación de los self shots: hablamos del cuarto de baño y del dormitorio (la habitación propia).

El cuarto de baño es el espacio más privado del hogar familiar contemporáneo, siendo generalmente el único habitáculo con pestillo y que, por tanto, permite a la adolescente gozar de la privacidad y seguridad que este le proporciona. Aunque se presupone que es un espacio para la práctica de la 
higiene diaria, la autorretratista o el autorretratista puede usarlo también como escenario donde realizar sus acciones fotográficas. Durante el largo periodo que supone una ducha, la adolescente tiene todo lo que necesita: privacidad, tiempo para experimentar, un gran espejo en el que fotografiar su reflejo y una pequeña y discreta cámara digital o smartphone. Es un espacio que se presta a la realización de mirrorpics, desde los más convencionales, a los más eróticos. Sean publicados o no, es un buen laboratorio de creación e investigación, como se puede ver en la abundante cantidad de self shots de "cuarto de baño" que estamos viendo a lo largo de estas páginas (Imagen 5.27).

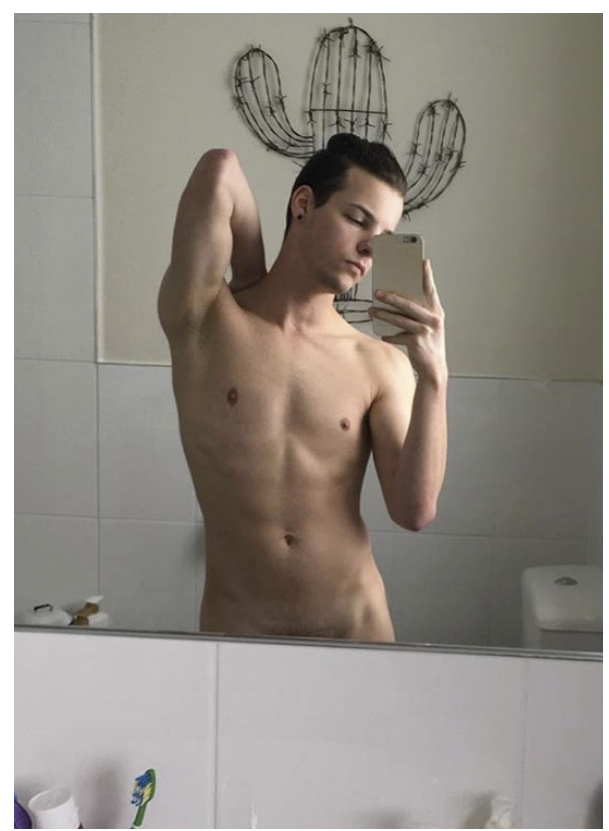

Imagen 5.27: Self shot de tipo mirrorpic o autorretrato de espejo publicado en la red realizado por un joven en su cuarto de baño.

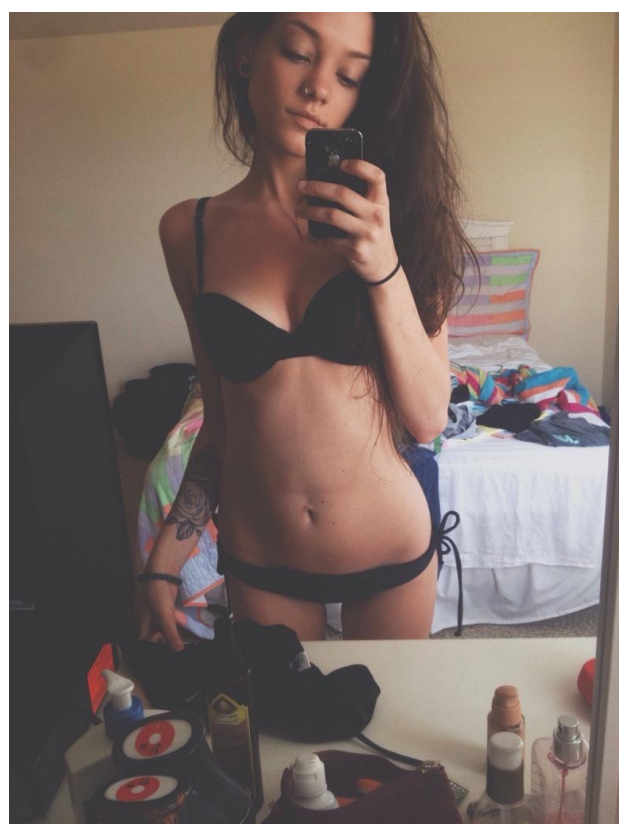

Imagen 5.28: Autorretrato digital publicado en la red de una joven en su habitación. Igual que la anterior imagen, una fotografía de carácter erótico que se ha hecho (con, o sin el consentimiento de su autora) pública en la red. 
No obstante, el dormitorio de la adolescente es su verdadero espacio privado, dado que, por lo general, no se halla compartido: se trata de su conquista en el hogar. En él también tiene un espejo donde observarse, además de su armario lleno de ropa y una considerable privacidad (Imagen 5.28). Además, en la habitación está la ventana bidireccional al mundo: el computador como vía de publicación de las imágenes creadas. Hay que decir que la figura del ordenador como complemento de salida para la fotografía recién realizada ha menguado tras la aparición de los smartphones que están asumiendo poco a poco su papel, a la par que añaden portabilidad y ejercen como monitores, actuando también como ventana desde la que se observa, se publica y se comenta.

La habitación de la adolescente es una de las principales salidas del self shot y de los selfies más íntimos, la puerta a las redes sociales y a las vías de publicación del autorretrato digital. Es, por ello, el otro escenario clásico de los mirrorpics, el espacio privado convertido en público a través de la imagen.

Remedios Zafra analiza importantes cuestiones acerca de estos "cuartos propios conectados" en su obra del mismo nombre. Sobre ellos dice:

"La primera cuestión a tener en cuenta en un ejercicio de actualización del cuarto propio es que este se concibe como un lugar inscrito, pero diferenciado, del lugarhogar en que se inserta. [...] Esta precisión fue en su momento medular y revolucionaria (y aún hoy tiene vigencia)"96.

Zafra asocia esta conquista de la mujer de la que hoy gozan las adolescentes, a su lucha por la independencia y privacidad en el hogar inspirada desde hace décadas por la fundamental obra de Virginia Woolf Una habitación propia: 
"Una habitación propia y una cantidad económica suficiente anual eran, decía Virginia Woolf, condiciones necesarias para que las mujeres pudieran dedicarse de manera autónoma a la creación. [...] La inspiradora propuesta de esta emblemática obra de Woolf hizo que el cuarto propio no tardara en convertirse en objeto de especulación, reivindicación feminista y símbolo de emancipación, y no solo para las mujeres escritoras a quien entonces Virginia Woolf dirigía su reflexión” ${ }^{97}$.

No nos parece nada azaroso la utilización de la figura de Virginia Woolf como precursora del derecho del espacio íntimo de creación privado que las mujeres han defendido y ganado desde las reivindicaciones de esta importante escritora: fue en el otoño de 1928, cuando Virginia Woolf estuvo invitada a dar una serie de conferencias sobre mujer y novela, en dos instituciones universitarias for ladies, porque las demás (consideradas las buenas) por aquella época aún estaban restringidas a los gentlemen. La escritora aprovechó la ocasión para intentar responder, larga y bellamente, una pregunta: “¿por qué las mujeres no habían escrito, hasta entonces y salvo poquísimas excepciones, buenas novelas?”. Paula Sibilia nos sintetiza la respuesta:

"[...] porque no tenían cuarto propio, porque carecían de un espacio privado, de una habitación exclusiva para ellas donde hubieran podido quedarse a solas. Si las dificultades siempre fueron grandes para quien quisiera crear una obra literaria, por lo menos hasta aquel momento todo había sido infinitamente más complicado para una mujer"98.

Para ellas, hasta principios del siglo XIX, tener un cuarto propio, para no hablar de una habitación tranquila o a prueba de ruidos, era algo inconcebible. Precisamente Woolf lo redacta así en su obra referenciada:

"Cuanto podía ofreceros era una opinión sobre un punto sin demasiada importancia: que una mujer debe tener dinero y una habitación propia para poder escribir novelas; 
y esto, como veis, deja sin resolver el gran problema de la verdadera naturaleza de la mujer y la verdadera naturaleza de la novela" ${ }^{99}$.

De manera similar, estas jóvenes adolescentes utilizan sus cuartos propios como laboratorios de creación fotográfica, como escenarios de representación, como lugares desde donde compartir su imagen, publicando estos autorretratos. La habitación propia sigue siendo, para muchas, un espacio de escritura y de reflexión a través de las plataformas que ofrece la Web. Un lugar que tiene todo lo que necesitan para construir sus diarios personales (Imagen 5.29):

"De todos los cuartos propios de mi vida, es en los cuartos conectados donde lo privado se funde literalmente con lo público, y entonces lo político se incrementa. Mantengo aún la esperanza de que el cuarto conectado amplificará la potencia de un cuarto propio y de una existencia emancipada. Pero no guardo la esperanza estúpida de que esto pasará por defecto"100.

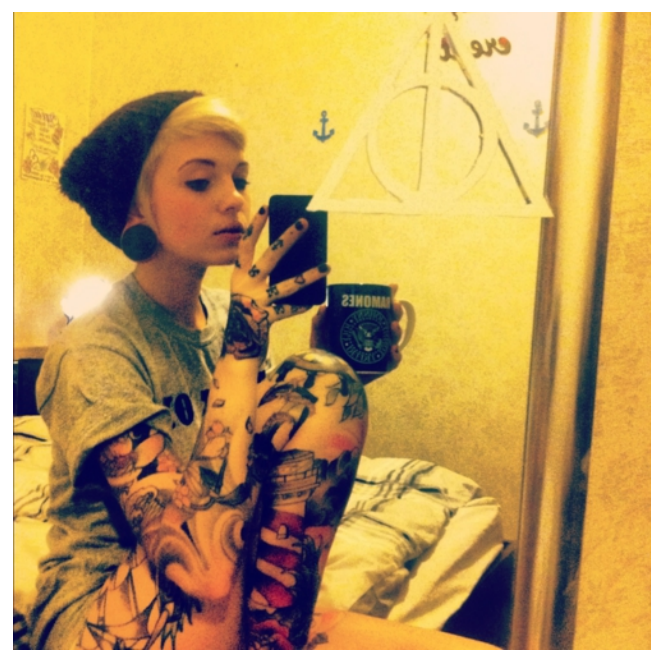

Imagen 5.29: Un mirrorpic que presenta a una adolescente en su habitación.

99 WOOLF, Virginia, Una habitación propia, Barcelona, Seix Barral, 2008, pág. 6.

100 ZAFRA, Remedios, op. cit., pág. 25. 


\subsubsection{La pantalla indiscreta.}

La red ha convertido las pantallas en una prolongación de los y las adolescentes. Es en estas pantallas donde se autopresentan y en donde en ocasiones divulgan sus experiencias íntimas mediante imágenes erotizadas ${ }^{101}$. Lugares donde el usuario afirma su poder y tiene el control, pudiendo evitar, gracias a estas prácticas telemáticas, las complicaciones, inseguridades $\mathrm{y}$ complejidades que plantea el contacto humano ${ }^{102}$.

“[...] la red hizo de la pantalla: ventana, espejo, pizarra y panóptico, y [...] era portátil. De forma que nos permitía ser productores y distribuidores de cosas e ideas digitalizadas, cosas que podíamos compartir y construir con los otros conectados desde un rincón de nuestra casa o de cualquier otro espacio online. Pasó además que la pantalla estaba diseñada «unipersonalmente» para unos ojos, unas manos con dedos que teclean y un individuo que podía liberar en la máquina parte de su memoria de archivo y presente" ${ }^{103}$.

Estos monitores conectados a Internet son un vórtice bidireccional por donde fluyen ideas e imágenes. Unos los emplean para difundir sus imágenes creadas. Otros los emplean para consumir esas mismas imágenes. Esta conexión puede ser unidireccional (persona-persona) o multidireccional (persona-mundo o mundo-persona). En este espacio virtual y telemático en el que el narcisista y el voyeur conviven y se retroalimentan, lo público y lo privado se mezcla y se confunde. Estos dos territorios quedan ahora separados por una fina y porosa membrana llamada red y que provoca su ósmosis.

101 CRESCEBZI, Lanna y TORTAJADA, Iolanda, "Privacy, Self-disclosure and Self-image of Spanish Teenagers on Social Networking Sites. The Case of Fotolog”, en Communication \& Society, vol. 26, no 2, 2013, pág. 75 .

102 LISTER, Martin (Comp.), op. cit., pág. 226.

103 Ibídem, pág. 16. 
"La red vincula el espacio privado de muchas y diferentes maneras con el mundo exterior y la esfera pública, aceptando que esta sería una expresión también en reflexión no limitada a clásicas tareas de trabajo y acción pública, sino promotora de otras por venir" ${ }^{104}$.

Sin embargo, esta "mezcla de la calidez del espacio íntimo y privado que regulado online se deja hacer público"105 atiende única y exclusivamente al desarrollo de la red y a los nuevos paradigmas de relación online que el adolescente (y gran parte del resto de la sociedad) ha redefinido tras la aparición de esta.

Podríamos decir, por tanto, que por mucha fotografía que se esté produciendo tras la democratización de los dispositivos digitales en la esfera doméstica, sin la existencia de la red no habría la escala de filtración que actualmente se produce. Una vida en directo solo puede ser obra, lógicamente, de una conexión online a tiempo real.

Así, la fotografía digital se consume en su propio soporte: la pantalla. En estas pantallas globales se desarrolla la vida moderna. Pueden ser grandes como una televisión de setenta pulgadas o pequeñas como un smartphone ${ }^{106}$, indiscretas como las conectadas a cámaras de seguridad o múltiples como las pantallas de las computadoras conectadas a la red. "La multiplicidad de formatos, en última instancia, apunta también a una multiplicidad de agentes, al cambio de paradigma del ya viejo individuo moderno a la colectividad, dentro de lo que ha dado en llamarse «cultura transmedia»"107.

104 Ibídem, pág. 51.

105 Ibídem, págs. 20-21.

106 Desde principios de esta década podemos decir que "El smartphone envuelve todas las dimensiones o esferas de la vida del adolescente". CUESTA, Ubaldo y GASPAR, Sandra, "Análisis motivacional del uso del smartphone entre jóvenes: una investigación cualitativa”, en Historia y comunicación social, vol. 18, nº 2, 2013, pág. 438.

107 RÓDENAS, Gabriel, “Capturar es compartir. Filosofía, redes sociales y fotografía 2.o”, en Enrahonar. An International Journal of Theoretical and Practical Reason, $\mathrm{n}^{\circ} 5^{\circ}$ (Ejemplar dedicado a: Estética 
La pantalla, como concepto y objeto desarrollado en occidente, ha sido uno de los principales atributos de la modernidad. La "pantalla clásica", representada por la pintura, la fotografía y la imagen gráfica, nos presentaba la existencia de otro espacio virtual, de otro mundo tridimensional, encerrado en un marco y situado dentro de nuestro espacio habitual. El cuadro ha separado dos espacios absolutamente distintos que, de algún modo, coexisten. Como evolución de la pantalla clásica, un nuevo tipo de pantalla se instauraría durante el siglo XX: la "pantalla dinámica". Esta nueva modalidad de pantalla ha conservado todas las propiedades de la pantalla clásica, pero añade algo nuevo: puede mostrar una imagen que cambia en el tiempo. Es la pantalla del cine, el vídeo y la televisión. Más adelante esta pantalla se basará en la presentación (en directo y en tiempo real) y finalmente en la interactividad ${ }^{108}$. Por tanto, la pantalla que nos ocupa, aquella por donde fluyen los selfies y resto de autorretratos digitales publicados en la red quedaría definida como "un tipo interactivo, que es un subtipo del tipo de tiempo real, que es un subtipo del tipo dinámico, que es un subtipo del tipo clásico"109.

Y precisamente van a ser estas pantallas indiscretas las que van a esparcir estas imágenes aparentemente privadas y que terminarán, por cualquier vía fáctica, publicándose en sus cálidas superficies LCD y OLED. En ellas se plasma esa línea borrosa entre el escenario y el detrás de bastidores o backstage: lo que parece un espacio íntimo para y con los amigos puede estar abierto a la mirada digital de una audiencia grande y desconocida. Lo que está siendo presentado "podría ser una mezcla de atributos de lo privado y lo público, un escenario inserto dentro de espacios privados que contienen relaciones personales y a veces íntimas. Sin embargo, también está abierto a personas externas. Así, "la

de las imágenes), 2015, pág. 61.

108 MANOVICH, Lev, El lenguaje de los nuevos medios de comunicación. La imagen en la era digital, Barcelona, Paidós, 2005, págs. 147-155.

109 Ibídem, pág. 155. 
performatividad en las redes sociales [...] enfatiza la yuxtaposición entre lo privado y lo público"110. Y esta yuxtaposición podrá abarcar desde el más inocente autorretrato compartido por diversión, hasta la declaración más erótica realizada, generalmente por medio del desnudo, por el sexter o la sexter ${ }^{111}$, y entre estos dos extremos, la posición de quien simplemente representa (o más bien presenta) su vida en directo: desde una pionera, JenniCam, hasta las actuales showcammers o las jóvenes influencers siempre online.

\subsubsection{JenniCam: una vida en directo.}

Aunque hoy encontramos muchos ejemplos de cuerpos publicados en la esfera pública gracias a las nuevas tecnologías (entre ellos, los representados en los self shots de las adolescentes), podemos recordar el primer caso que supuso la publicación de una vida en directo y que inspiró a tantos otros en el futuro. Se trató de una de las primeras brechas que empezó a plantear la imagen privada como dominio público a través de las nuevas tecnologías e Internet. Hablamos de JenniCam: la primera presentación voluntaria de un cuerpo en la red, el cuerpo de la pionera Jennifer Kaye Ringley.

Jennifer era una estudiante universitaria estadounidense. En 1996, y a la edad de 19 años, empezó a publicar su vida en directo a través de la webcam de su computadora y de otra serie de cámaras conectadas a la red. Su vida, su intimidad y su cotidianidad fueron desde ese año dominio público,

110 GIRALDO, Diana y RUEDA, Rocío, op. cit., 139.

111 Sexter, es decir, "una persona que expone algunos aspectos de su expresión sexual a través de medios digitales”. DE PIERO, José L., y NARVAJA, María E., "Prácticas juveniles éxtimas: sexting y vlogging”, en Aposta. Revista de ciencias sociales, nº 69 (Ejemplar dedicado a: El análisis del discurso digital en las ciencias sociales), 2016, pág. 250. 
retransmitidas ${ }^{12} 24$ horas al día y 7 días a la semana a través del sitio web que creó (y por el que más tarde, empezaría a cobrar): JenniCam (Imagen 5.30).

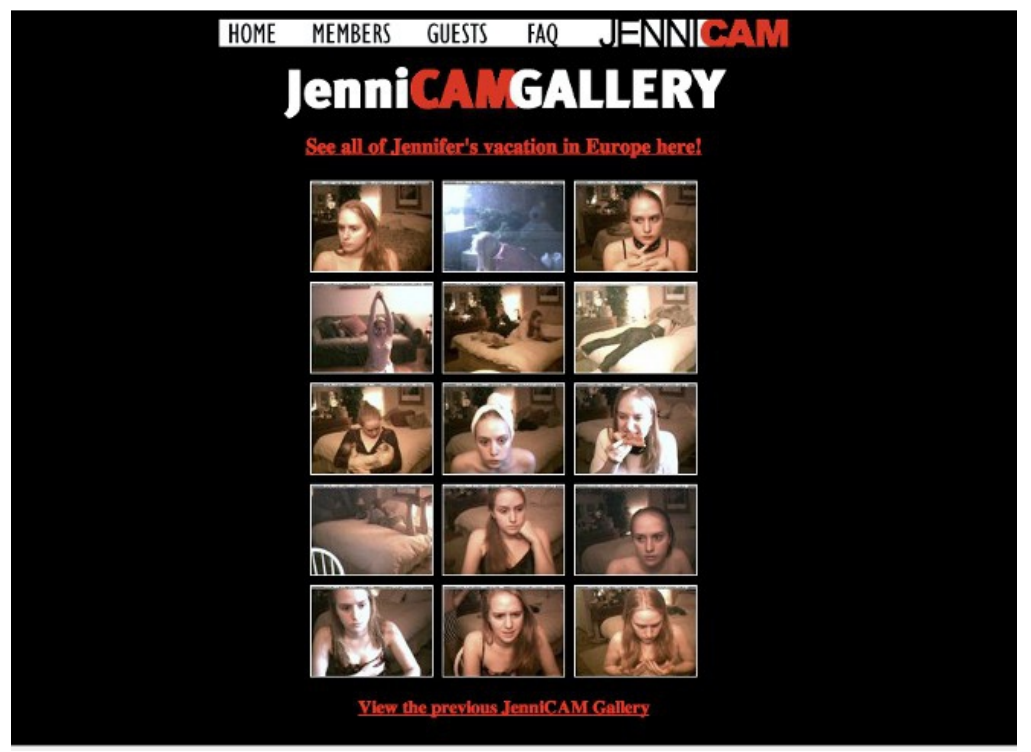

Imagen 5.30: Imagen (captura de pantalla) que muestra, como si de un fósil digital se tratara, el ya extinto sitio web de JenniCam.

Jenni se convierte así en una pionera del lifecasting que, en ese momento, ya estaban utilizando programas televisivos como Gran Hermano, tema que será abordado desde la ficción cinematográfica en películas como The Truman Show ${ }^{113}$.

Durante sus más de seis años de emisión, nada escapaba al ojo de la webcam de Jennifer. Ella se mostraba en las escenas más cotidianas, pero

Sus primeras retransmisiones no se realizaban exactamente sobre el soporte vídeo, en realidad eran imágenes estáticas que se actualizaban cada tres minutos dada la limitación que presentaban las conexiones de Internet de aquella época. No obstante, con el paso de los años JenniCam empezó a presentarse a través de vídeos cortos.

113 FELDMAN, Edward S.; NICCOL, Andrew; RUDIN, Scott y SCHROEDER, Adam (Productores), WEIR, Peter (Director), The Truman Show (El show de Truman) [Cinta cinematográfica], Estados Unidos, Paramount Pictures / Scott Rudin Productions, 1998. 
también en las más íntimas y sexuales. Por ese agujero, los voyeurs del otro lado de la pantalla podían disfrutar del estímulo que para ellos suponía ver en imágenes una vida completa retransmitida a tiempo real (Imagen 5.31), como si se tratara de una de las telenovelas diarias instauradas durante el auge de la televisión como medio de entretenimiento de masas, salvo por el carácter completo de realismo ${ }^{114}$. El sitio llegó a recibir visitas de todas las partes del mundo, marcando récords de cuatro millones de visitantes diarios ${ }^{115}$.
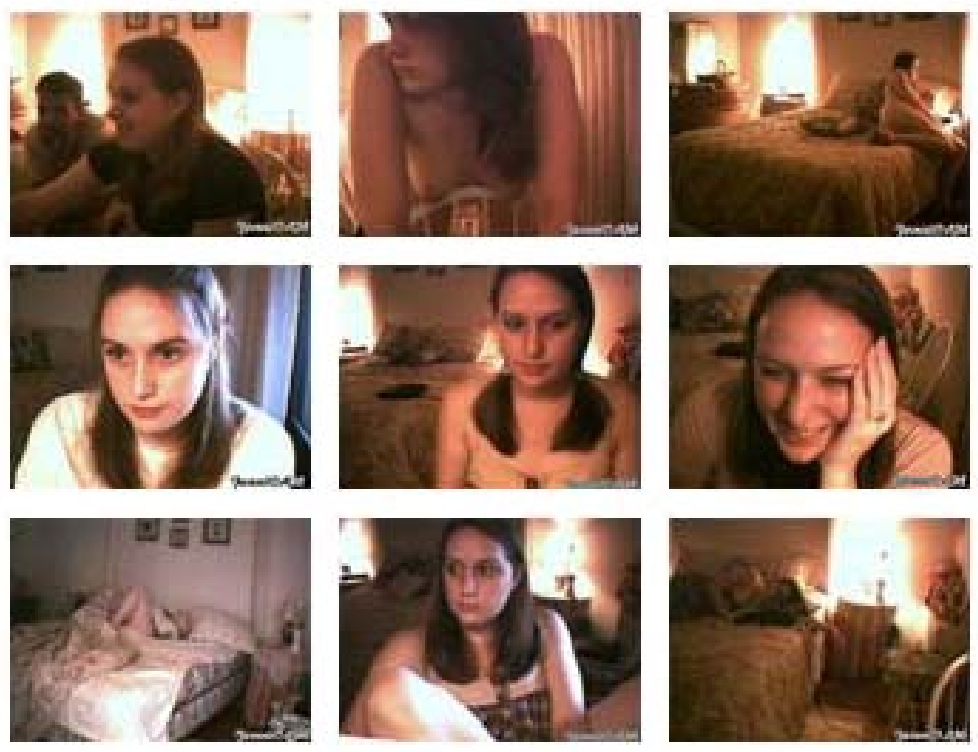

Imagen 5.31: Imágenes de Jennifer obtenidas a partir del buscador de imágenes de Google Inc.

114 GONZÁLEZ REQUENA, Jesús, El discurso televisivo. Espectáculo de la postmodernidad, Madrid, Cátedra, 1992, pág. 11.

115 Existen muchos documentos y artículos que atestiguan el fenómeno que supuso JenniCam. Hemos extraído la información aquí mostrada de un documento elaborado en 2011: DÍAZ, Carlos Alberto, "JenniCam y el cibervoyeurismo cumplen 15 años", disponible en: < http://www.enter.co/vidadigital/jennicam-y-el-cibervoyeurismo-cumplen-15-anos/> [Fecha de consulta: 20 de julio de 2016]. Asimismo, se pueden ver imágenes de los últimos días de emisión de JenniCam en: $<$ http://www.arttech.ab.ca/pbrown/jenni/jenni.html> [Fecha de consulta: 20 de julio de 2016]. 
Pero Jennifer no sería la única en mostrar su cuerpo y su vida privada a través de su imagen y de las nuevas tecnologías. Se trató de un hecho puntero, pero para nada aislado: en pocos años, miles y miles de adolescentes desarrollarán ejercicios similares mediante sus dispositivos de captura digital gracias a sus selfies y demás ejercicios de autorretrato. JenniCam empezó a marcar las pautas estableciendo esa relación entre cibervoyeur y selfshooter narcisista que tanto se iba a dar en el futuro, aliviando esa ansia de ojear por la mirilla de la habitación privada que han tenido las sociedades educadas en el valor de lo verdadero:

\footnotetext{
"Cuando más se ficcionaliza y estetiza la vida cotidiana con recursos mediáticos, más ávidamente se busca una experiencia auténtica, verdadera, que no sea una puesta en escena. Se busca lo realmente real. O, por lo menos, algo que así lo parezca. Una de las manifestaciones de esa «sed de veracidad» en la cultura contemporánea es el ansia por consumir chispazos de intimidad ajena. [...] Internet es un escenario privilegiado de este movimiento, con su proliferación de confesiones reveladas por un yo que insiste en mostrarse siempre real, pero el fenómeno es mucho más amplio y abarca diversas modalidades de expresión y comunicación”"116.
}

\subsubsection{El voyeur $y$ "la vecinita de al lado".}

Como hemos visto, JenniCam solo fue el principio de una vida íntima trasladada al espacio público de las pantallas que se propagó de manera masiva con la llegada de la Web 2.0 y sus redes sociales, así como con el uso de la fotografía para presentar el "cuerpo en el refugio" y su contexto mediante la autofoto. Estos hechos que tienen sus precedentes en la primera década del siglo

116 SIBILIA, Paula, op. cit., págs. 221-222. 
XIX, y que se institucionalizan durante la segunda, han actuado como referente histórico y perfecto caldo de cultivo para el crecimiento del cibervoyeur que, desde la privacidad de su (otra) habitación, espiará y coleccionará (mediante la mirilla hecha pantalla) el objeto a poseer: un archivo de imagen digital (JPG) almacenable y replicable. No obstante, el voyeur también podrá ser el propio productor de self shots, en los que se inspirará para seguir la cadena icónica, estableciendo una especie de pacto de voyeur a voyeur:

“¿Qué tiene que ver la representación del cuerpo, del self, a través del autorretrato, en todos estos procesos participativos en la esfera pública? En la era del synopticon, absolutamente todo, siempre y cuando la mera anécdota devenga narración a través de una serie. Bajo este punto de vista, la capacidad de autorrepresentación consiste en que yo soy, al mismo tiempo, un voyeur y un icono para otros que sancionan positivamente expresando su adhesión, bien mediante un comentario, bien con la discreta fórmula de la herramienta «Like» o «Favorito». En este contexto, el silencio es altamente significante en tanto que adquiere el valor expresivo opuesto al de dicha adhesión"117.

Este apunte hacia las redes sociales no es casual, pues también estos escenarios del ciberespacio son los habitáculos en los que el voyeur se asoma, además de manera ritual, a diario. Cualquier persona que consulte una red social sin dejar constancia lo es. Las redes sociales se han atrevido a redefinir la categoría de fotografía añadiendo un ingrediente que parecen dominar a la perfección: el voyeurismo ${ }^{118}$. Así pues, el compromiso con lo fotográfico y con su referente en la red social parecería claro: "El voyeurismo constituye un ejercicio importante en la economía del psiquismo humano, pues implica fuertemente al mirón en un compromiso con lo mirado" ${ }^{119}$.

117 BROULLÓN-LOZANO, Manuel A., "Por una semiótica del selfie en la cultura visual digital", en Fotocinema. Revista científica de cine y fotografía, $\mathrm{n}^{0}$ 11, 2015, pág. 229.

118 FAERMAN, Juan, op. cit., pág. 61.

119 GUBERN, Román, La imagen pornográfica y otras perversiones ópticas, Barcelona, Anagrama, 2004, pág. 17. 
"Una mirada, una distancia, un cuerpo que se exhibe afirmando como imagen que fascina. He aquí, entonces, los elementos necesarios para una situación de seducción. Pues lo que pretende el cuerpo que se exhibe es seducir , es decir, atraer -apropiarsede la mirada deseante del otro" ${ }^{120}$.

Ya hemos visto cómo "la cultura popular es una «máquina productora de deseo»"121. A continuación veremos cómo, durante finales de la década pasada, algunas autorretratistas saltaron a la fama entre varias comunidades y canales del ciberespacio de manera pasiva y sin buscarlo. Esta notoriedad, nacida de la nada, o mejor dicho, de un simple puñado de self shots en los que se reunían suficientes argumentos para justificar su comportamiento viral, convertiría el tranquilo anonimato en una pandemia que se vería prolongada por las clásicas obsesiones que conlleva la fama para con su público. De repente, la (generalmente) chica de Pasadena (Estados Unidos), de Zihuatanejo (México) o de Wellington (Nueva Zelanda), había pasado a convertirse en nuestra "vecina de al lado" ${ }^{122}$. Al fin y al cabo "conocer o reconocer al personaje en un retrato es el deseo original del voyeur"123.

\subsection{Del autorretrato a la fama.}

Según acabamos de apuntar, en nuestros días, miles de adolescentes de los países industrializados se presentan y representan a través del espejo y de su

\footnotetext{
120 GONZÁLEZ REQUENA, Jesús, op. cit., pág. 59.

121 KAUFFMAN, Linda S., Malas y perversos. Fantasías en la cultura y el arte contemporáneos, Madrid, Cátedra, 2000, pág. 20.

122 En el sentido clásico, el interpretado y personificado por Claudette Colbert o por Doris Day en el cine. ECO, Umberto, op. cit., pág. 425.

123 SÁNCHEZ-VIGIL, Juan Miguel, op. cit., pág. 82.
} 
imagen reflejada en los dispositivos de captura digital. Se trata de una tendencia casi mecánica, a medio camino entre lo habitual y costumbrista y lo patológico. Esos narcisistas cibernéticos han quedado petrificados en su imagen reflejada, inmortalizada en un autorretrato digital publicado. Gustan contemplarse y ser contemplados. Son imagen reflejada en sus pantallas-espejo.

"Narciso, pues, es en primera instancia un sorprendido mortal que contempla su propio retrato vivo, y su sorpresa es la certificación de que su percepción del mundo y de sí mismo, y la solidez de las cosas, su volumen y su forma, tiene una especie de envoltorio físico, al menos en su superficie, ya que no hay que olvidar que en el agua (o en el espejo), lo que apreciamos es la superficie de lo real, su aspecto. Pero quizá eso es lo que hace al reflejo tan necesario ya que propone sobre un plano de dos dimensiones una ficción convencional y ordenada de la extraña tridimensionalidad espesa de la realidad" ${ }^{124}$.

Pese a que esta tendencia de producción de imágenes llevada a cabo por nuestras autorretratistas contemplativas parece, en principio, no destinada necesariamente a buscar la fama ni la gloria (por lo menos a nivel global), en algunas ocasiones sus seguidores así lo procuran. Miles de fans de estas adolescentes primeramente anónimas y convencionales, consiguen catapultar su imagen hasta la reproducción casi infinita en la red. Existen casos de adolescentes selfshooters que pasan del reconocimiento exclusivo en sus vecindarios e institutos, a la fama global gracias a sus propias imágenes (fruto de sus autorrepresentaciones) distribuidas por unos admiradores que crecen tan rápido y paralelamente a los archivos digitales copiados y difundidos por las entrañas de la red. Repasaremos brevemente tres de estas jóvenes autorretratistas que se hicieron famosas en el ciberespacio cuando estas prácticas eran de realización casi exclusivamente adolescente, a principios de esta década. Nos referimos a Mónica Lizeth Murillo, Jaime Laycock y Leda Bunny.

124 CUETO, José L., El hecho pictórico. El acto fotográfico: la mirada y la memoria como material de la práctica artística, Valencia, Universitat Politècnica de València, 2001, pág. 57. 
Mónica Lizeth Murillo (Imagen 5•32), una adolescente anónima que hacía los quehaceres habituales de esas edades en la ciudad de Hermosillo, al noroeste de México, se vio catapultada a la fama virtual en cuestión de semanas gracias a su Metroflog ${ }^{125}$ y a sus autorretratos publicados en esta plataforma personal (Imagen 5.33). Tenía entonces 16 años. Mónica compartía en esta red social y de manera diaria un autorretrato realizado con su dispositivo digital (en esa época, una cámara compacta económica). Su selfies encuadrados de manera cenital ${ }^{126}$ (Imagen 5.34) empezaron a crear una tendencia (o quizá ya formaban parte de ella) practicada desde entonces por otras selfshooters. Su distribución en otros foros ajenos a esta red que funcionaba para Mónica como un diario personal, multiplicaron sus imágenes hasta la saciedad, y su Metroflog pasó a recibir miles de visitas diarias con sus respectivos comentarios. Hoy en día su imagen clonada sigue ocupando decenas de gigas en servidores y discos, basta con poner su nombre en Google (Imagen 5.35) para hacerse una idea. Sin embargo, la Mónica de 26 años ya no es tan mediática como la de antaño. Su Metroflog ${ }^{127}$ todavía existente, yace ahora abandonado e inactivo, aunque todavía conserva sus imágenes y comentarios, sirviéndonos así como vestigio histórico y huella de lo que ocurrió entre 2007 y 2009 con la imagen autorretratada de esta joven adolescente mexicana. Por otra parte, su nueva y más adulta fisonomía (Imagen 5.36) ha alcanzado cierta notoriedad en Instagram ${ }^{128}$ (curiosamente, también la red social característica de estos años) con la no desdeñable cifra de 112.000 seguidores que, sin embargo, no sirve para alcanzar las cotas aceptables por cualquier influencer contemporánea. De ahí que se puede afirmar que la Mónica Lizeth Murillo contemporánea es una perfecta desconocida si comparamos su

125 Red social basada en la imagen muy popular durante la década pasada y que repasaremos en el capítulo 6. Especialmente apreciada por la comunidad latinoamericana, hizo las veces de diario fotográfico para miles de adolescentes mexicanas entre 2006 y 2010 aproximadamente.

126 En gran parte, y como hemos estado repasando, capricho de la máquina.

127 Véase: <http://www.metroflog.com/MonicaPrinces> [Fecha de consulta: 30 de julio de 2017].

$128 \mathrm{Su}$ cuenta es pública, y se puede consultar en: <https://www.instagram.com/monica_murillogo/? $\mathrm{hl}=\mathrm{es}>$ [Fecha de consulta: 22 de marzo de 2018]. Entre sus fotografías publicadas, encontramos una en la que se compara fotográficamente con su yo pasado (Imagen 5.37). 
fama actual con la anterior, siendo ahora una más en la ingente maraña de atractivos chicos y chicas jóvenes que publican, con constancia, su vida en las redes sociales más contemporáneas.

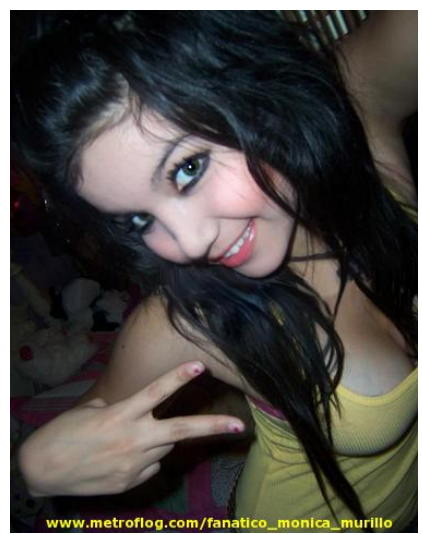

Imagen 5.32:

Autorretrato de Mónica Lizeth Murillo en 2008.

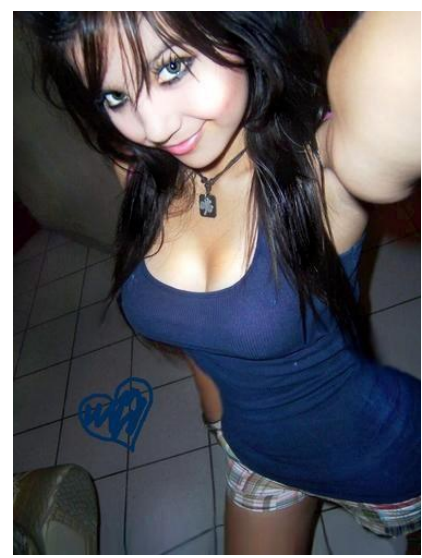

\section{Imagen 5.34:}

Autorretrato de Mónica Lizeth Murillo en 2009. Uno de los que más se ha clonado, tanto para su viralización, simulación de cuentas falsas y soporte de publicidad engañosa.

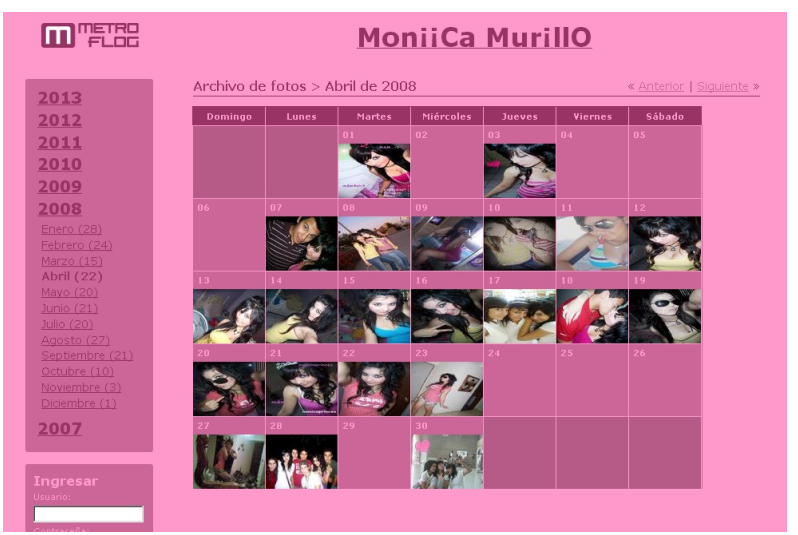

Imagen 5.33: Metroflog original y oficial de Mónica Lizeth Murillo. Muestra las fotos incorporadas al sitio durante abril de 2008.

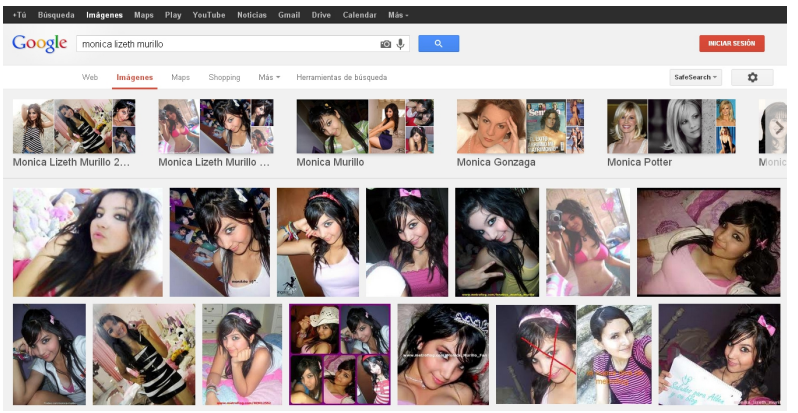

Imagen 5.35: Imágenes de Mónica Lizeth Murillo expuestas en Google. Lo visualizado en esta captura de pantalla es solo la punta del iceberg. 


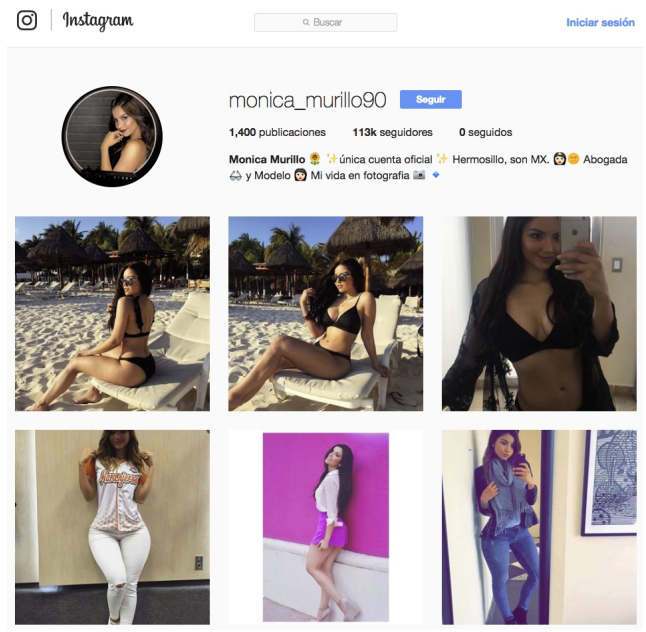

Imagen 5.36: Home de Instagram de Mónica, en la actualidad.
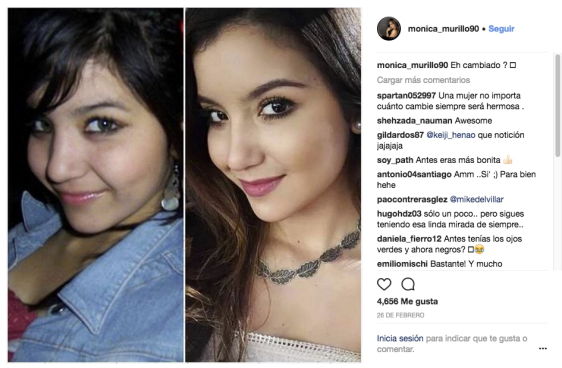

Imagen 5.37: Comparativa que la propia usuaria hace de su yo pasado con su yo presente.

El caso de Jaime Laycock (Imagen 5.38) es similar al de su anterior coetánea en prácticamente todo, incluida su actual discreta notoriedad en Instagram $^{129}$. A finales de 2010 su imagen también clonada de manera masiva alcanzó gran fama y visibilización, entre otras cosas por el gran impulso que le otorgó el testosterónico portal de opinión ForoCoches ${ }^{130}$. Los autorretratos digitales publicados en la red (Imagen 5.39) de esta chica australiana de Melbourne $^{131}$, se ajustan a las mismas pautas formales que los de Mónica: cumplen la función de imagen-diario, presentan cierta carga de erotismo y se exhiben en la red a través de herramientas-web, perpetuando la relación establecida entre el narcisismo creador y el voyeurismo contemplador.

129 <https://www.instagram.com/jaimelaycock/?hl=es> [Fecha de consulta: 22 de marzo de 2018].

130 Se puede consultar uno de los hilos principales, previo registro, en: <https://www.forocoches.com/ foro/misc.php?do=page\&template=Info\&tid=1494507> [Fecha de consulta: 22 de marzo de 2018].

131 Ciudad situada casi en la antípoda del hogar de nuestro anterior ejemplo. Dado que los desarrollos creativos de estas dos autorretratistas tuvieron lugar de manera simultánea, llama poderosamente la atención la lejanía geográfica, hecho que constata la importancia de la red como herramienta unificadora de la imagen cultural contemporánea. 


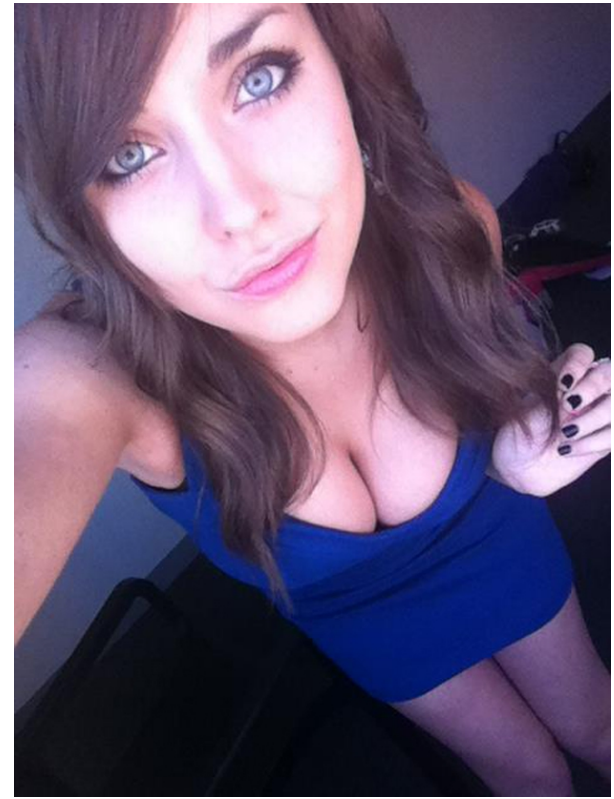

Imagen 5•38: Selfie de Jaime Laycock realizado en 2009.

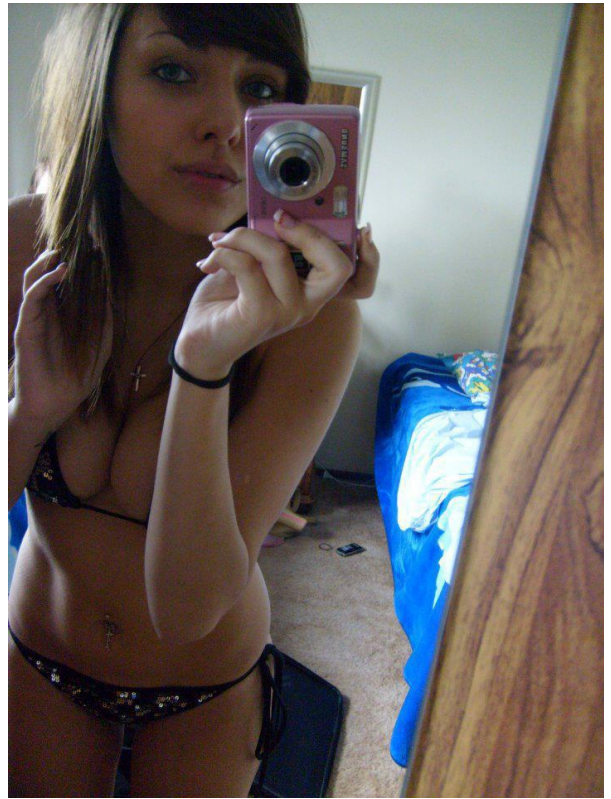

Imagen 5.39: Autorretrato digital publicado en la red de tipo mirrorpic realizado por Jaime Laycock en 2008.

Un caso menos pionero, pero sí más contemporáneo y con gran repercusión es el de la californiana Leda Bunny ${ }^{132}$ (Imagen 5.40). Esta adolescente ${ }^{133}$ cosechaba a sus 18 años más de 125.000 seguidores en la red social de microblogging por excelencia: Twitter ${ }^{134}$. Dicha red era uno de los espacios

132 Existe bastante información en la red aportada por sus usuarios en forma de wiki respecto a esta Scene Queen: VV. AA., "Leda Monster Bunny Wiki”, 2014, disponible en: <http://ledamuir.wikia.com/ wiki/Leda_Monster_Bunny_Wiki> [Fecha de consulta: 4 de marzo de 2017].

133 Desconocemos su nombre real. Usa el apelativo Leda Bunny pero también se ha anunciado durante toda su carrera en las redes hasta la actualidad como Leda Monster Bunny, Leda Muir o Tara Knight.

134 La primera cuenta de Twitter de Leda Bunny y que la catapultó a la fama en las redes se podía consultar en: <https://twitter.com/LedaBunnie> [Fecha de consulta: 20 de julio de 2013]. Pero tras una crisis, como veremos a continuación, tuvo la decisión de desconectarse de las redes y borrar todo su contenido. Actualmente la primera cuenta de Leda Bunny no existe, y sus restos ahora fósiles pueden encontrarse como capturas de pantalla (Imagel 5.42) o como imágenes desparramadas en los buscadores de imágenes de Google Inc. 
que utilizaba para difundir sus ideas y pensamientos, así como su prolífica producción de autorretratos fotográficos (antes de su retirada, más de 34.000 tuits ponían de manifiesto esta pauta hiperactiva en cuanto a producción y difusión de la imagen propia). La mayoría de los self shots de Leda Bunny siguen los patrones compositivos del selfie o autorretrato de rostro por reflejo (Imagen 5.41) que en nuestra contemporaneidad (y al contrario que ocurría con las dos anteriores selfshooters de la era pre-smartphone) se encuentran configurados por los actuales dispositivos de captura fotográfica móviles y sus lentes delanteras que proporcionan esa visión reflejada que desarrollamos en el pasado capítulo 3 .

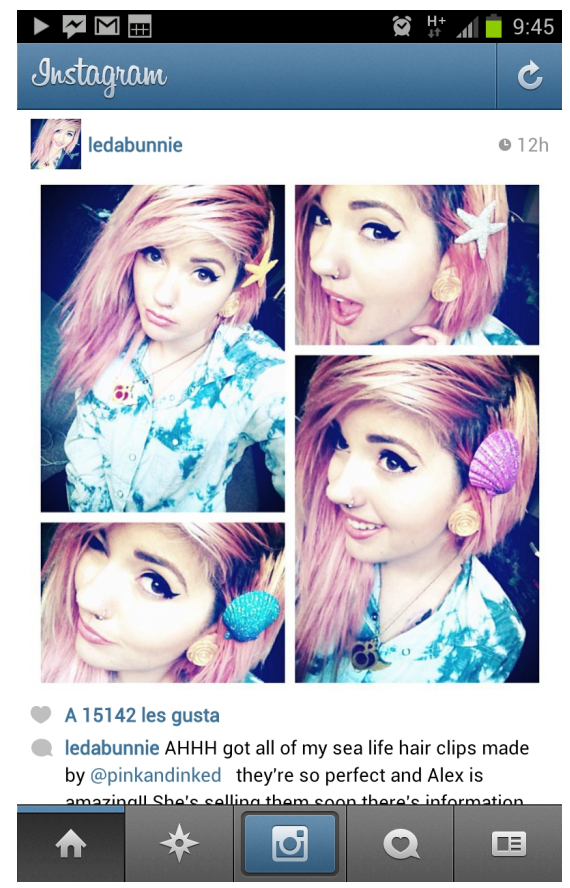

Imagen 5.40: Leda Bunny en 2012. Captura de pantalla de su extinta primera cuenta de Instagram. Hoy en día esta imagen ya no puede obtenerse en la Web.

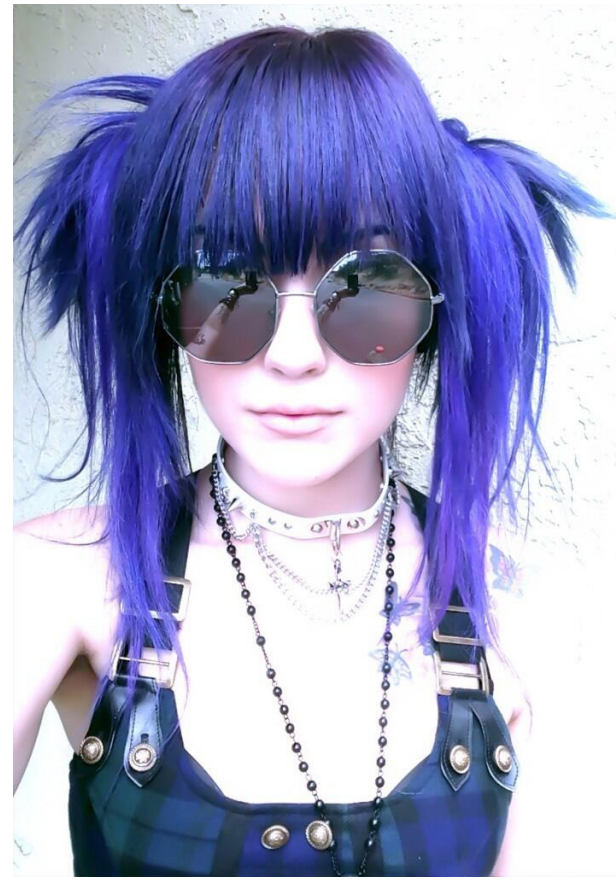

Imagen 5.41: Selfie de Leda Bunny realizado en 2012. Se puede ver el brazo sujetando el smartphone con el que realiza la fotografía a través del reflejo de sus gafas. 
Desgraciadamente para su cantidad de seguidores que quedaron huérfanos a lo largo del globo y tras lo que parece ser una crisis por saturación de presencia en los medios (cuestión que parecen experimentar muchos adolescentes cuya visibilidad en la red y fama acaba yéndoseles de las manos, pasando a sufrir una gran presión social y dependencia), Leda Bunny abandonó su vida en la pantalla el 27 de agosto de 2014, tras publicar un vídeo de despedida (Imagen 5.43) en su cuenta de YouTube ${ }^{135}$ y eliminar definitivamente todas sus cuentas y fotografías, en su gran mayoría autorretratos.

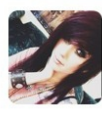

LedaMonsterBunny @LedaBunnie 3h You guys have no idea how free I feel after posting that. Really.

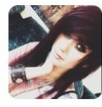

LedaMonsterBunny @LedaBunnie3h And if I lose people over that last tweet, so be it. I'm 1 month from being legal. But I won't keep secrets, promise. :') I'm happy.

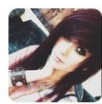

LedaMonsterBunny @LedaBu... (n 3h So, having a beautiful night and some drinks with friends. And happy. Very happy. :') pic.twitter.com/PsYnRKb5zy

Imagen 5.42: Un registro de lo que fue la popular cuenta de Leda en Twitter (antes de su marcha) representado por la captura de pantalla de varios tuits y que pudimos realizar durante los primeros años de nuestra investigación, cuando su cuenta aún existía.

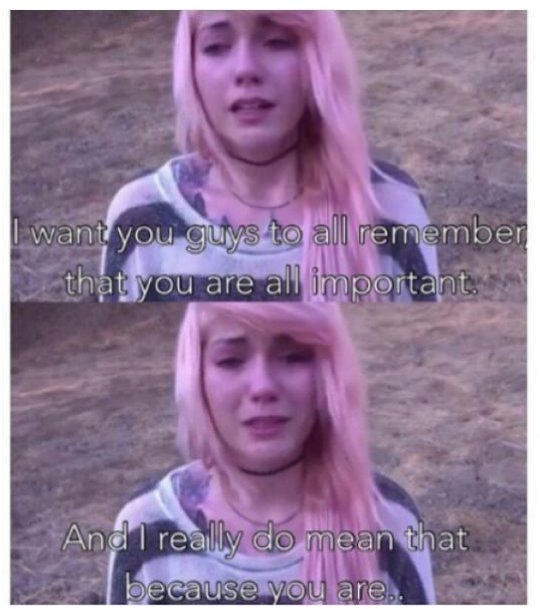

Imagen 5.43: Capturas de un par de frames del vídeo de despedida ya citado y ubicado en la Web.

Pero el dulce caramelo de la fama deja su sabor para siempre en la memoria, y como tantas personas que algún día dejan algo, Leda Bunny volvió a

135 Vídeo que alcanzó la sorprendente cifra de medio millón de visualizaciones: KNIGHT, Tara, "I Love You Guys Infinitely - Leda Muir's (Hailedabear) Goodbye Video", 2014, disponible en: <https:// www.youtube.com/watch?v=oUS9FsP_GpY> [Fecha de consulta: 4 de marzo de 2017]. 
las redes ${ }^{136}$ mediante su presencia e imagen el 21 de marzo de 2015, siete meses después de su marcha, publicando también un autovídeo en su cuenta de YouTube $^{137}$.

Pese a esta breve interrupción, Leda ha estado muy activa desde su aparición en las redes sociales, utilizando en cada momento la más popular. En ellas muestra diariamente representaciones de su rostro. Su compulsiva tendencia autotransformadora reflejada en la cantidad de veces que cambia su pelo de color, convierte una sencilla búsqueda de Google en un resultado visual de diversidad colorista (Imagen 5.44).

Pese a que Leda también presenta escenas relativamente íntimas de su cotidianidad en forma de mirrorpics (Imagen 5.45), podemos verificar, tras observar sus múltiples imágenes, que esta famosa selfshooter creadora de tendencia (influencer) no abusa del erotismo propio en la construcción de sus autorretratos.

Debido a ello, podemos afirmar que difunde así su belleza mediante otros circuitos representativos que tienen más que ver con la serenidad, la frescura o el romanticismo que muestra en sus autoposados, muchos de ellos de gran calidad formal (Imagen 5.46).

${ }_{136}$ Es muy difícil no estar en un mundo compartido por la totalidad de tus coetáneos. DOS SANTOS, Gesualda, "A prática do(a) selfie e modos de subjetivação na contemporaneidade", en Linguagem em (Dis)curso, vol. 16, $\mathrm{n}^{\circ} 1,2016$, pág. 132.

137 MUIR, Leda, "Hi I'm Back Babies ; . ;", 2015, disponible en: <https://www.youtube.com/watch? $\mathrm{v}=$ nh9rsvP9Gvk\&t=7s> [Fecha de consulta: 4 de marzo de 2017]. 


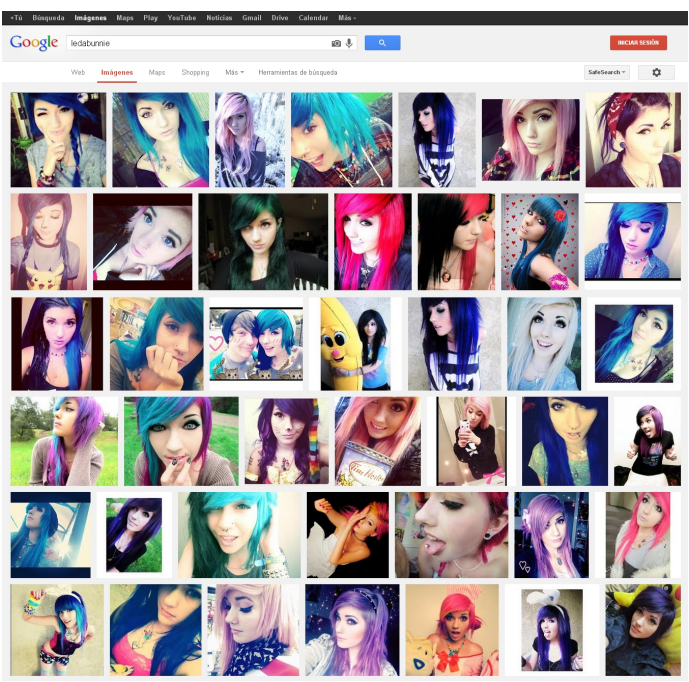

Imagen 5.44: Imágenes de Leda Bunny en Google.

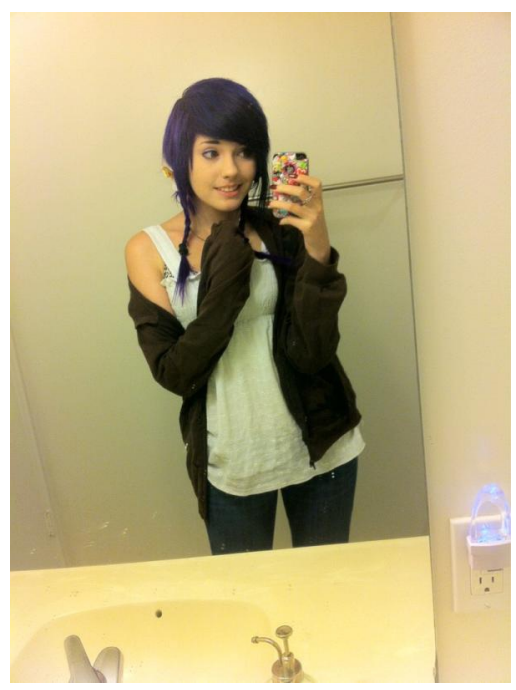

Imagen 5.45: Leda Bunny autorretratándose frente a un espejo en 2012.

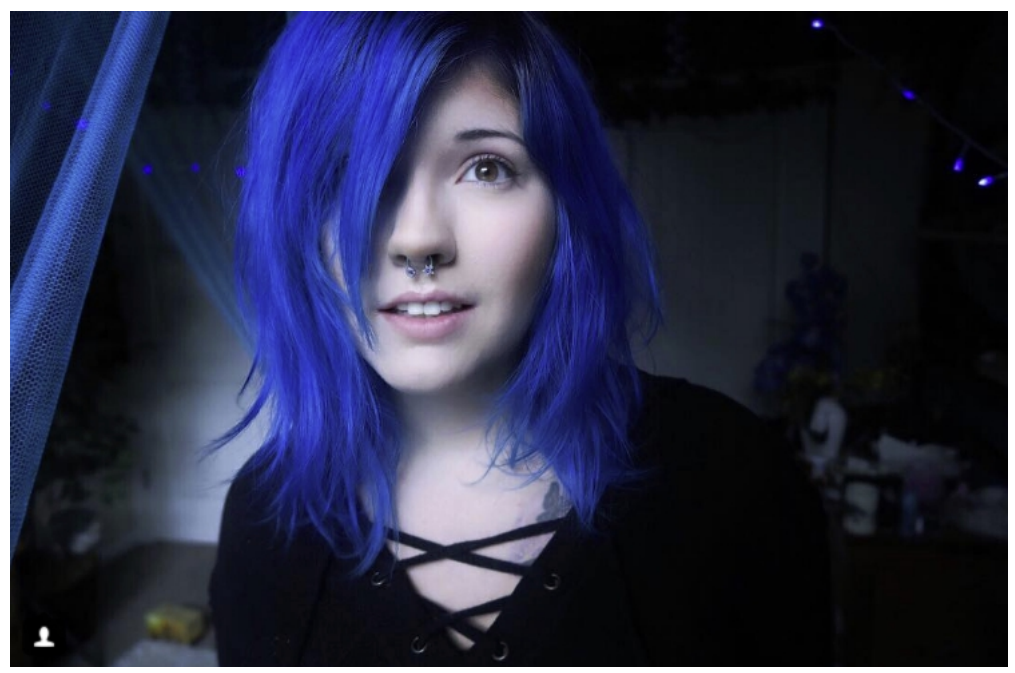

Imagen 5.46: Una de las imágenes más recientes de Leda, publicada en 2017 en su cuenta de Instagram (que actualmente cuenta con más de medio millón de usuarios adscritos). Fuente: <https://www.instagram.com/p/Bbp2uciloz6/?hl=es\&takenby=theledabunny $>$ [Fecha de consulta: 1 de enero de 2018]. 
Estos han sido solo tres ejemplos. Evidentemente, hay muchos más y todos ponen de manifiesto este hecho curioso: cómo personas completamente anónimas pueden acaparar, con o sin buscarlo, la atención de miles de seguidores y seguidoras a lo largo del globo y alcanzar cierta fama gracias a la distribución de su imagen propia en canales públicos voluntarios. Podría ser algo parecido a lo que ocurre con las $i d o l^{138}$ en Japón, con la salvedad de que, en estos casos, no existe una infraestructura publicitaria o comercial (y por tanto, cosechadora de dinero) detrás de estas autorretratistas. Su fama surge de manera espontánea y es fruto, no solo de los intereses del público masculino y femenino de la red, sino también de la naturaleza de los archivos digitales que construyen estas imágenes en relación al medio que las rodea: la copia rizomática inevitable.

Esta construcción de una identidad expandida hacia miles de observadores, por motivos obvios, no puede ser nunca simétrica. La propia naturaleza panóptico-unidireccional de la red genera un nuevo tipo de intimidad que antes no existía y que se diferencia en determinados aspectos fundamentales de las formas de intimidad características de la interacción personal. Es esta nueva forma mediática, la intimidad no recíproca que se extiende a través del tiempo y del espacio, la que subyace entre estas pioneras famosas del ciberespacio y que resulta similar a la que existía en la relación entre fan y estrella.

\footnotetext{
"Puede resultar muy estimulante, precisamente porque se encuentra libre de las obligaciones de la reciprocidad características de la «interacción cara a cara». Sin embargo, igualmente puede llegar a constituirse como forma de dependencia en la
}

${ }_{138}$ Un idol japonés (アイドル aidoru), cuya traducción castellana no corresponde exactamente con la palabra ídolo, es una celebridad que ha alcanzado gran renombre y fama en Japón debido en parte, a su apariencia. El término usualmente se refiere a celebridades femeninas japonesas que van desde adolescentes hasta jóvenes con poco más de veinte años que son consideradas kawaii (lindas, adorables) y han conseguido fama gracias a la publicidad en los medios de comunicación. 
que los individuos dependen de otros cuya ausencia e ineaccesibilidad los convierte en objeto de veneración" ${ }^{139}$.

Y, asimismo, puede resultar curioso constatar cómo esta nueva manera de visibilidad que idearon los y las adolescentes cuyas imágenes se viralizaron (primero de manera sorpresiva y después de manera controlada) en las redes, han sido imitadas por adultos y empresas de marketing. La paradoja se produce cuando, verdaderos actores de la escena mediática que ya habían alcanzado la fama antes de la llegada de las redes sociales, se apunten a estas prácticas sorprendidos por el hecho de que unos jóvenes sin ningún tipo de capacidad curricular (salvo la capacidad de presentarse bien por medio del autorretrato), les estuvieran superando holgadamente en número de fans.

"En la semiosfera contemporánea las barreras tecnológicas, económicas y teóricas entre emisor y receptor han derivado en las potencialidades de las redes, así que a esta proliferación de imágenes corresponde también una redistribución de las tradicionales formas de espectatorialidad, donde ya no se distingue entre un espacio de observación y un espacio performativo, sino que se concentra todo en un único público performer. Emerge de estas rápidas observaciones la nueva dimensión cultural de la imagen como objeto construido en lo social, además de variable en lo histórico: la discontinuidad reside en el hecho de que hoy la potencia de lo visual, su capacidad de fascinación, se encuentra diluida en una liquidez postmoderna que nivela lo alto y lo bajo y hace posible la convivencia entre diferentes registros, gracias a la omnipotencia de la plataforma de las redes. Si ya no existen jerarquías, el icono tiene que investigar otras formas de narración y de representación, no solo para volver a ejercer su poder sobre un público observador, cada vez más atento e informado, sino también para fortalecer aquella ilusoria naturaleza de referencia que le caracteriza. El icono ha sido destronado, obligado a bajarse del pedestal y a mezclarse con las otras imágenes, negociando continuamente su propio sentido" ${ }^{140}$.

139 THOMPSON, John B., Los media..., op. cit., pág. 270.

140 MATTEI, María M., op. cit., pág. 95. 


\subsubsection{Identidad e influencia.}

Estamos viendo cómo la fotografía se ha estado convirtiendo en un elemento fundamental para entender el proceso de construcción de las identidades virtuales en las redes $\operatorname{sociales}^{141}$. Así, la noción tradicional de identidad, concebida como "lo que define y delimita a un individuo como entidad estable e irrepetible y le sitúa dentro de un entorno social determinado" ${ }^{142}$, ha sufrido una importante mutación debido a la virtualización de la cultura. En este nuevo escenario, las identidades individuales y grupales son más visibles y afirmativas a la vez que más frágiles, transitorias y desechables.

\footnotetext{
"La identidad del sujeto del espacio virtualizado es fundamentalmente performativa y extrovertida, volcada hacia el proceso comunicacional del que deriva todo valor. El rostro y el cuerpo, la imagen personal o sus múltiples traducciones discursivas toman un valor axial en un escenario en el que el sujeto se concibe a sí mismo como vehículo de apariencias, como portador y transmisor del valor simbólico" ${ }^{143}$.
}

Respecto a la construcción de las identidades en estos nuevos escenarios, se constata cómo con el desarrollo de las sociedades modernas y las tecnologías adscritas a estas, el proceso de formación del yo se ha convertido en algo más reflexivo e indefinido, en el sentido de que los individuos (también los jóvenes) recurren cada vez más a sus propios recursos para construir una identidad coherente con ellos mismos ${ }^{144}$. De este modo, el desarrollo de la identidad mediante la práctica generalizada del autorretrato en la fotografía digital responderá a distintas motivaciones por parte de los jóvenes y del resto de

\footnotetext{
141 CALDEVILLA, David, op. cit., pág. 83 .

142 CARRILLO, Jesús, op. cit., pág. 36.

143 Ibídem, pág. 37.

144 THOMPSON, John B., Los media..., op. cit., pág. 269.
} 
usuarios y, en todo caso, no será solo una forma de representar y reflejar sus cuerpos, sino también una forma de imaginar su propia imagen corporal y de performar mediante esas imágenes la propia identidad personal y social, donde la identidad corporal se constituirá como un proyecto personal nunca cerrado ${ }^{145}$.

Las redes sociales son un entorno importante de cara a la exploración identitaria para los adolescentes. Sus autopresentacioones muestran la comparación social y la expresión de aspectos idealizados del sí mismo que se desearía ser. Estas redes tienen un gran peso en la socialización y, específicamente, en la construcción de la identidad de género. La identidad y las relaciones online están determinadas por una combinación entre las posibilidades técnicas que ofrecen las redes sociales y la cultura entre iguales ${ }^{146}$. Por otro lado, la propia naturaleza acumulativa y fungible de las timeline de las redes sociales constituiría el yo identitario y su publicación es un acto anacrónico, efímero y transitorio puesto que “cuando «yo» concluyo la realización de un objeto/obra ya he sido transformado por ella y, en el segundo siguiente, ya «soy diferente»"147.

El género del autorretrato se convierte en una herramienta perfecta para el desarrollo de la identidad online. Una de sus ventajas es el poder que otorga a su autor ${ }^{148}$ a la hora de contruir esta identidad. No se trata solamente de decir yo existo sino de yo existo y controlo la manera en la que me ven. Debido a ello, no es casual la difusión tan amplia del selfie como fenómeno del nuevo milenio, ya que es particularmente útil para quienes no tienen un acceso igualitario al poder $^{149}$. En este sentido, una de las herramientas con las que cuenta el o la

145 GÓMEZ-CRUZ, Edgar y ARDÈVOL, Elisenda, op. cit., pág. 190.

146 ARAUNA, Núria; MARTÍNEZ, Inmaculada J. y TORTAJADA, Iolanda, op. cit., pág. 178.

147 GALLIS, María I., Autorretrato y autorrepresentación: territorio de experimentación y cambio de paradigma en el siglo $X X$, Valencia, Universitat Politècnica de València, 2011, pág. 320.

148 PULTZ, John, La fotografía y el cuerpo, Madrid, Akal, 2003, pág. 7.

149 COLORADO, Óscar, "Autorretrato y fotografía”, 2013, disponible en: < https://oscarenfotos.com/ 
autorretratista a la hora de ejercer el poder tanto en la creación de una imagen de sí mismo como en la difusión de su yo identitario de cara a sus seguidores y fans es la capacidad de simulación de un yo que podría ser distinto al verdadero. "Baudrillard predijo hace mucho la desaparición de la realidad y nuestra absorción en las pantallas en la era del ciberespacio y de la red" ${ }^{150}$. Así, la fachada simulada mediante el uso del autorretrato se convertirá en una realidad empírica por derecho propio ${ }^{151}$, transformándolo en un objeto eficaz en la producción de subjetividad $^{152}$.

Con este régimen expansivo que han mostrado los jóvenes y algunos individuos más adultos en las redes sociales visibilizando su propia imagen conformadora de una identidad vendida al espectador, parece un hecho natural que también se conviertan en "influenciadores", tal y como un día lo fueron las estrellas de la música respecto a su manera de vestir, o los actores famosos anunciando marcas en la publicidad televisiva. Pese a que no debía de ser lo pretendido por las tres pioneras adolescentes que hemos ejemplificado antes, lo cierto es que hoy en día la figura del llamado influencer ${ }^{153}$ está profesionalizada y muchos adolescentes y jóvenes viven holgadamente gracias a los beneficios que les proporcionan marcas y plataformas cada vez que anuncian algo mediante sus redes a sus millones de seguidores ${ }^{154}$. Ello se debe a que parecería imposible que

2013/08/11/autorretrato-y-fotografia/> [Fecha de consulta: 25 de julio de 2017].

150 FREELAND, Cynthia, Pero cesto es arte? Una introducción a la teoría del arte, Madrid, Cátedra, 2004, pág. 211.

${ }_{151}$ GOFFMAN, Erving, La presentación de la persona en la vida cotidiana, Buenos Aires, Amorrortu, 1997, pág. 39.

152 GUASCH, Anna M., Autobiografías visuales, Madrid, Siruela, 2009, pág. 19.

153 Influencer, o influyente, lo define Monsoriu en su Diccionario de la Web 2.o de la siguiente manera: "En Internet, persona especializada en alguna temática concreta que goza de un amplio reconocimiento entre los interesados por esa misma área en la red. Suele tener además una enorme capacidad de recomendación sobre productos o servicios entre sus seguidores". MONSORIU, Mar, Diccionario Web 2.o. Todos los términos que se necesita conocer sobre las redes sociales y los medios sociales, Madrid, Creaciones Copyright, 2010, pág. 68.

154 Llegando a cobrar más de 10.000 euros por una sola publicación, aunque sean casos minoritarios. Bien sea por el pago que hacen las marcas, o por la publicidad insertada en sus redes, o incluso por donativos, pasamos de los influencers más humildes que pueden, con su profesionalización, cobrar 
en una sociedad capitalista como la nuestra, miles y miles de ojos expectantes hacia lo que una figura mediática diga o haga, pueda salir gratis. Así pues, estos jóvenes influenciadores quedan convertidos en "ciudadanos expertos en el uso de los medios y herramientas sociales capaces de comunicarse [...] y liderar a comunidades virtuales para crear estados de opinión y promover la movilización social" 155 .

\begin{abstract}
"Una evidente muestra de esto es la influencia [que estos individuos ejercen sobre] las modas urbanas, en las que llegan incluso a influir estéticamente en los videoclips y espectáculos de artistas conocidos internacionalmente. Esto significa que la participación a nivel individual desde casa contiene a la vez un carácter de colaboración colectiva a través de la red, la cual provoca una ráfaga de consecuencias estilísticas y temáticas que llegan a condicionar e influenciar las renovaciones para los espectáculos y puestas en escena de los artistas y cantantes" ${ }^{156}$.
\end{abstract}

De esta manera, como hemos visto anteriormente, también para los jóvenes influenciadores la necesidad de reconocimiento en la Web se convertiría en un aspecto vital, que podría reflejarse en la afirmación de la existencia en Internet. "Así, el cuerpo es utilizado como objeto de presentación, construyendo su marca ante los demás"157. Al margen de todo esto, dejamos para el final de este capítulo una faceta del cuerpo propio publicado que aún no hemos revisado: el tratamiento del desnudo mediante el autorretrato digital publicado en la red y las posibles virtudes y consecuencias que esto puede acarrear.

200 euros al mes, a los que pueden llegar a cobrar más de 3.ooo, quedando convertidos en un medio de comunicación humano. BERENGUERAS, Josep M., “¿Cuánto cobra un influencer?", 2017, disponible en: <https://www.elperiodico.com/es/economia/20170508/influencer-cuanto-cobra-gana6024716> [Fecha de consulta: 25 de julio de 2017].

155 RUIZ, Sonia, op. cit., pág. 279.

156 ROBLES, Elena, op. cit., pág. 99.

157 BORERO, Alejandra y LONDOÑO, Suanny, "Mujer selfie, construcción de un discurso femenino adolescente mediado por el consumo de la imagen", en $V$ Encuentro Internacional de Investigadores en Publicidad (RELAIP), Alicante, 2016, pág. 127. 


\subsection{El tratamiento del desnudo mediante el selfie y otros autorretratos publicados en la red.}

Otra curiosa propiedad natural de la imagen digital es su necesidad irrefrenable de saltar a la red y fundirse con ella, tal como le ocurría al protagonista de $E l$ cortador de césped ${ }^{158}$ al final del film. Prácticamente toda fotografía digital, tarde o temprano, acaba entrando en la red desde la cámara o el dispositivo con que se realizó. Si se trata de un smartphone, que combina en un mismo aparato una cámara fotográfica y una herramienta de publicación, el salto será más asequible ${ }^{159}$ que si se produce mediante una cámara sin conexión a Internet. En este caso, el archivo digital tendrá primero que copiarse en una computadora y de ahí dar el último paso al mundo virtual. Una vez allí, esa fotografía digital será compartida, clonada, distribuida y guardada en poco tiempo, haciendo prácticamente imposible su eliminación completa. Se escampará como un virus que desata una pandemia. Incluso la fotografía digital menos relevante tendrá varias hermanas gemelas binarias reposando en algún sitio y, dados los métodos de gestión del archivo de imagen contemporáneo, estará al mismo tiempo en equipos, tarjetas de memoria y copias de seguridad, así como en los múltiples servidores del servicio de intercambio de archivos con la que se compartió.

Como vemos, existe un número prácticamente incontable de cuerpos desnudos en la red, de corte amateur, y que se circunscriben formalmente en el marco de nuestro objeto de estudio. Históricamente, "la iconicidad del desnudo

\footnotetext{
158 EVERETT, Gimel (Productor), LEONARD, Brett (Director), The Lawnmower Man (El cortador de césped) [Cinta cinematográfica], Estados Unidos, Alliance Atlantis Communications / Allied Vision Lane Pringle Productions, 1992.

159 Sobre todo desde que llegó a los dispositivos con sistema operativo Android o iOS el guardado de copia de seguridad automática en la nube de manera preconfigurada.
} 
femenino ha constituido la más evidente metáfora sexual en la representación"160, además de ser un fin en sí mismo ${ }^{161}$. Repasando su recorrido histórico, podríamos decir que el desnudo, más que ser un tema del arte, es una forma de $\operatorname{arte}^{162}$. Esta forma, pues, entendida como una construcción estética y un artefacto de sublimación, cumple ciertos protocolos estrictos y sucede así casi desde su origen. Estos protocolos nos obligan a diferenciar cuerpo real de cuerpo ideal, así como a ser conscientes de que el ideal de cuerpo varía según cada momento determinado de la historia ${ }^{163}$. En nuestro principio de siglo, y no solo en las artes, la representación del cuerpo desnudo y la vivencia de la propia corporalidad asume una compleja y turbulenta realidad:

"Una realidad en la que el cuerpo, transformado en valor de cambio, queda definitivamente objetualizado y convertido en cosificada mercancía. De este modo lo corporal tan solo adquiere sentido como envoltorio y sombra, es decir, como producto y pantalla o, mejor aún, como envase e impostura”"164.

Esta parcela de la práctica comunitaria que guarda relación con las redes sociales virtuales, tiene que ver con la elección de nuestra propia imagen, su codificación y su representación a través del desnudo presentado, un desnudo que "atiende a cánones establecidos socialmente sobre lo bello y lo deseable y se atiene a ellos"165. En este sentido, exhibirse tendría relación directa con las ganas de agradar, "no siempre para gustar en términos amorosos o sensuales, sino para ser elogiado, popular y, de ello, aceptado"166.

160 SILVESTRE, María, La imagen de la preadolescente y su representación en el arte, Valencia, Universitat Politècnica de València, 2007, pág. 331.

161 CLARK, Kenneth, El desnudo: un estudio de la forma ideal, Madrid, Alianza, 2008, pág. 18.

162 Ibídem, pág. 335 .

163 ARBAÏZAR, Philippe y PICAUDÉ, Valérie (Eds.), La confusión de los géneros en fotografía, Barcelona, Gustavo Gili, 2004, pág. 166.

164 PÉREZ, David, La certeza vulnerable. Cuerpo y fotografía en el siglo XXI, Barcelona, Gustavo Gili, 2004, pág. 30.

165 LEONARDO, Norberto, op. cit., pág. 692.

166 Ídem. 
Muchos de los cuerpos desnudos amateurs que encontramos en la red están representados en forma de autorretratos digitales o self shots (mirrorpics y selfies). Podemos encontrar una gran cantidad de ejemplos de naturaleza muy variada, desde personas que suben fotografías donde insinúan y destacan partes concretas de su anatomía, hasta jóvenes adolescentes que se fotografían desnudos para llamar la atención de un grupo de usuarios de una red virtual o comunicativa o para conectar sexualmente con otro usuario o usuaria.

"Una vez superado el cuarto y penúltimo escalón de la pirámide de Maslow, llegamos a la autorrealización, la necesidad de explorar nuestras capacidades creativas que pueden proyectarse en infinidad de posibilidades"167.

Respecto a la proporcionalidad de género, y como hemos estado viendo, también este ejercicio es mayoritariamente femenino si evaluamos el material encontrado en la red. Ello no es óbice para que aceptemos que Internet no ofrece un posicionamiento subjetivo de las imágenes (hecho que nos suscita terribles dudas y un fuerte escepticismo). Las actitudes pueden coincidir entre géneros en tanto que se extienden desde el erotismo sutil hasta la pornografía explícita, no obstante, y como diferencia, los varones tienden a resaltar más la musculatura y el potencial de actividad de su cuerpo, destacando su poder y focalizando la atención en los abdominales y/o en los genitales (Imagen 5.47); mientras que ellas parecen exhibirse, sobre todo, para dar placer a la mirada masculina o para darse autoplacer, centrándose básicamente en el pecho y en los genitales (Imagen 5.48) y reproduciendo así los patrones de representación clásicos que también encontramos en otras autopresentaciones menos eróticas en las redes sociales cuando ellas se muestran atractivas y ellos fuertes y poderosos ${ }^{168}$. Este hecho, a su vez, vendría definido por la imitación del desnudo o del erotismo que se ha ido

167 CALDEVILLA, David, op. cit., pág. 82.

168 ARAUNA, Núria; MARTÍNEZ, Inmaculada J. y TORTAJADA, Iolanda, op. cit., pág. 180. 
heredando desde las prácticas más clásicas (artes plásticas) ${ }^{169}$, hasta las más contemporáneas (fotografía, cine, televisión y publicidad) ${ }^{170}$.

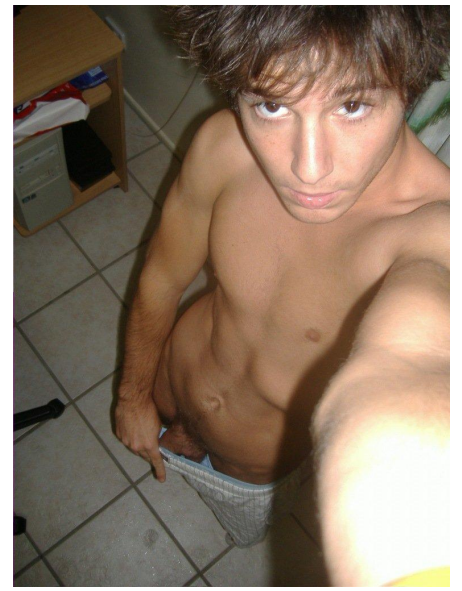

Imagen 5.47: Presentación de la figura del prototipo del hombre joven en el self shot erótico mediante un selfie.

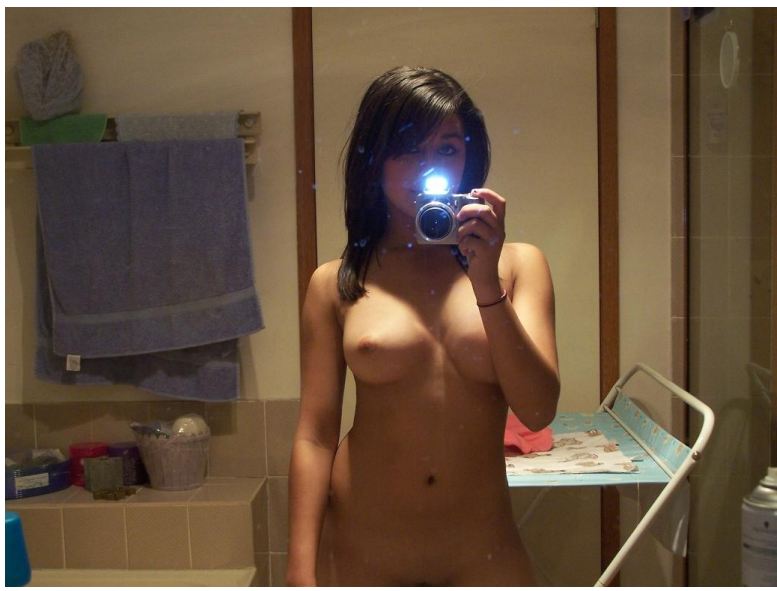

Imagen 5.48: Presentación del cliché de la mujer joven en el self shot erótico mediante un mirrorpic.

Asimismo, cabe señalar que es probable que parte de estos desnudos que estamos aquí tratando (y que son producidos con diferentes intencionalidades) hayan sido publicados en la red ante miles de ojos con un carácter voluntario por parte de sus generalmente autoras:

"Las imágenes corporales que elaboran no son consideradas por ellas como objetos para ser consumidos de una forma íntima y privada, sino creaciones para ser vistas por una amplia audiencia, y son, en este sentido, productos culturales (se consideren artísticos o no) de pleno derecho. Estas creaciones se pueden apreciar como un ejercicio de visualización de cada mujer en su particularidad, que pretende no solo ser mirada, sino ser vista «tal y como es», justamente a partir del juego que establece con

169 CLARK, Kenneth, op. cit., pág. 20.

170 AGUILERA, Emiliano, El desnudo en las artes, Madrid, Ediciones Giner, 1972, pág. 383. 
los estereotipos femeninos, pero también es una forma de incidir activamente en la configuración de las identidades de género y los valores sociales, morales, simbólicos, etc., asociados a la sexualidad. En definitiva, quieren hacerse visibles como creadoras de imágenes; agentes sociales capaces de transformarse a sí mismas y de intervenir en el mundo" ${ }^{171}$.

Entendemos que alguien que busca "cautivar las miradas de los otros para valorizar su imagen y posicionar la marca de su yo en el competitivo mercado de las apariencias", necesita a la par "encontrar la fortaleza de su producto" ${ }^{172}$. La sexualidad quedaría convertida así en una mercancía, y sería a través de ella por lo que los autorretratistas eróticos podrían ganar visibilidad, ya que en la era mediática "el voyeurismo se ha potenciado con los soportes de la información”"173. Por otro lado, y según los ojos de quien mire, podríamos encontrar en el consumo de este producto por parte del espectador o espectadora un abanico de intencionalidades: desde la influencia o fascinación, hasta su uso como pornografía alternativa, siendo este un paso más de la integración de este género en el hogar ${ }^{174}$.

No obstante, podemos constatar, casi con total seguridad, que el hecho de que esta ingente cantidad de cuerpos desnudos se encuentren publicados en la esfera visible que supone Internet no ha sido (en la mayoría de ocasiones) voluntad directa de sus autoras y autores:

"El contexto en el que se suele estudiar esta práctica manifiesta la naturaleza privada en el momento de la creación y el envío del contenido multimedia. Con esto el intercambio se realiza dentro de un marco supuesto de confianza y privacidad. Sin embargo, nos encontramos con la posibilidad de que ese material -cuya producción fue consentida y es de naturaleza privada y casera- pueda ser difundido a otros sin el

\footnotetext{
171 GÓMEZ-CRUZ, Edgar y ARDÈVOL, Elisenda, op. cit., pág. 205.

172 DE PIERO, José L. y NARVAJA, María E., op. cit., 254.

173 Ídem.

174 GUBERN, Román, op. cit., pág. 45.
} 
consentimiento del primer emisor. En este sentido, el mayor porcentaje de envíos de mensajes de sugerencia sexual se realiza a través del email, la mensajería instantánea y los mensajes de texto, etc., mientras que el porcentaje de publicación de este material en Facebook o Twitter disminuye a menos del 10\%” ${ }^{175}$.

No estamos con ello valorando moralmente el ejercicio de fotografiarse desnuda o desnudo delante de un espejo. Muchos de estos autorretratos eróticos, en su mayoría mirrorpics, son obras de gran belleza y, como hemos visto, suponen una continuidad del desnudo representado en la historia de la imagen y del arte (Imagen 4.49). A su vez, son fruto de la libertad que ejerce generalmente la mujer autorrepresentándose, y de la sensibilidad que pueda tener para hacerlo. En su mayoría, son ejercicios dignos y respetables ya que "posar es respetarse y exigir respeto" ${ }^{176}$. En este sentido, autorretratarse desnuda no es una práctica aislada, puesto que es algo a lo que invita la sociedad contemporánea gracias al carácter mercantilizado que se da al desnudo femenino en los mass media (no hay que olvidar que todavía vivimos en una sociedad machista y patriarcal). A ello se ha de unir también el hecho de que el autorretrato digital publicado en la red responde a un ejercicio de naturaleza ligera, rápida e instantánea que es propio del dispositivo digital, lo que permite disparar, ver y, si procede, borrar. Es probable que muchas de las más interesantes fotografías realizadas en este ámbito, han sido luego destruidas como los poemas no leídos del padre del personaje que interpretaba Javier Bardem en el film Vicky Cristina Barcelona ${ }^{177}$.

Con lo señalado tampoco estamos diciendo que sea ilícito compartir (con una o más personas) o publicar (en la esfera red, donde esperan miles de ojos desconocidos), estos desnudos autorretratados por parte de sus autoras. Las mujeres son dueñas absolutas de su imagen y, evidentemente, pueden hacer con

175 DE PIERO, José L. y NARVAJA, María E., op. cit., págs. 244-245.

176 BOURDIEU, Pierre. op. cit., pág. 143.

177 ARONSON, Letty; ROURES, Jaume; TENENBAUM, Stephen y WILEY, Gareth (Productores), ALLEN, Woody (Director), Vicky, Cristina, Barcelona (Vicky, Cristina, Barcelona) [Cinta cinematográfica], Estados Unidos / España, The Weinstein Company / Gravier Productions / Mediapro, 2008. 
ella y con sus cuerpos, lo que quieran: "Nuestros cuerpos, nosotras"178. De hecho, la fotografía (y su publicación) es un medio adecuado (como veremos más adelante a través de la autorretratista Natacha Merritt) con el que reivindicar ${ }^{179}$ cualquier tipo de belleza propia o cualquier modelo de sexualidad, y estas imágenes publicadas o compartidas, pueden formar parte tanto de un ejercicio de exhibición global, como de un mero juego de seducción particular (Imagen 4.50).

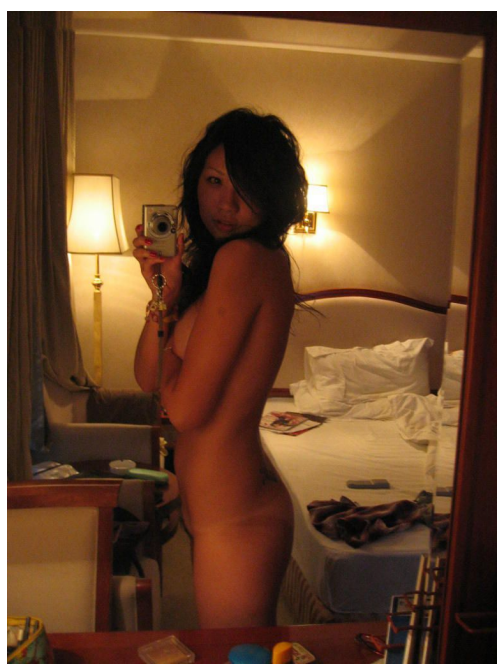

Imagen 5.49: Desnudo anónimo frente a un espejo realizado entre 2007 y 2010.

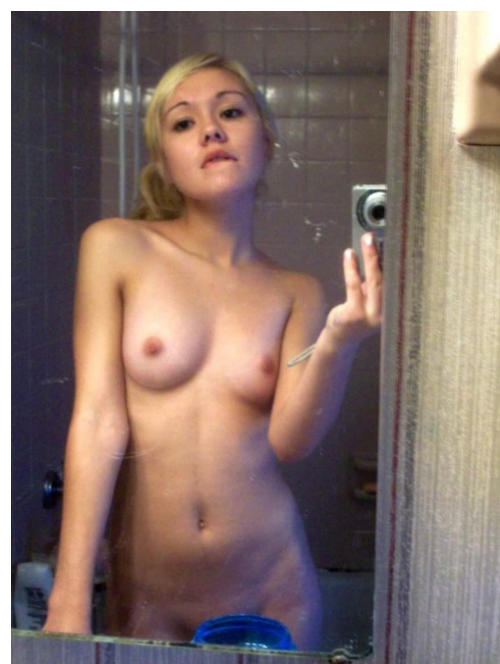

Imagen 5.50: Otro ejemplo similar de mirrorpic erótico.

178 Atendiendo a aquella afirmación feminista de los años setenta del siglo pasado. "La afirmación feminista de los setenta «Nuestros cuerpos, nosotras» coloca los temas del control y la identidad en el centro de la agenda política del movimiento. Reclamar el poder sobre sus cuerpos significaba para las mujeres reclamar control sobre los cuidados médicos y la regulación del cuerpo femenino y sobre las maneras en que el cuerpo es imaginado y representado en la cultura”. NEAD, Lynda, El desnudo femenino. Arte, obscenidad y sexualidad, Madrid, Tecnos, 1998, pág. 106.

$179 \mathrm{Y}$ es que la marca persona en las jóvenes-adolescentes podría ser entendida como un discurso feminista. BORERO, Alejandra, op. cit., 127. "Tomar un selfie puede ser un acto creativo, pero también puede ser una pose repetida, observada, estudiada, enmarcada en unos parámetros bien vistos socialmente. El rol de las mujeres no ha sido creativo, de emancipación, ahora sí tienen acceso a todos los ámbitos tecnológicos y son productoras de conocimiento y de mundo". GALÁN, Mercè, op. cit., pág. 47. En este sentido, bajo la lectura de las imágenes femeninas en la era del selfie, la naturaleza melancólica de la representación popular de la feminidad dramatiza precisamente la posición, imposiblemente dividida, de la feminidad de mujer en un mundo masculino. FERREDAY, Debra, "The Feminine Art of Failure: Queering Feminist Spectatorship", en Quaderns de psicologia, vol. 16, $\mathrm{n}^{0} 1$, 2014, pág. 141. 
Sin embargo, lo que sí que supone un problema dentro de esta cuestión de autofotos y desnudez, es la publicación accidental o no intencionada por parte de las autoras de estos autorretratos que, en tantas ocasiones, a través de segundas o terceras personas, acaban distribuidos por la red sin que sus dueñas legítimas puedan ya frenar su masiva difusión y vírica reproducción.

Esta carencia de control de la imagen propia y su difusión en la esfera pública representada por Internet (y que entendemos, es la causa en la mayoría de los mirrorpics de desnudo que nos encontramos, dadas las estrictas normas de censura que poseen la mayoría de redes sociales, foros y otros soportes de publicación del self shot) pueden apuntar a diversas causas, pero mayoritariamente consideramos que atienden a tres tipos de responsables directos: ladrones de dispositivos, hackers informáticos y ex-novios traidores.

De hecho, durante nuestra investigación hemos encontrado numerosos foros, como herselfpics.com ${ }^{180}$, en el que sus usuarios se dedican a recopilar y publicar este tipo de autofotos de desnudo aparentemente robadas y casi exclusivamente femeninas, desde mirrorpics de cuarto de baño hasta registros íntimos mediante webcam (Imagen 5.51), u otro tipo de portales como bonjourtoutlemonde.com ${ }^{181}$, espacio de corte pornográfico en el que sus gestores han creado apartados especiales donde depositar este tipo de imágenes encontradas (Imagen 5.52).

180 Muchos de estos espacios se encuentran a día de hoy prácticamente abandonados, en especial tras la herencia que resultó ser el portal 4chan (<http://boards.4chan.org/s/ $>$ [Fecha de consulta: 30 de julio de 2017]). Para unificar este tipo de contenidos en la Web se apuntaban directamente conceptos como los de: Girls in the mirror (chicas en el espejo), Self shot (autofoto), Her Self Pics (sus propias autoimágenes), Ex-boyfriend's Revenge (venganza del ex-novio) o Ex-girlfriend pics (imágenes de exnovias). <http://www.herselfpics.com/forums/f-in-the-mirror-self-shot-her-self-pics-77.html> [Fecha de consulta: 30 de julio de 2017].

181 Donde se pueden encontrar selfies más contemporáneos, con fechas de subida de 2017. <http://www.bonjourtoutlemonde.com/168-bonjour-self-shot> [Fecha de consulta: 30 de julio de 2017]. 


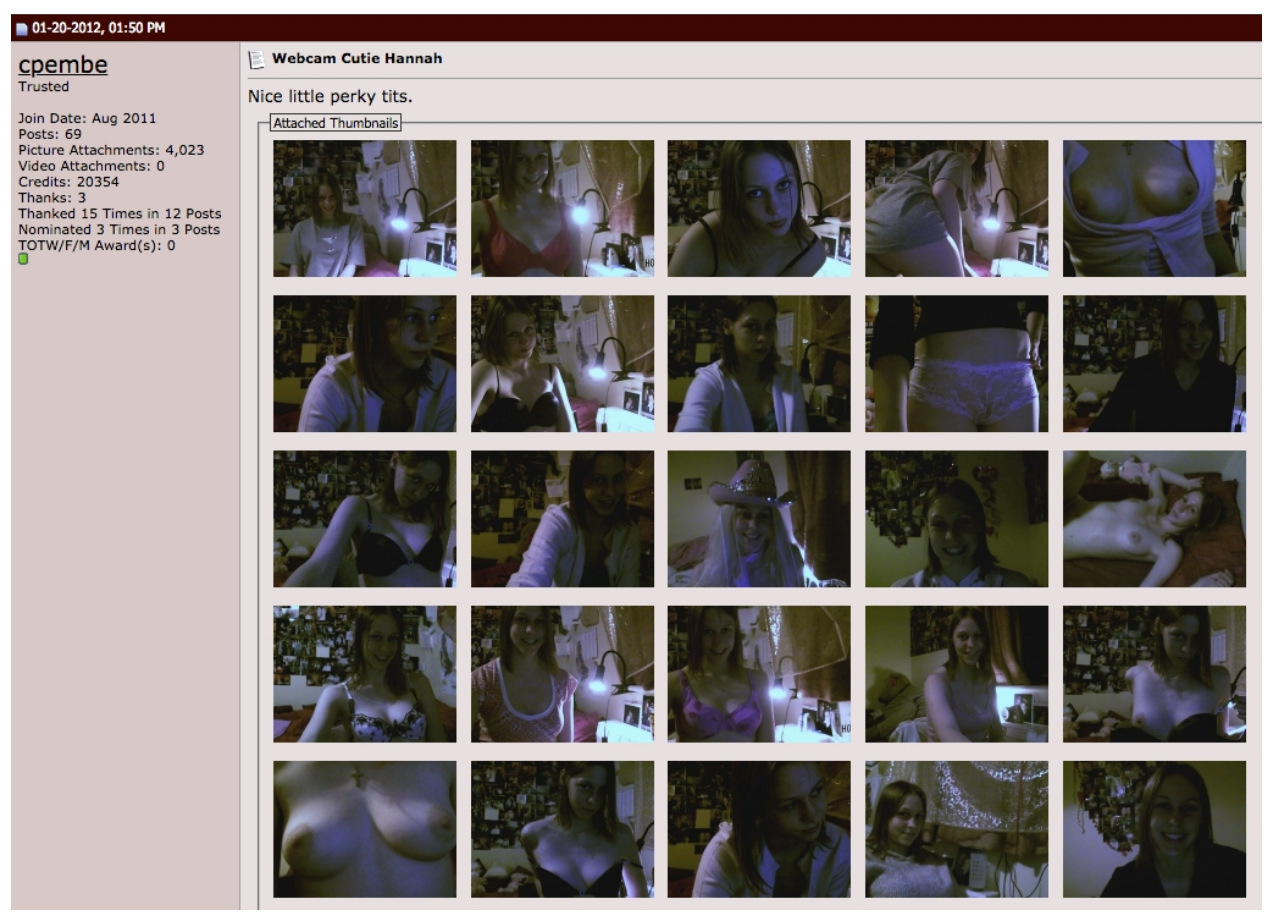

Imagen 5.51: Captura de pantalla de un post del foro herselfpics.com junto con su contenido específico.

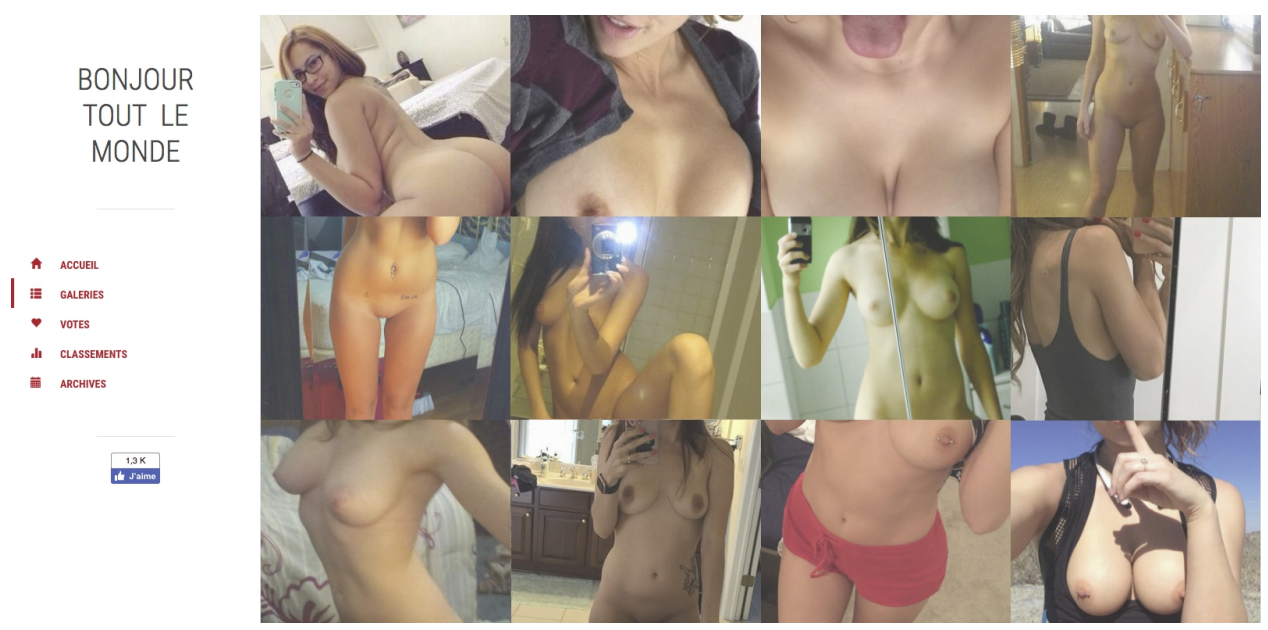

Imagen 5.52: Captura de pantalla del apartado self shot del portal bonjourtoutlemonde.com junto con su contenido específico. 
Existen, pues, muchos ejemplos de estas fraudulentas prácticas que, como hemos comentado, están implícitas en la mayoría de ocasiones en las que se publica a una selfshooter desnuda en la red. Pero, sin duda, el hecho más conocido referente a este tema (robo de imágenes privadas por parte de los hackers y publicadas en la red), quizá por el tipo de víctimas (famosas celebridades) y por su cantidad (más de cien), fue el acontecimiento apodado como Celebgate, cuyo inicio se remonta al 31 de agosto de 2014.

\subsubsection{The Celebgate Scandal.}

La filtración de fotografías de celebridades de 2014, también conocida como Celebgate (contracción de celebridad y Watergate) o como Fappening (contracción de happening y fap) fue un famoso robo y divulgación de casi 500 autorretratos eróticos privados de famosas celebridades de diversas escenas públicas, que fueron sustraídos directamente de sus espacios digitales personales y, supuestamente, blindados. La publicación de dichas fotografías se realizó a finales de agosto de 2014, colgándose en el tablón de imágenes japonés 4chan que ya hemos visto anteriormente. El material fue divulgado después por otros usuarios a través de redes sociales como Imgur, Reddit y Tumblr ${ }^{182}$. Pese a las órdenes de retirada de este material y las denuncias por parte de sus autoras, la rápida proliferación (en cuestión de minutos) de este material digital, hizo que actualmente existan millones de copias de cada una de estas imágenes que siempre quedarán vagando por la red.

182 VV. AA., "Filtración de fotografías de celebridades de 2014", 2018, disponible en: <https:// es.wikipedia.org/wiki/Filtración_de_fotografías_de_celebridades_de_2014> [Fecha de consulta: 4 de enero de 2018]. 
Este tipo de filtraciones no era algo nuevo. Tres años antes, un caso similar de robo afectó también a varios personajes relevantes dentro de la esfera mediática. Hablamos de los dos self shots robados y difundidos por un hacker directamente desde el smartphone de Scarlett Johansson, aparato que contenía estas imágenes y con el que ella misma se había autorretratado desnuda. Una de esas fotografías (Imagen 5.53), similar en construcción formal al autorretrato de Sasha Grey que veremos más adelante al final del capítulo 8, es un destacado ejercicio fotográfico por parte de la actriz, al margen de que su publicación involuntaria constituya un atentado hacia su libertad e intimidad. La imagen, por otro lado, se viralizó mucho en la red y no sería el único caso de robo de imágenes perpetrado a famosas en Estados Unidos antes del Celebgate: a ella se sumarían los casos de artistas como Vanessa Hudgens, Miley Cyrus, Jessica Alba, Selena Gómez, Demi Lovato o Christina Aguilera.

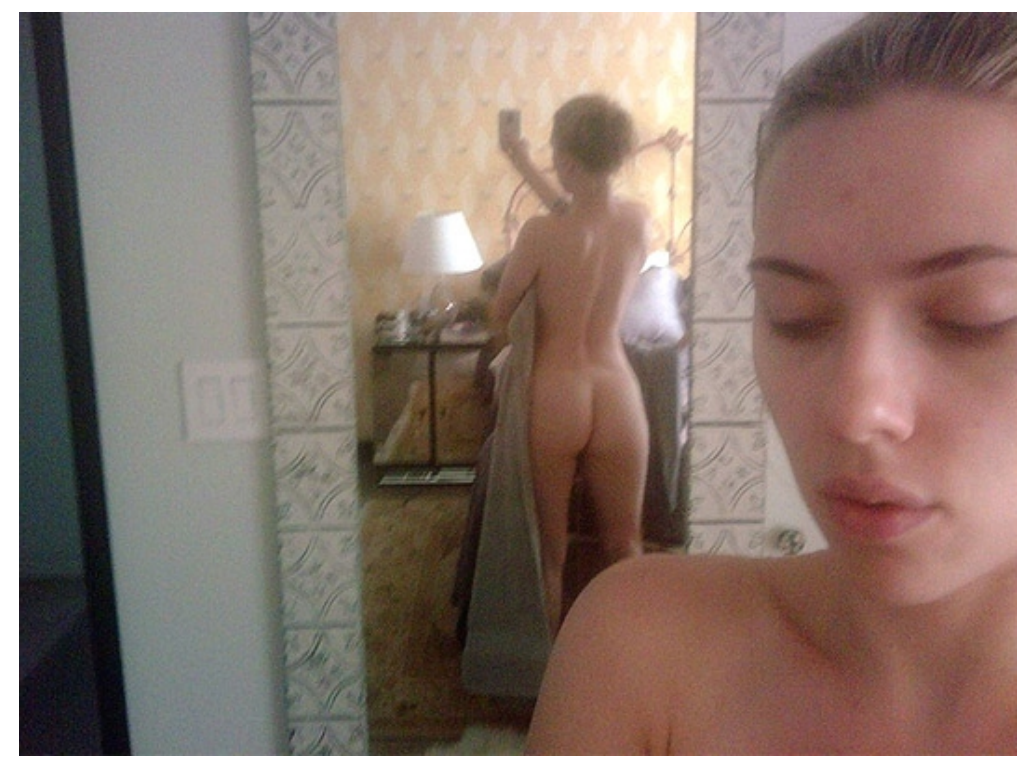

Imagen 5.53: El famoso self shot de Scarlett Johansson robado y publicado en 2011.

Volviendo al Celebgate de 2014, se cree que estas fotografías fueron obtenidas violando el servicio de almacenamiento en nube de Apple, iCloud. La 
empresa posteriormente confirmó que los hackers responsables de la filtración lograron su objetivo obteniendo información de las contraseñas de las cuentas de las víctimas, y no a través de algún fallo en el servicio iCloud. La filtración tuvo un gran impacto en los medios de comunicación y elevó la preocupación de los analistas respecto a la seguridad ofrecida por los servicios de almacenamiento en la nube, poniendo particular énfasis en su eficiencia para albergar información personal y sensible. Los hackers responsables de la filtración, quienes se describieron a sí mismos como coleccionistas, distribuyeron las imágenes en los portales que hemos comentado a cambio de dinero digital o criptomoneda. La versión que se distribuyó originalmente contenía fotos (Imagen 5.54) y vídeos de más de cien celebridades ${ }^{183}$. Según el experto en seguridad Nik Cubrilovic, además de las fotografías, otra información personal, como mensajes de texto, agendas, libretas de direcciones, registros de llamadas y otros datos almacenados en los teléfonos y las copias de seguridad alojadas en el servicio de almacenamiento, probablemente también fueron robados ${ }^{184}$. Hay que tener en cuenta que los hackers obtuvieron los álbumes fotográficos completos de los dispositivos de sus víctimas, sin embargo, discriminaron cualquier imagen que no fuera un desnudo antes de su publicación masiva. Esto podría dar a entender que las imágenes que componen el archivo del Celebgate son exclusivamente

183 Fueron: Abigail Spencer, Alana Blanchard, Alexa Jane, Alison Brie, Allegra Carpenter, Alyson Michalka, Amanda Michalka, Angelina McCoy, Anna O'Neill, Ariana Grande, Ashley Blankenship, Aubrey Plaza, Abby Elliott, AnnaLynne McCord, Avril Lavigne, Amber Heard, Becca Tobin, Brie Larson, Brittany Booker, Candace Smith, Candice Swanepoel, Cara Delevingne, Carley Pope, Carmella Carcia, Carrie Michalka, Cat Deeley, Carly Foulkes, Chloe Dykstra, Clare Bowen, Dave Franco, Dove Cameron, Elena Satine, Elle Evans, Ellenore Scott, Emily Browning, Emily DiDonato, Emily Ratajkowski, Erin Cummings, Erin Heatherton, Farrah Abraham, Gabrielle Union, Gabi Grecko, Hayden Panettiere, Hope Solo, Heather Marks, Hillary Duff, Jacqueline Dunford, Janelle Ginestra, Jennifer Lawrence, Jessiqa Pace, Jessica Dunford, Jessica Ricardi, Jesse Golden, JoJo, Joanna Krupa, Jenny McCarthy, Josie Loren, Joy Corrigan, Kaley Cuoco, Kaime Oteter, Kate Upton, Kate Bosworth, Kelly Brook, Keke Palmer, Kim Kardashian, Kirsten Dunst, Krysten Ritter, Lake Bell, Laura Ramsey, Lea Michele, Leelee Sobieski, Leven Rambin, Lisa Kelly, Lisalla Montenegro, Lindsay Clubine, Lizzy Caplan, Mary-Kate Olsen, Mary Elizabeth Winstead, McKayla Maroney, Melissa Benoist, Meagan Good, Megan Boone, Michelle Keegan, Mikayla Pierce, Misty May-Treanor, Nina Stavris, Rachel Nichols, Rihanna, Sarah Shahi, Sahara Ray, Sarah Schneider, Scarlett Johansson, Selena Gomez, Shannon McNally, Tameka Jacobs, Teresa Palmer, Uldouz, Vanessa Hudgens, Victoria Justice, Wailana Geisen, Winona Ryder e Yvonne Strahovski.

184 VV. AA., "Filtración de fotografías...”, op. cit., s/n. 
eróticas, quizá desnudos frente al espejo del cuarto de baño para evaluar la figura propia, o tal vez selfies de zonas prohibidas con los que practicar sexting con la pareja o amante. No obstante, pese a encontrar estos ejemplos repetidos en casi cada una de las celebridades afectadas, también encontramos interesantes escenas cotidianas sin ningún tipo de intencionalidad sexual (Imagen 5.55) y en las que se puede ver algún descuido o zona censurable (que justificaría su publicación), aportando al curioso o al voyeur un material relacionado con las costumbres también mundanas de la vida privada de los famosos que son muy difíciles de encontrar en la red entre tanto desnudo erótico.

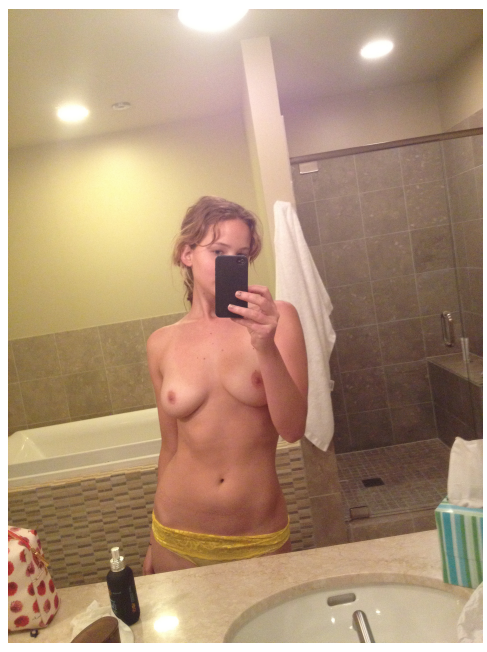

Imagen 5.54: Una autofoto erótica de la aclamada actriz Jennifer Lawrence, una de las más viralizadas en los medios tras el Celebgate.

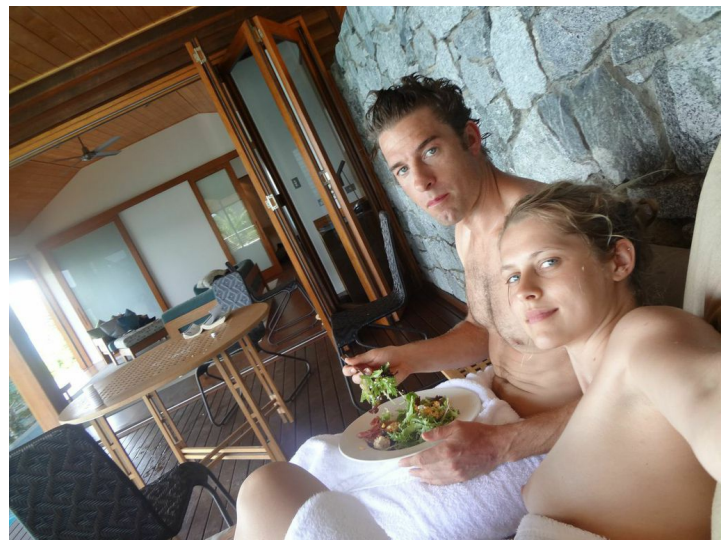

Imagen 5.55: Un selfie también robado que muestra a la actriz y modelo australiana Teresa Palmer con su pareja en una escena cotidiana durante unas vacaciones. El resto de fotografías robadas de Teresa también presentan desnudos masculinos y femeninos, pero en un ambiente relajado y hogareño.

Con posterioridad, se han producido publicaciones similares a las del Celebgate, pero ninguna tan notoria como la aquí nombrada, y todas ellas han incrementado, aún más si cabe, la cantidad de desnudos amateurs que fluyen por la red. Con independencia de que su publicación sea fruto de prácticas delictivas, 
estos self shots eróticos hacen las veces de documento que atestigua su realización, ya que "una fotografía no es solo [...] una interpretación de lo real; también es un vestigio, un rastro directo de lo real, como una huella o una máscara mortuoria" ${ }^{185}$. Esas fotografías se hicieron en un momento dado y su elevado número nos está certificando que es una práctica muy extendida.

De hecho, el exhibicionismo es algo propio del adolescente contemporáneo, existiendo ejemplos de prácticas recientes que combinan la autofotografía, el exhibicionismo del cuerpo y su publicación voluntaria en la red, tal como sucede con el dedipix (Imagen 5.56), una nueva tendencia entre la gente joven que consiste en publicar self shots en los que los protagonistas son textos con mensajes autoescritos sobre ciertos límites permitidos o prohibidos de la propia piel $^{186}$.

Por otro lado, el desafío de One Finger Challenge ${ }^{187}$, también muy extendido entre la gente joven, propone hacerse una autofoto desnuda frente a un espejo colocando un dedo frente a la lente que sea capaz de tapar genitales y pezones $^{188}$. El ejercicio es posible ya que el dedo no reflejado tapa la zona inferior y el reflejado la superior gracias al juego especular con el reflejo (Imagen 5.57).

185 SONTAG, Susan, op. cit., pág. 150.

186 DELCLÓS, Tomàs, "Francia alucina con la moda de los dedipix", 2013, disponible en: <http:// tecnologia.elpais.com/tecnologia/2009/10/13/actualidad/1255424465_850215.html> [Fecha de consulta: 20 de julio de 2016].

187 YE, Susana, "One Finger Challenge: desafiar la censura del cuerpo desnudo en las redes sociales con un solo dedo", 2016, disponible en: <http://www.elmundo.es/f5/comparte/2016/12/04/ 5841cee2468aeb61028b4614.html> [Fecha de consulta: 20 de julio de 2017].

188 Precisamente el hecho de ocultar estas dos partes del cuerpo femenino da la posibilidad de publicar estas imágenes en cualquier red social (como Facebook o Instagram), ya que son las dos únicas partes del cuerpo que censuran estas plataformas. 


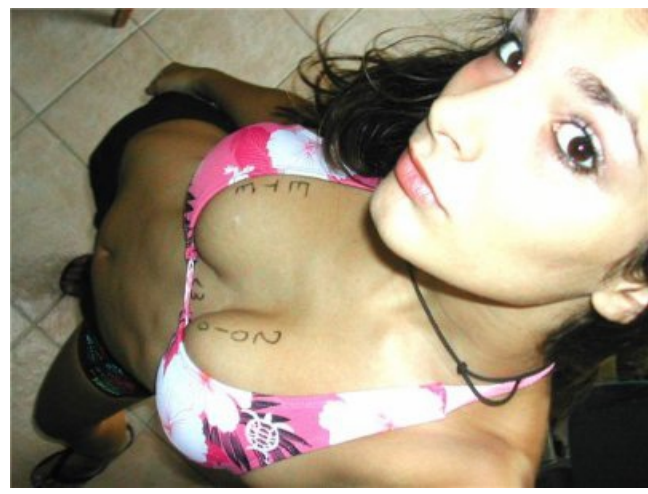

Imagen 5.56: Autofoto en la que se practica el dedipix.

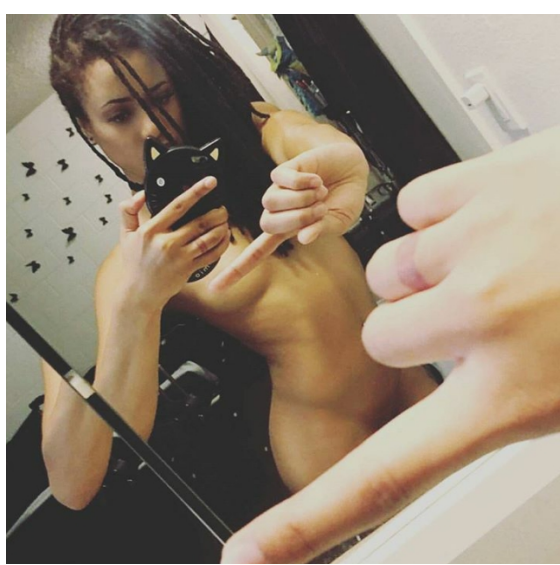

Imagen 5.57: Autofoto donde se practica el One Finger Challenge.

Estos y otros ejercicios, considerados como curiosos usos que los jóvenes hacen de Internet y de su imagen ${ }^{189}$, constituyen la punta del iceberg de un problema relacionado con este vulnerable colectivo. Hablamos del sexting y del ciberbullying, un tema que estamos moralmente obligados a tratar en un estudio que, como este, habla del autorretrato adolescente. No debemos, pues, descuidar la cara oculta y nociva de los self shots, algo que vamos a plantear analizando el caso de Amanda Todd.

\subsubsection{El suicidio de Amanda Todd.}

El 10 de octubre de 2012 Amanda Todd se quitó la vida. Sus padres la encontraron ahorcada en su casa de Port Coquitlam, Canadá. Tenía quince años. 
El caso del suicidio de Amanda Todd no ha sido el único que conocemos de adolescentes que deciden quitarse la vida tras ser víctimas de la fatal y vejatoria combinación que suponen el sexting ${ }^{190}$ y ciberbullyng ${ }^{191}$ practicados de manera conjunta. No obstante, la muerte de Amanda Todd fue una de las más mediáticas ${ }^{192}$ quizá por el hecho de que, además de tratarse de un terrible drama, su protagonista (Imagen 5.58) dejó una nota de despedida en forma de vídeo (Imagen 5.59) en el que se autopresentó desplegando una serie de notas con un mensaje escrito ${ }^{193}$.

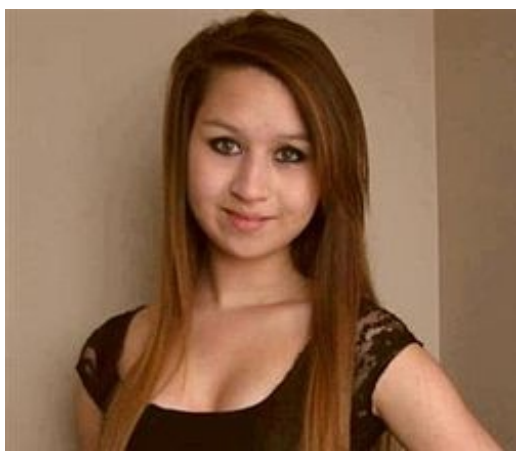

Imagen 5.58: Amanda Todd (27 de noviembre de 1996 - 10 de octubre de 2012).

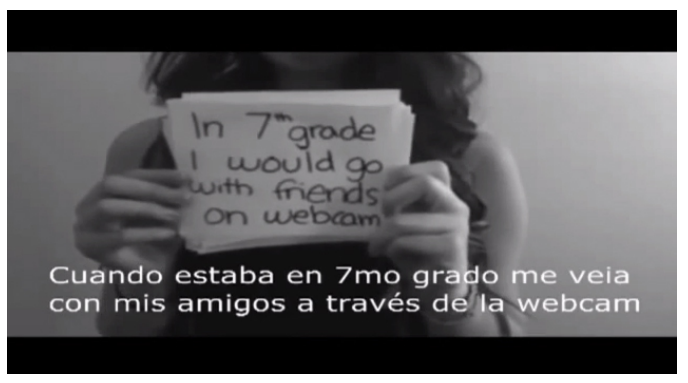

Imagen 5.59: Frame del vídeo de despedida de Amanda Todd.

190 El sexting es el envío de imágenes (fotografías o vídeos) con contenido sexual por medio del móvil. Abarca desde la producción a la distribución. La página web Pantallas amigas, informa, visibiliza y da consejos para prevenir esta cuestión. Está enfocada a su lectura por parte de padres, pero también de jóvenes. Véase: <http://www.pantallasamigas.net/> [Fecha de consulta: 20 de julio de 2016].

191 Ciberacoso (también llamado cyberbullying por el origen anglosajón del término) es el uso de información electrónica y medios de comunicación tales como correo electrónico, redes sociales, blogs, mensajería instantánea, mensajes de texto, teléfonos móviles y websites difamatorios para acosar a un individuo o grupo, mediante ataques personales u otros medios. Puede constituir un delito penal.

192 Aunque muchos medios se hicieron eco, aquí hemos encontrado una noticia que resume bastante bien el caso completo: McGUIRE, Patrick, "El pervertido que destruyó la vida de Amanda Todd", 2012, disponible en: <http://www.vice.com/es/read/el-pervertido-que-destruyo-la-vida-de-amanda-todd> [Fecha de consulta: 20 de julio de 2016].

193 El vídeo, que está disponible en: <http://www.youtube.com/watch?v=Pc1sK1WX2LA> [Fecha de consulta: 20 de julio de 2013], es un ejercicio crudo y sensible. Puede recordarnos al videoclip de Bob Dylan, Subterranean Homesick Blues (1965). 
Amanda Todd sufría acoso en el colegio y a través de las redes sociales. Además, había compartido meses atrás una imagen (que no mostraremos aquí) de su torso desnudo con un extraño a través de un servicio de chat. Este self shot, registrado con la webcam de su computadora, viajó en forma de ceros y unos hasta la pantalla de Kody Maxson, un adulto degenerado que aprovechó esta misma imagen para coaccionar a Amanda. La imagen se hizo pública y esto incrementó el acoso que la joven sufría a través de la red y en el instituto. No pudo soportar tanta presión.

Además de por el uso extensivo que hacen de Internet, los adolescentes han sido etiquetados como grupo de riesgo en la medida que son considerados como la franja de edad más vulnerable en el desarrollo de comportamientos conflictivos en la red ${ }^{194}$. Además de los problemas que venimos tratando, la llegada del smartphone y su institucionalización entre los jóvenes posibilitó el desarrollo por parte de este colectivo de conductas cercanas a la adicción, destacando la importancia de WhatsApp como una herramienta que potencia la intensidad de uso del móvil y cuya carencia temporal puede desembocar en estados de gran frustración entre los usuarios ${ }^{195}$. Una vez pasada la brecha de los trece años, estos riesgos y problemas pueden ser más acusados entre el género femenino:

\begin{abstract}
"Las adolescentes europeas son más vulnerables a sufrir trastornos psicológicos y estos problemas resultan, además, mucho más incapacitantes en comparación con los jóvenes. Esta es una de las conclusiones del Informe de la Oficina Regional de Europa de la Organización Mundial de la Salud (OMS) titulado «Evidencia para intervenciones sensibles al género que promuevan la salud mental». Se establece que los problemas de salud mental en adolescentes presentan un patrón diferente en función del género una vez superados los trece años. A partir de dicha edad, las niñas
\end{abstract}

194 CATALINA, Beatriz; GARCÍA, Antonio y LÓPEZ DE AYALA, María C., op. cit., pág. 463.

195 CARO, Lucía, "WhatsApp y la búsqueda de control de la situación informacional por parte de los jóvenes", en Sphera publica. Revista de ciencias sociales y de la comunicación, vol. 1-2, $\mathrm{n}^{0} 15$ (Ejemplar dedicado a: Tensiones y desafíos contemporáneos de la comunicación), 2015, págs. 81-82. 
son más propensas a los trastornos psicológicos que los niños, en especial los de depresión y ansiedad, que suponen el doble de casos en niñas que en niños, y también a la hora de puntuar su autoestima, cuyos índices bajan mucho. Todo esto parece indicar que, en buena medida, las adolescentes están sometidas a más situaciones de estrés, violencia, normas culturales y carga de trabajo que los varones” ${ }^{196}$.

Si retomamos la cuestión del sexting, que antes simplemente hemos nombrado como una de las dos principales causas que pueden convertirse en problemáticas para los adolescentes contemporáneos, el término puede quedar definido como:

“[...] aquellas conductas o prácticas consistentes en la producción, por cualquier medio, de imágenes digitales en las que aparezcan personas de forma desnuda o semidesnuda, y en su transmisión ya sea a través de telefonía móvil o correo electrónico, o mediante su puesta a disposición de terceros a través de Internet (por ejemplo, subiendo fotografías o vídeos en redes sociales) [...] incluyendo el intercambio de mensajes de texto con contenido sexual explícitamente provocativos, siempre que se pueda deducir de ellos una clara intencionalidad provocativa de acuerdo con los usos sociales"197.

Sexting se trata de un término anglosajón que resulta de la combinación de sex (sexo) y texting (envío de mensajes de texto), de hecho, "las primeras aportaciones a la temática partían de una visión restrictiva, limitándolo al envío de mensajes de texto". Con posterioridad, y partiendo de "la rápida evolución de los dispositivos tecnológicos, se amplía la definición incluyendo fotografías, vídeos y/o textos" ${ }^{198}$.

196 PERALBO, Ángel, De niñas a malotas, Madrid, La Esfera de los Libros, 2013, pág. 17.

197 DE PIERO, José L. y NARVAJA, María E., op. cit., pág. 244.

198 ALONSO, Patricia; MAGALHÃES, María José; PÉREZ, Carmen y RODRÍGUEZ, Yolanda, "Estudio cualitativo en un grupo de estudiantes ourensanos/as sobre el fenómeno del sexting", en Revista de estudios e investigación en psicología y educación, $\mathrm{n}^{0} 13,2015$, pág. 58. 
Respecto al sexting, hay que puntualizar que el protagonista produce y envía ese contenido de forma voluntaria, sin coacción, y en muchos casos también sin presión alguna por parte de la persona destinataria del mismo.

\footnotetext{
"Estamos por lo tanto ante una conducta libre, que no surge del error, la intimidación o la coacción; como mucho, cabría hablar de inconsciencia, ya que los protagonistas pueden no enjuiciar meditadamente la repercusión que este tipo de imágenes puede llegar a tener dentro de su círculo social o incluso fuera de él. [...] El sexting tiene una naturaleza fundamentalmente casera: es producido, protagonizado e inicialmente difundido con una finalidad exclusivamente privada" ${ }^{199}$.
}

En este sentido, el sexting no sería malo ni bueno, sino solamente una extensión de la sexualidad ${ }^{200}$. Sin embargo, y como hemos comentado durante el punto 5.4, serán decisiones posteriores, traiciones o hurtos los que distribuirán el producto generado por la práctica del sexting a terceras personas que nunca fueron el objetivo de envío por parte de sus autores o autoras. Este ejercicio de agresión o maltrato frente a la salida obvia que sería la denuncia es una práctica común entre los adolescentes, y una de las variantes o un subtipo del cyberbullying.

El cyberbullying es un término inglés que hemos integrado en el lenguaje y que básicamente significa lo mismo que ciberacoso, también denominado acoso virtual o acoso cibernético. El mismo hace referencia al uso de medios de comunicación digitales para acosar a una persona o grupo de personas, mediante ataques personales, divulgación de información confidencial o falsa y puede constituir un delito penal. El cyberbullying implica un daño recurrente y repetitivo infligido a través de los medios electrónicos y pretende causar angustia emocional y preocupación, además de no tener propósito legítimo para la

\footnotetext{
199 MARTÍNEZ, Juan M., "La difusión de sexting sin consentimiento del protagonista: un análisis jurídico", en Derecom, no 12, 2013, págs. 2-3.

200 LÓPEZ, Nina, “Consejos para hacer sexting seguro”, 2016, disponible en: <https://elpais.com/elpais/ 2016/o8/12/videos/1471022240_891226.html> [Fecha de consulta: 20 de julio de 2017].
} 
elección de comunicaciones $^{201}$. "En la mayoría de casos, el cyberbulling complementa el bullyng (acoso) escolar, convirtiéndose en una especie de refuerzo de este" ${ }^{202}$, de hecho ocho de cada diez casos de bullying tradicional se convierten en cyberbullying ${ }^{203}$. En 2016 el 70\% de los escolares había sufrido, presenciado o realizado ciberacoso mediante el llamado "triángulo del bullying", en el que tres factores toman partido en un mismo escenario: acosador, víctima y testigo, que con su pasividad permite que el problema crezca ${ }^{204}$. Como en el caso del sexting, la proliferación de los smartphones ha incrementado estas tendencias de ciberacoso escolar ya que una mayoría de los implicados como agresores y víctimas disponen de un teléfono móvil propio. Además, los resultados indican que tener acceso a Internet en el móvil está relacionado con la participación de los menores en episodios de ciberacoso y cibervictimización ${ }^{205}$. También igual que en el sexting el género es un factor determinante de proporcionalidad, ya que entre los trece y los dieciséis años, la incidencia del ciberacoso es del $12 \%$ en el caso de las chicas y del $2 \%$ en el de los $\operatorname{chicos}^{206}$.

Vistas estas cuestiones, podría quedar en manos de los estados, de las autoridades y gestores de las escuelas la reponsabilidad de minimizar los riesgos que pueden sufrir menores y adolescentes. Ello podría implementarse mediante

201 VV. AA., "Ciberacoso", 2018, disponible en: <https://es.wikipedia.org/wiki/Ciberacoso> [Fecha de consulta: 18 de enero de 2018].

202 GUERREIRO, Regina N., Competencias socioemocionales y bullying en adolescentes, Extremadura, Universidad de Extremadura, 2016, pág. 129.

203 GÓMEZ, Sergio, "El cyberbullying afecta a ocho de cada diez casos de acoso escolar", 2016, disponible en: <http://www.publico.es/sociedad/cyberbullying-afecta-ocho-diez-casos.html> [Fecha de consulta: 12 de noviembre de 2017].

204 ALPUENTE, Enrique, "El 70\% de los escolares ha sufrido, presenciado o realizado ciberacoso", 2016, disponible en: <http://www.elmundo.es/sociedad/2016/04/16/571129ff468aebb6748b465o.html> [Fecha de consulta: 20 de julio de 2017].

205 GIMÉNEZ, Ana M. y MAQUILÓN, Javier J., "Usos problemáticos y agresivos de las TIC por parte de adolescentes implicados en cyberbullying", en Revista de investigación educativa, vol. 33, $\mathrm{n}^{0} 2,2015$, pág. 345 .

206 CASADO, Miguel A.; GARITAONANDIA, Carmelo; GARMENDIA, Maialen S. y MARTÍNEZ, Gemma "Els menors a Internet. Usos i seguretat des d'una perspectiva europea", en Quaderns del CAC, $\mathrm{n}^{\circ} 38$ (Ejemplar dedicado a: Reptes de l'audiovisual europeu), 2012, pág. 41. 
patrones educacionales y de alerta ante los primeros síntomas visibles. Aunque en última instancia es el propio adolescente el que debería encontrar salidas razonables ante posibles problemas relacionados con cualquier tipo de ciberacoso, incluido el que utilice el sexting como marco operativo. En ese sentido, se sabe que en la actualidad, seis de cada diez jóvenes usuarios de Facebook o de Instagram en España afirman conocer las herramientas de privacidad de estas redes sociales, un pensamiento reforzado en ocasiones por los propios padres, quienes confían en el uso que hacen sus hijos de las redes.

\begin{abstract}
"Recientemente (2015) Facebook España lanzó la campaña «Piensa antes de compartir», realizada en colaboración con el Grupo de Sociología de la Infancia y la Adolescencia, en la que informa a los jóvenes y adolescentes sobre la importancia de la privacidad en esa red, enfatizando una serie de riesgos reales a los que los jóvenes restan importancia" ${ }^{207}$.
\end{abstract}

De hecho, el caso del suicidio de Amanda Todd nos recuerda el especial cuidado que debemos tener con la imagen del menor en Internet ${ }^{208}$. Aunque en ocasiones es difícil averiguar la edad de una persona a través de su imagen, debemos estar siempre en alerta permanente cuando nos enfrentamos a las imágenes que nos muestran las pantallas conectadas a la red, o cuando investigamos sobre estas cuestiones, como por ejemplo, en este estudio. Es necesario que seamos sensibles con este colectivo tan vulnerable. Tanto Internet

207 MARCELINO, Georgina V., "Migración de los jóvenes españoles en redes sociales, de Tuenti a Facebook y de Facebook a Instagram. La segunda migración", en Icono14, vol. 13, n 2 (Ejemplar dedicado a: Comunicación y redes sociales), 2015, pág. 51.

208 La serie de televisión de 201713 Reasons Why (Por trece razones, en español), es una serie estadounidense de misterio y drama adolescente basada en la novela de 2007 Por trece razones de Jay Asher y adaptada por Brian Yorkey para Netflix que podemos considerar como una perfecta dramatización en el ámbito audiovisual para entender (bajo las limitaciones del drama) los casos de suicidio relacionados con el tipo de prácticas dañinas contemporáneas que estamos revisando en estas páginas. La trama de 13 Reasons Why (Imagen 5.60) gira en torno a una estudiante de secundaria que se suicida después de una serie de fracasos culminantes, provocados por determinados individuos dentro de su escuela. Una caja de cintas de casete grabadas por Hannah antes de su suicidio, detalla las trece razones por las que decidió acabar con su vida. VV. AA., "13 Reasons Why (serie de televisión)", 2018, disponible en: <https://es.wikipedia.org/wiki/13_Reasons_Why_(serie_de_televisión) > [Fecha de consulta: 12 de enero de 2018]. 
como los smartphones y sus aplicaciones son tecnologías muy recientes y aún cambiantes. No han sentado todavía muchas bases, de ahí que estemos constantemente adaptándonos máquina y humano. Con todo, lo que es una cuestión irrefutable es que el abuso, la vejación, el chantaje al menor y, sobre todo, la pederastia, son un grave cáncer social que ha de ser combatido con contundencia y valentía.

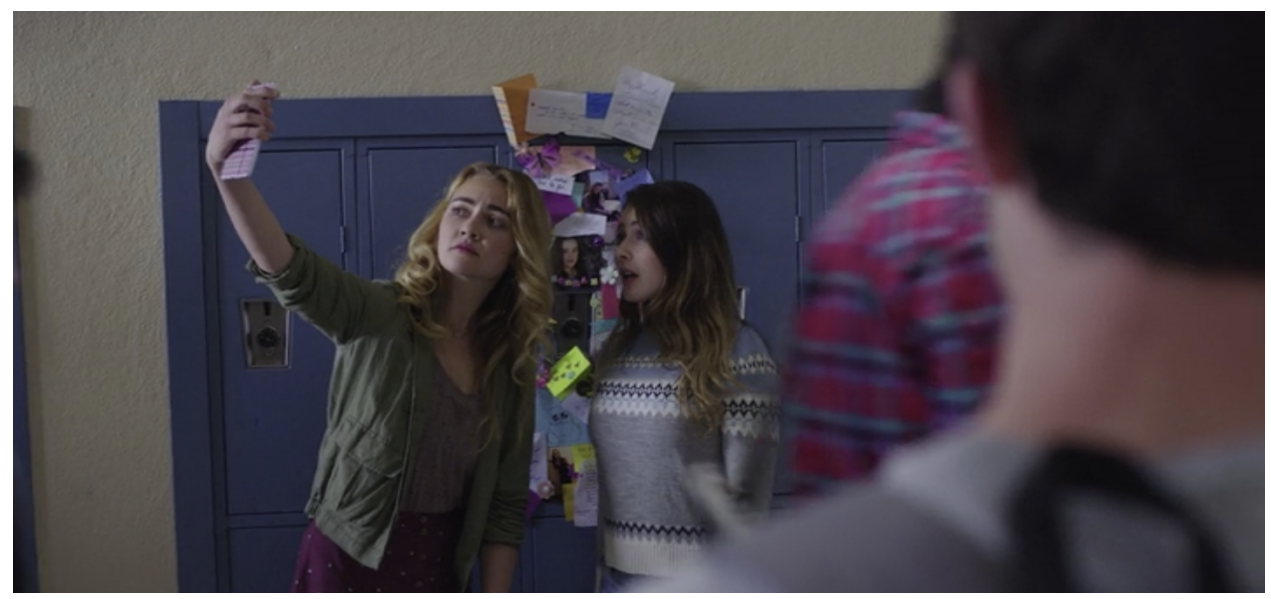

Imagen 5.60: Un fotograma de la serie 13 Reasons Why (Por trece razones) que recoge una escena en la que dos alumnas de instituto se hacen un selfie frente al improvisado altar que se ha erigido sobre la antigua taquilla de Hannah Baker, la suicida adolescente protagonista en torno a la que gira todo el argumento de esta serie.

\subsubsection{Otros riesgos en torno a la práctica del selfie.}

Hemos visto la nociva combinación que suponen las malas prácticas de sexting y ciberacoso, pero no son los únicos riesgos que puede acarrear la práctica de los selfies, sobre todo entre la gente joven. Como siempre que se da 
un nuevo paso (no necesariamente conducente a una confrontación frontal) en el ámbito tecnológico, surgen apocalípticos e integrados ${ }^{209}$. No importa que se trate del telégrafo, la televisión o el smartphone: por cada nueva especie mediática que irrumpe en la ecología de la comunicación no tardan en brotar sus defensores y detractores:

"Cuando apareció el telégrafo en la primera mitad del siglo XIX, algunos soñaron un mundo sin guerras donde reinaría el diálogo; seguramente las empresas que transmitían mensajes a caballo de una costa a otra de Estados Unidos no vieron con nuevos ojos el new media que mandaba mensajes en código Morse en pocos segundos. Como escribió James Gleick, autor de The Information, «cuando la gente dice que Internet nos convertirá a todos en genios, eso ya fue dicho sobre el telégrafo. Por otro lado, cuando dicen que Internet nos volverá estúpidos, eso también se dijo del telégrafo». La historia se repite, primero como apocalipsis, simultáneamente como redención” ${ }^{210}$.

Intuimos hoy entre los integrados a quienes podemos considerar como los gurús entusiastas de los social media:

"[... estos] bien podrían enumerar diez razones para convencer de la idoneidad de contar a través de Twitter qué estás haciendo o de hacerte un autorretrato en tus lugares favoritos. Estos canales serían -del mismo modo que Narciso busca su espejo en el Aqueronte- medios privilegiados para dar rienda suelta a la libertad de expresión (producción), a la libre elección (acceso) entre una pluralidad de información disponible en el gran archivo de la red"211.

Junto a estos gurús, otros muchos estudiosos, fascinados también por las nuevas tecnologías, apuntan que la habilidad informática en torno a nuestras nuevas herramientas parece ayudar a los jóvenes a conseguir una especie de

\footnotetext{
209 Volvemos a hacer referencia al estudio de Umberto Eco que citábamos el pasado capítulo.

210 SCOLARI, Carlos, "De Picasso a Pikachu", 2016, disponible en: <https://elpais.com/cultura/2016/10/ 07/babelia/1475841791_221262.html> [Fecha de consulta: 20 de julio de 2017].

BROULLÓN-LOZANO, Manuel A., op. cit., pág. 220.
} 
status social entre sus congéneres, originando el refuerzo de la autoestima, fortaleciendo el aprendizaje y la sociabilización. Ello hace que en lugar de estar creando aislamiento, la tecnología más reciente se configure como una poderosa herramienta comunicativa que permite relacionarse mejor con los demás ${ }^{212}$. Así, el ciberespacio sería entendido sobre todo como un medio "para la exploración sensorial creativa, inteligente y beneficiosa y para la relación colectiva" ${ }^{213}$.

Por otro lado, los apocalípticos parecen ganar la batalla en cuanto a la cantidad de argumentos que podrían avalar sus teorías, y los ejemplos que nosotros hemos encontrado tampoco son escasos. ¿Se declararía en 2018 Umberto Eco un antiapocalítico ante tal panorama? Entre estos innumerables timoratos están los celosos de su privacidad y de su imagen que, asustadizos como Edipo, renuncian a ver y a ser vistos. "Los apocalípticos contratan a empresas privadas para borrar su huella digital de la red de redes: el derecho a ser olvidados cuando el pasado pesa como una losa, cuyo peso en el presente resulta insoportable”214. El apocalíptico podría estar sospechando de que la red es un instrumento del panopticon para extender y organizar lo que puede ser visto y controlado por las instancias del poder, especialmente, las económicas, que aprovecharían estos datos para generar estrategias en un mercado segmentado.

\footnotetext{
"Bajo este punto de vista, no soolo el derecho a la privacidad de la correspondencia sino también las libertades de expresión e información estarían amenazadas en función del adagio latino verba volant, scripta manent, oportuna definición para el gran archivo global que es la red" ${ }^{215}$.
}

Ciertamente, el uso de la red en general, y la práctica del selfie en particular, pueden llevar hasta el más fatal de los males. Y es que los noticieros y

\footnotetext{
212 VÁZQUEZ, María F., op. cit., pág. 33.

213 FREELAND, Cynthia, op. cit., pág. 212.

214 BROULLÓN-LOZANO, Manuel A., op. cit., pág. 212.

215 Ídem.
} 
telediarios se han llenado de sucesos que relacionan muertes accidentales con el autorretrato digital publicado en la red. De hecho, el número de decesos relacionados con los selfies en el mundo durante los años 2014, 2015 y 2016, fue de 49 (más que las muertes por ataque de tiburón). La media de edad de las víctimas era de 21 años, algo que tiene lógica si tenemos en cuenta que el 30\% de los selfies que hay en la red están hechos por personas entre 18 y 24 años. Curiosamente, la mayoría de las víctimas (un $75 \%$ ) fueron hombres ${ }^{216}$.

Dejando al margen la cantidad de turistas (Imagen 5.61) que han muerto en el momento exacto en el que intentaban realizar el autorretrato perfecto (o bien por el choque de una ola, una fuerte racha de viento o una eventual pérdida del equilibrio que ha sido el prólogo de un despeñamiento o ahogo), existen gran cantidad de jóvenes que se apuntan a la moda (Imagen 5.62) de subir al punto más alto de un rascacielos y autorretratarse en equilibrio con la ciudad a sus pies (y cientos de metros de caída libre ${ }^{217}$. Obviamente estos ejercicios no siempre salen bien $^{218}$, tampoco en nuestro país ${ }^{219}$.

216 ALPAÑÉS, Enrique, "Muerte por selfie: la realidad que esconden los números", 2016, disponible en: <https://elpais.com/elpais/2016/02/o4/tentaciones/1454589530_250716.html> [Fecha de consulta: 20 de abril de 2017].

217 RUIZ, David, "Selfies extremos que llevan a la muerte", 2015, disponible en: <http:// www.lavanguardia.com/sucesos/20150705/54433730328/selfies-muerte.html> [Fecha de consulta: 30 de mayo de 2017].

218 LOVYT, Brynn, "Death by Selfie: 11 Disturbing Stories of Social Media Pics Gone Wrong", 2016, disponible en: <https://www.rollingstone.com/culture/pictures/death-by-selfie-10-disturbing-storiesof-social-media-pics-gone-wrong-20160714/selfie-stick-lightning-rod-20160714> [Fecha de consulta: 30 de mayo de 2017].

219 PAÑOS, José V., "Un menor, grave tras caer al vacío en la fábrica de El Turia cuando se hacía un selfi”, 2017, disponible en: <http://www.levante-emv.com/sucesos/2017/05/29/menor-grave-caer-vaciofabrica/1573087.html $>$ [Fecha de consulta: 30 de mayo de 2017]. 


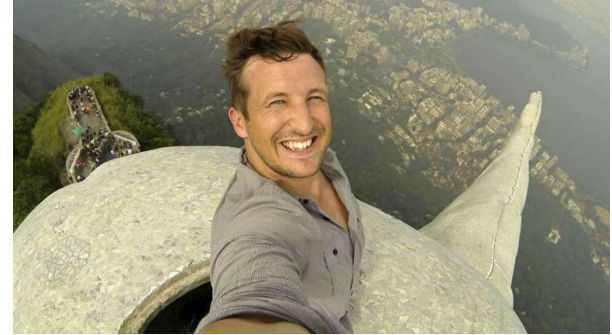

Imagen 5.61: Un turista haciéndose un selfie asomado sobre la cabeza del Cristo Redentor de Río de Janeiro.

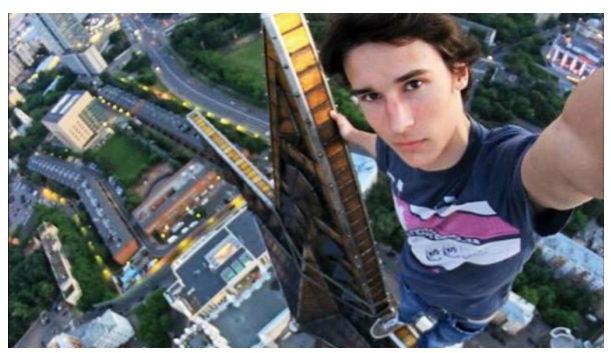

Imagen 5.62: Kirill Oreshkin, un famoso autorretratista extremo en la red, haciéndose un selfie tras escalar hasta el punto más alto de la Universidad del Estado de Moscú.

Por otro lado, algunos secuestros o asesinatos podrían tener consecuencia directa con la obsesión de volcar en las redes sociales la imagen propia, las rutinas e incluso el domicilio, lo que facilita el trabajo a los delincuentes y violadores. Entre los ejemplos, el de la bloguera de fitness Karina Vetrano, que fue violada y asesinada por un perturbado que había analizado sus recorridos geolocalizados y publicados en las redes sociales de la mujer, así como el contexto de sus autorretratos y directos ${ }^{220}$. Respecto a esta falta de consciencia acerca de "qué detalles de nuestra vida hacemos públicos en Internet", algunas empresas y organismos públicos se han posicionado ${ }^{221}$ al respecto haciendo alusión a una necesaria educación en este ámbito, no solo entre los jóvenes, sino también entre los padres obsesionados por exponer las vidas de sus hijos menores en estas plataformas públicas ${ }^{222}$ en las que tan peligroso puede resultar el sharenting,

220 VV. AA., “Asesinada una conocida bloguera de fitness en un parque de EE.UU.", 2016, disponible en: <http://www.abc.es/recreo/abci-instagram-encuentran-violada-y-asesinada-conocida-bloguerafitness-parque-eeuu-201608051326_noticia.html> [Fecha de consulta: 20 de diciembre de 2016].

221 VV. AA., "Peligros del ciberpostureo en las redes sociales", 2017, disponible en: <http://www.levanteemv.com/vida-y-estilo/tecnologia/2017/o8/15/peligros-ciberpostureo-redes-sociales/1604987.html> [Fecha de consulta: 12 de noviembre de 2017].

222 LANTIGUA, Isabel F., “iMamá, papá! Dejad de contar mi vida en vuestras redes sociales”, 2017, disponible en: <http://www.elmundo.es/sociedad/2017/o5/20/59159abc468aeb4c678b462c.html> [Fecha de consulta: 22 de mayo de 2017]. 
tratándose sobre todo de imágenes que registran a un colectivo tan vulnerable como son los menores de doce años.

También son muchos los que, analizando el panorama mediático contemporáneo, podríamos afirmar que han percibido más molestias ${ }^{223}$ que ventajas en el uso de las tecnologías y de la difusión de la imagen propia. Un exceso de distracción ${ }^{224}$ por parte de las redes sociales, su compromiso y dependencia, así como su reciprocidad casi obligatoria, ha generado una nueva raza de "desconectados" o "exconectados" que ha preferido, pese a haber vivido un pasado de selfies diarios, abandonar todo contacto con estas redes y prácticas para vivir una vida más "real" y menos "esclava" 225.

"Soy la chica que lo tuvo todo y quiero decirte que tenerlo todo en las redes sociales no significa nada en tu vida real. He dejado que se me definiera por los números y lo único que realmente me hacía sentir bien era conseguir más seguidores, más megustas, más repercusión y visitas. Nunca era suficiente”226.

Aunque, al margen de estas anécdotas, también constituye un verdadero problema social vinculado a la obsesión compulsiva de la constante realización y publicación de autofotos en las redes sociales y demás plataformas ${ }^{227}$, la aparente

223 SALAS, Javier, "Esta notificación te está robando un pedazo de vida", 2017, disponible en: <https:// elpais.com/elpais/2017/05/04/ciencia/1493890150_694485.html> [Fecha de consulta: 1 de julio de 2017].

224 EBOLA, Joseba, "El smartphone, ese arma de distracción masiva", 2017, disponible en: <https:// elpais.com/elpais/2017/06/23/ciencia/1498217993_075316.html > [Fecha de consulta: 1 de julio de 2017].

225 BOZA, Pepe, “Exconectados: ¿̇algo más que una moda?”, 2016, disponible en: <http:// www.medioambientesimbolico.asumearagon.es/exconectados-algo-mas-que-una-moda/> [Fecha de consulta: 20 de noviembre de 2016].

226 Ídem. Última declaración online de Essena O’Neill, una bloguera australiana que contaba con 500.000 seguidores en Instagram, 20.000 en SnapChat y 250.000 en YouTube y que, en 2015, decidió acabar con la obsesión cuantitativa de perfección que marcaba su vida.

227 "La cámara obliga a su poseedor (al que es poseído por ella) a tomar fotos sin cesar, a fabricar más y más imágenes redundantes”. FLUSSER, Vilém, Una filosofía de la fotografía, Madrid, Síntesis, 2001, pág. 56. 
adicción ${ }^{228}$ que puede ocasionar esta producción (y también su consulta y redifusión), sobre todo entre los adolescentes y colectivos de gente joven. Algo que ciertos entendidos se han atrevido a catalogarlo como una enfermedad: la selfitis ${ }^{229}$.

Y es que 2017 arrojó datos como que el 22\% de los adolescentes de nuestro país pasa más de seis horas diarias en la red. Este hecho puso sobre la mesa estudios y textos que hacían una crítica profunda a la realidad que estaban generando estos modelos de autoexhibición en las redes sociales: "Los adolescentes experimentan una sensación de recompensa inmediata al dar al «me gusta» en las redes sociales que no debería confundirse con la felicidad" ${ }^{230}$. Además, se han registrado apuntes incluso acusadores de patologías muy graves con el uso de dichas redes ${ }^{231}$. Ante tal panorama, muchos centros educativos, gestores de esos jóvenes conectados, han decidido poner coto a los dispositivos de sus estudiantes ${ }^{232}$, algo razonable tras las repetidas muestras de adicción que, como vemos, pueden fácilmente ser detectadas en los jóvenes usuarios de estos $\operatorname{dispositivos}^{233}$.

228 Que como toda adicción, tras la retirada de su causa, el afectado puede mostrar niveles altos de ansiedad por no poder acceder al dispositivo, tendiendo al aislamiento en su habitación y cambio en los ritmos de sueño. GIMÉNEZ, Ana M. y MAQUILÓN, Javier J., op. cit., pág. 345.

229 "La dependencia del móvil en la era de la hiperconexión puede ser extrema. Tanto que ya se ha puesto incluso nombre a la enfermedad de aquellos que no pueden estar ni un minuto separados de su teléfono: nomofobia. Y también de los que se dejan literalmente los dedos en la pantalla whatsappitis o los adictos a hacerse todo el rato fotos a uno mismo y compartirlas en las redes sociales: lo llaman selfitis". DE LA CAL, Lucas, "Olvida tu smartphone, este móvil vuelve a estar de moda", 2016, disponible en: <http://www.elmundo.es/papel/todologia/2016/04/04/56fe4a8a22601d52618b4678. html $>$ [Fecha de consulta: 20 de julio de 2017].

230 VV. AA., "Usuarios extremos: un 22 \% de los adolescentes que pasa más de seis horas diarias en la red", 2017, disponible en: <https://www.20minutos.es/noticia/3038407/o/usuarios-extremos-22adolescentes-pasa-mas-seis-horas-diarias-internet-red/> [Fecha de consulta: 20 de agosto de 2017].

231 VV. AA., "Un estudio revela que Facebook o Twitter dañan la salud mental de los jóvenes", 2017, disponible en: <https://www.20minutos.es/noticia/3042029/o/estudio-revela-redes-socialespopulares-danan-salud-mental-jovenes/> [Fecha de consulta: 24 de diciembre de 2017].

232 RECIO, Enrique, "Un instituto de Lleida prohíbe usar el móvil a los alumnos para que hablen en el patio entre ellos", 2017, disponible en: <http://www.elmundo.es/sociedad/2017/01/17/ 587e1a94268e3ea95b8b4661.html> [Fecha de consulta: 20 de julio de 2017].

233 CUESTA, Ubaldo y GASPAR, Sandra, op. cit., pág. 436. 
Así pues, cuando se les pregunta cuántas veces al día y cuánto tiempo usan el móvil, los jóvenes y adolescentes responden: "Constantemente, todo el día”. La utilización del móvil se ha convertido en un hábito diario. "Se chequea el móvil incluso sabiendo que ha transcurrido poco tiempo para que hayan llegado mensajes nuevos y aunque la pantalla no se haya iluminado, por si acaso". Estas conductas adictivas en general respecto al dispositivo, a la red y a sus prácticas, también son aplicables al selfie en particular, así como a su producción, uso y consumo. Un claro ejemplo, a nuestro entender, de esta cuestión y traído de la mano de un testimonio real es el episodio del programa crítico con las situaciones sociales Salvados, producido y dirigido por el periodista Jordi Évole, un episodio que fue emitido en la cadena de televisión La Sexta la noche del 19 de febrero de 2017, llevando como título Conectados (Imagen 5.63) ${ }^{234}$. En dicho programa, además de una interesante entrevista realizada al sociólogo y filósofo Zygmunt Bauman en torno a la absorbente conexión permanente que las sociedades contemporáneas sufren mediante Internet y los nuevos dispositivos electrónicos, encontramos los testimonios y las actividades de Belén Sensat (Imagen 5.64), una joven que no deja el móvil ni cuando está en clase, sobre todo pendiente de la red Instagram, lugar en el que publica compulsivamente decenas de selfies a la semana. En este programa de corte documental, Belén es seguida por el equipo mientras la filma durante un día normal de su vida dando visibilidad a la común (y en ocasiones problemática) actividad de muchos de estos adolescentes y postadolescentes. Ella afirma: "En cada sitio que estoy me hago una foto". "Nunca me he dejado el móvil en casa y soy capaz de llegar tarde para ir a recogerlo". "Lo primero que hago cuando me levanto y antes de acostarme es consultar Instagram”.

234 ÉVOLE, Jordi y LARA, Ramón (Productores), ÉVOLE, Jordi (Director), Salvados: Conectados [Programa de televisión], España, Producciones del Barrio, 2017. Puede visualizarse en: <http://www.atresplayer.com/television/programas/salvados/temporada-12/capitulo-11-conectados_ 2017022400581.html> [Fecha de consulta: 12 de enero de 2018]. También en: <https://vimeo.com/ 205141030> [Fecha de consulta: 12 de enero de 2018]. 


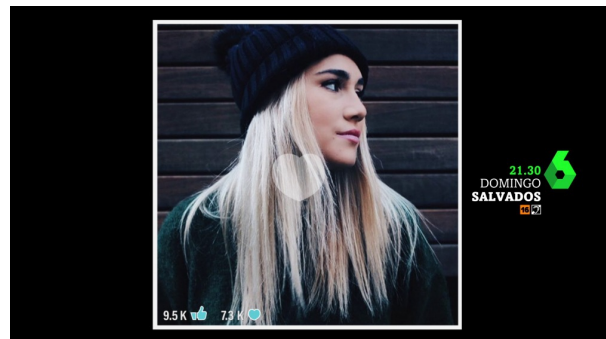

Imagen 5.63: Cuña para anunciar el programa Conectados de la serie de documentalismo social Salvados, que utiliza uno de los selfies de la entrevistada como marco referencial.

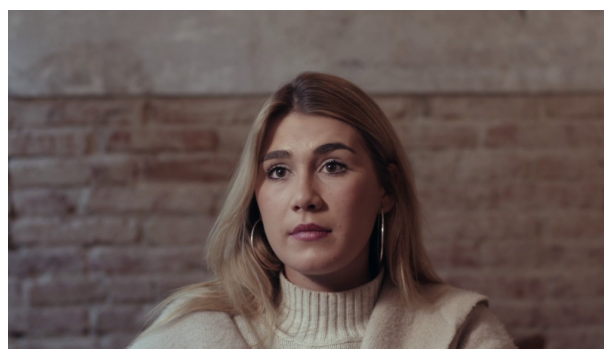

Imagen 5.64: Belén, la adolescente adicta a los selfies y al uso de las redes sociales mediante el smartphone, entrevistada en el programa citado en la imagen precedente.

Tras esto, si somos capaces de dejar al margen tanto apocalipsis, podemos incentivar, incluso alabar, el ejercicio del selfie y su producción como un objeto de valor plástico y creativo insertado dentro de las prácticas populares de las masas en cuanto objeto fotográfico iniciado y perfeccionado por el colectivo adolescente. Sin embargo, aún nos queda repasar cuál es fundamentalmente su soporte que, además de darle visibilidad, ha permitido su viralización: la red que supone ser Internet en general y las redes sociales en particular. 


\section{EL CIBERESPACIO: UNA GALERÍA VISUAL INFINITA EN LA RED GLOBAL}

[...] una red de varios computadores, conectados mediante líneas de banda ancha dando las funciones hoy existentes de las bibliotecas junto con avances en el grabado y adquisición de información y otras funciones simbióticas.

JOSEPH C. R. LICKLIDER, La simbiosis hombre-máquina, 1960.

El ciberespacio, es decir, esa pseudorrealidad (hoy realidad) simulada y que se encuentra germinada dentro de la red electrónico-digital que conforma la maraña de computadoras de todo el planeta que se hallan conectadas mediante este tejido, es el último ingrediente que configura y hace posible nuestro objeto de estudio. La red (o Internet) en general, y el ciberespacio creado por el hombre dentro de esta red en particular, así como las estructuras de redes sociales y otro tipo de plataformas y aplicaciones creadas dentro de la misma, serán los recorridos que abordemos a lo largo de este capítulo.

La existencia de Internet ha hecho posible que los autorretratos digitales publicados alcancen la notoriedad y la visibilidad de la que hoy en día gozan, dicho de otra manera, la red ha hecho posible la popularización de lo que hoy llamamos selfie. Además, Internet forma parte de la propia realidad de este tipo de imágenes, ya que están íntimamente emparentadas con el medio donde son 
expuestas, formando parte de las autopistas de distribución de imágenes que construyen este mismo ciberespacio. La mayoría de estas fotografías no serían realizadas de no existir las estructuras de publicación e intercambio que las invita a extenderse hacia miles de ojos. Y estas estructuras engloban (como hemos resumido) desde Internet en las computadoras hasta las redes sociales, pasando por los servicios de mensajería e intercambio de imágenes y aplicaciones de los smartphones donde son compartidas. Los selfshooters se autorretratan para mirarse, pero también para ser vistos. Su público será una o más personas, desde el amante de la habitación de la casa de al lado, hasta espectadores y voyeurs distribuidos por el planeta entero. Y la red será su escaparate. Las autofotos, íntimas o no, han saltado y saltan así, de pantalla a pantalla. Se multiplican rizomáticamente, cacofónicamente. Estas imágenes de base fotográfica, construidas sobre las superficies electrónicas en forma de unos y ceros, ejecutarán estas pautas de reproducción que tanto cabe esperar de ellas dada la naturaleza digital que las conforma.

El ciberespacio cierra el círculo alrededor del self shot como tercer elemento conformador. Este tipo de imágenes son y han sido fruto de la popularización de los dispositivos de captura fotográfico-digital, de la emancipación del adolescente como hacedor de imágenes (junto con su contagio a otros usuarios) y de la propia red. El autorretrato digital publicado es producto de su relación con el soporte que lo construye y que, a su vez, se desarrolla para albergarlo.

Y es que la red funciona como esa autopista de envío instantánea, ya que nos permite efectuar el casi directo (o el directo), sin que importen las distancias, las fronteras o las horas, utilizando para ello nuestros autorretratos fotográficos recién realizados como objeto transmitible. $\mathrm{Y}$ mirando con cierta perspectiva, el ciberespacio ha conferido esta capacidad de desplazamiento virtual de las imágenes fotográficas desde hace relativamente poco tiempo: veinte años aproximadamente. Resulta por tanto curioso y anécdótico recordar cómo, sin 
embargo, ese anhelo ha estado presente en torno a la fotografía desde hace más de un siglo.

Por ejemplo, a finales del siglo XIX un hombre radicado en Pau (ciudad ubicada a unos $750 \mathrm{~km}$ al suroeste de París) le envió una carta a un reconocido fotógrafo de la época: Nadar. Esa carta contenía un particular pedido: que le hiciese un retrato fotográfico desde su estudio en la capital francesa. En aquel entonces, Nadar desestimó la carta, puesto que hacer una fotografía a distancia era considerado como algo imposible. ¿Cómo fotografiar a una persona ubicada a kilómetros de distancia? No había posibilidad en el imaginario de la época de pensar otra forma de registro fotográfico que no fuera en copresencia, producto de la ligazón indisoluble entre la existencia de un referente real, la radiación por él emitida y la alteración material de los haluros de plata de la emulsión fotosensible del soporte ${ }^{1}$.

Ha sido pues, durante estas últimas décadas, cuando el crecimiento de Internet y el desarrollo de nuevas tecnologías fotográficas en materia de comunicación digital han traído aparejado el achicamiento de las distancias, así como la posibilidad de enviar fotografías de manera instantánea más allá de las fronteras, simplemente permaneciendo sentados frente a la pantalla de la computadora o del smartphone. En este contexto, un pedido como el que recibió Nadar podría no sonar tan descabellado ${ }^{2}$.

Al margen de este hecho anecdótico que citamos como excusa para entender lo novedoso y a la vez notorio que es enviar (compartir) fotografías por todo el mundo mediante el uso de la red, acotaremos ahora, de manera sintética, el desarrollo histórico, el recorrido y la amplitud de este mismo ciberespacio. Para ello analizaremos los primeros recorridos de la computación y la llegada de

1 CALABRESE, Natalia, “iPor qué llamarlo fotografía?”, en Question, vol. 1, nº 51, 2016, pág. 353.

2 Ídem. 
los ordenadores personales, así como la evolución, desarrollo y actual situación de Internet durante estas últimas dos décadas, poniendo asimismo una especial atención en las plataformas sociales donde se aloja y distribuye el actual selfie. No obstante, nunca perderemos la perspectiva de lo dificultoso que es escribir y recopilar datos tecnológicos, pues dada la actual vertiginosa evolución de estas áreas, nuestro estudio, finalizado en 2018, podría correr el riesgo de "quedar obsoleto en pocas semanas"3.

\subsection{Breves apuntes sobre la historia de la computación.}

Así como la radio y la televisión surgieron a partir de tecnologías ya existentes como el teléfono, el telégrafo, la fotografía fija, la fotografía en movimiento y las grabaciones sonoras ${ }^{4}$, algo similar ocurrirá con las primeras computadoras $^{5}$.

Pero la máquina que conocemos como computadora, y que comenzó a desarrollarse en sus formas estructurales más contemporáneas durante la Guerra Fría y los orígenes de la era del microchip, tuvo precedentes durante décadas anteriores. De hecho, fue hace casi dos siglos cuando un visionario matemático

3 SCOLARI, Carlos, Hacer clic. Hacia una sociodemiótica de las interacciones digitales, Barcelona, Gedisa, 2004, pág. 16.

4 McQUAIL, Denis, Introducción a la teoría de la comunicación de masas, Barcelona, Paidós, 1985, pág. 27.

5 Pese a que en España se ha popularizado el término ordenador para referirnos a las máquinas domésticas de computación (ordenador personal), el término correcto por traducción, también utilizado en América Latina, sería computador o computadora (ya que estas máquinas computan datos más que ordenarlos). Computer también es el término utilizado en la lengua inglesa (las siglas PC, por ejemplo, hacen referencia a Personal Computer, en la traducción: computadora personal). Asimismo, la mayoría de lenguas efectúan sus propias traducciones a partir del término Computer. En este sentido, nos referiremos a computadora o a computador, si no de manera exclusiva, sí la mayoría de veces frente a su análogo castellano ordenador. 
inglés intuyó la posibilidad de la computadora. Esa intuición le haría famoso incluso en una época tan remota como los años 30 del siglo XIX. Ese matemático, Charles Babbage, profesor de la Universidad de Cambridge, concibió la posibilidad de un dispositivo mecánico que fuera capaz de efectuar una cadena de cálculos relacionados. En una época tan temprana, Babbage imaginó que la información se podía manipular mediante una máquina, si dicha información se convertía primero en números (algo que no han dejado de compartir las actuales máquinas digitales basadas en el sistema binario). La máquina de Babbage (Imagen 6.1), movida por vapor, podía utilizar clavijas, ruedas dentadas, cilindros y otras partes mecánicas que eran los aparatos de la entonces nueva edad industrial. Babbage pensó que su "ingenio analítico" desterraría del cálculo la pesadez y la imprecisión ${ }^{6}$.

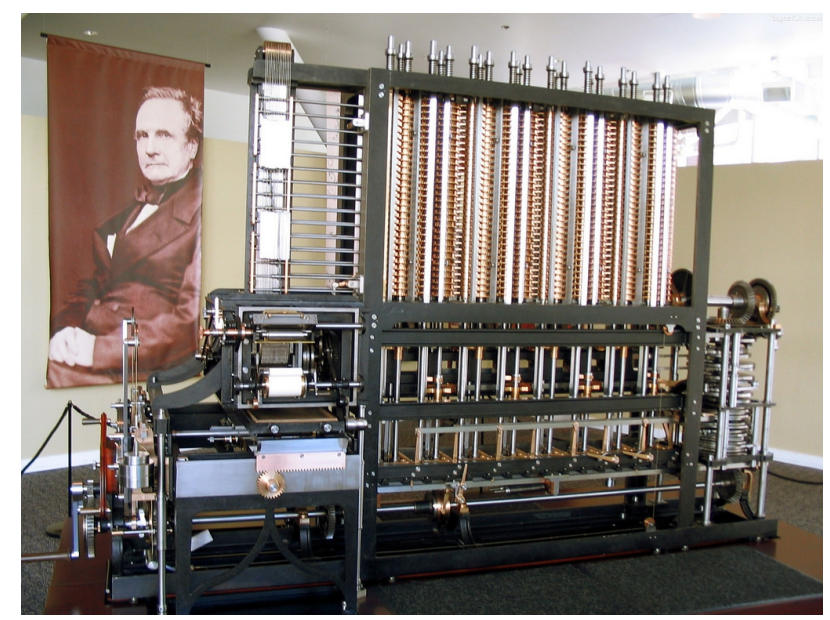

Imagen 6.1: Prototipo que simula el ingenio ideado por Charles Babbage. El mismo se halla ubicado y es propiedad del Museo Histórico de Ordenadores (Computer History Museum), de Mountain View, California (Estados Unidos de América).

6 GATES, Bill, Camino al futuro, Madrid, McGraw-Hill, 1997, pág. 23. 
Pese al pionero ingenio de Babbage en pleno siglo XIX, el verdadero desarrollo de la computación corresponde a los inicios de la segunda mitad del siglo XX. Aunque la historia de la tecnología no sea el único aspecto del recorrido de los medios en estas décadas centrales y convulsas del siglo pasado, los ordenadores deben ocupar el primer lugar en cualquier análisis histórico, puesto que una vez que se dejó de concebirlos en general como meras máquinas de calcular (lo que no ocurriría antes de comienzos de los años 1970) este hecho iba a posibilitar la adopción de nuevas formas a todo tipo de servicios, incluidos, por supuesto, los de comunicación. Sin embargo, para ello tuvieron que reducir su tamaño y coste. $\mathrm{Y}$ en esa tarea fue Estados Unidos quien dominó el curso de los acontecimientos ${ }^{7}$.

Pero antes de llegar a ese punto en el que los ordenadores comenzarán a comercializarse y a ocuparse de tareas más mundanas, hay que repasar diversos momentos previos, como el protagonizado por el papel que los mismos iban a desempeñar durante los años cuarenta del siglo XX, en plena Segunda Guerra Mundial. Es cierto que, si bien tras la teorización de Babbage muchos matemáticos trabajarán con ideas derivadas de las suyas, no será hasta mediados de estos años cuarenta cuando se producirá la construcción de una computadora totalmente electrónica (también basada en las ideas de Babbage ${ }^{8}$ ).

Es difícil especificar la paternidad de esta computadora moderna, porque mucha de la labor de concepción y la construcción se realizó en los Estados Unidos y en Gran Bretaña bajo un férreo secreto propio de las economías y los tiempos de guerra. Sabemos que Alan Turing, Claude Shanon y John von Neumann fueron tres contribuyentes principales en esta tarea ${ }^{9}$.

7 BRIGGS, Asa y BURKE, Peter, De Gutenberg a Internet: una historia social de los medios de comunicación, Madrid, Santillana, 2002, pág. 313.

8 GATES, Bill, op. cit., pág. 24.

9 Ídem. 
Cuatro años antes de que Adolf Hitler invadiera Polonia, Alan Turing, que al igual que Babbage era un gran matemático británico formado en Cambridge, propuso lo que se conoce hoy como "máquina de Turing”. Fue su versión de una máquina de calcular de propósito general a la que se podría instruir para trabajar con casi todo tipo de información ${ }^{10}$. Durante la Segunda Guerra Mundial, Alan Turing trabajó en descifrar los códigos nazis, particularmente los de la máquina Enigma $^{11}$, y durante parte del conflicto fue el director de la sección Naval Enigma de Bletchley Park, a las afueras de la Londres bombardeada. Se ha estimado que su trabajo y el desarrollo de su máquina (que permitió descifrar los códigos secretos y encriptados de los alemanes), acortó la duración de esa guerra entre dos y cuatro años ${ }^{12}$.

Sin embargo fue Claude Shannon, al final de los años treinta y cuando era todavía estudiante, el que demostró que una máquina que ejecutase instrucciones lógicas podía manipular información.

"El descubrimiento de Shannon [...] consistía en que los circuitos de la computadora -cerrados para verdadero y abiertos para falso- podían realizar operaciones lógicas utilizando el número uno para representar verdadero y el cero para representar falso. Sería esta la primera teorización y puesta en práctica del actual código binario con el que funcionan todos los aparatos electrónico-digitales del mundo” ${ }^{13}$.

Durante los años siguientes a la finalización de la Segunda Guerra Mundial y en los comienzos de la Guerra Fría, los primeros computadores digitales electrónicos y operativos continuaron desarrollándose a ambos lados del

$10 \quad$ Ibídem, pág. 25 .

11 La película de 2014 The Imitation Game muestra los hechos acontecidos en torno a Alan Turing y su máquina durante los años del conflicto, desde el propio punto de vista de Turing, interpretado por el actor Benedict Cumberbatch. GROSSMAN, Nora; OSTROWSKY, Ido y SCHWARZMAN, Teddy (Productores), TYLDUM, Morten (Director), The Imitation Game (Descifrando Enigma) [Cinta cinematográfica], Estados Unidos, Black Bear Pictures, 2014.

12 VV. AA., "Alan Turing”, 2018, disponible en: <https://es.wikipedia.org/wiki/Alan_Turing > [Fecha de consulta: 2 de enero de 2018].

GATES, Bill, op. cit., pág. 26. 
Atlántico con fines militares. El estímulo, fue la guerra, pero el beneficio terminarían teniéndolo los civiles ${ }^{14}$.

La evolución y decrecimiento en el tamaño fue uno de los objetivos primordiales a alcanzar, ya que a principios de 1946 las computadoras operativas Colossus y ENIAC (Imagen 6.2) eran máquinas gigantescas y monstruosas que dependían de miles de válvulas (no siempre fiables y a las que en Estados Unidos se llamaba tubos de vacío). Esta situación cambió radicalmente cuando los transistores sustituyeron a las válvulas. Años más tarde, en 1954, Gordon Teal cambiará el germanio por el silicio en lo que pronto dio en llamarse chip. Con el advenimiento del circuito integrado, un chip de silicio con una superficie menor a un centímetro cuadrado podía incluir 2.250 transistores miniaturizados en su interior tenía la misma potencia y rendimiento que el ENIAC, que ocupaba toda una habitación ${ }^{15}$.

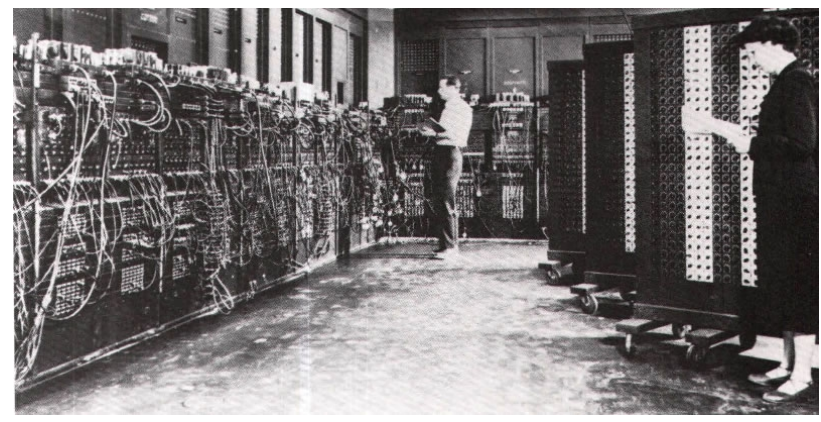

Imagen 6.2: Una parte de ENIAC manejada por dos operarios. Fuente: Techspot.

Durante la siguiente década, las grandes corporaciones de los países más desarrollados, así como muchos centros tecnológicos y de investigación, 
integraron las máquinas computadoras a sus flujos de trabajo, ganando así operatividad. Pero no será hasta la década de 1970 cuando oficinistas y otros usuarios podrán disfrutar de ordenadores personales con un tamaño, una pantalla y una interfaz más prácticos. No obstante, la evidente falta empática entre los fabricantes y los usuarios convertirán a estos primeros ordenadores personales en "los productos de consumo más antipáticos que jamás se habían construido desde el monociclo"16.

A partir del principio de la década de 1980, las empresas que ya producían computadoras personales para el hogar y para la oficina, se esforzaron cada vez más en ofrecer sistemas operativos amigables, así como entornos de uso atractivos y de fácil manejo. Fueron muchas las empresas y emprendedores que intentaron despuntar, pero el progreso de estas máquinas estuvo principalmente en manos de IBM, Apple Macintosh y Microsoft. En 1980 Apple Macintosh (Imagen 6.3) se convirtió en empresa pública, evaluada en 1.200 millones de dólares. Sólo un año más tarde, IBM entraba en liza con su propio ordenador personal, del que ese primer año vendió 35.000 unidades. También en ese año, una firma pequeña (Microsoft) comenzaría a desarrollar los fundamentos de lo que en el futuro sería el sistema operativo Windows y en el término de tres años, el 40\% de los ordenadores personales utilizarían sus programas. Cuando en 1982 Microsoft comenzó a cotizar en bolsa, Bill Gates, que tenía diecinueve años en el momento de fundarla, se hizo instantáneamente millonario ${ }^{17}$.

No podemos tampoco despreciar el hecho de que en estos mismos años se desarrollaron a la misma velocidad y con el mismo ímpetu, las primeras consolas de ocio electrónico, integrando los videojuegos en las salas privadas y en el hogar. En 1974 Nicholas Bushnell, uno de los responsables del desarrollo del videojuego, empezó a vender un juguete llamado Pong (Imagen 6.4), impulsado

16 Ibídem, pág. 321.

17 Ibídem, pág. 324. 
por un microprocesador, que se podía fijar a un aparato de televisión. Seis años más tarde, su compañía (Atari) vendió al por menor videojuegos y simples ordenadores de hogar por valor de 100 millones de dólares. "Los adultos, lo mismo que los niños, se convertirán en hábiles jugadores de los juegos de ordenador" ${ }^{\prime 18}$.

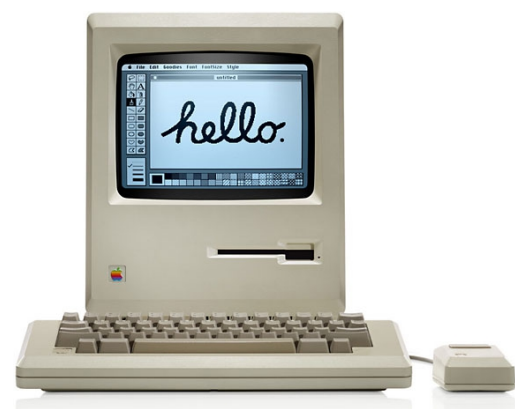

Imagen 6.3: El Macintosh de Apple presentado en 1984. Fuente: Low End Mac.

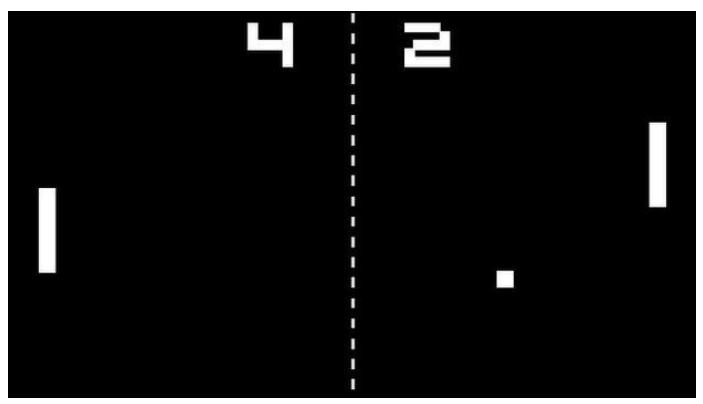

Imagen 6.4: Pantalla del videojuego Pong de 1974. Fuente: IGN.

Esa misma década trajo consigo una escalada y carrera de competitividad e innovación en la que las empresas e iniciativas se esforzaron por convertir a las computadoras en lo que son hoy: numerosas e imprescindibles. Están en todos los hogares, en todas las instituciones y empresas e integradas en cualquier cultura del planeta. Sirven para todo y las necesitamos para todo. Los ordenadores han dado paso a los smartphones (de manera aditiva y, de momento, no sustitutiva), llevando los protocolos de la computación y sus usos hasta nuestros bolsillos. También recientemente se han incorporado a los vehículos y a los objetos más cotidianos. 
Repasar de este modo tan breve los devenires de la computación desde sus orígenes hasta nuestros días nos puede dotar de un sustrato teórico sobre el que desarrollar el siguiente punto dedicado a Internet. $\mathrm{Y}$ es que este último no hubiera podido desarrollarse sin la matriz que lo aloja: la red y su ciberespacio. Y es que los lugares donde han surgido y por donde fluyen los selfies son, ante todo, una proyección comunicativa de la computación, una proyección que acerca a los humanos mediante sus canales, como si todos nosotros estuviéramos conviviendo en una misma habitación cuya bombilla oscila parpadeante proporcionando luces y sombras. La era de la red global empezó hace décadas, pero sigue siendo nuestro hoy.

\subsection{Aproximación al recorrido operado por Internet.}

Internet, las redes, el ciberespacio... no han sido siempre lo que son hoy en día. Sus orígenes fueron complejos y difíciles, basados en las decisiones de unos pocos. Aunque con el paso de los años podemos decir, de manera metafórica, que Internet se ha desarrollado (y se desarrolla) como una especie de ser vivo que se modula siguiendo las prácticas que emanan de pequeñas decisiones de algunos, así como de las necesidades e ideas de millones de personas. Internet ha sido transformado por nosotros y a su vez nos ha transformado en una "sociedad red", término acuñado ${ }^{19}$ por Manuel Castells que resume las causas de su inevitable desarrollo:

19 Le ha dedicado, incluso, un ensayo entero: CASTELLS, Manuel, La sociedad red, Madrid, Alianza, 2000. 
"En el último cuarto del siglo XX coincidieron tres procesos independientes, que han derivado en una nueva estructura social basada predominantemente en las redes. Las necesidades de la economía de flexibilidad en la gestión y de globalización del capital, la producción y el comercio. Las demandas de una sociedad en la que los valores de la libertad individual y la comunicación abierta se convirtieron en fundamentales. Y, en fin, los extraordinarios avances que experimentaron la informática y las telecomunicaciones, y que han sido posibles gracias a la revolución de la microelectrónica. En estas condiciones, Internet, una oscura tecnología que tenía poca aplicación más allá de los mundos aislados de los científicos informáticos, los hackers y las comunidades contraculturales, se convirtió en la palanca de la transición hacia una nueva forma de sociedad: la sociedad red [...]”"

Que este tipo de red se convirtiera en lo que es hoy no fue la intención original de sus fundadores durante sus primeros años de desarrollo (como suele ocurrir con muchos ingenios humanos ${ }^{21}$ ), aunque podemos constatar que hoy en día (para bien o para mal) Internet ha cambiado el mundo y está plenamente arraigado en el tejido comunicativo-social de los habitantes humanos del planeta. $\mathrm{Su}$ invención y explosiva expansión fue una revolución, de hecho ningún invento ha transformado tanto la comunicación humana como Internet. A su vez, ha tenido un ritmo de crecimiento mucho mayor que cualquiera de los medios que le precedieron. Una de las principales causas que contribuyó a ello fue que Internet integra todos los medios anteriores: teléfono, televisión, radio $\mathrm{y}$ medios impresos $^{22}$.

CASTELLS, Manuel, La galaxia Internet, Barcelona, Debolsillo, 2003, pág. 16.

De hecho, lo que puede resultar curioso de las tecnologías es que "la gente acaba haciendo de ellas un uso totalmente diferente de aquel para el que habían sido concebidas". Internet es "el producto de la apropiación social de una tecnología por parte de usuarios productores" y las tecnologias a veces se conciben para una cosa y son otras las que ponen en práctica sus usuarios. Las personas acaban "modelando lo creado y lo re-estructuran hacia un producto final". PISANI, Francis y PIOTET, Dominique, La alquimia de las multitudes. Cómo la web está cambiando el mundo, Barcelona, Paidós, 2008, págs. 96-97. una comunicación móvil, instantánea y accesible", en RÖMER, Max (Coord.), Miradas a las pantallas en el bolsillo, Madrid, Universidad Camilo José Cela, 2013, pág. 162. 
Pero Internet no ha estado estas décadas oscilando y zozobrando bajo el ímpetu y los caprichos de los habitantes humanos. Para hacer accesible este medio y a su vez proporcionar una segura globalidad, ha sido y sigue siendo coordinado por un organismo que citaremos más de una vez a lo largo de las próximas páginas. Y es que pese a que el World Wide Web Consortium actúa más como un notario que como un juez, su constitución sigue siendo la inspiración de las instituciones de este vasto imperio. $\mathrm{El} \mathrm{W}_{3} \mathrm{C}^{23}$ (siglas que hacen referencia al World Wide Web Consortium) ha conseguido que lleguemos a este nivel de entrada y entendimiento, ya que sus principales objetivos han sido y son el acceso universal, "promocionando tecnologías que tengan en cuenta las enormes diferencias en cultura, idiomas, educación, capacidad, recursos materiales, dispositivos de acceso y limitaciones físicas de los usuarios en todos los continentes" ${ }^{24}$.

Respecto al recorrido trazado por Internet desde sus orígenes hasta nuestros días, a modo de resumen y antes de entrar en materia, podemos señalar que cada década desde años después de sus primeros prototipos ha consolidado el medio en algún aspecto importante. Durante la década de los setenta se diseñó y validó Internet. Durante los ochenta nació Internet como una red operativa y comenzó su despliegue en universidades y centros de investigación. En la década siguiente, los años noventa del siglo pasado, Internet superó con éxito su adaptación a un uso masivo a través de proveedores comerciales y además florecieron las aplicaciones. En la primera década del nuevo milenio Internet se ha consolidado como la troncal hegemónica de la sociedad de la información, llegándose a unificar y a propiciar el acceso a prácticamente todos los servicios

23 Cuyos objetivos están expuestos online en: VV. AA., "23 World Wide Web Consortium. About the World Wide Web Consortium (W3C)”, 2017, disponible en: <http://www.w3c.es/Consorcio/> [Fecha de consulta: 9 de enero de 2017].

24 FERNÁNDEZ, Lilia C., Accesibilidad y usabilidad de contenidos digitales. Por una sociedad de la información y el conocimiento no excluyente, Valencia, Universitat Politècnica de València, 2009, pág. 22. 
relacionados con la información ${ }^{25}$. Asimismo, la Web 2.0 ha situado la creación de contenidos en manos de los usuarios, convirtiendo la plataforma en algo mucho más social y modelado por no especialmente expertos en materia de informática. Finalmente, durante la década de los años diez del siglo XXI ha sido cuando, gracias a la inclusión del smartphone como gadget casi imprescindible para las prácticas cotidianas humanas, hemos podido colocar Internet en nuestros bolsillos y también en el resto de nuestros aparatos y tecnologías.

Y ahí estamos. Citando un concepto de Manuel Castells de su ensayo homónimo: "Del mismo modo que la difusión de la imprenta en Occidente dio lugar a lo que McLuhan denominó la Galaxia Gutenberg, hemos entrado ahora en un nuevo mundo de la comunicación: la Galaxia Internet”"26.

\subsubsection{Orígenes de Internet.}

Aunque Internet ya se imaginó (tal como demuestra la cita del principio de este capítulo) mucho antes de su existencia, no fue hasta la década de los años setenta del siglo pasado cuando se concibió experimentalmente, siendo a principios de la década siguiente cuando empezó a desarrollar sus primeros brotes. Años antes, un proyecto militar americano llamado ARPANET, había conseguido conectar dos universidades separadas con protocolos similares a los de las actuales redes, pero en 1982 es cuando se desarrolla el lenguaje común con el que se comprenden las computadoras entre sí: el protocolo TCP/IP con el que 
se logra posibilitar la existencia de una auténtica red global. No obstante, ¿qqué habia pasado antes de 1982 con los primeros desarrollos del Internet primitivo?

Podemos considerar al ingeniero e investigador estadounidense Vannevar Bush como el desarrollador conceptual de este avance tecnológico justo antes de sus primeros pasos. Algunos de sus documentos escritos en 1945 no hablan de otra cosa: se interesó no solo por los protocolos que podrían asumir unas supuestas redes de información, sino también por los problemas que plantearía la organización tradicional de la información, la inadecuación de la estructura arborescente y la importancia de poder proceder por "asociaciones" como lo hace la mente humana. Para él: "Lo importante sería el procedimiento que consiste en relacionar dos elementos”27. De hecho, Bush describiría el funcionamiento de lo que el llamaba Memex, un prototipo imaginado de ordenador analógico cuya idea le había estado rondando durante los años previos a la guerra, cuando era miembro del Massachusetts Institute of Technology (MIT). Según la definición de Bush, el Memex sería "un ingenio en el que los individuos almacenarían todos sus libros, documentos e informes, mecanizado de tal modo que estos pudieran ser consultados de un modo rápido y flexible”. Cabe destacar que Bush incidía en los modos de acceder de un modo inmediato a documentos textuales y gráficos $a$ priori dispersos y de naturaleza variada, así como en los mecanismos por los que, durante el curso de la consulta, se iban generando automáticamente nexos entre dichos documentos, dando lugar a un nuevo libro, cuyo orden e índice sería resultado de las decisiones del usuario. Este tipo de organización flexible de la información, dependiente de las alternativas tomadas por los usuarios a partir de una multiplicidad de opciones, será el fundamento de lo que se ha venido a denominar hipertextualidad y, por extensión, la base también de la estructura flexible y rizomática de la red de Internet ${ }^{28}$.

27 PISANI, Francis y PIOTET, Dominique, op. cit., pág. 54. 
Sin embargo, y pese a estas precoces ideas, el desarrollo de una red operativa entre varias máquinas no llegaría hasta finales de los años sesenta con el encendido del ya citado ARPANET (Imagen 6.5). ARPANET fue una red de ordenadores establecida por ARPA en septiembre de 1969. El Departamento de Defensa de Estados Unidos fundó esta Agencia de Proyectos de Investigación Avanzada (Advanced Research Projects Agency) en 1958, principalmente para movilizar recursos procedentes del mundo universitario con la finalidad de alcanzar la superioridad tecnológica militar sobre la Unión Soviética, que acababa de lanzar su primer Sputnik en 1957. La construcción de ARPANET se justificó como un medio rápido de compartir los tiempos de computación online de los ordenadores entre varios centros de informática y grupos de investigación de la agencia ${ }^{29}$.

ARPANET fue diseñada por científicos de la RAND capitaneados por Lawrence G. Roberts, del MIT, y está considerada como la primera red de transmisión de información por paquetes. Empezó a funcionar en noviembre de 1969, momento en el que se instaló el primer nodo en la Universidad de California, en el laboratorio de uno de los padres teóricos del sistema, Leonard Kleinrock. Simultáneamente, se constituiría formalmente el Grupo de Trabajo de Redes (NWG) a partir del grupo de científicos involucrados en el proyecto ARPANET, tomando Steve Crocker $^{30}$ la iniciativa de recopilar todas las sugerencias y opiniones que fueran útiles para la formulación de un protocolo unificado que permitiera la codificación y decodificación de la información por cualquiera de las distintas máquinas conectadas a la red que se estaba gestando ${ }^{31}$.

CASTELLS, Manuel, La galaxia..., op. cit., págs. 23-24.

destacar que la aportación de Steve Crocker al desarrollo de Internet no terminará aquí, ya que será también quien años más tarde ideará el primer protocolo de la red: el NCP (Network Control Protocol), capaz de regular los intercambios entre máquinas diferentes. PISANI, Francis y PIOTET, Dominique, op. cit., pág. 85 .

Ídem. 


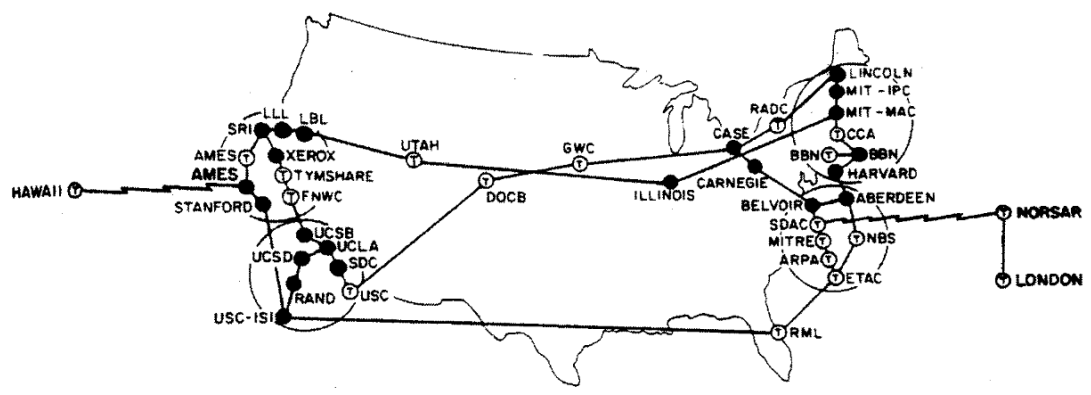

Imagen 6.5: Cartografía de la red de ARPANET en 1976 sobre el mapa de Estados Unidos y con conexiones a territorios exteriores como, por ejemplo, Londres. Fuente: PISANI, Francis y PIOTET, Dominique, op. cit., pág. 87.

Es curioso descubrir cómo, incluso en sus orígenes, las primeras redes dieron pie al intercambio de los gustos y las pasiones entre sus distanciados usuarios, ya que no solo se hacía un uso científico o laboral de estos canales. Por ejemplo:

“[...] un estudio realizado por Arpanet en 1973 revelaba que el número de usuarios de la red era de alrededor de 2.000 y que el 75\% de la comunicación de la red estaba formada por correo electrónico, gran parte de él de contenido exclusivamente personal. De hecho, las primeras listas de correo generadas entre miembros de la comunidad académica eran de carácter no científico (una de las primeras en establecerse con éxito estaba dedicada al intercambio de información entre los muchos amantes de la ciencia ficción)" ${ }^{32}$.

Muy poco tiempo después del encendido de ARPANET, en 1974, Vinton Cerf y Bob Kahn idearon y desarrollaron el protocolo TCP -Transmission Control Protocol-, que en 1978 se dividiría en el par TCP/IP, dando lugar al estándar vigente que utilizamos hoy en día. La expansión universal de este tipo de protocolos más allá de la primitiva red de ARPANET dará lugar al nacimiento de 
lo que hoy denominamos Internet ${ }^{33}$, pero antes de esto, ARPANET seguiría creciendo y modelando este concepto. Su siguiente paso fue conectarse con otras redes de ordenadores, comenzando por las redes de comunicación que ARPA estaba gestionando: PRNET y SATNET. Esta posibilidad introduciría un nuevo concepto: la red de redes ${ }^{34}$.

ARPANET, que seguiría desarrollándose bajo los mismos objetivos hasta 1983 (momento en el que se convertiría en ARPA-INTERNET y se destinaría exclusivamente a la investigación, dejando de lado su uso militar ${ }^{35}$ ), fue el primer germen que propiciaría Internet y quizá el proyecto más importante basado en redes digitales comunicacionales desarrollado durante estas dos décadas (aunque no fuera el único), de ahí que hayamos querido dedicarle estas páginas a modo de resumen.

Con todo, Internet continuará desarrollándose durante los años setenta y principios de los ochenta mientras el mundo seguía expectante tal revolución tecnológica, caracterizada por los avances de la tecnología de la información y de la comunicación, siendo pieza clave, además, como motor de desarrollo y crecimiento de todos los sectores productivos de los países más desarrollados ${ }^{36}$.

A su vez, Internet demostró durante esas dos décadas su gran capacidad de adaptación, y sobre todo, de estandarización, y esto le otorgará el carácter global y abierto del que hoy goza. La razón de esta enorme capacidad de adaptación se debe probablemente a la estructura participativa de las organizaciones que desde sus orígenes rigieron la evolución de Internet, ISOCIETF y W3C. Ambas aglutinaron desde principios de los años ochenta una gran 
comunidad de investigadores y de usuarios fuertemente involucrados en mejorar la red y en adaptarla a sus necesidades. La estrecha relación que usuarios e investigadores han mantenido siempre a través de la red, permitió alinear desde un principio los desarrollos de aplicaciones y servicios con las necesidades de uso, acelerando el despliegue y la consolidación de oportunidades en la red ${ }^{37}$.

Durante la década de 1980 se produjo el desmontaje sistemático (y muy a menudo traumático) del viejo sistema de producción junto con la desviación de todas las energías científicas, económicas y humanas hacia la puesta a punto de una red de telecomunicaciones que permitiera optimizar los flujos informacionales ${ }^{38}$. Y aunque Internet se desarrolló rápidamente durante esta década, todavía no pudo llegar a las manos del gran público, siendo solo alcanzable para las élites universitarias norteamericanas y europeas ${ }^{39}$. Pese a ello, en esta década investigadores y usuarios asumirán grandes esfuerzos para estandarizar y unificar pautas que en sus orígenes estaban tan dispersas que hubiera sido difícil llegar a un pacto global en muchas de las facetas que conforman nuestro Internet ${ }^{40}$. Por ejemplo, la “@” de las direcciones de correo electrónico ( $e$-mail) se introdujo cuando este circulaba solo entre académicos durante esta década. A su vez, también en 1986 se introdujeron las abreviaturas “.com” para comercio, “.mil” para militar y “.ed” para educación ${ }^{41}$.

Hacia el final de la mencionada década, todos los esfuerzos de mejora de Internet se centraron, por un lado, en la creación de un sistema de indexación homogéneo de los millones de documentos de todo tipo archivados en los más de 100.00o ordenadores de la red. Esta indexación debería permitir su fácil rastreo 45.

QUEMADA, Juan, op. cit., págs. 59-60.

CARRILLO, Jesús, op. cit., pág. 22.

Ibídem, pág. 88 .

HERRERA, Ángel María y VILlABONA, Jorge, 15 años de Internet, Madrid, Grupo Búho, 2008, pág.

BRIGGS, Asa y BURKE, Peter, op. cit., pág. 347. 
y acceso. Por otro lado, también era necesario el diseño de una interfaz atractiva y clara que sustituyera al inhóspito rostro del sistema Unix, hasta entonces manejado, y en el que se pudiera traducir la acción de búsqueda en términos que fueran reconocibles intuitivamente por los usuarios y no solo por expertos en informática. Sin embargo, habría de darse aún un salto conceptual cualitativo que articulara mediante una lógica unificada y eficaz las tres cuestiones principales que por entonces planteaba Internet: "por un lado, la estructura real de la red, por otro la imaginación de la misma por parte de sus usuarios y, por último, los modos de operar en ella a traves de los interfaces diseñados al respecto" ${ }^{42}$. Integrar esos tres vectores constituirá el objetivo de los desarrolladores durante los inicios de la siguiente década y hasta la llegada de la Web.

Esta importante transición se producirá durante los primeros años de la década de los noventa del siglo pasado, solucionando problemas y desarrollando nuevas ideas ${ }^{43}$. Será entonces cuando Internet, "esa oscura tecnología” a la que como ya hemos señalado, aludía Castells, dará pie a la sociedad red ${ }^{44}$.

\subsubsection{Tim Berners-Lee inventa la Web.}

A principios de los años 1990 se dio el verdadero gran salto revolucionario que constituirá la base actual de Internet. Un salto que nos ha permitido durante más de dos décadas navegar entre páginas e hipervínculos por

CARRILLO, Jesús, op. cit., págs. 93-94.

RODRÍGUEZ, Daniel, Ceros y unos: la increíble historia de la informática, Internet y los videojuegos, Madrid, Ciudadela, 2011, págs. 33-34.

CASTELLS, Manuel, La galaxia..., op. cit., pág. 16. 
la red. Nos referimos a la invención de la Web (World Wide Web), creada y desarrollada por Tim Berners-Lee (Imagen 6.6).

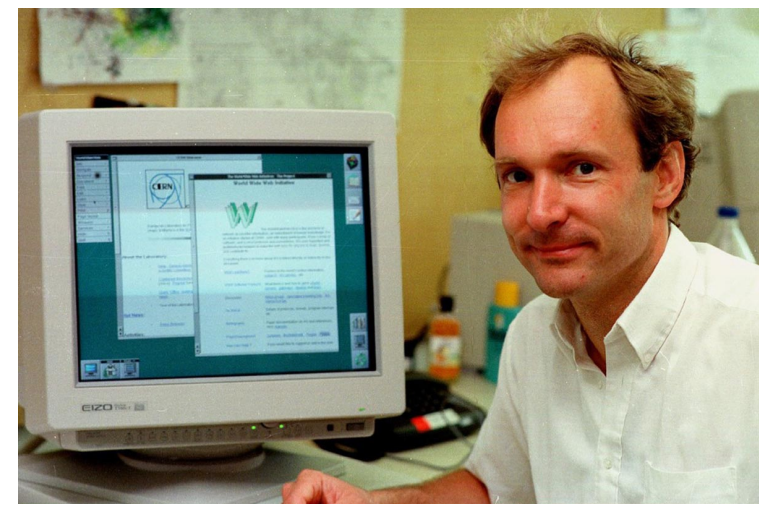

Imagen 6.6: Tim Berners-Lee en 1992 al lado de su recientemente inventada Web. Fuente: Equipo Veinte $^{45}$.

La combinación de la noción de hipertexto y el desarrollo de la red que iba a propiciar el nacimiento de la World Wide Web entre 1989 y 1991 se producirá y se pondrá a prueba lejos del entorno geográfico en el que había surgido Internet veinte años antes, es decir, lejos de Estados Unidos. Dicho lugar será Ginebra (Suiza), sede del CERN, una institución multinacional de investigación de física nuclear y de materiales cuyas instalaciones en dicha ciudad incluyen el famoso acelerador de partículas que en 2013 demostró de manera experimental la existencia de una partícula similar al bosón de Higgs. El autor o la cabeza visible del proyecto que llevará a cabo la invención de la Web durante el inicio de esta última década del siglo XX fue Tim Berners-Lee, un joven investigador de Oxford que, tras el éxito de su idea, se trasladará al MIT de

45 VICIOSA, Mario, "Breve historia de Internet", 2009, disponible en: <http://equipoveinte.com/ garajebinario/breve-historia-de-internet/> [Fecha de consulta: 17 de julio de 2016]. 
Boston, desde donde hoy tutela el desarrollo de la red como director del consorcio de la World Wide Web ${ }^{46}$.

La idea de Berners-Lee se basó en un conjunto de protocolos que operaban por encima de los protocolos de Internet y permitían un acceso muy flexible y generalizado a la información almacenada en la red en diversos formatos. Al igual que ocurrió con Internet, esta característica de acceso a todo tipo de formatos, máquinas, sistemas operativos y normas fue lo que hizo que su uso se generalizase de manera muy rápida. Según lo que Tim Berners-Lee recuerda "lo que le inspiró su creación fue ver cómo físicos de todo el mundo se reunían para debatir cuestiones científicas en los edificios del CERN" 47 . Por tanto su idea siempre fue la de teleconectar al personal de un centro más grande que una habitación.

Tim Berners-Lee ya tenía la idea de la World Wide $\mathrm{Web}^{48}$ en su cabeza en la primavera de 1989. En este momento, propuso al CERN trabajar en un sistema para compartir información y resultados de los experimentos del centro. $\mathrm{Su}$ supervisor dio la respuesta: impreciso pero emocionante. Con esa ambigua luz verde Berners-Lee siguió trabajando y el 12 de noviembre de 1990 publicó un informe detallado sobre su proyecto, que, según él, ya se encontraba en un avanzado estado de gestación. Así, tras un rápido desarrollo final de poco más de un mes, el 20 de diciembre de ese año Berners-Lee puso en marcha el primer servidor web y la primera página web del mundo. Tras un proceso de se pronunciaban, tenían nueve sílabas. De todos modos, decidí seguir adelante. Llamaría a mi sistema el World Wide Web". BERNERS-LEE, Tim, Tejiendo la red. El inventor del World Wide Web nos descubre su origen, Buenos Aires, Siglo XXI, 2000, pág. 22.

CARRILlO, Jesús, op. cit., págs. 93-94.

CERUZZI, Paul E., “Tim Berners-Lee y el origen de la Web”, 2015, disponible en: <https:// www.bbvaopenmind.com/tim-berners-lee-y-el-origen-de-la-web/> [Fecha de consulta: 2 de julio de 2016].

Respecto a esta nomenclatura, el propio Berners-Lee escribe: “Amigos en el CERN me hicieron pasar malos ratos, diciendo que el asunto nunca despegaría, sobre todo porque tenía unas siglas que, cuando 
refinamiento y pruebas, la primera versión pública del software debutó el 6 de agosto de $1991^{49}$.

Además de la World Wide Web, Berners-Lee también desarrolló otro programa mediante el que se facilitaba el acceso a esta desde un ordenador personal. Este programa, denominado buscador, fue un factor clave adicional en la popularización del uso de Internet ${ }^{50}$, ya que será el germen de los futuros navegadores que nos permiten ver (y operar en) Internet.

Berners-Lee desarrollaría poco después el lenguaje HTML con el que se escriben las webs (Imagen 6.7.) y mediante el cual los navegadores pueden traducirlas a construcciones visuales donde se distribuyen los contenidos. Estos contenidos empezarían siendo caracteres con hipertexto y cuerpos de correos electrónicos, pero más adelante serían gráficos, imágenes, fotografías y finalmente vídeos, animaciones, etc.

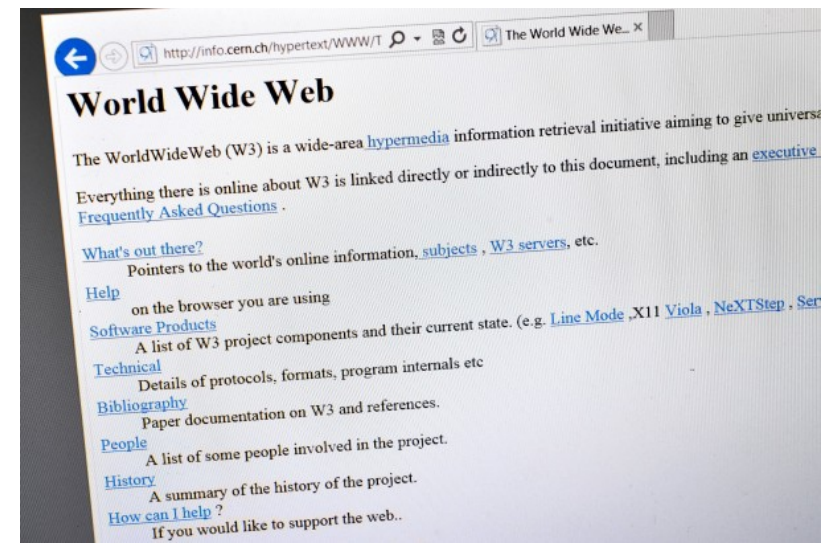

Imagen 6.7: Primera página web de la historia. Fuente: Fayer Wayer. 
El desarrollador de todo este complejo proceso recuerda en su libro:

"Un día, cuando volvía del instituto, encontré a mi padre trabajando en un discurso para Basil de Ferranti. Estaba leyendo libros sobre el cerebro, buscando pistas acerca de cómo hacer que un ordenador fuese intuitivo, capaz de efectuar conexiones, igual que hace el cerebro. Hablamos del tema; entonces mi padre siguió con su discurso y yo me fui a hacer los deberes. Pero me quedé con la idea de que los ordenadores podrían llegar a ser mucho más potentes si pudieran ser programados para relacionar información inconexa" ${ }^{51}$.

Berners-Lee había inventado sobre la matriz operativa de Internet un espacio que desde el principio tuvo la particularidad de ser fácilmente accesible y de hacer sus contenidos (sus sitios), fácilmente localizables mediante el uso de un protocolo especial: el protocolo para la transferencia de hipertextos, más conocido como http.

"Cada uno de los archivos de cualquier tipo que conforman la Web tiene una localización exacta dentro de la trama de hipertextos a la que se puede acceder a través de una dirección que no es sino el itinerario que, atravesando sucesivos estratos, lleva hasta ellos. Dicha dirección lleva en su misma formulación la situación relativa del archivo específico dentro de la Web. A tal dirección se la denomina URL o localizador de recursos uniformes. Aunque con ese nombre designamos el modo general de localizar los sitios en Internet, este cobrará su sentido más acabado en el entorno de la Web"52.

Nacerá a partir de aquí el concepto de navegación, y tras su extensión y uso, la Web pasará a ser un nuevo canal visible y un receptáculo de información y cultura visual. Una especie de computadora global accesible desde cualquier puerto telefónico (y pantalla asociada a él) que contendrá, en sus múltiples servidores deslocalizados, toneladas de información ${ }^{53}$.

Ibídem, pág. 3 .

CASTELLS, Manuel, La galaxia..., op. cit., págs. 96-97.

Usamos la palabra "toneladas" como recurso expresivo ya que la información no puede ser pesada, 
Puede resultar curioso constatar cómo, si bien para muchos inventores el desarrollo y puesta en práctica de un ingenio suele darles pie a la posibilidad de su explotación lucrativa, para Berners-Lee, crear la Web no fue una tarea encaminada a la producción de beneficios, sino un medio de ampliar las oportunidades. Tim trató de mantener a la Web sin propietario, abierta y gratuita ${ }^{54}$. Sin embargo, al igual que los empresarios norteamericanos que sí desarrollaron Internet con fines lucrativos, se vio impulsado por una ferviente creencia en su uso global potencial: la Web podía y debía ser World Wide (mundial). En el futuro, la revista Time, que lo ensalzó como padre único de la Web, calificó su logro de "casi gutenberguiano", pues había utilizado un poderoso sistema de comunicaciones que solo una élite podía usar y lo había convertido en un medio de masas ${ }^{55}$. Aunque, pese a todo, cuando la Web se extienda por nuestros hogares, seguirá estando alojada sobre un soporte que sí será privado ${ }^{56}$ : Internet.

Cabe destacar, por último, que el ingenio de Tim Berners-Lee fue concebido y desarrollado de una manera tan precisa que, a día de hoy, 25 años después de su lanzamiento, seguimos utilizando prácticamente sus mismas pautas y protocolos en lo que atiende, por ejemplo, a la dirección URL:

"La formulación básica de las URL de la Web es: http (aludiendo al protocolo de transferencia de hipertextos que se usa como vehículo básico de comunicación), al

aunque son muchos los medios digitales que apuntan hacia el hecho de que todo el contenido que circula por Internet pesa, aproximadamente, 50 gramos (el peso de un fresón). VV. AA., "Internet pesa lo mismo que un fresón", 2011, disponible en: <http://www.telegraph.co.uk/technology/internet/ 8865093/Internet-weighs-the-same-as-a-strawberry.html> [Fecha de consulta: 17 de julio de 2015].

54 Este hito respaldará en el futuro la idea de que "la cooperación y la libertad de información pueden favorecer la innovación en mayor medida que la competencia y los derechos de propiedad". CASTELLS, Manuel, La galaxia..., op. cit., pág. 23. BRIGGS, Asa y BURKE, Peter, op. cit., pág. 346.

$\mathrm{Y}$ es que en 1995, al cerrarse NSFNET, se daría paso al uso privado de Internet. Una serie de proveedores de servicios de Internet (Internet Service Providers) construirían sus propias redes y establecerían pasarelas (gateways) propias con fines comerciales. A partir de ese momento, Internet comenzó a desarrollarse rápidamente, como una red global de redes informáticas. CASTELLS, Manuel, La galaxia..., op. cit., pág. 26. 
que sigue, tras los signos ://, la abreviatura de la web -www- para especificar el ámbito de la red de Internet en que se encuentra el archivo. A continuación y separado por un punto se escribe el nombre del servidor que alberga la información, nombrado al modo tradicional en que se designan los dominios en Internet .es, .com, .org, etc. A partir de ahí el itinerario que lleva al documento o archivo concreto vendrá especificado por los nombres de las páginas de hipertexto sucesivas que lo envuelven como si se tratara de una muñeca rusa, separándose los distintos estratos por una barra inclinada: /" ${ }^{57}$.

Actualmente, Berners-Lee sigue trabajando en desarrollos para la web contemporánea. Muchos autores consideran encomiable su labor como inventor de uno de los más importantes logros humanos, un logro de los que cambian el mundo, sus costumbres y la manera de comunicación, tal como en su día lo hicieran la fotografía, y antes, la imprenta:

"En 1991, en el congreso del hipertexto de San Antonio (Texas), Tim Berners-Lee, que sin duda será un día tan célebre como Gutenberg y Niépce, presentó una demostración de su protocolo World Wide Web. En 1995 se consultaba libremente Internet en todo el mundo" 58 .

\subsubsection{Algunos apuntes acerca del hipertexto.}

El hipertexto ha sido y es la base estructural de la Web, del Internet que utilizamos hoy en día, además de ser "la forma simbólica hegemónica en la sociedad de la información contemporánea” ${ }^{59}$.

CARRILLO, Jesús, op. cit., pág. 97.

MELOT, Michel, Breve historia de la imagen, Madrid, Siruela, 2010, pág. 96.

59

CARRILLO, Jesús, op. cit., pág. 109. 
Se trata de una herramienta con estructura no secuencial que permite crear, agregar, enlazar y compartir información de diversas fuentes por medio de unos enlaces que son asociativos. En informática, su forma más habitual es la de hipervínculos o referencias cruzadas automáticas que van a otros documentos (lexías). Si el usuario selecciona un hipervínculo, el programa da un salto al documento enlazado. El hipertexto no está limitado a datos textuales, ya que podemos encontrar dibujos del elemento especificado, sonido o vídeo referido al tema. El programa que se usa para leer los documentos de hipertexto se llama navegador, browser, visualizador o cliente, y cuando nos movemos entre enlaces decimos que estamos navegando por la $\mathrm{Web}^{60}$.

Aunque, como hemos visto, Vannevar Bush teorizaría en 1945 su funcionamiento mediante los postulados acerca de la máquina Memex, fue Ted Nelson, un visionario profesional, el primero en acuñar el término. Nelson escribió en 1965 acerca de "máquinas literarias", computadoras que permitirían a la gente escribir y publicar en un nuevo formato no lineal, al que llamó hipertexto. "El hipertexto era un texto no secuencial en el que un lector no estaba obligado a leer en un orden determinado, sino que podía seguir nexos de unión y llegar al documento original a partir de una breve cita" ${ }^{11}$.

Respecto al tema que nos interesa abordar, pese a que Andy van Dam fue la primera persona que puso en funcionamiento un sistema de hipertexto, y que estos proyectos seguirían desarrollándose durante las décadas de los años 1970 y 1980, nuevamente tenemos que recordar a Tim Berners-Lee como el primero en introducir la tecnología hipermedial en Internet, proporcionándonos la Web y creando una tabula rasa en la que disponer todos los hipertextos que manejamos contemporáneamente entre las páginas web que consultamos en

\footnotetext{
6o VV. AA., "Hipertexto", 2018, disponible en: <https://es.wikipedia.org/wiki/Hipertexto> [Fecha de consulta: 4 de enero de 2018].

61 BERNERS-LEE, Tim, op. cit., pág. 5 .
} 
nuestros navegadores y en algunas de las aplicaciones que utilizamos mediante nuestros smartphones. $\mathrm{Y}$ es que a partir de la adopción del hipertexto como módulo genérico, Internet ha dejado de ser un mero vehículo de información académica y de comunicación interpersonal para convertirse en una trama casi infinita y que es capaz de articular un número creciente de actividades humanas: distribución de noticias e información, adquisición de bienes de consumo, provisión de servicios, diversión, relación con las instituciones... ${ }^{62}$. Asimismo, Internet se transformará en el soporte por donde fluirán los primeros autorretratos digitales publicados y en donde se desarrollará la actividad humana vinculada a las redes sociales virtuales, todo ello mediante la pantalla que es su expositor interactivo: el navegador.

\subsubsection{Los navegadores web y las primeras interacciones sociales en el ciberespacio.}

Un navegador web (browser) es un software, aplicación o programa que permite el acceso a la Web, interpretando la información de distintos tipos de archivos y sitios web para que estos puedan ser visualizados. Podríamos decir que, por lo menos en su origen, se trata de la interfaz de Internet que permite al usuario interactuar con la Web.

"La funcionalidad básica de un navegador web es permitir la visualización de documentos de texto, posiblemente con recursos multimedia incrustados. Además, permite visitar páginas web y hacer actividades en ella, es decir, enlazar un sitio con otro, imprimir, enviar y recibir correo, entre otras funcionalidades más”³3.

62 CARRILLO, Jesús, op. cit., pág. 117.

63 VV. AA., "Navegador web”, 2018, disponible en: <https://es.wikipedia.org/wiki/Navegador_web> 
Ya estábamos acostumbrados a cierto tipo de navegación por las emisoras de radio o utilizando la televisión, con la que a través del simple cambio de canal que no exigía más que el contacto con un botón del mando a distancia, el destinatario o consumidor podía desplazarse constantemente a través de la múltiple oferta de programas que tenía (y sigue teniendo) de manera simultánea ${ }^{64}$. De manera paralela, podemos afirmar que los navegadores nos iban a permitir convertirnos en consumidores de Internet desde principios de los años 1990 hasta nuestros días.

Los diseñadores y programadores de las interfaces de los navegadores se esforzaron en desarrollar entornos user-friendly, es decir, interfaces intuitivas y amigables para el uso popular ${ }^{65}$. Dichas mejoras se aplicaron de forma inmediata dado el precendente que había supuesto la transformación de la interfaz alfanumérica del sistema Ms-DOS a las interfaces gráficas en los sistemas operativos. Gracias a ello se fue extendiendo también entre diseñadores digitales e investigadores de la interacción persona-ordenador y navegadores, una visión de los procesos de relación en términos puramente instrumentales. "La interfaz, se decía por entonces y se repite todavía hoy, sería una especie de prótesis o extensión de nuestro cuerpo que, cuando ha sido bien diseñada, desaparece cuando la utilizamos" ${ }^{66}$.

El navegador que puede ser considerado como la primera plataforma fuera de laboratorio para consultar páginas web se llamaba Mosaic. Fue diseñado para un uso cotidiano y multifuncional y fácilmente adaptable a cualquier sistema operativo existente en los ordenadores personales ${ }^{67}$. A finales de 1994 se

[Fecha de consulta: 4 de enero de 2018].

64 GONZÁLEZ REQUENA, Jesús, El discurso televisivo. Espectáculo de la postmodernidad, Madrid, Cátedra, 1992. 
lanzó la primera versión de Netscape, que es considerado el heredero de Mosaic, y pocos meses más tarde también entró en escena Internet Explorer, integrado en el sistema operativo Windows 95 de Microsoft. La competencia entre navegadores estimuló en los años siguientes una mejora considerable de las posibilidades que se ofrecían a los usuarios para la búsqueda y lectura de archivos de todo tipo ${ }^{68}$.

Internet Explorer fue el navegador más utilizado durante una década, también por encima del navegador Safari de Apple, ya que estaba integrado en cada ordenador personal que utilizara el sistema operativo más extendido de la época: Microsoft Windows. Sin embargo, esta hegemonía descenderá, primero con la salida del navegador de código abierto Mozilla Firefox en 2004, y después con la del navegador también de código abierto Google Chrome a principios de 2008. Actualmente el navegador Chrome es utilizado por uno de cada dos usuarios de computadoras personales y, además, también es el barco insignia de cualquier smartphone que utilice el sistema operativo Android, el más extendido en este tipo de dispositivos (Imagen 6.8).
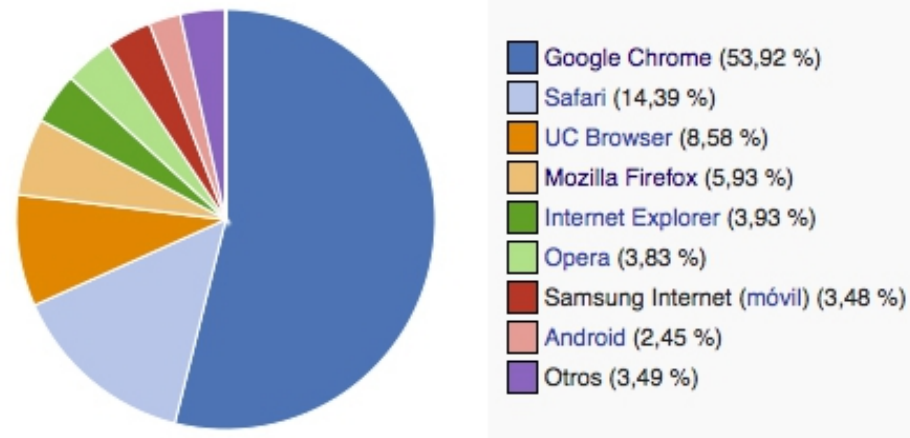

Imagen 6.8: Cuota de uso de navegadores web a fecha de junio de 2017, según StatCounter. Disponible en: <http://gs.statcounter.com/browsermarket-share\#monthly-201706-201706-bar> [Fecha de consulta: 31 de enero de 2018]. 
Los navegadores nos han mostrado las páginas web durante más de veinte años, sin embargo no será hasta la llegada del nuevo milenio cuando el desarrollo revolucionario de la Web 2.0 (como veremos a continuación) cambiará radicalmente la manera en la que los usuarios interaccionarán con Internet, puesto que la Web 2.0 va a permitir al navegante de la red dejar de ser un lector y observador pasivo para convertirse en interventor, manipulador y creador de contenidos online sin necesidad de tener conocimientos informáticos o acceso a servidores. La Web e Internet se convertirán en una herramienta mayoritariamente social y comunicativa que favorecerá, por ejemplo, la aparición de las redes sociales.

No obstante, y antes de llegar a este momento de desarrollo y cambio en torno al año 2000, Internet y la Web gozarán durante un lustro de cierta interacción social, aunque fuera de una manera mucho más rudimentaria y compleja. Será entonces cuando empiezará a gestarse el término de vida en la pantalla o el de ciberespacio. A su vez, aquellos que aprendieron a programar y a montar servidores tenían sus llamadas páginas web personales, lo que iba a permitir a sus autores y autoras a señalar quiénes eran y cómo deseaban ser vistos por los demás ${ }^{69}$. Fueron los años también del intercambio de mensajes en la distancia a través del correo electrónico ${ }^{70}$ y de las conversaciones masivas a través de los grupos de correo.

Además, fue la era de los chats: programas integrados en los navegadores o para instalar externamente mediante los cuales dos o más usuarios podían tener conversaciones de pantalla a pantalla y a tiempo real de manera escrita. De este modo estaba naciendo una nueva manera de

69 ARAUNA, Núria; MARTÍNEZ, Inmaculada J. y TORTAJADA, Iolanda, "Estereotipos publicitarios y representaciones de género en las redes sociales", en Comunicar. Revista científica iberoamericana de comunicación y educación, $\mathrm{n}^{0}$ 41, 2013, pág. 179.

70 TURKLE, Sherry, La vida en la pantalla: la construcción de la identidad en la era de Internet, Barcelona, Paidós, 1997, pág. 16. 
comunicarse de manera telemática que iba a suponer una revolución más discreta que la del teléfono pero, a nuestro entender, igual de importante. El chat más popular de finales de la década de los años 1990 fue el Internet Relay Chat (comúnmente conocido como IRC). Se trataba de un foro de conversación ampliamente utilizado en el que cualquier usuario podía abrir un canal y atraer invitados ${ }^{71}$.

Similar a los chats, aunque en un campo mucho más lúdico, los MUDs (siglas de Multi User Dungeon) también fueron muy populares entre los jóvenes universitarios de aquel último lustro del milenio. Los MUD nos situaban (y nos sitúan, aquellos pocos que quedan operativos) en espacios virtuales en los que somos capaces de navegar, conversar y contruir. Se trataban de una especie de videojuego de simulación o rol basado en texto y contruido por sus usuariosjugadores y por la programación de sus administradores. Se accedía a un MUD a través de una orden que enlazaba nuestro ordenador con el ordenador en el que residía el programa. Los MUD fueron "ejemplos espectaculares de cómo la comunicación mediada por ordenador puede servir como un lugar para la construcción y reconstrucción de la identidad”72.

Llegados a este punto, y pese a las posibilidades propiciadas por los primeros navegadores y por la interacción que nos permitieron los primeros canales comunicacionales online, el cambio más abrupto y radical que transformaría nuestras prácticas y consolidaría el concepto de ciberespacio iba a llegar con la introducción y el desarrollo de la Web 2.0, momento en el que los usuarios íbamos a convertirnos en los creadores y transformadores de los mundos virtuales de Internet. 


\subsubsection{La Web 2.0 y la institucionalización del Internet social.}

La verdadera democratización de Internet, la construcción de la Web por medio de la voluntad colaborativa de sus usuarios y el desarrollo de las redes sociales llegará con la implantación de la Web 2.o, popularizada en 2004 por Tim $\mathrm{O}^{\prime}$ Reilly ${ }^{73} \mathrm{y}$ puesta en funcionamiento unos años antes.

"La aparición de la Web 2.0, también conocida como red social porque es la que de verdad ha permitido que las cosas vayan de abajo arriba y no de arriba abajo como venía siendo habitual en la Web 1.0, esa del sitio web, que ya con la aparición del concepto de portal sufrió un primer envite [puesto] que no tenía otra intención que trasladar el zapeo televisivo al botón del ratón por un simple cambio en el dedo decisorio" 74 .

Y es que hasta esa fecha, las páginas web (los elementos más importantes y visibles de Internet) eran estáticas y rígidas. Se encontraban construidas por unos pocos profesionales, y la gran mayoría de personas eran legas en la materia de programación y desarrollo. Así pues, la Web no era participativa, ya que se movía en una única dirección: la de la lectura. Es lo que llamaban la Web 1.o en donde las páginas web estaban principalmente construidas en lenguaje HTML8, siendo estáticas y actualizándose muy de vez en cuando. Con el surgimiento de las .com se hacía necesario que las páginas fueran mucho más dinámicas, de ahí que entraran en juego los CMS (o gestores de contenidos), para actualizar de un

73 Tim O'Reilly es director y fundador de una conocida empresa editorial norteamericana que lleva su nombre. Es también la persona que popularizó el término Web 2.0 al organizar la primera conferencia Web 2.0 en San Francisco, en octubre de 2004, sentando las primeras bases del concepto en un artículo de 2005 que podemos encontrar en su blog: O'REILLY, Tim, "What Is Web 2.o. Design Patterns and Business Models for the Next Generation of Software", 2005, disponible en: <http://www.oreilly.com/pub/a/web2/archive/what-is-web-20.html> [Fecha de consulta: 17 de julio de 2017].

74 CASARES, Nilo, Del net.art al web-art 2.o, Valencia, Diputación de Valencia, Institució Alfons el Magnànim, 2009, pág. 135. 
modo más ágil las páginas y así conseguir más visitas. “Algunos autores han llamado a este modelo la Web 1.5"75.

En 2001 surge la Web 2.0 en la cual primará lo social y la interacción entre usuarios. Será ante todo una nueva filosofía de uso de la Web, donde los usuarios tomarán un rol activo como productores de contenidos y los sitios construidos con la tecnología de la Web 2.0 constituirán solo los puntos de encuentro ${ }^{76}$. Ello hará que surja un espacio en el que estarán anidados servicios y aplicaciones de uso muy sencillo para ser utilizados en la misma plataforma web y propiciar la relación y creación de contenidos por parte de los usuarios.

"Es una etapa en la que el usuario adquiere un gran protagonismo. Pasa de ser mero espectador y consumidor de lo que le ofrece Internet a convertirse en creador y generador de contenidos y servicios. Es un usuario que participa de manera activa" ${ }^{77}$.

Por lo tanto, la llegada de nuevos lenguajes de programación que operaban desde los servidores y no desde los navegadores, permitió el desarrollo de las webs participativas, es decir, modificables por los usuarios aunque estos no tuvieran conocimientos de programación. Cualquiera podía ahora construir Internet. La segunda revolución había llegado a la Web:

\begin{abstract}
"Ahora la Web pertenece a los que la utilizan... en ambos sentidos: para recibir y para crear, para acceder a la información y compartirla, para hacerla circular. Los usuarios le dan forma y la utilizan a su vez para cambiar el mundo. Este cambio de práctica (no de herramienta) está en el centro de la evolución actual, que es la que tenemos que comprender hoy"78.
\end{abstract} la Web 2.o, Málaga, Universidad de Málaga, 2009, pág. 49. Ídem. 
Estos nuevos protocolos darán una nueva dimensión al contrato entre emisores y receptores. La Web 2.0 conjuga ambos roles "y es esto lo que definitivamente constituye al receptor en agencia del trabajo cognitivo [... en] proveedor de la propia información que él mismo -como participante de una red colectiva de retroalimentaciones en interacción recíproca- consume"79.

Es decir, la nueva faceta de la Web no solo globalizó el mundo, sino que se convirtió en escenario de experimentación (generalmente en manos de los jóvenes, como hemos visto en el capítulo anterior), cambiando los usos y las costumbres de parte de la población mundial:

"[...] fue en los primeros años, de la primera década, pasado el año 2000, entonces Internet se normalizó en el mundo globalizado, mejor dicho, Internet globalizó irreversiblemente el mundo, conectándonos. [...] Pasó entonces que un día nos descubrimos enganchados a las teclas de nuestros ordenadores para ser y estar en el mundo"8o.

A partir del nacimiento de la Web 2.0, los sitios web pasarán a convertirse, esta vez de manera masiva, en "punto de encuentro" de sus usuarios $^{81}$, siendo sus plataformas fácticas las redes sociales, cuestión que abordaremos más adelante.

Y es que este giro terminará por privilegiar la enunciación en primera persona como el modelo que le es propio. En consecuencia, los rasgos predominantes en el discurso digital serán dos "la construcción del selfy la palabra clave social" ${ }^{22}$.

BREA, José Luis, Las tres eras de la imagen, Madrid, Akal, 2010, págs. 90-91.

ZAFRA, Remedios, Un cuarto propio conectado. (Ciber)espacio y (auto)gestión del yo, Madrid, Fórcola ediciones, 2010, pág. 15.

81 FAERMAN, Juan, Faceboom. El nuevo fenómeno de masas Facebook, Barcelona, Alienta, 2010, pág. 34.

BROULLÓN-LOZANO, Manuel A., "Por una semiótica del selfie en la cultura visual digital", en Fotocinema. Revista científica de cine y fotografía, $\mathrm{n}^{0}$ 11, 2015, pág. 220. 
Precisamente, la puesta en práctica de esto que empezaba a ser una cultura participativa en la cual se exigía cada vez más espacio para los ciudadanos, los cuales tenían más posibilidades para expresarse y distribuir sus creaciones (un tipo de posibilidades que hasta hace poco tiempo estaban reservadas únicamente a las grandes corporaciones ${ }^{83}$ ), será expuesta por los medios como un nuevo movimiento social.

Como consecuencia de la apuntado, la revista Time propondrá en 2006 al usuario como único protagonista en una portada que rezaba: "TÚ. Sí tú. Tu controlas la era de la información. Bienvenido a nuestro mundo". Mediante este titular la revista se refería al personaje más destacado del año ${ }^{84}$.

La Web 2.0 no ha cambiado demasiado hasta nuestros días a nivel mecánico pero, tal como hemos visto, sí que ha generado (junto a los usuarios y de manera retroactiva) una serie de escenarios, herramientas y pautas que han convertiro a Internet en lo que es hoy, por lo menos a nivel social en materia de uso, disfrute y hasta cierto punto dependencia. Comunicación, $\mathrm{n}^{0}$ 34, 2016, pág. 34.

84 NAVARIDAS, Fermín y SANTIAGO, Raúl, "La Web 2.0 en escena”, en Pixel-Bit. Revista de medios y educación, $\mathrm{n}^{\circ}$ 41, 2012. págs, $23-24$. 


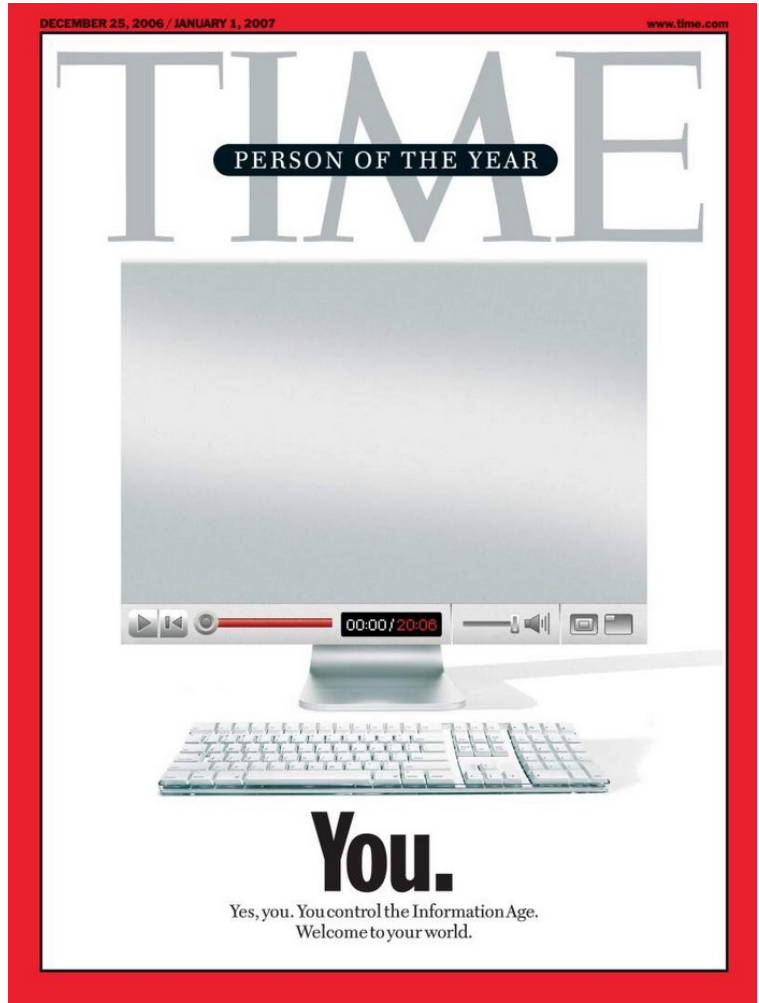

Imagen 6.9: Portada de la revista Time de diciembre de 2006 en referencia a que "Tú" (nosotros, usuarios ahora constructores de Internet) fuiste el personaje del año. Fuente: LIRA, Francisco, "Estos son los 88 personajes del año de la revista Time desde su inicio", 2015, disponible en: <http://www.upsocl.com/comunidad/estosson-los-88-personajes-del-ano-de-la-revista-timedesde-su-inicio/> [Fecha de consulta: 12 de julio de 2017].

\subsubsection{Internet hoy.}

La década pasada se utilizaba Internet a modo de consulta, de distracción, de búsqueda o de contacto. El usuario dejaba a un lado sus quehaceres y se 
aproximaba la pantalla de un ordenador con conexión a la red para entrar en Internet. Ahora ya no se entra a Internet. Se está en Internet. Ya no solo por el hecho del desarrollo de las redes Wi-Fi inalámbricas y la oportunidad de permanente conexión que tienen prácticamente la totalidad de las computadoras de nuestras sociedades, sino también porque los smartphones que poseen casi todos los individuos nos ofrecen (o condenan) a un Internet constante en nuestros bolsillos y mesitas de noche.

En 2017, y permítasenos la prolija extensión de la cita, los datos del invento que nos ha cambiado la vida y que dejan entrever lo mejor y lo peor de la realidad conectada del siglo XXI son los siguientes:

"Hay 3.773 millones de usuarios de Internet en el mundo. En 2016, la cifra de internautas era de 3.419 millones y en 2015, 3.010 millones, lo que supone un crecimiento de más del 25\% en los últimos dos años. En España hay 37,87 millones de usuarios, una buena subida respecto a los años previos, cuando la cifra apenas subió: pasó de 35,7 millones en 2015 a 35,71 millones en 2016. El 58\% de la población mundial todavía no puede permitirse una conexión a Internet. Hay un consenso general de que un precio razonable es menor al $5 \%$ del PIB per cápita para un nivel básico de servicios de banda ancha, pero hasta ese es un precio excesivo para el Internet lento y poco confiable en muchos países. También hay 2.789 millones de usuarios de redes sociales en el mundo. El subidón ha sido grande. En 2016 eran 2.307 millones y en 2015, 2.078 millones. En España, se ha pasado de los 22 millones de usuarios que tenían las redes en 2015 y 2016 a 25 millones en 2017. 23.000.00o de usuarios españoles acceden todos los días a Internet. El 91,7\% de los internautas se conecta con un smartphone, el 73,1\% de los internautas (una cifra que baja cada año) accede desde el ordenador y el 15,2\% de los hogares ya se conectan desde el televisor. Crece un 219\% el uso de tabletas conectadas a la red entre los mayores de 65. Además, en 2016, el uso de Internet subió un 11\% en este sector de la población en España. Entre los mayores, aumentan en 13,1 puntos porcentuales aquellos cuya primera motivación para conectarse a Internet es el ocio. Estas cifras revelan una significativa reducción de la brecha digital. Un 94,5\% de los usuarios usan apps de mensajería instantánea. El 50,1\% de los internautas españoles realizaron compras por Internet en 2016. El vídeo online es la estrella de la formación: el 79,6\% recurren al vídeo online 
con intenciones formativas, porcentaje que se eleva hasta el 95,1\% en los jóvenes de entre 14 y 19 años. El vídeo también avanza en la comunicación: el uso de la videollamada aumenta un 106\% entre los jóvenes. Entre los datos curiosos se encuentra que el 79\% de los internautas que tiene móvil de empresa lo utiliza para su vida personal y el 68\% instala aplicaciones personales en él. El 45\% de los internautas españoles abandonó alguna red social en 2016. La mayoría de desertores fueron de Twitter (el 13\%), seguidos por los de Telegram (10\%), Google+ (9\%) y SnapChat (8\%).

Se usan unas 4,7 redes por usuario. Facebook sigue siendo la red social por excelencia (91\%), seguida de WhatsApp (89\%), YouTube (71\%) y Twitter (50\%). WhatsApp lidera en valoración y tiempo de uso, con más de 5 horas al día. El smartphone es el primer dispositivo de acceso a las redes sociales, con un 94\%, superando por primera vez al ordenador, que se mantiene en un 93\% de penetración. El peso de la tableta aumenta significativamente, pasando de un $28 \%$ a un $55 \%$. El horario de uso más intensivo de las redes va de las 20.30 hasta las 00.30 horas. El 69\% de los estudiantes españoles declaran sentirse realmente mal si no tienen conexión a Internet. Entre 2012 y 2015, el 22\% de los alumnos españoles declaró usar Internet fuera de clase durante más de 6 horas un día cualquiera de la semana. En promedio, los alumnos españoles navegan por Internet durante 167 minutos diarios entre semana y 215 minutos el fin de semana. El 17\% de los estudiantes españoles empezaron a utilizar Internet cuando tenían 6 años. El 61\% comenzó a usar esta tecnología antes de los 10 años. Los estudiantes que dijeron usar Internet más de 6 horas al día entre semana obtuvieron de media 35 puntos menos en ciencias que los estudiantes que se conectan menos. Además, manifestaron una menor satisfacción con su vida. El 52\% del total de sitios web está en inglés a pesar de que solo el $25 \%$ de la población mundial entiende ese idioma. El porcentaje de contenido en inglés, que en 1998 era del 75\%, disminuye, pero muy lentamente. El chino es el segundo idioma en Internet en términos de usuarios, pero solo el $2 \%$ del contenido web está en chino" ${ }^{85}$.

85 Datos obtenidos de APARICIO, Daniel G., "El Día de Internet y las impresionantes cifras del invento que nos ha cambiado la vida", 2017, disponible en: <https://www.20minutos.es/noticia/3038210/o/ dia-internet-cifras/> [Fecha de consulta: 20 de julio de 2017]. Véase también: VV. AA., La sociedad de la información en España 2016, Madrid, Fundación Telefónica, 2016; VV. AA., "2017 Digital Yearbook: Digital Data for Every Country in the World", 2017, disponible en: <https:// wearesocial.com/uk/special-reports/2017-digital-yearbook> [Fecha de consulta: 20 de julio de 2017]; ACEBES, Belén y MONTANERA, Ramón, "Estudio anual de redes sociales 2017 (IABS)", 2017, disponible en: <http://iabspain.es/wp-content/uploads/iab_estudioredessociales_2017_vreducida. pdf?ct=t(Texturas_Express_110_copy_01_2_19_2017)\&mc_cid=cf5502273a\&mc_eid=42cf8a663d > [Fecha de consulta: 20 de julio de 2017]; SCHLEICHER, Andreas, "El bienestar de los estudiantes: resultados de PISA 2015 (OECD)", 2015, disponible en: <http://www.oecd.org/pisa/PISA2015- 
Analizando estas cifras podemos constatar que las redes de Internet y sus webs, junto con el resto de canales de conexión digital de nuestras computadoras y smartphones, nos enlazan cotidianamente ${ }^{86}$ mediante muchas facetas de uso y que, además, ese uso sigue una escalada de extensión en todos los estratos poblacionales.

Ahora bien, pese a que el futuro apunta hacia una Web de carácter más semántico ${ }^{87}$, es decir, se encamina hacia el llamado Internet de las cosas (en cada electrodoméstico y automóvil del hogar) y hacia el desarrollo de la IA (inteligencia artificial) en los sistemas operativos y cámaras de nuestros smartphones, de momento nos encontramos en un momento de estabilidad y permanencia. Un momento en el que nuestras prácticas cognitivas, relacionales, "confesionales" ${ }^{88}$ y de ocio en torno a Internet se han asentado alrededor de los canales, comunidades y redes sociales contruidos por nosotros mismos, especialmente tras el uso durante quince años de una Web 2.0 consolidada e institucionalizada en lo que podemos considerar como el fenómeno de masas contemporáneo más representativo ${ }^{89}$.

Students-Well-being-Country-note-Spain-Spanish.pdf> [Fecha de consulta: 20 de julio de 2017] y VV. AA., "Informe de salud de Internet", 2017, disponible en: <https://internethealthreport.org/ vo1/es/> [Fecha de consulta: 20 de julio de 2017].

De hecho, "la introducción de las latitudes digitales en nuestra cotidianidad ya es irreversible y no puede soslayarse para continuar haciendo las cosas como siempre, del mismo modo que no pudo ser ignorada la llegada de la imprenta y la expansión letrada que supuso". CASARES, Nilo, op. cit., págs. 910.

FERNÁNDEZ, Lilia C., op. cit., pág. 22.

Como ya hemos visto en capítulos pasados, es precisamente este carácter confesional el que hace que "millones de usuarios de todo el planeta -gente común- [...] se hayan apropiado de las diversas herramientas disponibles online, que no cesan de surgir y expandirse, y las utilicen para exponer públicamente su intimidad. Así es como se ha desencadenado un verdadero festival de vidas privadas, que se ofrecen impúdicamente ante los ojos del mundo entero. Las confesiones diarias están ahí, en palabras e imágenes, a disposición de quien quiera husmear; basta apenas con hacer clic. Y, de hecho, todos nosotros solemos dar ese clic". SIBILIA, Paula, La intimidad como espectáculo, Buenos Aires, Fondo de Cultura Económica, 2008, págs. 332-338.

89 De hecho, ahí radica el poder contemporáneo de este tipo de redes: "La razón por la que la Web es hoy tan poderosa es porque permite que las personas organicen sus actividades con la audiencia y con la comunidad que ellos eligen. Se trata de una especie de mundo reducido cuyo contenido generan los usuarios, con una dimensión añadida de comunicación, de espacio compartido, de socialización y de puesta en común entre amigos”. PISANI, Francis y PIOTET, Dominique, op. cit., pág. 49. 


\subsubsection{Un nuevo medio de comunicación de masas.}

A finales de los años 1990, E. M. Noam, por entonces director del Institute for Tele-Information de la Universidad de Columbia, aventuró este juicio: "cuando se escriba la historia de los medios del siglo XX, se considerará a Internet como su mayor contribución” ${ }^{\circ 0}$. Podemos destacar pues que, según este comentario, Internet es nuestro último medio de comunicación de masas y, como hemos visto antes, también el más extendido. El anterior medio de masas destacable antes de la llegada de Internet, la computación personal o los videojuegos, fue la televisión. Sin embargo, al contrario que la televisión que se definía como un medio frío en el que la pantalla suministraba meras sinécdoques, y era el receptor quien las hacía significantes ${ }^{91}$, Internet y los contenidos que fluyen por sus redes son construidos y decididos por las masas, convirtiendo al usuario en emisor y receptor (tanto de textos como de imágenes ${ }^{92}$ ) al mismo tiempo. Puede ser cierto que Internet comparta con la televisión algunas facetas que se han convertido en una proyección de esta, por ejemplo, en lo relativo a la publicidad, los cánones de $\operatorname{moda}^{93}$ y la dictadura de la imagen ${ }^{94}$; sin embargo, esa faceta abierta, libre y constructiva que tiene la red la ha transformado en una herramienta con la que poder ejercer la democracia ${ }^{95}$, y no con la que sufrir, como ocurría con la televisión, una opresión simbólica ${ }^{96}$.

BRIGGS, Asa y BURKE, Peter, op. cit., pág. 343.

SABORIT, José, La imagen publicitaria en televisión, Madrid, Cátedra, 1992, pág. 165.

Gracias al desarrollo de las redes de telecomunicaciones (que cada vez poseen un mayor ancho de banda para el envío y recepción de imágenes digitales), podemos enviar imagen fija y en movimiento a tiempo real, como hacía la televisión. SOLER, María, Las empresas de fotografía ante la era digital. El caso de la Comunidad Valenciana, Madrid, Ediciones de las Ciencias Sociales, 2007.

ECO, Umberto, Historia de la belleza, Barcelona, Lumen, 2004, pág. 418.

EGUIZÁBAL, Raúl, Fotografía publicitaria, Madrid, Cátedra, 2006, pág. 28.

Como se pudo constatar en 2011 con los movimientos revolucionarios $15 \mathrm{M}$ y Primavera árabe, cuyo brote y organización fue posible gracias a la comunicación deslocalizada mediante el uso de Internet.

BOURDIEU, Pierre, Sobre la televisión, Barcelona, Anagrama, 1997, pág. 11. 
Pese a esto, cuesta posicionarse respecto a si Internet, como un nuevo medio de masas, se construye principalmente de abajo hacia arriba, de arriba hacia abajo, o de una manera recíproca y retroalimentanda en lo que se refiere a creadores de estructuras y a creadores de contenidos. McLuhan ya fue un profeta de algunos de los fenómenos actuales con sus trabajos en los años 1960 ${ }^{97}$, proponiendo una reflexión sobre los medios de comunicación y las tecnologías de la información y la comunicación en términos de extensiones de los seres humanos. Para McLuhan, las nuevas tecnologías estaban alterando la sensibilidad y la conciencia de la humanidad. De hecho, algunas de sus hipótesis apuntan a que "cada modificación o novedad en los medios es una modificación o novedad de la sensibilidad del organismo humano" y "a que el medio es ya un mensaje" 98 . También opinaba que "la naturaleza de los medios condiciona más a la sociedad que al contenido de la información transmitida" 99 . Otra de sus ideas era que "cada medio hace participar de manera diferente al receptor en la comunicación” ${ }^{100}$. Y quizá la más importante en lo que nos ocupa: "que el medio no es solo un mensaje, sino también un masaje, que presiona sobre los individuos, manipulándolos y modificando su manera de ser" ${ }^{\text {"101. }}$. Sin embargo, Manuel Castells se posiciona contra las formulaciones de McLuhan, ya que para él la tecnología no es la que determina la organización social, sino al contrario:

"La propia sociedad y el sistema económico actual son los encargados de adaptar a sus necesidades las nuevas tecnologías y sus avances correspondientes. Esta nueva tecnología tiene un fuerte impacto en la sociedad, pero los efectos son variables dependiendo de los procesos políticos, sociales y culturales, ya que son los que determinan la producción y uso de los nuevos medios tecnológicos” ${ }^{102}$.

\footnotetext{
97 McLUHAN, Marshall y JEROME, Agel, El medio es el masaje, Barcelona, Paidós, 1988. VÁZQUEZ, María F., La cultura visual en la adolescencia, Sevilla, Universidad de Sevilla, 2015, págs. 11-12.

99 Ídem.

100 Ídem.

101 Ídem.

102 ROBLES, Elena, Tumblr: estudios estéticos sobre la plataforma web Tumblr. Construcción de la
} 
Es problable que en un punto equidistante entre estas dos posturas enfrentadas o, mejor dicho, en la suma de ambas encontremos una cierta virtud. Opina así Elena Robles en su estudio de 2014 sobre la red social Tumblr:

\footnotetext{
"Creemos que las cosas son más complejas y este proceso de condicionamiento según las tecnologías del momento, es un pez que se muerde la cola, en el sentido de que está claro que las herramientas tecnológicas son creadas a partir de una necesidad humana, del tipo que sea, pero tras la aplicación social de estas y su uso se modifican patrones de comportamiento y nacen nuevas formas que hasta la aparición de estas herramientas no existían" ${ }^{103}$.
}

Como nuevo medio de comunicación de masas puede entenderse como razonable que Internet, al igual que los medios de comunicación que le precedieron ha alterado el modo en que los seres humanos se comunican entre sí, ya que ha ampliado su capacidad comunicativa ${ }^{104} \mathrm{y}$, como hemos visto, ha alterado profundamente nuestras vidas ${ }^{105}$.

Antes de adentrarnos en la segunda parte de este capítulo (dedicada a las redes sociales como receptáculos expositivos de los selfies y resto de autorretratos digitales), podemos concluir esta primera a modo de resumen señalando que la Web 2.0 ha cambiado la manera de crear, compartir, encontrar y comunicarnos en la red, aunque en nuestros días no solo de Web vive el hombre. Hasta hace pocos años, los navegadores y sus contenidos suponían la cara visible de Internet. La gran mayoría de usuarios se comunicaba a través de esas ventanas, por medio de chats, canales, foros especializados, galerías, y más

identidad a través de la creación colectiva, Valencia, Universitat Politècnica de València, 2014, pág. 18.

103 Ibídem, pág. 19.

104 MELENDO, Laura, op. cit., 2013, pág. 148.

105 CASTELLS, Manuel, La Galaxia..., op. cit., pág. 19. 
tarde lo haría a través de redes sociales. Hoy en día la red ha extendido sus dominios a los smartphones. Son nuevas ventanas por las que entrar en ella. Primero los teléfonos móviles brindaron al mundo la posibilidad de tener un terminal de voz en el bolsillo. La mensajería de texto también supuso un avance en el campo de la comunicación portátil.

Fue entonces cuando el teléfono móvil evolucionó hacia el smartphone: un teléfono inteligente que, además de sus funciones habituales y cámara de fotos, disponía también de navegador web, mapas, aplicaciones de mensajería instantánea gratuita (y por tanto, infinita), y lo más importante respecto al tema que aquí tratamos: herramientas para el intercambio de imágenes, y redes sociales de bolsillo, algunas incluso exclusivas de ese nuevo medio y basadas en la imagen, como Instagram. Todo esto convertía al smartphone en mucho más que un ordenador de bolsillo: si , como hemos visto, al principio la red era cosa de unos pocos, y luego de todo el mundo, los smartphones habían convertido Internet en cosa de todo el mundo, a todas horas y en todas partes. Habían asumido una función carnal: eran nuestro nuevo apéndice. Gracias a ellos nos hemos fusionado con la red a nivel corporal. Hemos pasado de ser el homo sapiens sapiens a ser el homo ex machina.

La nueva situación de la Web actual y del resto de redes ha cambiado nuestra manera de enfrentarnos al mundo: cada día se hacen más compras por Internet, muchos tipos de encuentros entre personas empiezan por una cita en el ciberespacio y nuestras propiedades digitales están cada vez más deslocalizadas, es decir, dejan de ser locales y se ubican en la denominada nube ${ }^{106}$. También han

$106 \mathrm{Si}$ parafraseamos lo recogido en Wikipedia, la computación en la nube son servidores desde Internet encargados de atender las peticiones en cualquier momento y sitio. Se puede tener acceso a su información o servicio, mediante una conexión a Internet desde cualquier dispositivo fijo o móvil ubicado en cualquier lugar. Asimismo, se sirve a los usuarios desde varios proveedores de alojamiento repartidos frecuentemente por todo el planeta. Esta medida reduce los costes, garantiza un mejor tiempo de actividad y hace que los sitios web sean invulnerables a los hackers, a los gobiernos locales y a sus redadas policiales. VV. AA., "Computación en la nube", 2018, disponible en: <https:// es.wikipedia.org/wiki/Computación_en_la_nube> [Fecha de consulta: 2 de febrero de 2018]. 
cambiado las leyes que nos amparan, se han creado términos y condiciones para casi todo (en algunas ocasiones, oscuras y perversas, como narra el documental dirigido en 2013 por Cullen Hoback: Terms \& Conditions May Apply ${ }^{107}$ ) y, a veces, la rapidez con la que avanza el medio hace que las políticas de derecho y protección vayan a remolque de estos nuevos paradigmas que impulsa la red global.

Con todo, se ha de señalar que el mayor logro de la Web ha sido el influjo democratizador que ha ejercido Internet en el mundo. Primero con páginas de consulta, luego con la llegada del correo electrónico, foros, blogs, redes sociales... Gracias a estas superficies de aprendizaje y de estilos de vida nuevos, la popularidad en el uso de la red ha llegado a todos, y a casi todas las franjas de edad, empezando por los más jóvenes. Ellos lo tienen mucho más fácil como ya vimos en el capítulo 5. El ejemplo lo hallamos en el hecho de que son los que mejor utilizan estos medios, y los que más rápido aprenden a desenvolverse con ellos. El motivo es evidente: entre otras cosas, estos jóvenes han nacido en la era virtual: son nativos digitales o early adopters ${ }^{108}$. Para ellos la red ha existido desde que tienen uso de razón, y "en su infancia, al poco de controlar los movimientos de las manos, hace[n] de la máquina un apéndice, ampliando sus brazos hacia el ratón y sus preguntas hacia las placas base"109.

Y es precisamente en las redes sociales donde mejor habitan estos nativos digitales. Estos espacios de la Web y de los smartphones son sus salas de exposiciones. Es donde publican sus selfies y resto de autofotos, expuestos en sus perfiles virtuales, formando parte de sus álbumes cotidianos y construyendo sus

107 HOBACK, Cullen; KHANNA, Nitin y RAMOS, John (Productores), HOBACK, Cullen (Director), Terms and Conditions May Apply (Terms and Conditions May Apply) [Cinta cinematográfica], Estados Unidos, Variance Films, 2013.

108 "El comportamiento de los jóvenes en Internet crea grandes tendencias. [...] Porque los jóvenes son los primeros en apropiarse de la Web y familiarizarse con ésta, su papel de early adopters «adoptadores tempranos»". PISANI, Francis y PIOTET, Dominique, op. cit., pág. 26.

109 ZAFRA, Remedios, op. cit., pág. 20. 
diarios personales. En este sentido, el desarrollo que ha experimentado el self shot estos últimos años no solo es fruto de la evolución de los dispositivos de captura digital, sino que también lo es del desarrollo de las distintas redes sociales que los han contenido.

\subsection{Redes sociales: nuevas sociedades y galerías globales.}

Tras los desarrollos técnicos efectuados en torno a Internet durante la última década, las redes sociales han pasado a estar presentes en muchos hábitos de la vida cotidiana y se extienden cada vez más tras las fronteras del mundo occidental. Gran cantidad de usuarios de casi todas las edades y condición las utilizan para realizar multitud de cometidos: relación social, divertimento, diario personal, incluso gestión empresarial, dividiendo su uso, por lo tanto, entre el mundo privado y el comercial ${ }^{110}$. Las usamos y estamos en ellas aunque no nos demos cuenta porque plantean un nuevo paradigma de relación social entre humanos, que en algunas ocasiones afecta a terceros, un paradigma en el que se ha fundido la privacidad con la exhibición pública desde que Internet se consolidó como medio de comunicación de masas ${ }^{111}$. Se podría decir que las redes sociales son un nuevo sistema de comunicación virtual basado en texto, en imagen y en participación activa y pasiva.

Existen redes sociales de todo tipo, y sus estructuras y usos han variado a lo largo de su evolución, siendo Facebook, Twitter o Instagram las más

\footnotetext{
110 COLLE, Raymond, "La revolución de la fonofotografía. Teléfonos con cámara y redes sociales", en Revista mediterránea de comunicación. Colección mundo digital, $\mathrm{n}^{\circ}$ 4, 2013, págs. 19-20.

111 THOMPSON, John B., Los media y la modernidad una teoría de los medios de comunicación, Barcelona, Paidós, 1998, pág. 51.
} 
populares. Como hemos visto, son fruto de la Web 2.0 y comenzaron su andadura en Internet como páginas web en los navegadores de las computadoras conectadas a la red. Hoy en día también las podemos encontrar en forma de aplicación para smartphone, lo que amplía mucho más las posibilidades de conectarnos a través de ellas con el mundo y con nuestras amistades.

Y ¿̇para qué sirven las redes sociales? Además de sus usos principales, que son mantener el contacto con las personas con las que ya se tiene relación, así como disponer nuestros datos de contacto actualizados, y establecer relaciones con otras personas de nuestro interés a través de nuestros contactos iniciales; al mismo tiempo los servicios de redes sociales han incluido una serie de funciones para ayudar a potenciar el uso de las mismas: buzones de correo para enviar mensajes entre miembros, lo que en teoría elimina la posibilidad del spam; foros temáticos, a los que solo pueden acceder los miembros registrados; búsqueda de personas con las que se puede tener una cierta empatía y organización de eventos físicos a los que solo pueden asistir los miembros ${ }^{112}$. Y todo ello sin olvidarnos de lo mucho que las redes sociales son utilizadas en las empresas no solo como ejercicio de marketing a través de la figura especializada del community manager, sino también como difusoras de la imagen cultural contemporánea que retroalimentan sus usuarios-creadores de contenidos, o incluso como gran ventana a la que precitipa al espectador voyeur.

"En todas las sociedades, los seres humanos se dedican a la producción e intercambio de información y contenido simbólico" ${ }^{113}$. Las redes sociales operan adaptándose a esta necesidad. El internauta es concebido como un consumidor de la cultura y formas simbólicas convertidas en bienes de consumo ${ }^{114}$ que generan estas redes sociales, y esta idea puede ser completada con el hecho de

112 RUIZ, Sonia, op. cit., pág. 204.

113 THOMPSON, John B., op. cit., pág. 26.

114 Ibídem, pág. 38. 
que es un usuario activo con posibilidad de apropiación, creación e interacción con esa cultura: "Es lo que algunos autores han calificado como prosumidor"115.

El desarrollo del software de las redes sociales parte de la teoría de los seis grados de separación postulada por el sociólogo Duncan Watts ${ }^{116}$, según la cual toda la gente del planeta está conectada a través de no más de seis personas. Estas conexiones, nodos con relaciones bidireccionales, crean madejas complejas en forma de comunidades sociales.

Los individuos más activos y productivos dentro de estas comunidades son, mayoritariamente, los jóvenes y los adolescentes. Las redes sociales son para ellos nuevos espacios de reunión:

"La red ha sustituido al coche de Harrison Ford en American Graffiti, así como al aparcamiento o al acantilado apartado, es decir, aquel lugar en el que, en el cine, los jóvenes se reúnen para encontrar su identidad, a salvo de la intervención de los adultos. La Web es, al mismo tiempo, una herramienta relacional y el espacio en el que tienen lugares las relaciones”117.

Los jóvenes, llevan años apropiándose de la red. Su presencia en las redes sociales es amplia y recientemente también han colonizado el territorio de los smartphones:

"La Web permite que los jóvenes empleen esta herramienta como quieran, y les ayuda a construir su identidad en relación con los demás al margen de cualquier mecanismo institucional tradicional. Las herramientas como Facebook, MySpace o los blogs les permiten hacerlo, pues son plataformas abiertas, modificables y con reglas flexibles.

115 ROBLES, Elena, op. cit., pág. 14.

116 WATTS, Duncan J., Six Degrees: The Science of a Connected Age, Nueva York, W. W. Norton \& Company, 2003, pág. 23. A su vez, esta teoría servirá de excusa para desarrollar a finales de los años noventa del siglo pasado una de las primeres redes sociales basadas en estas teorías (sixdegrees.com) que daba acceso a la información según los grados de separación de tus contactos. RUIZ, Sonia, op. cit., pág. 199.

117 PISANI, Francis y PIOTET, Dominique, op. cit., pág. 26. 
Los SMS y la mensajería instantánea ofrecen la posibilidad de expresarse de manera espontánea, con sus propias palabras, su propio lenguaje (mientras que el $e$-mail introduce la distancia de la palabra escrita y del envío diferido). Crear, publicar y modificar su perfil en un sitio de red social les permite ajustar su identidad en relación con los demás con pequeños retoques. Crear un blog, o escribir comentarios en los de los amigos, implica construir su opinión, afirmarse, decir lo que uno piensa y enfrentarse a otros. [...] Para los jóvenes, el interés de la Web se encuentra en primer lugar en el ámbito relacional: no existen normas preestablecidas, hay libertad de expresión, disponen de múltiples herramientas y medios, hay un gran número de usuarios, algunos más cercanos y otros más lejanos. Existe una posibilidad de encuentro, de descubrimiento" ${ }^{118}$.

No obstante, si por algo destacan las redes sociales entre los adolescentes, es por la labor que cumplen como galería de exposición fotográfica para la representación digital pública de sus identidades ${ }^{119}$. Son sus espacios de relación a través de la imagen y uno de sus métodos para intercambiarlas. Como hemos visto en el capítulo anterior, los jóvenes usan las redes sociales como diario personal y como laboratorio experimental en la creación fotográfica. Aunque no se trate del único, como luego veremos, la red social es uno de los más importantes escenarios en la publicación y en la difusión del selfie.

"Todo es fotografiable y más aún, todo es mostrable. Se han creado photologs, blogspots, Flikr, Facebook, Twitter, MySpace... un surtido de sitios en la red donde la gente cuelga sus fotografías para que todos las puedan ver y comentar" ${ }^{20}$.

Sin embargo, esta práctica que iniciaron los jóvenes la década pasada, es hoy practicada por un extenso número de usuarios perteneciente a cualquier estrato poblacional de edad y condición. La práctica de la subida fotográfica a la

118 Ibídem, págs. 42-43.

119 Ibídem, pág. 33.

120 FONTCUBERTA, Joan, La cámara de Pandora. La fotografi@ después de la fotografía, Barcelona, Gustavo Gili, 2010, pág. 30. 
red social y el discurso que ello genera está perfectamente institucionalizado en la cultura popular contemporánea:

"Cuando subimos una fotografía a una red social se genera un doble discurso. Por un lado, aquel que nosotros elaboramos cuando publicamos la fotografía: seleccionamos la imagen, previamente procesada o no, agregamos una pequeña descripción textual para contextualizarla y posteriormente, si es posible, añadimos una capa de información a través de las etiquetas. Por otro, los usuarios que puedan acceder a la foto y comentarla crearán un discurso de respuesta al primero que, según la actitud y el tono de los comentarios, reforzará, destruirá o convertirá el original. Por ejemplo, si un usuario publica una foto de su equipo favorito tras haber ganado un partido se genera un discurso donde se ensalza la victoria y los ideales de ese equipo; si su red de contactos es seguidora del mismo equipo posiblemente genere en los comentarios un texto de apoyo que refuerce el original. Si en cambio sabe que sus amigos lo aborrecen, sabe que el discurso será más controvertido y el segundo discurso intentará ir en su contra como respuesta a la provocación” ${ }^{121}$.

Un poco más adelante efectuaremos un breve recorrido por algunas de las redes sociales más significativas y que más han aportado al adolescente como fotógrafo y autorretratista en el transcurso de estos últimos años, así como al resto de usuarios practicantes del selfie: desde la primitiva pero pionera MySpace, hasta la contemporánea y exclusiva de los dispositivos de bolsillo Instagram. Pero antes de profundizar en este hecho, debemos exponer algunos apuntes aclaratorios y definitorios sobre las redes sociales, acotar sus orígenes y hablar de los hashtags como elemento fundamental para la popularización del autorretrato digital publicado.

121 CALDEVILLA, David, "Las redes sociales. Tipología, uso y consumo de las redes 2.0 en la sociedad digital actual", en Documentación de las ciencias de la información, $\mathrm{n}^{\circ} 33,2010$, pág. 84 . 


\title{
6.3.1. Definiciones, catalogación y algunos conceptos asociados a las redes sociales.
}

En el Diccionario de la Web 2.o de Mar Monsoriu, el cual hemos estudiado en su totalidad para poder desarrollar partes de este capítulo 6, la red social queda definida de la siguiente manera:

\begin{abstract}
"Portal web donde los usuarios, previamente registrados, pueden crear un perfil personal (que pueden hacerlo público o semipúblico) y además ponerse en contacto con amigos con los que compartir todo tipo de contenidos digitales. En cualquier red social, la creación del perfil suele ser muy sencilla. Consiste en completar los campos de unos formularios que están prediseñados. En estos campos se añade información personal (fecha de nacimiento, lugar de residencia, etc.) o profesional (lugar de trabajo, especialidad, expectativas, etc.) En inglés: Social Networking Site o SNS"122.
\end{abstract}

Podemos completar por otro lado esta definición con los apuntes que aportan los usuarios anónimos en Wikipedia:

\footnotetext{
"Una red social es una estructura social compuesta por un conjunto de actores (tales como individuos u organizaciones) que están relacionados de acuerdo a algún criterio (relación profesional, amistad, parentesco, etc.). Normalmente se representan simbolizando los actores como nodos y las relaciones como líneas que los unen. El tipo de conexión representable en una red social es una relación diádica o lazo interpersonal” ${ }^{123}$.
}

Sin embargo, nos parece mucho más completa la definición que expone Isabel Ponce:

122 MONSORIU, Mar, Diccionario Web 2.o. Todos los términos que se necesita conocer sobre las redes sociales y los medios sociales, Madrid, Creaciones Copyright, 2010, p, 119.

123 VV. AA., "Red social”, 2018, disponible en: <https://es.wikipedia.org/wiki/Red_social> [Fecha de consulta: 2 de enero de 2018]. 
“[...] podemos definir las redes sociales online como estructuras sociales compuestas por un grupo de personas que comparten un interés común, relación o actividad a través de Internet, donde tienen lugar los encuentros sociales y se muestran las preferencias de consumo de información mediante la comunicación en tiempo real, aunque también puede darse la comunicación diferida en el tiempo, como en el caso de los foros. No solo nos relacionamos y compartimos con los demás, sino que, además, exponemos abiertamente y en tiempo real nuestros gustos y tendencias, expresando la propia identidad. Uno de los eslóganes de Flickr es, sin ir más lejos, «Comparte tu vida en fotos». En conclusión, las redes sociales online las crean los usuarios a través de las posibilidades de uso que ofrecen los servicios de Internet” ${ }^{124}$.

Pese a que, tal y como vemos en la (Imagen 6.10.), las prácticas sociales que pueden ejercerse en el medio que es Internet giran en torno a una serie de espacios en los que poder publicar y micropublicar, compartir, discutir, transmitir a tiempo real, chatear, jugar en mundos virtuales, (sociales o abiertos) e interactuar en las propias redes sociales; estas últimas se pueden dividir también en muchos conjuntos. No obstante, podemos agruparlas en tres tipologías de uso mayoritario:

"El primero de estos grupos sería el formado por los servicios de redes sociales para relaciones sentimentales, enfocadas como su nombre indica a la interacción entre sus usuarios con objeto de iniciar una posible relación sentimental. [...] Otro de los tipos básicos de servicios de redes sociales serían las estrictamente sociales o comunidades de amigos, destinadas a mantener el contacto con nuestros amigos, conocidos previamente, así como hacer nuevos amigos en función de nuestros contactos más cercanos. [...] y un último tipo de redes, que sería el de redes profesionales, enfocadas a conseguir establecer relaciones entre profesionales, y que puede ser una buena herramienta para perfiles comerciales"125.

\footnotetext{
124 PONCE, Isabel, “Monográfico: redes sociales", 2012, disponible en: < http://recursostic.educacion.es/ observatorio/web/es/internet/web-20/1043-redes-sociales?start $=1>$ [Fecha de consulta: 5 de julio de 2017].

125 RUIZ, Sonia, op. cit., págs. 204-207.
} 


\section{Social Media Landscape}

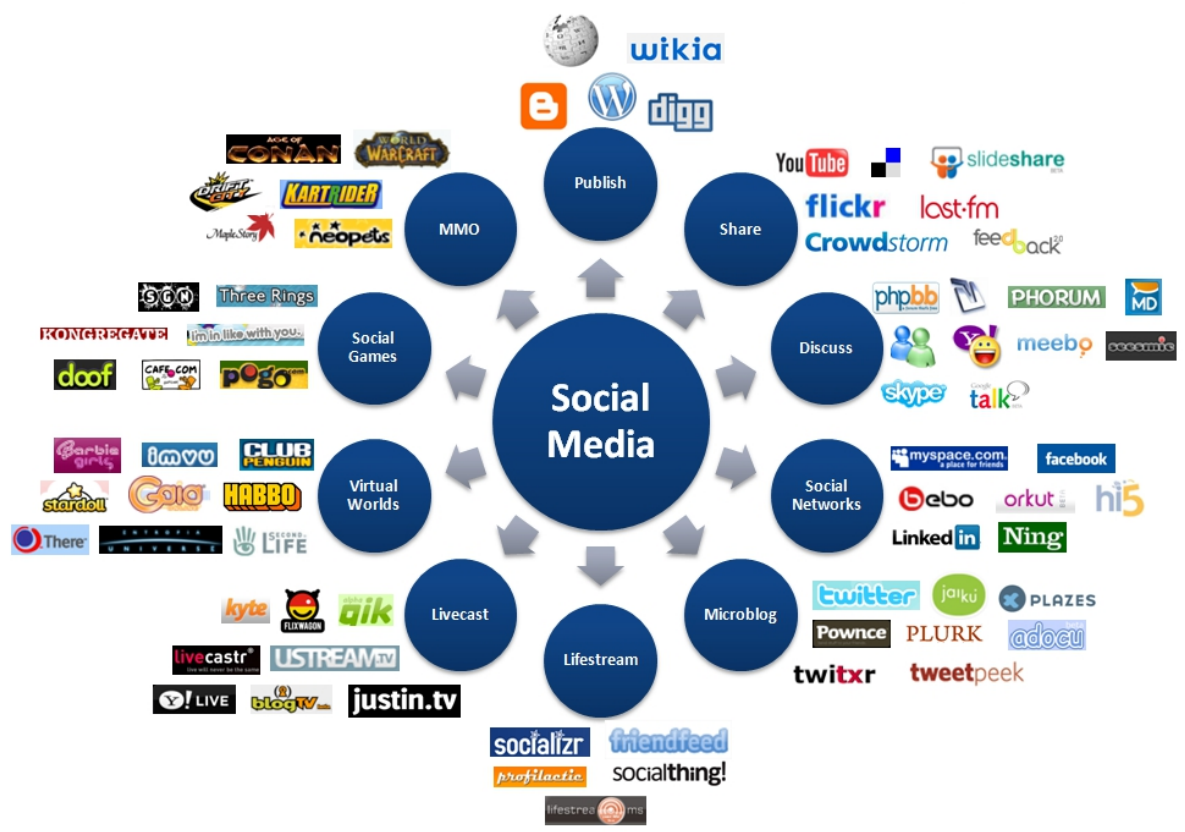

Imagen 6.10: Panorama de los medios sociales. Fuente: Mylearningnetwork.

Por otro lado, y de manera paralela, podemos dividir las redes sociales en horizontales y verticales. En este sentido, las redes sociales horizontales no se definen por la especificidad de su temática, sino por el tipo de contacto que se establece entre sus usuarios, que suele responder a un propósito de interrelación general, sin un tema concreto. Todos los usuarios utilizan las mismas herramientas para su perfil y para comunicarse, dado que la función es relacionar personas. Los mejores ejemplos de esto son Facebook, Badoo o Google+. Sin embargo, las redes sociales verticales son más difíciles de clasificar debido a que dentro de una misma red social se pueden dar comunidades con diferentes intereses en una especialidad, lo que constituye la base de su verticalidad. Además, con la adhesión de nuevos usuarios y relaciones, se crean nuevas temáticas con el paso del tiempo. Dentro de estas redes sociales verticales cabría 
distinguir dos tendencias vinculadas a la temática y a la actividad. Por temática encontramos: profesionales de identidad cultural, de aficiones, de movimientos sociales, de viajes, etc. Y por actividad: microblogging, juegos, geolocalización y la que se ocupa de compartir objetos. Esta última actividad da pie a otra clasificación interna basada en el contenido compartido: música, fotos, vídeos, documentos, presentaciones, noticias, lectura... Por ejemplo Tumblr encaja en el tipo de red social vertical, dado que la finalidad es compartir contenido ${ }^{126}$.

Asimismo, no podemos pasar al siguiente punto sin antes definir rápidamente algunos conceptos aplicados a la mayoría de redes sociales y que nos van a servir de ayuda cuando, en unas cuantas páginas, repasemos las más importantes relacionadas con la visibilidad del autorretrato digital publicado. Para esta lista nos hemos servido también del citado diccionario de Monsoriu, que define por ejemplo el perfil en una red social tipo Facebook, como un espacio personal en el que "cada usuario registrado [...] expone información sobre sí mismo, además de fotos o vídeos, notas, blogs, enlaces y comentarios de estado, así como de los grupos, páginas o causas a los que pertenece, y también los amigos que tiene en ese red. En inglés: Profile"127.

A su vez, define el perfil falso como aquel "que un usuario crea bajo una personalidad inventada. En inglés: Fake Profile" ${ }^{\text {128 }}$. También el control de la privacidad que ofrecen estos espacios lo define Monsoriu como "la opción que se le ofrece a los usuarios, previamente registrados, para que el contenido de sus perfiles no pueda ser visto fácilmente por personas que no estén en esa red ni catalogado por motores de búsqueda tipo Google. En inglés: Privaticy"129.

\footnotetext{
126 ROBLES, Elena, op. cit., págs. 17-18.

127 MONSORIU, Mar, op. cit., pág. 108.

128 Ídem.

129 Ibídem, pág. 111.
} 
Por otro lado, nos referimos a menudo a un concepto fundamental para la estructura y funcionamiento de las redes sociales: el concepto de amigos. Estos son:

\begin{abstract}
"Usuarios que tienen un perfil en la misma red social donde se está dado de alta y a los que se agrega para estar en contacto y poder compartir contenidos digitales de diverso tipo. No necesariamente tienen que ser amigos a los que se conozca de verdad dentro o fuera de Internet. Puede tratarse de personas a las que se acepta porque se quiere conocer, bien por intereses de tipo personal, bien por motivos profesionales. En algunas redes los denominan contactos. En inglés: Friends" ${ }^{\prime 30}$.
\end{abstract}

Este término, el de amigo, suele ir acompañado de otro concepto: el de agregar.

"En una red social, proceso mediante el cual un usuario acepta entre sus contactos a otro usuario que pasa a formar parte de los anteriores. Lo contrario de agregar es ignorar. En las redes sociales cuando un usuario recibe una solicitud de amistad para agregar a un nuevo contacto debe hacer clic en el botón aceptar, o en el botón ignorar si prefiere rechazarlo. En inglés: $A d d^{{ }^{\prime 131}}$.

En lo que se refiere a nuestro principal objeto de estudio, es importante definir el concepto de álbum, noción que alude a la herramienta para compartir imágenes o al "conjunto de fotografías etiquetadas bajo el mismo nombre y que habitualmente muestran un tema común, por ejemplo, un viaje o una fiesta de cumpleaños. En inglés: Album” ${ }^{132}$. Estas imágenes podrán ser compartidas o comentadas:

"En una red social, mensaje que un usuario, previamente registrado en la misma, escribe en su propio muro, o en el muro de otros usuarios, acerca de los textos, los enlaces, las fotos, los vídeos o cualquier otro contenido digital que previamente se

\footnotetext{
130 Ibídem, pág. 5 .

131 Ibídem, pág. 4.

132 Ídem.
} 
haya publicado. En muchas redes sociales también se da la opción de hacer comentarios sobre el mensaje de estado (status, en inglés), sobre las notas o sobre los blogs que escriben los usuarios. En inglés: Comment" ${ }^{\prime 33}$.

Visto esto, y a falta de definir y analizar un último concepto, actor en las redes sociales, y que, entre otras cosas, ha hecho posible la popularización (y, a su vez, una práctica cíclica y retroalimentada) del término \#selfie. Hablamos de la etiqueta con almohadilla, también denominada hashtag (\#).

\subsubsection{El \#hashtag.}

El 16 de enero de 2011 la red social basada en la exposición/exhibición por medio de la imagen fotográfica Instagram habilitó el uso de los hashtags en las publicaciones de sus usuarios. A los pocos minutos, Jennie Lee (Imagen 6.11) subió una foto a Instagram con un hashtag hasta entonces desconocido: \#selfie.

Desde ese momento, cientos de millones (lo decimos a modo de dato literal y no como figura retórica ${ }^{134}$ ) de fotos se han subido a las redes sociales con ese hashtag (Imagen 6.13). Y el número sigue creciendo. Según Selfigraphic ${ }^{135}$,

133 Ibídem, pág. 28.

134 De hecho, en 2015 la palabra \#selfie "era nombrada mediante hashtags 287.158.353 veces en Instagram, mientras que \#autorretrato solo 45.320" (o \#selfportrait, menos de medio millón). CEREIJO, María, El yo frente a la cámara. Construcción de la imagen mediante el selfie y el retrato fotográfico, Valencia, Universitat Politècnica de València, 2015, pág. 22. A día de hoy (2018), como se puede ver en la imagen 6.12 el número de fotografías que contienen el hashtag \#selfie asciende a 336.340.242.

135 ALPAÑÉS, Enrique, "Muerte por selfie: la realidad que esconden los números", 2016, disponible en: <https://elpais.com/elpais/2016/o2/04/tentaciones/1454589530_250716.html> [Fecha de consulta: 20 de abril de 2017]. 
sitio web que analiza este fenómeno, diariamente se suben más de un millón de selfies a la red.

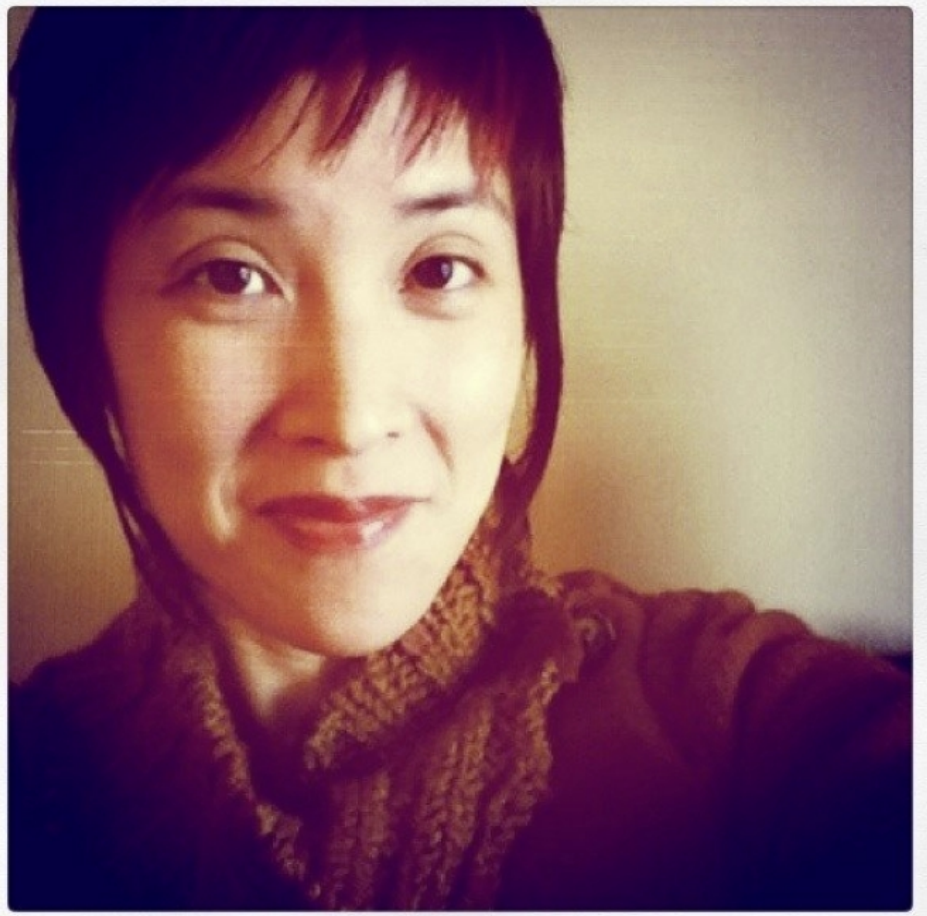

Imagen 6.11: Autorretrato digital publicado de Jennie Lee (usuaria @jeniee) subido a Instagram el 16 de enero de 2011. Fue el primero en incluir el hashtag \#selfie. En la fecha de publicación de este trabajo todavía podía verse online como registro original y no como captura fósil en: LEE, Jenny, "I <3 my new Anthro sweater", 2011, disponible en: <https://www.instagram.com/p/ BDas2/> [Fecha de consulta: 20 de abril de 2018]. 
Pero ¿qué es el hashtag? ¿Cuál es su utilidad? No se trata de una etiqueta habitual, de las que se usan en los blogs mediante sus gestores de publicación, aunque cumple una función similar: enlazar o agrupar (con una actitud similar a la que hemos visto con el hipertexto) diferentes contenidos mediante una misma palabra y que en origen se encuentran dispersos por el ciberespacio aunque dentro de una misma aplicación. La red social más notoria que empezaría a utilizar el hashtag como parte fundamental de su funcionamiento fue Twitter. De esta época encontramos la siguiente definición de hashtag en el Diccionario de la Web 2.O:

"Término del argot del inglés americano que, en Twitter, define a una palabra (etiqueta o tag, en inglés) precedida por el signo almohadilla o «\#» (hash mark, en inglés). Sirve para facilitar las búsquedas relacionadas con determinadas palabras o asuntos. Esta «etiqueta de almohadilla» (en una traducción un poco forzada al español) hace más sencillo seguir un tema o una discusión que sea del interés en Twitter" ${ }^{136}$.

No obstante, y como acabamos de ver, otras redes sociales implementarán el hashtag dentro de sus estructuras rizomáticas: primero lo hará Instagram (con un uso también fundamental) y luego Facebook (de manera más discreta), así como otras. Una definición más ampliada y a nuestro parecer también más contemporánea sería:

"Un hashtag es una cadena de caracteres formada por una o varias palabras concatenadas y precedidas por una almohadilla o numeral (\#). Es, por lo tanto, una etiqueta de metadatos precedida de un carácter especial con el fin de que tanto el sistema como el usuario la identifiquen de forma rápida. Se usa en servicios web tales como Twitter, Telegram, FriendFeed, Facebook, Google+, Instagram, Weibo o en mensajería basada en protocolos $I R C$ para señalar un tema sobre el que gira cierta conversación” ${ }^{137}$.

136 MONSORIU, Mar, op. cit., pág. 63.

137 VV. AA., "Hashtag", 2018, disponible en: <https://es.wikipedia.org/wiki/Hashtag> [Fecha de 
Por tanto, la utilización del hashtag en Instagram proporcionará a los usuarios y usuarias hacedoras y contempladores del \#selfie las mismas experiencias y el mismo desarrollo en la construcción de la cultura visual de lo que ya lo habían hecho el resto de etiquetas (tags) concebidas para los usos relacionales de la Web: el hashtag será, por consiguiente, la palabra clave del webactor (del Insta-actor en este caso), por oposición a la palabra clave del motor de búsqueda. Reflejará su manera de calificar y clasificar su propia información. Con el hashtag, el usuario adquiere poder sobre el dato (la imagen fotográfica), e integra en ella su inteligencia (pudiendo compartirla con los demás), lo que hará que sus relaciones sean más dinámicas.

El hashtag, pues, más allá de su aspecto práctico para el usuario, que lo utiliza como una herramienta inteligente de clasificación, publicación y búsqueda, adquiere su verdadera dimensión cuando se publica y se contrasta con otros hashtags disponibles, y cuando de todos estos datos marcados se desprende una cierta inteligencia.

Esta manera de dar inteligencia colectiva a los datos se encuentra en la base de la evolución actual de la red.

"Esto se denomina folksonomía, neologismo que deriva del término folk (popular) y de taxonomía (o administración del orden tal y como lo conciben los archiveros y los bibliotecarios). La folksonomía es la clasificación realizada por los webactores cuando etiquetan los objetos web y comparten estos tags"138.

consulta: 4 de enero de 2018].

${ }_{13} 8$ PISANI, Francis y PIOTET, Dominique, op. cit., págs. 83-84. 


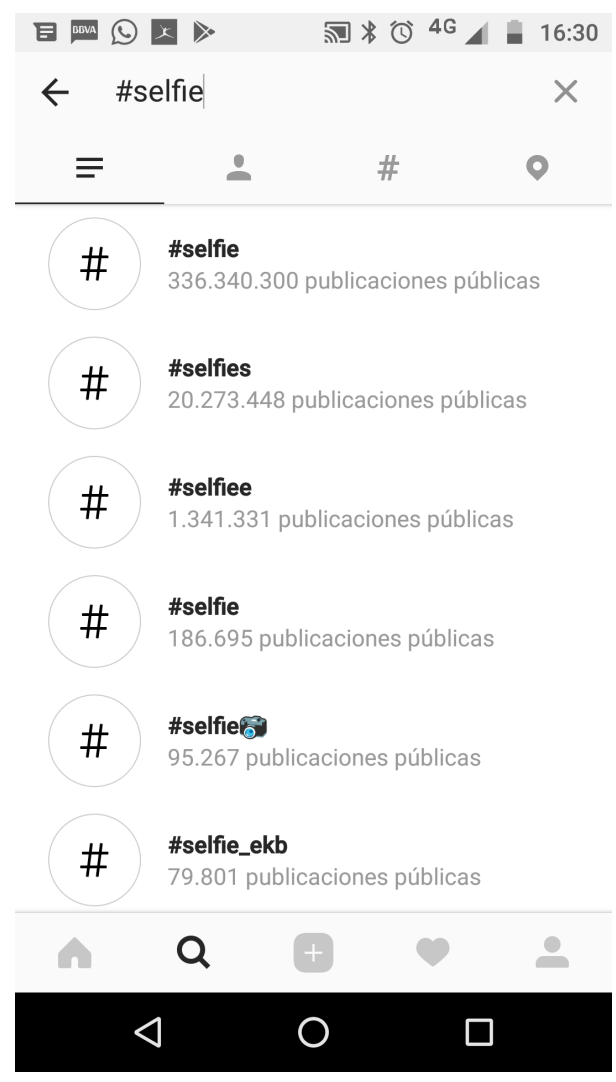

Imagen 6.12: Búsqueda mediante el hashtag \#selfie en Instagram.

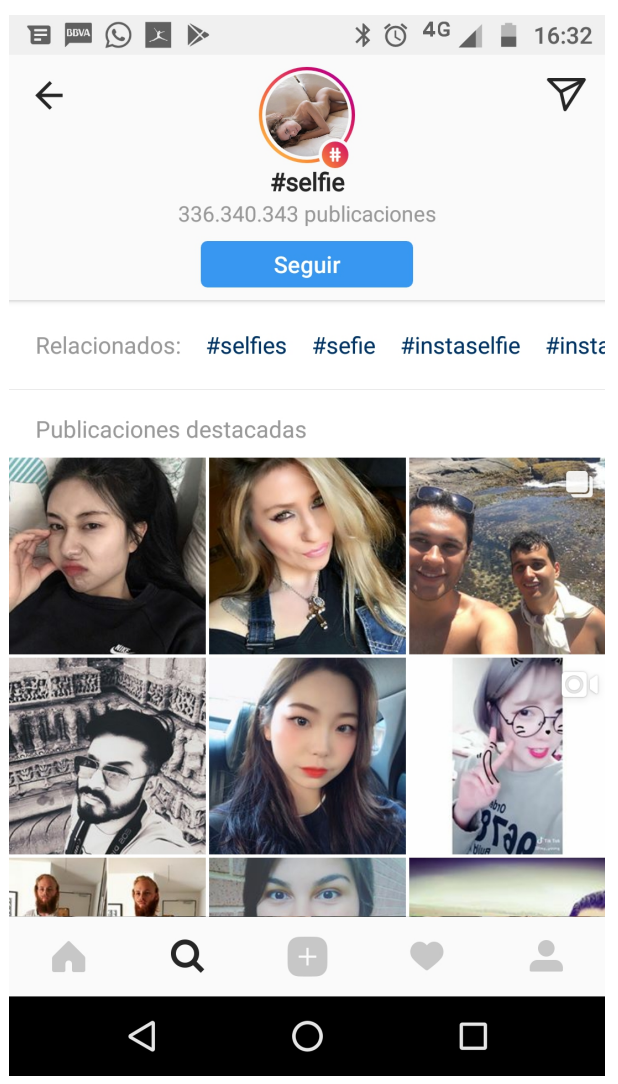

Imagen 6.13: Muestra de resultados tras la búsqueda por hashtag \#selfie en Instagram el día 5 de marzo de 2018 a las 16:32.

\subsubsection{Principales redes sociales en las que son notorias las autofotos y otros medios de exhibición y distribución del selfie.}

Ya hemos visto cómo las redes sociales han implosionado y modificado para siempre las maneras de comunicarse, estableciendo nuevos roles, vínculos y 
modos de relación entre nosotros ${ }^{139}$. Recordemos que empezaron a popularizarse a finales de la década pasada y ya en 2010 plataformas como Facebook, Flickr, Twitter, MySpace y YouTube, entre muchas otras, constituían un fenómeno social siendo parte de la textura de la experiencia cotidiana de quienes tenían acceso y capacidades digitales para darles un uso significativo ${ }^{140}$.

Esta cultura de redes sociales, al igual que la cultura de las computadoras y de Internet, generará nuevas mediaciones y se infiltrará en los resquicios más íntimos de la sociedad, dando lugar a una transformación de las categorías de lo humano, de la máquina y de lo real, y de las posiciones relativas entre tales términos ${ }^{141}$. Esta cultura seguirá evolucionando y cambiando a lo largo de nuestra década, ampliando su parrilla a través de redes tan determinantes para nuestro trabajo basado en el selfie $e^{142}$ como Instagram (red social de la que se apropiarán principalmente los jóvenes, cansados de un Facebook lleno de padres ${ }^{143}$ ). Las modas y los cambios de tendencia también proporcionarán otras migraciones, así como el surgimiento de nuevas redes específicas como Tinder o Badoo, y aplicaciones de mensajería instantánea mediante el uso del smartphone (también consideradas redes sociales y por las que fluirán los selfies y resto de autofotos a un ritmo todavía mayor) como WhatsApp, LINE, Telegram o SnapChat.

139 BONAVITTA, Paola; CAMACHO, Jeli E. y DE GARAY, Jimena, "Mujeres, feminismos y redes sociales. Acceso, censura y potencialización”, en Question, vol. 1, n 48, 2015, pág. 33.

140 MESENES, María E. J., "La red es el mensaje. Redes sociales virtuales en la esfera pública”, en Revista mexicana de comunicación, vol. 23, $\mathrm{n}^{\mathrm{o}} 123$ (Ejemplar dedicado a: Facebook: la reina de las redes sociales), 2010, pág. 20.

141 CARRILLO, Jesús, op. cit., pág. 56.

142 Aunque, como veremos, herramientas previas consideradas también redes sociales dieron al autorretrato digital publicado en red o self shot el pistoletazo de salida para conformar esta cultura de la imagen fotográfica generada por adolescentes que influyó, por ejemplo, en los selfies de Instagram. Estas redes sociales of fotoblogs fueron Fotolog y Metroflog.

143 MARCELINO, Georgina V., "Migración de los jóvenes españoles en redes sociales, de Tuenti a Facebook y de Facebook a Instagram. La segunda migración”, en Icono14, vol. 13, no 2 (Ejemplar dedicado a: Comunicación y redes sociales), 2015, pág. 67. 
En 2017, las diez redes sociales más utilizadas a nivel mundial eran: Facebook (con 1.900 millones de usuarios activos), WhatsApp (con 1.200 millones), YouTube (con 1.000 millones), Messenger (también con 1.000 millones de usuarios activos desde 2016), WeChat/Weixin (889 millones), QQ (869 millones), Qzone (638 millones), Instagram (600 millones de usuarios activos), Twitter (319 millones) y Weibo (313 millones) ${ }^{144}$.

Abordaremos ahora, una por una, las que consideramos como principales y fundamentales redes sociales que han hecho posible el desarrollo y la institucionalización cultural del selfie y otras autofotos digitales. Este recorrido no necesariamente seguirá un orden cronológico basado en la inauguración y puesta en marcha de estas redes sociales, sino que mostrará unas agrupaciones (si bien a veces ordanadas de manera cronológica) en la mayoría de casos realizadas por afinidad, por ritmos de migración o por temática. Empezaremos, pues, con una de las redes sociales pioneras y que primero empezaron a utilizar los jóvenes como plataforma de desarrollo público de la identidad y de muestreo de la imagen del yo mediante el autorretrato digital publicado en red: MySpace.

\subsubsection{MySpace.}

MySpace puede ser considerada como la primera red social que existió a nivel global y, de hecho, fue la que primero se popularizó entre las masas. Antes, otras redes redes sociales habían llevado a cabo su entrada en el mundo de la Web, pero no tuvieron demasiada repercusión. Ello se debió, entre otras cosas, a

144 RODRÍGUEZ DE LUIS, Eva, “¿Quieres saber qué red social es la que tiene más usuarios?”, 2017, disponible en: <https://www.ipadizate.es/2017/04/10/facebook-whatsapp-red-social-ranking/> [Fecha de consulta: 20 de julio de 2017]. 
que funcionaban a nivel local, como el sitio destinado a antiguos compañeros de clase en Estados Unidos Classmates, que hizo su aparición en 1995 y que aún hoy continúa funcionando igual de minoritariamente. Más tarde, en 2002 se inauguró Friendster que fue algo más global y, aunque las redes sociales aún no se habían popularizado, esta nueva iniciativa presentó los protocolos de contacto en línea entre amistades y el establecimiento de nuevas relaciones a través de Internet. Y ello por medio de una plataforma visible basada en los principios de la red social. Su uso se extendió principalmente entre la gente joven ${ }^{145}$.

Tras estos tímidos inicios, MySpace entró en escena:

“Creado por unos apasionados de la música independiente de Los Ángeles, MySpace contaba, a finales de 2007, con más de 100 millones de cuentas abiertas. En febrero de 2006, recibió 35 millones de visitas que vieron 22 mil millones de páginas. En 2008, registró 300.000 inscripciones al día. El usuario medio mira unas 500 páginas web al mes y 37 páginas por visita. Este considerable flujo llamó la atención de Rupert Murdoch, el magnate de los medios de comunicación, que compró el sitio por 580 millones de dólares en julio de 2005. [...] Muchos jóvenes estadounidenses pronto se identificaron con MySpace. El límite de edad, en un principio establecido en los 18 años, bajó hasta los 16, y luego hasta los 14"146.

Así pues, y como hemos visto, los jóvenes adolescentes encontraron en MySpace su nueva herramienta relacional, su espacio de comunicación e intercambio de imágenes personal y su territorio de desarrollo del yo. En poco tiempo, más de la mitad de los adolescentes estadounidenses usarían esta red de manera habitual ${ }^{147}$, y esta práctica también se extendería por el resto de países con acceso a Internet. Habían nacido los perfiles: las personalidades digitales. El adolescente aprendió a definir virtualmente su imagen mediante la fotografía.

\footnotetext{
145 PISANI, Francis y PIOTET, Dominique, op. cit., pág. 32.

146 Ibídem, pág. 33 .

147 SIBILIA, Paula, op. cit., pág. 17.
} 
Sus autorretratos en forma de self shots individuales, y sus palabras escritas, hacían pública su personalidad, sus ideas y su imagen. Podían, casi a tiempo real, recibir las impresiones de sus amistades en forma de comentarios, participar en foros de debate, chatear y, algo bastante propicio para el desarrollo del autorretrato digital publicado, asimilar sin darse cuenta la nueva cultura visual que estaban creando alrededor de la autorrepresentación atrevida por medio de las nuevas y popularizadas cámaras digitales.

Además, MySpace fue también plataforma de muchos músicos que se iniciaban como profesionales y que encontraron en esta red un sitio desde el que promocionar sus trabajos con cierto nivel de éxito. Tanto es así, que su por entonces actual propietario, Fox Interactive Media, creó en 2008 la compañía de discos MySpaceRecords con el objetivo de descubrir nuevos talentos entre los usuarios del servicio ${ }^{148}$. Para finales de 2009, MySpace ya formaba parte integral de las prácticas que se llevaban a cabo en redes sociales por parte de un número elevado de músicos, siendo utilizada como medio para promocionar, comercializar y distribuir música de manera sencilla. Por ejemplo, uno de los primeros que lo haría, el cantante y compositor James Blunt lanzó su álbum en MySpace en 2007. Cualquier persona podía descargarse este álbum por 9,99\$ directamente desde la plataforma. En 2009 Lily Allen también utilizaría MySpace como un medio alternativo no solo para comercializar su nuevo álbum mediante la serie Secret Show de MySpace, sino también para anunciar que iba a actuar en Tokyo ${ }^{149}$.

MySpace fue solo el principio. Hoy en día ya no goza de la misma popularidad, respira con dificultad ahogada en parte por las nuevas y atractivas

148 RUIZ, Sonia, op. cit., pág. 209.

149 SUHR, Hiesun C., "Comprendiendo la aparición de los protocolos sociales en MySpace. Impacto y ramificaciones", en Comunicar. Revista científica iberoamericana de comunicación y educación, $\mathrm{n}^{\mathrm{o}}$ 34 (Ejemplar dedicado a: Música y pantallas: mediaciones en el nuevo escenario digital), págs. 45-53, 2010, pág. 46. 
redes sociales. A pesar de ello ha vuelto a recuperar las funciones para las que se creó: servir de plataforma musical para artistas independientes. Con todo, hay que destacar la labor que supuso este espacio de la Web en los orígenes y desarrollo de la red social adolescente.

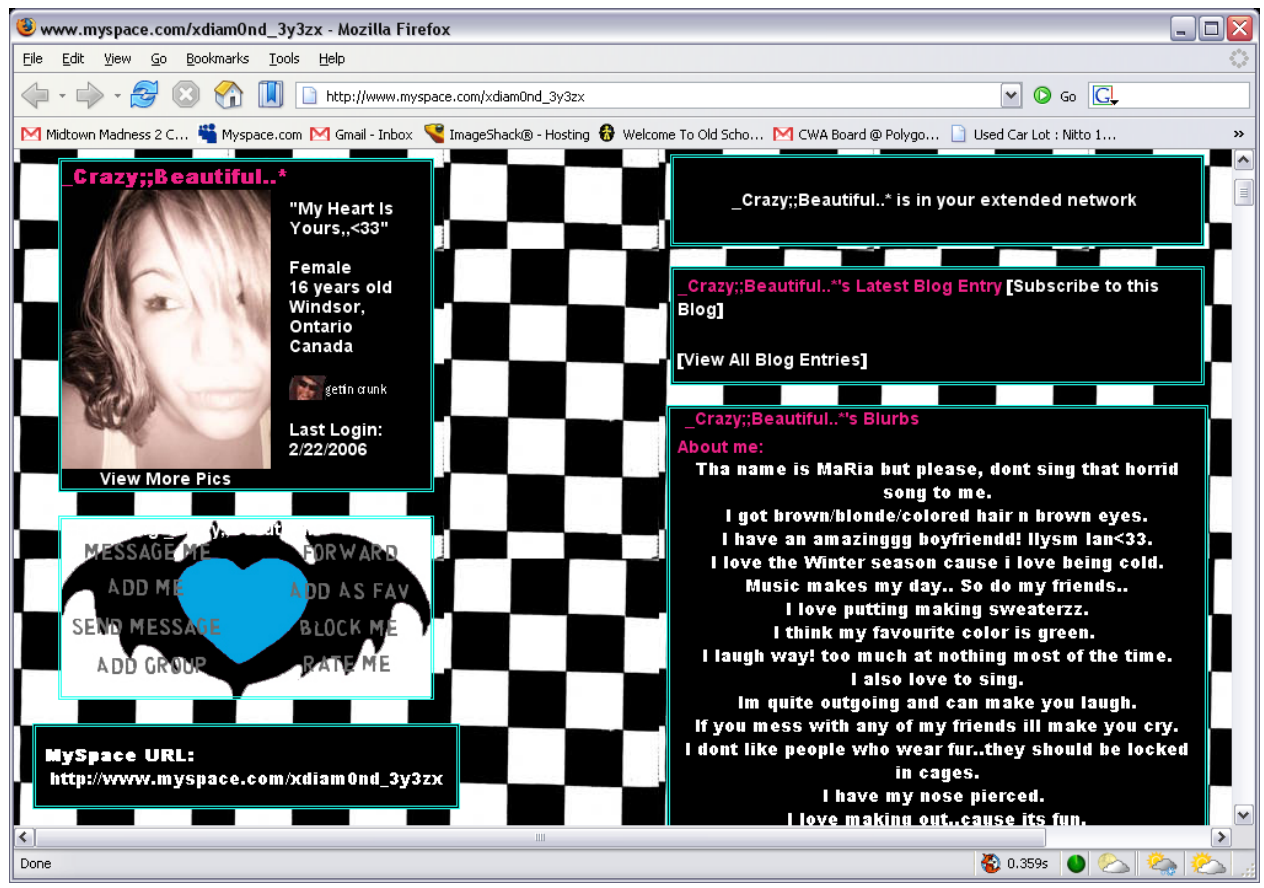

Imagen 6.14: Imagen que muestra un perfil clásico de un adolescente en MySpace. El perfil es de 2006 y pertenece a una adolescente de nombre desconocido que se presenta con una autofoto con los parámetros fotográficos de esa época, junto con el resto de disposición de textos e intereses. Esta imagen, a modo de fósil digital, ha sido recuperada como captura de pantalla por MATT, Samantha, "Flashback Friday: MySpace”, 2013, disponible en: <http://forevertwentysomethings.com/2013/01/04/ flashback-friday-myspace/ $>$ [Fecha de consulta: 4 de agosto de 2017]. 


\subsubsection{Los blogs y el desarrollo de Blogger.}

Los blogs habían entrado en escena años atrás en relación a la irrupción de las redes sociales generalistas ${ }^{150}$. Se presentaron como superficies de escritura y publicación en línea. Los mismos fomentaban las dotes periodísticas, poéticas y reflexivas de un gran número de cibernautas. En ellos se ha escrito desde entonces hasta nuestros días sobre cualquier cosa, se han colgado imágenes y vídeos y se han vinculado temas a través de palabras clave o tags.

Pese a que su uso comenzó a reducirse aproximadamente a partir de 2007, en ese momento y tras menos de diez años de uso, se estima que había más de 100 millones de $b \log s^{151}$.

$\mathrm{Al}$ poco tiempo de institucionalizarse, los blogs ya eran el eje central y punta de lanza de la revolución que supuso la irrupción de los nuevos medios sociales, al ser los más extendidos y populares entre los usuarios y haber alcanzado un alto nivel de visibilidad ${ }^{152}$. Los blogs fueron definidos como un género en sí mismos y también supusieron la introducción de un nuevo concepto: la blogosfera ${ }^{153}$.

Una definición sencilla del blog es:

"Sitio web cuyo contenido lo producen los usuarios (el o los autores y los lectores que participan con sus comentarios). Suele adoptar el estilo de un periódico, cuyas entradas más recientes figuran en los primeros lugares. Si bien al principio los blogs

\footnotetext{
150 De hecho, muchos manipuladores de código los hicieron posibles antes de la irrupción de la Web 2.0, aunque fue tras la aparición de esta cuando se convirtieron en una herramienta masiva y popular. CASARES, Nilo, op. cit., pág. 135.

151 PISANI, Francis y PIOTET, Dominique, op. cit., pág. 82.

152 RUIZ, Sonia, op. cit., pág. 175.

153 MONSORIU, Mar, op. cit., pág. 18.
} 
proponían fundamentalmente textos e imágenes, se fueron enriqueciendo con sonidos (podcast) y vídeos (videoblogs)"154.

En cuanto a sus elementos formales normalmente encontramos en sus pantallas un acceso a un archivo cronológico (y eventualmente temático) de las historias publicadas, una lista de enlaces que suelen corresponder a los otros blogs que el autor lee con frecuencia, un buscador interno, algún sistema de estadísticas, breve información acerca del autor o autora y una dirección de correo electrónico de contacto ${ }^{155}$.

Aunque existen multitud de blogs que suponen un soporte visual para el selfie y resto de autorretratos digitales publicados en la red, como los self shots más clásicos, característicos de la época (Imagen 6.15), todos cumplen la función de galería recopilatoria realizada por admiradores del fenómeno, en tanto que unifican el material recopilado en la red. Hasta donde hemos podido constatar, entendemos que pocas veces funcionan los blogs como herramienta propia de publicación de los autorretratos personales.

154 PISANI, Francis y PIOTET, Dominique, op. cit., pág. 83.

155 RUIZ, Sonia, op. cit., pág. 176. 


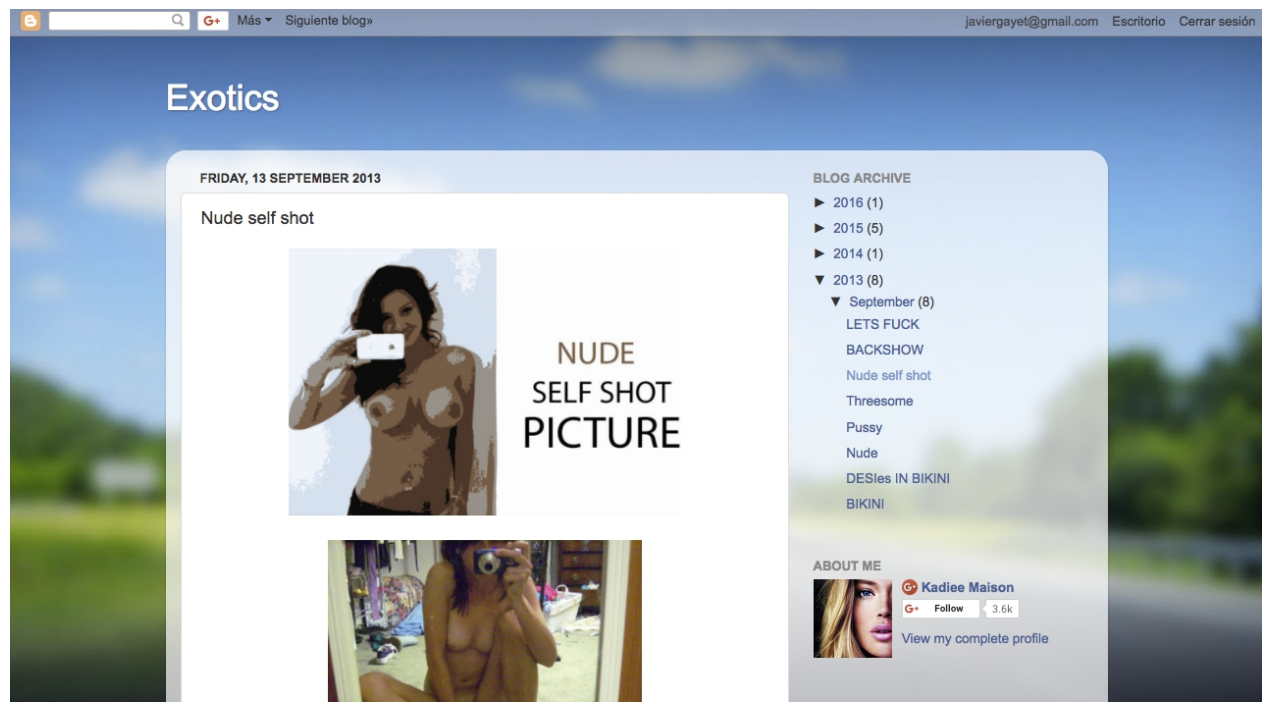

Imagen 6.15: Uno de los muchos blogs que hemos encontrado como soporte y difusión del self shot (titulado Exotics y autoría de Kadiee Maison). En este caso el blog recoge autorretratos digitales de carácter erótico y exclusivamente femeninos que, como vimos en el capítulo 5, habrán llegado a esa plataforma de publicación seguramente de manera involuntaria por parte de sus autoras y sin que estas tengan el conocimiento de hasta donde han llegado las imágenes que realizaron de sus cuerpos desnudos. Disponible en: <http://exoticsbykm.blogspot.com.es/2013/o9/ nude-self-shot.html?zx=dbeecocf 5 a1038c3 $>$ [Fecha de consulta: 10 de agosto de 2017].

Sin embargo, sí que hemos encontrado un caso que fue notorio en 2008, además de bastante mediático: el blog de Eva Ros (Imagen 6.16), que tituló Eva se desnuda ${ }^{156}$. El blog constituyó un ejemplo de autorrepresentación y publicación del cuerpo desnudo unido al discurso comunicativo y reivindicativo. Eva, una estudiante de Ciencias Políticas, quiso hacer visible su mensaje reflexivo acerca de la situación del país durante esos años a través de su imagen en vídeo. En el mismo, y por entregas, mostraba un striptease de la autora autorrepresentada a través de la webcam de su computadora. La imagen se asociaba a una idea. Aunque no se trate exactamente de un self shot fotográfico,

156 ROS, Eva, “4 años después, Eva se desnuda”, 2011, disponible en: <http://evasedesnuda.blogspot. com.es/> [Fecha de consulta: 11 de agosto de 2017]. 
las vías de publicación y exhibición utilizadas por Eva Ros fueron similares a la difusión de la imagen erótica que han practicado los adolescentes, y ello con independencia de las causas que motivaron su acción.

\section{EVA SE DESNUDA}

\subsection{1 .11 \\ 4 años después...}

Otro debate insustancial basado en la desacreditación. Todo sigue igual, decepción \#10.

Ya que me sobraron 3 vídeos en $2008 \ldots$ vamos a seguir dándonos una alegría.

Fuera braguitas!

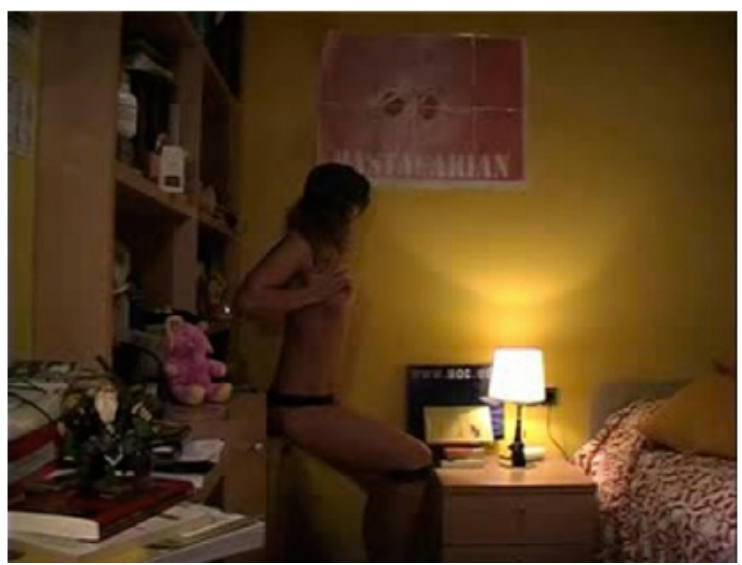

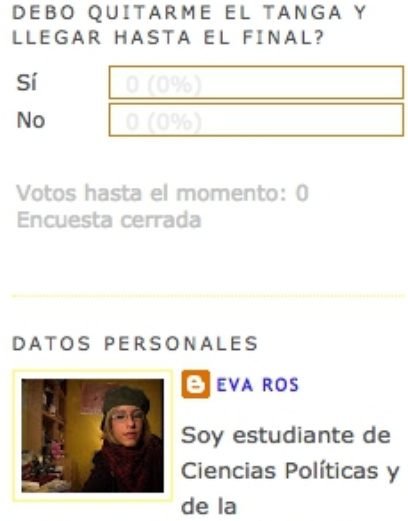

Administración. No sé qué quiero ser de mayor, pero por ahora me encanta lo que estudio, aunque gran parte del tiempo que dedico a pensar en política termino rabiosa del circo que tenemos montado en casa. No se salva ni uno.

VER TODO MI PERFIL

Imagen 6.16: El blog de Eva se desnuda. En pantalla puede verse el último post que redactó cuatro años después de su ejercicio reivindicativo. Pese a que los vídeos han sido censurados con el paso del tiempo por la plataforma en la que estaban sujetos (Youtube) tras sus cambios de política (lo que vuelve a evidenciar la destrucción que sufren las webs abandonadas con el paso del tiempo), aún pueden leerse algunas de las reflexiones políticas de Eva Ros. 
Pese a la importancia del ejemplo señalado, se puede apuntar que el blog está siempre mucho más basado en la palabra y la reflexión escrita, que en la imagen:

"El blog sería además hábitat preferente de lo fragmentario, del discurso-red. Nada de grandes tratados; el aforismo triunfa; las visiones breves y desnudas que buscan llegar al otro en lo que nos une, compartir unos ojos detenidos en una cita o una imagen; «Mira, estos son fragmentos de mi mundo, frescos, recién cogidos, en crudo, instantes de mi vida. Vuelve mañana y te daré más»; la continuidad importa" ${ }^{157}$.

Fueron muchas las plataformas que proporcionaron la posibilidad de crear, desarrollar y mantener un blog, Pero aquí queremos destacar la denominada Blogger. Actualmente y desde 2003 es propiedad de Google Inc. y es la plataforma con mayor número de blogs de la blogosfera, además de ser considerado como el primer editor popular de aplicaciones de blogs. Blogger fue crerada por Evan Williams y Meg Hourihan bajo su empresa de San Francisco, Pyra Labs. Gratuita y fácil de utilizar, esta aplicación tuvo éxito de forma muy rápida $^{158}$. La aparición de Blogger coincidiría en el tiempo con la publicación de los primeros blogs en español ${ }^{159}$.

\subsubsection{Los fotoblogs: Fotolog.}

Sin embargo, Fotolog (junto con redes sociales ofotoblogs de corte similar o casi idéntico como Metroflog), sí que funcionó como soporte del self shot en sus primeros años, desarrollando sus pautas en muy poco tiempo. En este sentido, podemos afirmar que estos soportes de publicación fotográfica se

\footnotetext{
157 ZAFRA, Remedios, op. cit., pág. 81.

158 PISANI, Francis y PIOTET, Dominique, op. cit., pág. 83.

159 RUIZ, Sonia, op. cit., pág. 177.
} 
constituyeron en redes sociales fundamentales para el asentamiento de este fenómeno, así como en una de sus principales vías de difusión. En Fotolog, las usuarias y usuarios tenían la posibilidad de publicar una fotografía al día. Estas fotos podían ser comentadas y destacadas.

Fotolog ${ }^{160}$ se inauguró en mayo de 2002 bajo el nombre de Fotolog.net y fue en diciembre de 2005 cuando cambió su nombre a Fotolog.com ${ }^{161}$. Se considera "la mayor web de publicación de fotografías del mundo, con más de 20 millones de visitantes únicos al mes [...] y, hasta septiembre de 2008, Chile es el país con más usuarios registrados, con un total de 4,8 millones. En total son más de 22 millones de miembros" ${ }^{162}$ que se extienden por numerosos países.

Dicho tipo de aplicaciones de la Web asumieron el papel de diarios personales públicos basados en la imagen y se popularizaron entre la gente joven. Los y las adolescentes publicaban principalmente fotos documentales de su vida y autorretratos digitales.

El hecho de publicar solo una fotografía al día moderó, desarrolló modales y cambió las pautas de muestra masiva de imágenes que se efectuaba antes de la aparición de estos soportes. A finales de la década pasada, e igual que ocurría con MySpace, casi cualquier adolescente de nuestro país tenía abierta una cuenta en Fotolog donde exponía públicamente mediante fotografías y texto su imagen propia, sus costumbres, su intimidad e, incluso, sus pensamientos más profundos y personales en relación a otros usuarios, pensamientos que pese a tener un tono aparentemente reservado, eran expuestos de manera totalmente

\footnotetext{
160 Todavía en funcionamiento aunque con mucha menos actividad en: <http://www.fotolog.com $>$ [Fecha de consulta: 20 de julio de 2017].

161 Además, desde 2007 será propiedad de la empresa Group Hi-media USA Inc., teniendo desde entonces su sede central en Nueva York, Estados Unidos. MONSORIU, Mar, op. cit., pág. 52.

162 RUIZ, Sonia, op. cit., pág. 113.
} 
pública, como una carta de correspondencia abierta y pegada en el ascensor de la comunidad de vecinos.

"Carla Lerín Bermejo creo que a estas alturas no hay nada que yo pueda hacer para impresionarte, porque creo que te lo he dicho muchas veces, y siempre tengo que escribir las mismas paridas porque esta amistad vale mucho más que 17384937625 palabras, enserio y ahora es cuando tu querida befe dice:

Tequiero muchisimo, no lo olvides:\$ Tú? mi mitadd, mi media naranja, mi todo\&hearts; Te acuerdas de lo que dijimos una vez? Tú y yo cogidas de la mano bien fuerte para que nada ni nadie nos separe nunca, jamás. aaaaah! que se me olvidaba gracias por esta mañana en la villa olimpica, y por no dejarme pagar cacho pánfilA! :)"163.

Los perfiles de adolescentes en Fotolog o Metroflog se convertirían en un clásico de la Web, siendo muy reconocibles a nivel visual (Imagen 6.17). Tan reconocibles, no obstante, como el propio estilo formal de esas primeras autofotografías publicadas.

163 Comentario, traído aquí de manera totalmente literal, asociado a una de las fotografías (en este caso, selfie primitivo) que el adolescente podía subir diariamente a Fotolog. La usuaria "Quieresungomet" nacida en 1996, se dirige así en 2010 a su amiga Carla. Todavía disponible en: $<$ http://www.fotolog.com/quieresungomet/14367439/\#profile_start> [Fecha de consulta: 20 de julio de 2017]. 


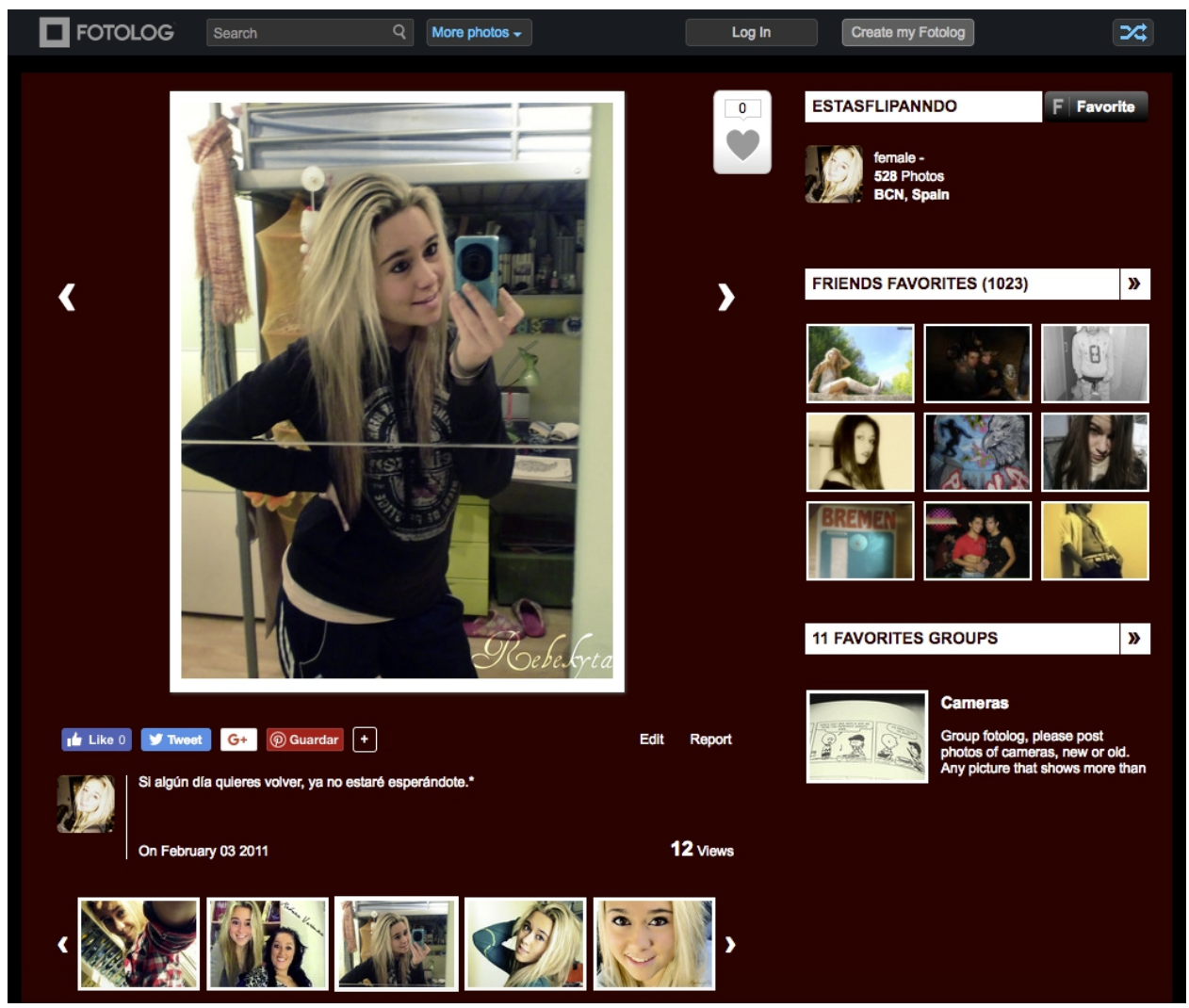

Imagen 6.17: Perfil público de la usuaria adolescente “estasflipanndo” que dejó de actualizarse en 2011 y que aún reside (de momento) como espacio consultable en la Web. Puede apreciarse la galería de autofotos diarias realizada por la usuaria, de tipo selfie primitivo y mirrorpic. disponible en:

<http://www.fotolog.com/estasflipanndo/62258212/> [Fecha de consulta: 20 de julio de 2017].

Estos espacios públicos en la red, a su vez, fueron los primeros mediadores de la viralización y fama de algunas usuarias, básicamente mujeres adolescentes, que serían pioneras en alcanzar una cierta repercusión mediática, partiendo del anonimato, gracias a unos autorretratos digitales que las mostraban como atractivas o especiales. Recordemos, al respecto, lo señalado en el capítulo 5 en relación al famoso Metroflog de Mónica Lizeth Murillo. En relación a esta manera de mostrar, Remedios Zafra apunta: 
"Nadie les obliga a visitarlo, nadie les engaña diciendo que lo que allí van a encontrar es otra cosa que visión personal, selección, firma, actitud, escrutinio de la experiencia vivida. Cansados de imposturas, el yo firmante responde con voz propia (incluso cuando el yo que habla lo hace bajo un nombre ficticio)”164.

En el caso particular de Fotolog, hemos encontrado un interesante estudio de 2013 publicado en inglés por Iolanda Tortajada y Lanna Crescebzi en relación al impacto de estas plataformas en la vida del adolescente. Ofrecemos aquí la traducción de alguna de sus conclusiones:

"En línea con otras investigaciones, se puede concluir que Fotolog es una ventana de oportunidad para la autopresentación y la gestión de la privacidad, la exploración de la identidad sexual y el juego, y abre nuevas formas de abordar el género y la sexualidad. Sin embargo, en relación a la construcción del género se sugiere que se enfaticen las sugerencias que abordan algunos problemas que podrían surgir a raíz de esto en el ámbito de la educación: y es que los adolescentes podrían construir espacios de comunicación en línea que son mucho más igualitarios y beneficiosos. Mientras tanto, las investigaciones futuras deberían considerar la inclusión de los estudios longitudinales con el fin de estudiar las tendencias y los cambios en la información personal que se comparte en las redes sociales, además de recoger las motivaciones y el significado estratégico que los adolescentes atribuyen a estos hábitos. Como resultado, los estudios cuantitativos como los que se presentan aquí deberían complementarse con estudios cualitativos que incluyan las voces de los participantes en las redes sociales" ${ }^{\prime 65}$.

En la actualidad Fotolog ha dejado de gozar de la popularidad y uso que tuvo hace unos años y el número de usuarios activos en esta red ha descendido drásticamente al encontrar los adolescentes nuevos espacios de publicación y gestión del yo, mucho más cómodos y manejables y adaptados a los nuevos

\footnotetext{
164 ZAFRA, Remedios, op. cit., pág. 81.

165 CRESCEBZI, Lanna y TORTAJADA, Iolanda, "Privacy, Self-disclosure and Self-image of Spanish Teenagers on Social Networking Sites. The Case of Fotolog”, en Communication \& Society, vol. 26, $\mathrm{n}^{\mathrm{o}}$ 2, 2013 , pág. 76 .
} 
tiempos y dispositivos, como Instagram o SnapChat. No obstante, como hemos mostrado en este punto, muchos de los perfiles utilizados durante los últimos años de la década pasada han quedado todavía visibles, como una imagen residual de las prácticas de aquellos años, prácticas que hoy se nos presentan como una huella con carácter puramente documental.

\subsubsection{Redes sociales basadas en la imagen: Flickr, Tumblr y Pinterest.}

Han existido y existen otras redes sociales muy populares basadas en la imagen, redes que han albergado una buena parte de las fotografías que hay dispuestas y visibles en Internet. Estas redes fotográficas, como Flickr, Tumblr o Pinterest ${ }^{166}$, han sido y son herramienta de fotógrafos, creativos, rastreadores de la imagen cultural contemporánea y, cómo no, de autores de selfies y de otros autorretratos digitales.

Entendemos que estos soportes de publicación también han cambiado muchos de los hábitos y de los usos que los actores de nuestro objeto de estudio practican, ya que no solo influyen en la manera de mostrar la fotografía, sino también en cómo construirla a nivel formal.

No obstante, la mayor aportación que hacen este tipo de redes sociales basadas en la imagen visual y en la fotografía es la de transformar y desplazar la

166 Aunque, desde 2007 hasta nuestros días, "Tumblr se ha ganado el título de la red social de las imágenes por excelencia”, las tres plataformas aquí estudiadas gozan de gran popularidad y todavía mantienen buena salud, y además tienen un carácter totalmente diferente pese a perseguir fines parecidos. Y es que mientras Tumblr se centra en la distribución masiva de imágenes encontradas sobre un soporte personalizable y bajo una visibilidad más efímera y volátil, Pinterest compila esas mismas imágenes encontradas otorgándole cierto orden y clasificación como si se tratara de un panel de notas. Por otro lado, Flickr presenta las imágenes de una manera más selectiva y casi reverencial, por ello ha sido una de las plataformas virtuales expositivas favoritas de fotógrafos y aficionados a la fotografía en esta era digital. ROBLES, Elena, op. cit., pág. 13. 
propia cultura de Internet (tal como ha ocurrido en otros mass media anteriores) hacia territorios más visuales que se imponen sobre los escritos. La imagen termina por someter a la palabra, tal como ha ocurrido desde los propios orígenes de la fotografía.

"La explotación y duplicación fotográfica del mundo fragmenta las continuidades y acumula las piezas en un legajo interminable, ofrece por lo tanto posibilidades de control que eran inimaginables con el anterior sistema de registro de la información: la escritura" ${ }^{167}$.

Asimismo, debemos indicar que si bien estas tres redes sociales tratadas en este punto son de corte generalista y fluyen por ellas todo tipo de imágenes e intereses, existen también redes, páginas y foros especializados en la difusión de nuestro objeto de estudio, generalmente autorretratos eróticos de mujeres que, como hemos visto más arriba y en otros capítulos, fluyen por la red multiplicándose de manera rizomática y, seguramente, con el desconocimiento de sus autoras, debido a la facilidad que tienen este tipo de objetos de escapar del control de sus dueñas y dueños una vez saltan a los servidores de Internet por descuidos, robos, traiciones o excesos de confianza. Entre la gran cantidad de sitios web encontrados a lo largo de esta investigación (algunos de ellos han dejado de existir) y que habitualmente huyen de las autofotos más recatadas, recopilando directamente imágenes dignas de ostentar la etiqueta de pornografía (y cuya recopilación y exhibición sería producto, entendemos, de gestores masculinos heterosexuales) destacamos, Girlfriend Galleries ${ }^{168}$, Girls in Mirror of The Chive ${ }^{169}$ y Self Shot Babes ${ }^{170}$.

167 SONTAG, Susan, Sobre la fotografía, Barcelona, Debolsillo, 2008, pág. 152.

168 <http://www.girlfriendgalleries.net/user,Sweetescape9900,8617.html> [Fecha de consulta: 22 de julio de 2017].

169 <http://thechive.com/category/sexy-girls/girls-in-mirror,/> [Fecha de consulta: 22 de julio de 2017].

$170<$ http://www.selfshotbabes.com/> [Fecha de consulta: 22 de julio de 2017]. 


\subsubsection{Facebook.}

Facebook nació como un sencillo catálogo electrónico de fotos y nombres de estudiantes universitarios que se fue ampliando desde finales del año 2006 hasta llegar a convertirse en una plataforma de gran éxito ${ }^{171}$. Como hemos visto antes, en la actualidad Facebook es la red social con mayor número de usuarios activos, además de ser la página web más visitada del mundo, ya que diariamente acceden a ella millones de personas, y más de mil millones de habitantes del planeta poseen una cuenta activa en esta red social ${ }^{172}$. Eso significa que una de cada siete personas del planeta, está en Facebook.

Facebook inició su actividad en febrero de 2004 y, en principio, estaba pensada como una red para estudiantes de la Universidad de Harvard, pero en su primer mes ya se había inscrito la mitad de la población estudiantil de esa Universidad ${ }^{173}$. Fue, de esta manera, un red social ideada para ser utilizada en un ámbito local y cerrado (lo que nos recuerda al invento de la Web de Tim BernersLee que hemos analizado más arriba), aunque luego sus andaduras abarcaran otros derroteros.

Su principal ideólogo y desarrollador fue Mark Zuckerberg, un joven universitario (hoy una de las personas más ricas del mundo) y que por aquel entonces se propuso crear una plataforma digital más intuitiva que sus redes sociales predecesoras, añadiendo herramientas que generaban una interacción emocional ${ }^{174}$. Zuckerberg y sus colaboradores, animados por el éxito de este

\footnotetext{
171 PISANI, Francis y PIOTET, Dominique, op. cit., pág. 32.

172 BORERO, Alejandra y LONDOÑO, Suanny, "Mujer selfie, construcción de un discurso femenino adolescente mediado por el consumo de la imagen”, en V Encuentro Internacional de Investigadores en Publicidad (RELAIP), Alicante, 2016, pág. 126.

173 RUIZ, Sonia, op. cit., pág. 210.

174 BORERO, Alejandra y LONDOÑO, Suanny, op. cit., pág. 126.
} 
Facebook primigenio, decidieron en el mes de marzo ampliar sus redes hasta las Universidades de Stanford, Columbia y Yale; acabando el año con la incorporación de la mayoría de universidades estadounidenses y canadienses ${ }^{175}$. En los siguientes cuatro meses tuvo que ofrecer sus espacios al público de cualquier país e idioma del mundo ${ }^{176}$. Pero aún pasarían dos años, hasta septiembre de 2006, para que Facebook abriera completamente sus puertas virtuales a cualquier usuario que quisiera registrarse (siempre y cuando fuera mayor de trece años y diera una dirección de correo electrónico válida). Probablemente, una buena parte del éxito de Facebook se debió al hecho de haber permitido el desarrollo de aplicaciones por terceros, lo que posibilitó la integración de otros muchos servicios 2.0, como la publicación de fotografías ${ }^{177}$ (de hecho, a fines de 2012, Facebook contaba con más de 240.000 millones de imágenes ${ }^{178}$ ). Su función desde su popularización sería la de "hacer que las personas puedan compartir y hacer del mundo un lugar más abierto y conectado" 179 .

Desde la evolución que sufrió Facebook tras su salto del ámbito local al mundial, esta red social ha ido aunando muchas de las funciones de sus redes sociales predecesoras: principalmente funciona como un diario, siendo un espacio de desarrollo del yo y de su perfil virtual. No obstante, también funciona como un blog, como una galería fotográfica, como un notebook personal y como una plataforma de divertimentos. Además, por su propia naturaleza de hacer público lo privado, es un agujero para voyeurs, que pueden espiar la vida pública de sus amistades cercanas a través del cotilleo de sus fotografías sin que los propietarios y autores de estas lo sepan.

\footnotetext{
175 RUIZ, Sonia, op. cit., pág. 210.

176 MONSORIU, Mar, op. cit., pág. 49.

177 RUIZ, Sonia, op. cit., pág. 210.

178 COLLE, Raymond, op. cit., pág. 25.

179 BORERO, Alejandra y LONDOÑO, Suanny, op. cit., pág. 126.
} 
Además, aunque Facebook puede parecer un pasatiempo, en apariencia inútil y frívolo que mantiene atrapados por igual a cientos de millones de personas en todo el planeta (prácticamente sin distinciones intelectuales, idiomáticas, folclóricas o de nivel sociocultural ${ }^{180}$ ), en realidad también es utilizado de manera empresarial (muchas empresas prosperan gracias a su página en Facebook), así como carta de presentación y gestor de noticias de personalidades (por ejemplo, Barack Obama y Nicolás Sarkozy hicieron de Facebook uno de los canales de comunicación más importantes en sus campañas para alcanzar la presidencia de sus países ${ }^{181}$ ).

Facebook se ha convertido para muchos en una herramienta imprescindible para relacionarse virtualmente, de hecho, ese espacio de relación en muchas ocasiones sustituye al real. Ello sucede porque convierte los acontecimientos de nuestra vida en noticias para los demás, nos visibiliza y nos despliega en una especie de aldea cibernética. Se trata, por tanto, de la plaza del pueblo. Y es, asimismo, una herramienta fundamental para la publicación del selfie y otro tipo de autorrepresentaciones (Imagen 6.18). Facebook, como diario fotográfico, ha sustituido a los álbumes familiares del siglo pasado:

"El álbum familiar expresa la verdad del recuerdo social. [...] Las imágenes del pasado, guardadas en un orden conológico, el «orden de las razones» de la memoria social, evocan y transmiten el recuerdo de sucesos que merecen ser conservados porque el grupo ve un factor de unificación en los monumentos de su unidad pasada o, lo que viene a ser lo mismo, porque toma de su pasado la confirmación de su unidad presente. Por ello, nada es más decoroso, más tranquilizante y edificante que un álbum de familia" ${ }^{182}$.

\footnotetext{
180 FAERMAN, Juan, op. cit., págs. 29-30.

181 Ibídem, pág. 10.

182 BOURDIEU, Pierre, Un arte medio, Barcelona, Gustavo Gili, 2003, pág. 69.
} 


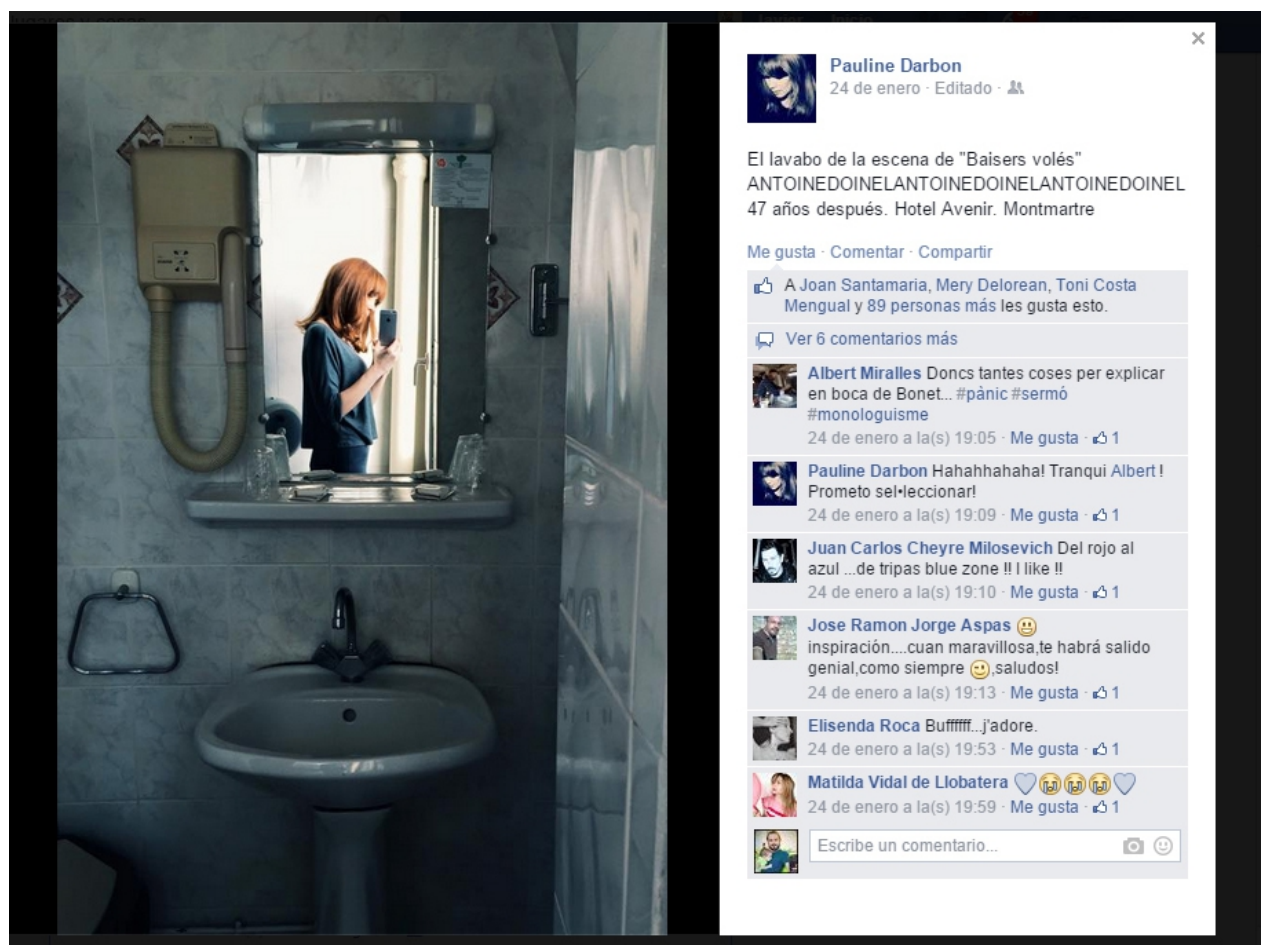

Imagen 6.18: Autorretrato de espejo mediante dispositivo móvil y publicado en Facebook por la artista e ilustradora Paula Bonet, durante una investigación para uno de sus proyectos, realizado en enero de 2013.

Pese a que en sus orígenes Facebook fue, al igual que había sido anteriormente MySpace y Fotolog, una red social utilizada por el público joven para el desarrollo de su identidad por medio de la exhibición de sus pensamientos y su autorrepresentación fotográfica ${ }^{183}$ (Imagen 6.19), pronto el público adolescente consideraría esta red social llena de adultos un territorio no

${ }_{183}$ "[...] en busca de crear la mejor presentación posible de sí mismos”. BASILE, Diego y LINNE, Joaquín, "Performances de autopresentación a través de fotografías digitales. El caso de los adolescentes de sectores populares en Facebook»" en Cuadernos.Info, $\mathrm{n}^{0} 35$ (Ejemplar dedicado a: Comunicación y educación), 2014, pág. 210. 
válido y la declararía obsoleta para sus intereses ${ }^{184}$, migrando a plataformas más recientes como Tuenti o Instagram.

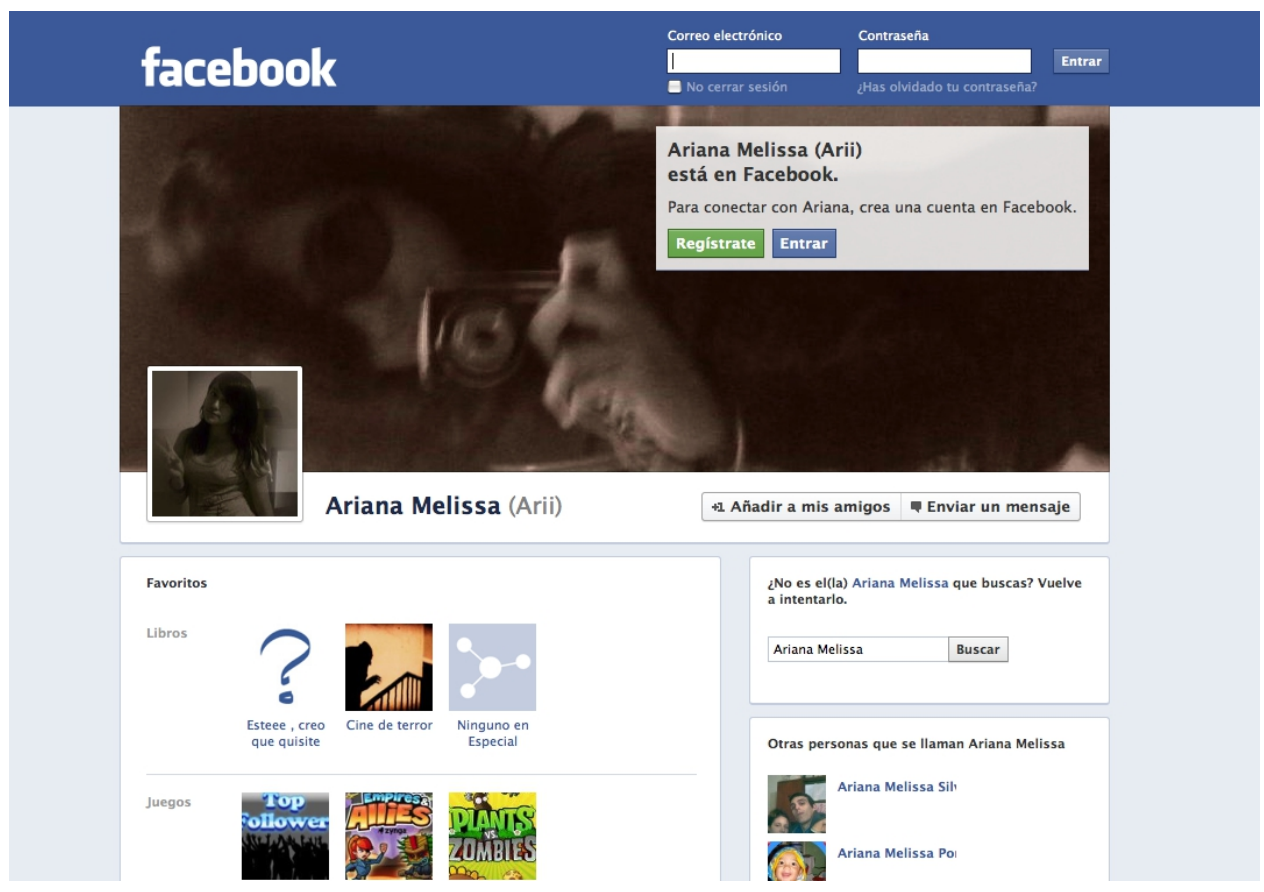

Imagen 6.19: Perfil de una adolescente en Facebook, capturado durante 2010 y ahora extinto en la red por su eliminación por parte de esta misma usuaria. Se puede apreciar la fotografía de portada, un autorretrato de espejo realizado con una de las cámaras compactas populares durante aquella época.

184 BORERO, Alejandra y LONDOÑO Suanny, op. cit., pág. 127. 


\subsubsection{La desaparecida Tuenti.}

Tuenti fue una red social española que dejó de existir en 2016. En ese momento tenía 20 millones de usuarios. Fue fundada por Zaryn Dntzel, Kenny Bentley, Adeyemi Ajao, Félix Ruiz, y Joaquín Ayuso de Paul en 2006. Fue propiedad de la empresa Tuenti Technologies, que tenía su sede central en Madrid $^{185}$. Actualmente Tuenti es la marca de un proveedor de servicios móviles, siendo el resultado de la evolución de esta red de la que aprovechó su fama y el logotipo. Pese a ser, como muchas otras redes sociales que aquí no nombramos, similar en casi su totalidad al formato de Facebook, nos parece interesante incluirla en este listado, ya que se trató de una red social destinada exclusivamente para el público joven.

Además, si sumamos a una posible moda casual, el "desamparo" en el que quedaron los adolescentes al abandonar Facebook, entenderemos los motivos que la convirtieron en la plataforma perfecta sobre la que efectuar la migración ${ }^{186}$. Efectivamente, a finales de 2008 Tuenti ya era la red favorita entre los jóvenes españoles ${ }^{187}$. De hecho en nuestro país Tuenti fue más usada que Facebook $^{188}$ durante casi la totalidad de su vida operativa por parte del público adolescente entre catorce y veinte años ${ }^{189}$.

185 MONSORIU, Mar, op. cit., pág. 137.

186 Aunque con el paso del tiempo esta migración también se volverá inversa: jóvenes que sobrepasen los veinte años volverán (o entrarán) a Facebook. Actualmente la red social preferida por los jóvenes es Instagram. MARCELINO, Georgina V., op. cit., pág. 67.

187 RUIZ, Sonia, op. cit., pág. 222.

188 "Según datos de la Fundación Pfizer, un 92,6\% de los jóvenes entre 11 y 20 años participan en redes sociales. Por este orden, Tuenti, Facebook y Fotolog son las tres redes más usadas por los entrevistados”. ARAUNA, Núria; MARTÍNEZ, Inmaculada J. y TORTAJADA, Iolanda, op. cit., pág. 178.

189 DÍEZ, Emeterio; PERELLÓ, María M. y RÖMER, Max, "Análisis semiótico de la fotografía de perfil de jóvenes en Tuenti”, en Estudios sobre el mensaje periodístico, $\mathrm{n}^{0}$ 18, 2012, pág. 812. 
Pese a que Tuenti ya no existe, debido a su naturaleza joven y a una casi totalidad de usuarios que no superaban la veintena, podemos constatar que fue una red social en la que el autorretrato digital publicado tuvo uno de sus más importantes marcos expositivos y difusorios en nuestro país. Hoy en día nos puede resultar difícil construir una investigación en torno a esta civilización extinta que fue Tuenti, y es que, al margen de las publicaciones y estudios que la nombran, no quedan demasiados fósiles visuales que desenterrar (salvo algunas capturas de imagen que se pueden encontrar en foros o buscadores, como la aquí mostrada (Imagen 6.20).

No obstante algunos de los testigos que utilizaban aquella plataforma hace un lustro podrán (y nos han podido) verificar lo que supuso la misma para el desarrollo del selfie y de los autorretratos de cuarto de baño realizados por los jóvenes adolescentes.

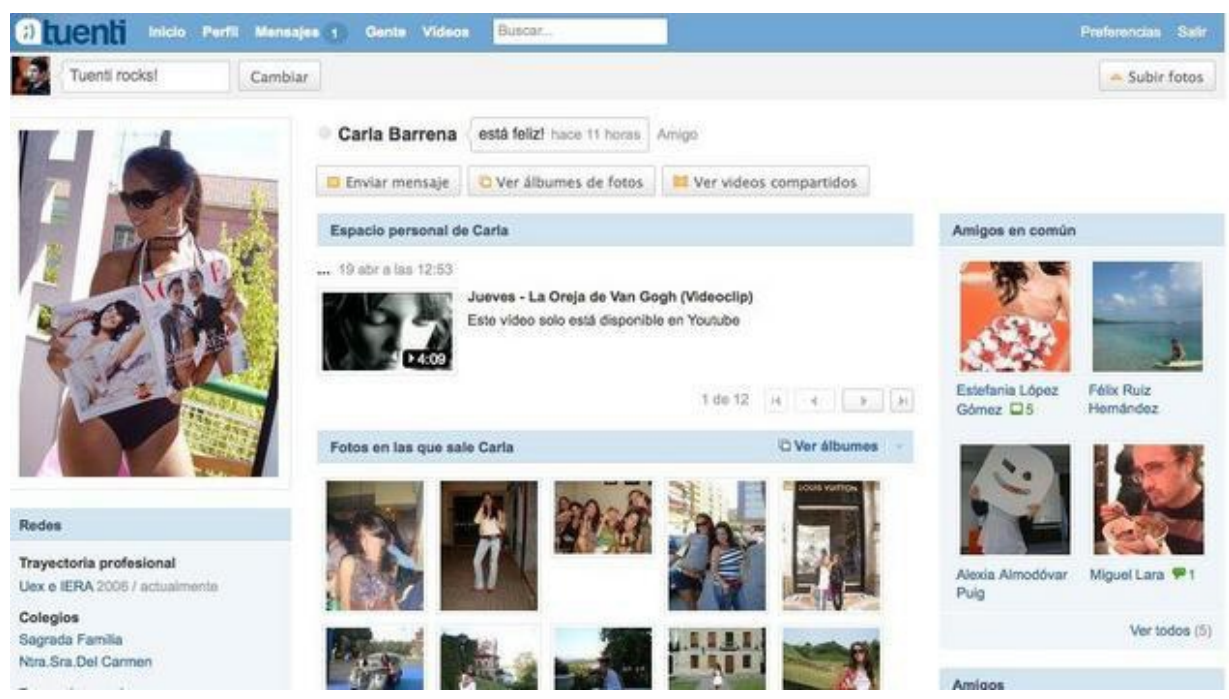

Imagen 6.20: Interfaz de Tuenti y perfil de una joven en esta extinta red social que desapareció en 2016. 


\subsubsection{Plataformas y perfiles para relaciones y encuentros.}

Existen multidud de redes sociales y plataformas para navegadores web y smartphones cuya finalidad es la de unir a la gente en la vida real a partir de un contacto en el ciberespacio basado en la consulta de la imagen fotográfica en el perfil ajeno y en una descripción personal. Algunas de estas redes, además, contienen algoritmos de emparejamiento determinados por intereses registrados, afinidades o geolocalización. Estas redes han sido muy populares desde el desarrollo del ciberespacio en la red y de la Web 2.0.

Dentro de su interminable lista, podemos destacar redes como Meetic (Imagen 6.21) o eDarling especializadas en la búsqueda de pareja estable, Badoo (Imagen 6.22) o Tinder (Imagen 6.23) para encuentros más esporádicos, o meras páginas prácticamente obsoletas como "Sexy o no" o "Vota mi cuerpo" (Imagen $6.24)^{190}$, que, si bien cumplían la misma finalidad que las anteriores, se basaban en rankings de votación en torno a autofotos relativamente eróticas proporcionadas por sus generalmente jóvenes usuarios.

Sería lógico, por lo tanto, señalar que este tipo de plataformas han sido un buen caldo de cultivo para los selfies y autofotos eróticas de cuarto de baño con las que los usuarios han cosificado su yo como medio para encontrar dichos encuentros carnales, aprovechando, dicho sea de paso, esa fantástica propiedad del selfie que, como vimos en el capítulo 4, convierte al habilidoso autorretratista en un ser más hermoso de lo que es en la realidad.

190 Direcciones URL por orden de aparición: <https://www.meetic.es/>; <https://www.edarling.es/ eDarling >; <https://badoo.com/es/signin/>; <https://tinder.com/?lang=es-ES >; <http:// www.sexyono.com/>; <http://www.votamicuerpo.com/> [Fecha de consulta: 29 de julio de 2017]. 


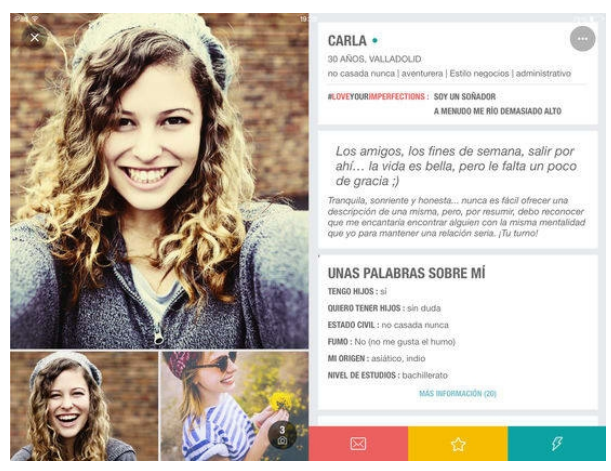

Imagen 6.21: Simulación por parte de la empresa Meetic de uno de sus perfiles privados.

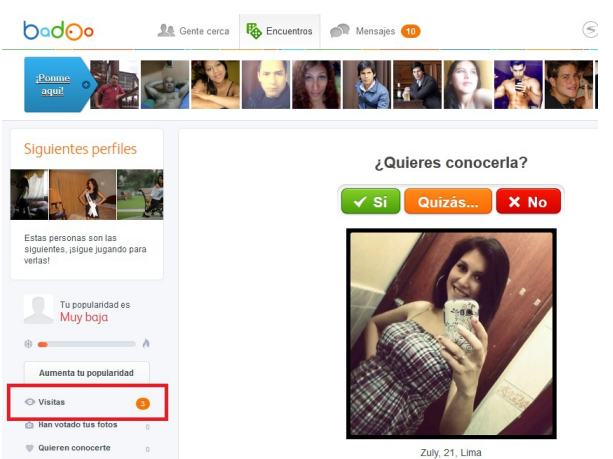

Imagen 6.22: Perfil de una adolescente en la red social de contactos Badoo.

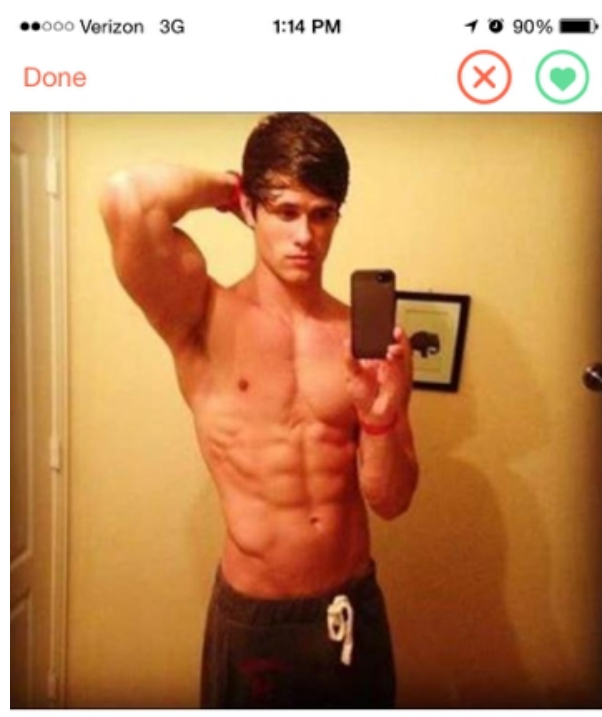

Tony, 23
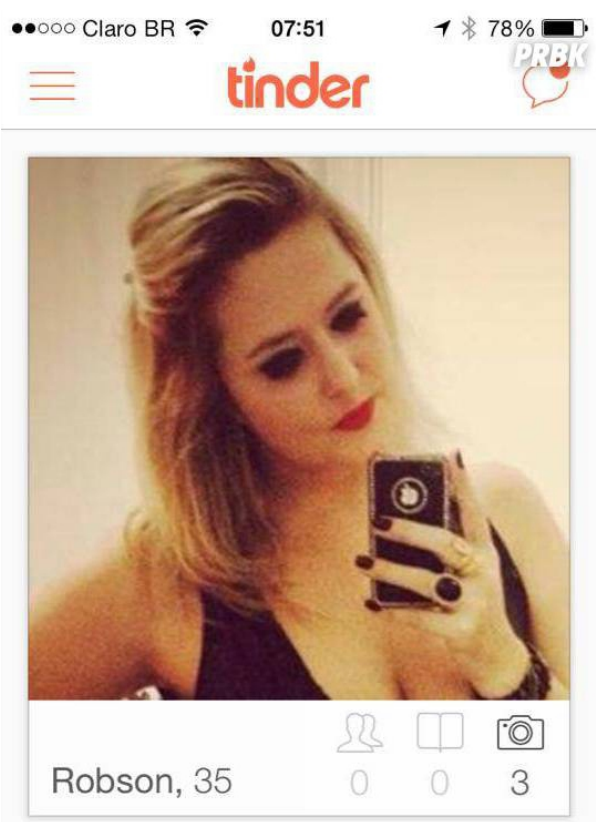

About Tony

Looking for some naughty snapchat fun with sexy girls so snap me ladies : smokeout007 당

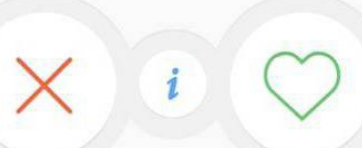

(C) Reproduıgăo

Imagen 6.23: Autorretratos de espejo de un chico y una chica como fotografías de perfil en Tinder a modo de reclamo. 


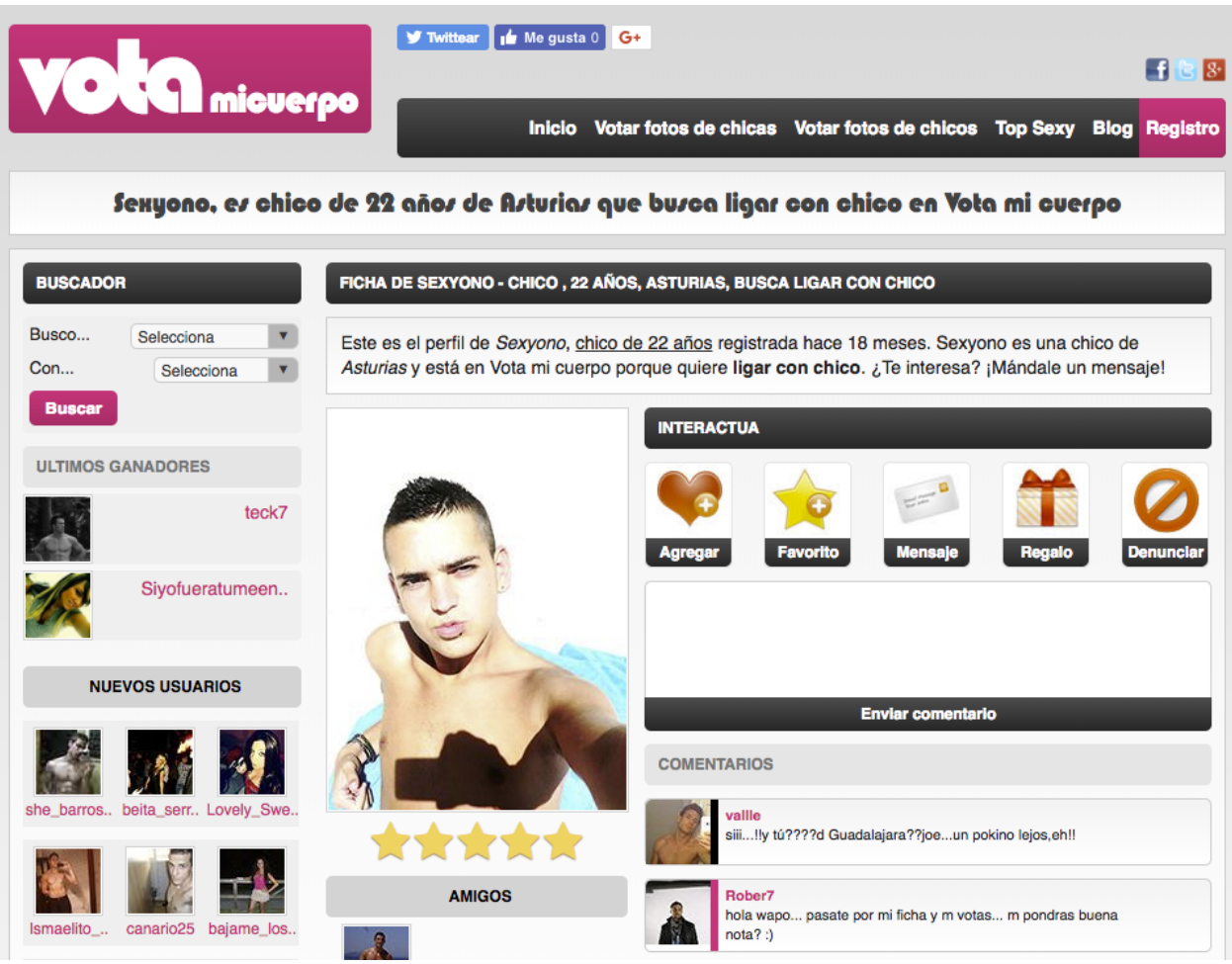

Imagen 6.24: Perfil de un chico en "Vota mi cuerpo". Puede apreciarse que la foto de perfil es un selfie, además, también se corrobora este hecho por la sombra proyectada por el smartphone.

\subsubsection{Twitter.}

Twitter ha recuperado el espíritu de los blogs a través del microblogging ${ }^{191}$. Esta red social fue lanzada por Jack Dorsey en 2006 y es

191 RUIZ, Sonia, op. cit., pág. 255. 
propiedad de la empresa Twitter Inc., que tiene su sede central en San Francisco, California $^{192}$. La diferencia con sus predecesoras es que cada entrada, o tuit, solo puede contener 140 caracteres $^{193}$ y una imagen. Simplifica así el mensaje y su rápida difusión, considerándose como el telégrafo de la Web 2.0 ${ }^{194}$. Twitter comenzó siendo una herramienta basada en la palabra, luego se pasó a la imagen. Es muy popular y se trata de una red tan integrada en la sociedad como la propia prensa o la televisión, de hecho ya existen normas tipo de citación de tuits para estudios académicos.

Esta realidad social se ha convertido en una herramienta muy usada en los medios de comunicación y en un rápido gestor de acontecimientos, a través de la conciencia colectiva, algo que podemos constatar, por ejemplo, en el 15M o en la Primavera árabe, las más recientes revoluciones culturales ocurridas a principios de esta década. Se constata Twitter así como la más informativa de las redes sociales ${ }^{195}$ y su presencia no debe de ser despreciada, ya que para comprender las transformaciones asociadas al ascenso de las sociedades modernas, deberíamos conceder un papel central al desarrollo e impacto de los nuevos medios de comunicación ${ }^{196}$.

Twitter es una red social todavía muy activa y que mantiene viva la blogosfera:

\footnotetext{
“Claro que a veces los «yoes», protagonistas de la blogosfera - multitud de vocesparecen ser subsumidos por una estrategia fatal: «todo el mundo escribe». Y como si de un organismo se tratara, la blogosfera evoluciona, obligada a superarse a sí misma,
}

\footnotetext{
192 MONSORIU, Mar, op. cit., pág. 139.

193 En 2017 este límite se amplió a 280 caracteres.

194 FAERMAN, Juan, op. cit., pág. 56.

195 MESENES, María, op. cit., pág. 19.

196 THOMPSON, John B., op. cit., pág. 11.
} 
exigiéndose más y más novedad, más chispa, un sentido, fidelidad, y reclamando que entre «todo el mundo escribe» alguien todavía lea" ${ }^{197}$.

Twitter sirve como soporte también para los selfshooters, autorretratistas y difusores del selfie (ya hemos visto en el capítulo 5 el ejemplo de la famosa Leda Bunnie). Sin embargo, algo que ha conseguido Twitter para unificar también sus contenidos fotográficos es el desarrollo de los hashtags, palabras clave asociadas a sus palabras e imágenes (y que las ponen en común), vinculándolas entre sí a través de una red compleja que las visibiliza y une. Ya hemos hablado de los hashtags anteriormente en este capítulo. Pues bien, Twitter fue la primera red social en popularizarlos y generar ese carácter rizomático que poseen muchas de estas plataformas ${ }^{198}$. Solo hay que darse un paseo por Twitter entre hashtags como \#selfshot, \#selfie o \#mirrorpic para obtener un buen registro y descripción (visual y escrito), del objeto de estudio que abordamos en esta investigación.

\subsubsection{Instagram y su importancia postfotográfica.}

Instagram es una de las redes sociales más contemporánea y novedosa que podemos encontrar hoy en día. Aunque reúne y unifica principios básicos de redes sociales como las ya vistas Facebook, Twitter, Flickr o Fotolog (considerándose una fusión simplificada y minimalista de todas ellas), lo característico de Instagram es que se trata de una red social desvinculada del

197 ZAFRA, Remedios, op. cit., pág. 82.

198 Precisamente Twitter hace gala de ser una representación muy práctica del concepto de rizoma de Deleuze y Guattari: "Cualquier punto del rizoma puede ser conectado con cualquier otro, y debe serlo. Eso no sucede en el árbol ni en la raíz, que siempre fijan un punto, un orden. [...] En un rizoma [...] cada rasgo no remite necesariamente a un rasgo lingüístico: eslabones semióticos de cualquier naturaleza se conectan en él con formas de codificación muy diversas, eslabones biológicos, políticos, económicos, etc., poniendo en juego no solo regímenes de signos distintos, sino también estatutos de estados de cosas”. DELEUZE, Gilles y GUATTARI, Félix, Rizoma (Introducción), Valencia, Pre-Textos, 2005, pág. 17. 
soporte web. Es una plataforma exclusiva de los smartphones y no se puede gestionar desde otro tipo de dispositivo, por lo tanto, deviene una prolongación de la máquina fotográfica contemporánea. A su vez, es la vía de salida y publicación de la imagen digital desde su máquina hacedora. Fue lanzada en 2010 en el Apple App Store y, más adelante, en 2012 se popularizó también en dispositivos Android, consiguiendo más de un millón de descargas en menos de 24 horas $^{199}$.

Instagram ha sido fundamental para el desarrollo de la fotografía actual (o de la postfotografía). Ha cambiado las costumbres y los usos que las personas hacen de las imágenes, generado nuevas formas y transformándose en uno de los sumideros de la cultura visual fotográfica contemporánea. Sobre todo esta aplicación para smartphones ha emancipado a la gente joven (y no tan joven) como fotógrafos activos publicadores. Para muchos, Instagram supone la muerte de la fotografía. Nosotros pensamos, sin embargo, todo lo contrario. De hecho algunos catalogan Instagram como herramienta fundamental para entender parte de la fotografía del siglo XXI:

"Sin duda se trata del fenómeno social relacionado con la imagen más importante de la Historia. Supone la democratización definitiva de algo que ya había democratizado la obtención y posesión de imágenes durante el siglo XX: la fotografía”"200.

Esta aplicación gratuita ${ }^{201}$ unifica, por tanto, dispositivo de captura y dispositivo de publicación en un único objeto, cambiando nuestra manera de enfrentarnos al mundo desde la imagen fotográfica. Es nuestro diario, memoria, ojos, voz, plaza, ventana y agujero. Por otro lado, esta popular aplicación a nivel mundial, no solo actúa como una red social basada en la imagen: por sí misma

199 BORERO, Alejandra y LONDOÑO, Suanny, op. cit., pág. 126.

200 CASTILLO, José M., "La composición en los tiempos del selfie", en Espéculo. Revista de estudios literarios, $\mathrm{n}^{\mathrm{O}} 54$ (Ejemplar dedicado a: Narrar en la era digital), 2015, pág. 131.

201 Gratuita hasta cierto punto, ya que, como se sabe en el mundo de la publicidad, si por algo no estás pagando, tú no eres el cliente: eres el producto. 
define un estilo de vida en el que todos compartimos lo que fotografiamos y en el que nos conectamos socialmente desde nuestro dispositivo de bolsillo hasta la distancia gracias a esas imágenes fotográficas.

Respecto a su estrategia de comunicación "se basa en subir fotos de las experiencias vividas por una persona, teniendo la posibilidad de etiquetar, comentar, compartir en redes sociales, explorar fotografías de quienes se siguen”. No obstante, "el elemento fundamental de Instagram es el «corazón», con el que se puede expresar la popularidad del usuario" ${ }^{202}$.

Hemos hablado de que Instagram unifica las estrategias visuales y organizativas de las redes sociales predecesoras, siendo uno de sus aciertos el minimalismo: nada sobra en esta plataforma. Un usuario, unos contactos a los que sigue y que puede ver en su home, otros contactos que le siguen y que a su vez le ven, una fotografía, un comentario ${ }^{203}$, un like, una posibilidad de incluir hashtags y un orden cronológico en el que se ordenan dichas fotografías ${ }^{204} \ldots$ Nada sobra y nada falta.

Además, y de manera opcional, Instagram ha permitido intervenir la imagen fotográfica realizada con el smartphone que la aloja por medio de filtros

202 CASTILLO, José M., op. cit., pág. 131.

203 Comentario que podría reforzar la imagen como un texto que amplía su propia dimensión, así como ha ocurrido en otras épocas de la imagen: "Un segundo tipo de expectativa de verdad atribuido a la imagen no depende ya, en efecto, ni de su supuesta relación con lo real ni de su contenido visual, sino del comentario verbal que lo acompaña, directa o indirectamente". JOLY, Martine, La interpretación de la imagen entre memoria, estereotipo y seducción, Barcelona, Paidós, 2003, pág. 134.

204 Aunque, pese a lo democrático y neutro de este orden de visualidad, hecho que bajo nuestro punto de vista era todo un acierto, esta red social se renovó en 2017 interviniendo esta imparcialidad con algoritmos que, como los usados en Facebook, pasarían a intervenir y manipular los contenidos que el usuario vería a partir de ahora: "Intagram, una de las redes sociales del momento, se reinventa para no morir. Así esta aplicación de fotografías ha cambiado el algoritmo que mostraba de forma cronológica las imágenes para dar prioridad a las que más likes acumulen y las de los perfiles que más visitemos. Estos cambios se producen después de las múltiples quejas que la compañía ha recibido por la imposibilidad de estar conectados permanentemente. De esta manera, desde Instagram pretenden que «el 30\% que veas sea el mejor 30\% posible»". VV. AA., "Instagram deja de mostrar las imágenes en orden cronológico", 2016, disponible en: <http://www.lasprovincias.es/tecnologia/201606/o7/ instagram-deja-mostrar-imagenes-20160607205410.html > [Fecha de consulta: 20 de julio de 2017]. 
que la retocan ${ }^{205} \mathrm{y}$ le dan un aspecto vintage ${ }^{206}$ en un claro intento de recuperar cierta "retroestética" ${ }^{207}$. Si bien con el paso del tiempo esta propiedad de la aplicación ha pasado relativamente de moda y el usuario prefiere subir imágenes sin filtro, esta circunstancia fue uno de sus principales atractivos durante sus primeros años de juventud.

Aunque Instagram es una red utilizada por personas de muchas edades y también por empresas, principalmente es una herramienta manejada por parte de los adolescentes. De hecho, ha sido un territorio destinado a albergar a muchos de los jóvenes migrantes de otras redes sociales ${ }^{208}$.

Para estos jóvenes Instagram no solo funciona como un agujero para el voyeur desde donde observar la vida pública de sus contactos, sino también como un espacio de influencia del que contagiarse a nivel de prácticas y costumbres. Sobre todo para ellos es una carta de presentación ${ }^{209}$ en la que desarrollar el yo que muestran al mundo y donde construir su identidad virtual. También en ocasiones la propia interfaz de Instagram invitará a realizar cierta secuencialidad fotográfica ${ }^{210}$ en el diario personal que supone pertenecer a esta

205 Algo inevitablemente ligado a la fotografía digital. SÁNCHEZ-VIGIL, Juan Miguel, El documento fotográfico. Historia, usos, aplicaciones, Gijón, Trea, 2006, pág. 25.

206 De hecho, las fotografías (generalmente con la proporción de 2:3 o de 3:4) captadas con el smarphone, acabarán en Instagram siendo cuadradas y con los bordes redondeados por la intervención de la aplicación, en un homenaje a las cámaras Kodak Instamatic y Polaroid o simplemente como signo de diferenciación. CASTILLO, José M., op. cit., pág. 131.

207 GIRALDO, Diana y RUEDA, Rocío, "La imagen de perfil en Facebook. Identidad y representación en esta red social”, en Folios. Revista de la facultad de humanidades, nº 43, 2016, pág. 131.

208 MARCELINO, Georgina V., op. cit., pág. 68.

209 "Si antes la imagen de la estrella se tenía cerca a modo de carte de visite, hoy el contacto es mediático y multiplicado por los personal devices, móviles y similares, que actúan como multiplicadores de imágenes a través de las redes sociales". MATTEI, María M., "El divismo en tiempos de \#Instagram", en CIC. Cuadernos de información y comunicación, $\mathrm{n}^{\circ} 20$ (Ejemplar dedicado a: Ídolos e iconos en la semiosfera mediática), 2015, pág. 96.

210 "Por eso, la secuencialidad [...] aparece como un método básico para instalar a la fotografía en el curso del tiempo, a través de una sucesión. Se pasa así de la cronología implícita y significante de la foto individual a la construcción de una temporalidad a partir de la sucesión de imágenes instantáneas: una suma de tiempos cero que produce -paradoja- un flujo en desarrollo". ZUNZUNEGUI, Santos, Pensar la imagen, Madrid, Cátedra, 2010, pág. 136. 
plataforma (Imagen 6.25), donde la vida estaría contada a través de postales; pequeños momentos cool puestos en un marco cuadrado: "la atomización del glamour de nuestras vidas" ${ }^{211}$.
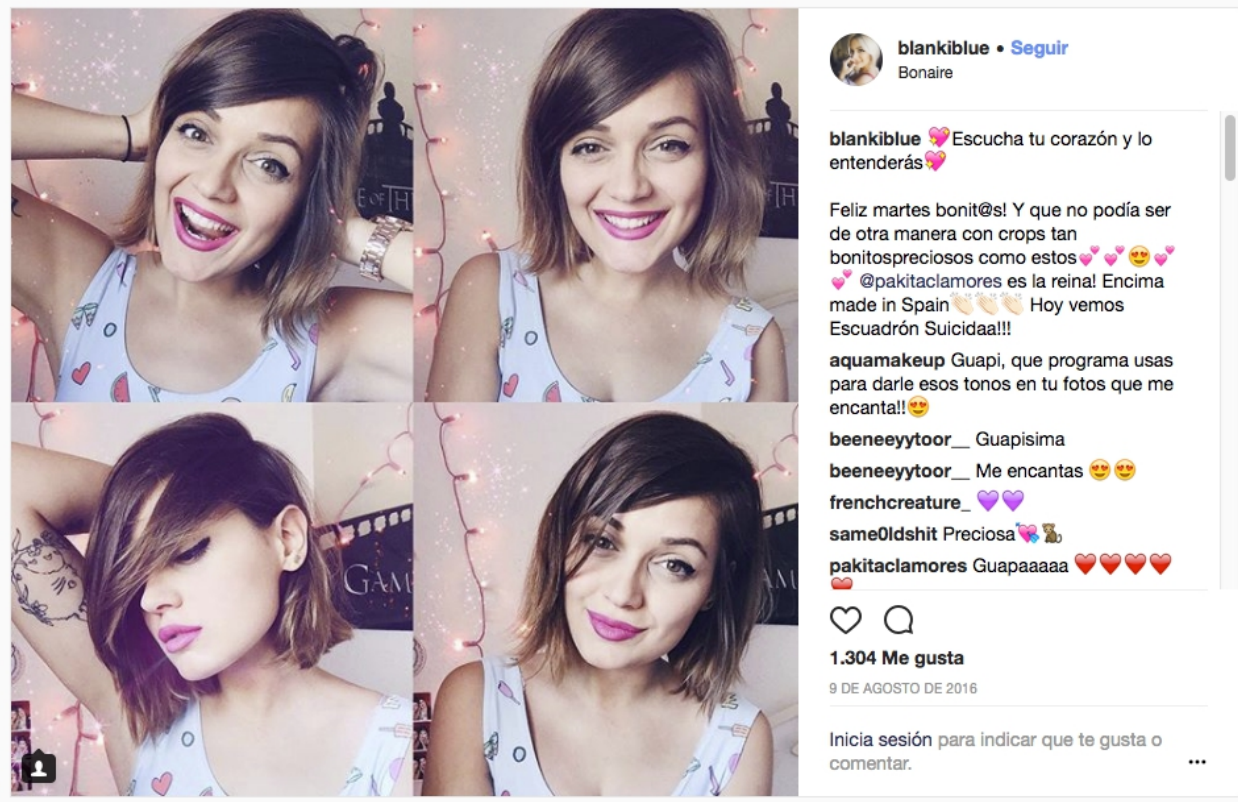

Imagen 6.25: Secuencia fotográfica en una publicación de Instagram de la usuaria Blanki Blue realizada en agosto de 2016. Se puede visualizar en: <https:// www.instagram.com/p/BI4yFX2DgTt/?taken-by=blankiblue $>$ [Fecha de consulta: 23 de julio de 2017]. También este tipo de uniones entre texto y fotografía (relato e imagen), al que precede una espera y posterior respuesta, nos recuerda a unas palabras de Berger: "Poner en forma de palabras es esperar que esas palabras serán oídas, y los hechos que describen, juzgados". BERGER, John, Y nuestros rostros, mi vida, breves como fotos, Madrid, Hermann Blume, 1986, pág. 103. 
Instagram ya planteaba en 2013 un nuevo horizonte para el self shot (Imagen 6.26) y ha sido, a nuestro parecer, la herramienta más fundamental tanto para el desarrollo formal más actual, como para la difusión de lo que hoy conocemos como selfie (Imagen 6.27). Aunque a mediados de 2013 había 90 millones de fotos en Instagram etiquetadas como $\# \mathrm{me}^{212}$, ya hemos visto en el punto 6.3.1.1 cómo la etiqueta con almohadilla ganadora ha sido \#selfie, ascendiendo el número de autorretratos publicados hasta 2018 a más de trescientos millones, y eso sin tener en cuenta el resto de redes sociales y espacios donde se publican o distribuyen.

En función de lo apuntado, podemos aventurarnos a pensar que esta década ha sido la década del selfie, practicado primero por adolescentes y luego por gente de todas las edades. Gracias a esta institucionalización de la forma y uso del aparato, y gracias también a los nuevos paradigmas compositivos basados en la visión reflejada que ofrece el smartphone, hechos a los que hay que sumar lo que supone llevar una herramienta de publicación en el bolsillo (convirtiendo ambas acciones, fotografía y publicación, en la misma cosa), gracias a todo ello, repetimos, nos encontramos con ejemplos evidentes de los cambios que está experimentando formal y culturalmente el fenómeno que estamos analizando.

Instagram nos plantea un territorio vasto y novedoso donde el self shot, los autorretratos digitales publicados en red, mayoritariamente selfies, podrán seguir desarrollándose en los años venideros o, por el contrario, quedar estancados en las formas que hoy plantean.

212 GALÁN, Mercè, "El posicionamiento subjetivo del \#selfie”, en Asparkia. Investigació feminista, nº 27, 2016, pág. 32. 

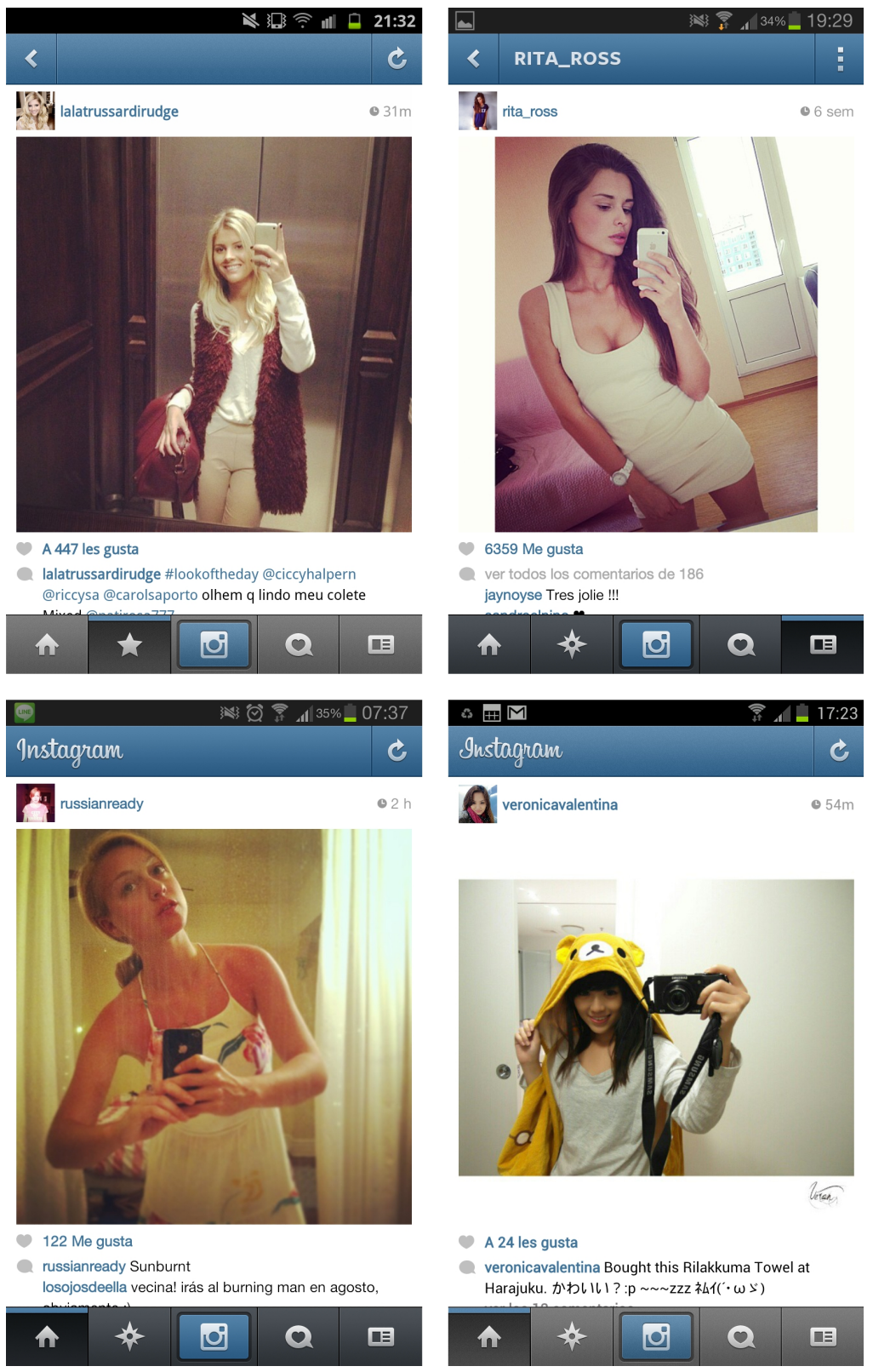

Imagen 6.26: Cuatro autofotos de tipo mirrorpic publicadas en 2012 (momento en el que ya habíamos comenzado a investigar sobre estos temas) en Instagram por sus usuarias. Las imágenes muestran un abanico de diferentes intenciones y métodos vinculados a este procedimiento por entonces ya común. 

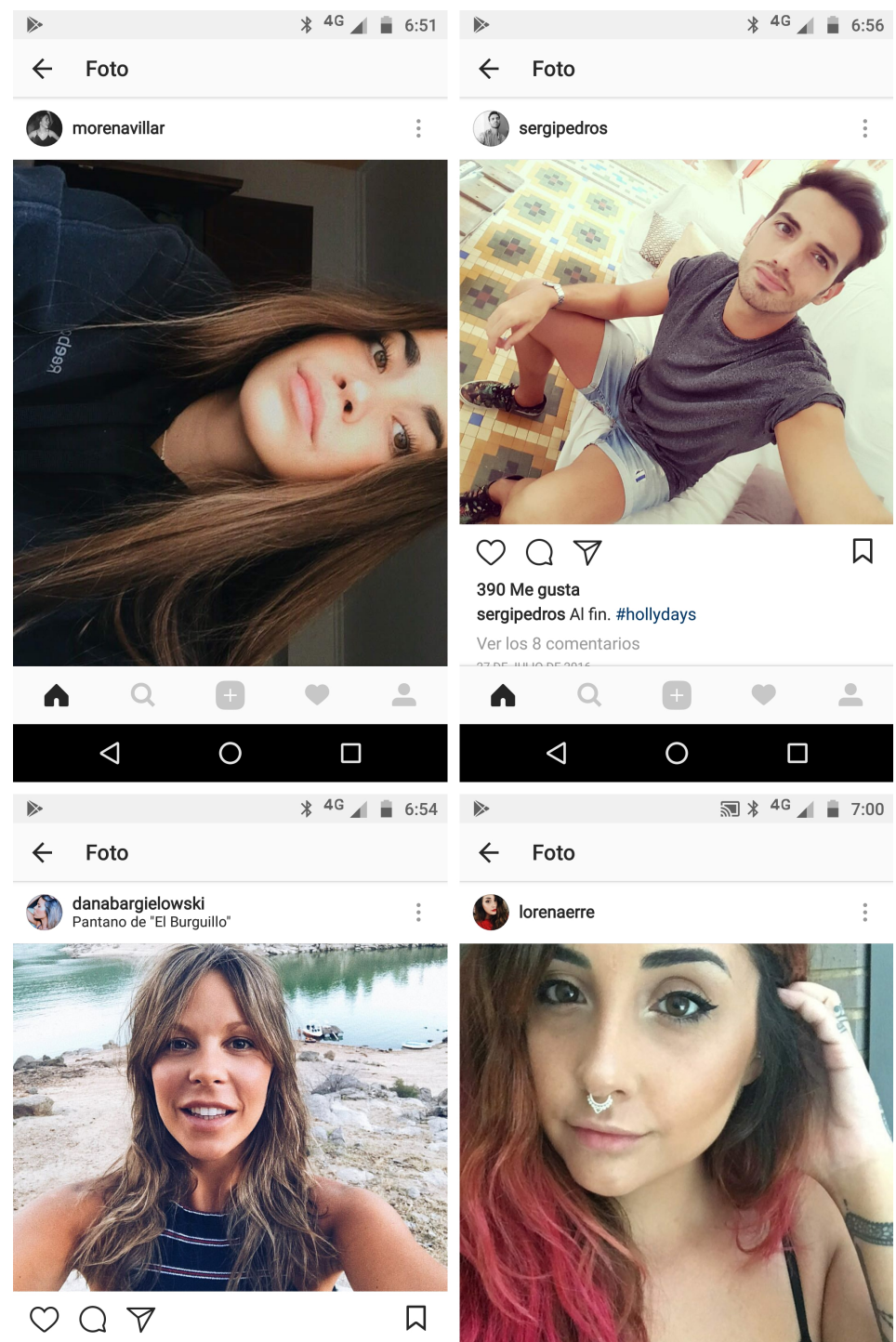

Le gusta a sherezadesv, ainagimeno y 87 personas más

danabargielowski Atardecer en el pantano. Los hombres recogiendo el chiringuito \#elburguillo \#nantann \#cundave \#anndvihes \#cuncet

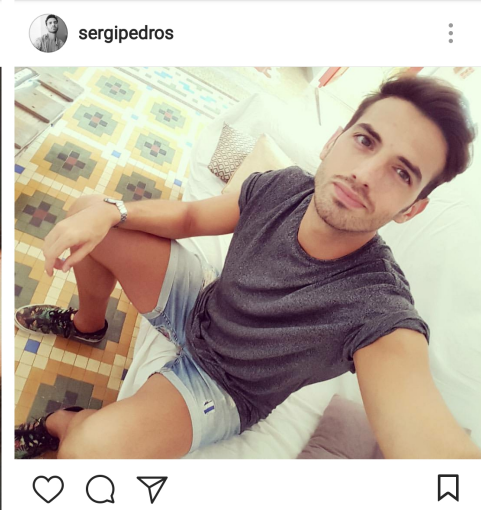

390 Me gusta

sergipedros Al fin. \#hollydays

Ver los 8 comentarios

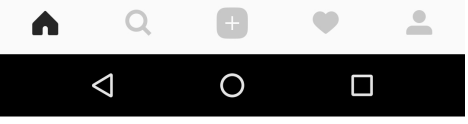

$\nabla$

目 $* 4 \mathrm{G}$ - $7: 00$

$\leftarrow$ Foto

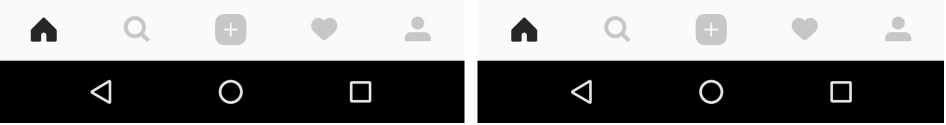

Imagen 6.27: Cuatro autofotos de tipo selfie publicadas seis años después (2018) en Instagram. Además de las diferencias en la interfaz de la aplicación, hemos observado también durante estos años un cambio de tendencia hacia un mayor uso de la lente delantera del smartphone. 


\subsubsection{Otros soportes donde habita el selfie: las aplicaciones de mensajería instantánea WhatsApp, SnapChat y Messenger.}

Ya hemos comentado con anterioridad que muchos de los autorretratos digitales, sobre todo los más íntimos, no se dirigen a las redes sociales ni a los espacios expositivos de Internet. Suelen enviarse, compartirse o almacenarse. La filtración de estos archivos digitales en las redes, su publicación indebida y su hurto hace que se coleccionen y se muestren de manera recopilada en algunos sitios privados de Internet, como foros y páginas web eróticas y que se utilicen como imagen en publicidades engañosas (como ya vimos en el capítulo 3 ).

Al margen de que, cuando una imagen digital que abandona su dispositivo hacedor saltando a una red conectada a Internet deja de ser propiedad exclusiva de su autora o autor, dado que estos pierden su control sobre las derivas que sus autorretratos puedan alcanzar, el propio uso que terceras personas otorgan a estas fotografías podría vulnerar ciertos derechos debido a malas prácticas, sobre todo porque muchos de los autorretratos que fluyen por la red y se almacenan en servidores son representaciones de menores de edad, tal como ya hemos puesto de relieve. $\mathrm{Y}$ pese a que en ocasiones resulta difícil determinar la edad concreta de un autorretratista, debemos de estar en alerta permanente y combatir con decisión esta problemática que las nuevas tecnologías sufren ${ }^{213}$, especialmente si tenemos en cuenta el hecho de que no se han hallado soluciones al respecto.

${ }_{213} \mathrm{Y}$ es que, de momento, las máquinas capturadoras de fotografías digitales y los softwares que las rodean son incapaces de determinar la edad exacta de la persona a la que registran. Legalmente, según la Convención de Naciones Unidas sobre los Derechos del Niño, en su artículo 1, niño es cualquier persona menor de dieciocho años de edad. SILVESTRE, María, La imagen de la preadolescente y su representación en el arte, Valencia, Universitat Politècnica de València, 2007, pág. 342. 
En relación a este tipo de aplicaciones de mensajería instantánea por las que fluye (quizá hoy en mayor medida) el selfie, y al margen de los chats que las precedieron, podemos citar el Windows Messenger (Imagen 6.28) como una de las aplicaciones pioneras de la mensajería privada entre personas conectadas de ordenador a ordenador que, además, permitía mandar fotografías o autorretratos, generalmente producidos con las webcams de dichos ordenadores o con cámaras compactas de la época. Desde esta perspectiva, Windows Messenger fue especialmente popular, sobre todo entre los adolescentes (Imagen 6.29) y los universitarios de la primera mitad de la década pasada (1999 a 2005), momento en el que descendería su uso y empezaría a sufrir transformaciones hasta convertirse en su aplicación heredera de videollamadas Skype. Sin embargo, su actitud también ha sido heredada por el Messenger de Facebook. Al respecto, es muy probable que los primeros self shots eróticos se distribuyeran por el ciberespacio a través del correo electrónico y de Windows Messenger.

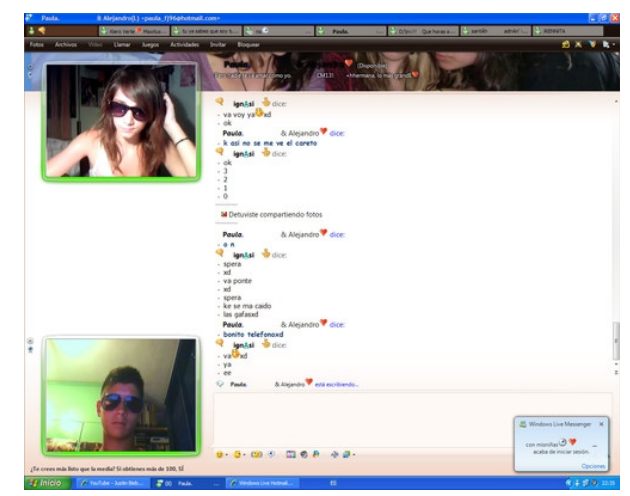

Imagen 6.28: Interfaz de Windows Messenger.

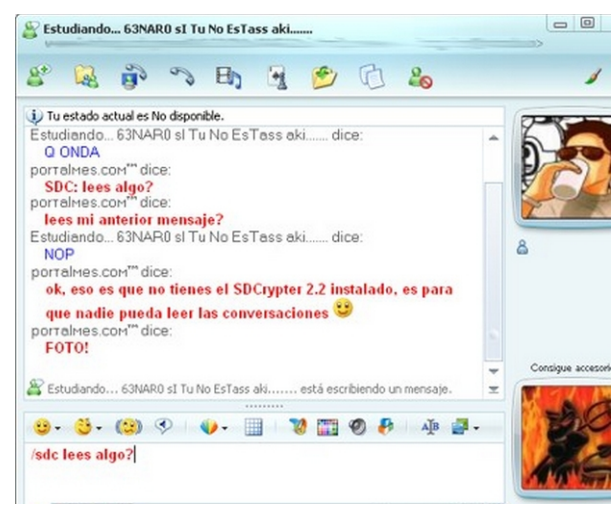

Imagen 6.29: Conversación entre dos usuarios adolescentes en un Windows Messenger algo más primitivo que el del ejemplo anterior. 
Con todo, la verdadera revolución en el campo de las aplicaciones de la mensajería instantánea y del envío de fotografías mediante estas se producirá a comienzos de nuestra década con la llegada de los smartphones con cámara que, a su vez, disponían de aplicaciones gratuitas (o muy baratas) de mensajería instantánea con las que estar siempre conectados con otras personas, desde cualquier parte. A través de estos dispositivos se podía también mandar fotografias que, a su vez, podían ser realizadas con la cámara trasera o delantera ${ }^{214}$ de ese mismo aparato.

Pese a la gran cantidad de estas aplicaciones, la más extendida para este cometido en Europa y Estados Unidos fue (y todavía es) la denominada como WhatsApp, siendo su principal virtud (o maldición) el hecho de que casi cualquier poseedor de un smartphone tiene presencia en WhatsApp, por lo que podemos comunicarnos o enviar contenido de manera instantánea a casi cualquier persona de la que tengamos (o podamos obtener) su número de teléfono o contacto.

WhatsApp se ha perfilado como una de las principales redes digitales del eje de socialización online entre los jóvenes, constituyendo "un espacio de experiencias compartidas, donde se inician, se mantienen y/o se rompen amistades o relaciones" ${ }^{215}$. No obstante, esta aplicación ha anidado también entre gente de todas las edades, siendo la principal herramienta de comunicación contemporánea entre los adultos, superando en uso a las llamadas telefónicas ${ }^{216}$. En este sentido, y pese a la hegemonía de Facebook durante los pasados años,

214 La cámara creada de manera casi exclusiva para hacerse selfies.

215 CARO, Lucía, "WhatsApp y la búsqueda de control de la situación informacional por parte de los jóvenes", en Sphera publica. Revista de ciencias sociales y de la comunicación, vol. 1-2, $\mathrm{n}^{\mathrm{0}}{ }^{15}$ (Ejemplar dedicado a: Tensiones y desafíos contemporáneos de la comunicación), 2015, pág. 81.

216 VV. AA., "WhatsApp supera en uso a todas las llamadas de móvil y de fijo en España", 2017, disponible en: <hhttp://www.eleconomista.es/telecomunicaciones-tecnologia/noticias/8403828/o6/17/ WhatsApp-supera-en-uso-a-todas-las-llamadas-de-movil-y-de-fijo-en-Espana.htmll> [Fecha de consulta: 2 de enero de 2018]. 
recientemente se ha detectado cierto cansancio de los usuarios jóvenes hacia esta red social, hecho que ha provocado la consolidación de servicios como WhatsApp.

\begin{abstract}
"El modo en que cada plataforma crea diferentes situaciones informacionales explicaría la percepción de Facebook como espacio de escenario, mientras que WhatsApp, donde predomina la interfaz y diseño de interacción del chat, se consideraría más controlable y privado (backstage)”217.
\end{abstract}

Tanto las propiedades y capacidades de la plataforma WhatsApp en cuanto a comunicar y compartir contenido, como el dispositivo de producción fotográfica en el que se aloja, parecen invitar y animar a quienes hacen uso de esta red, aparentemente privada y discreta, a que compartan autorretratos íntimos y/o de caracter erótico.

Podríamos presentarla, por ello, como una de las mas contemporáneas herramientas de difusión (por voluntad o no de los que inicien la cadena) de las autofotos más intimistas (Imagen 6.30), y también de las más generalistas. Sin embargo, los desarrolladores de aplicaciones de mensajería instantánea y envío de imágenes fotográficas capturadas mediante la lente del smartphone que las aloja aún darán un paso más en la evolución de este fenómeno cuando den a conocer SnapChat y este se vuelva todavía más popular entre el público adolescente.

217 CARO, Lucía, op. cit., pág. 76. 

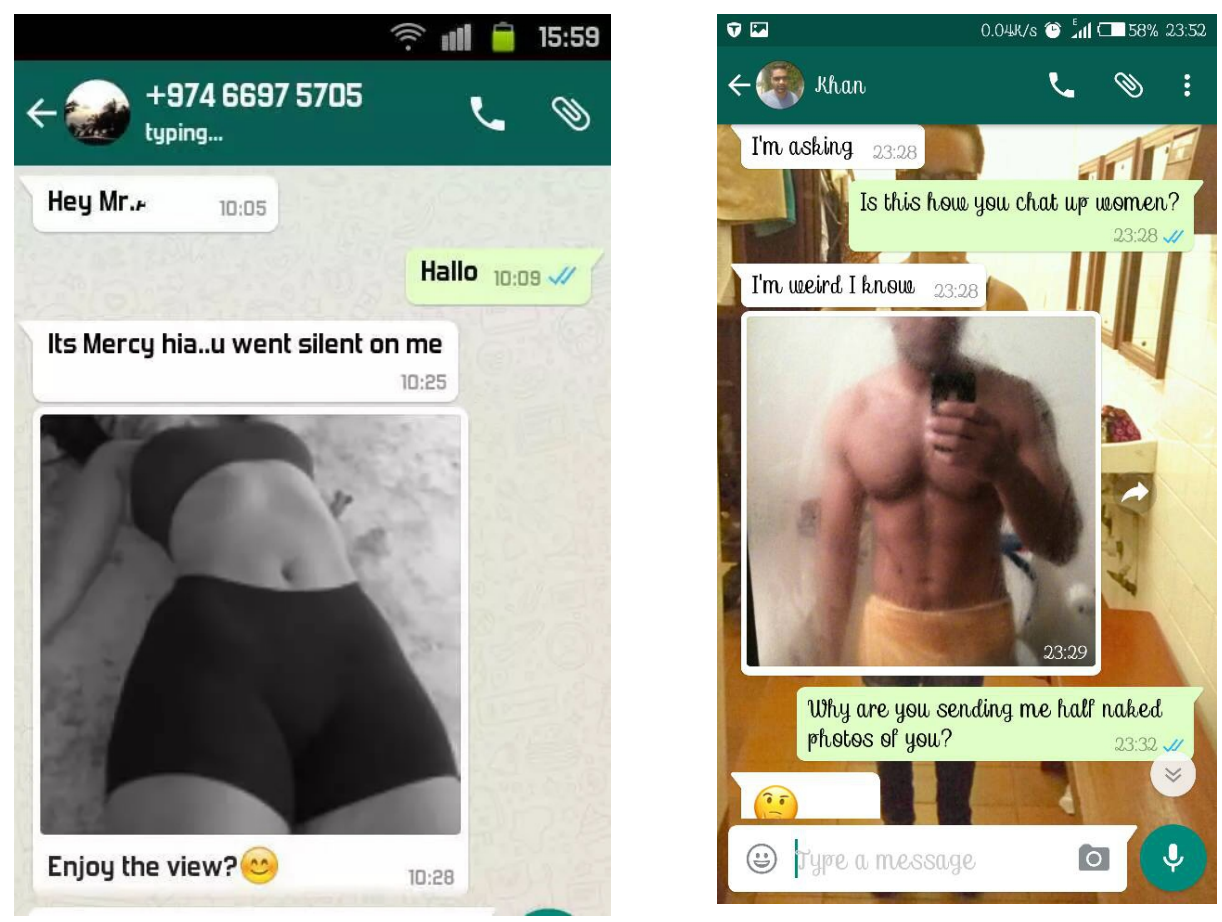

Imagen 6.30: Capturas de pantalla encontradas en Google Imágenes de conversaciones de WhatsApp de usuarios estadounidenses en las que se comparten autorretratos íntimos, el primero realizado mediante un palo-selfie y el segundo en un espejo de cuarto de baño.

SnapChat es otra aplicación de mensajería instantánea, muy similar a WhatsApp y de estructura y funcionalidad parecida, pero con sutiles diferencias que, sin embargo, la han convertido en una popular herramienta de la difusión del yo identitario por medio de la autorrepresentación fotográfica, desde el selfie más casual y divertido (Imagen 6.31) hasta el más erótico. Como vimos en el caso del SnapGate en el capítulo anterior, una pequeña parte del contenido compartido por SnapChat puede considerarse pornografía amateur privada entre dos partes. Y es que la principal diferencia que presenta SnapChat frente a las aplicaciones de mensajería que la han precedido es que las imágenes mandadas por el emisor, son destruidas a los pocos segundos de que el receptor las haya visto en su pantalla, imposibilitando (salvo alguna trampa) su guardado o 
registro. Este hecho justificaría un cierto grado más de desinhibición por parte de sus usuarios ${ }^{218}$.

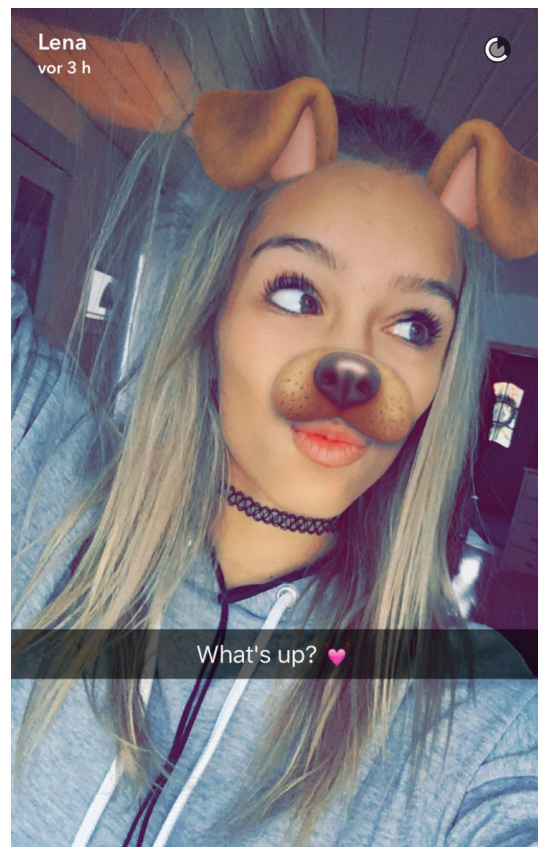

Imagen 6.31: Fotografía compartida a través de SnapChat por una joven que ha aprovechado uno de los filtros que, a modo de diversión, expanden la experiencia del autorretrato fotográfico.

218 Esta cuestión, y en relación a la gente joven, también debería preocuparnos socialmente dada la problemática que, como hemos visto, puede desencadenar el mal uso de estas nuevas herramientas. Es habitual encontrar guías para padres de SnapChat en la red que muestran consejos de uso por parte de las comunidades educativas y sanitarias: "SnapChat está teniendo éxito entre los jóvenes, ya que les sirve para intercambiar imágenes o vídeos de contenido sexual o pornográfico... Aunque la imagen desaparezca a los pocos segundos, siempre se pueden hacer capturas de pantalla. Si esto sucede, la aplicación te avisa. No obstante, para entonces el daño ya estará hecho. [...] Además de ser prudentes, ya que nunca se sabe quién nos puede dañar o viceversa, se recomienda restablecer la contraseña cada cierto tiempo y no tener la misma para todo. Por otra parte, la política de privacidad de la propia app recoge en sus términos y condiciones que tiene derecho a almacenar y compartir cualquier foto que se publique en la app. Por lo que las imágenes o vídeos no son realmente temporales. Es importante revisar los ajustes de privacidad, la lista de amigos y comprobar que cuenta con gente que se conoce de verdad para evitar a los delincuentes sexuales que se hacen pasar por otras personas. Además, existe un gran riesgo al conectar a SnapChat aplicaciones de terceros, ya que algunas podrían ser espías y recopilar fotos íntimas". VV. AA., "Todo lo que los padres deben conocer sobre SnapChat", 2016, disponible en: <http://www.elmundo.es/sapos-y-princesas/2016/o8/30/57c54ba522601ddb3c8b 45d3.html > [Fecha de consulta: 20 de julio de 2017]. 
Alejandra Borero y Suanny Londoño hacen un buen resumen de lo que supone esta aplicación para el público adolescente, así como su funcionamiento:

\begin{abstract}
"SnapChat es una de las apps más descargadas entre los jóvenes, funciona como un chat de imágenes a las que además de filtros, se les puede agregar mensajes cortos, dibujos, marcos, stickers y más. A través de SnapChat, se envían diariamente alrededor de 350 millones de fotos, lo que evidencia su gran acogida desde que surgió en el 2011, su diferencial la ha hecho muy popular, ya que retrata aspectos de la vida cotidiana que no son lo suficientemente relevantes para permanecer en la Web, al contrario de Instagram y Facebook, se realiza de forma rápida, efímera e imperfecta, sus fotos se «autodestruyen» al cabo de unos segundos (de uno a diez), haciendo que la permanencia de imágenes en el tiempo sea imposible a no ser que el usuario decida tomar una foto de pantalla para [...] guardarla” ${ }^{219}$.
\end{abstract}

Así pues, estas plataformas podrían estar propiciando un nuevo escenario en el que la cosificación sexual pase a ser un medio habitual en lugar de un fin puntual. A su vez, también ponen de relieve un hecho para el cual siempre ha estado preparado el ser humano y que solo necesita nuevas tecnologías para ser aplicado y/o llevado a un nuevo nivel. Al fin y al cabo, esta experiencia en torno a cuerpo y fotografía siempre ha respondido no solo a un mecanismo fisiológico, sino a un proceso ideológico. "Este es el motivo por el cual decir cómo el cuerpo ha sido y continúa siendo dicho desde la fotografía supone reconstruir el relato de una relación que pone en evidencia las tensiones y contradicciones que genera nuestra propia corporalidad" 220 .

Dos apuntes para finalizar esta segunda parte de capítulo dedicada a las redes sociales. Primero, tras haber analizado tantos escenarios de exhibición del

219 BORERO, Alejandra y LONDOÑO, Suanny, op. cit., pág. 127.

220 PÉREZ, David (Ed.), La certeza vulnerable. Cuerpo y fotografía en el siglo XXI, Barcelona, Gustavo Gili, 2004, pág. 13. 
selfie y resto de self shots dentro ciberespacio (redes sociales, aplicaciones, servicios...), podemos reconocer que la superficie física de este tipo de fotografías es la pantalla de cristal líquido, o bien del computador, o bien del smartphone. El autorretrato digital, en tanto que fotografía de la nueva era, es un objetopantalla. Rara vez llegará al soporte papel, quedando solo la mirada y desapareciendo el tacto del papel ${ }^{221}$ (que no de la pantalla):

\footnotetext{
"Asistimos a un proceso imparable de desmaterialización. La superficie de inscripción de la fotografía argéntica era el papel o material equivalente, y por eso ocupaba un lugar: trátese de un álbum, un cajón o un marco. En cambio, la superficie de inscripción de la fotografía digital es la pantalla: la impresión de la imagen sobre un soporte físico ya no es imprescindible para que la imagen exista, por lo tanto, la foto digital es una imagen sin lugar y sin origen, desterritorializada, no tiene lugar porque está en todas partes. Asimismo cambia el contrato visual”222.
}

De este modo, las pantallas de nuestros smartphones podrían ser entendidas como un objeto físico portador de no solo una, sino de múltiples fotografías: como una hiperfotografía. Aunque no se trate de papel, sino de cristal líquido, podemos entenderlas como objetos planos donde yace (o puede yacer) la imagen fotográfica, superando además la unicidad representada, ya que un smartphone puede cargar todo el inventario de cientos de millones de fotografías que hay en la red o las muchas que tengamos almacenadas en este, nuestro dispositivo. Debido a ello, se puede seguir considerando esta hiperfotografía retroiluminada, como el objeto talismánico, posesivo y sustituto de la realidad que suscitaban sus antepasadas imágenes sobre papel:

"La foto del amante escondida en la billetera de una mujer casada, el cartel fotográfico de una estrella de rock fijado sobre la cama de una adolescente, el retrato de propaganda del político prendido a la solapa del votante, las instantáneas de los hijos

221 SÁNCHEZ-VIGIL, Juan Miguel, op. cit., pág. 86.

222 FONTCUBERTA, Joan, op. cit., págs. 12-13. 
del taxista en la visera: todos los usos talismánicos de las fotografías expresan una actitud sentimental e implícitamente mágica; son tentativas de alcanzar o apropiarse de otra realidad" ${ }^{223}$.

De esta manera, hoy en día no es un hecho en absoluto aislado encontrar la imagen de la persona amada, congelada como imagen fotográfica, detrás de los iconos de nuestros teléfonos inteligentes (Imagen 6.32).

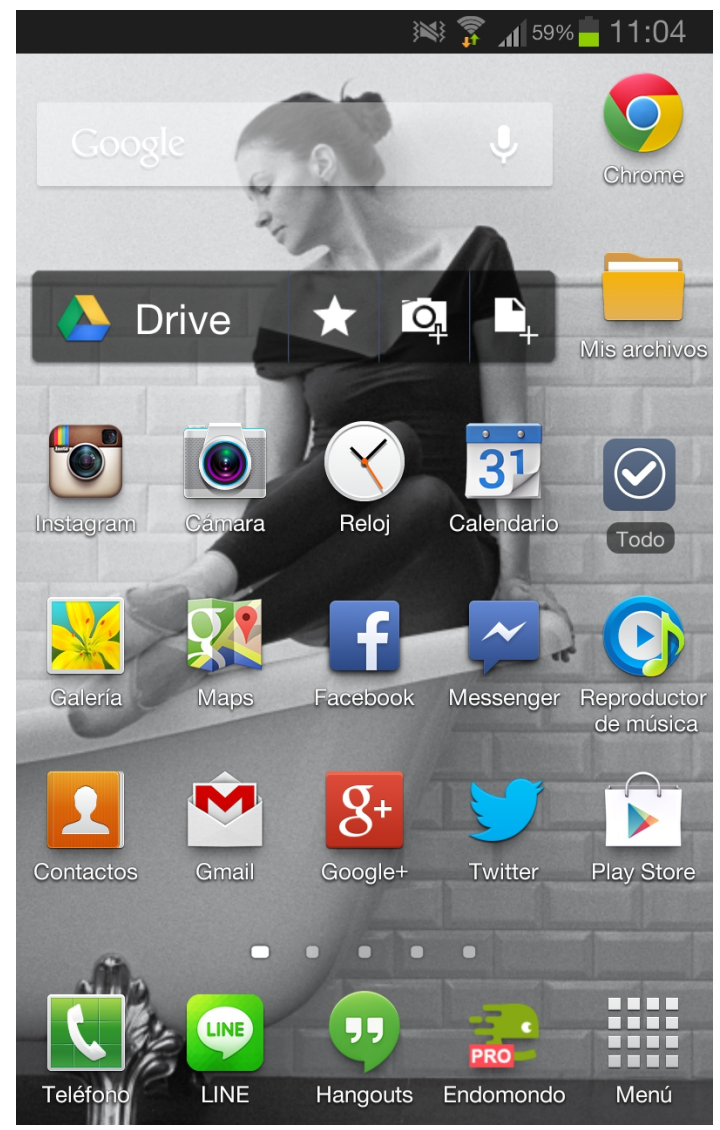

Imagen 6.32: Fotografía talismánica del ser amado sobre un soporte-pantalla. Se trata del fondo de escritorio del smartphone, que actúa como lecho fotográfico.

223 SONTAG, Susan, op. cit., pág. 26. 
Como segundo apunte, y para finalizar este capítulo, nos gustaría disponer, a modo de listado, del resto de redes sociales que hemos encontrado durante nuestra investigación y que, si bien no procede abordarlas para no incrementar la extensión de este trabajo, sí que nos gustaría enunciarlas, acompañándolas con la fecha de inauguración de su primera versión estable y su dirección URL. Pese a que muchas han sido descartadas, en las aquí incluidas (igual que en las ya analizadas), el selfie juega un papel fundamental, o bien como avatar, o bien como elemento icónico comunicativo, de ahí que nos parezca adecuado citarlas, aunque sea de esta manera fugaz y a modo de registo. Dichas redes sociales son, por orden alfabético, las siguientes:

A small world (2013) <https://www.asmallworld.com/>

Alianzo (2004) <http://www.alianzo.com>

Amigos.com (1996) <www.amigos.com>

ANnobii (2006) <www.anobii.com>

Asoboo (2008) <www.asoboo.com>

Babbel (2007) <es.babbel.com>

Batanga (1999) <www.barrapunto.com>

Bebo (2005) <www.bebo.com>

Bitácoras (2002) <www.bitacoras.com>

Campux (2006) <www.campux.com>

Chatous (2014) <https://chatous.com/ >

Cheeef (2008) <www.cheeef.com>

ClusTIC (2010) <www.clustic.com>

Cocoloop (2008) <www.cocoloop.com>

Cuspidis (2009) <www.cuspidis.com>

Cyloop (2007) <www.cyloop.com >

Dailymotion (2004) <www.dailymotion.com>

Descorchados (2007) <www.descorchados.com>

DontStayIn (2003) <www.dontstayin.com>

Dorbit (2007) <www.dorbit.net>

E-learningsocial (2004) <e-learningsocial.com>

Ebuga (2008) <www.ebuga.com>

EduFire (2007) <www.edufire.com> 
Eventful (2005) <www.eventful.com>

Fanbit (2011) <fanbit.co.in/>

Fansgao (2009) <www.fansgao.ning.com>

Festuc (2006) <www.festuc.com>

Fetlife (2012) <https://fetlife.com/>

Focax (2009) <www.focax.com>

Footbo (2007) <es.footbo.com>

Foursquare (2010) <es.foursquare.com>

Gaaper (2008) <gaaper.com>

GenePartner (2011) <www.genepartner.com/>

Geoviajes (2006) <www.geoviajes.com>

Goodreads (2006) <www.goodreds.com>

Happn (2010) <https://www.happn.com/es>

Hatebook (2009) <www.hatebook.org/>

Hi5 (2003) <www.hi.com>

I Just Made Love (2010) <https://www.ijustmadelove.com/>

Ideas4all (2008) <www.ideas4all.com>

Incondicionales (2009) <www.incondicionales.com>

IndieMV (2006) <www.indiemv.com>

Italki (2007) <www. Italki.com>

Jamendo (2007) <www.jamendo.com/en>

Keevu (2007) <es.keevu.com>

Kendin (2008) <www.kedin.es>

LibraryThing (2005) <www.librarything.com>

LinkedIn (2003) <www.linkedin.com>

Livemocha (2007) <www.livemocha.com>

Lovento (2003) <www.lovento.com/es>

Ludicum (2007) <www.ludicum.com>

May Feelings (2011) <https://www.mayfeelings.com/es/>

Meetup (2001) <www.meetup.com>

Metacafe (2002) <www.metacafe>

Mi nube (2008) <www.minube.com>

Miradas de apoyo (2009) <www.miradasdeapoyo.org>

MobiLuck (2003) <www.mobiluck.com>

Musical.ly (2015) <www.musical.ly/> 
My Free Implants (2012) <myfreeimplants.com/>

My Pet Bum (2009) <www.mypetbum.com>

MyCityMate (2003) <www.mycitymate.com>

Myngle (2007) <www.myngle.com>

Mysofa (2004) <www.mysofa.es >

Needish (2007) <http://needish.cl $>$

Neopolis (2008) <http://neopolis.com>

Netlog (2007) <http://www.netlog.com>

Nvivo (2008) <www.nvivo.es>

OleOle (2006) <www.oleole.es>

Peach (2015) <www.peach.cool>

Pequelia (2008) <www.pequelia.com $>$

PerfSopt (2002) <www.perfsopt.com>

Quepasa (1997) <www.quepasa.com>

Sclipo (2008) <www.sclipo.com>

Shareling (2008) <www.shareling.com>

Shelfari (2006) <www.shelfari.com>

Shoomo (2007) < http://es-shoomo.com>

Shvoong (2005) <www.shvoong.com>

Skyrock (2002) <www.skyrock.com>

Sonico (2007) <www.sonico.com>

Stache Passions (2012) <https://stachepassions.com/>

Strands (2008) <www.strands.com>

Summamos (2009) <www.summamos.com>

Swarm (2014) <https://es.swarmapp.com/>

Tall Friends y Date a Little (2009) <https://www.tallfriends.com/>

Taringa! (2004) <www.taringa.net>

Tenistas (2009) <www.tenistas.net>

UFO Social (2010) < ufosocial.yooco.org/>

Videolever (2007) <www.videolever.com>

Vinogusto (2007) <www.vinogusto.com/es>

Vinorati (2007) <www.vinorati.com>

vTime (2010) < https://vtime.net/>

Wamba (2007) <www.wamba.com>

Wayn (2006) <www.wayn.com> 
Xing (2003) <www.xing.com>

Yik Yak (2013) <yikyakapp.com>

Yuglo (2008) <www.yuglo.com>

Ziudad (2009) <www.ziudad.es> 


\section{TERCERA PARTE: DE DIARIOS Y OTRAS ARTES}





\section{LA MUSEIFICACIÓN DEL SELFIE}

No existe, realmente, el Arte.

Tan sólo hay artistas.

ERNST H. GOMBRICH, Historia del arte, 1950.

Pensamos que no nos corresponde a nosotros (ni en estos momentos ni en estas páginas) debatir o intentar dilucidar si el self shot y sus variantes de autorretratos digitales publicados en la red son arte o no lo son. En su conjunto sabemos que son fotografías (o algo muy parecido a fotografías ${ }^{1}$ ), también sabemos que las mismas responden a unas referencias y que pueden estar inspiradas en imágenes consideradas como artísticas. Hemos visto que se publican y que tienen su público. Sabemos que comunican cosas y que, en la mayoría de ocasiones, son el resultado de un ejercicio de creatividad, de experimentación, de prueba y error, de voluntad y de búsqueda de una determinada idea de belleza por parte de sus jóvenes creadoras y creadores. A veces, una colección de selfies realizados por una misma persona a lo largo de un

1 Ya que la fotografía se sigue situando, sobre todo hoy, entre las Bellas Artes y los medios. CHEVRIER, Jean-François, La fotografía entre las Bellas Artes y los medios de comunicación, Barcelona, Gustavo Gili, 2007, pág. 207. 
periodo de tiempo puede ser entendida como un proyecto. Estos tipos concretos de autorretrato se han extendido por el mundo y lo han cambiado.

No es menos cierto, sin embargo, que aun teniendo en cuenta estos factores aquí enumerados, no podemos afirmar de manera taxativa si los self shots son objetos artísticos en sí mismos. Para legitimar este hecho, o tacharlo de falacia, necesitaríamos más tiempo y más páginas de las que pretende este estudio, y, pese a todo, seguiríamos albergando las mismas dudas, o quizá más. Evitar estos terrenos tan pantanosos será así lo más prudente. Pasaremos de puntillas, bordeando la orilla, y usando esta cita de Debray como disculpa a la falta de valentía:

\begin{abstract}
"Entre nuestras imágenes y nosotros se alza una palabra pantalla: «arte». Todos hemos tropezado en distintas ocasiones, y como maquinalmente, con ese trasto. La engañosa palabra bisilábica constituye un obstáculo para toda elucidación de las variables de la imagen. Presenta un artefacto como producto natural, un instante como esencia y un folclore como universal. La retórica sumaria del arte, gran embuste, es demasiado omnipresente para eludirla. Nos contentaríamos con verla de nuevo en el sitio que le corresponde" ${ }^{2}$.
\end{abstract}

Sí que podemos, sin embargo, aventurarnos en tildar al selfshooter como persona, artista o no (no nos importa), que maneja formas y figuras, y que hilvana las imágenes que produce con algunos principios propios de la creación fotográfica (o artística). Continuando la cita de Gombrich que daba inicio a este capítulo podemos apuntar:

"Claro que no somos artistas, (...) Pero esto no quiere decir que no nos hayamos encontrado frente a problemas semejantes a los que integran la vida del artista. En efecto, estoy deseoso de demostrar que difícilmente habrá nadie que no haya, vislumbrado problemas de tal índole, aun en el terreno más modesto. Quien quiera

2 DEBRAY, Régis, Vida y muerte de la imagen. Historia de la mirada en occidente, Barcelona, Paidós Ibérica, 1998, pág. 127. 
que haya tratado de componer un ramo de flores, mezclando y cambiando los colores, poniendo un poco aquí y quitando allí, ha experimentado esa extraña sensación de equilibrar formas y matices, sin ser capaz de decir exactamente qué clase de armonía es la que se ha propuesto conseguir"3.

En este sentido, es cierto que las teorías artísticas en competencia han llevado muchas veces a la gente a levantar las manos y declarar de manera idealista que el arte podría ser indefinible. Robert Irwin comentó refiriéndose a la vaguedad del término arte que "ha venido a significar tantas cosas que ya no significa nada". Pero esto no le impediría exponer su propia definición: "un continuo examen de nuestra conciencia perceptiva y una continua expansión de la conciencia del mundo que nos rodea”. La definición de Irwin pone de relieve el papel del arte en la instensificación de nuestra conciencia tanto de nosotros mismos como del mundo. El arte puede hacer las dos cosas.

"Un fetiche con clavos africano se centra en la conciencia que tienen de los acuerdos legales los participantes de la comunidad; un mandala budista tibetano, en asuntos espirituales; el jardín de Versalles, en el rango que se posee dentro de un determinado mundo social jerárquico; las fotografías de Cindy Sherman, en el artificio de los papeles de género. $\mathrm{Y}$ en cada caso, el arte existe en un medio sensorial y afectivo e implica una interacción con él”4.

Este ejercicio popular del autorretrato fotográfico publicado en la red que, como hemos visto y veremos, puede estar conformado por grandes dosis de creatividad formal o amparado bajo un serio proyecto personal, podría haber sido entendido por algunos teóricos del siglo pasado como un ejercicio artístico practicado por las masas, pues en cierto modo debería ser absurda la oposición entre arte y medios de masas: "lo comparable a la pintura y escultura del Renacimiento o el Barroco, no es el arte de nuestras galerías, sino las imágenes

3 GOMBRICH, Ernst H., Historia del arte, Madrid, Debate, 2003, págs. 32-33.

4 FREELAND, Cynthia, Pero cesto es arte? Una introducción a la teoría del arte, Madrid, Cátedra, 2004, págs. 213-214. 
de los cómics, de los carteles, del cine o la televisión”.5. Asimismo, los teóricos de estas dos décadas también podrían apuntar hacia horizontes más expandidos:

"Los Goyas y Serranos del futuro seguirán sin duda encontrando medios siempre nuevos de conmocionar y expandir nuestra conciencia, utilizando la sangre y otras secreciones para alertarnos de las complejidades de nuestra vida espiritual y política. Y los futuros Botticellis y Bachs están sin duda esperando ya entre bastidores para deleitarnos con la belleza de sus nuevas imágenes y sonidos”6.

Aunque parecen más numerosos los detractores que se resisten a unificar ciertas prácticas de la fotografía digital con las aptitudes (y actitudes) artísticas, este hecho no constituye óbice alguno para considerar lo siguiente:

"[...] que el autorretrato en la fotografía digital se configura como una práctica cultural popular distinta al autorretrato artístico, aunque mantiene conexiones con este"7.

Junto a ello, se ha dicho que los usos de la fotografía en torno al autorretrato son variados y no necesariamente tienen que estar ligados a condiciones artísticas, ya que estos usos también pueden ser sociales, lúdicos o documentales ${ }^{8}$.

Además, también se ha de tener en cuenta que para algunos el arte está fuertemente asociado a una institucionalización actualmente bien definida, puesto que podemos acotar esa constelación de prácticas que, unidas a un cierto y específico régimen de producción, distribución y regulación de la recepción de

5 RAMÍREZ, José Antonio, Medios de masas e historia del arte, Madrid, Cátedra, 1976, pág. 12.

6 FREELAND, Cynthia, op. cit., pág. 216.

7 GÓMEZ-CRUZ, Edgar y ARDÈVOL, Elisenda, “Cuerpo privado, imagen pública: el autorretrato en la práctica de la fotografía digital” en Revista de dialectología y tradiciones populares, vol. $67, \mathrm{n}^{0} 1$, 2012, pág. 183 .

8 DURAND, Régis, El tiempo de la imagen. Ensayo sobre las condiciones de una historia de las formas fotográficas, Salamanca, Universidad de Salamanca, 1998, pág. 13. 
las imágenes (junto con un determinado mercado y un conjunto estabilizado de instituciones sociales) se integra en un conjunto más amplio que define y al que se extiende la cultura visual contemporánea ${ }^{9}$. Incluso podemos contar también con opiniones que enlazan la fotografía con este arte institucional acabado de citar como una unión relativamente reciente y que solo da validez a la obra dentro de la galería, del museo, o del mercado, creando así una paradoja (de difícil desenredo para nosotros) en relación a los selfies que vamos a ver a lo largo de este capítulo. Planteando la cuestión de una manera directa y sin ambages: ¿̇son los selfies artísticos por su contrucción o por su ubicación?:

\begin{abstract}
"Tanto en la órbita de los Estados Unidos como en la de los países europeos más avanzados, la década de los setenta significó para la fotografía el inicio de su doble institucionalización como materia académica y museística. Se puede argüir que con anterioridad la fotografía ya había recibido un tratamiento universitario y era coleccionada en museos. Lo cual es cierto; pero es a partir de esos años cuando su implantación se popularizaría entre las estructuras canonizadoras del saber y de la cultura. Tal proceso de difusión y valorización, obviamente, vino acompañado por la imbricación de la fotografía en la escena del arte contemporáneo, así como por la dinamización de un mercado de la fotografía como objeto artístico" ${ }^{\text {"10 }}$.
\end{abstract}

Vistas estas opiniones enfrentadas (y muchas otras no desplegadas aquí e igual de contrapuestas) y en relación a lo rápido que las nuevas tecnologías y prácticas adolescentes han cambiado el panorama de la imagen contemporánea y de los valores artísticos, consideramos que la teoría del arte ${ }^{11}$ debe de ser constantemente revisionista y adaptarse a estos nuevos paradigmas ${ }^{12}$ : "Cada momento histórico produce un arte que le es propio y, en este sentido, el

9 BREA, José Luis, Las tres eras de la imagen, Madrid, Akal, 2010, pág. 114.

10 FONTCUBERTA, Joan (Ed.), Fotografía. Crisis de historia, Barcelona, Actar, 2002, pág. 7.

11 "Una teoría es más que una definición; es un marco que proporciona una explicación ordenada de unos fenómenos observados. Una teoría debe ayudar a que las cosas cobren sentido y no a crear oscuridad utilizando una jerga y un lenguaje árido. Debe unificar y organizar sistemáticamente un conjunto de observaciones partiendo de principios básicos”. FREELAND, Cynthia, op. cit., pág. 11.

ECO, Umberto, La definición del arte, Barcelona, Martínez Roca, 1970, pág. 285. 
conocimiento del marco cultural de cada época es fundamental para comprender la producción artística que le corresponde” ${ }^{13}$. A ello, además, se une otro hecho: "la función del arte en cada periodo histórico es un problema conceptual dependiente de la propia definición de arte"14.

Pese a nuestro intento por enunciar este problema, seguiremos cautelosos ante la catalogación de nuestro objeto de estudio como ente artístico o no, y ello teniendo en cuenta que, en las siguientes páginas, veremos ejemplos de formas basadas (o directamente encarnadas) en los selfies y mirrorpics que han sido introducidas en circuitos artísticos (como pueden ser las galerías de arte, los museos, las plataformas proyectuales o las instituciones culturales). No obstante, no hay que olvidar, junto con Sontag, que al final "el tiempo termina por elevar casi todas las fotografías, aun las más inexpertas, a la altura del arte” ${ }^{15}$.

\subsection{El selfie utilizado como objeto artístico.}

Aunque existe una innumerable cantidad de artistas que trabajan sobre la autorrepresentación por medio de la fotografía, veremos a lo largo de estas páginas ejemplos de estructuras basadas (o encarnadas) en (o con) selfies y mirrorpics que se han encontrado expuestas en espacios o en contextos artísticos y proyectuales. Debido a ello, vamos a intentar traer a colación distintas propuestas que nos recuerdan a la imaginería y a la práctica del self shot adolescente y, en este primer apartado, analizaremos de manera muy breve y 
concisa cinco ejemplos de artistas o exposiciones que han utilizado el selfie directamente como objeto.

\subsubsection{La autorrepresentación terapéutica de Cristina Núñez.}

El primer ejemplo que encontramos del self shot museificado o adscrito a circutos artísticos es el trabajo de Cristina Núñez, una artista que elabora su propia representación fotográfica mediante autorretratos privados. Si bien actualmente trabaja con medios digitales y publica sus imágenes en Internet, sus primeras obras fueron realizadas antes del desarrollo de la red y de la democratización de las cámaras digitales.

Estas primeras obras eran mirrorpics avant la lettre (Imagen 7.1). Y lo eran en forma y en metodología, aunque en este caso, su motivación fuera diferente a la de nuestras adolescentes contemporáneas: Cristina Núñez empezó a realizar estas autorrepresentaciones en 1988 como terapia para superar problemas de autoestima que le habían hecho drogodependiente durante su adolescencia.

Sus prácticas eran, pues, ejercicios de proyección hacia el mundo de su anteriormente deteriorado yo. Las mismas daban forma a sus emociones y permitían establecer una lectura de sí misma, consolidándose como un método de cura.

Más tarde, y completamente recuperada, llegó a realizar ejercicios de reflexión y denuncia a través de su propia imagen, como este autorretrato que dialoga sobre el holocausto judío en Mauthausen (Imagen 7.2). 
En la actualidad, Cristina Núñez continúa realizándose autorretratos frente a espejos (Imagen 7.3). Además, imparte talleres de autorrepresentación fotográfica para adultos, bajo el apelativo The Self Shot Experience ${ }^{16}$, uniendo así arte y terapia. Su objetivo es que su alumnado, al igual que ella hizo, conviertan sus emociones en obras de arte por medio de la práctica y desarrollo del autorretrato fotográfico ${ }^{17}$.

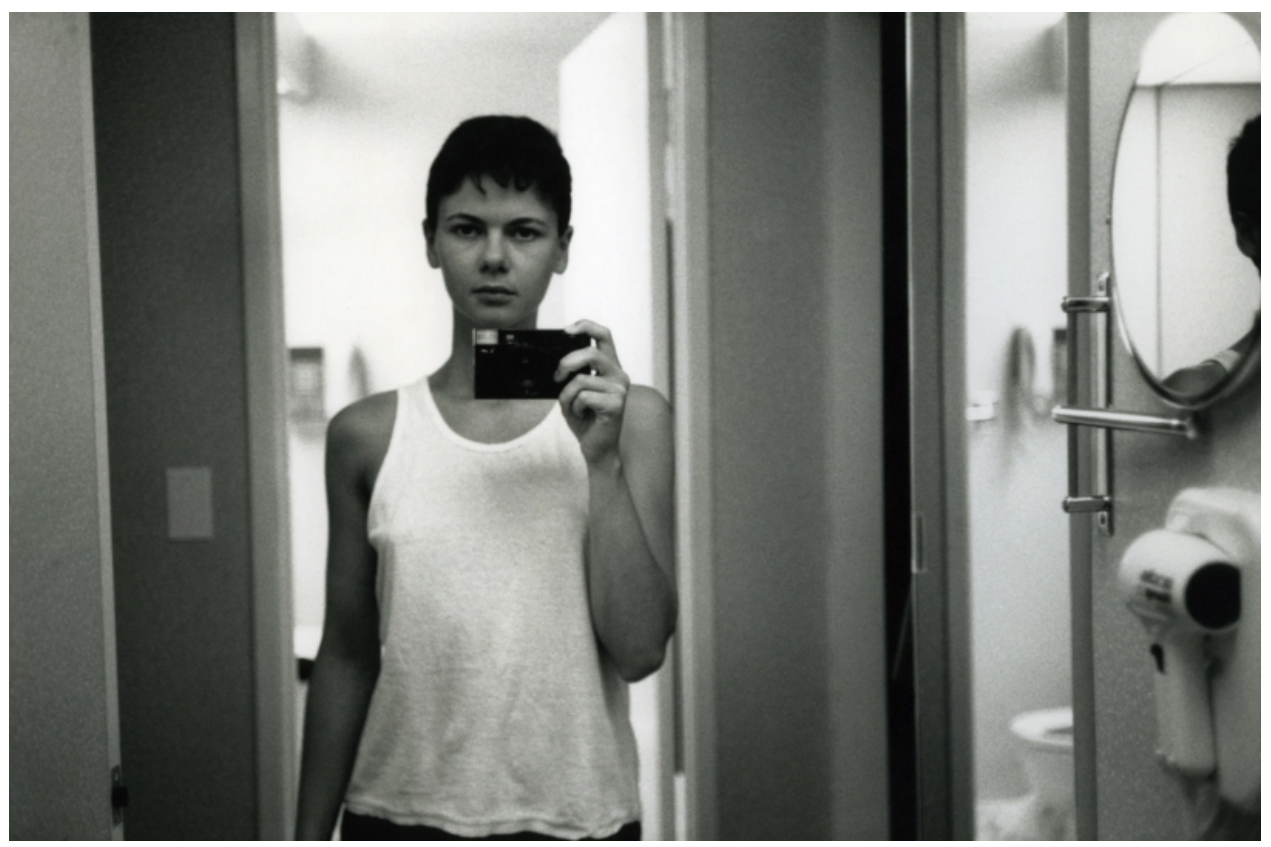

Imagen 7.1: Cristina Núñez, Autorretrato, 1988.

16 Web del proyecto en: <http://www.self-portrait.eu/home/> [Fecha de consulta: 16 de julio de 2013].

17 Hay una recopilación publicada en 2013 de material audiovisual de Cristina Núñez en relación a su desarrollo y a sus proyectos en: DOMÍNGUEZ, Chus y SOLÁ, Belén, "El trabajo sobre autobiografía de Cristina Núñez", disponible en: <http://raraweb.org/el-trabajo-sobre-autobiografia-de-cristinanunez.html > [Fecha de consulta: 16 de julio de 2016]. 


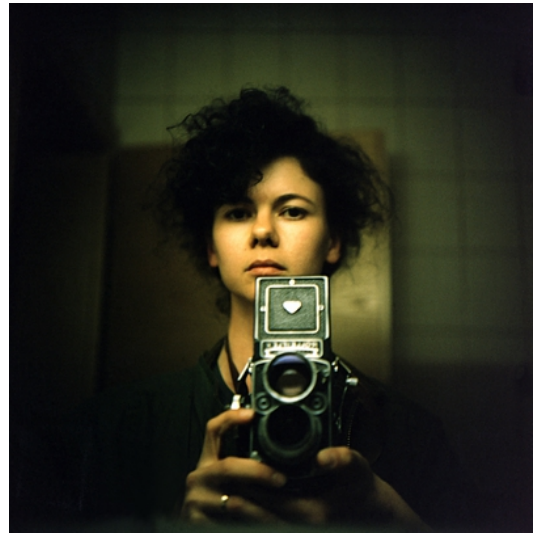

Imagen 7.2: Cristina Núñez, Mauthausen, 1995.

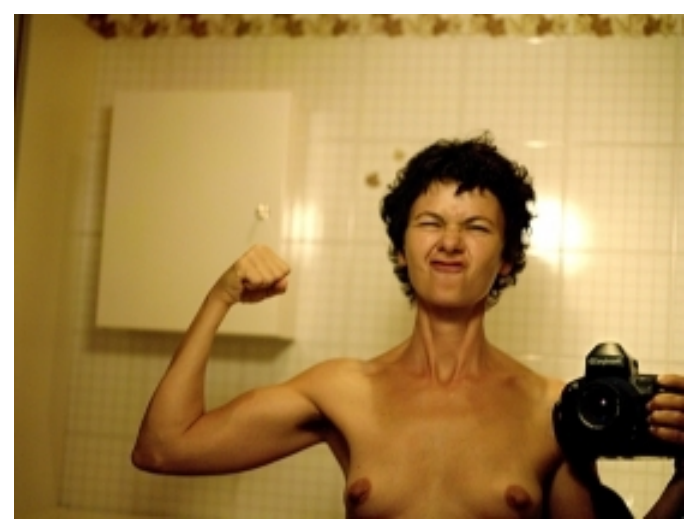

Imagen 7.3: Cristina Núñez, My Mamiya es my Medicine, 2008.

\subsubsection{Tete de Alencar: Cinderella Flash.}

Hablaremos ahora de Tete de Alencar ${ }^{18}$, artista afincada en Londres, que realizó entre 2005 y 2012 un proyecto expositivo relacionado con la fotografía y la performance, y que responde al título de Cinderella Flash (Imagen 7.4). Esta serie se compone de un número de fotografías de gran formato que representan a la artista mediante sus autorretratos digitales de tipo mirrorpic. Estos son realizados con la cámara en la mano y siempre frente al espejo de un probador. E lflash del dispositivo nubla su cara, desde donde dispara, pero podemos apreciar el resto de su cuerpo luciendo vestidos de fiesta que nos remiten a los de las princesas y otros miembros de la nobleza. Esta serie realizada en probadores

18 Web de la artista: <http://www.tetedealencar.com/> [Fecha de consulta: 16 de julio de 2016]. 
de Londres, París o Nueva York (capitales de la moda) pretende ser una crítica a la sociedad de consumo, y ha sido expuesto en diferentes salas ${ }^{19}$.

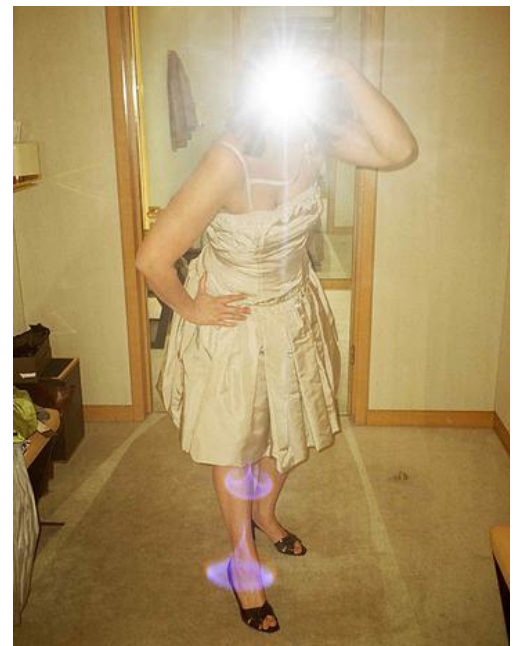

Imagen 7.4: Tete de Alencar, Cinderella Flash, entre 2005 y $2012,160 \times 80 \mathrm{~cm}$.

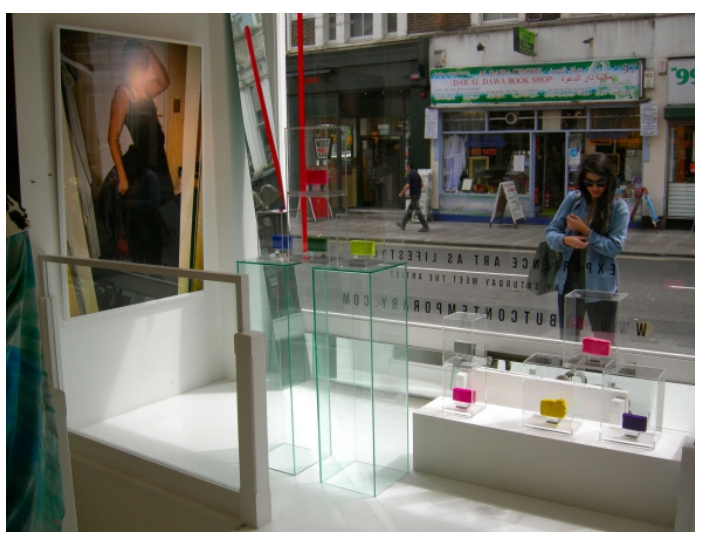

Imagen 7.5: Fotografía desde el interior de la galería de arte Debut Contemporary de Londres en 2011.

\subsubsection{Los reflectogramas de Joan Fontcuberta.}

El teórico y artista Joan Fontcuberta, cuyos textos están muy presentes en este estudio, ya que ha sido de los primeros en reconocer y hablar del fenómeno del self shot ${ }^{20}$, también ha utilizado esta práctica como referencia (en este caso

19 Por ejemplo, en la galería de arte Debut Contemporary de Londres en 2011 (Imagen 7.5) o en el Museu Valencià de la Il·lustració i la Modernitat (MuVIM) en 2013 y también en 2018.

20 Joan Fontcuberta llama a estos autorretratos propios de las redes sociales reflectogramas. En declaraciones a Óscar Colorado explica que en ellos "la voluntad lúdica y autoexploratoria prevalece sobre la memoria. Tomarse fotos y mostrarlas en las redes sociales forma parte de los juegos de 
como amalgama) en varios de sus proyectos expositivos. Además, no ha utilizado sus principios como doctrina para jugar con la autorrepresentación, sino que ha ido mucho más allá: ha empleado los propios self shots encontrados en los espacios públicos de la red (algunos de ellos, directamente demandados a un público que los practicó y los cedió) como ingrediente con los que construir su obra. Los mismos, por tanto, han constituido la materia prima de algunos de sus proyectos. Uno de estos fue la exposición A través del espejo que se pudo visitar en Barcelona durante la feria de fotografía e imagen Sonimagfoto y Multimedia $2011^{21}$. En ella, Fontcuberta mostraba más de 3000 autorretratos de espejo que circulaban a través de multitud de proyectores con intervalos de dos segundos (Imagen 7.6). A su vez, también hizo reproducciones de estos autorretratos sobre papel, que junto con las proyeccciones, y a modo de instalación, generaban discursos que tenían que ver con la construcción de la identidad del individuo en las redes sociales y con la visibilización de este tipo de prácticas fotográficas que tan difíciles son de encontrar fuera de su propio medio. Por otro lado, la propia naturaleza de la exposición facilitó el debate acerca de los derechos de imagen en la era de Internet y del uso que se puede o no hacer de ellas: muchos de los autorretratos eran desnudos de jóvenes que seguramente nunca sabrán que sus cuerpos formaron parte de esa exposición pública (aunque no debería importunarles, ya que esas mismas imágenes ya eran públicas en un espacio expositivo mucho más vasto y visible: Internet).

seducción y los rituales de comunicación de las nuevas subculturas urbanas postfotográficas de las que, aunque capitaneadas por jóvenes y adolescentes, muy pocos quedan al margen. Las fotos ya no recogen recuerdos para guardar sino mensajes para enviar e intercambiar: se convierten en puros gestos de comunicación cuya dimensión pandémica obedece a un amplio espectro de motivaciones. [...] millones de personas empuñan la cámara y se enfrentan a su doble en el espejo: mirarse y reinventarse, mirarse y no reconocerse. Aunque paradójicamente sea ocultándonos como nos revelamos, el mero hecho de posar implica a la vez ubicarnos en una puesta en escena y sacar a relucir una máscara: el autorretrato por tanto no puede sino cuestionar la hipotética sinceridad de la cámara". COLORADO, Óscar, "Autorretrato y fotografía", 2013, disponible en: <https://oscarenfotos.com/ 2013/08/11/autorretrato-y-fotografia/> [Fecha de consulta: 25 de julio de 2017].

21 Hay muchas noticias en los medios que narran la exposición de este artista, entre ellas, la del diario $\mathrm{La}$ Vanguardia. VERA, Carlos y COLLAZOS, Carlos, "Joan Fontcuberta provoca en Sonimag", 2011, disponible en: <http://videos.lavanguardia.com/20110325/54132752234/joan-fontcuberta-provocaen-sonimag.html $>$ [Fecha de consulta: 16 de julio de 2013]. 


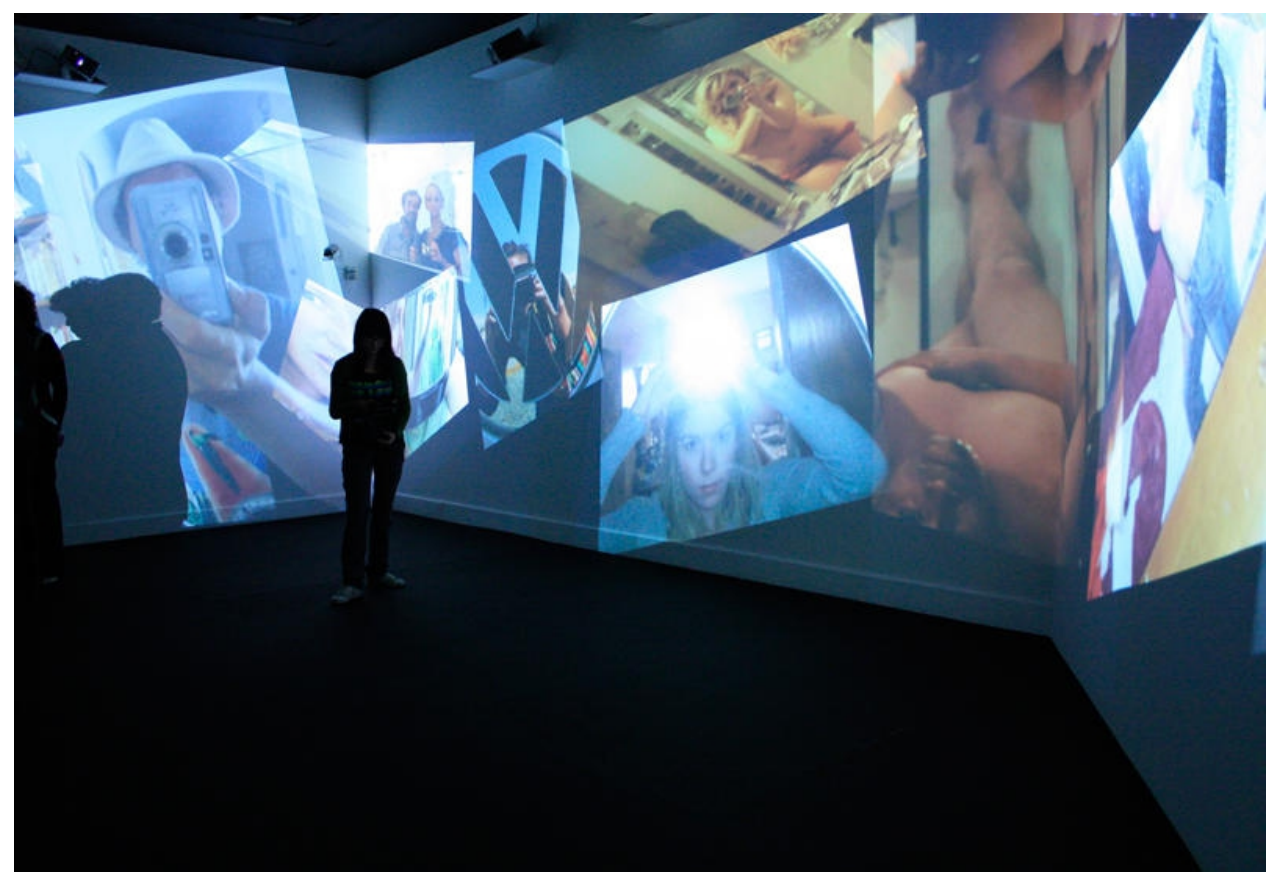

Imagen 7.6: Instalación de Joan Fontcuberta, dentro de su exposición A través del espejo, realizada en 2011.

\subsubsection{Self-timer Stories.}

Del 16 de mayo al 13 de septiembre de 2015 se pudo visitar en el MUSAC (Museo de Arte Contemporáneo de Castilla y León) la exposición titulada Selftimer Stories (Imagen 7.7), que fue comisariada por Felicitas Thun-Hohenstein y coordinada por Kristine Guzmán. 
En esta muestra se exhibieron obras de artistas que abarcaban cuatro generaciones, presentando un diálogo en torno a una práctica que ha sido y es popular tanto en la vida cotidiana como en la fotografía artística, y a cuya revitalización a través del uso de las nuevas tecnologías asistimos ahora con regularidad (como hemos visto a lo largo de este estudio): el autorretrato fotográfico popular. A partir de un corpus de alrededor ochenta obras de más de treinta $\operatorname{artistas~}^{22}$ de la Federal Photography Collection y de la Colección MUSAC, la exposición se centró en interactuar estas obras con fotografías de enfoque más amplio de artistas españoles e internacionales. De este modo, la exposición contempló una serie de piezas que realizaban un recorrido desde los objetos fotográficos manufacturados con los autodisparadores de las máquinas de captura analógica durante el siglo pasado, hasta las contemporáneas composiciones de brazo extendido que nos han enseñado las autoras de los self shots. Los textos publicados en el catálogo de la exposición destacaron, en parte, el protagonismo de la mujer en relación a estas prácticas fotográficas, tanto en las clásicas (debido a su emancipación tras la democratización de la fotografía), como en las contemporáneas (como hemos estado viendo en pasados capítulos):

\footnotetext{
"El autorretrato fotográfico lleva en su interior un gesto feminista de empoderamiento. Mientras que las mujeres en el pasado tenían prohibido el acceso a las academias de arte, la fotografía abrió un espacio artístico de acción para ellas. Hoy en día, ese aspecto no está reñido con incluir en la reflexión las posiciones masculinas al respecto" ${ }^{23}$.
}

22 Bernadette Anzengruber, Renate Bertlmann, AA Bronson, Katrina Daschner, Carola Dertnig, Valie Export, Esther Ferrer, Heidi Harsieber, Jessyca R. Hauser, Philipp Hauss, Sharon Hayes, Matthias Herrmann, Juan Hidalgo, Birgit Jürgenssen, Barbara Kapusta, Susi Krautgartner, Friedl Kubelka, Roberta Lima, Anja Manfredi, Dorit Margreiter, Ana Mendieta, Michaela Moscouw, Laurel Nakadate, Lilo Nein, Cristina Núñez, Carlos Pazos, Sasha Pirker, Àngels Ribé, Constanze Ruhm, Hans Scheirl, Toni Schmale, Carolee Schneemann, Peter Weibel, Hans Weigand, Judith van der Werff, Martha Wilson y Francesca Woodman.

23 THUN-HOHENSTEIN, Felicitas (Ed.), Self-Timer Stories, Viena, Austrian Federal Chancellery, 2015, pág. 16. 
Algunas imágenes de la exposición y de sus obras (Imagen 7.8) pueden consultarse en la página web del MUSAC, donde también podemos encontrar una pertinente reflexión en torno a las pácticas clásicas y contemporáneas exibidas en esta muestra:

"Ahora el temporizador funciona como una herramienta operativa y simbólica de revuelta, sirviendo menos para satisfacer la necesidad de representarse a uno mismo que para llevar a cabo un acto de auto-estilización. La práctica de fotografiarse a uno mismo interactúa con los avances tecnológicos. Esto se muestra en la composición, que deja a la vista los cables de los disparadores remotos, el disparador remoto digital o simplemente la mano extendida, entre otras cosas. Ser el fotógrafo y el sujeto fotografiado al mismo tiempo requiere varias formas de mecanismos de control. La mirada a la cámara, en sí misma, crea una distancia y, sin embargo, también sirve para mantener el propio yo bajo vigilancia. Así, surge una relación visual entre el sujeto y el mundo que se desarrolla bajo las condiciones mediáticas vigentes en ese momento. Como puede observarse en las propias obras, la publicación de lo privado en ocasiones viene acompañada de la creación de una ficción y, en última instancia, de una pérdida del control artístico" ${ }^{24}$.

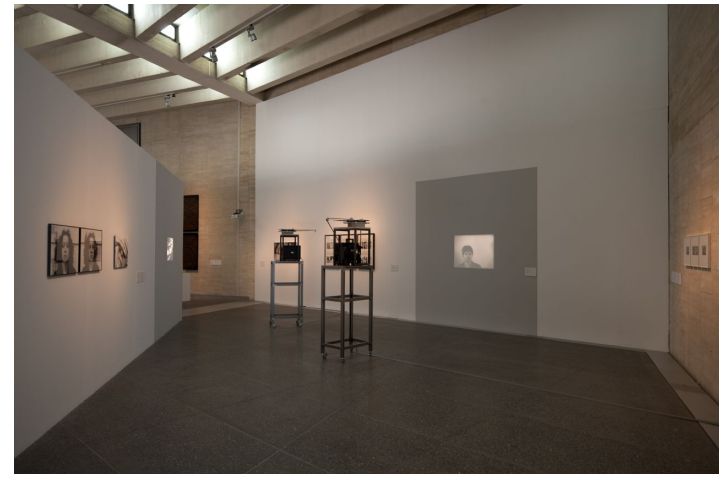

Imagen 7.7: Imagen del montaje de la exposición Self-timer Stories, 2015.

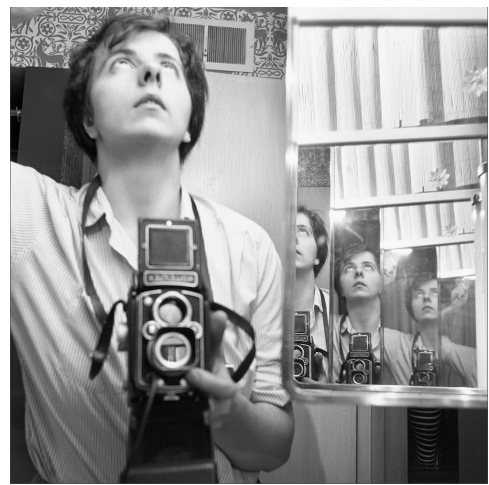

Imagen 7.8: Vivian Maier, Autorretrato, 1956, $40 \times 50 \mathrm{~cm}$.

24 VV. AA., "Self-timer Stories", 2015, disponible en: <http://musac.es/\# exposiciones/expo/?id=6250 \&from=futuras $>$ [Fecha de consulta: 20 de abril de 2018]. 


\subsubsection{Lucía del Carmen Luque Rodríguez.}

Y por último dentro de este apartado, pero no por ello menos importante, destacar la figura de la joven fotógrafa madrileña Lucía del Carmen Luque Rodríguez, que en 2011, y con tan solo catorce años de edad, expuso su obra Esa soy yo (Imagen 7.9), seleccionada para la exposición 2010, retratos de una generación, en la que participaban jóvenes de catorce a dieciocho años, todos alumnos estudiantes de lengua francesa en colegios y liceos de toda España ${ }^{25}$. Dicha muestra se pudo ver del 3 de marzo al 1 de abril de 2011 en la sala de exposiciones del Instituto Francés de Valencia.

Entre las fotos de los participantes había trabajos de diversa índole: todos apuntaban a diferentes maneras de representar la juventud de la época de una manera más anecdótica o documental y sin basarse en el autorretrato, pero Lucía fue la única que utilizó las formalidades del autorretrato de espejo como estrategia para auto-rrepresentarse y poder establecer el discurso fotográfico. La fotografía es un mirrorpic al uso. Nada más que añadir, por tanto, salvo el curioso guiño casi metonímico que supone este tipo de ejercicio en una exposición planteada bajo esta temática. También destacar la útil explicación de la obra que se narraba en una cartela bajo la misma pieza: "Pienso que esta fotografía es parte de la generación 2010, ya que representa a la juventud de hoy en día y a la adolescencia”. Gracias Lucía.

25 La noticia puede localizarse en la edición digital del periódico El País: <http://sociedad.elpais.com/ sociedad/2009/12/02/actualidad/1259708416_850215.html> [Fecha de consulta: 16 de julio de 2016]. 


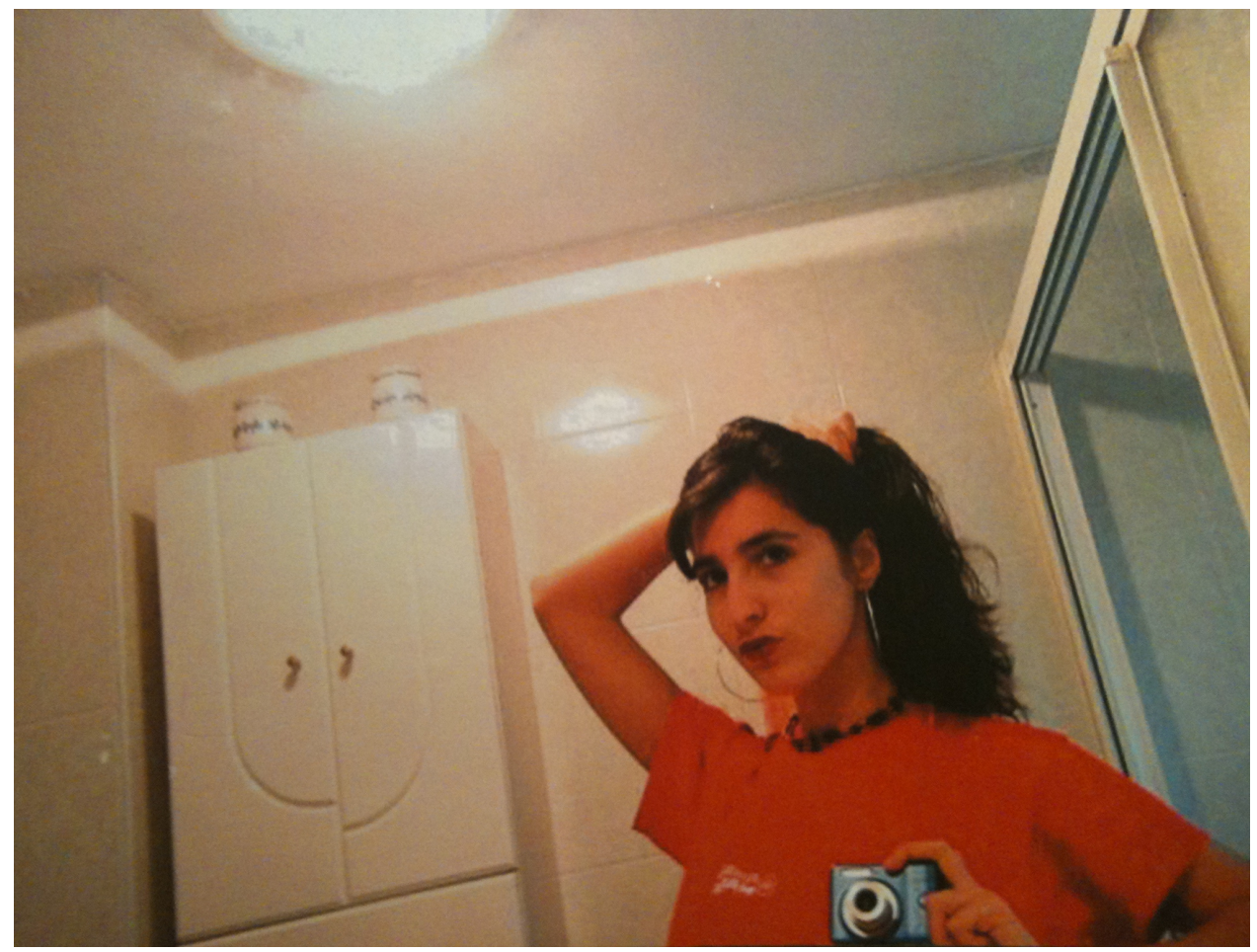

Imagen 7.9: Lucía del Carmen Luque Rodríguez, Esa soy yo, 2010.

\subsection{Selfies representados mediante las Bellas Artes.}

Si en el primer punto de este capítulo veíamos ejercicios próximos al selfie ubicados directamente en la sala expositiva como un objeto o realidad per $s e$, en este segundo apartado veremos selfies representados mediante otras técnicas o géneros, pero que utilizan su imaginería y reflejo cultural como marco referencial para desarrollar otro producto asociado aunque diferente. Nos enfrentamos, pues, ante representaciones de representaciones o quizá ante representaciones de presentaciones. 


\subsubsection{Juan Francisco Casas y sus selfies realizados con bolígrafo.}

Vamos a detenernos en primer lugar, en el artista Juan Francisco Casas ${ }^{26}$, reconocido por su obra de dibujos a bolígrafo de pequeño y gran formato. En su exposición (A)Utopic, realizada en la Galería Fernando Pradilla de Madrid en $2014^{27}$, pudo verse una selección de dibujos que no son sino las representaciones (en forma de dibujo) de mirrorpics íntimos y eróticos enviados al artista por mujeres selfshooters de todo el mundo (Imágenes 7.10 y 7.11). Según otra reseña web de la exposición recogida en Metropoli $^{28}$, apuntaremos que el título de la exposición remitía a los vocablos ingleses autopic (abreviatura de autopicture, traducida como autofoto) y de utopic, término que alude a la representación de un mundo idealizado en la virtualidad de las redes sociales.

En dicha exposición Juan Francisco Casas mostró más de sesenta dibujos realizados con un bolígrafo BIC azul y negro, y con predominio, en esta ocasión, del pequeño formato. El artista continuaba así en su línea, siempre en estrecha vinculación con el medio fotográfico, como punto de partida y herramienta imprescindible para sus trabajos. La metodología que siguió para el desarrollo de este proyecto fue la demanda, a través de su página de Facebook, del envío de autofotos tomadas ante el espejo (mirrorpics) y que permitieran ver el dispositivo de la captura (consecuencia casi indisoluble). Con esta serie, el autor planteó una reflexión sobre la necesidad de autorrepresentarse, de descubrirse en la intimidad y de dejar constancia de ello. Del más de un centenar de fotografías

26 Su trabajo puede verse en la página web del artista: <http://www.juanfranciscocasas.com/> [Fecha de consulta: 19 de abril de 2015].

27 Una reseña a la exposición de este artista puede consultarse en diversas publicaciones y sitios web, por ejemplo, en PAC, Plataforma de Arte Contemporáneo: GARCÍA, Óscar, "Selfies para Juan Francisco Casas", 2014, disponible en: <http://www.plataformadeartecontemporaneo.com/pac/selfies-parajuan-francisco-casas/> [Fecha de consulta: 21 de abril de 2015].

28 <http://metropoli.elmundo.es/b/exposiciones/21664/juan-francisco-casas-autopic.html> [Fecha de consulta: 19 de abril de 2015]. 
recibidas de chicas jóvenes de diversos países, seleccionó sesenta para trasladarlas al dibujo.

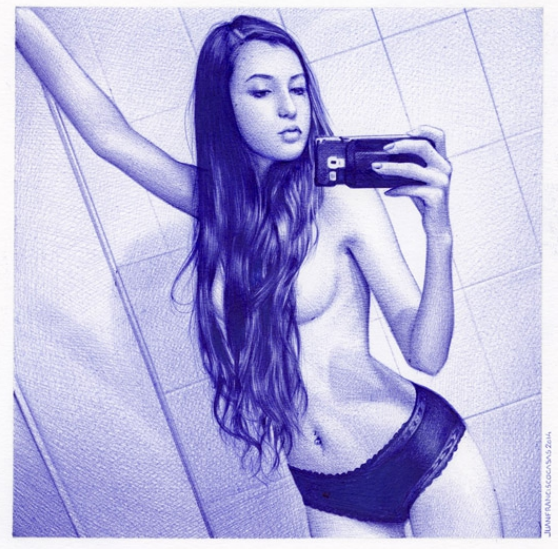

Imagen 7.10: Juan Francisco Casas, Ana Sofía/Guadalajara/México\#3, 2014, bolígrafo sobre papel, $15 \times 15 \mathrm{~cm}$.

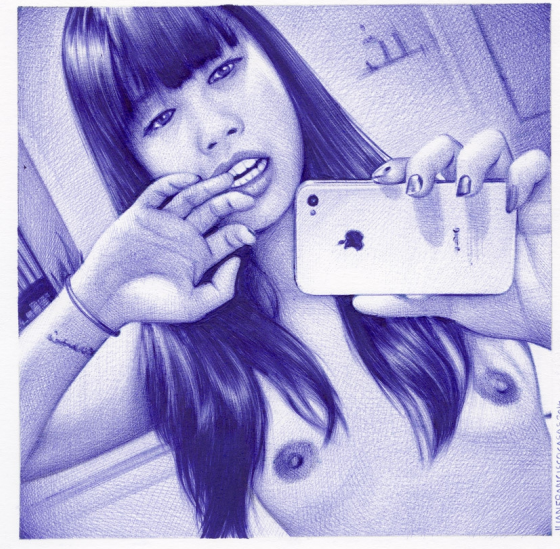

Imagen 7.11: Juan Francisco Casas, Aisa/Tokorozawa/Japan\#1, 2014, bolígrafo sobre papel, 15 x $15 \mathrm{~cm}$.

\subsubsection{La certeza de uno mismo en Begoña Riera.}

Encontramos un ejercicio similar desarrollado también de manera proyectual por la artista gráfica Begoña Riera a lo largo de 2014 y 2015. Sus planteamientos conceptuales surgen de la visión de su propia imagen en diferentes superficies reflectantes sobre las que efectúa un ejercicio de autorretrato digital. Este retrato será posteriormente manipulado mediante procesos gráficos: desde los más tradicionales, como la xilografía (Imagen 7.12), 
hasta los más modernos, como la impresión offset o la combinación con otras técnicas ajenas a la gráfica como la cianotipia (Imagen 7.13) o las transferencias de imagen (Imagen 7.14) ${ }^{29}$.

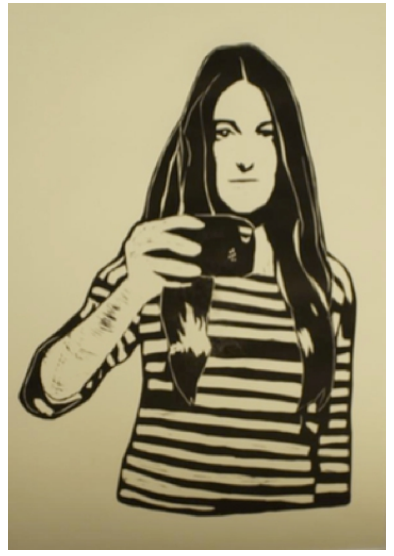

Imagen 7.12: Begoña Riera, Autorretrato $n^{\circ}$, 2014-2015, xilografía.

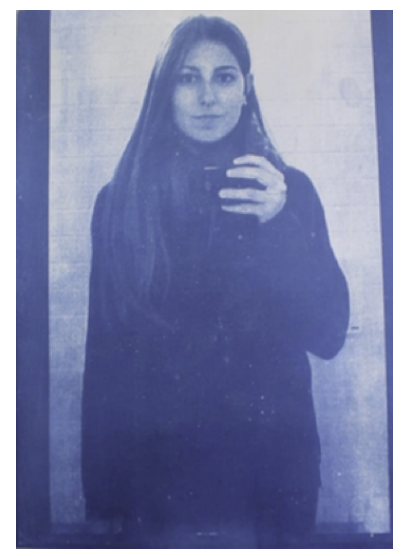

Imagen 7.13: Begoña Riera, Autorretrato ${ }^{\circ} 8$, 2014-2015, cianotipia.

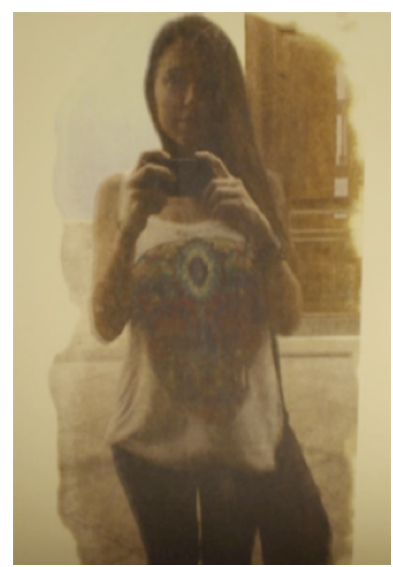

Imagen 7.14: Begoña Riera, Autorretrato $n^{\circ} 12$, , 2014-2015, transferencia.

\subsubsection{Una escultura bajo el agua.}

En 2017 ha abierto en Lanzarote el primer museo submarino de Europa. $\mathrm{Su}$ objetivo es el de preservar el medio marino a través de 300 esculturas inspiradas en los lugareños y realizadas en hormigón de $\mathrm{pH}$ neutro, beneficiosas para el medio, pero que son también piezas interesantes para los buceadores en un medio atípico para estas volumétricas piezas artísticas como pueda ser el

29 RIERA SOLER, Begoña, La certeza de uno mismo, Valencia, Universitat Politècnica de València, 2015, págs. 21-22. 
espacio marino. Las obras se descubren haciendo snorkel, buceo con botella o a través de un submarino. Estas esculturas representan personas realizando tareas sociales cotidianas y contemporáneas y, por supuesto, el referente del selfie se muestra en varias de ellas, así que en el ejemplo que mostramos (Imagen 7.15), más que la representación escultórica de un selfie encontramos la representación escultórica de la práctica del selfie.

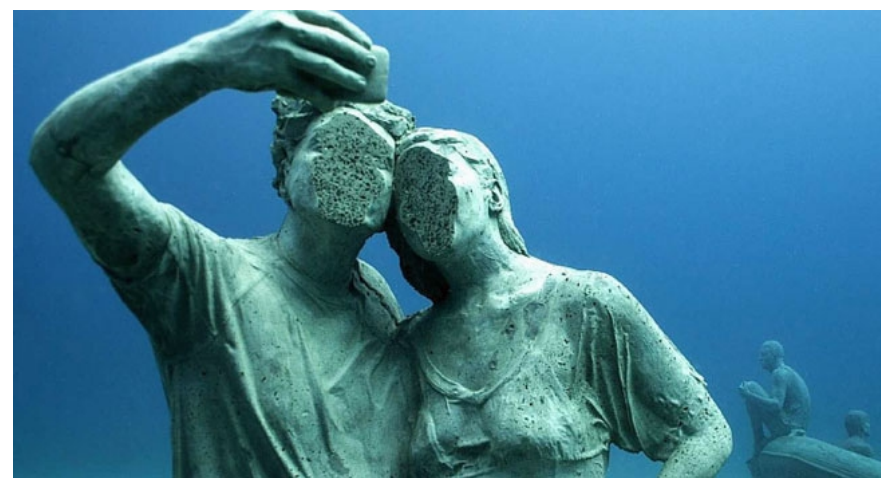

Imagen 7.15: Escultura acuática del museo submarino de Lanzarote que representa a una pareja haciéndose un selfie.

\subsubsection{El selfie pintado.}

Para finalizar este apartado aludiremos a dos ejemplos más, en esta ocasión expuestos en el ámbito de la pintura de la mano de los artistas Sierk van Meeuwen (Imagen 7.16) y Wenli Liu (Imagen 7.17). Las dos obras que aquí incluimos constituyen ejemplos que igualmente ponen de manifiesto el uso de esta imaginería ya asentada formal y culturalmente. 


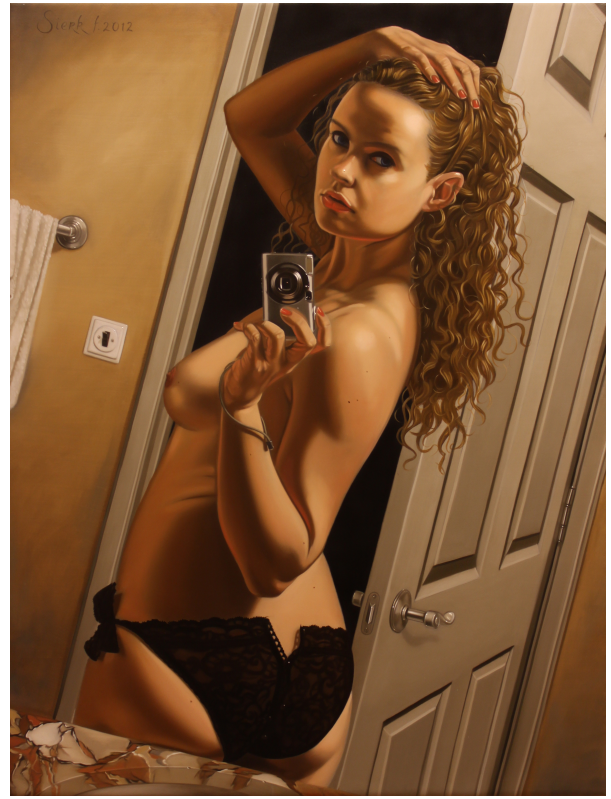

Imagen 7.16: Sierk van Meeuwen, Self shot $n^{o_{2}}$, 2012, óleo sobre lienzo, $40 \mathrm{x}$ $30 \mathrm{~cm}$.

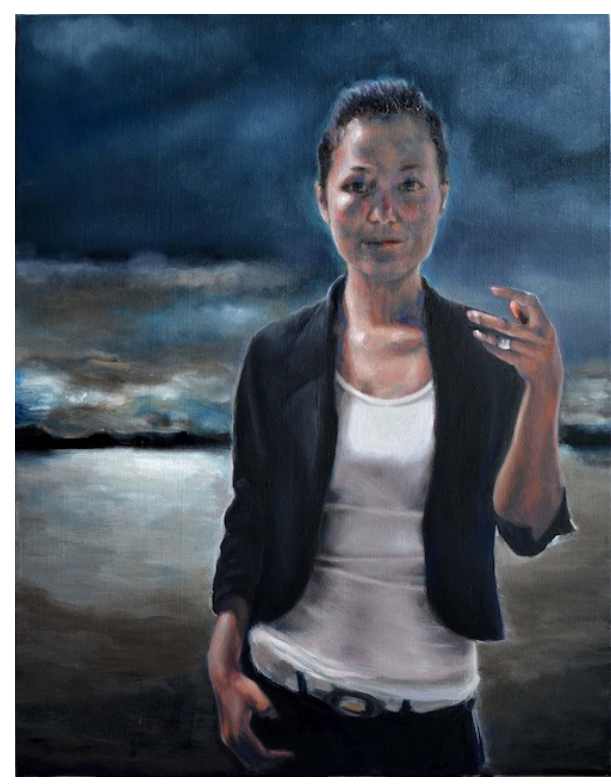

Imagen 7.17: Wenli Liu, Self shot at Dusk, 2013, óleo sobre lienzo, $71 \times 56$ $\mathrm{cm}$.

\section{7•3. El selfie acumulado y utilizado como proyecto artístico.}

También hemos encontrado durante nuestra investigación numeroso material relacionado con una serie de iniciativas desarrolladas por diferentes personas o colectivos, que atienden a una naturaleza proyectual (o bien artística o bien sociológica), pero con una metodología similar a la de muchos proyectos artísticos expuestos en otros ámbitos. La manufactura de estos proyectos ha hecho posible, en algunos ejemplos, su exposición en una sala o en un museo, sin 
embargo, en otros tantos, su lugar de exposición ha sido un escenario virtual en lugar de físico.

\subsubsection{Selfiecity.}

El proyecto Selfiecity ${ }^{30}$, investiga la forma y el estilo de una cantidad de selfies realizados por los habitantes de cinco ciudades del mundo: Bangkok, Berlín, Moscú, Nueva York y São Paulo. Aunque a primera vista se trata de una recopilación de imágenes expuestas en la red, Selfiecity (Imagen 7.18) también es un proyecto de investigación ${ }^{31}$ que examina datos y obtiene conclusiones mediante el estudio de estos autorretratos ${ }^{32}$.

Este proyecto resulta pertinente de cara a evidenciar la predominancia femenina en el uso de la tecnología móvil dirigida a la ejecución del autorretrato digital publicado. A su vez, el proyecto (que investigó el estilo de los selfies en las ciudades citadas) demostró que existe un amplio margen de diferencia entre las mujeres y los hombres que se toman selfies, llegando a ser femenino en un $82 \%$ del total de la muestra en Moscú, de un 65,4\% en São Paulo, de un 61,1\% en Nueva York y de un 59,4\% en Berlín ${ }^{33}$.

La web del proyecto y sus resultados pueden consultarse en: <http://selfiecity.net/> [Fecha de consulta: 24 de abril de 2015].

Liderado por el conocido analista de datos audiovisuales Lev Manovich y en el que participan diseñadores, programadores, teóricos de la comunicación, historiadores de arte y otro tipo de científicos.

Algunas de estas conclusiones (junto con una breve explicación del proyecto) quedan recogidas en nuestro idioma en el artículo del sitio web Yoroboku: CABRIA, Elsa, "Anatomía del selfie", 2014, disponible en: <http://www.yorokobu.es/anatomia-del-selfie/> [Fecha de consulta: 22 de abril de 2015].

33 BORERO, Alejandra y LONDOÑO, Suanny, "Mujer Selfie, construcción de un discurso femenino adolescente mediado por el consumo de la imagen", en $V$ Encuentro Internacional de Investigadores en Publicidad (RELAIP), Alicante, 2016, pág. 114. 


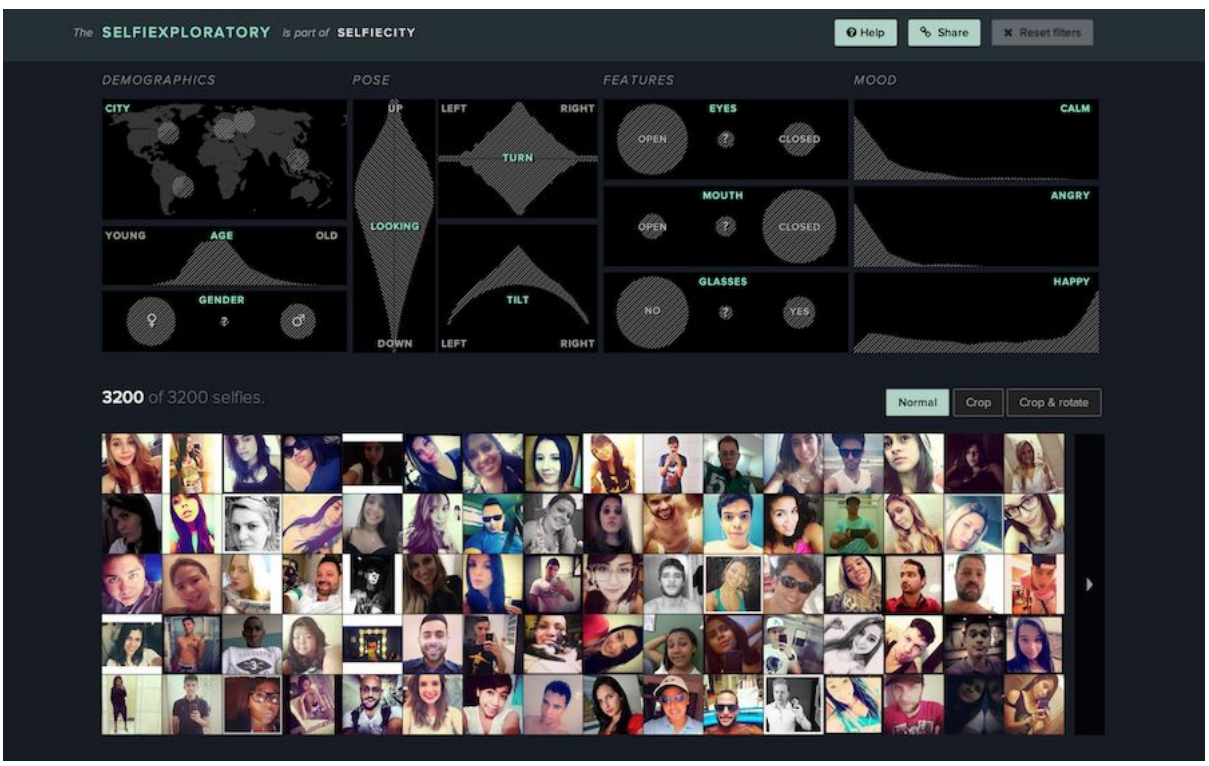

Imagen 7.18: Algunos datos y selfies del proyecto Selfiecity.

\subsubsection{The Adaption to my Generation.}

Destacamos también por (a nuestro entender) su importante relevancia dentro de las claves que intentamos enumerar en nuestra investigación, el interesante e inquietante proyecto de autorretrato diario, The Adaption to My Generation, que desarrolla desde 1998 el artista estadounidense Jonathan K. Keller $^{34}$ (Imagen 7.19). Este tipo de ejercicios, además, ha sido realizado por otros usuarios, también realizándose un selfie diario durante muchos años con el mismo encuadre para mostrar el paso del tiempo, como Noah Kalina, un usuario de YouTube, que en 2012 publicaba una sucesión de autorretratos digitales

34 En un apartado de su página web <http://jk-keller.com/daily-photo/> [Fecha de consulta: 25 de abril de 2015] podemos ver el desarrollo del proyecto, sus imágenes y un time-lapse que muestra, hasta la fecha, el paso del tiempo sobre su rostro a lo largo de 16 años y mediante la sucesión rápida de miles de selfies tomados y publicados por Jonathan durante estos años. 
realizados a lo largo de seis años (Imagen 7.20). "En cinco minutos y cuarenta y seis segundos Noah había resumido parte de sus seis años de vida y de su propia evolución durante este periodo" 35 . En una línea similar destaca el ejemplo del joven Hugo Cornellier, que pasa de niño de 12 años a hombre de 20 y comparte este cambio en Internet: ocho años y medio de selfies que lo reflejan en un vídeo time-lapse ${ }^{36}$ (Imagen 7.21).

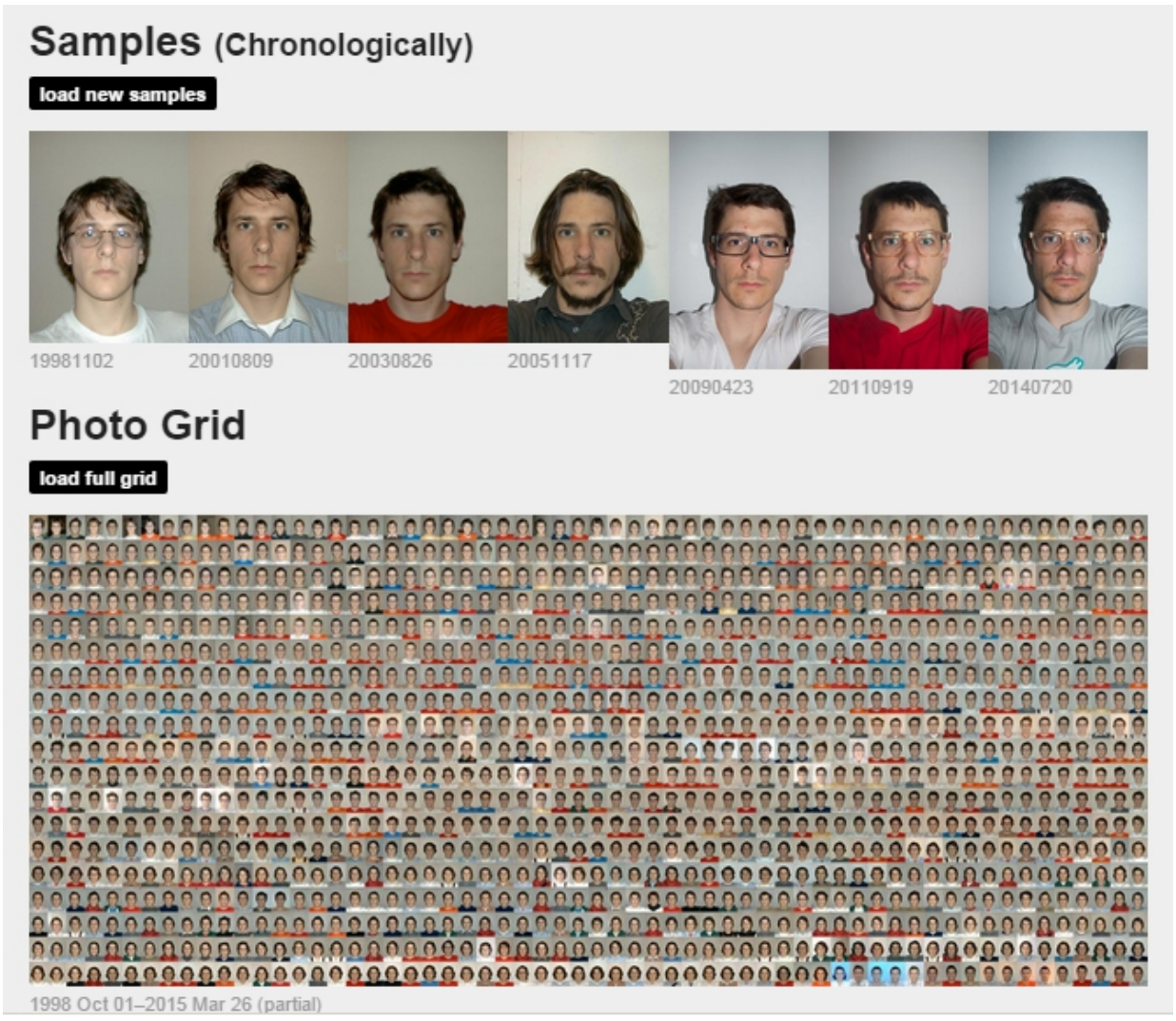

Imagen 7.19: Selfies del proyecto The Adaption to My Generation de JK Keller mostrados en su página web.

35 CALDEVILlA, David, "Las redes sociales. Tipología, uso y consumo de las redes 2.o en la sociedad digital actual”, en Documentación de las ciencias de la información, $\mathrm{n}^{\circ} 33,2010$, pág. 79.

36 VV. AA., "El cambio que reflejan 8 años y medio de selfies”, 2017, disponible en: <http:// videos.elmundo.es/v/o_ab7t4569-el-cambio-que-reflejan-8-anos-y-medio-de-selfies?uetv_pl=virales \&count $=0>$ [Fecha de consulta: 20 de julio de 2017]. 


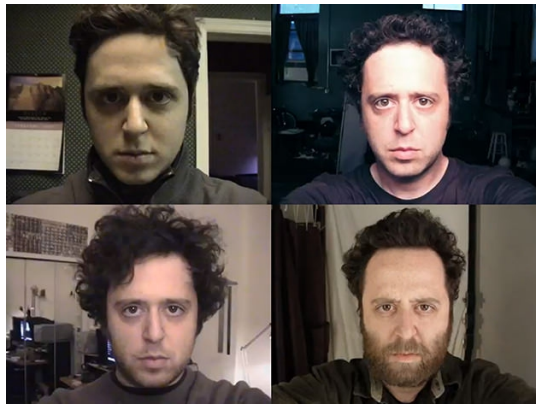

Imagen 7.20: Selfies del proyecto de Noah Kalina.

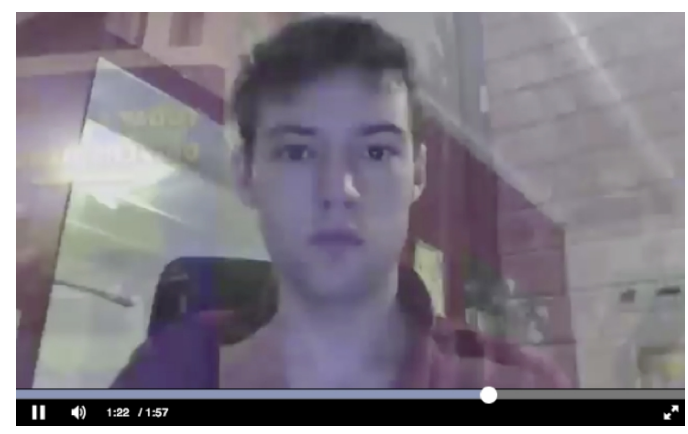

Imagen 7.21: Vídeo del proyecto de Hugo Cornellier.

\section{7•3.3. El yo frente al espejo.}

Ya hemos visto en el capítulo 5 un ejemplo del trabajo de la artista María Cereijo en el que contrastaba sus retratos de una mujer con los selfies realizados por esa propia mujer, poniendo en evidencia la diferencia que podía haber entre ambos rostros en relación a la belleza o a la frescura.

Aprovechamos ahora este apartado para recoger dos ejemplos más (Imagen 7.22 y 7.23) que pueden ayudarnos a definir mejor la intencionalidad de su proyecto artístico, su relación con el selfie y cómo en estas piezas impresas se encuentran relacionadas sus diversas partes ${ }^{37}$.

37 CEREIJO, María, El yo frente a la cámara. Construcción de la imagen mediante el selfie y el retrato fotográfico, Valencia, Universitat Politècnica de València, 2015, pág. 27. 

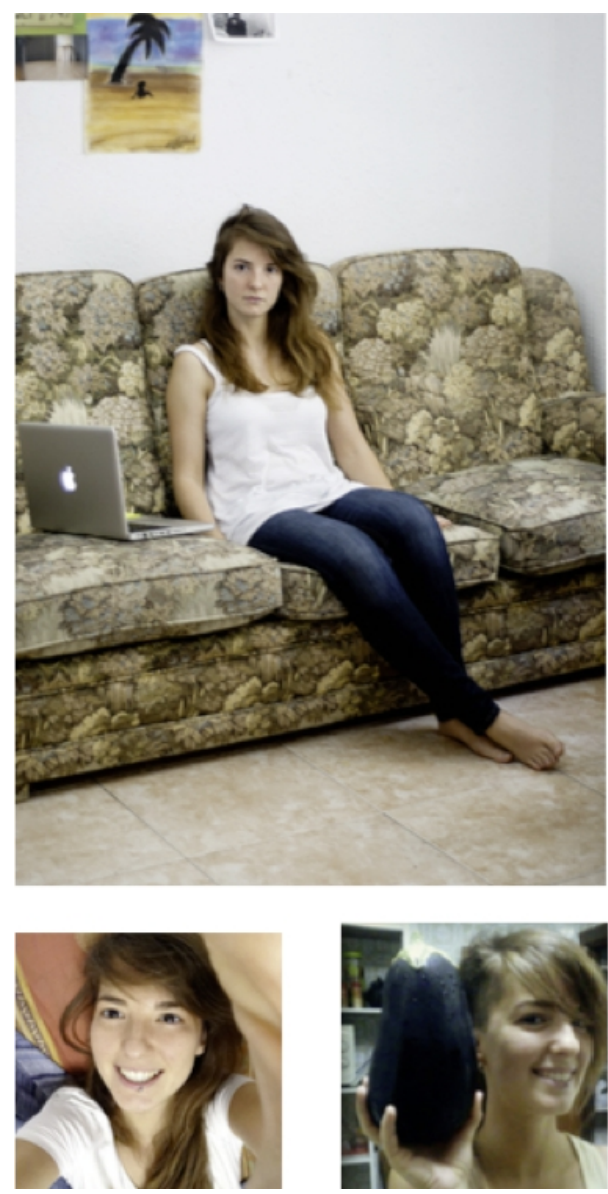

Imagen 7.22: María Cereijo, Lucía. Fuente: El yo frente a la cámara.
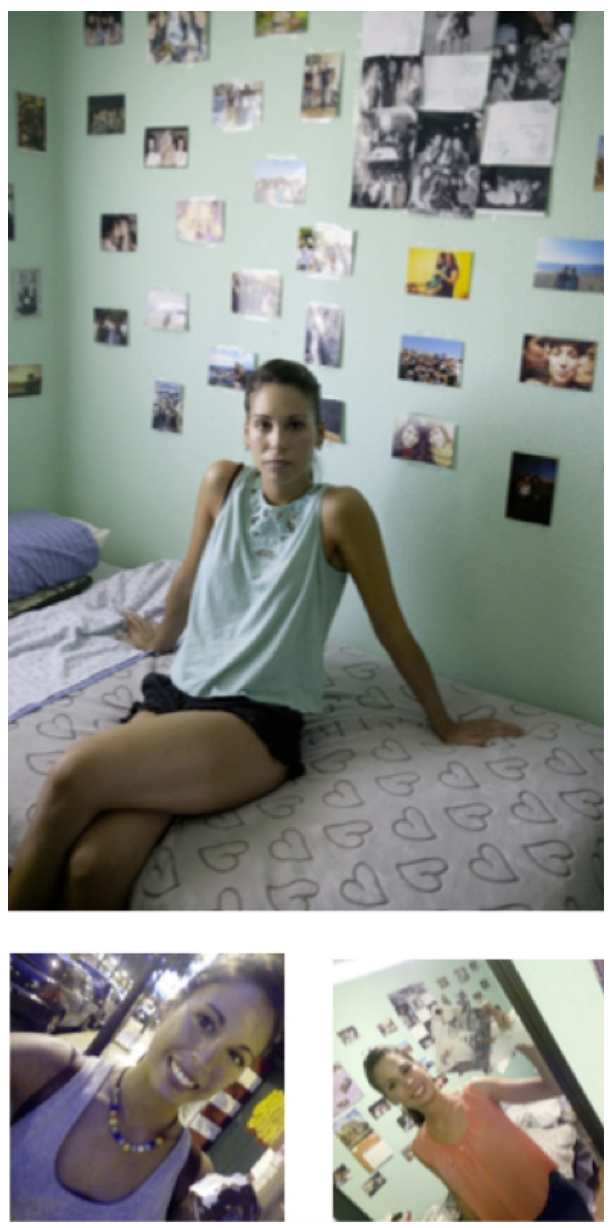

Imagen 7.23: María Cereijo, Susito. Fuente: El yo frente a la cámara.

\section{7·3.4. En torno a la cara.}

También funciona como proyecto artístico que utiliza el selfie como elemento de construcción formal la exposición que realizó Noemí Genaro en la 
Universidad de Granada durante 2013. Su proyecto, Identidad en mano: esta es mi cara (Imagen 7.24), consistía en la recopilación de autorretratos digitales que esta artista invitaba a hacer a jóvenes adolescentes alumnos mediante una serie de premisas relacionadas con la identidad social y con la persecución de un modelo integrante realizado bajo estrategias educativas ${ }^{38}$.
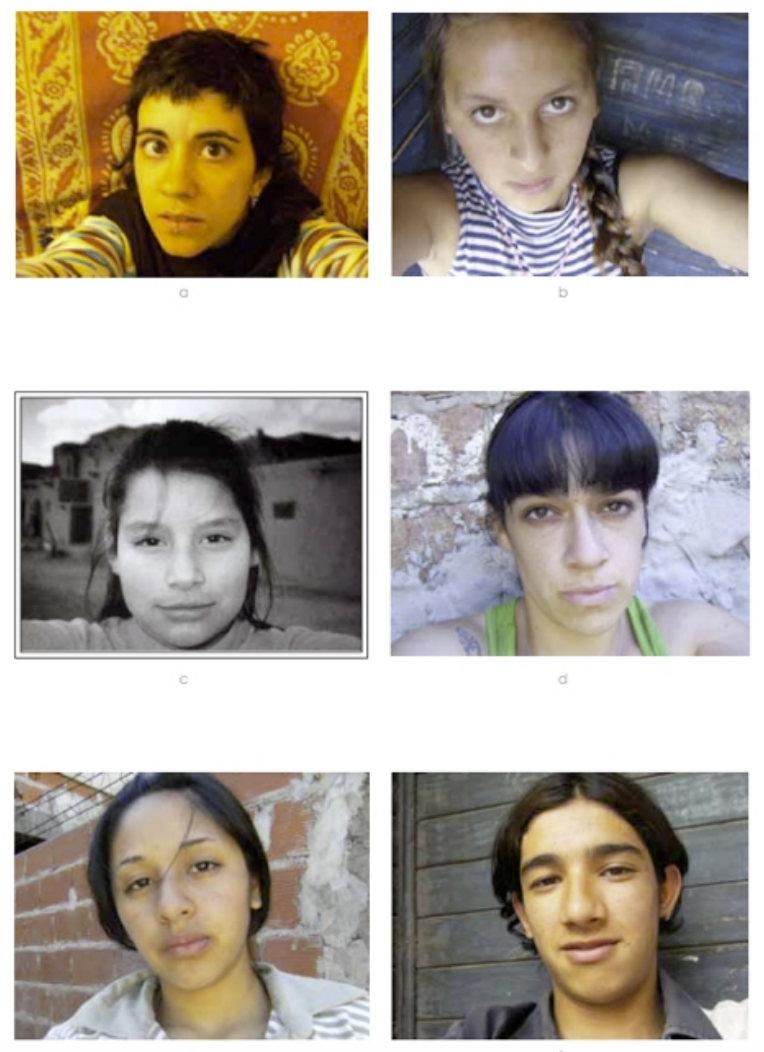

Imagen 7.24: Algunos de los autorretratos realizados por los participantes en el proyecto de Noemí Genaro.

38 GENARO, Noemí, El autorretrato fotográfico como herramienta educativa, Granada, Universidad de Granada, 2013, págs. 244-245. 


\section{7•3.5. Exposición Avatares.}

Por último, dentro de este apartado debemos aludir también a la exposición Avatares que se realizó en clave 2.0 (físicamente pero con herramientas web) en 2010. Fue coordinada por Ángeles Saura Pérez. Un centenar de profesores-artistas de Argentina, Brasil, Bulgaria, Chile, Colombia, Costa Rica, Cuba, España, Estados Unidos, Irán, México, Portugal y Venezuela quedaron conectados a través de la red social NING Educación artística en clave 2.0 ${ }^{39}$ (que cuenta con más de 500 miembros, en su mayoría artistas iberoamericanos).

Los participantes colaboraron a través de la Web para organizar (sin intermediarios) una exposición de autorretratos (posteriormente avatarizados) que les permitiese hablar de arte y conocerse mejor. En voz de Ángeles Saura: "El arte ha sido la excusa perfecta para aprender a trabajar en red y el diseño de Avatares, una excelente ocasión para practicar el uso de todo tipo de herramientas digitales de creación" ${ }^{40}$.

Esta iniciativa (Imagen 7.25) tuvo también un registro en formato vídeo ${ }^{41}$ donde se recogieron los autorretratos digitales publicados para la exposición.

<http://arteweb.ning.com > [Fecha de consulta: 25 de abril de 2015]. 


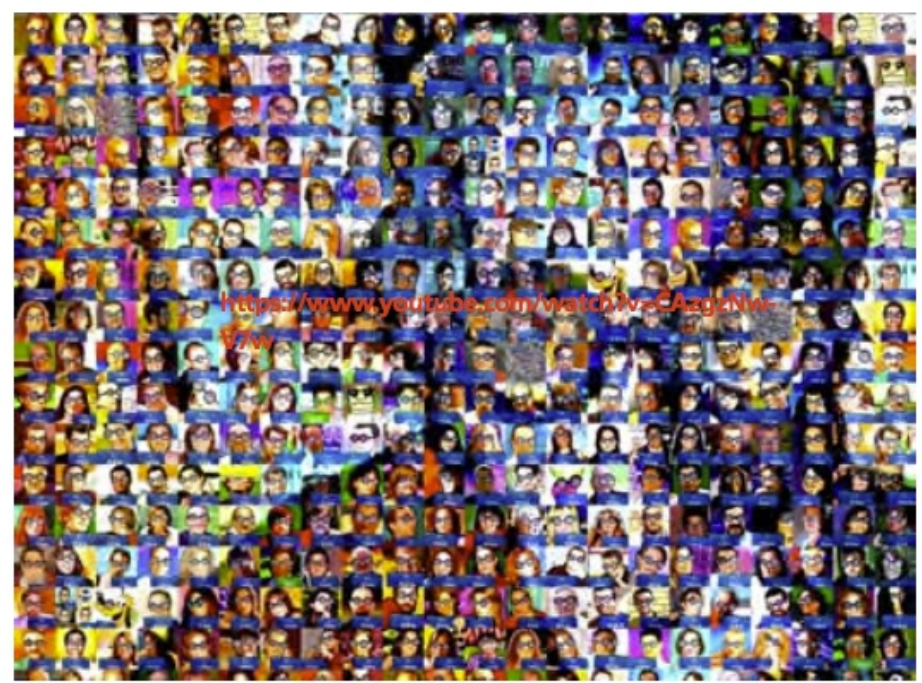

Imagen 7.25: Infografía de Avatares construida por medio de autorretratos digitales.

\subsection{El selfie como simulación o herramienta museística.}

En algunas exposiciones artísticas el selfie se ha conformado como concepto fundamental en su integración dentro del museo (siendo ya considerado como un claro objeto cultural practicado en masa que deja un registro imaginario formal). En estos casos el selfie es simulado y/o invitado a ser practicado como ejercicio susceptible de quedar integrado entre las paredes de algunos museos del mundo. 


\subsubsection{Face to Facebook.}

Los artistas italianos Paolo Cirio y Alessandro Ludovico inauguraron en 2011 la primera de una serie de exposiciones que, de manera itinerante, culminaría el proyecto de una trilogía titulada Hacking monopolismo trilogy. Para realizar esta muestra que denominaron Face to Facebook, los artistas eligieron la compañía Facebook para estudiar su software hasta que detectaron un "agujero conceptual" a partir del cual poder realizar la obra: el desarrollo de la simulación consistió en apropiarse de esa misma red social y, de manera aleatoria, de más de un millón de selfies que representaban las "fotografías de perfil" de los usuarios. Los artistas filtraron dichas fotos por un software de reconocimiento facial y enviaron 250.000 de estos autorretratos de diferentes personas a un sitio web de citas creado por ellos mismos: Lovely-Faces.com (Imagen 7.26). Allí archivaban los rostros según unas pocas categorías sarcásticas y muy limitadas basadas en la expresión del retratado: "trepador", "tranquilo”, “divertido”, "suave”, “astuto” y "presumido”. Así, las imágenes eran remezcladas, recontextualizadas y reutilizadas según la voluntad del software, que al mismo tiempo emparejaba los rostros, ajustándose a la similitud expresiva de cada uno de los usuarios. La fabricación de este sitio web les ocupó dos largos años, y el proyecto resultante lo inauguraron como parte de una instalación en el festival de arte digital Transmediale de Berlín en 2011 (Imagen 7.27). Finalmente imprimieron los rostros usados en la página web en muy pequeño formato sobre un total de tres paneles, acompañados de vídeos que mostraban la página creada y una explicación periodística del proyecto, así como una proyección con esquemas del proceso. Tras la apropiación de un material a priori público, la muestra no estuvo carente de polémica. 


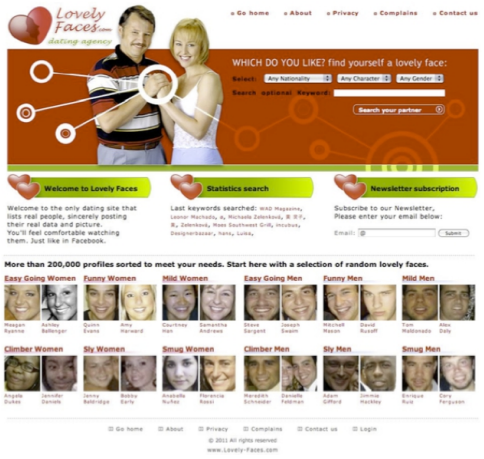

Imagen 7.26: Lovely-Faces.com, sitio web creado por Paolo Cirio y Alessandro Ludovico como medio donde realizar las simulaciones.

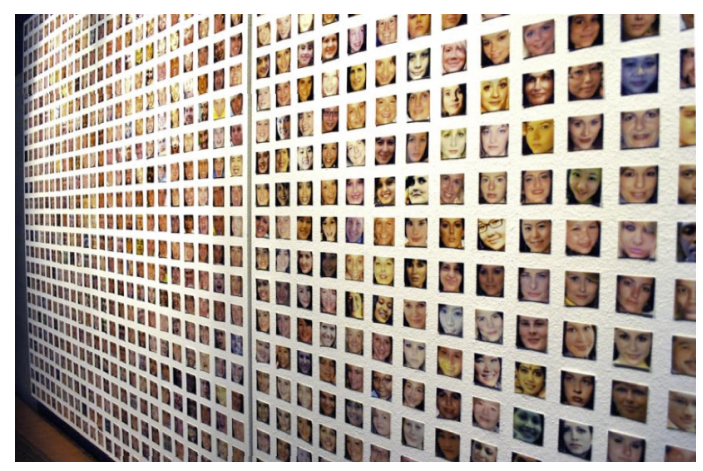

Imagen 7.27: Paolo Cirio y Alessandro Ludovico. Montaje de los selfies y otras fotografías de perfiles sobre panel. En Transmediale (Berlín, Alemania, 2011).

\subsubsection{Selfies realizados en el museo.}

Por otro lado, y enmarcado en lo que podríamos considerar como una práctica artística y expositiva insertada en el contexto museístico, presentamos el proyecto recientemente seleccionado dentro de la convocatoria de mediación cultural TANGENT del Museo de Bellas Artes de Castellò. Dicho proyecto titulado Del autorretrato al selfie (Imagen 7.28), fue desarrollado y expuesto durante 2017 y 2018 en el mismo museo.

El proyecto aunaba un taller y una exposición dirigidos a difundir la cultura visual contemporánea y la creación artística mediante una actividad intergeneracional. Así, partiendo de la idea del autorretrato, se unían dos vertientes: la pintura y la fotografía, haciendo hincapié en "la identidad del yo" y la temporalidad del ser. 
El objetivo se encaminó a la creación de un cuadro de múltiples autorretratos, donde el participante puede dejar huella de su paso por el museo, desarrollando su creatividad y reflexionando acerca de su identidad. La inciativa, como su propio título indica, tuvo en cuenta de manera especial la imaginería del selfie ya asentada culturalmente, y contó con la coordinación y dirección de Nayra López Martos y Ángeles Cózar Moyano ${ }^{42}$.

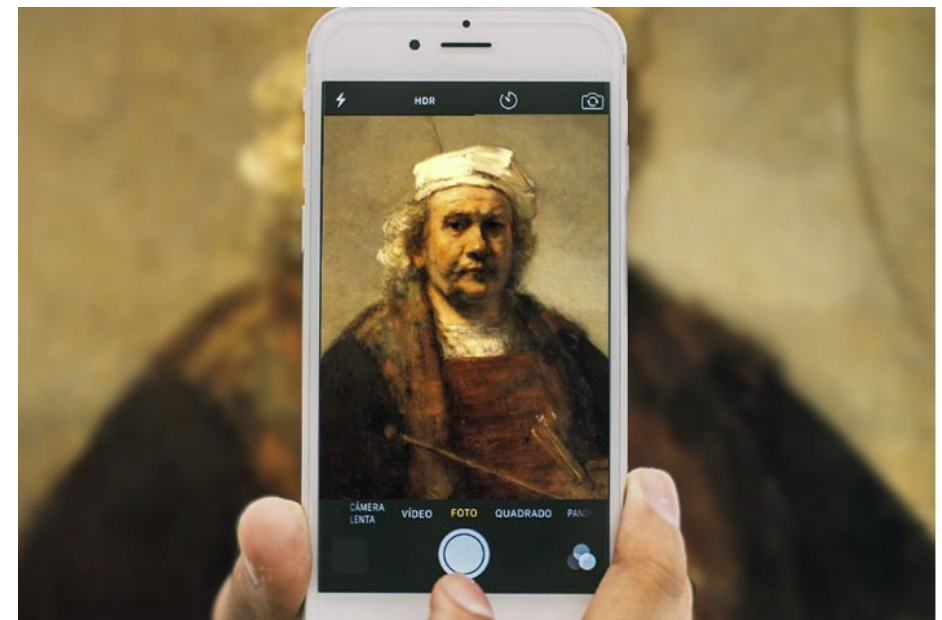

Imagen 7.28: Infografía realizada para la promoción de la actividad por parte del museo y que representa un autorretrato pictórico de Rembrandt que simula, a modo de chiste visual (como veíamos en el capítulo 3), un supuesto (e imposible) selfie del pintor (del pintor pintado) por medio de un smartphone.

42 Se pueden consultar los datos del taller del museo, y en un futuro sus resultados en: <http:// www.consorcimuseus.gva.es/aprende/del-autorretrato-al-selfie/?lang=es $>$ [Fecha de consulta: 20 de septiembre de 2017]. 


\subsubsection{Selfies permitidos en el museo.}

El ejercicio o la práctica del self shot no está muy bien visto en el interior de los museos, bien por cuestiones obvias de atentado al decoro (el acto del selfie banaliza un espacio culto reverencial), o bien por el riesgo que supone para la seguridad (el palo-selfie puede dañar accidentalmente una obra de arte).

No obstante, son algunos los museos que, paradójicamente, fomentan la práctica de esta costumbre cultural de masas cuando los visitantes acuden a las exposiciones. Así, conseguir un selfie que demuestre que se ha estado allí, en una exposición, frente a un cuadro famoso (o frente a su simulación), es la premisa de Art in the Island, un museo físico e interactivo situado en Filipinas (Imagen 7.29) que ofrece al público fotografiarse junto a La Gioconda o con una obra de Van Gogh (réplicas, eso sí), además de muchas otras representaciones, conocidas o no.

\footnotetext{
"De esta manera, la galería asiática hace alarde de transgredir las normas de las instituciones de arte tradicionales donde, en la mayoría de los casos, está prohibido hacerse fotos y, según opinan desde este museo, reducen al espectador a un observador silencioso que no puede interactuar con la obra"43.
}

Además, las redes sociales y la cultura del selfie son el abono ideal para que los espacios que invitan al público a autorretratarse cuelguen frecuentemente el cartel de entradas agotadas.

Por otro lado, la artista japonesa Yayoi Kusama (que suma más de medio millón de imágenes en Instagram de su muestra Infinity Rooms, recientemente

\footnotetext{
43 MORALEDA, Alba, "Cuando el museo quiere que te saques un selfi con el cuadro", 2017, disponible en: $<$ https://retina.elpais.com/retina/2017/12/12/tendencias/1513094758_374018.html> [Fecha de consulta: 20 de diciembre de 2017].
} 
expuesta en el museo The Broad en Los Ángeles) plantea unos espacios expositivos (que funcionan a modo de obra artística) que invitan al espectador a realizarse autofotos dentro de ellos que luego pueden publicar en la red. De hecho, se vendieron más de 50.000 entradas durante la primera hora en la que la exposición fue abierta. En cada una de las seis habitaciones de la exposición (Imagen 7.30), el público formaba parte de la pieza, disponiendo de 30 segundos para obtener una fotografía suya aprovechando los juegos de espejos, luces y colores de la obra de la artista nipona ${ }^{44}$.

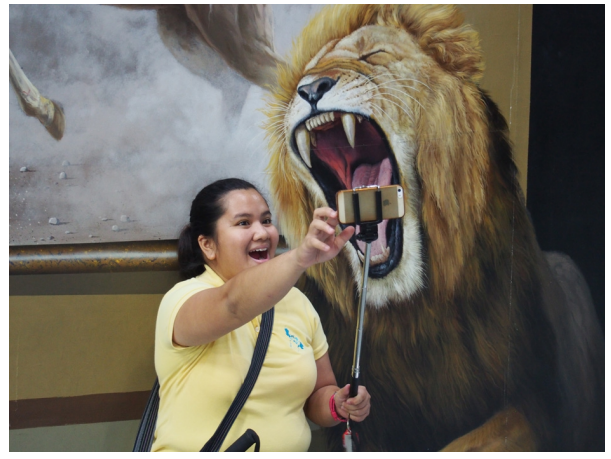

Imagen 7.29: Una visitante del museo Art in the Island de Filipinas se hace un selfie con una de las obras expuestas.

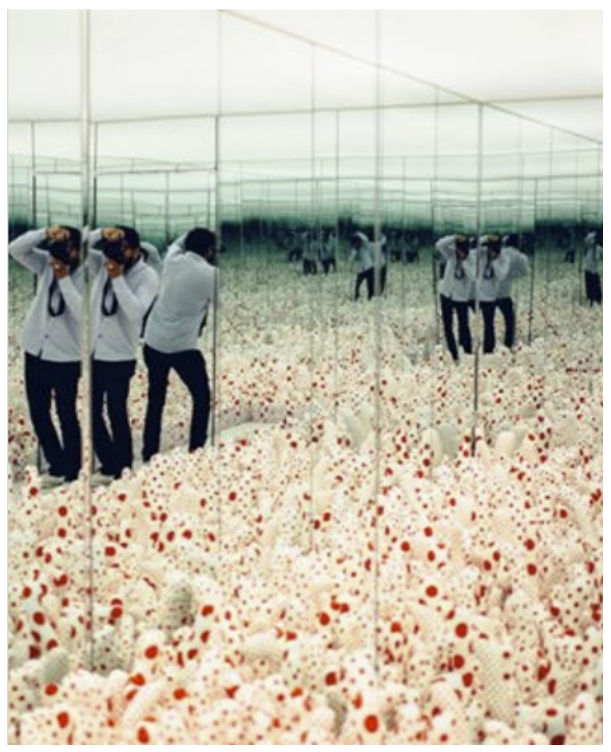

Imagen 7.30: Una de las habitaciones de Infinity Rooms de la artista Yayoi Kusama, con un espectador autorretratado, también como parte performativa de la pieza. 


\subsection{El selfie representado en otras artes.}

Para finalizar y no engrosar una lista que podría incluir muchos más ejemplos, brevemente traeremos un caso de selfie representado en las artes escénicas como marco referencial de una pieza de danza contemporánea (Imagen $7 \cdot 31)$.

En realidad, más que un selfie representado se trata de algo más complejo: por un lado, la representación de hacerse un selfie (como estrategia conceptual y como elemento simbólico a lo largo de los actos del número) y, por otro, una presentación fotográfica y de vídeo a tiempo real mediante las autorrepresentaciones digitales también practicadas por las bailarinas y que igualmente actúan como apoyo conceptual, performativo y visual.

La pieza titulada Re-Bish fue interpretada, además de escrita y coreografiada, por Lucía Soro, Julia Zac e Inka Romaní, bajo la dirección de su propia asociación artística, Las Palmas Colectivo, siendo ofertada en el marco del VII Festival de otoño de artes escénicas Russafa Escènica, entre el 23 y el 24 de septiembre de 2017 en el espacio Imprevisual Galería de Valencia ${ }^{45}$. 

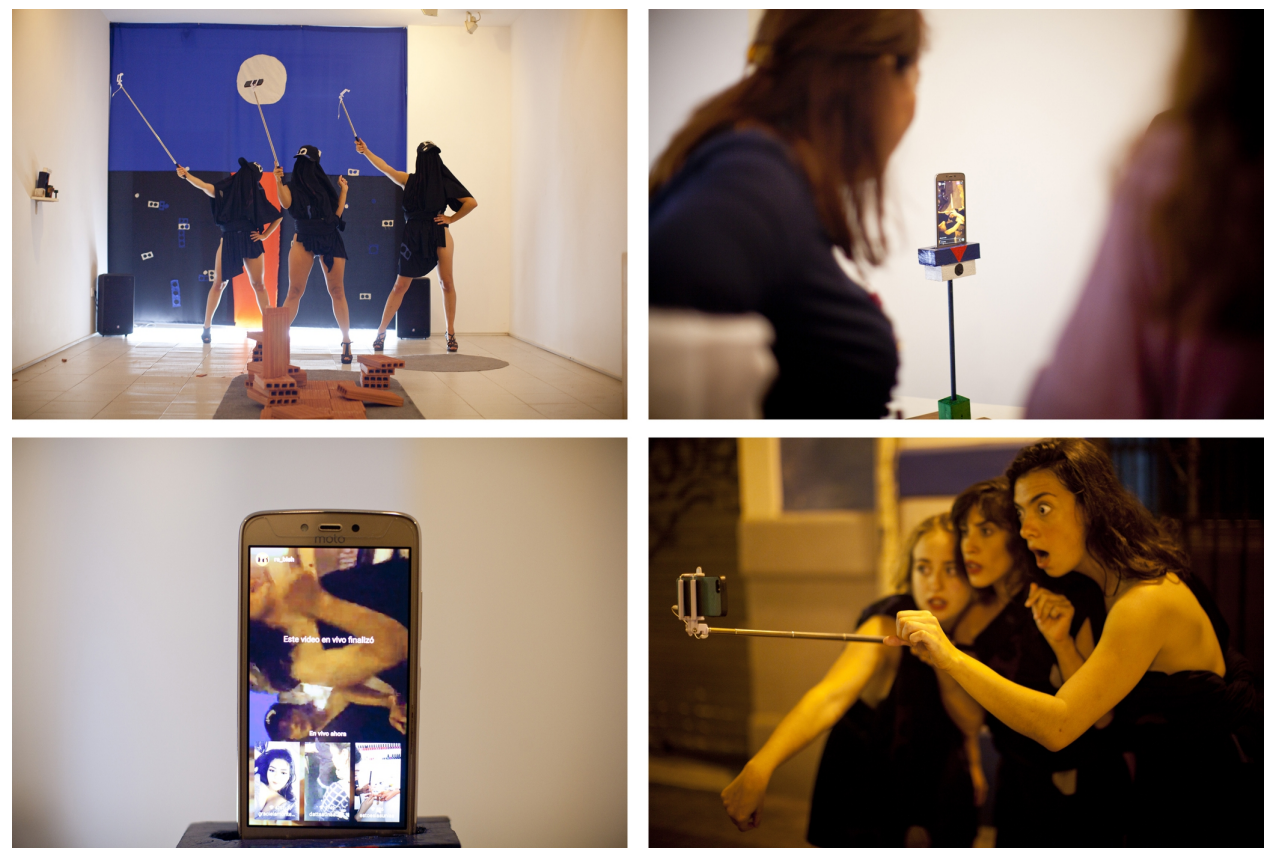

Imagen 7.31: Fotografías que muestran el desarrollo de la pieza de danza contemporánea y performativa $R e$-Bish, que utiliza el selfie como marco referencial y conceptual.

Tras los ejemplos que hemos puesto sobre la mesa a lo largo del presente capítulo, dejamos cerrado (en esta investigación) el espacio que aborda la representación (o presentación, o simulación...) del selfie en el ámbito artístico, museístico, galerístico y/o mercantil, y ello, como nos temíamos al inicio del capítulo, sin haber aclarado de manera determinante el sentido artístico o no de estas iniciativas.

No obstante, sí que hemos constatado que la imagen cultural del autorretrato digital publicado en la red o self shot (y sus variantes y vertientes) está ya tan asentado como imagen cultural y práctica popular reconocible (y en ocasiones reconocida) que puede servir perfectamente como imagen u objeto de 
un ámbito ajeno a su propio soporte natural que es el ciberespacio. Así pues, la presencia del selfie en el espacio físico de la sala de exposiciones podría reafirmarlo, o desintegrarlo, tal y como puede ocurrir (suponemos) con el graffiti extraído de su contexto-calle para disponerlo en el contexto-galería. Pese a ello, su uso supone un paso más (de mano de los artistas) en la interpretación y utilización de las nuevas tecnologías (y sus productos y subproductos), de cara a mostrar otro tipo de mensajes mediante la exposición de unas obras contruidas a partir de los medios más recientemente surgidos:

\begin{abstract}
"Necesitamos artistas que interpreten las nuevas tecnologías, pues únicamente ellos tienen los medios para ir más allá de la tecnología y analizar las motivaciones subyacentes y los impulsos contradictorios inherentes en esta. Solo ellos pueden exponer el significado manifiesto y latente del mundo que ya nos envuelve de manera invisible. Estos artistas son los verdaderos traductores de la cultura contemporánea, revelando lo que sucede realmente en un momento en que nos dirigimos hacia una comprensión muy diferente de la cultura" ${ }^{46}$.
\end{abstract}

Quizá el selfie no necesite para nada la pretendida ayuda de los artistas, o quizá sí. En todo caso dejamos aquí este repaso (posiblemente más anecdótico que reflexivo) sobre el selfie y su relación con el arte sin entrar a valorar si un selfie en su contexto original (Internet y las redes sociales) en tanto que es una fotografía (o algo similar) puede o no puede ser un objeto artístico en sí mismo. En cualquier caso, el arte va a seguir estando presente en los ámbitos de la vida y de la creación humana mientras esta no desaparezca ${ }^{47}$.

\footnotetext{
46 KAUFFMAN, Linda S., Malas y perversos. Fantasías en la cultura y el arte contemporáneos, Madrid, Cátedra, 2000, pág. 13.

47 FISCHER, Ernst, La necesidad del arte, Barcelona, Nexos, 1985, pág. 270.
} 
Los orígenes adolescentes del selfie y su representación en el arte y en los medios de masas

$-486-$ 


\section{EL SELF SHOT PUBLICADO EN FORMATO LIBRO}

No me gusta hablar de mí.

KIM KARDASHIAN, Brainy Quote, 2017.

A lo largo de las páginas que componen el capítulo anterior hemos podido revisar mediante un puñado de ejemplos cómo el selfie y el resto de self shots o autorretratos digitales publicados en la red pueden dar un salto desde su propio medio y soporte hasta espacios físicos que los disocien de ese lugar que les corresponde y donde, de manera natural, deben habitar (el ciberespacio). Esos espacios físicos de los que hablamos han sido los más relacionados con el ámbito artístico expositivo. Nos referimos a salas, museos, galerías... Sin embargo, no hemos incidido en otro soporte del mundo material que, durante años y antes de la llegada de la fotografía digital, había sido un perfecto y familiar habitáculo para la imagen fotográfica emergida y que, tras el sísmico cambio de paradigma que sustituiría la química por la electrónica y los haluros de plata por fotositos y píxeles, parecía haber quedado en un aparente olvido. Hablamos del formato libro o catálogo. Un lugar aparentemente cada vez más obsoleto entre tanta pantalla LCD y archivo PDF y JPG, y por supuesto mucho más ajeno a un tipo de ejercicio fotográfico que nace desde lo digital y que, a priori, nada se le ha 
perdido entre las páginas de un volumen matérico. No obstante, es nuestro deseo traer aquí cuatro ejemplos que consideramos pertinentes en tanto que muestran selfies que han conseguido dar el salto también hasta la física palpable y quedar plasmados sobre esa celulosa que tan paradójica les resulta como superficie de existencia y visualidad. Iniciaremos estas contribuciones que, entre libro y diario también plantean una timeline de las vidas de las selfshooters protagonistas, y lo haremos haciendo alusión a una de las semillas primigenias del autorretrato digital adolescente publicado en la red y que con rapidez fue editorialmente reconducida al formato de libro fotográfico: Natacha Merritt.

\subsection{Los diarios digitales de Natacha Merritt.}

Natacha Merritt es una pionera en el ámbito del autorretrato digital publicado en la red (y sobre papel). La mayoría de sus trabajos fotográficos, que empieza a realizar con tan solo dieciocho años de edad, están cargados de erotismo y sensibilidad a través de la autorrepresentación de su cuerpo desnudo, frente al espejo o no, en compañía o no... Incluso algunas de sus fotografías pueden catalogarse como imágenes pornográficas. Pero por encima de esto, las recopilaciones digitales que hace Merritt responden a la creación de un diario basado en imágenes fotográficas y en el uso personal de las mismas, unas imágenes que se desarrollan desde la experimentación y que empezó a poner en práctica desde finales de los años 90 del siglo pasado, gracias a las primeras y precarias cámaras digitales caseras que por aquellos años comenzaban a entrar tímidamente en el mercado.

“Tomé mi primera fotografía erótica en 1997. Mi novio de por entonces (yo debía de tener dieciocho o diecinueve años) me dio una de sus cámaras digitales y yo empecé 
de inmediato a sacar fotos de nuestra vida sexual. La tecnología era tan nueva que los fotogramas tenían una resolución bajísima, de 340 por 480 (el tamaño de las miniaturas actuales). No tenía flash, ni tarjeta de memoria: cada veinte fotos tenía que parar y pasarlas a un disquete, porque ni siquiera tenía ordenador. Aun así me enganché de inmediato. La cámara, a su vez, hizo más interesante el sexo; aquellos escasos píxeles amplificaban las sensaciones"1.

Ciertamente Merritt empezó a trabajar con cámaras digitales precarias que producían imágenes de baja resolución y, por tanto, de escasa nitidez y detalle. Son fotografías ruidosas y pobres, sin embargo, tal como se puede apreciar (Imágenes 8.1, 8.2 y 8.3), esto no resta calidad a las sensaciones que nos transmiten estas autorrepresentaciones, fruto de la recién nacida cámara fotográfica de sensor electrónico. Estas imágenes, tan novedosas y difíciles de entender para todos aquellos que aún poseían aquella cultura visual basada en los productos de las cámaras de película argéntica, nos siguen sugiriendo erotismo, privacidad íntima, proximidad y belleza.

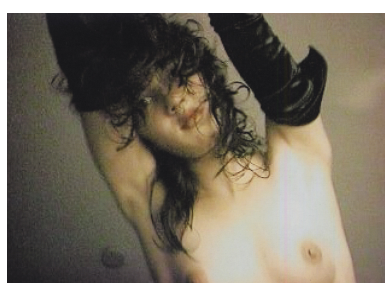

Imagen 8.1: Natacha Merritt, Erotica15.jpeg, 1998.

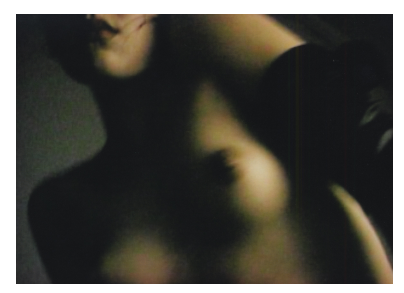

Imagen 8.2: Natacha Merritt, Painted nipples, 1998.

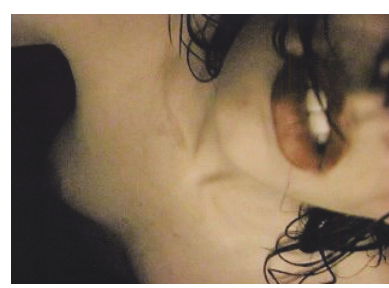

Imagen 8.3: Natacha Merritt, Lips parted.JPG, 1998.

$1 \quad$ VV. AA., The new erotic photography, Colonia, Taschen, 2005, pág. 393. 
Aunque Natacha Merritt comenzó a realizar este tipo de ejercicios ${ }^{2}$ para producir fotografías de uso personal ("Creo que he hecho una foto verdaderamente erótica cuando esa imagen consigue excitarme a mí. Lo digo en serio: las fotos que saco son para mí. Descubrir ángulos, facetas, momentos que antes no había sido capaz de apreciar es algo que me excita”3), pronto empezó a hacer públicas estas recopilaciones en la red, mostrándolas en su fotoblog personal, uno de los primeros que surgieron tras la implementación de la Web 2.o y que empezaron a deslumbrar a esa nueva raza de voyeurs cibernéticos. Fue así como la descubrió Eric Kroll, un fotógrafo especializado en erotismo que acabaría por presentarla a la editorial Taschen, donde él mismo ya publicaba sus propios trabajos. Nacerá así en el año 2000 un libro de fotografías con gran repercusión e importancia: Digital Diaries ${ }^{4}$, donde Natacha Merritt publicará los trabajos realizados hasta la fecha. El libro constituirá el primer ejemplo de self shot expuesto en el ámbito de la edición artística. Dian Hanson, la editora, habla de la autora:

"En 1998, Eric Kroll me enseñó una foto desenfocada, evidentemente un autorretrato de una joven de dulces rasgos entregada a actividades bastante sucias. Fue uno de los primeros desnudos digitales que vi, y Eric estaba convencido de que la fotógrafa iba a llegar muy alto. Digital Diaries, con su irresistible combinación de curiosidad juvenil, sana belleza y erotismo ajeno a todo tipo de límites, le dio la razón e hizo de Natacha Merritt la más cautivadora e influyente pionera de la fotografía en la nueva era digital" 5 .

2 Ejercicios experimentales de descubrimiento del cuerpo y de la sexualidad que, como hemos visto anteriormente, no dejan de ser una práctica natural para algunos jóvenes que se encuentra propiciada por el propio dispositivo digital, algo que en su día también se produjo a nivel analógico con la cámara Polaroid. Dicha práctica viene determinada por la naturaleza de la producción de las imágenes: básicamente por la no necesidad de procesos de revelado por parte de terceros y por la fácil posibilidad de destrucción que poseen.

3 VV. AA., op. cit., pág. 393.

4 MERRITT, Natacha, Digital Diaries, Colonia, Taschen, 2000.

5 VV. AA., op. cit., pág. 393. 
Digital Diaries contiene una selección de fotografías que son fruto de los tres primeros años de producción de Natacha Merritt. Con posterioridad seguirá trabajando y desarrollándose como artista, de hecho en la actualidad continúa realizando y publicando estos ejercicios siempre construidos en una línea similar. No obstante, Digital Diaries supuso un hito. En sus páginas, organizadas cronológicamente, no solo vemos la evolución de su discurso y el resultado de la experiencia adquirida con el paso de las series, también podemos apreciar la evolución técnica de las imágenes, fruto de las diferentes y novedosas máquinas que Merritt va adquiriendo. De este modo, el auge competitivo en el desarrollo de la fotografía digital queda reflejado en fotografías cada vez más nítidas y coloristas.

Pero la huella de la máquina no está presente solo en sus resultados técnicos: como podemos observar en algunas de sus obras (Imágenes 8.4 y 8.5), Merritt empieza a practicar esos nuevos encuadres propios de los autorretratos digitales que años más tarde inundarán la red en forma de self shots y que, como hemos visto anteriormente, son perspectivas compositivas diferentes a las establecidas en otras eras de la fotografía, unas composiciones que, más que capricho del fotógrafo, constituyen resultados propiciados por las nuevas máquinas poseedoras de esa visión directa y/o visión reflejada que estudiamos en el capítulo 3.

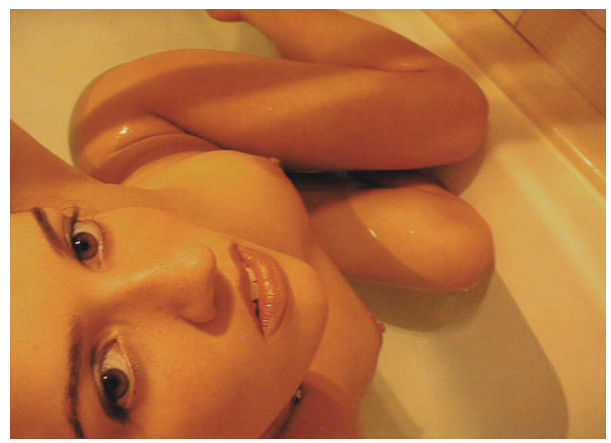

Imagen 8.4: Natacha Merritt, AGFOOO12.JPG, 1999.

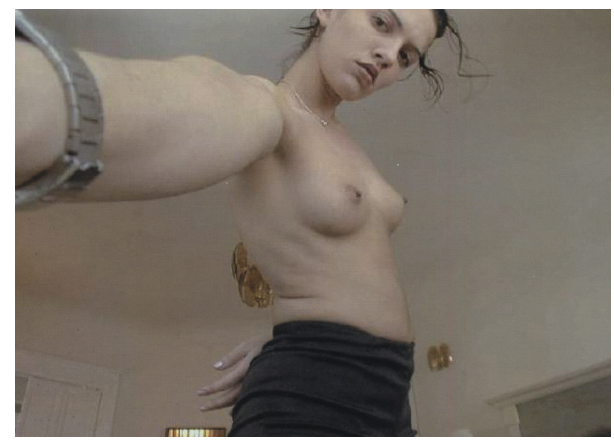

Imagen 8.5: Natacha Merritt, Reachtif, 1999. 
Natacha Merritt, nuestra Francesca Woodman contemporánea de la era digital, incluso se ve abocada a disparar contra el espejo (Imágenes 8.6 y 8.7). No obstante, ni sus mirrorpics, ni sus anteriormente citados selfies van a ser la inspiración de los futuros adolescentes que los practiquen, desconocedores casi con total seguridad del trabajo de esta fotógrafa autorretratista digital. La tendencia a utilizar estas nuevas formas fotográficas, así como los nuevos usos íntimos de la captación de la imagen propia, serán una patrón, tal como hemos comentado, promovido no por otro ser humano, sino por la máquina que este ha inventado.

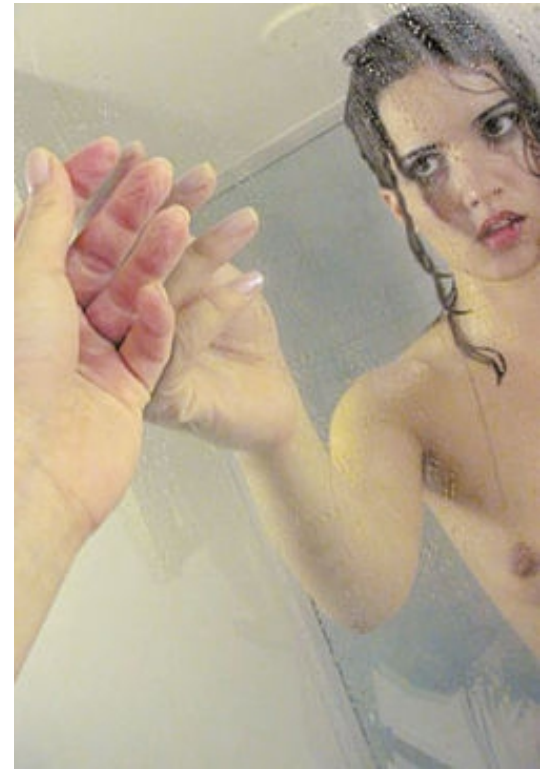

Imagen 8.6: Natacha Merritt, 97-99_self seacho40.jpg, 1999.

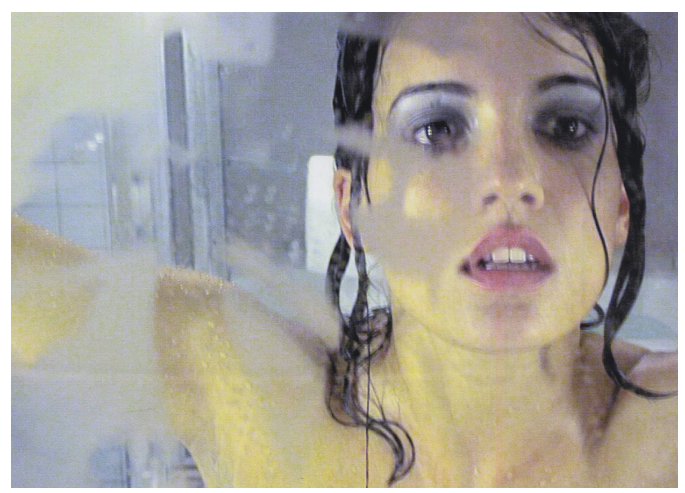

Imagen 8.7: Natacha Merritt, 9-7-99_self seach041.jpg, 1999. 


\subsection{Sasha Grey: Neü Sex.}

Neü Sex es otro ejemplo algo más contemporáneo de self shots editados en formato libro. Este, al igual que el ejemplo anterior, cumple las funciones de un diario fotográfico, que en este caso narra las peripecias de carretera y moteles de su protagonista: Sasha Grey.

Sasha fue una actriz pornográfica que, con tan solo dieciocho años de edad, destacó especialmente en la industria norteamericana si tenemos en cuenta el poco tiempo que ejerció esta profesión: tres años tras los cuales, en 2011, anunciaba su retirada. Durante esa etapa cosechó premios y fama. Actualmente, se dedica a diferentes actividades ejerciendo como modelo, como actriz en largometrajes comerciales e independientes y también como cantante y músico. En 2013 escribió una novela titulada La sociedad Juliette, traducida a varios idiomas y editada en España por Grijalbo ${ }^{6}$.

Tras abandonar el mundo de la pornografía, Sasha publicó Neü Sex , un libro autobiográfico con muchas fotografías y algo de texto que muestra, a través de sus autorretratos digitales, aquellos días en los que colaboraba con la industria de las tres equis y lo que acontecía entre rodaje y rodaje. Curiosamente, este diario cargado de imágenes no contiene ninguna referencia pornográfica, aunque la mayoría de fotografías son especialmente eróticas, desenfadadas e irreverentes. De hecho, son el reflejo de la creatividad y juventud de su protagonista. Si analizamos el contenido del libro, observaremos que una gran parte de sus fotografías son autorretratos, realizados en espejos de cuartos de baño, de habitaciones de motel, en la carretera, entre bambalinas... Todo al más

6 GREY, Sasha, La sociedad Juliette, Barcelona, Grijalbo, 2013.

7 GREY, Sasha, Neü Sex, Nueva York, Vice Books, 2011. 
puro estilo self shot: cámara digital en mano, produciendo mirrorpics y selfies (Imágenes 8.8, 8.9 y 8.10). La actriz no pensaba editar con todo este material un libro, ya que consideraba estas imágenes como ejercicios personales de registro, o como muestras para compartir en Internet. Pero finalmente se decidió, y hay que reconocer la coherencia que adquieren estas fotografías cuando se muestran sobre el formato impreso y cosido. Neü Sex fue editado en Nueva York por Vice Books, y aunque posteriormente editoras de otros países han puesto en el mercado ediciones más modestas del compendio, su edición original es hoy en día una pieza de coleccionista que alcanza precios elevados en el mercado de segunda mano.
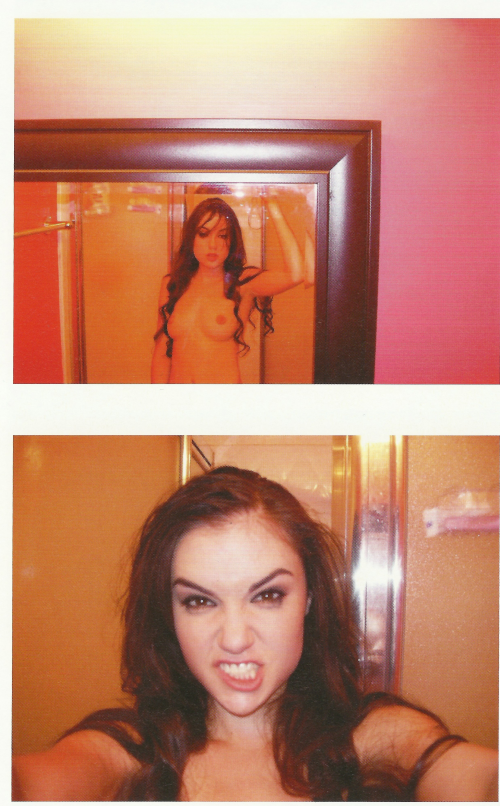

Imagen 8.8: Sasha Grey, autorretratos realizados entre 2009 y 2011.
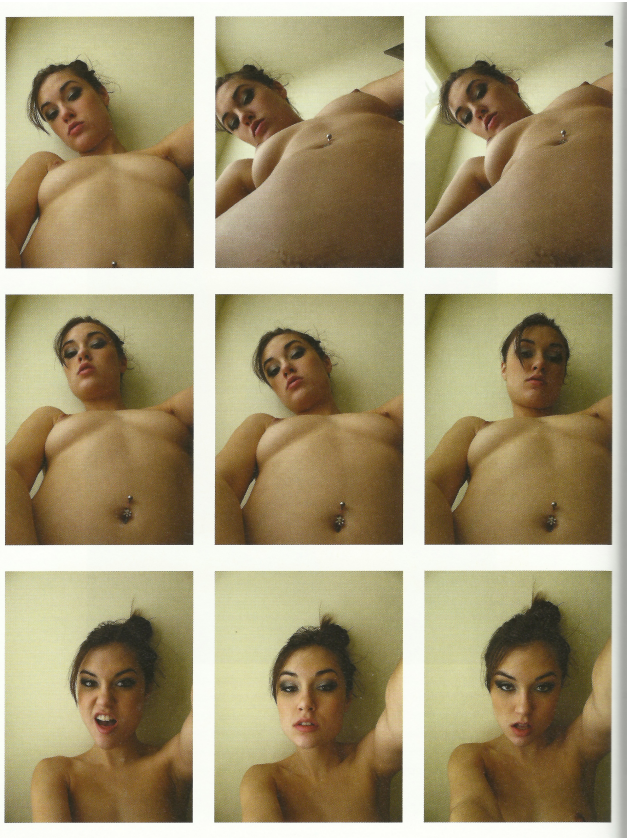

Imagen 8.9: Sasha Grey, autorretratos realizados entre 2009 y 2011. 
Sasha Grey no es la primera actriz o modelo que se que se practica autorretratos digitales de corte erótico o vinculados al género del desnudo ${ }^{8}$. Tampoco es pionera en experimentar con su cámara digital y, a modo de diario, publicar sus pruebas en un libro (vimos antes que ella a Natacha Merritt). Sin embargo, Neü Sex de Sasha Grey es un buen ejemplo contemporáneo de lo mucho que puede repercutir un ejercicio tan sencillo y aparentemente banal como es el self shot en el campo de la publicación institucional y del libro fotográfico.
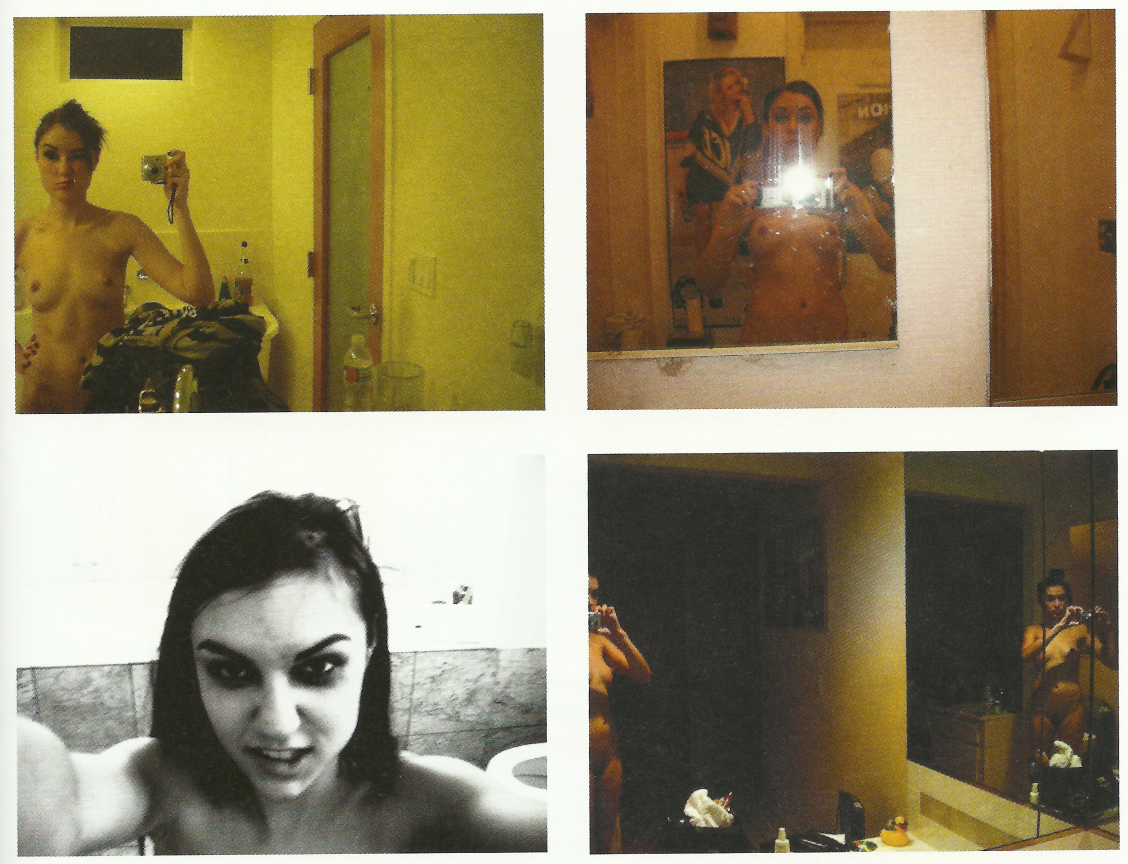

Imagen 8.10: Sasha Grey, autorretratos realizados entre 2009 y 2011.

8 Tenemos, entre muchísimas otras, a su compañera de profesión Alina Li (Imagen 8.11) y a la modelo británica de fotografía erótica Mellisa Clarke (Imagen 8.12), que si bien no han editado libro impreso, sus autorretratos frente a espejo o con cámara girada inundan la red tras ser publicados voluntariamente por ellas en espacios que lo permiten (quedarían descartadas, como hemos visto, redes sociales que apliquen censura como Facebook o Instagram, pero no las que posibiliten la muestra de estas partes del cuerpo prohibidas, como Twitter o Tumblr). 


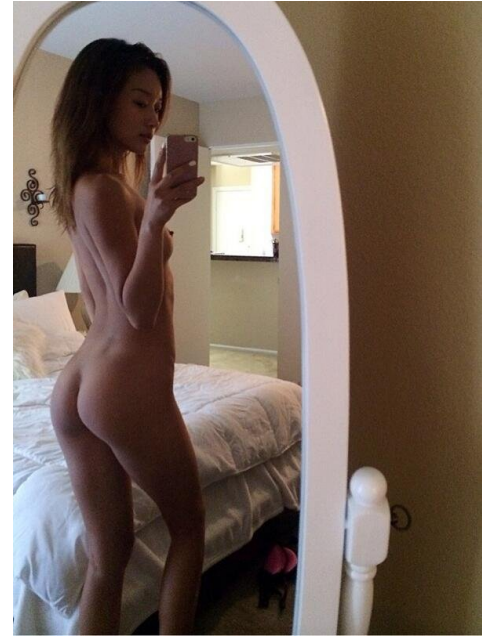

Imagen 8.11: Alina Li, mirrorpic realizado en 2015. Un ejercicio parecido a los que realizara Sasha Grey tres años antes, pero de mayor calidad de imagen al estar capturada con un dispositivo más novedoso. Alina tenía veintitrés años cuando realizó esta fotografía.

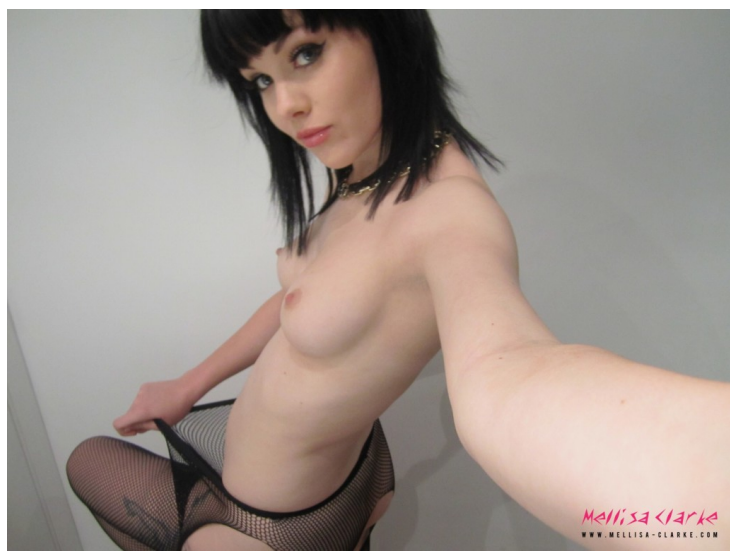

Imagen 8.12: Autorretrato de Mellisa Clarke, 2011. Un autorretrato con cámara en mano, que representa otro ejemplo de las nuevas perspectivas compositivas del selfie y que son generadas por los nuevos dispositivos de captura digital y el uso que se les da.

\subsection{Las modelos autorretratadas de Uwe Ommer.}

Otro catálogo fotográfico, Do It Yourself de Uwe Ommer ${ }^{9}$, es un tercer ejemplo que, pensamos, merece ser nombrado. No obstante, destacaremos que se aleja ligeramente de las prácticas anteriores. Ommer, afamado autor erótico, fotografía mujeres desnudas de diferentes partes del planeta. Sus libros fotográficos están disponibles en casi cualquier librería especializada. Acostumbra a mostrar imágenes de desnudo protagonizadas por vigorosas y 
desarolladas modelos que, sin embargo, suelen posar calmadas y nostálgicas. En cierto sentido puede recordar a un Helmut Newton descafeinado y en color. Pero en Do It Yourself no interviene (supuestamente) la mano de este fotógrafo. Ommer brinda a sus modelos la posibilidad, por medio de sus equipos fotográficos y algunas indicaciones técnicas, de intervenir en las imágenes. En boca de la editorial:

\begin{abstract}
"Inspirado por el día en que sorprendió a la canguro haciéndose fotos frente al espejo del baño con su Polaroid, el fotógrafo Uwe Ommer decidió hacer un libro de autorretratos eróticos de fotógrafas inexpertas. De modo que armó a las participantes del experimento con cámaras, les dio unas instrucciones técnicas básicas y les pidió que se fotografiaran como mejor les pareciera, liberadas, por así decir, de su ojo voyeur de fotógrafo. Unas decidieron hacerlo con espejos, mientras que otras se desenvolvieron con la cámara sin ayuda de su reflejo. Mientras que muchas de ellas se las arreglaron solas, en otros casos Ommer hizo de «fotógrafo fantasma» ayudándolas con la iluminación y otros detalles técnicos. En cualquier caso las modelos fueron en todo momento libres de expresarse con la cámara como quisieran, poniéndose desde sexis y provocativas hasta románticas o naturales” ${ }^{10}$.
\end{abstract}

El libro contiene infinidad de autorretratos femeninos realizados por diferentes modelos y con diferentes máquinas. En algunas fotografías la cámara no es visible, ya que la modelo se sitúa enfrente de ella, a una distancia prudente (dos o tres metros), efectuándose el registro por medio de un disparador remoto. El resultado es un conjunto de autorretratos fotográficos convencionales. Sin embargo, también encontramos una gran cantidad de mirrorpics, en los que la modelo se enfrenta directamente a su reflejo, y la cámara queda representada en la escena. Algunas de estas imágenes son mirropics auténticos, realizados con cámaras digitales y ofreciendo imágenes complejas e interesantes en composición (Imagen 8.13). Muchos otros autorretratos de la publicación son en

10 Sinopsis del catálogo extraído de la página web de Taschen que puede consultarse en: <http:// www.taschen.com/pages/es/catalogue/photography/all/45716/facts.uwe_ommer_do_it_yourself.ht $\mathrm{m}>$ [Fecha de consulta: 16 de julio de 2016]. 
blanco y negro, realizados con cámaras de película (Imágenes 8.14 y 8.15), aunque dada la asimetría con la que la máquina se presenta en la imagen respecto a sus bordes, podemos intuir la mano del fotógrafo en lo concerniente a reencuadre (seguramente durante las ampliaciones de esas fotografías de naturaleza química). En otros ejercicios de supuesto autorretrato, sin embargo, su manufactura es más evidente: en este falso y simulado mirrorpic (Imagen 8.16), podemos adivinar la posición desde la que el fotógrafo disparó su cámara, siendo esta imagen fruto de ella y no de la máquina que sujeta una de las modelos. Como hemos visto en el capítulo 3, en un mirrorpic auténtico la cámara siempre es paralela a los bordes de la imagen, ya que presenta un punto de vista paralelo al plano de la lente, no pudiéndose ver nunca los laterales del dispositivo.

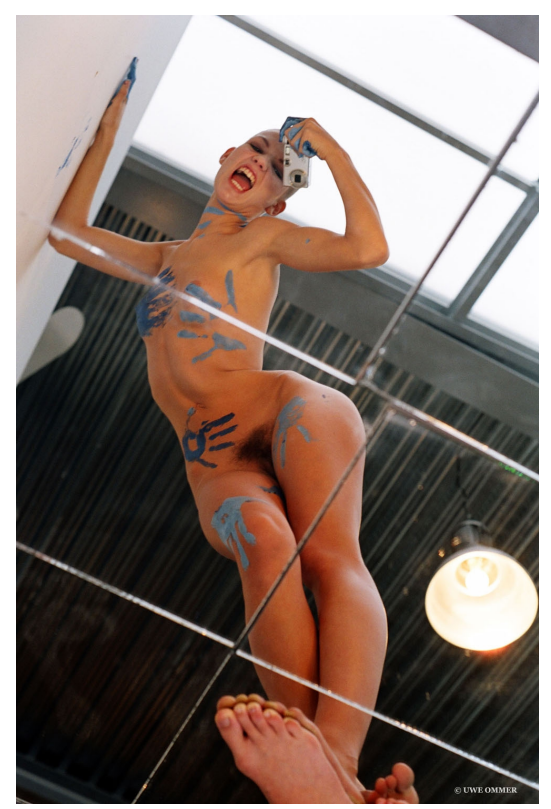

Imagen 8.13: Anónimo, Autorretrato, fecha desconocida ${ }^{11}$.

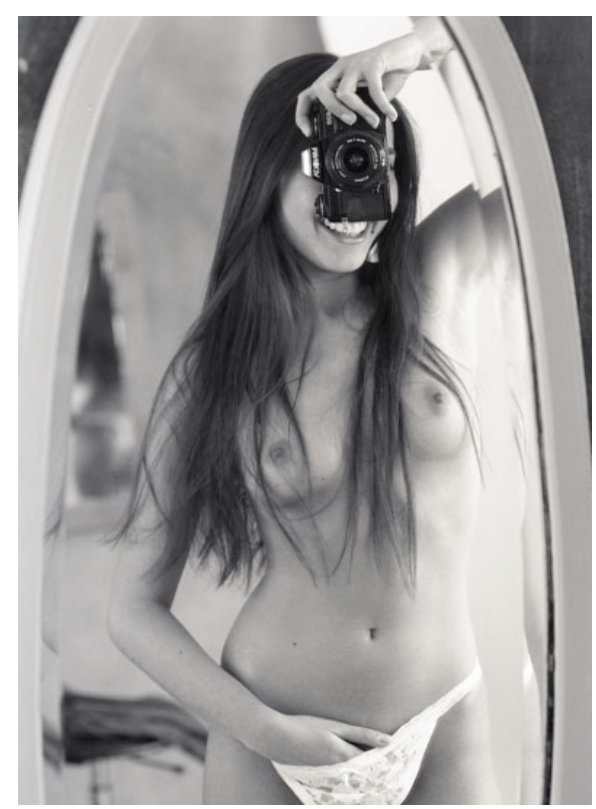

Imagen 8.14: Anónimo, Autorretrato, fecha desconocida.

11 No hemos encontrado, de momento, ni el nombre de las modelos que se autorretratan, ni el título de las fotos, ni la fecha de su realización. 


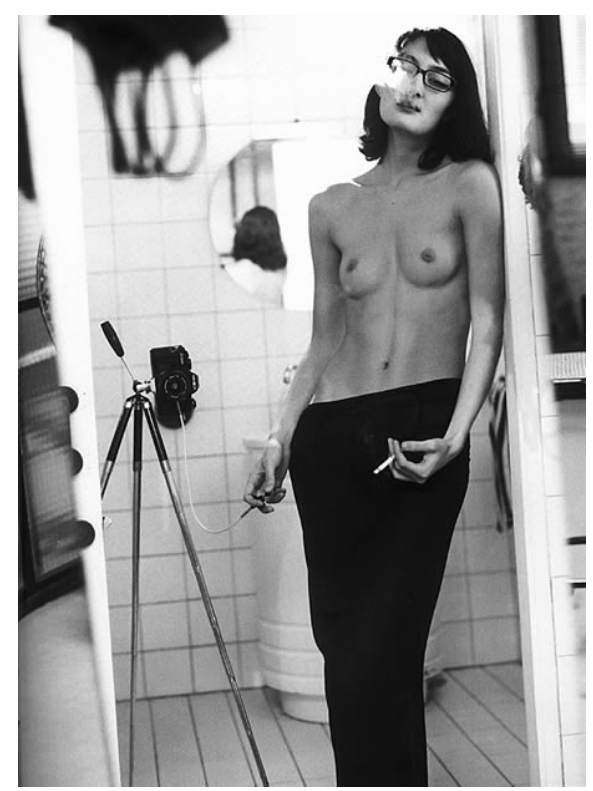

Imagen 8.15: Anónimo, Autorretrato, fecha desconocida.

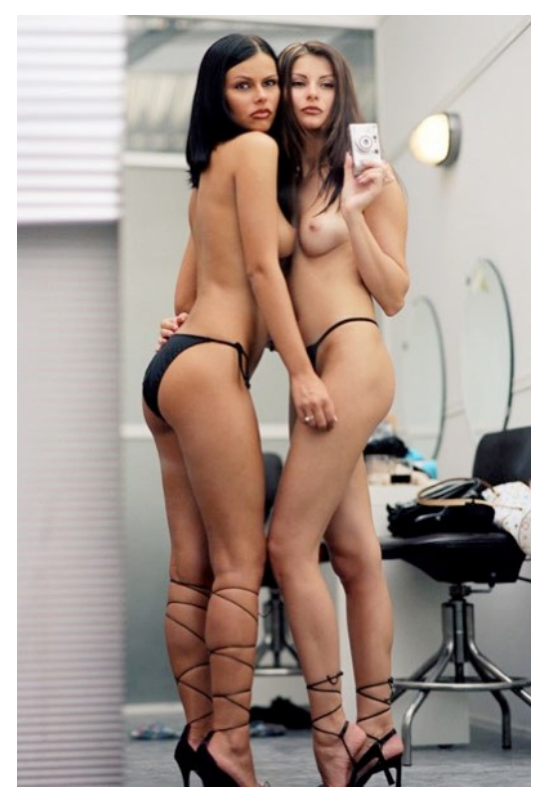

Imagen 8.16: Anónimo, Autorretrato, fecha desconocida.

\subsection{Selfish, por Kim Kardashian.}

Kimberly Noel Kardashian West, más conocida como Kim Kardashian (Los Ángeles, 21 de octubre de 1980), es una empresaria y un personaje público estadounidense de telerrealidad. Su verdadero salto a la escena pública y al mundo de la fama fue en enero de 2011 con el estreno de Kourtney and Kim Take New York, un programa que compartió con su hermana Kourtney Kardashian, mientras dejaban Los Ángeles para abrir su tercera tienda DASH en Nueva York. En 2010, fue una de las famosas con más ganancias, estimándose las mismas en seis millones de dólares. Ha lanzado múltiples fragancias y accesorios, ha sido estrella invitada en destacados programas de televisión y ha tenido 
papeles discretos en algunas películas estadounidenses. En 2010, junto con sus hermanas Kourtney y Khloé Kardashian, lanzó una autobiografía ${ }^{12}$.

Kardashian es una de las celebrities más activa en las redes sociales, publica tantos selfies que esta imagen cultural fotográfica ha quedado automáticamente asociada a su persona en diversos medios, pudiendo presumir de ser toda una experta en autofotos, pues ronda los cuarenta millones de seguidores en Instagram. Por estos méritos se la ha considerado como una de las "reinas del selfie". Para hacer honor y legitimar dicho título, en 2015 tuvo la ya no tan original ocurrencia de llevar también sus autorretratos digitales publicados en la red al formato libro.

En ese año editó Selfish (Imagen 8.17), un libro-catálogo con una selección de sus múltiples autofotos (Imágenes 8.18 y 8.19) y unas páginas con texto en las que da consejos de cómo practicar técnica y metodológicamente este tipo de producto fotográfico que parece dominar y controlar (aunque de manera y calidad no muy diferente al resto de autoras que hemos visto a lo largo de este estudio, incluidas las adolescentes, principales artífices del fenómeno).

\section{Entre sus reflexiones Kardashian señala:}

"La luz lo es todo [...] El ángulo también. Y todo tiene que ver en cómo lo encuadras. [...] Si hay algo de tu cuerpo que no te gusta, simplemente córtalo. [...] bajar la cara, subir los ojos y apretar la mandíbula para que se noten los pómulos” ${ }^{13}$.

12 VV. AA., “Kim Kardashian”, 2018, disponible en: <https://es.wikipedia.org/wiki/Kim_Kardashian>, [Fecha de consulta: 12 de enero de 2018].

13 GARCÍA, Atenea, "Kim Kardashian presenta su libro Selfish con trucos para autofotos", 2015, disponible en: <https://computerhoy.com/noticias/life/kim-kardashian-presenta-su-libro-selfishtrucos-autofotos-28011> [Fecha de consulta: 1 de marzo de 2018]. 


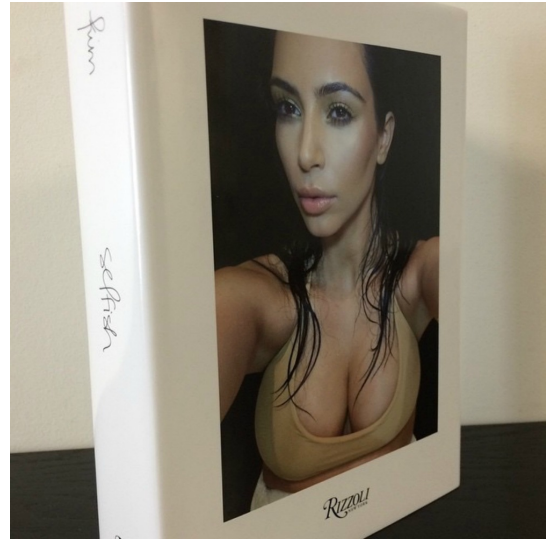

Imagen 8.17: Libro Selfish, publicado por Kim Kardashian

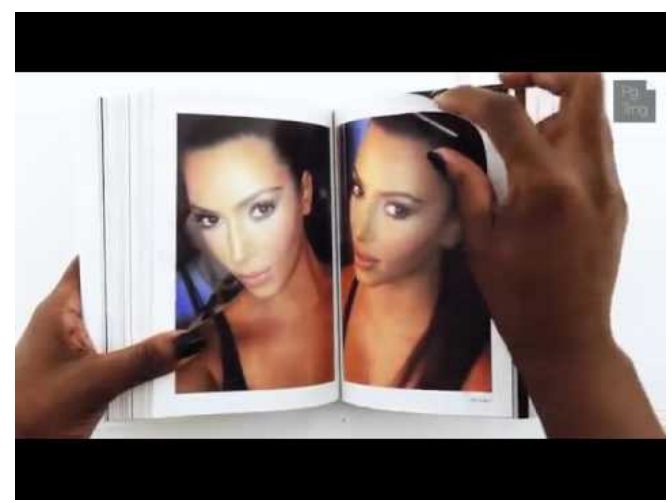

Imagen 8.18: Imágenes en el interior del libro.

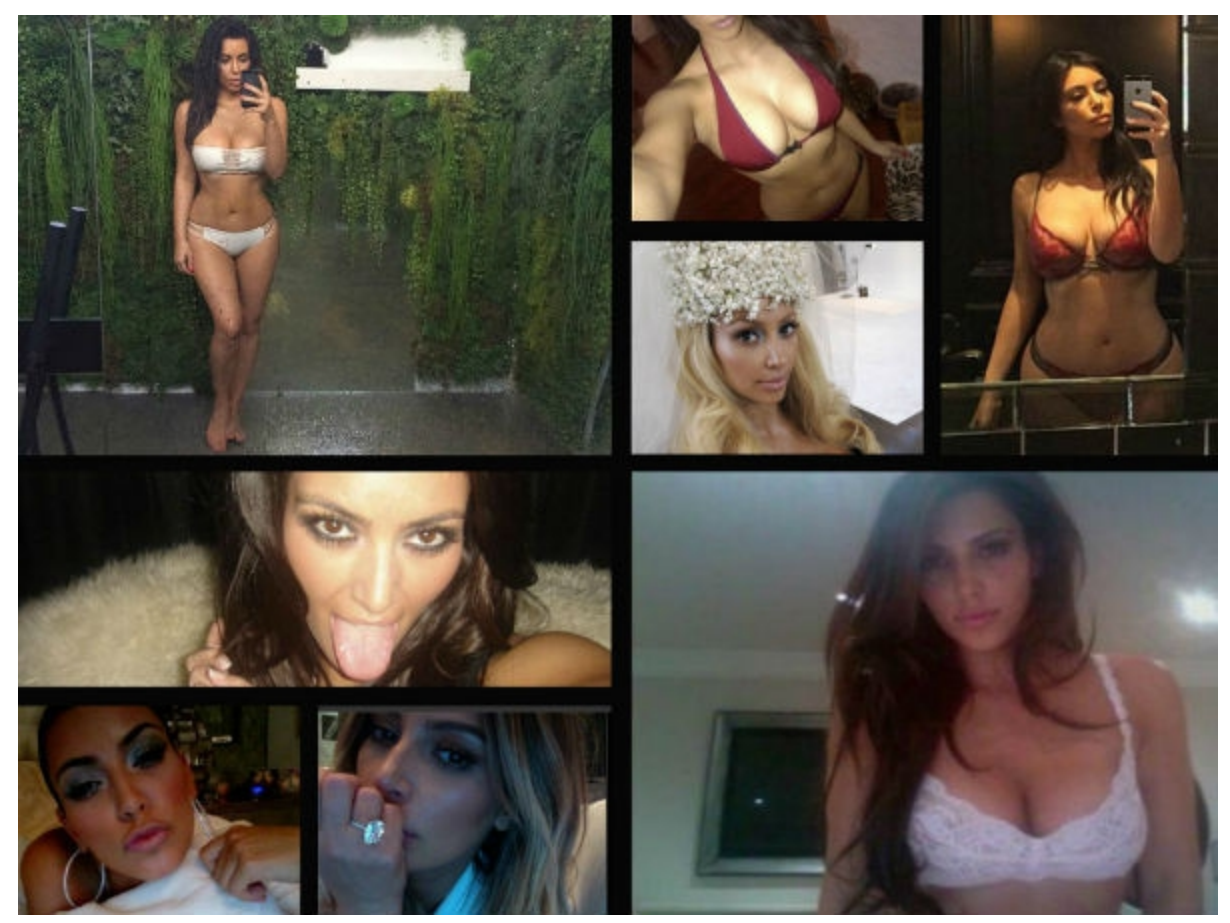

Imagen 8.19: Algunas imágenes más de las que se pueden encontrar dentro de la publicación física en formato libro, y que comprenden todo tipo de self shots, desde selfies hasta mirrorpics. 
Selfish $^{14}$ (título contruido mediante un juego de palabras entre selfie y egoísta en inglés) fue un fracaso de ventas al no haber alcanzado las esperadas por su autora. Por otro lado, el libro recibido diversas críticas ${ }^{15}$. A pesar de ello, hemos decidido incluirlo al final de este capítulo por tratarse también del ejemplo más actual de este tipo de publicaciones físicas en las que el selfie parece sentirse un poco incómodo (fuera de su medio natural de publicación: la red), unas publicaciones que dejarán constancia en el mundo material, en tanto que libros, de lo que ha supuesto este fenómeno de masas en torno a la fotografía (digital) y a la práctica del autorretrato del rostro y del cuerpo. nuevo modelo popular de autorretratos que aquí tratamos: "Es un documento de lo que es hoy la fotografía y de una parte de cómo se emplea: ese exhibicionismo profesional, el usar y tirar sin técnica, y ahí puede tener un interés. Pero lo único fotográfico aquí es el medio". VV. AA., "Kim Kardashian fracasa en la venta de su libro", 2015, disponible en: <https://elpais.com/elpais/2015/o8/o5/estilo/ 1438794037_803613.html> [Fecha de consulta: 20 de marzo de 2018]. 


\section{LA PRESENCIA Y EL USO DEL SELFIE EN LA PUBLICIDAD Y EN OTROS MEDIOS DE MASAS}

Dios mueve al jugador, y este, la pieza. ¿Qué Dios detrás de Dios la trama empieza [...]?

JORGE LUIS BORGES, Ajedrez (Poema), 1960

Para finalizar, vamos a realizar un recorrido prácticamente visual por una serie de ámbitos relacionados con algunos medios de masas como la publicidad, el cine o la televisión y que, de una u otra manera, se han hecho valer del cliché formal o de la imaginería del autorretrato digital publicado en la red (y de algunas de sus variantes como el selfie y el mirrorpic) como herramienta representativa o referencial para sus propias construcciones y estrategias comunicativas o intencionales. Esta referencialidad o representación del selfie en un ámbito externo a sí mismo no dejará de evidenciar que estamos ante un fenómeno fuertemente asentado a nivel cultural como práctica icónica. Un fenómeno que (según hemos ido viendo a lo largo de los capítulos de este estudio) podemos calificar como tal, dado el aluvión de repeticiones que ha generado a lo largo de más de una década.

¿Sería posible entonces plantearnos el hecho de que ya nos encontramos (a día de hoy, en 2018) viviendo una era post-selfie en la que dicha práctica ha 
alcanzado su máximo grado de asentamiento icónico y solo nos queda enfrentarnos a los ecos de unos hechos pasados y a su propia repetición referencial? Como comentamos en el capítulo 3, no sabemos cual será el futuro del selfie, y si seguirá un grado transformativo en su práctica y en su cuerpo fotográfico. Lo que sí que podemos aventurarnos a afirmar es que, en la actualidad y tras un lustro de popularidad, su impacto en los medios como icono puede resultar constatable si observamos los ejemplos que hemos querido traer a este último capítulo.

Como se podrá observar, hemos ido reuniendo dichos ejemplos desde que empezamos nuestra investigación y, si bien algunos de los mostrados a continuación han tenido un impacto internacional o tienen su origen en países como Estados Unidos, otros tantos atienden a iniciativas surgidas en nuestro ámbito cotidiano, siendo su impacto meramente nacional (España) o provincial (Valencia). Por lo tanto muchos de estos ejemplos han sido encontrados durante nuestros recorridos cotidianos y registrados con nuestras cámaras móviles y no buscados en la red, por lo que su recopilación podría ser entendida como un trabajo puramente de campo, de encuentro y de observación del entorno mediático y de sus soportes físicos. Es cierto que otra parte de ejemplos ha sido obtenida de la red, aunque sin responder a una búsqueda exhaustiva. La imposibilidad, por motivos obvios, de mostrar en este estudio todo el material encontrado nos ha hecho descartar gran parte de él, pero podemos confirmar tras nuestras observaciones que el aluvión mediático del selfie referenciado y mostrado en, por ejemplo, nuestra publicidad local, ha sido un fenómeno también producido y mostrado en la mayoría de ciudades y países del mundo desarrollado.

Queremos también puntualizar que el orden de los ejemplos mostrados a continuación no tiene por qué ser escrupulosamente cronológico, sino que se halla agrupado por temas, y dentro de estos temas, a su vez, por importancia (bajo nuestro criterio), hecho que hace que no siempre coincidan los parámetros cronológicos y los geográficos. 


\subsection{La utilización del selfie y del mirrorpic en campañas de publicidad y como estrategia de marketing.}

Vamos a ver a continuación diversos ejemplos visuales, con su correspondiente descripción, que muestran el uso del self shot y sus variantes como marco referencial, inspiración o icono mediático utilizado en campañas publicitarias, en spots televisivos y como estrategia de marketing ${ }^{1}$. A su vez, incidiremos en la utilización del selfie no solo como objeto directamente trasladado o simulado en una perfecta importación de su forma, sino también en el uso del mismo como práctica cultural, algo que constatamos cuando una persona o un grupo de personas practican la realización de una autofoto. $\mathrm{Y}$ todo ello sin olvidar su empleo como invitación para el incentivo de una campaña publicitaria con fines más o menos nobles.

Es probable que tanto de la repetición de esta práctica (primero de mano de los adolescentes y luego del resto del público usuario de la red $^{2}$ ), como los procesos de globalización ${ }^{3}$ en los que está inmerso el planeta y que hacen que cualquier suerte de imágenes se convierta en icono cultural a lo largo del globo en

1 Continuando el legado e impronta que la fotografía ha suscitado en este medio durante las últimas décadas del siglo XX. FONTCUBERTA, Joan, La cámara de Pandora. La fotografi@ después de la fotografía, Barcelona, Gustavo Gili, 2010, pág. 9.

2 Que tal y como hemos repasado, utilizaban sus habitaciones como espacio íntimo de experimentación, generando y popularizando el producto fotográfico aqui representado. Véase ZAFRA, Remedios, Un cuarto propio conectado. (Ciber)espacio y (auto)gestión del yo, Madrid, Fórcola ediciones, 2010, págs. 87-88. Recordemos, a su vez, que además de estos espacios íntimos, las imágenes obtenidas también adoptaban lógicas propias del proceso publicitario: BORERO, Alejandra y LONDOÑO, Suanny, "Mujer selfie, construcción de un discurso femenino adolescente mediado por el consumo de la imagen”, en V Encuentro Internacional de Investigadores en Publicidad (RELAIP), Alicante, 2016, pág. 127.

3 Globalización que presenta una íntima relación con los medios publicitarios desde finales del siglo pasado: "En la medida en que circulan materiales simbólicos a escala cada vez mayor, los lugares se convierten en puntos en que se reciben los productos mediáticos globalizados, se interpretan y se incorporan a la vida diaria de los individuos. Mediante el proceso localizado de apropiación, los productos mediáticos son incorporados a conjuntos de prácticas que dan forma y alteran su significado". THOMPSON, John B., Los media y la modernidad. Una teoría de los medios de comunicación, Barcelona, Paidós, 1998, pág. 231. 
poco tiempo ${ }^{4}$, constituyan factores causantes de la viralización de las estrategias aquí mostradas en la mayoría de países del mundo. De hecho, no hemos de olvidar que su familiaridad y aceptación social en costosas campañas publicitarias, pone de relieve la fuerte institucionalización que ha sufrido a lo largo de estos años nuestro objeto de estudio ${ }^{5}$.

\subsubsection{El selfie como objeto fotográfico en sí mismo trasladado o simulado.}

Entre las diversas campañas publicitarias que hemos encontrado y que utilizan el selfie o el mirrorpic de manera metonímica y como referente en torno al que se articula toda la estrategia visual de la propuesta mediática, podemos encontrar desde traslaciones simuladas hasta la utilización directa y no manipulada del mismo. Este último hecho puede dotar a la campaña de una sorprendente naturalidad y realismo, ya que el autorretrato fotográfico solo cambia de soporte, desde su natural superficie-pantalla-red hasta el tabloide

4 Tal y como había comenzado a realizar la televisión que, a finales del siglo pasado, ocupó un lugar hegemónico en la creación del universo visual que nos rodeaba y del que diariamente obteníamos gran parte de los datos que determinaban nuestra concepción general del mundo y de nosotros mismos. SABORIT, José, La imagen publicitaria en televisión, Madrid, Cátedra, 1992, pág. 13. En todo caso, la publicidad en el siglo XXI dará un salto difusorio gracias a los nuevos medios de comunicación de masas como Internet y las redes sociales que, a su vez, continúan el legado de la revolución de la comunicación de masas que se había ido desarrollando desde la invención de la imprenta durante el siglo XV. McQUAIL, Denis, Introducción a la teoría de la comunicación de masas, Barcelona, Paidós, 1985, pág. 20.

$5 \quad \mathrm{Y}$ es que "muchas veces, una de las primeras maneras en las cuales la gente se relaciona frente a las nuevas tecnologías es tratando de hacer lo que ya es habitual en otras, antes de empezar a experimentar nuevos usos. Así, mientras viejas prácticas pueden estar siendo redefinidas y hasta desplazadas, ellas también coexisten con las nuevas. Por lo tanto, es importante no solo mirar los cambios en la fotografía como una práctica cotidiana, sino también las continuidades”. GIRALDO, Diana y RUEDA, Rocío, "La imagen de perfil en Facebook. Identidad y representación en esta red social”, en Folios. Revista de la facultad de humanidades, nº 43, 2016, pág. 135. 
publicitario o spot televisivo, añadiendo aún más crudeza en su invitación a una puesta en escena povera ${ }^{6}$ o descuidada.

El primer ejemplo que deseamos mostrar dentro de este punto 9.1.1 que atiende exclusivamente al selfie o mirrorpic desplazado o falseado como objeto en sí mismo dentro de una campaña de marketing, es también el ejemplo más antiguo que hemos encontrado, fechado en agosto de 2007, y que supuso ser la campaña de marketing viral ${ }^{7}$ conocida como el caso de Tiffy Toodlepoo (Imagen 9.1).

La chica autorretratada en el citado mirrorpic se llama Wendy (Imagen 9.2), pero a lo largo de lo que sin duda debemos de tratar como un relato (dada la propia naturaleza del marketing viral que, como en este caso, se basa en una engaño o fake), seguiremos refiriéndonos a ella por su nombre falso: Tiffy Toodlepoo.

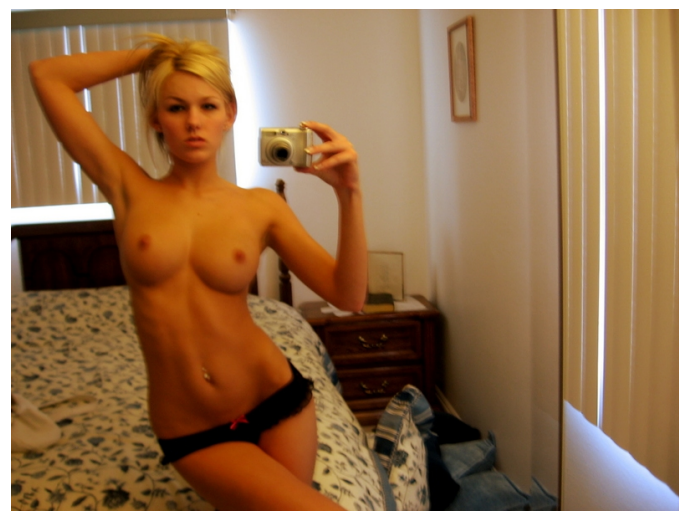

Imagen 9.1: Un mirrorpic de Tiffy Toodlepoo.

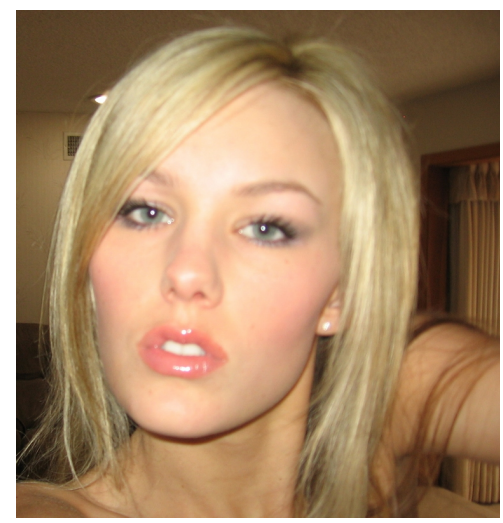

Imagen 9.2: La modelo Wendy.

6 CHÉROUX, Clément, Breve historia del error fotográfico, México D.F., Ediciones Ve, 2009, págs. 5253.

7 El marketing viral, muy utilizado por las empresas de publicidad, no es algo nuevo, aunque actualmente es un procedimiento en auge, cuyo objetivo sigue siendo el mismo: difundir al mayor número de personas posibles un mensaje comercial, todavía más potenciado por la naturaleza panóptica de Internet. ROJO, Leticia, Análisis del marketing viral. Estudio de casos, Valencia, Universitat Politècnica de València, 2014, pág. 113. 
Durante los primeros días en los que las imágenes de Tiffy circularon por la red, lo único que supimos era que esta joven estaba de vacaciones en una playa estadounidense con unas amigas durante el mes de agosto (Imagen 9.3). Disfrutaba esos días de relax mañanero en la playa, así como de locas fiestas nocturnas. Todo lo registraba con su económica (y popular en aquella época) cámara compacta digital. Las imágenes, tanto selfies primitivos, mirrorpics y fotografías realizadas por sus amigas, narraban a modo de diario las peripecias y divertimentos de su joven protagonista. La tarjeta de memoria, alojada dentro de la cámara, grababa electrónicamente los dígitos que escribían estas fotografías. Como si de un carrete de película se tratara, las fotos también permanecerían latentes en ese contenedor hasta que Tiffy volviera a casa una vez transcurrida su escapada, momento en el que las volcaría (almacenaría) en su computador para conservarlas (electrónicamente), compartirlas o disfrutarlas en el futuro recordando sus maravillosos días de verano.

Pero nuestra fotógrafa también realizó otro tipo de registros: al igual que hicieron infinidad de selfshooters antes que ella (y, como hemos visto a lo largo de este estudio, también después), Tiffy se autorretrató desnuda frente a un gran espejo de puerta de armario, en la soledad de su privada habitación de hotel (Imagen 9.4). Estas fotografías, cargadas de erotismo, sensualidad y exhibicionismo narcisista, hubieran hecho las delicias de cualquier voyeur en la red, aunque dan a entender que su verdadero destino era el de ser compartidas de manera exclusiva con un amante lejano, o el de ser conservadas por la propia modelo.

Aunque aquí solo mostramos algunos de esos autorretratos eróticos y registros vacacionales, nuestra protagonista realizó un buen puñado de ellos ${ }^{8}$. Y todas estas imágenes seguían contenidas en el interior de su cámara cuando Tiffy

8 Pueden consultarse en: <http://imgur.com/a/Q2HCE\#g9ZfA> [Fecha de consulta: 15 de julio de 2016]. 
Toodlepoo la extravió de manera accidental (supuestamente) durante aquel verano.

El dispositivo perdido fue encontrado por un filántropo anónimo llamado Craig Radford que, deseoso de reunir a la cámara con su dueña, publicó todas las fotos en la por aquel entonces incipiente red social Facebook ${ }^{9}$. Su objetivo iba dirigido a que la entonces aún discreta y reducida comunidad de usuarios lograra localizar a la muchacha, o a que la fotógrafa pudiera contactar con el altruista poseedor de su máquina digital y así recuperar (pagando el alto precio de la exhibición) su valioso aparato. Durante aquellos días, Facebook incrementó sus filas con 17.000 nuevos usuarios que se registraron deseosos de poder contemplar estas fotografías y ayudar a la pobre turista.

Las fotos de Tiffy se extendieron como un virus por la red. Se clonaron, se guardaron, se compartieron. En menos de veinticuatro horas desde su publicación original, más de 600 páginas web habían sido creadas con este propósito. Los diarios se hicieron eco. En pocos días todo el mundo hablaba del "famoso caso de la cámara perdida de Tiffy Toodlepoo"

Días más tarde se descubrión ${ }^{11}$ que el verdadero nombre de Tiffy Toodlepoo era Wendy, y que las fotos habían sido un encargo hecho a esta modelo profesional originaria de Orlando. Todo había formado parte de una

9 Antes de que esta famosa red social aplicara su rígida política actual de censura de genitales y pezones. Las fotos fueron publicadas en el grupo Help us reunite this lass with her camera (Ayúdanos a volver a unir esta chica con su cámara).

10 Cuyo desarrollo y desenlace quedó explicado en varios sitios de Internet durante 2007 y 2008, entre ellos, el más completo que hemos encontrado: JUAN SANZ, Miriam, "El caso de Tiffy Toodlepoo", disponible en: <http://publimarketing-viral.blogspot.com.es/2008/o4/el-caso-de-tiffy-toodlepoo. html $>$ [Fecha de consulta: 15 de julio de 2016].

11 También se volvió a publicar a modo de noticia en diferentes medios, como en el diario español 20 minutos: Redacción 20 minutos, "La chica rubia que perdió su cámara", 2007, disponible en: <http://www.20minutos.es/noticia/271106/o/camara/rubia/marketing/> [Fecha de consulta: 15 de julio de 2016]. 
inteligente campaña de marketing viral y la anecdótica estancia vacacional era en realidad una simulación.

Las mentes que orquestaron esta infraestructura del engaño, se basaron en la imagen cultural del self shot, ya asumida por la población de Internet. $\mathrm{Ni}$ siquiera necesitaron que la modelo se esforzara en asimilar referentes visuales. No prepararon ningún montaje escénico y no se empeñaron en conseguir anomalías técnicas sobre las imágenes para que estas resultaran creíbles (Imagen 9.5) o para que simularan ese aspecto povera del que hemos hablado. La mejor manera de conseguir simular un mirrorpic era simplemente dejar que alguien lo hiciera en su contexto natural. Seguramente, para lograr producir estas imágenes tan reconocibles y veraces, la modelo solo necesitó una cámara, unas sencillas instrucciones y una habitación de hotel donde poder desarrollar su creatividad. Saldría bien a la primera, ya que, probablemente, se trataba de un ejercicio que Wendy ya habría realizado con anterioridad.

La campaña viral de Tiffy Toodlepoo solo es un ejemplo anecdótico de ejercicio publicitario (a continuación veremos más), pero podemos considerarlo como la primera práctica post-self shot que pondría poner en evidencia cómo el fenómeno fotográfico aquí tratado ha podido ser asimilado por los lectores de la imagen contemporánea occidental.

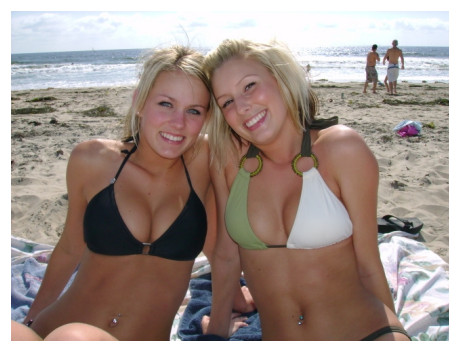

Imagen 9.3: Tiffy

Toodlepoo y su supuesta amiga en la playa.

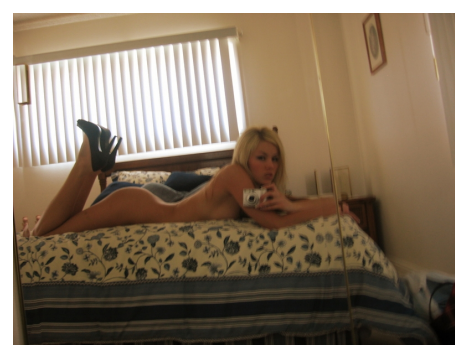

Imagen 9.4: Autorretrato frente a un espejo, objeto de la campaña viral.

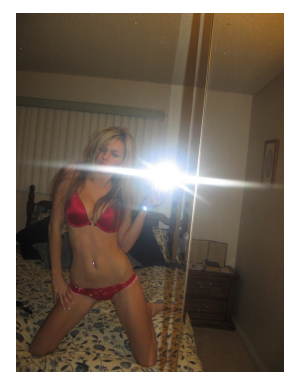

Imagen 9.5: Otro mirrorpic para la campaña. 
Por otro lado, tenemos un ejemplo más reciente de, en este caso, una mayor y más mediática campaña publicitaria internacional que se ha hecho servir del autorretrato digital joven con carga erótica, estableciendo como soporte este propio material también directamente autoproducido por las y los modelos protagonistas. Se trata de la campaña publicitaria exhibida a lo largo de 2014 por la marca de perfume y moda Calvin Klein bajo el slogan Me for me, realizada por Mario Sorrenti. Se trata de una sensual apuesta acerca de la manera que tienen los jóvenes de autorregistrar y hacer públicos sus escenarios privados. Para ello se utilizan una serie de selfies directamente trasladados que nos pueden recordar a la iconografía desarrollada por Natacha Merritt (vista en el capítulo 7). Esta campaña emitió tanto material gráfico (Imagen 9.6) expuesto mediante carteles y pósters en el espacio público de las ciudades, como spots publicitarios televisivos $^{12}$ (Imágenes 9.7, 9.8 y 9.9) construidos con las mismas estrategias compositivas, pero en formato vídeo.

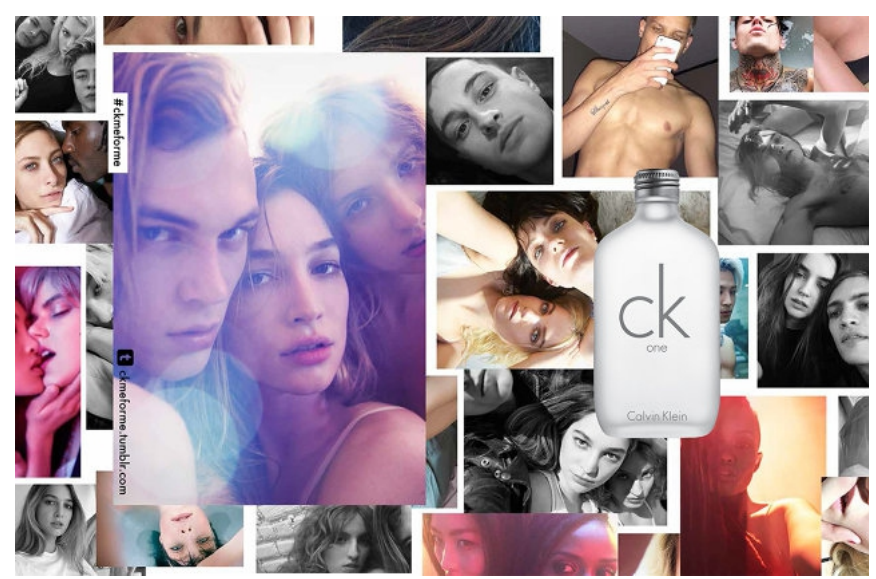

Imagen 9.6: Materal gráfico de la campaña de $2014 \mathrm{Me}$ for me de Calvin Klein, conformado por una serie de selfies directamente ejecutados por las y los modelos.

12 Véase: <https://www.youtube.com/watch?v=pn7cyNr-qko> [Fecha de consulta: 10 de febrero de 2015]. En el vídeo puede observarse que la mejor manera de conseguir la iconografía buscada es hacer que los modelos del spot sean los propios ejecutores de las tomas: a modo de selfie vivo todos sujetan y encuadran con el dispositivo en la mano. 


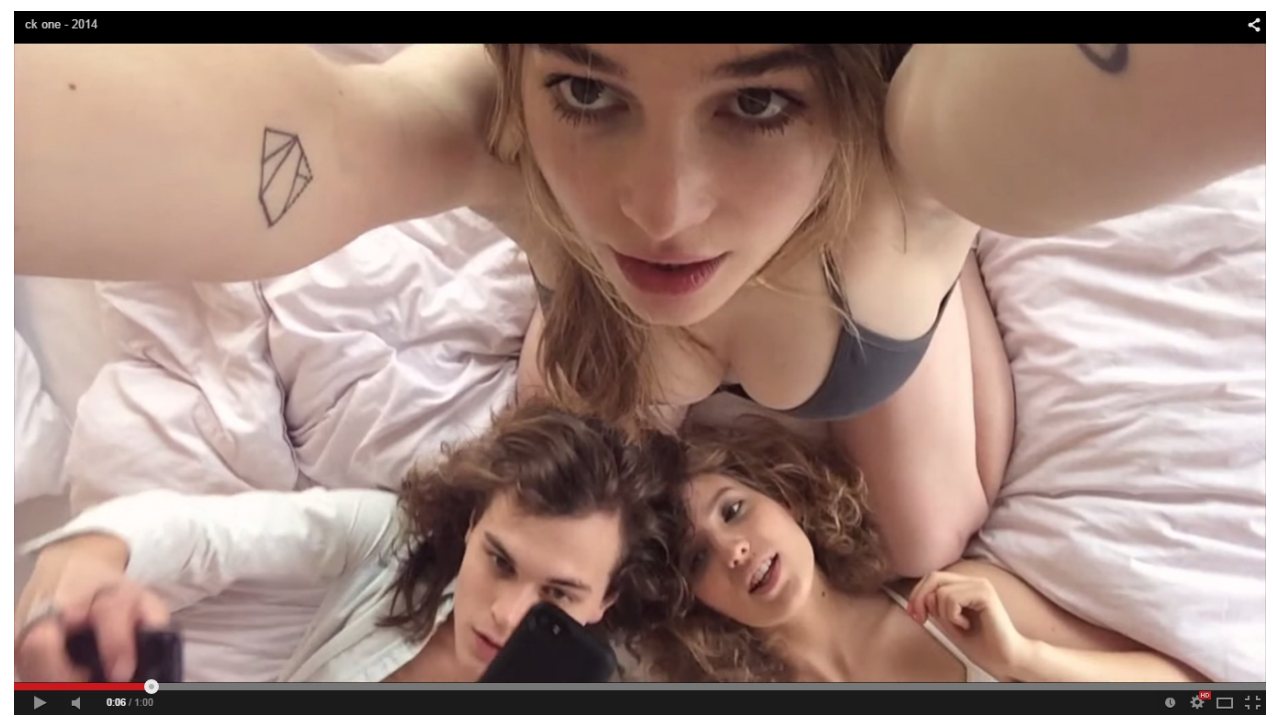

Imagen 9.7: Frame del anuncio publicitario televisivo de la campaña de $2014 \mathrm{Me}$ for me de Calvin Klein que no estuvo carente de polémica ${ }^{13}$.

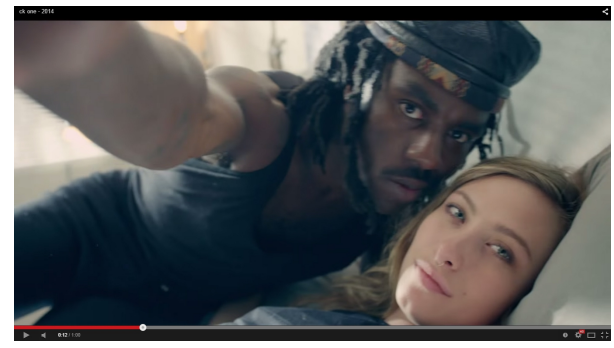

Imagen 9.8: Frame de la campaña $M e$ for me de Calvin Klein, 2014.

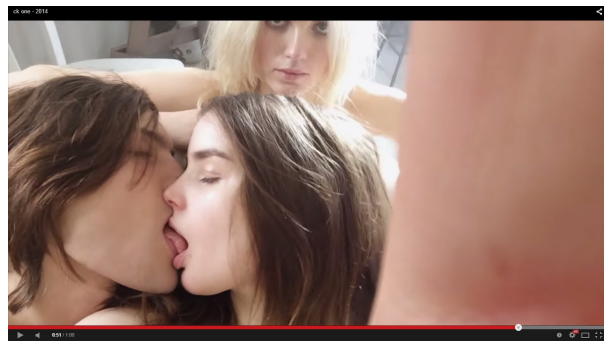

Imagen 9.9: Frame de la campaña $M e$ for me de Calvin Klein, 2014.

Y es que el Jurado de Ética Publicitaria de Bélgica (JEP en sus siglas en francés), un "organismo independiente de autorregulación publicitaria", cuya misión es "asegurar una publicidad justa, veraz y socialmente responsable”, pidió que se retirase esta campaña por considerar que banalizaba un asunto preocupante como el de las "autofotos eróticas entre los jóvenes". SUANZES, Pablo R., "Bélgica, contra Calvin Klein por «banalización de los selfies eróticos»", 2016, disponible en: <http:// www.elmundo.es/television/2016/11/16/582c93a4e5fdeaofo28b466e.html $>$ [Fecha de consulta: 20 de agosto de 2017]. 
Hemos querido traer también como tercer ejemplo en este apartado la campaña realizada en 2015 por la marca japonesa de cosméticos Shiseido (Imagen 9.10) que utilizó como objetos fotográficos, también directamente trasladados, unos cuantos selfies de la cantante Lady Gaga realizados para el anuncio y simultáneamente expuestos en su cuenta de Instagram ${ }^{14}$.
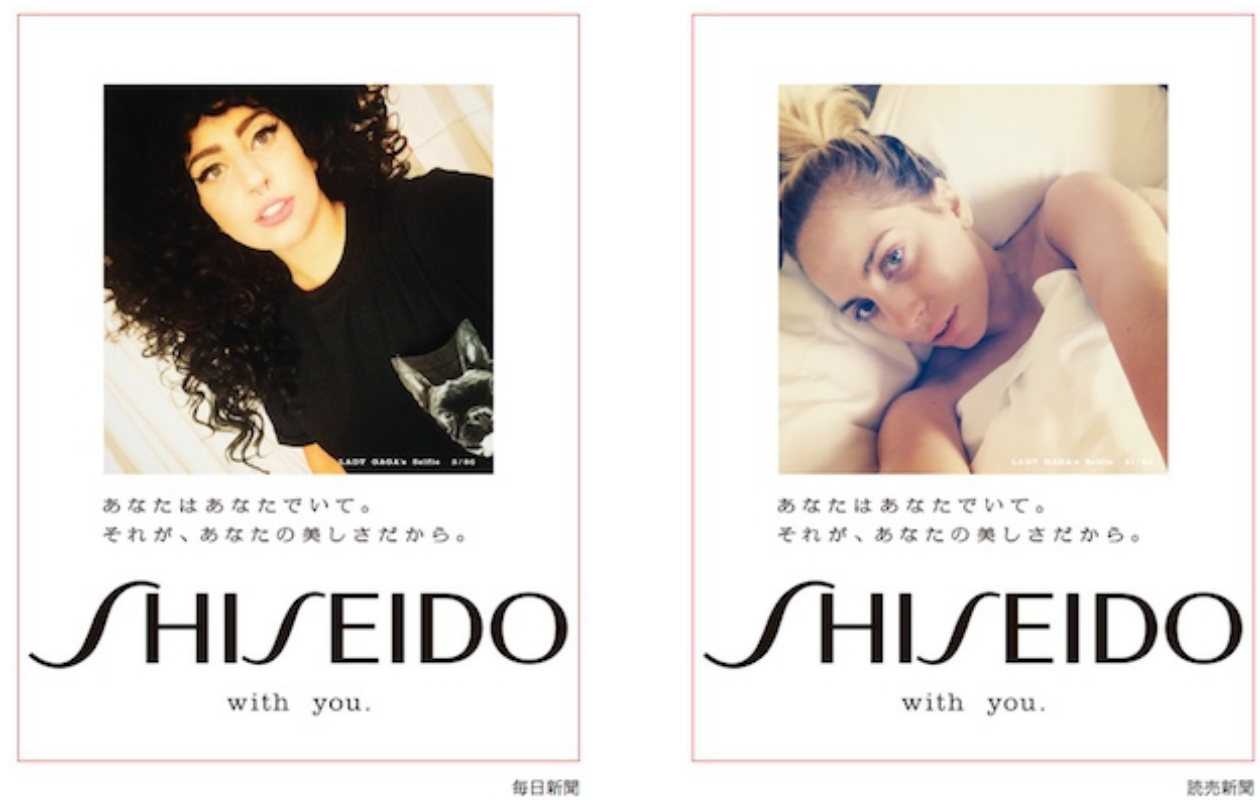

Imagen 9.10: Dos imágenes de la campaña de Shiseido construida con selfies de la cantante Lady Gaga. La campaña se desarrolló en soportes publicitarios de tipo cartel y en las paradas de transporte público de diversas ciudades niponas durante 2015 .

Mientras redactábamos estas páginas, hemos encontrado en nuestros habituales recorridos callejeros una serie de campañas publicitarias realizadas por entidades bancarias que, también, incluyen selfies reales o perfectamente simulados como estructuras formales en torno a las que se articula el soporte

14 YOUNG, Katy, “Lady Gaga's Selfie Campaign for Shiseido”, 2015, disponible en: <http:// fashion.telegraph.co.uk/beauty/news-features/TMG11329722/Lady-Gagas-selfie-campaign-for-Shisei do.html> [Fecha de consulta: 21 de julio de 2017]. 
visual de dichas campañas y cuya intención comunicativa podría ser la familiaridad y posible gancho que aportan estas imágenes fotográficas a la generación millennial (jóvenes nacidos entre los años 80 y los años 90 del siglo pasado y, como hemos visto, «inventores» de los self shots), un grupo generacional estimado como posible cliente potencial para la banca actual y que suscita uno de sus mayores retos de captación ${ }^{15}$. De los diversos ejemplos que hemos fotografiado directamente con nuestras cámaras en la calle destacamos dos, la campaña realizada por Caixabank en 2018 (imagen 9.11) y la realizada por Kutxabank en 2016 (Imagen 9.12), que junto con otras campañas paralelas presentan ejercicios muy similares de selfie trasladado.

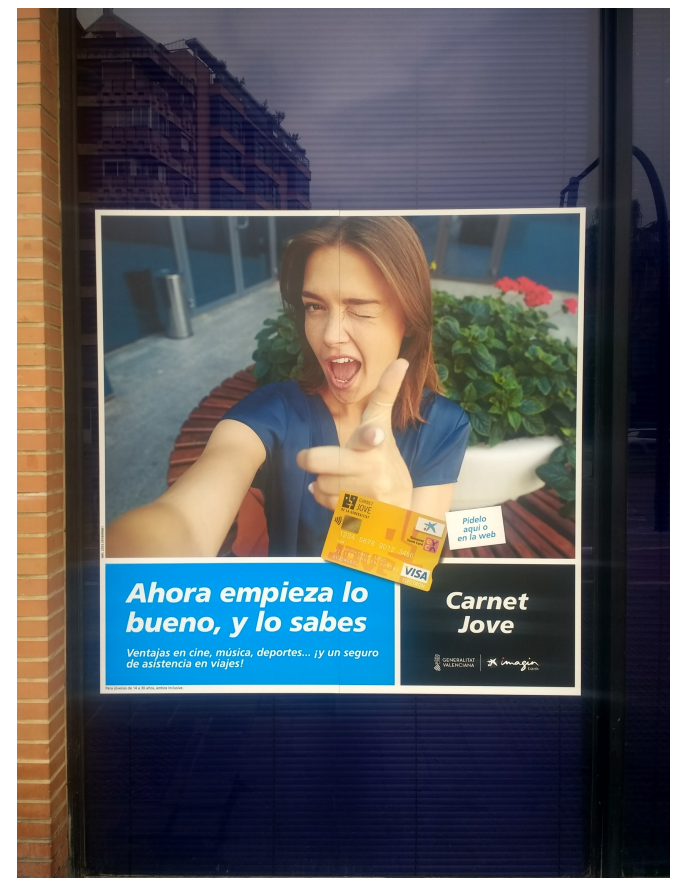

Imagen 9.11: Campaña publicitaria de Caixabank, 2018.

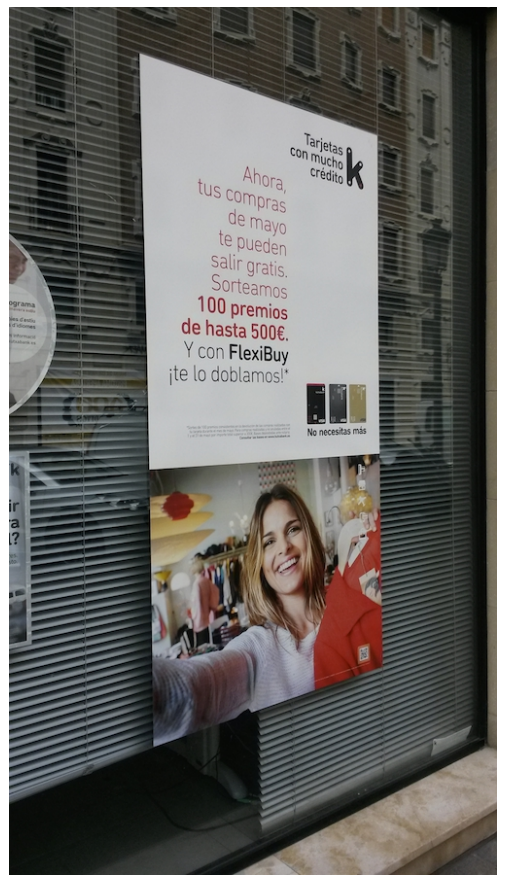

Imagen 9.12: Campaña publicitaria de Kutxabank, 2016.

15 VV. AA., "Los millennials: un desafío para la banca", 2015, disponible en: <https://www.bbva.com/ es/millennials-desafio-banca/> [Fecha de consulta: 2 de abril de 2018]. 
Queremos asimismo citar, por su curiosidad y acierto, la campaña publicitaria para promocionar su propio producto, realizada en 2013 por el diario sudafricano Cape Times ${ }^{16}$. En relación a este importante medio de noticias local y a su trayectoria, el diario quiso promocionar su propia naturaleza enlazándola con la actualidad por medio de una serie de infografías alteradas digitalmente que simulaban fotografías históricas presentadas como si hubieran sido selfies tomados por sus protagonistas (Imágenes 9.13, 9.14, 9.15 y 9.16).

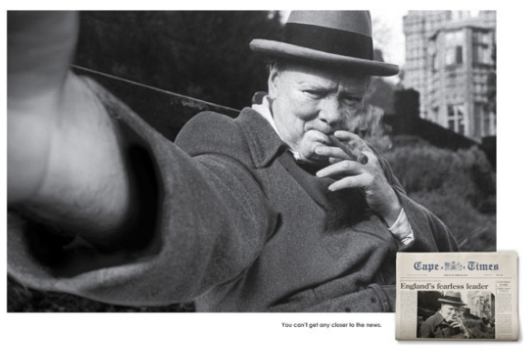

Imagen 9.13: Campaña publicitaria del periódico Cape Times, 2013.

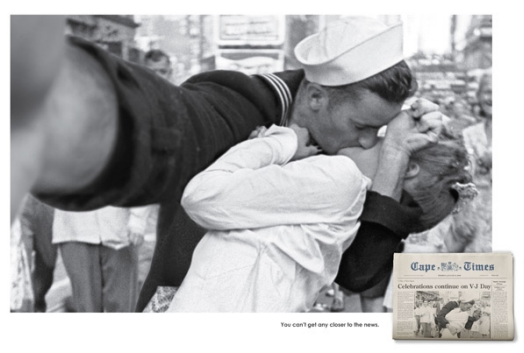

Imagen 9.15: Campaña publicitaria del periódico Cape Times, 2013.

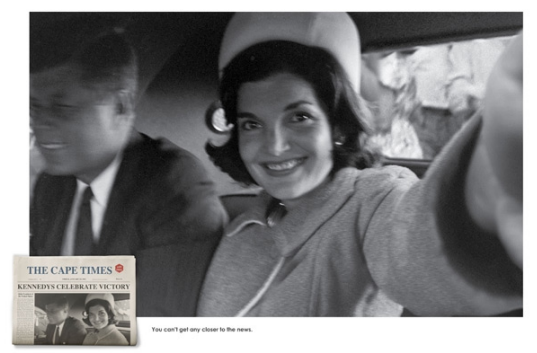

Imagen 9.14: Campaña publicitaria del periódico Cape Times, 2013.

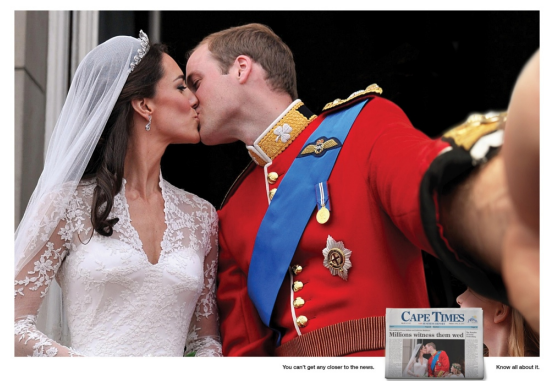

Imagen 9.16: Campaña publicitaria del periódico Cape Times, 2013.

16 “A mediados de 2013 en las redes sociales se difundieron las imágenes creadas en año anterior por la agencia publicitaria Loew Cape Town para el periódico sudafricano Cape Times donde se recrean fotografías históricas reinterpretadas como selfies. La serie incluye imágenes de Jackie y John F. Kennedy, Winston Churchill, [...] y el icónico beso capturado por Alfred Eisestaedt en Times Square". COLORADO, Óscar, “Autorretrato y fotografía”, 2013, disponible en: <https://oscarenfotos.com/ 2013/o8/11/autorretrato-y-fotografia/> [Fecha de consulta: 1 de julio de 2017]. 
Continuando esta línea de simulaciones, traemos a colación también dos campañas que se aprovechan de la manipulación digital propia de la infografía para emular la imaginería y las formas fotográficamente compositivas del mirrorpic o del selfie, como fin para comunicar visualmente sus protocolos retóricos.

La primera campaña (Imágenes 9.17 y 9.18), realizada por la revista de naturaleza National Geographic, bajo el lema There are lots of terrible animal pictures out there. The best nature images are here, aprovecha la banalización que generalmente se asocia con los self shots (también cómicamente realizados por animales) dada su supuesta escasa calidad. Dicha calidad es contrapuesta a la obtenida por las fotografías (de estos mismos animales) que presenta la publicación en su interior. La campaña fue dirigida en 2014 por Silvio Medeiros ${ }^{17}$.

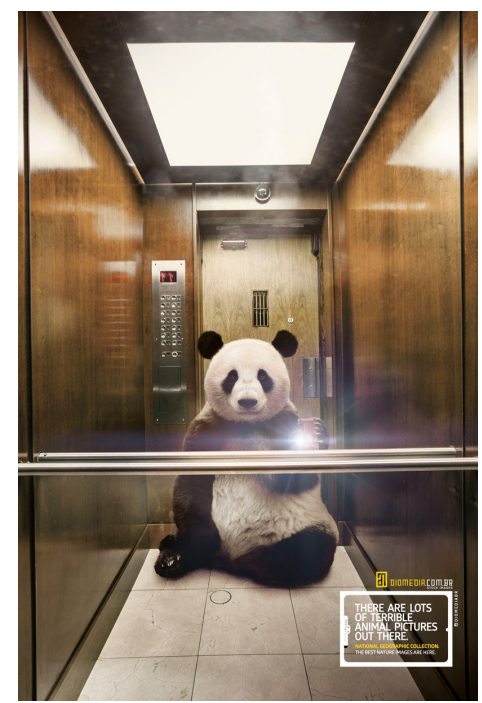

Imagen 9.17: Campaña publicitaria de National Geographic, 2014.

17 CHAYKA, Kyle, "National Geographic's New Ad Campaign Features Animals Taking Selfies”, 2014, disponible en: <http://time.com/97561/national-geographics-new-ad-campaign-features-animalstaking-selfies/ $>$ [Fecha de consulta: 10 de julio de 2017]. 


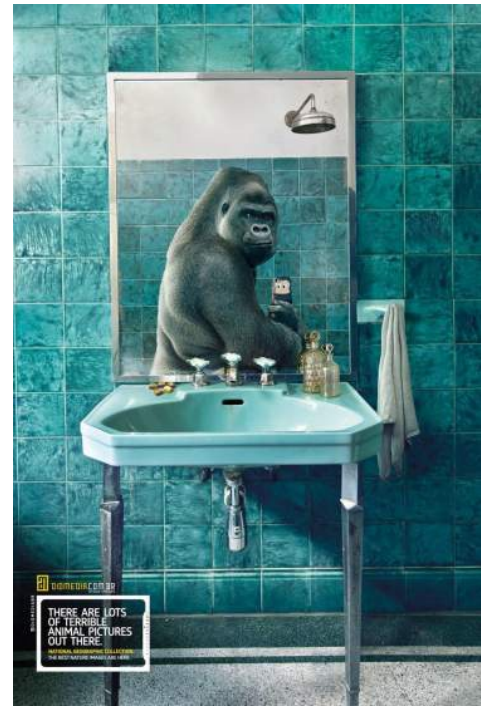

Imagen 9.18: Campaña publicitaria de National Geographic, 2014.

La segunda campaña (Imágenes 9.19 y 9.20) también presenta self shots simulados, en este caso selfies en lugar de mirrorpics. Se trata de una campaña de prevención y seguridad vial internacional que la empresa Volkswagen quiso realizar en 2015 para luchar contra la incipiente moda que tienen los jóvenes de algunos países desarrollados de realizarse selfies al volante mientras el coche está en funcionamiento por las carreteras. En las paradójicas imágenes simuladas se puede observar a las vícitmas de esos accidentes realizándose el selfie a posterori, también con la imaginería formal y composición típica de estas autofotos. La campaña fue realizada por la empresa de publicidad DDB de Ciudad de México ${ }^{18}$.

18 Consultable en la base de datos publicitaria Ads of the World, disponible en: <http://time.com/97561/ national-geographics-new-ad-campaign-features-animals-taking-selfies/> [Fecha de consulta: $10 \mathrm{de}$ julio de 2017]. 


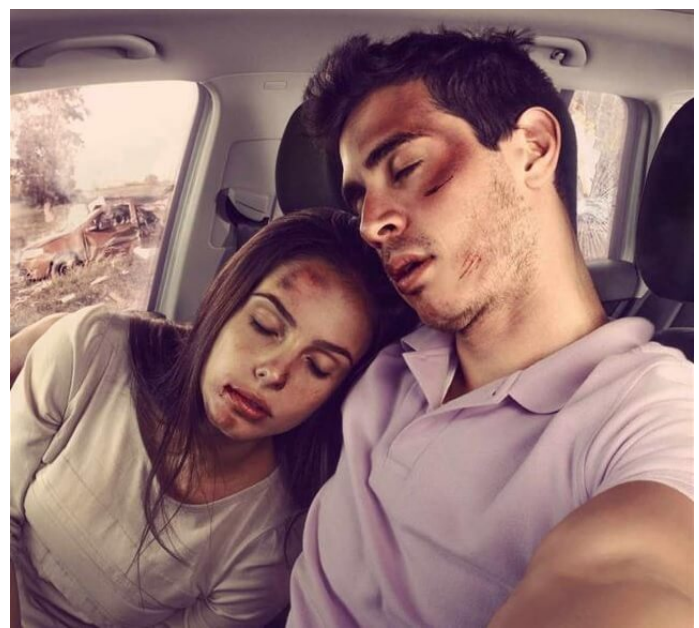

Imagen 9.19: Campaña publicitaria de concienciación realizada por Volkswagen en 2015 .

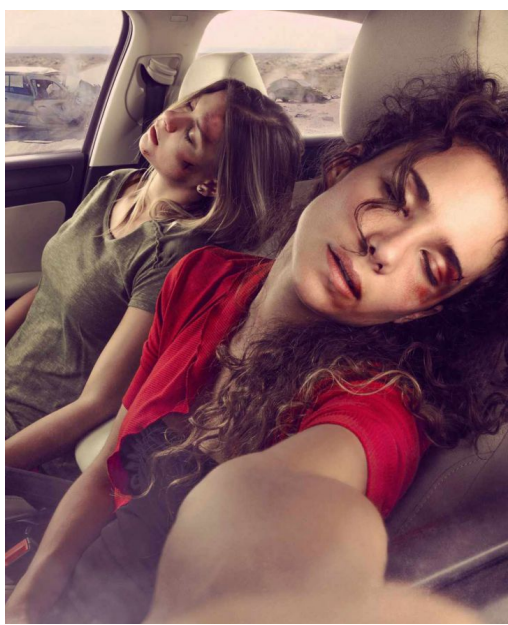

Imagen 9.20: Campaña publicitaria de concienciación realizada por Volkswagen en 2015 .

Para finalizar el recorrido visual de este apartado, añadiremos tres campañas más que nos parecen pertinentes, ya que han utilizado el selfie directamente trasladado como marco referencial. En la primera de estas campañas podemos observar cómo la empresa de ropa Diesel publicita su propia marca (más que su producto) mediante un guiño a la supuesta adicción a los selfies que tiene la franja generacional de los millennial, mostrando a una mujer joven estadounidense que, pese a recibir una parada policial y multa en la carretera, aprovecha la situación para realizarse una autofoto (Imagen 9.21). Esta publicidad visual, además, presenta ese carácter povera o de error fotográfico clásico en este tipo de imágenes: la figura enfocada (la del agente) es, precisamente, la que no pretendía serlo y viceversa. Ejercicios similares han sido utilizados por la marca de equipamientos para motoristas X-lite bajo el lema Love your selfie (Imagen 9.22). Asimismo, en nuestro escenario local, un similar recurso ha sido utilizado por la empresa de transportes públicos de la ciudad de 
Valencia (EMT) como estrategia para conectar sus servicios con la gente joven (Imagen 9.23).

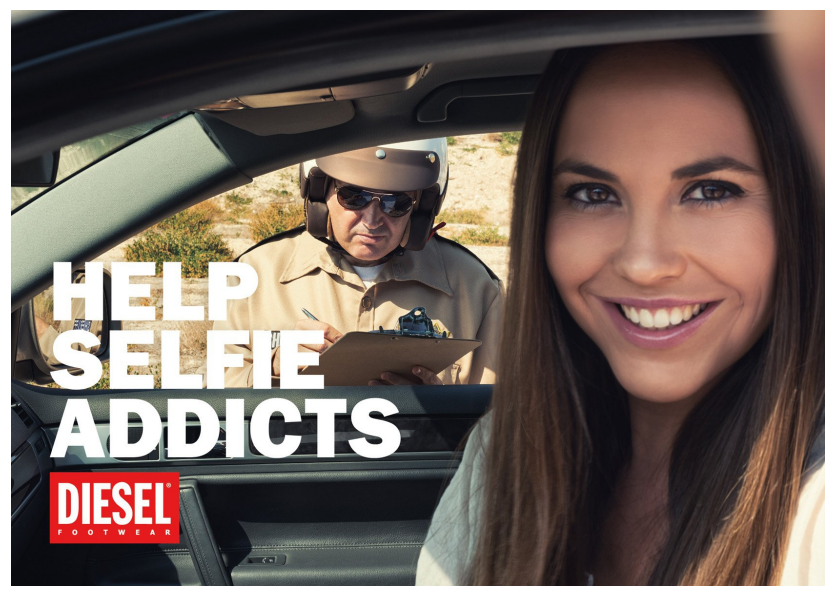

Imagen 9.21: Campaña publicitaria de la marca de ropa Diesel bajo el lema Help Selfie Addicts, 2013.

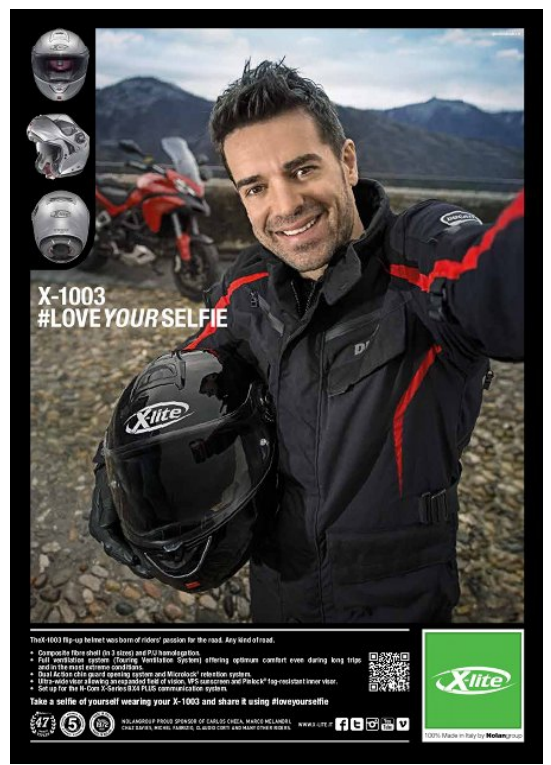

Imagen 9.22: Campaña publicitaria realizada en 2014 por la marca de equipamientos para motoristas X-lite.

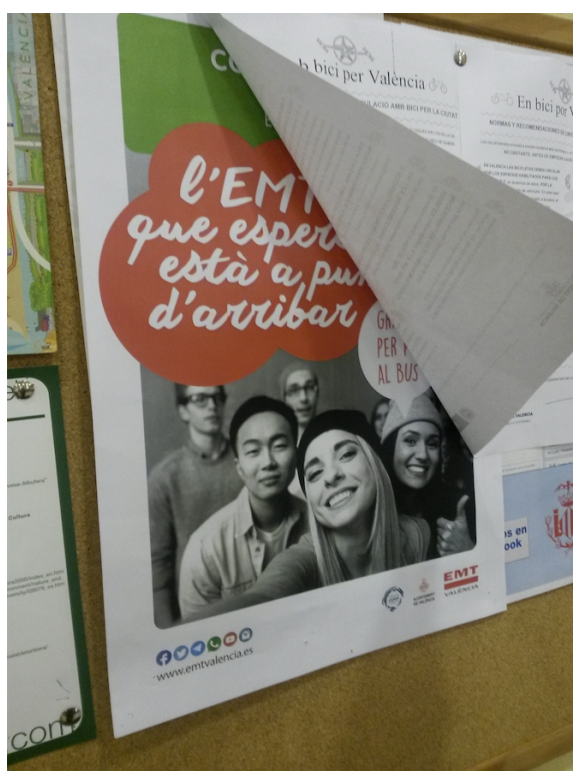

Imagen 9.23: Campaña publicitaria realizada en 2015 por la empresa de transporte público de Valencia EMT. 
Al margen de lo aquí ya mostrado y con la intención de no seguir excediendo la cantidad de imágenes de este subapartado, citaremos únicamentre de forma nominal iniciativas, empresas y campañas de publicidad que han utilizado estas mismas estrategias retóricas durante la segunda parte de nuestra década. Nos referimos a empresas, marcas o instituciones como Dolce \& Gabbana, Cillit Bang, Vanish, Granini, los canales televisivos Zero y Discovery Max, la sección de turismo de la Xunta de Galicia e, incluso, partidos políticos de nuestro país como UPyD (campaña de elecciones de 2016).

\subsubsection{El selfie como representación de su acto y práctica.}

En este segundo apartado, también adscrito a la imaginería del self shot aplicada a la publicidad como marco referencial y estrategia visual, encontraremos otros tantos ejemplos (en este caso muchos más) en los que, a diferencia del apartado anterior, lo que aquí se utiliza no es un selfie o un mirrorpic trasladado directamente al soporte publicitario, sino el acto de hacerse un selfie o un mirrorpic como dramatización representada.

Alude así esta estrategia a mostrar un referente claramente reconocible, dado que apunta a una práctica socialmente aceptada y asimilada tras su constante observación en las calles y en otros ámbitos.

Con ello las estrategias de marketing irían encaminadas a mostrar un ambiente joven, distendido, divertido y sofisticado, relacionado con la belleza y/o erotismo que suele quedar asociado a este tipo de práctica (de ahí su abuso en la representación aunque, en la mayoría de casos, no deje de ser una simulación y no una práctica realmente realizada, tal como sucedía en algunos casos del apartado anterior). 
Para iniciar este muestreo partimos de dos de los primeros ejemplos que localizamos cuando empezamos a desarrollar esta área publicitaria de nuestra investigación en 2013. Se trata de dos campañas: la primera realizada por la marca de cerveza española Mahou para la promoción de su producto en el verano de 2013, campaña que se iniciaba con un anuncio en las televisiones de nuestro país.

El $\operatorname{spot}^{19}$ se desarrolla bajo un eslogan que reconoce el esfuerzo y la creatividad que habitualmente despliegan los usuarios de las redes sociales durante la producción de las autofotos que lucirán en sus perfiles públicos. En el anuncio son mostrados jóvenes que se practican autorretratos con sus dispositivos de captura digital, encontrándose realizados algunos de ellos en los espacios privados propios del hogar (Imagen 9.24).

Esta acción de autorretratarse y publicarse mediante el smartphone también se representó en 2013 en relación a otra marca de cerveza, en este caso Desperados, igualmente mediante un $s p o t^{20}$ en el que diversos jóvenes se practican selfies, esta vez en el escenario público propio de los locales de ocio nocturno (Imagen 9.25). de 2013]. 

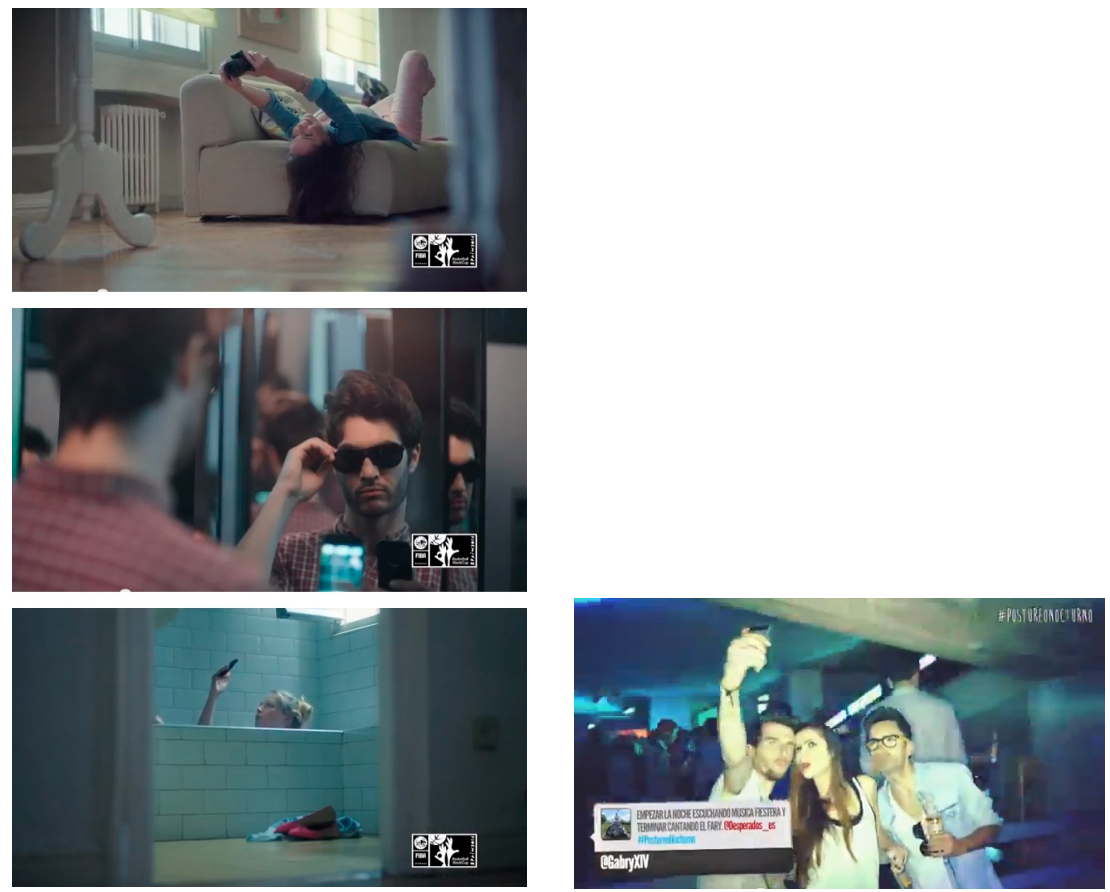

Imagen 9.24: Frames del anuncio televisivo ideado por la marca de cervezas Mahou, publicitado durante el verano de Imagen 9.25: Frame del anuncio publicitario utilizado en 2013 por la marca de cerveza Desperados. 2013 .

Por otro lado, hemos encontrado a lo largo del desarrollo de este estudio algunos ejemplos exhibidos en la red y en las calles que utilizan la misma estrategia, en esta ocasión aprovechando el soporte fotográfico y la imagen fija. Todos los mostrados a continuación están relacionados con la industria de la moda y de los complementos. En la primera campaña, realizada por la marca de moda French Connection, no solo vemos representado el acto y la pose de hacerse un selfie en manos de una joven modelo, sino que además se aprovecha la propia palabra (selfie) para vender una idea (Imagen 9.26). En esta misma línea hemos encontrado otra campaña similar realizada por la marca de lencería y ropa de baño femenina Woman Secret (Imagen 9.27). 


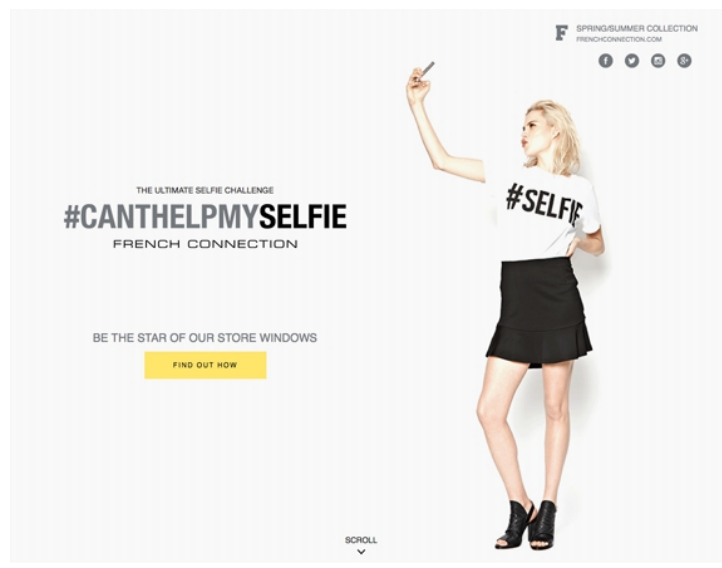

Imagen 9.26: Campaña de la marca de moda French Connection de 2015 bajo el lema Can't help my selfie.

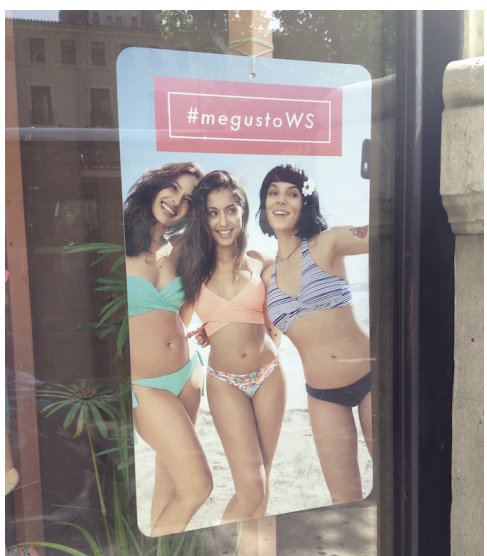

Imagen 9.27: Campaña de la marca de moda Woman Secret Connection de 2016 bajo el lema Me gusto WS.

También el cuerpo del hombre ha sido representado en torno a la imaginería y pose del mirrorpic por campañas como la realizada en 2015 por la marca de moda (en este caso en su sección de ropa interior masculina) Diesel.

Bajo el lema Selfie hero fit (Imágenes 9.28 y 9.29) explota este icono que supone la suma de smartphone y espejo de cuarto de baño en relación a la exhibición erótica del cuerpo del hombre por medio de un semidesnudo y su relación con el fitness.

La industria de la moda en ámbito de los complementos también ha abusado de este recurso icónico: tenemos dos ejemplos tomados en escaparates de nuestro entorno en 2014 y 2017 que muestran las campañas realizadas por las marcas Lotus (Imagen 9.30) y Dolce \& Gabbana (Imagen 9.31). 


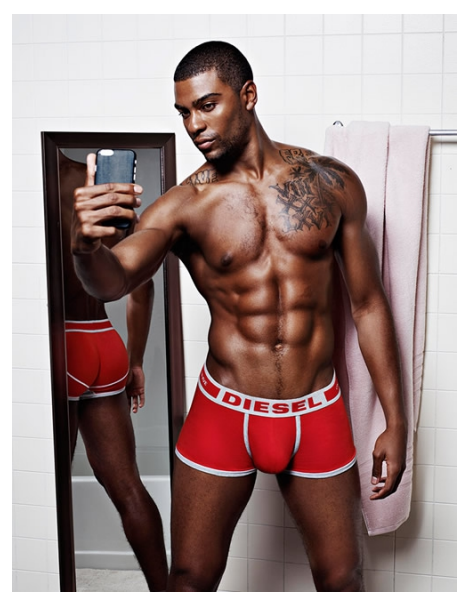

Imagen 9.28: Campaña de la marca de moda Diesel realizada en 2015 .

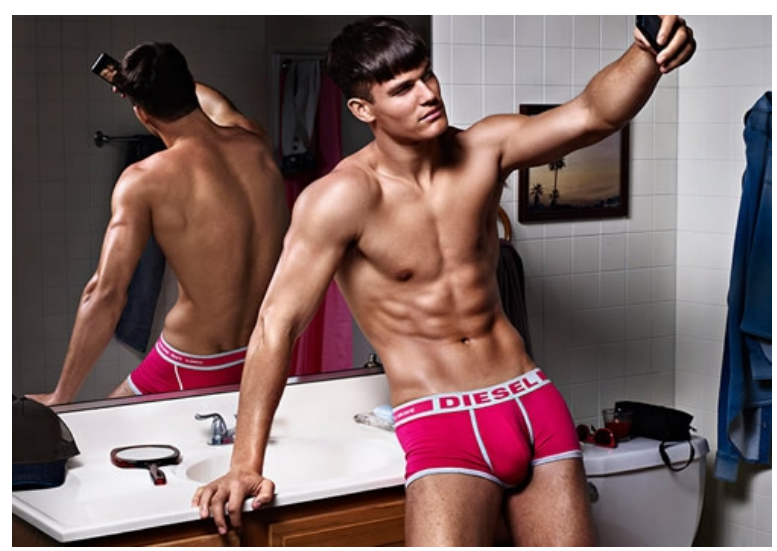

Imagen 9.29: Campaña de la marca de moda Diesel realizada en 2015 .

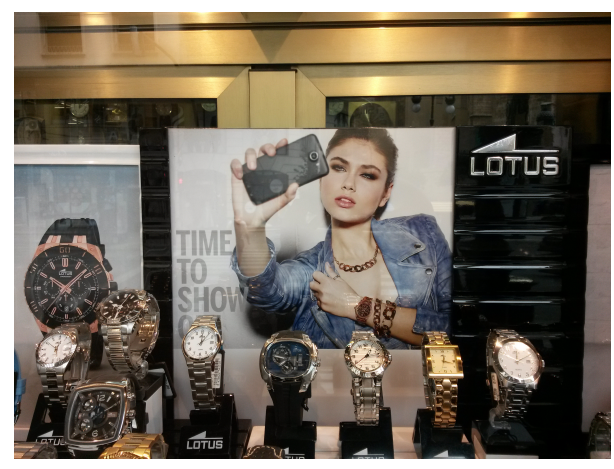

Imagen 9.30: Campaña de la marca de complementos Lotus realizada en 2014.

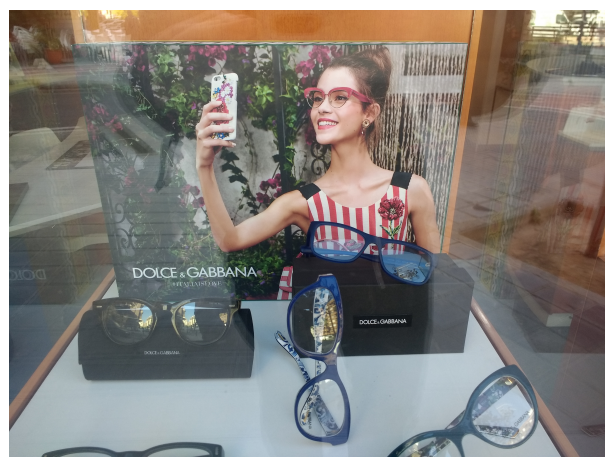

Imagen 9.31: Campaña de la marca de moda y complementos Dolce \& Gabbana realizada en 2017.

De una manera similar, la banca se ha aprovechado de este recurso. Tal como veíamos en el apartado anterior, las intenciones y los protocolos son los mismos, con la salvedad de que, por encontrarse en este segundo punto se trata de un acto representado y no de un producto fotográfico presentado. Asimismo, cabe reseñar que en estos casos el marco de edad de los protagonistas de las 
campañas es mayor. Traemos aquí tres ejemplos que siguen estas pautas: las campañas efectuadas por Caixa Popular (Imagen 9.32) y Deutsche Bank (Imagen 9.33) en 2015 y la realizada por el Banco Santander (Imagen 9.34) durante 2016.

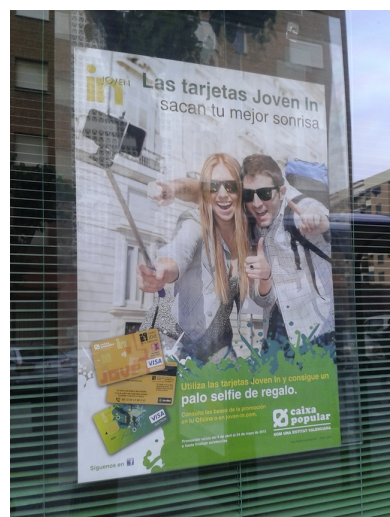

Imagen 9.32: Campaña de Caixa Popular, 2015.

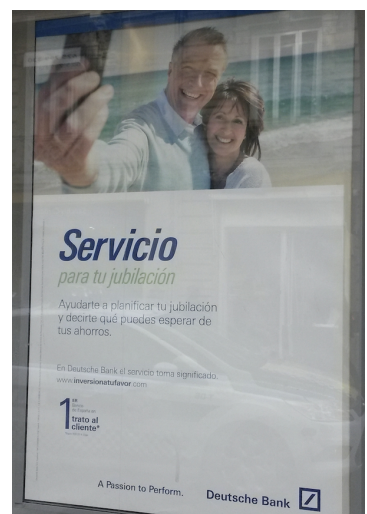

Imagen 9.33:

Campaña de Deutsche Bank, 2015 .

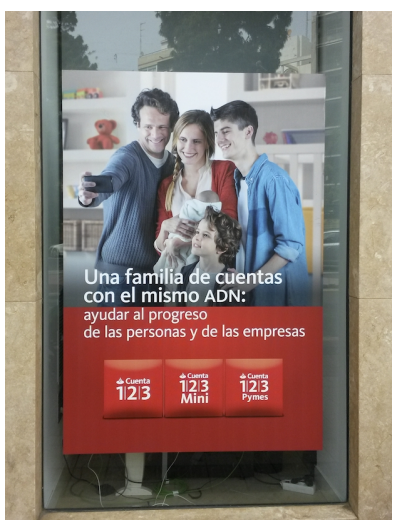

Imagen 9.34: Campaña de Banco Santander, 2016.

De entre los sectores empresariales que hemos encontrado y que se han hecho servir del uso de este tipo de representaciones, sin duda el que más ha empleado este recurso ha sido el sector del turismo, ya sea a través de agencias de viaje o iniciativas locales de festejos y promoción del territorio. Entendemos que el turismo puede ser proclive a apropiarse de dicha imaginería, dada la facilidad con la que se produce actualmente el acto público de hacerse un selfie en un contexto turístico o de viaje, siendo uno de sus iconos más habituales, tal como lo fue en el pasado siglo la fotografía de turistas agrupados en torno a un monumento que pedían a un desconocido que realizara la toma (como vimos en el capítulo 2). Así pues, traemos como un mero ejemplo de todas las agencias de viajes que han hecho y hacen uso de este recurso, la campaña realizada por la empresa Nautalia en 2014 (Imagen 9.35). Se trata de una campaña que resume muy bien, por su repetición, esta estrategia publicitaria. 
f $y$ tsetienasta

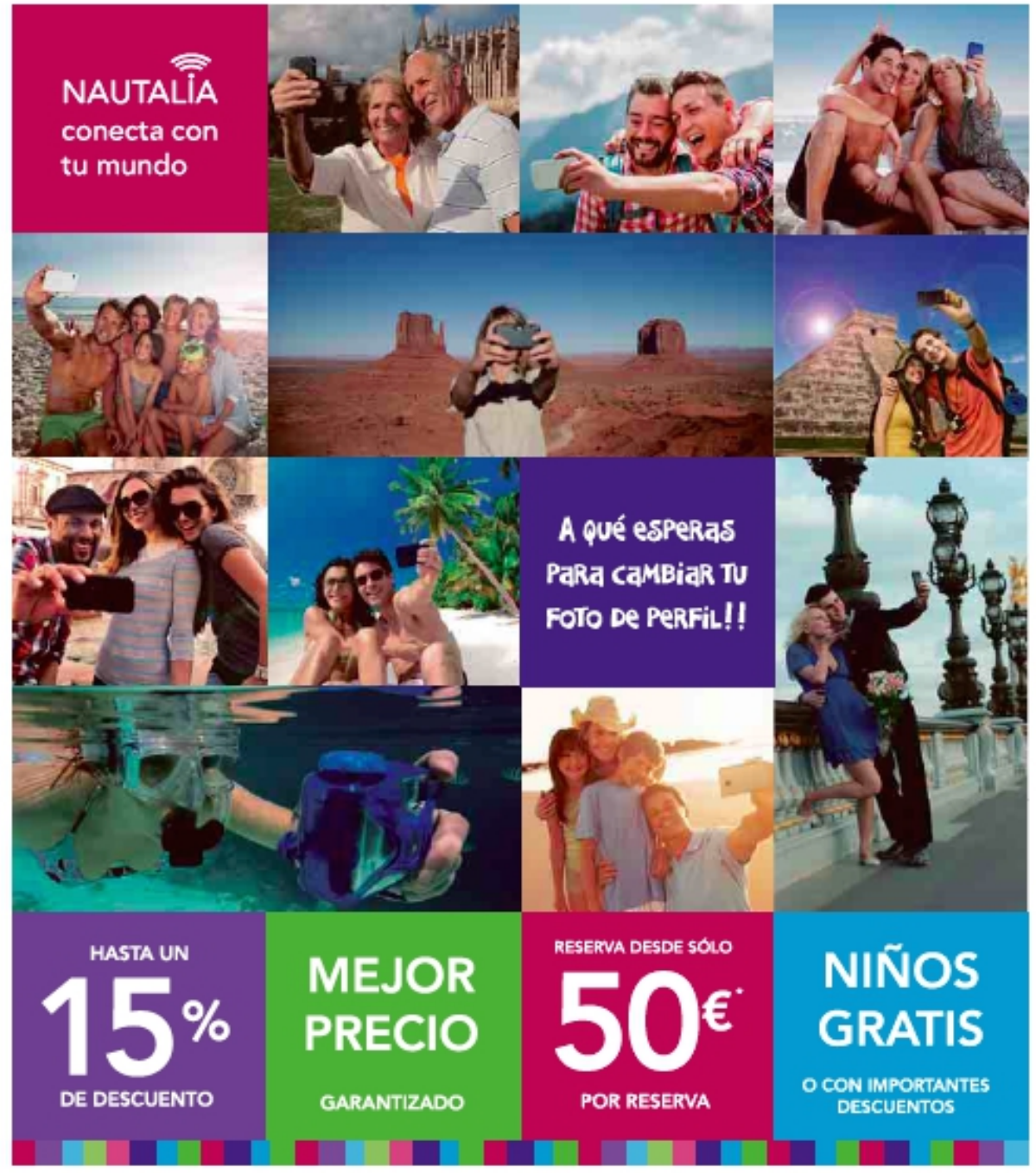

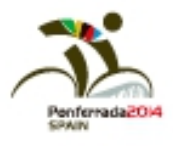

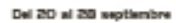

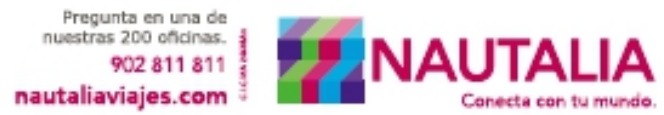

Imagen 9.35: Campaña realizada por la franquicia de agencia de viajes Nautalia, en la que también vemos el uso de la representación del acto de hacerse un selfie. 
A su vez, en el ámbito del turismo y de los viajes, las empresas productoras de las actualmente populares "cajas de viaje" o "paquetes de experiencias", como Smartbox, se han apropiado de esta imaginería para el desarrollo visual de sus campañas de marketing (Imágenes 9.36 y 9.37).

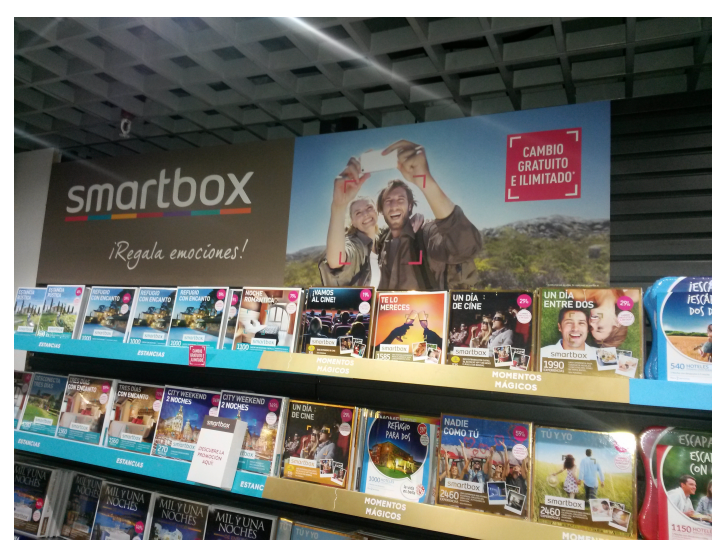

Imagen 9.36: Soporte publicitario de Smartbox, registrado en su ámbito en 2016.

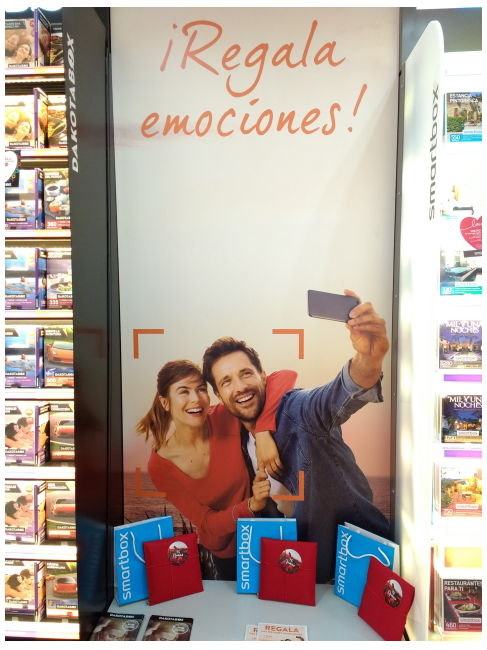

Imagen 9.37: Soporte publicitario de Smartbox, registrado en su ámbito en 2017.

Hemos encontrado también este mismo uso en muchas localidades para promocionar sus fiestas o actividades culturales. Como ejemplo de lo reseñado, podemos destacar la campaña desarrollada con motivo de la feria de artesanía de la ciudad alicantina de Xàbia (Jávea) que en 2017 hizo uso de la ilustración para evocar este acto fotográfico en sus soportes de publicidad y difusión del evento (Imagen 9.38). 


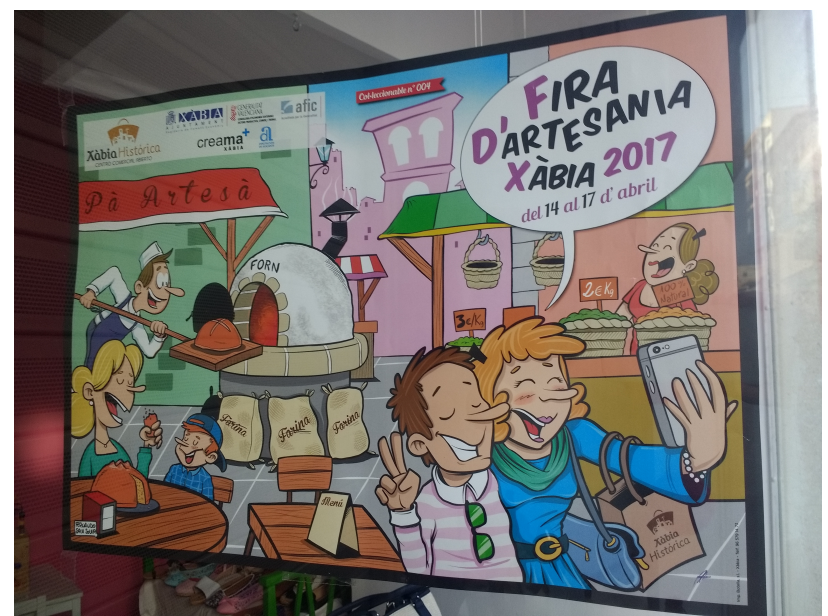

Imagen 9.38: Ilustración anunciadora de la Fira d'artesania de Xàbia en 2017.

Por supuesto, las compañías productoras de smartphones y cámaras digitales de fotografía, por ser artífices del ingenio productor de nuestro objeto de estudio, no iban a quedarse atrás en estrategias de marketing que emplearan la referencialidad hacia el acto de hacerse un selfie. Así, tenemos el original anuncio de la compañía surcoreana Samsung, promocionando su cámara compacta de lentes intercambiables y pantalla abatible $180^{\circ}$ que hace las veces de pantalla-espejo, denominada Samsung NX mini. La cámara salió a la venta en 2014, momento en el que realizó esta campaña (Imágenes 9.39 y 9.40). En ella podemos ver una serie de ilustraciones o infografías que simulan famosos autorretratistas de la historia de la pintura (como Vincent van Gogh o Frida Kahlo) practicándose selfies mediante el uso de la cámara promocionada y la ayuda de su pantalla-espejo. El resultado de esta práctica no sería pues un selfie al uso, sino su propio autorretrato pictórico, de ahí que la argumentación publicitaria sea la supuesta elevada calidad que produce esta cámara cuando el usuario se practica este tipo de autorretratos fotográficos. 


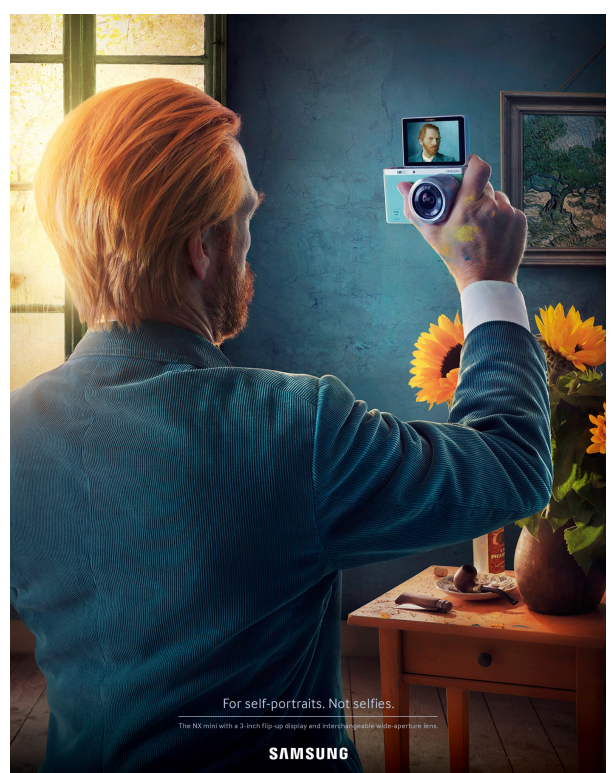

Imagen 9.39: Imagen para la campaña publicitaria de 2014 del Samsung NX mini que muestra al artista Vincent van Gogh realizándose un selfie.

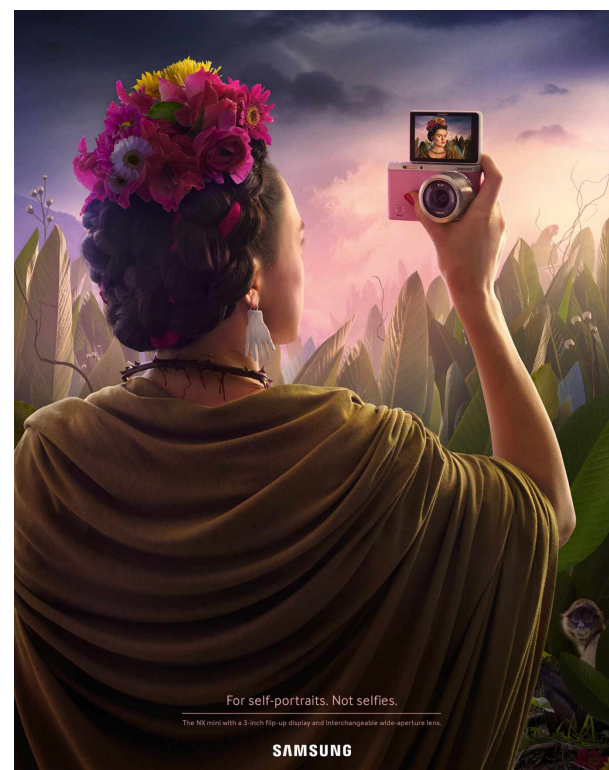

Imagen 9.40: Imagen para la campaña publicitaria de 2014 del Samsung NX mini que muestra a la artista Frida Kahlo realizándose un selfie.

Entre otros múltiples ejemplos relacionados con la industria fotográfica que, en este caso, muestran representaciones de este acto, tenemos las estrategias de imagen presentadas por la marca de cámaras Nikon tanto en la publicidad, como en la caja de su modelo Coolpix S66 de 2016 (Imagen 9.41), una estrategia que también ha sido utilizada por Fujifilm en las pantallas de sus máquinas reveladoras de fotografías desde 2014 (Imagen 9.42).

Estas campañas apuntan hacia el hecho de que cierta cantidad de fotografías actualmente materializadas en papel son también selfies realizados en el contexto turístico. 


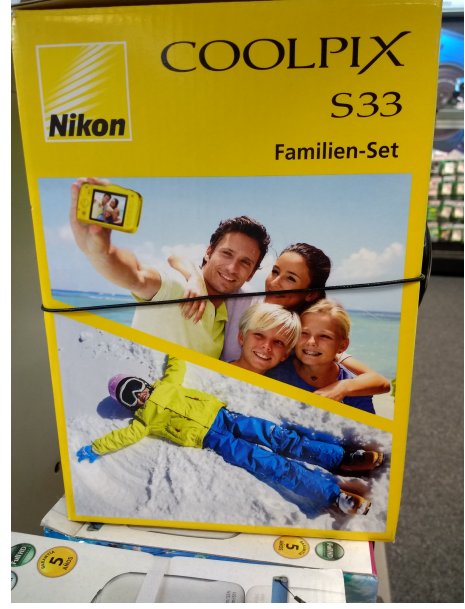

Imagen 9.41: Carátula de la caja de la cámara Nikon Coolpix S33, de 2016.

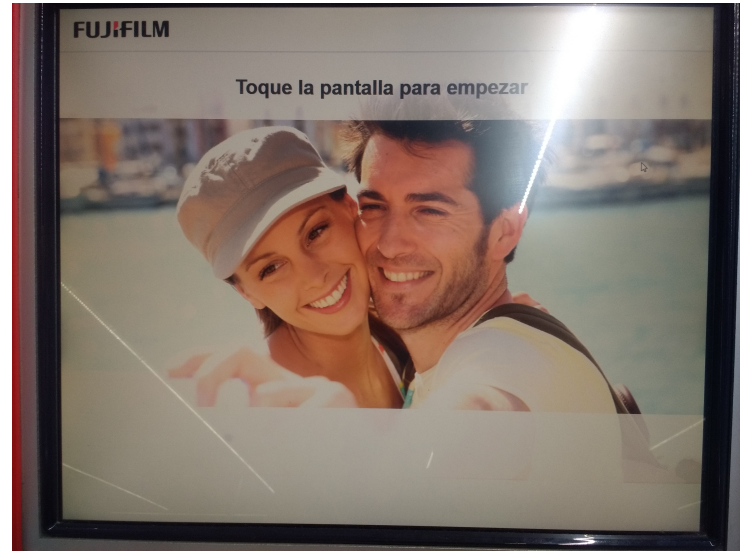

Imagen 9.42: Imagen mostrada en la pantalla de un modelo de máquina reveladora de fotografías de Fujifilm.

Asimismo, la industria del cine y de las series de televisión se han hecho valer de esta imaginería y de la representación de la pose que estamos aquí tratando para vender su producto por medio de publicidad gráfica en diversos soportes. De este modo, carteles de películas como Helicopter Mom $^{21}$ (Imagen 9.43), iGracias jefe! ${ }^{22}$ (Imagen 9.44) o la cinta española Los del túnel ${ }^{23}$ (Imagen 9.45) han empleado este recurso tanto por medio de la fotografía, como de la ilustración. Por otro lado, series televisivas como Young \& Hungry ${ }^{24}$ (Imagen 9.46) o Donny! ${ }^{25}$ (Imagen 9.47) han repetido este ejercicio en sus promociones.

BREZINER, Salomé, et al. (Productores), BREZINER, Salomé (Directora), Helicopter Mom (Mi madre contra todos) [Cinta cinematográfica], Estados Unidos, American Film Productions, 2014. SILVA, Johanna, et al. (Productores), RUFFIN, François (Director), Merci Patron! (iGracias jefe!) [Cinta cinematográfica], Francia, Fakir / Mille et Une Productions, 2015.

23 CARMONA, José; FIGUEROA, Ana; TUSELL, Félix y VALLS, Arturo (Productores), MONTERO, Pepón (Director), Los del túnel [Cinta cinematográfica], España, Estela Films / Pipa Film / Pólvora Films, 2017.

24 TISDALE, Ashley, et al. (Productores), CADIFF, Andy; LEWIS, Phil y SANFORD, Arlene (Directores), Young \& Hungry (Una chef en casa) [Serie de televisión], Estados Unidos, Emitida por ABC family; Blondie Girl Productions / The Tannenbaum Company, 2014.

25 SAVAGE Christopher y VARGAS Kevin (Productores), LAHAIE, Michael (Director), Donny! (Donny!) [Serie de televisión], Estados Unidos, Left / Right, 2015. 


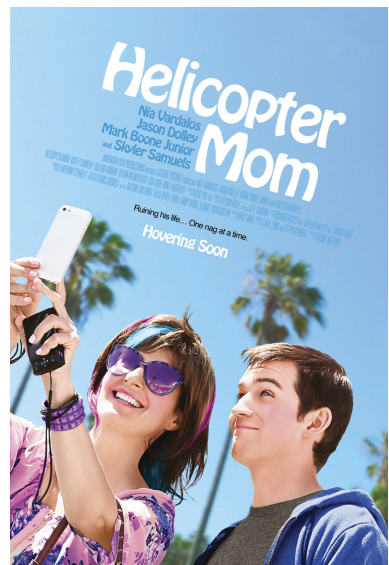

Imagen 9.43: Cartel de la película Helicopter Mom de 2014.

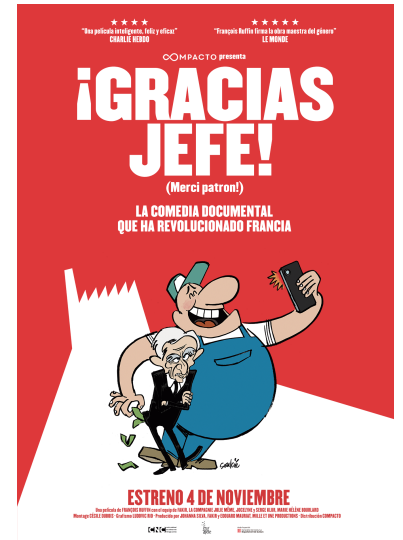

Imagen 9.44: Cartel de la película iGracias jefe! de 2015 .

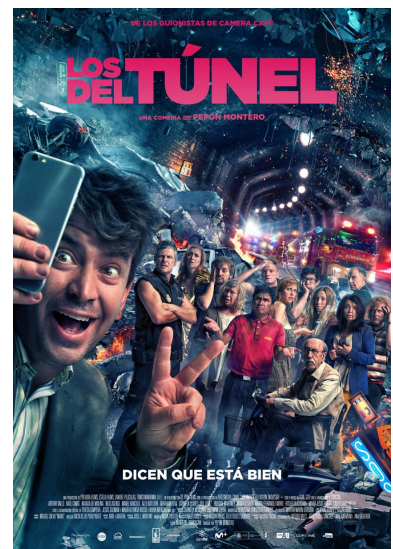

Imagen 9.45: Cartel de la película Los del túnel de 2017.

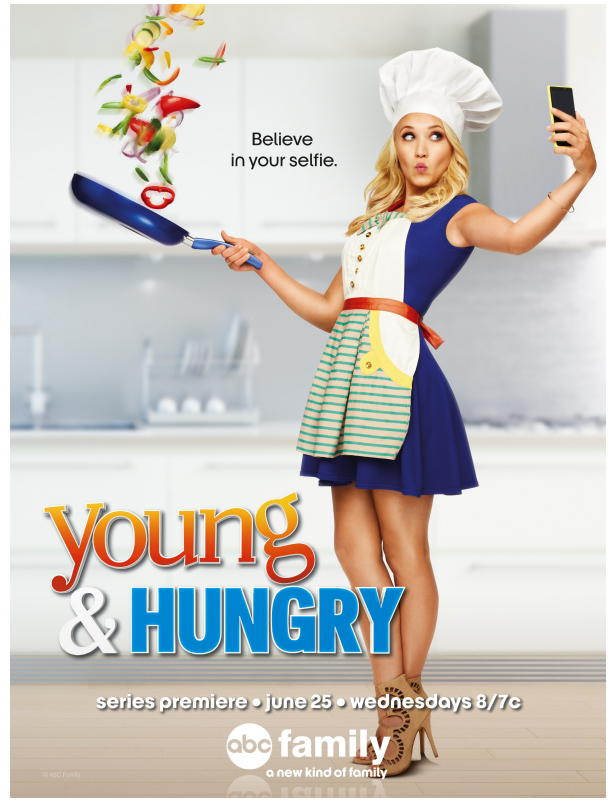

Imagen 9.46: Cartel de la serie de televisión Young \& Hungry de 2014.

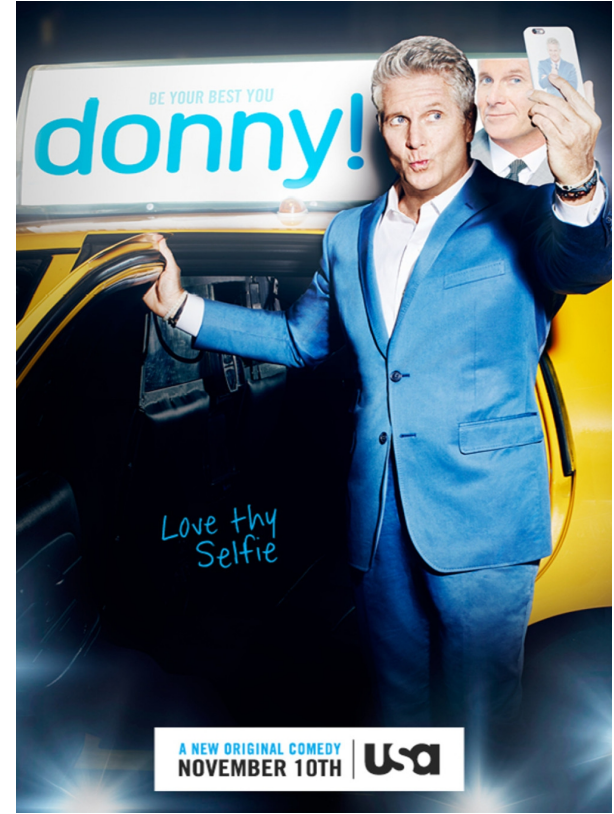

Imagen 9.47: Cartel de la serie de televisión Donny! de 2015. 
En esta línea, multitud de marcas han abusado de este recurso por medio de diversas campañas visuales de publicidad y marketing. Aquí mostramos algunas de las imágenes de campañas realizadas entre 2014 y 2017 por las empresas segundamano.es (Imagen 9.48), Fanta (Imagen 9.49), Colgate (Imagen 9.50), Fnac (Imagen 9.51), El Corte Inglés (Imagen 9.52) y Renault (Imagen 9.53). Además, este tipo de tratamientos gráficos no solo ha sido publicitado por medio de carteles callejeros y grandes paneles retroiluminados, sino también por medio de los soportes más diversos, como paneles de ferias (Imagen 9.54) o autobuses (Imagen 9.55). Aunque no mostramos las imágenes por motivos evidentes de ahorro en la extensión de este apartado, también marcas como cosméticos L'Oréal, caramelos Tic Tac, zumos Zumosol, automóviles Seat, álbumes fotográficos Hoffman, la lechera Central Lechera Asturiana, productos de higiene íntima Tampax, la empresa de alimentación Dr. Oetker, supermercados Lidl, licores Ruavieja, seguros médicos Adeslas, moda femenina Calzedonia o la compañía telefónica Lowi, se han hecho servir igualmente de este tipo de recurso de representación del acto de practicarse un selfie mostrado a lo largo del presente apartado.

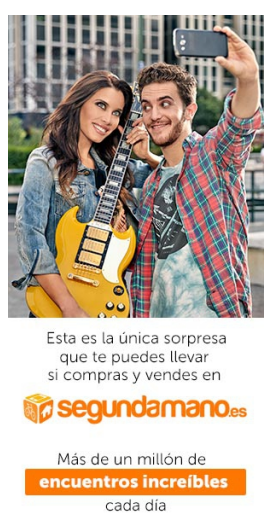

Imagen 9.48: Campaña del portal segundamano.es.

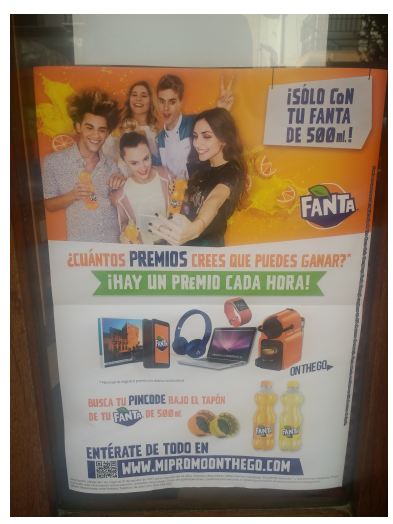

Imagen 9.49: Campaña de Fanta.

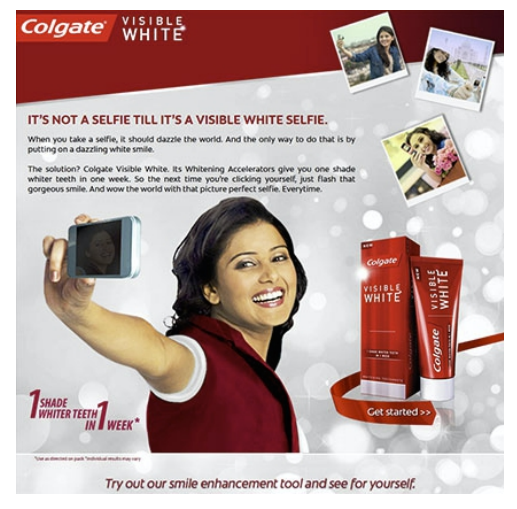

Imagen 9.50: Campaña de Colgate. 


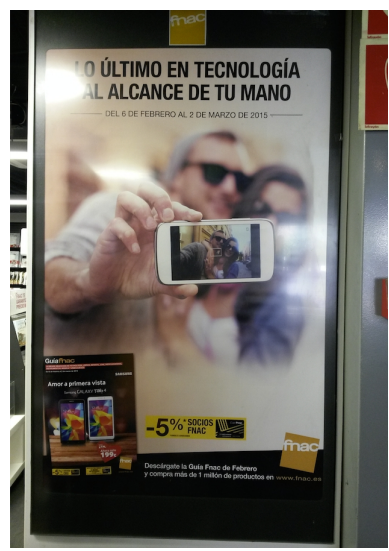

Imagen 9.51: Campaña de Fnac.

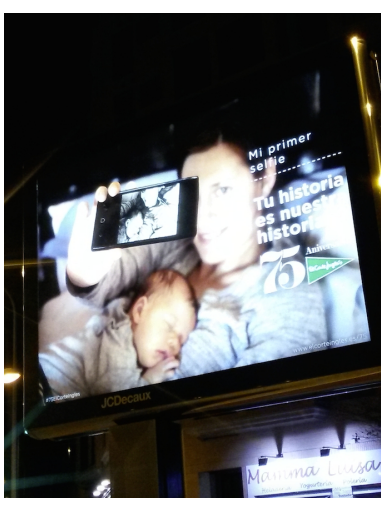

Imagen 9.52: Campaña de El Corte Inglés.

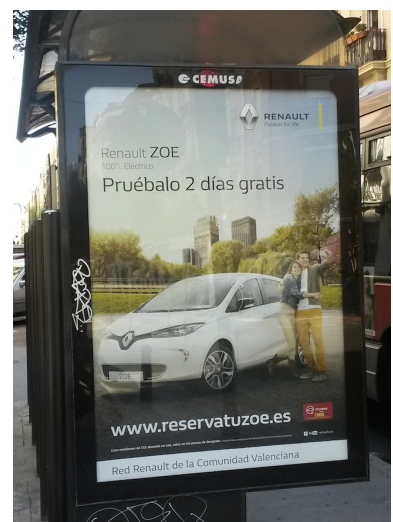

Imagen 9.53: Campaña de Renault.

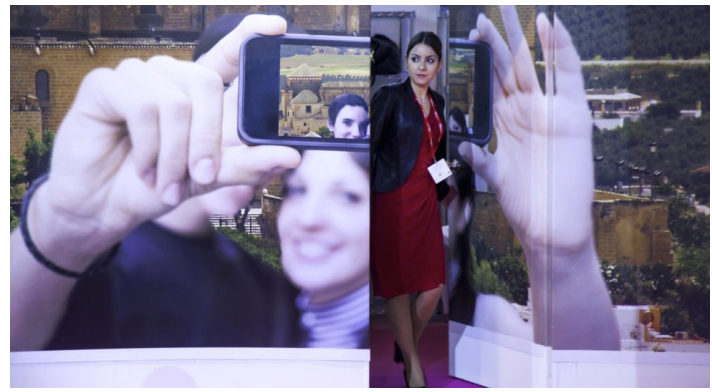

Imagen 9.54: Stand en la feria internacional FITUR, feria dedicada al sector turístico, celebrada en Madrid en 2016.

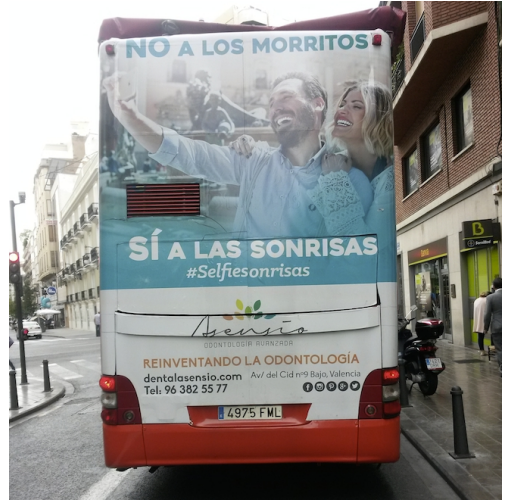

Imagen 9.55: Campaña de Dental Asensio, promocionada en un autobús en Valencia durante 2016. 


\subsubsection{La autofoto como invitación para el desarrollo de una campaña de marketing.}

De forma paralela a los ejemplos previos, hemos encontrado a lo largo de estos años una serie de iniciativas realizadas por diversas marcas que también se sirven de la actual popularización y práctica del selfie, aunque esta vez no como recurso visual, sino como una novedosa estrategia de marketing en la que se busca una interactuación directa, realizada por un plausible cliente potencial, invitándole a que este se realice un selfie y lo publique en un determinado espacio o portal.

Esta acción retroalimentaría los beneficios publicitarios de una manera bidireccional, puesto que la publicación de un selfie por un usuario participante en la campaña y, a su vez, enlazado mediante los hashtags propuestos por la promoción como requisito en la maraña rizomática que, como veíamos en el capítulo 6 generan las redes sociales, actuaría de forma beneficiosa para la viralizacón de dichas campañas.

Así, encontramos varios ejemplos que hemos podido detectar en nuestra cotidianeidad, como por ejemplo la campaña publicitaria de difusión turística que el complejo hotelero Pueblo Acantilado de El Campello, Alicante, realizó en 2017 para promocionar en las redes sociales su existencia.

En la citada campaña los usuarios, por medio de selfies realizados en determinados selfie points destinados al efecto (Imágenes 9.56 y 9.57), intervenían en la promoción y podían participar en un sorteo de estancias a cambio de la colaboración publicitaria llevada a cabo. 


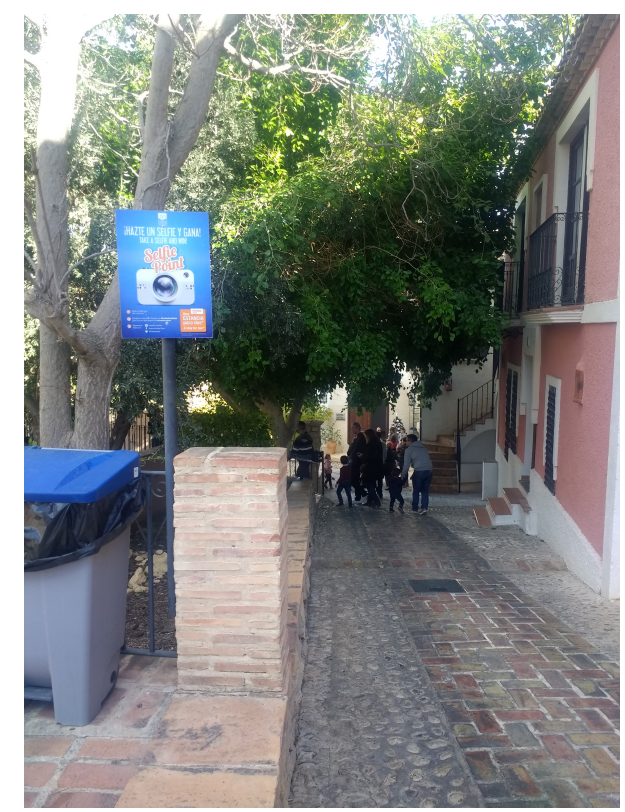

Imagen 9.56: Cartel ubicado en diferentes puntos del complejo hotelero Pueblo Acantilado de El Campello, Alicante, 2017.

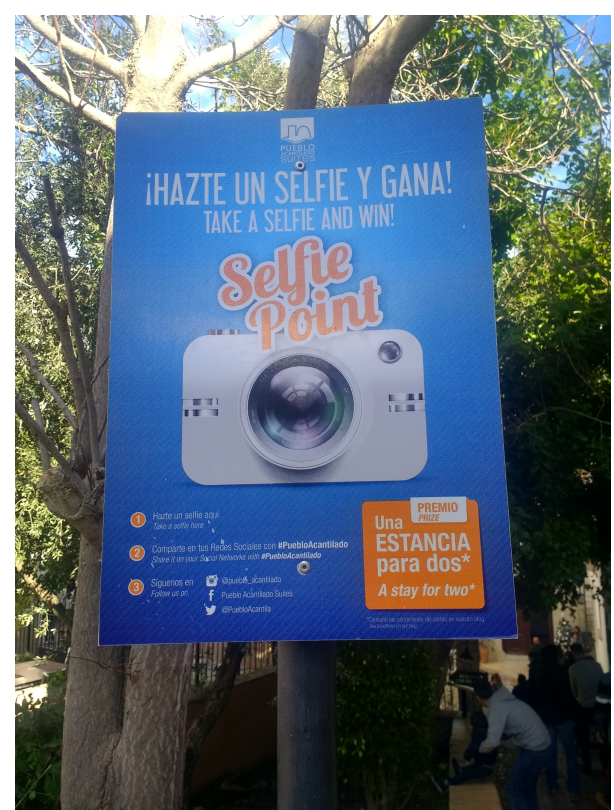

Imagen 9.57: Cartel de la campaña colaborativa en la que el participante del sorteo por medio de la publicación de un selfie también es el difusor y el propio producto de esta campaña.

En esta misma línea y mediante un tipo de publicidad menos local y más nacional, la empresa de cámaras fotográficas Canon utilizó una estrategia similar mediante el hashtag denominado \#selfieless, durante las navidades de 2016, dentro de una campaña solidaria con Cruz Roja Española (Imagen 9.58).

Pese a los nobles motivos, la publicación de selfies realizados por los participantes, a trvés de la inclusión de un etiquetado dirigido hacia la propia promoción y hacia los contactos de sus redes, provocaba una rápida viralización rizomática que posibilitaba la extensión de la campaña a los usuarios de dichas redes. Desde sus respectivas páginas web, tanto Canon como Cruz Roja 
Española ${ }^{26}$ explicaban perfectamente (Imagen 9.59) los pasos a seguir como una invitación para el desarrollo de las autofotos por parte de los clientes participantes que, como en el caso anterior, también quedaban convertidos en producto exhibido.

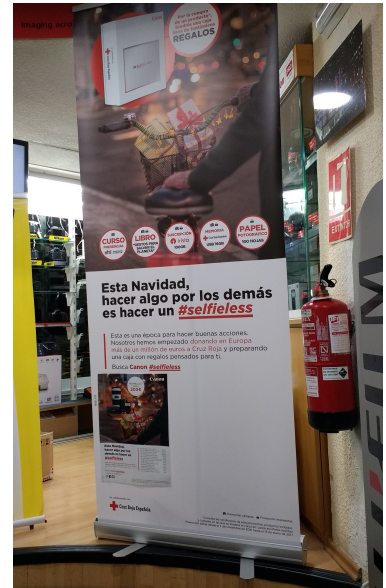

Imagen 9.58: Mupi gráfico promocionador de la campaña de Canon y Cruz Roja Española \#selfieless, 2016.
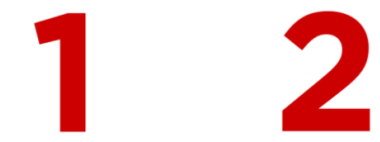

Haz algo bueno.

Publica tu foto \#selfieless.

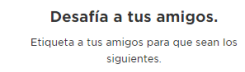

Con independencia de estas promociones, también deseamos destacar dos campañas locales que pueden contrastar entre ellas por su distancia y, a la vez, evidenciar lo globalizado que está, como hemos visto, tanto este fenómeno, como su práctica publicitaria. La primera, se encontraba realizada por el Institut Valencià d'Art Modern (IVAM) de nuestra ciudad (Imagen 9.60), mientras que la segunda fue llevada a cabo por una empresa de mobiliario del hogar (CenturyPly) ubicada en la India (Imagen 9.61). 


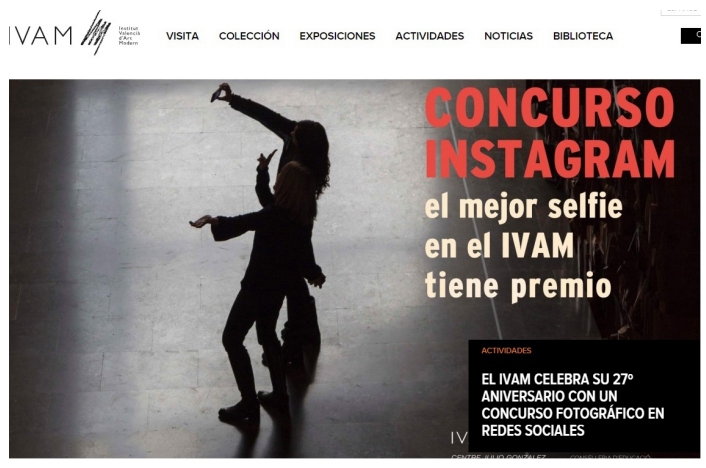

Imagen 9.60: Campaña-concurso del Instituto Valenciano de Arte Moderno (IVAM) realizada en 2016 bajo el lema El mejor selfie en el IVAM tiene premio.

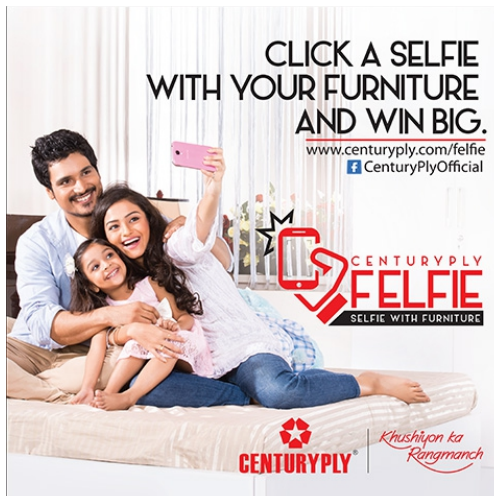

Imagen 9.61: Campaña realizada por la empresa india de muebles CenturyPly.

A veces, las iniciativas publicitarias o de marketing han decidido que la realización de un selfie sea condición sine qua non para la obtención de un beneficio comercial o para que forme parte de la metología de contacto del cliente con la empresa anunciadora. En todo caso, el cliente estaría obligado a realizarse un selfie para poder interactuar con la compañía de la que espera algún tipo de servicio. Traemos dos ejemplos en relación a este tipo de estrategia de venta, el primero puesto en práctica por la entidad bancaria BBVA en 2016. Bajo el lema Hazte cliente con un selfie (Imagen 9.62) el citado banco obligaba a los nuevos clientes a que se realizaran un selfie con la aplicación de smartphone aportada por la entidad mediante la tienda de aplicaciones del propio terminal. Curiosamente, el selfie serviría también como fotografía del perfil de la cuenta online creada. La estrategia comercial no solo estaba basada en lo irreverente y a la vez familiar de la metodología empleada a la hora de abrir la cuenta bancaria, sino en la supuesta sencillez para realizar este trámite burocrático: "tan sencillo como hacerse un selfie".

También, dando un paso más allá, encontramos la iniciativa de marketing objetual realizada en 2017 por The Tea Terrace, una cafetería de 
Oxford Street (Londres), que cobra 7,5 libras por cada café que prepara bajo su nomenclatura inventada de selfieccino (término que combina la palabra selfie y la palabra capuccino). Se trata de una taza llena de café con un selfie del cliente representado en la propia espuma del café (Imagen 9.63). El procedimiento es muy sencillo: "Simplemente hay que enviar por WhatsApp una de las fotos que tenemos en el móvil y una máquina, que han bautizado como Cino, la escanea e imprime en la espuma de tu café. En cuatro minutos estará listo para beber” ${ }^{27}$.

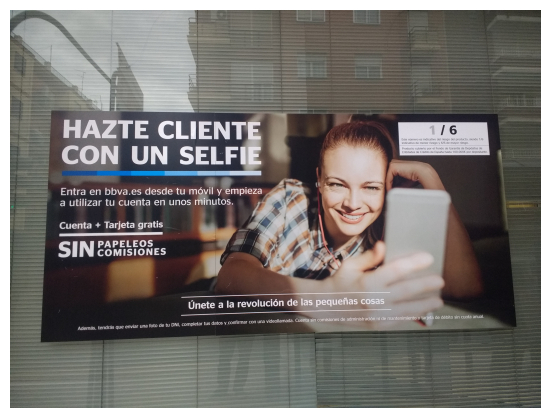

Imagen 9.62: Campaña de promoción de cuentas online por parte de la entidad bancaria BBVA en 2016 bajo el lema: Hazte cliente con un selfie.

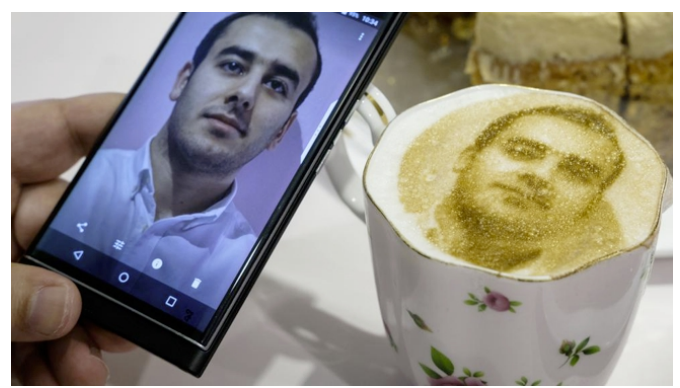

Imagen 9.63: Selfieccino realizado en The Tea Terrace de Londres en 2017: un selfie realizado y enviado por el cliente e impreso en la propia espuma del café capuccino.

Otra buena cantidad de iniciativas publicitarias y de marketing se han basado en este tipo de desarrollos, propuestas e iniciativas para hacer llegar su mensaje al cliente mediante su propia interactuación por medio del selfie, como la realizada por Sharon Tucker bajo el lema Signos vitales durante 2016. La campaña fue destinada a visibilizar la labor de la enfermería en los hospitales de todo el mundo ${ }^{28}$. En relación con esta estrategia, también cabe reseñar el

NEAL, Leon, "Selfieccino, la nueva moda gastro que arrasará en 2018", 2018, disponible en: <http://www.lavanguardia.com/comer/tendencias/20180109/434168994051/selfieccino-la-nuevamoda-gastro-que-arrasara-en-2018.html $>$ [Fecha de consulta: 20 de marzo de 2018]. 
Selfiefestival, que tuvo lugar en el madrileño centro comercial La Vaguada durante el mes de mayo de $2104^{29}$ y que bajo los mismos parámetros que venimos comentando buscó la promoción de dicho centro y de sus comercios. A su vez, otras marcas como Lays, El Corte Inglés o Euromillones han establecido también estas mismas actuaciones en alguna de sus campañas, y siempre bajo similares protocolos e intenciones:

\begin{abstract}
"[...] estrategias determinadas, asimismo, por operaciones de marketing bien calculadas y la búsqueda explícita de una rentabilidad económica, lo cual confirma que, más allá de los usos individuales, la práctica del selfie ha acabado convirtiéndose en un fenómeno de masas donde el aficionado ha ido adquiriendo un papel protagónico, utilizándolo incluso como un medio de autopromoción" ${ }^{30}$.
\end{abstract}

\title{
9.1.4. La publicidad engañosa basada en la apropiación del autorretrato ajeno.
}

Tanto en los primeros años de nuestras investigaciones en relación al tema aquí tratado, como recientemente hemos encontrado ejemplos en la red que publicitan material (en ocasiones de dudosa veracidad) relacionado con la industria sexual de contactos y de citas que se han hecho servir de selfies y mirrorpics directamente de las galerías visuales de Internet. Este material se ha obtenido en la mayoría de casos sin pedir permiso a sus autores (por otro lado, imposibles de contactar, dado el carácter viral, reproducible y difícil de rastrear

Voice of Nursing Since 19oo, vol. 116, $\mathrm{n}^{\circ}$ 5, 2016, p. 11.

29 CANGA, Manuel, “Introducción al fenómeno del selfie: valoración y perspectivas de análisis", en Fotocinema. Revista científica de cine y fotografía, $\mathrm{n}^{\mathrm{0}} 10,2015$, p. 386.

3o Ídem. 
que, como hemos visto, supone la dispersión en la red de este tipo de imágenes). En todo caso, la dificultad de encontrar al autor de un self shot viralizado y disperso no justifica el hecho de realizar un supuesto engaño o usurpación de la identidad visual de una persona para sugerir un perfil falso o un usuario ficticio ${ }^{31}$. Desde 2013 (Imagen 9.64) hasta 2018 (Imagen 9.65) hemos encontrado una gran cantidad de ejemplos que hemos agrupado a modo de collage en estas dos imágenes. Las mismas incluyen algunos de las autofotos digitales que más se han viralizado estos últimos años. Pese al paso del tiempo, podemos comparar ambas imágenes y constatar que las actitudes y estrategias existentes en este submundo operativo son las mismas: publicidad engañosa o de dudosa lealtad que sigue abundando en los foros y espacios patrocinados de Internet. Estas prácticas fraudulentas en forma de banners o de publicidades gráficas, previsiblemente engañosas, que continúan ofertando desde redes sociales para solteros en busca de encuentros sexuales, protocolos de contacto con mujeres de otros países, o publicidad de aplicaciones para citas y contactos, son aparentemente un presunto ejercicio de robo de imágenes públicas, cuando no una simple y directa suplantación de identidades. Sus ideólogos, además de vender humo, se han servido de imágenes de terceros (adolescentes y jóvenes cuyas fotografías acabaron en la red pública por motivos de diversa índole) que no guardan relación alguna con los perfiles y personas simuladas, y ello con el objetivo de engañar a algún internauta despistado. Si revisamos nuevamente la imagen 9.64 podemos imaginar que ni Jaime Laycock ni Mónica Lizeth Murillo (cuyos selfies, tal como vimos en el capítulo 5 , se viralizaron y todavía vagan en muchas galerías de Internet) fueron informadas de su protagonismo en estas publicidades, de ahí que resulte improbable que percibieran algún tipo de remuneración por tal trabajo de modelaje. El hecho de que se realicen este tipo de prácticas pone de manifiesto la falta de soluciones que existe hoy en día en la creciente,

31 FANJUL, Sergio C., “¿Por qué estas muchachas sexys quieren ser mis amigas en Facebook?”, 2016, disponible en: <https://verne.elpais.com/verne/2016/o7/o9/articulo/1468087028_159176.html> [Fecha de consulta: 20 de julio de 2017]. 
deslocalizada y líquida red global en lo concerniente, entre otras cuestiones, a los derechos de las imágenes y al uso fraudulento de estas.
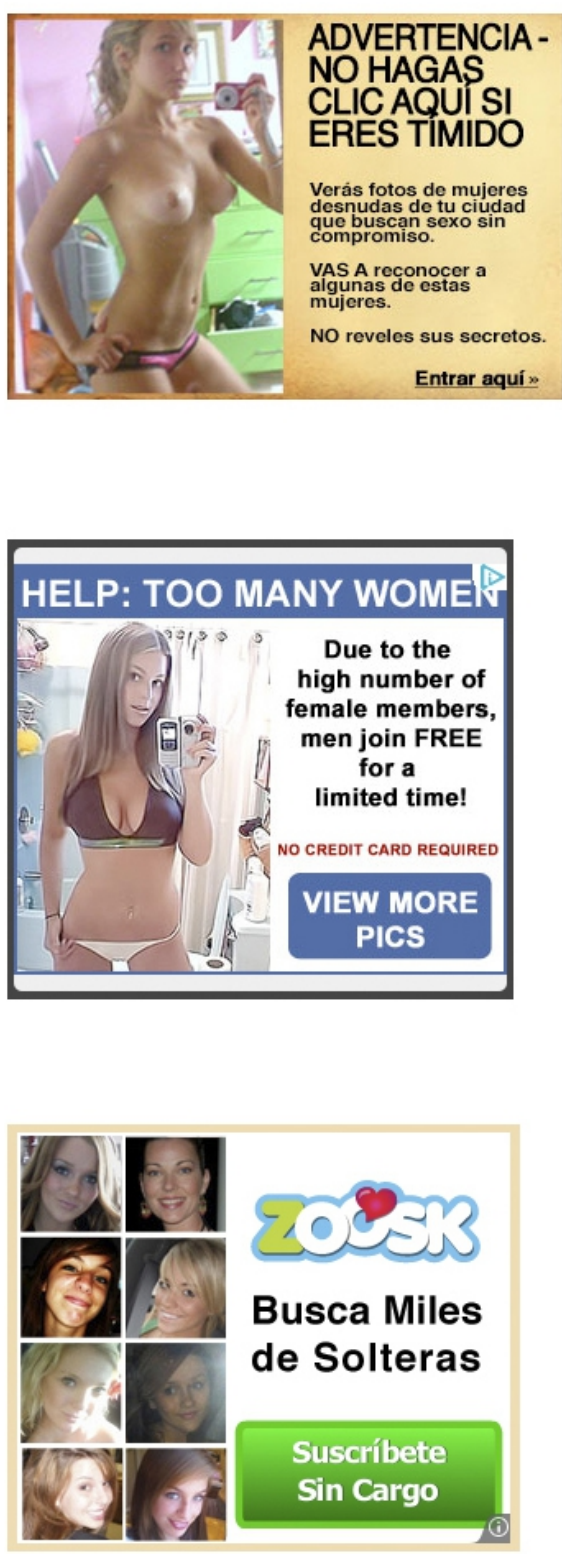

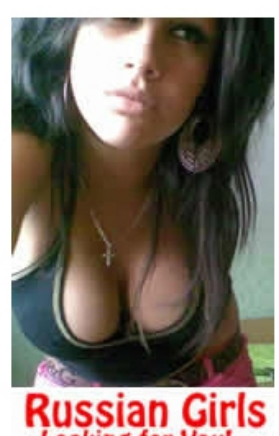

Looking for You!

\section{They want to Date You.}
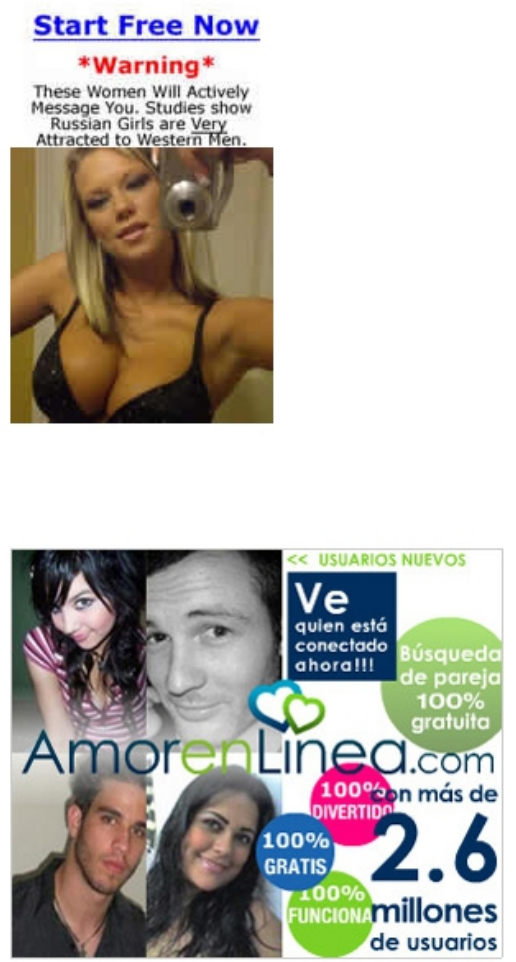

Imagen 9.64: Diversos ejemplos del uso de self shots reales de manera fraudulenta en publicidad engañosa y que no guarda relación con los autorretratados de los que se sirve. Montaje realizado con ejemplos encontrados en 2013. 

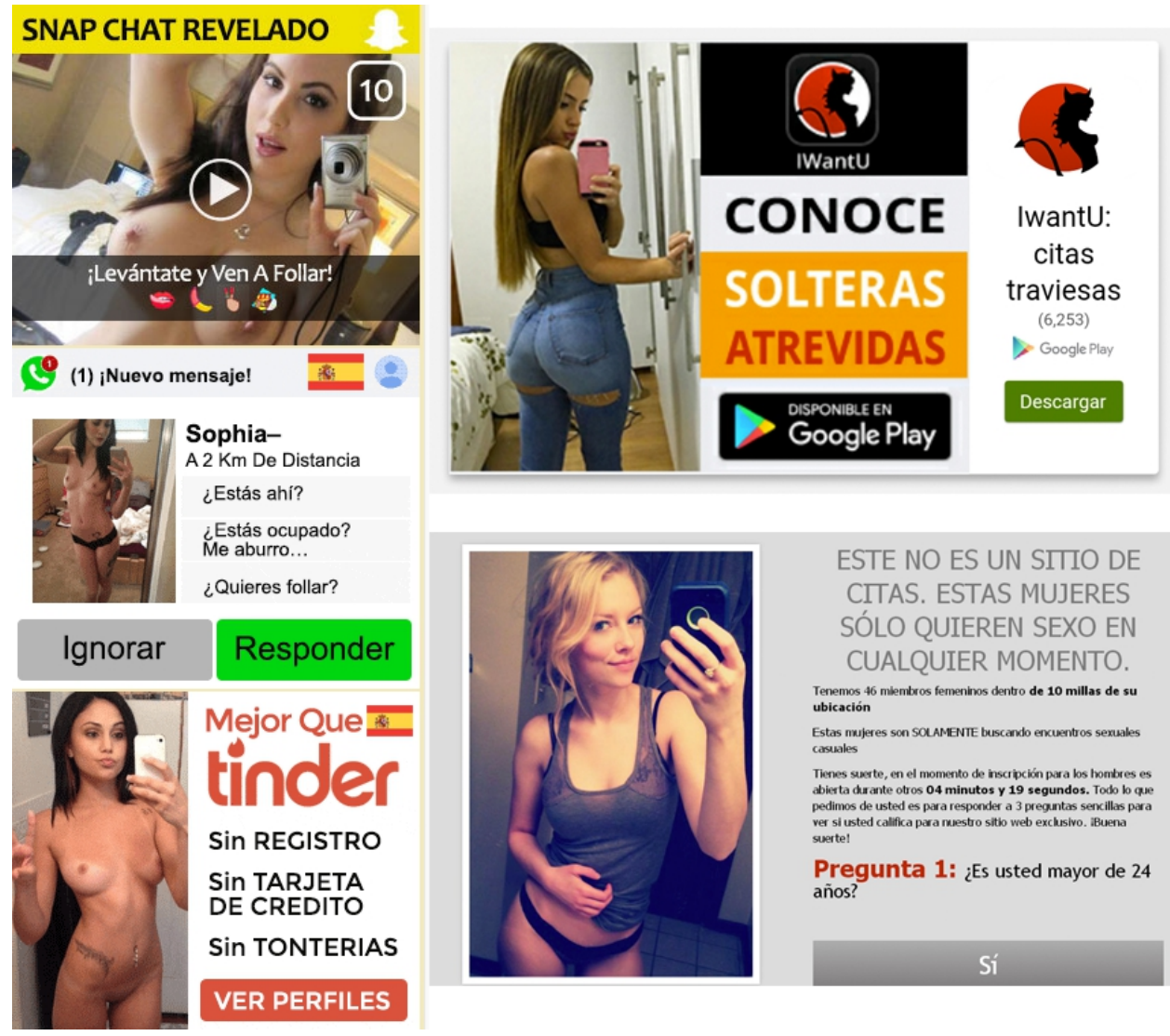

¿Estás ahí?

Estás ocupado?

Me aburro...

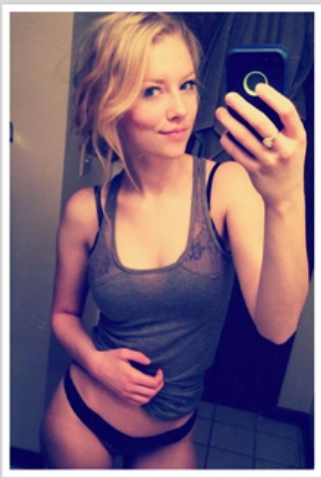

ESTE NO ES UN SIIIO DE CITAS. ESTAS MUJERES SÓLO QUIEREN SEXO EN CUALQUIER MOMENTO. Tenemos 46 mbembros femeninos dentro de 10 millas de su ubicación

Estas mujeres son SOLAMENIE buscando encuentros sexuales costales

Thenes suxste, en el momento de inscripción para los hombres es abierta durante ofros 04 minutos y 19 segundos. Todo b que pedimos de usted es para responder a 3 preguntas sencillas para ver si usted califica para nuestro sitio web excusivo. Buena

Pregunta 1: ¿Es usted mayor de 24 años?

$$
\text { Sí }
$$

Imagen 9.65: Otro montaje similar al reseñado en la imagen precedente, aunque con muestras de 2018. 


\subsection{La presencia del selfie en el cine y en las series televisivas.}

El cine siempre ha actuado, en tanto que medio de representación de la sociedad que lo acoje, como un buen reflejo o impronta testimonial de su propia contemporaneidad. Lo mismo ha ocurrido recientemente con las series televisivas, mostradas en novedosas plataformas como Netflix que, mediante una suscripción mensual y por medio del streaming (visualización desde un servidor por medio de una conexión de red), permiten consumir material audiovisual desde cualquier dispositivo multimedia. Ciertamente, las series se han convertido en un "segundo séptimo arte" debido a su gran consumo durante las dos últimas décadas y a las grandes inversiones económicas y de marketing que implementan muchas productoras en torno a ellas. En todo caso, cine y series están siendo reflejo de nuestro tiempo, dejando ese registro y testimonio también sobre nuestro objeto de estudio: el autorretrato digital publicado en la red.

Analizaremos, por ello, ahora algunos ejemplos que nos pueden parecer relevantes en torno a esta cuestión, ejemplos como el representado por el corto

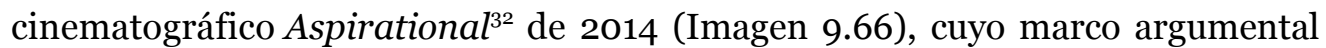
se basa en la obsesión por los selfies por parte de algunos jóvenes, hecho que puede llegar a sobrepasar, incluso, la realidad más extraordinaria. En este cortometraje en el que la actriz Kirsten Dunst se interpreta a sí misma, la protagonista comparte un encuentro con unas supuestas admiradoras que desean autorretratarse con ella por medio de un selfie, pero que en realidad están más pendientes de sus propias poses, registro, publicación y taggeo que de la propia celebridad. Bajo nuestro punto de vista el cortometraje plantea una crítica 
pertinente a la relación superficial que hoy puede asociarse al acto del selfie o a la presencia y actividad en las redes virtuales que asumen los jóvenes.

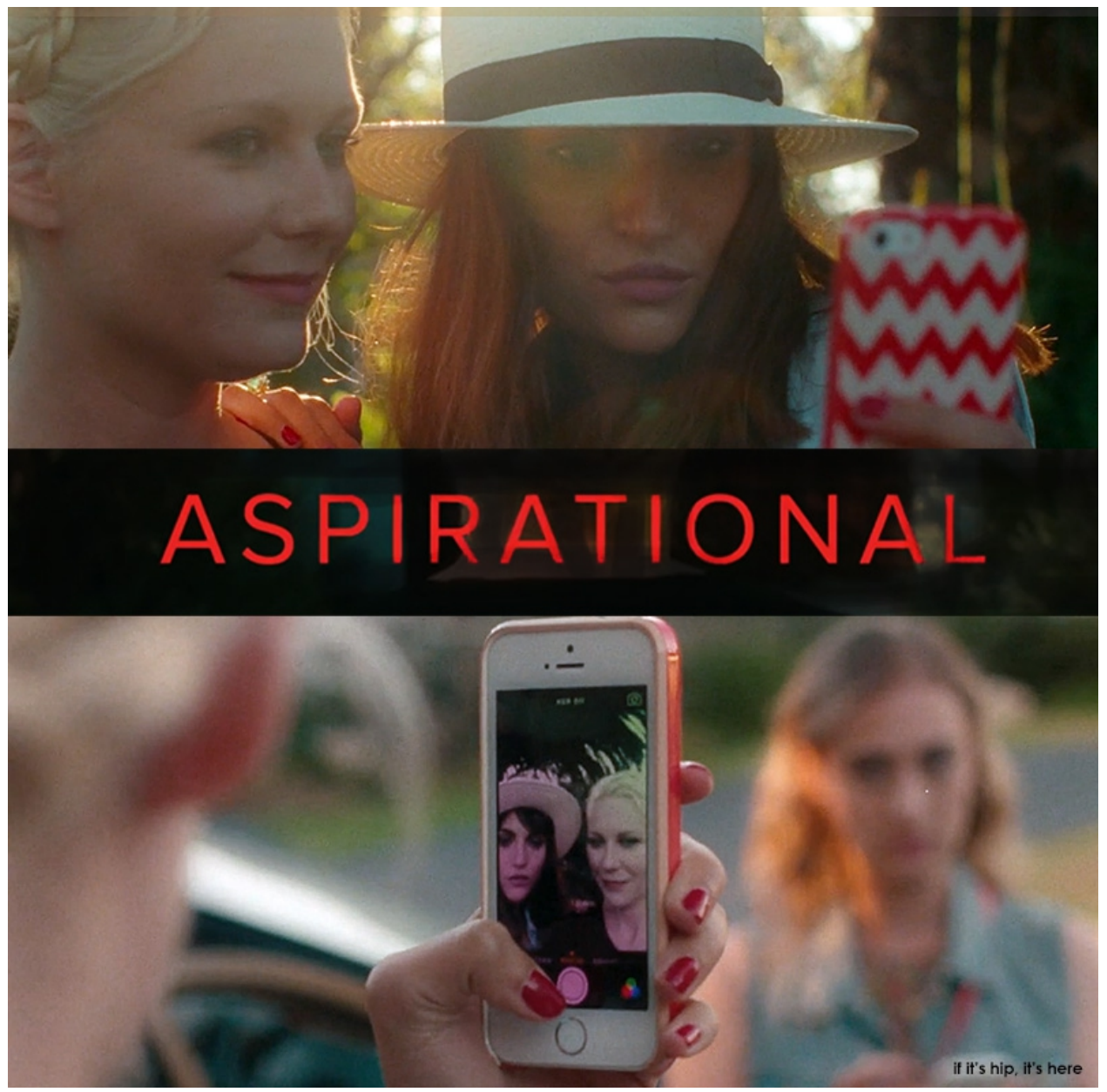

Imagen 9.66: Cartel promocional del cortometraje Aspirational de Matthew Frost, 2014.

No obstante, el acto de la práctica del selfie es abordado de una manera mucho más satírica en el segundo episodio de la primera temporada de 
Unbreakable Kimmy Schmidt ${ }^{33}$ (Imagen 9.67), una serie cómica emitida en Netflix desde 2015 que cuenta la historia de una joven que, desde su adolescencia en la década de 1990, ha vivido encerrada en un búnker. De esta privación de libertad a la que se ha visto sometida por parte de un fundamentalista religioso, logra escapar en 2015. A partir de ese momento ha de hacer frente a todos los cambios producidos en la sociedad, durante los veinte años en los que ha estado desconectada de la misma. Esta pelirroja protagonista llamada Kimmy curiosea y descubre (como una adolescente con cuerpo de adulta que es) todas las alocadas novedades de nuestro futuro, como la práctica del selfie por medio de un smarthpone que su empleadora, una adinerada y excéntrica propietaria de Nueva York, le muestra mediante una instructiva escenificación de su acto tras ver que ella se ha autorretratado accidentalmente desde el ombligo: "Así te saldrá papada, tienes que alzar el teléfono por encima de la cabeza, poner morritos y entornar los ojos" (Imagen 9.68).

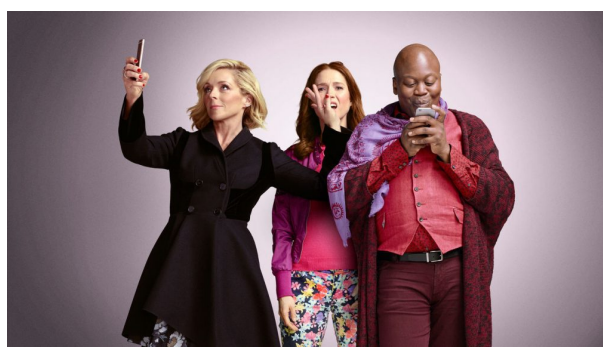

Imagen 9.67: Imagen promocional de la serie Unbreakable Kimmy Schmidt en la que también vemos la representación del acto de hacerse un selfie por parte de una de sus protagonistas. La serie comenzó a emitirse en 2015.

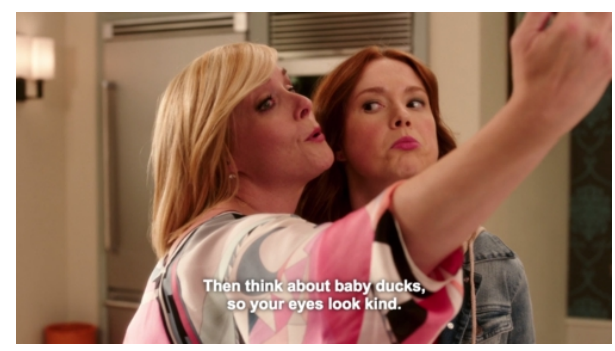

Imagen 9.68: Frame extraído de la serie Unbreakable Kimmy Schmidt.

33 KUPFER, Jerry; MEANS Sam y SCHNAPPER, Schnapper (Productores), SHAPEERO, Tristram, et al. (Directores), Unbreakable Kimmy Schmidt (Unbreakable Kimmy Schmidt) [Serie de televisión], Estados Unidos, Little Stranger / Universal TV / Netflix, 2015. 
Pese a que también por cuestiones obvias hemos tenido que ceñirnos aquí a la exposición de unos escasos ejemplos en relación a la gran cantidad de material disponible, nos parece pertinente incluir la representación del mirrorpic erótico compartido, a modo de sexting, por una de las protagonistas de la aclamada primera temporada de la serie True Detective ${ }^{34}$ creada y dirigida por Nic Pizzolatto en 2014. Lo interesante de esta circunstancia es, bajo nuestro punto de vista, el hecho de que parte de la serie (también la escena aquí mostrada en la Imagen 9.69) narra hechos transcurridos en 2002 por lo que, pese ha haber sido rodada en 2014, los realizadores tuvieron que simular este pionero self shot con la calidad visual y el tipo de celular con cámara que hacía posible esta práctica en aquella época, llegando a un grado de credibilidad muy próximo a aquellos primeros autorretratos publicados que veíamos en el capítulo 3 .

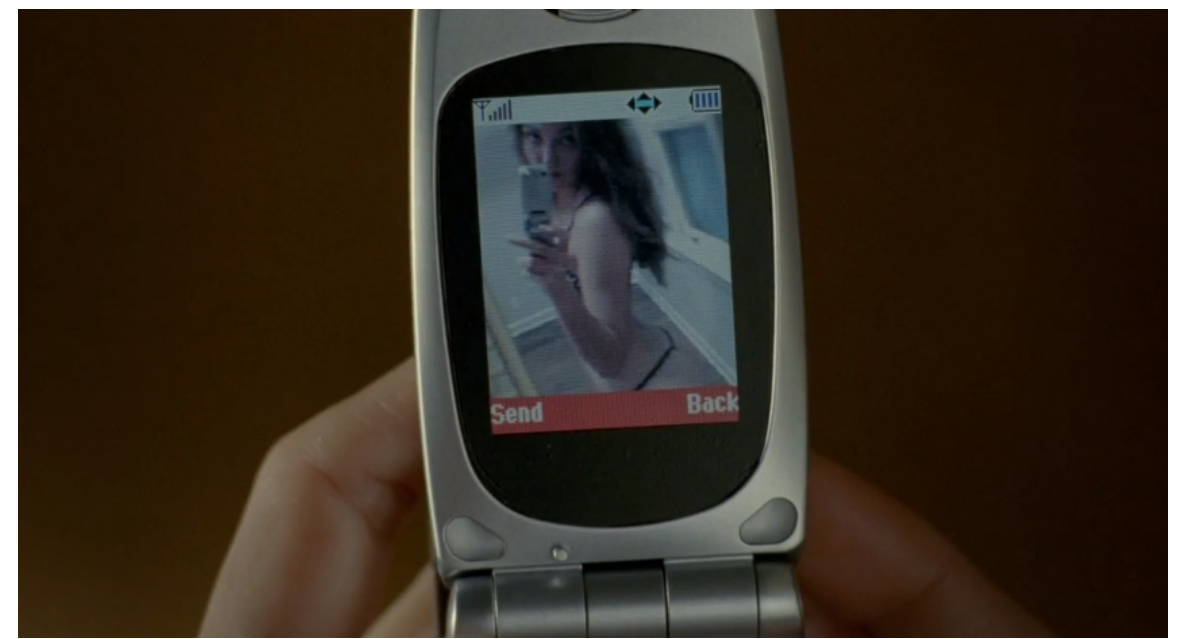

Imagen 9.69: Frame de la serie True Detective de 2014 que muestra la simulación de un mirrorpic erótico compartido por vía MMS entre dos teléfonos celulares desplegables de la época narrada (2002). 
Asimismo, hemos observado el uso del selfie como herramienta de control y extorsión por parte del villano de la serie de Netflix y Marvel Studios titulada Jessica Jones ${ }^{35}$. En la primera temporada de dicha serie, la protagonista (Jessica) se ve forzada a remitirle a su antagonista un selfie diario para constatar su presencia en determinado lugar y mostrar, así, su predisposición a colaborar con dicha extorsión (Imágenes 9.70 y 9.71).

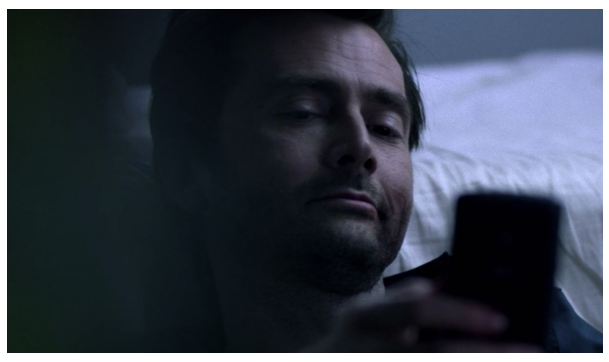

Imagen 9.70: Frame de la serie Jessica Jones. Se trata del momento en el que el villano extorsiona a su víctima, 2015-2016.

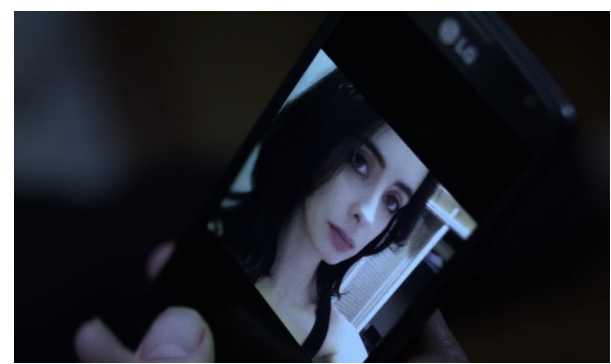

Imagen 9.71: Otro frame de la misma serie que muestra el selfie de la protagonista, prueba de la extorsión.

Entre otros ejemplos, el selfie y su utilización para el ciberbullying en los institutos ha sido ampliamente representado en la cruda serie a la que ya hicimos mención durante el capítulo 5 Por trece razones ${ }^{36}$ (Imagen 9.72), y también en una representación, a modo de graffiti, en los créditos iniciales de la película de fantasía urbana Bright $^{37}$ (Imagen 9.73).

35 IACOFANO, Tom (Productor), RYMER, Michael, et al. (Directores), Jessica Jones (Jessica Jones) [Serie de televisión], Estados Unidos, American Broadcasting Company [USA] / Marvel Studios / Netflix, 2015.

36 INCAPRERA, Joseph (Productor), YORKEY, Brian, et al. (Directores), 13 Reasons Why (Por trece razones) [Serie de televisión], Estados Unidos, Netflix / Kicked to the Curb Productions / Anonymous Content / July Moon Productions / Paramount Network Television Productions, 2017.

37 AYER, David; NEWMAN, Eric; SARANDOS, Ted y UNKELESS, Bryan (Productores), AYER, David (Director), Bright (Bright) [Cinta cinematográfica], Estados Unidos, Netflix / Overbrook Entertainment / Clubhouse Pictures, 2017. 


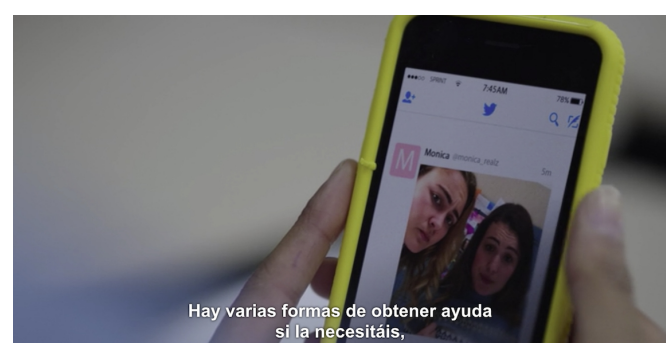

Imagen 9.72: Frame de la serie Por trece razones, 2017.

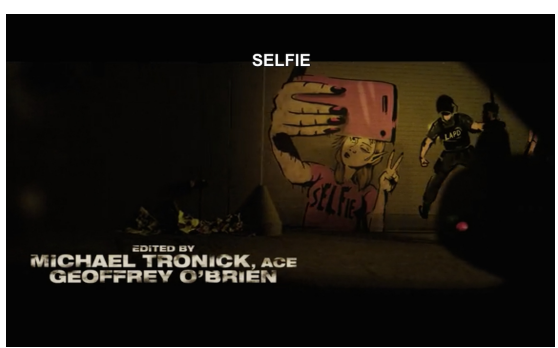

Imagen 9.73: Frame de la cinta Bright, 2017.

Para finalizar, señalar que hemos encontrado tanto una película como una serie televisiva cuyos títulos aluden al término selfie. Se trata de una cinta española ${ }^{38}$ de 2017 dirigida por Víctor García (Imagen 9.74), así como de una serie homónima estadounidense ${ }^{39}$ emitida en el canal ABC durante 2014 (Imagen 9.75).

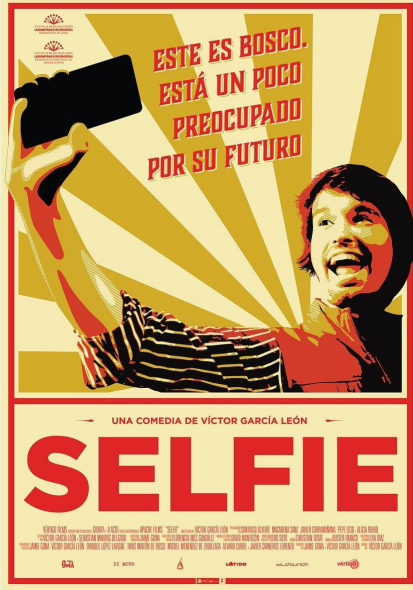

Imagen 9.74: Cartel de la película española Selfie de 2017.

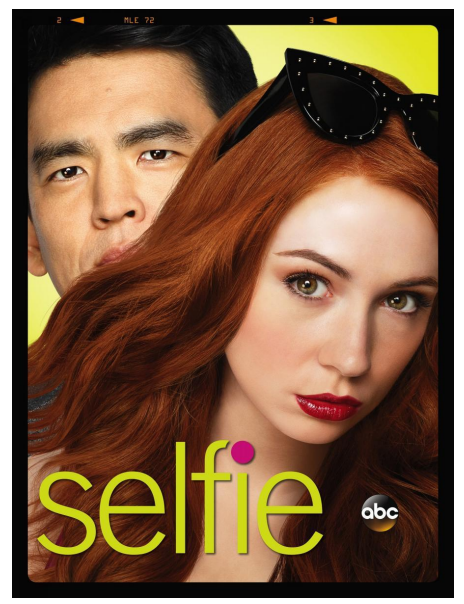

Imagen 9.75: Cartel de la serie televisiva estadounidense Selfie, 2014.

GARCÍA, Víctor; GONA, Jaime y LÓPEZ, Enrique (Productores), GARCÍA, Víctor (Director), Selfie [Cinta cinematográfica], España, Gonita / II Acto / Apache Films, 2017.

39 KAPNEK, Emily y ROBINSON, Julie A. (Productores), KAPNEK, Emily (Directora), Selfie (Selfie) [Serie de televisión], Estados Unidos, Piece of Pie Productions / Warner Bros, 2014. 
Por último, más allá del naming, y pasando a la esfera infantil y juvenil, la industria de la animación tampoco se queda corta en lo que a representación del selfie se refiere, introduciendo con dudosa inteligencia este concepto y práctica entre los más pequeños. Así, tanto grandes producciones como Zootrópolis $^{40}$ (Imagen 9.76) o Big Hero $6^{41}$ (Imagen 9.77), o series más discretas como We Bare Bears ${ }^{42}$ (Imágenes 9.78 y 9.79) se han hecho servir de este recurso en una o más ocasiones durante sus metrajes.

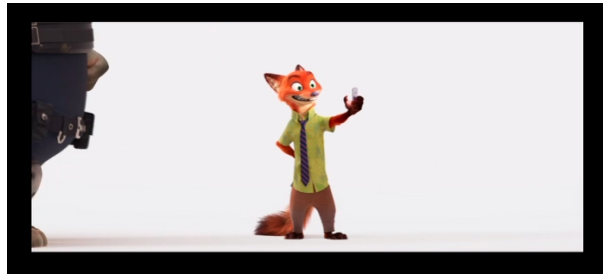

Imagen 9.76: Escena promocional de la película de Disney Zootrópolis de 2016.

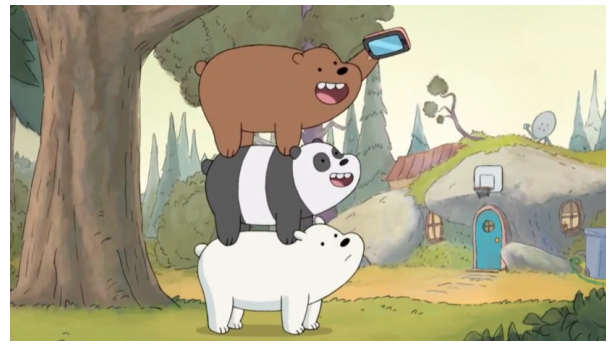

Imagen 9.78: Frame de la cabecera de la serie de Cartoon Network We Bare Bears de 2015.

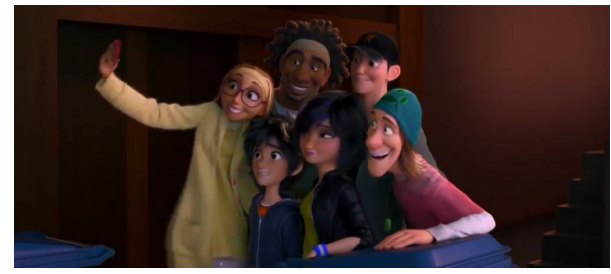

Imagen 9.77: Frame de la película de Disney Big Hero 6 de 2014.

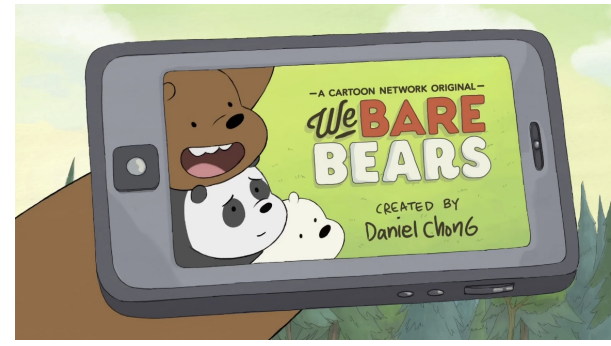

Imagen 9.79: Frame de la cabecera de la serie de Cartoon Network We Bare Bears de 2015.

SPENCER, Clarck (Productor), HOWARD, Byron y MOORE, Rich (Directores), Zootopia (Zootrópolis) [Cinta cinematográfica], Estados Unidos, Walt Disney Animation Studios, 2016.

41 CONLI, Roy y REED, Kristina (Productores), HALL, Don y WILLIAM, Chris (Directores), Big Hero 6 (Big Hero 6) [Cinta cinematográfica], Estados Unidos, Walt Disney Animation Studios / Marvel Studios, 2014.

42 WILKSEN, Carrie (Productora), CHONG, Daniel y HERNÁNDEZ, Manny (Directores), We Bare Bears (Somos osos) [Serie de televisión], Estados Unidos, Cartoon Network Studios, 2015. 


\subsection{El selfie como marco argumental en los shows televisivos, en los programas de radio y en la música.}

Siquiera sea muy brevemente nos referiremos ahora a varios ejemplos en los que tanto el naming, como su marco conceptual, ha sido asociado al término selfie en diversos programas televisivos, de radio o en alguna canción.

Traemos el ejemplo del show televisivo que se emitió en la cadena privada española Cuatro entre 2016 y 2017 y que tenía como título Hazte un Selfi ${ }^{43}$ (Imagen 9.80), o el emitido por la cadena infantil Boing entre 2015 y 2016, llamado Selfie Show ${ }^{44}$.

También la radio ha utilizado este recurso. Así, por ejemplo, el dial Valencia Radio de nuestra ciudad (en el 99.9 de la FM) dispone del programa cómico, político y de variedades dirigido y presentado por Antonio Expósito y que lleva por nombre Selfie Radio Show ${ }^{45}$ (Imagen 9.81), emitido desde 2014 hasta 2017. Reseñar, finalmente, que por existir existe hasta una canción titulada Selfie, interpretada por The Chainsmokers ${ }^{46}$.

VV. AA., "Hazte un selfi", 2018, disponible en <https://es.wikipedia.org/wiki/Hazte_un_selfi > [Fecha de consulta: 2 de julio de 2018].

VV. AA., "Boing estrena «Selfie Show», programa que mostrará el talento de los más pequeños", 2015, disponible en <https://www.mediaset.es/Boing-Selfie-Show-mostrara-pequenos_o_1968750175. html $>$ [Fecha de consulta: 2 de julio de 2017].

Página web del programa disponible en: <http://selfieradioshow.es/ $>$ [Fecha de consulta: 2 de julio de 2017].

BORERO, Alejandra y LONDOÑO, Suanny, op. cit., p. 126. 


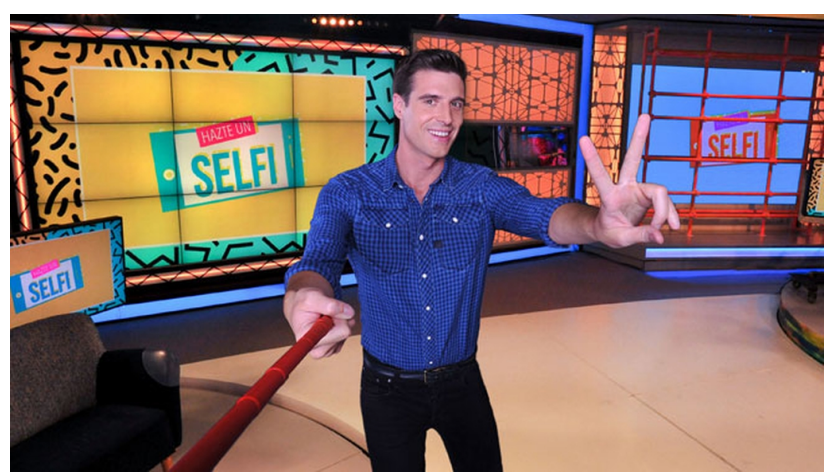

Imagen 9.80: Imagen promocional del show televisivo Hazte un selfi emitido por la cadena nacional Cuatro entre 2015 y 2016.

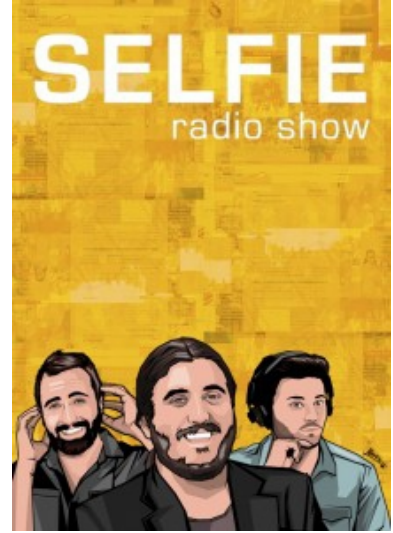

Imagen 9.81: Cartel promocional del programa de radio Selfie Radio Show de Valencia Radio.

\subsection{El uso del selfie en los videojuegos.}

El self shot y sus variantes también han hecho acto de presencia en la esfera de los videojuegos. Hemos encontrado tres ejemplos. En el primero, la compañía Rockstar Games (conocida desarrolladora de videojuegos) utilizó la iconografía formal del mirrorpic en una de las imágenes gráficas que, a modo de ilustraciones, sirvieron en la campaña de promoción para la quinta entrega de su saga titulada Grand Theft Auto en 2013. En concreto la imagen representa a una joven habitante de la costa oeste norteamericana contemporánea (escenario donde se desarrolla la trama del juego), autorretratándose, frente a un simulado espejo o superficie reflectante, con su smartphone (Imagen 9.82). 


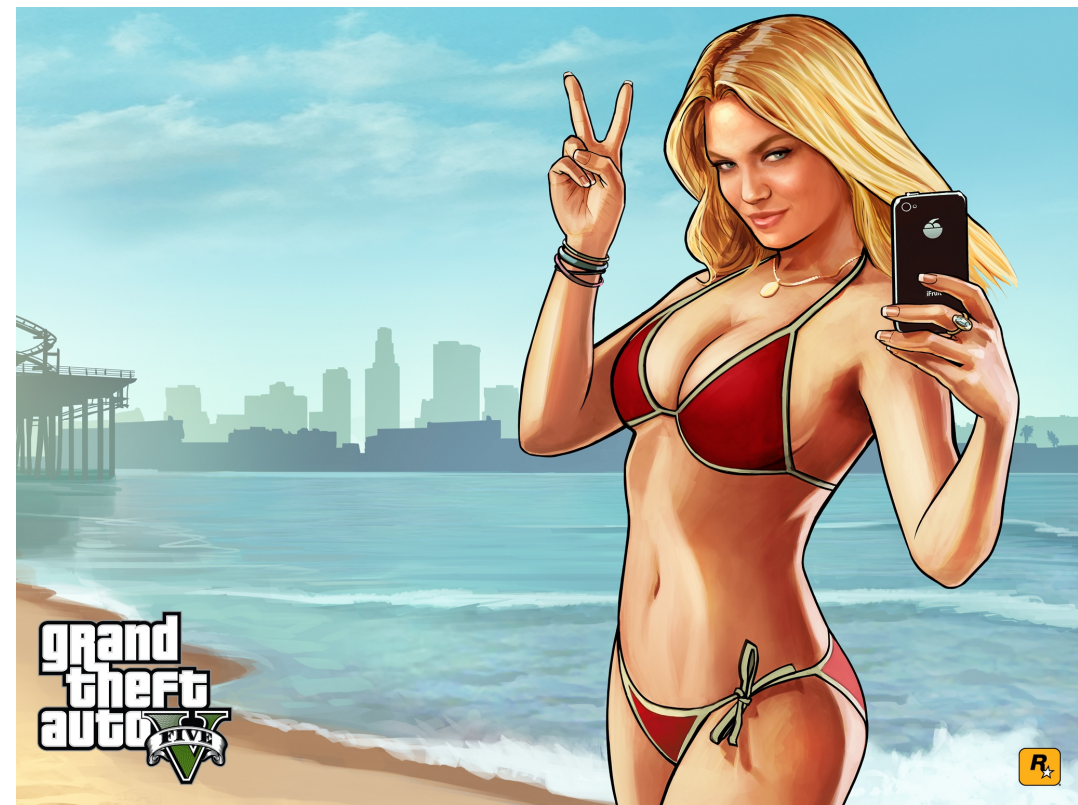

Imagen 9.82: Rockstar Games Inc., ilustración digital perteneciente a la campaña del videojuego Grand Theft Auto V, 2013.

Por otro lado, dentro de los propios videojuegos hemos hallado escenas en las que los protagonstas de las aventuras se practican selfies que podemos ver representados en diversas escenas.

Estas incluyen desde la simulación de las propias fotografías tomadas, como en el ejemplo del mismo título visto anteriormente en Grand Theft Auto $V$ (Imagen 9.83), hasta la representación de su propia toma o acto, como en el ejemplo tomado de Lego Minifigures Online de 2014 (Imagen 9.84). 


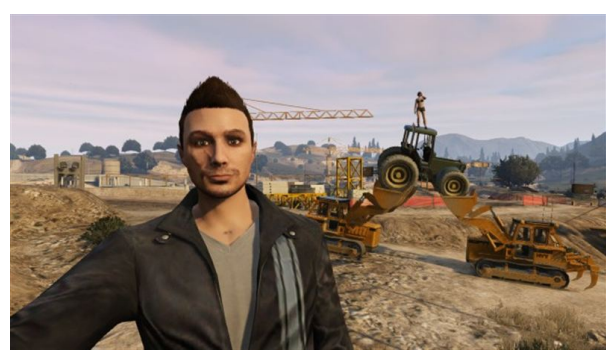

Imagen 9.83: Captura extraída de una partida del juego Grand Theft Auto $V$, que representa una fotografía tomada por el avatar del jugador.

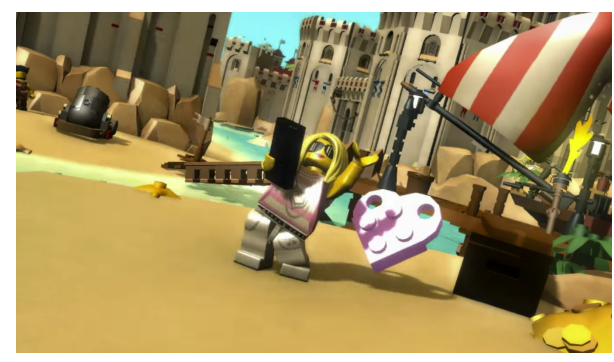

Imagen 9.84: Captura extraída de una partida del juego Lego Minifigures Online, que representa al avatar del jugador practicándose un selfie con un smartphone.

\subsection{Infografías, memes y chistes gráficos relacionados con el selfie.}

Un fenómeno poseedor de las características populares ya vistas, así como de un extenso impacto mediático, aceptación y fama, forzosamente debe producir contenidos relacionados con el humor, con los chistes gráficos o con los tan populares memes que abundan en Internet generados por sus usuarios y que tanta relación tienen con la acualidad.

El ya fallecido dibujante de viñetas y humorista gráfico Forges, muy reconocido en nuestro país, nos presentó en 2015 y 2016 sendas viñetas (Imágenes 9.85 y 9.86), publicadas en el diario El País, que hacen referencia al selfie de manera crítica por su banalidad e histrionismo. 


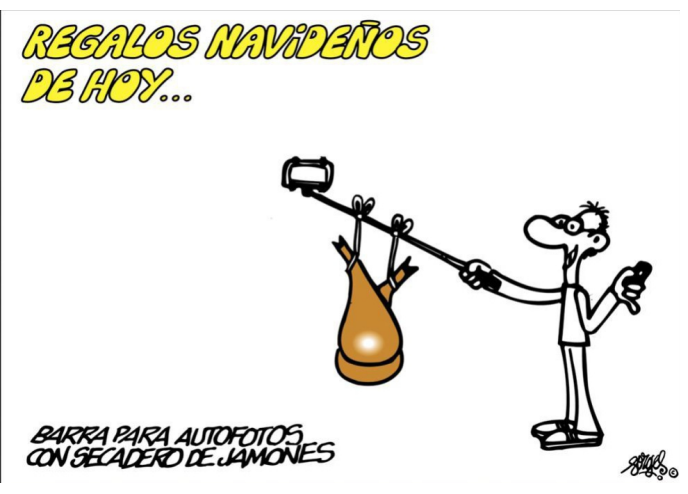

Imagen 9.85: Viñeta publicada por Forges en el diario El País.

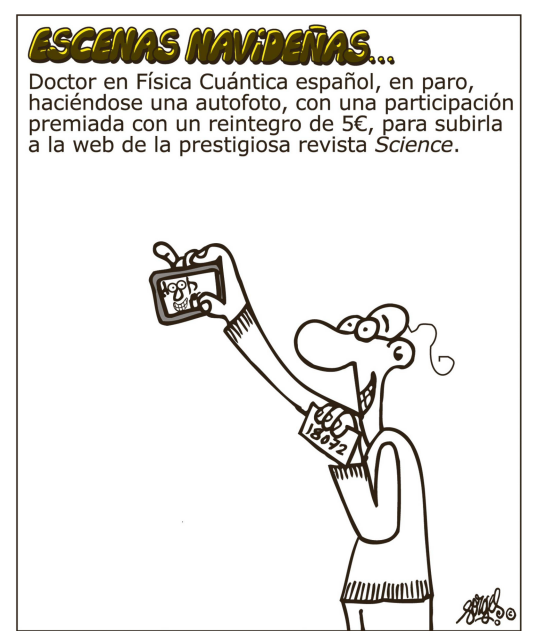

Imagen 9.86: Viñeta publicada por Forges en el diario El País.

Los usuarios de las redes, generalmente anónimos o bajo seudónimos, también son productores de contenidos de humor que acaban convirtiéndose en memes muy difundidos durante un corto periodo de tiempo en según que canales. Portales como Cuánta razón ${ }^{47}$, en el que se difunden este tipo de contenidos, han hecho y hacen con relativa frecuencia referencias al fenómeno aquí tratado desde cualquier punto de vista (Imagen 9.87), al igual que otros foros y canales distribuidores de imágenes generadas por usuarios anónimos con aplicaciones de smartphone que también recurren a nuestro objeto de estudio de manera satírica o cínica y, en ocasiones incluso, a modo de protesta (Imágenes $9.88,9.89$ y 9.90$)$.

El portal web Cuánta razón, es uno de los mayores recopiladores de memes de Internet en nuestro idioma. Con meme de Internet nos referimos a aquel medio virtual o construcción multimedia colectiva que se populariza rápidamente a través de Internet tras su viralización por parte de usuarios generalmente anónimos y que sirve para describir una idea, concepto, situación, expresión y/o pensamiento. Véase: <https://www.cuantarazon.com> [Fecha de consulta: 20 de julio de 2017]. 


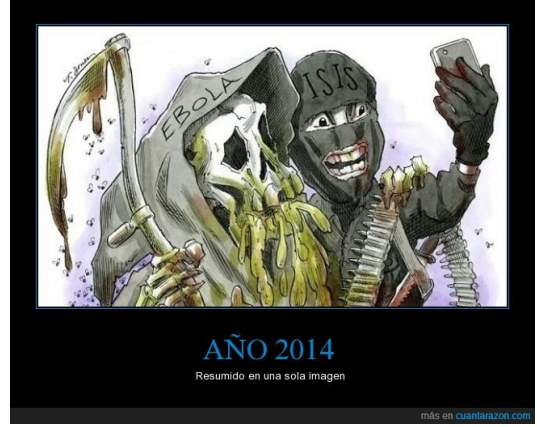

Imagen 9.87: Cartel publicado en el portal Cuánta razón a finales de 2014.

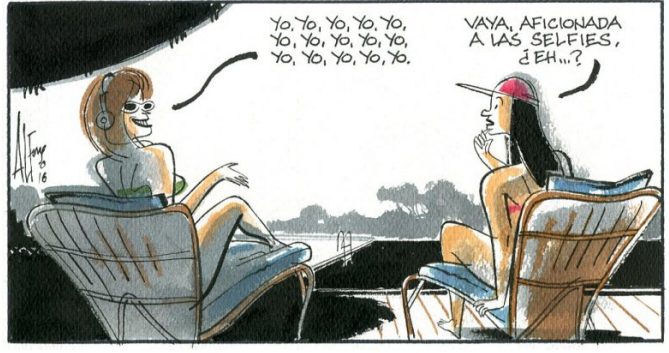

Imagen 9.88: Ilustración encontrada en un buscador de imágenes, muy repetida en la red.

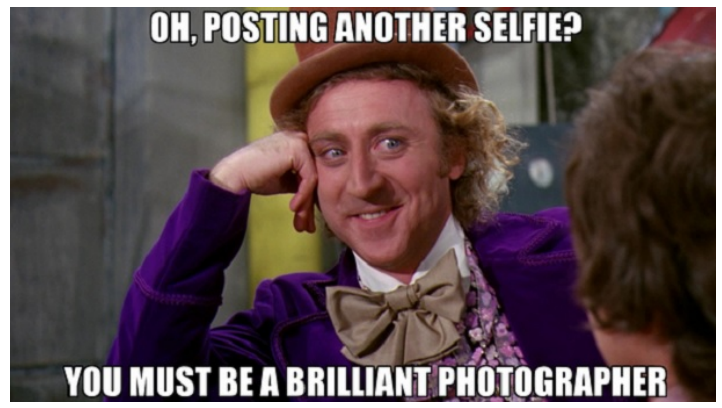

Imagen 9.89: Meme de Internet.

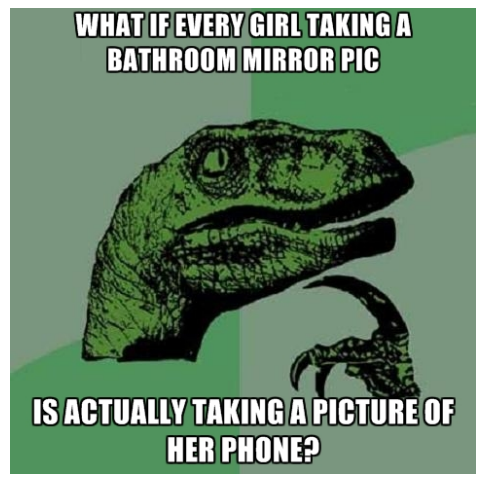

Imagen 9.90: Meme de Internet.

La capacidad que tienen muchos de los usuarios de Internet en el dominio de ténicas digitales de simulación o fotomontaje ha permitido ejercicios de descontextualización en los que se presentan personajes de la esfera popular cinematográfica (Imagen 9.91 y 9.92), representaciones artísticas conocidas (Imagen 9.93 y 9.94) o utilización de celebridades históricas (Imagen 9.95). Todo este material se ha visto publicado en diversos medios. 


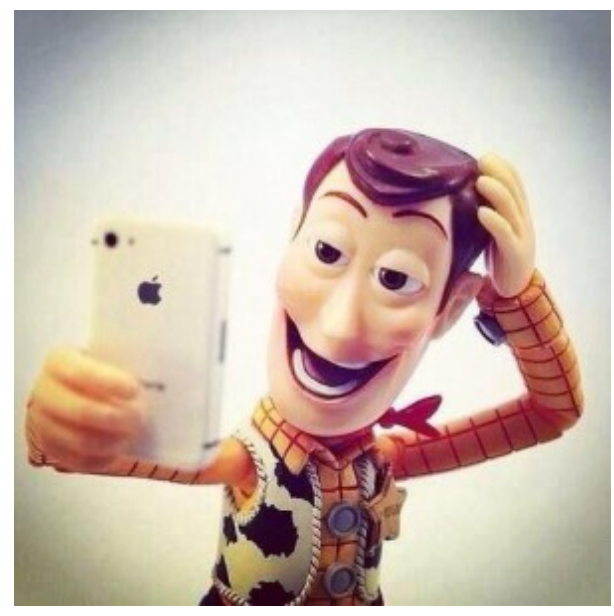

Imagen 9.91: El personaje Woody de la película Toy Story haciéndose un selfie.

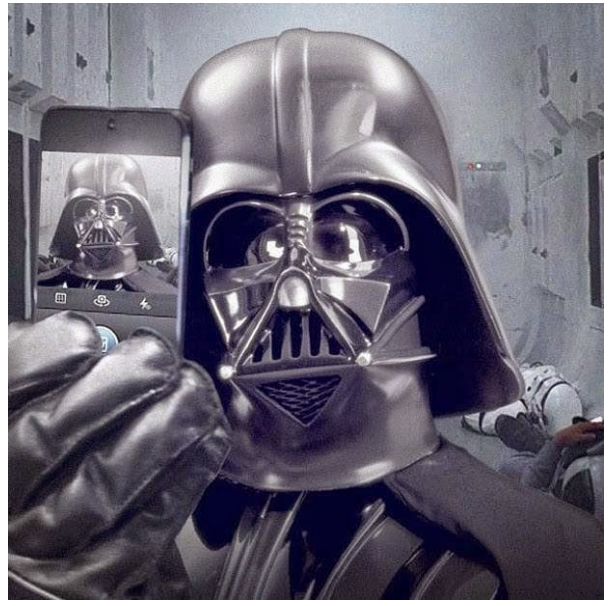

Imagen 9.92: El personaje Darth Vader de la saga de películas Star Wars haciéndose un selfie primitivo.
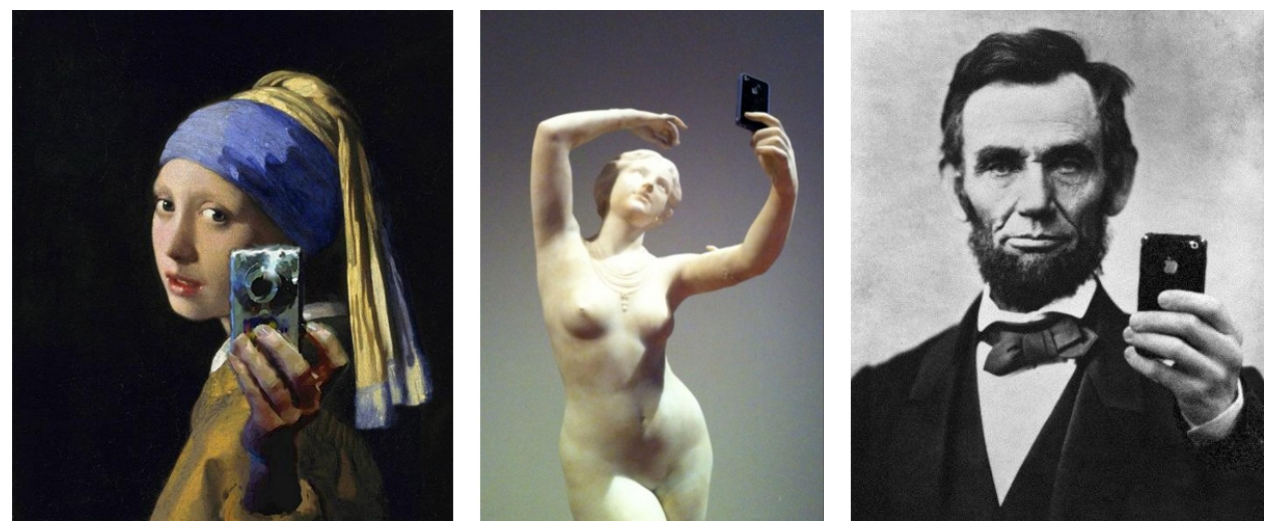

Imágenes 9.93, 9.94 y 9.95: Diversas obras de arte e imágenes fuera de contexto practicándose selfies o mirrorpics.

De hecho, estas descontextualizaciones no solo se han realizado en torno a la esfera de lo popular o del arte, sino también se han llevado a cabo abordando temas más delicados (en los que según una parte de la opinión pública contemporánea los límites del humor se adentran en unos terrenos pantanosos y de difícil acotación). Nos referimos a cuestiones que inciden en aspectos culturales o religiosos (Imágenes 9.96, 9.97, 9.98 y 9.99). 


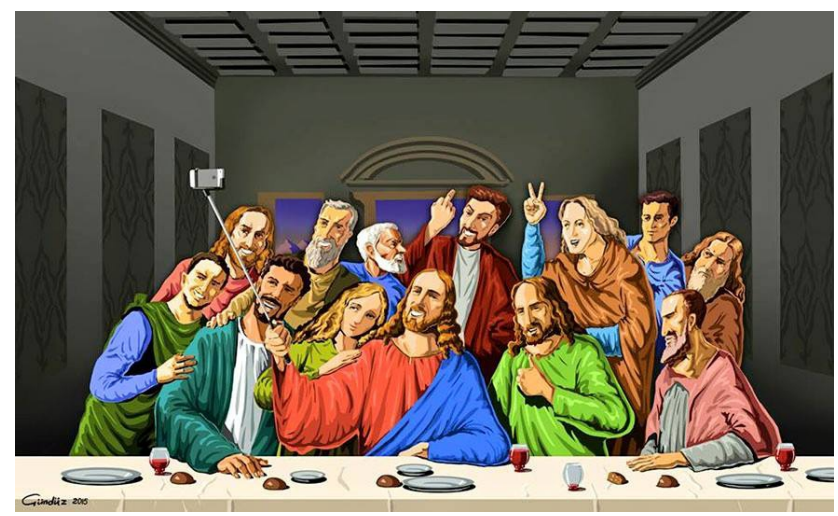

Imagen 9.96: Otra escenificación de la práctica del selfie fuera de contexto y/o como chiste o retórica visual.
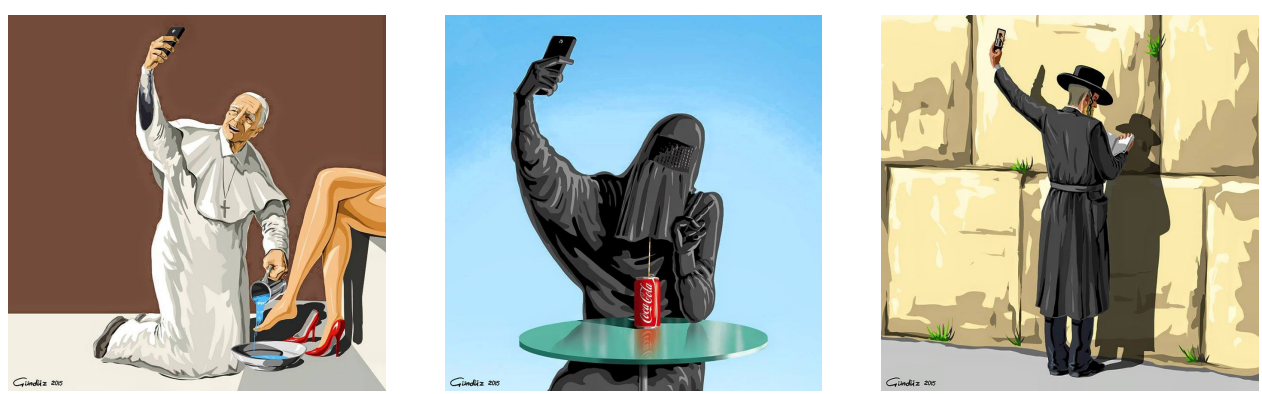

Imagen 9.97, 9.98 y 9.99: Diversos selfies fuera de contexto que siguen el esquema señalado en la imagen 9.96.

Al margen de no extender más este apartado, vemos que tanto técnicas de ilustración como modelado en $3 \mathrm{D}$ y animación se han puesto también a las órdenes del humor en forma de parodias más o menos reivindicativas (Imágenes 9.100 y 9.101) en torno a un fenómeno que, tal como venimos poniendo de relieve, se encuentra adscrito, como signo y como imagen, a la cultura visual y popular de comienzos del siglo XXI. 


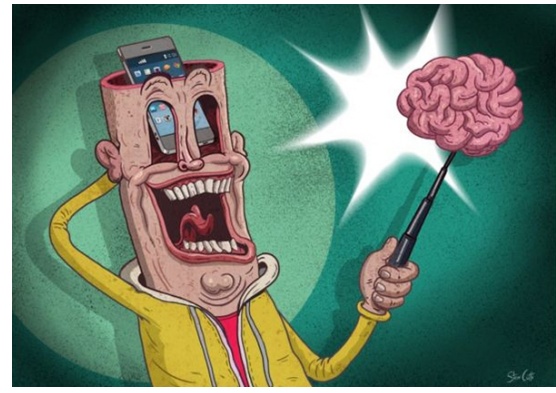

Imagen 9.100: Crítica satírica del fenómeno del selfie utilizando la ilustración como soporte.

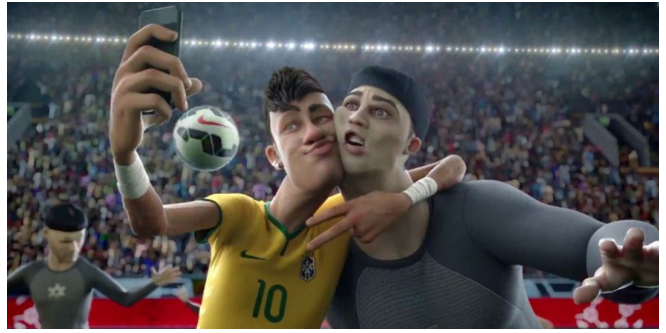

Imagen 9.101: Otro ejemplo similar al precedente aunque extraído de una producción audiovisual que utiliza el modelado y la animación 3D.

\subsection{El selfie vendido a través de otros soportes.}

Por último, remitir de manera sucinta a la cantidad de artículos que hemos encontrado que utilizan la iconografía o la referencia al selfie en cualquiera de sus formas, aplicándolo en superficies de diversa índole, ya sea portadas de cómics (Imagen 9.102), prendas de ropa (Imagen 9.103) o también en objetos infantiles como carteras o figuras de juguete (Imágenes 9.104 y 9.105). El hecho de que la cultura del selfie sea exportada a las esferas más infantiles, como hemos visto a lo largo de este último recorrido y como también hemos alertado en el capítulo 5, es un hecho que debería obligarnos a estar en alerta permanente, valorando las luces relacionadas con la creatividad, expresión y autoafirmación de la práctica del self shot, pero también detectando las sombras que puedan resultar perjudiciales para los integrantes más jóvenes y vulnerables de nuestras sociedades. 


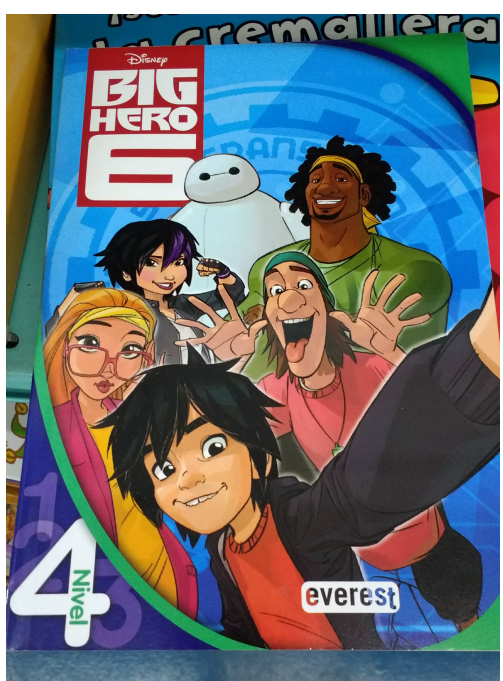

Imagen 9.102: El protagonista del cómic Big Hero 6 se autorretrata junto con sus compañeros.

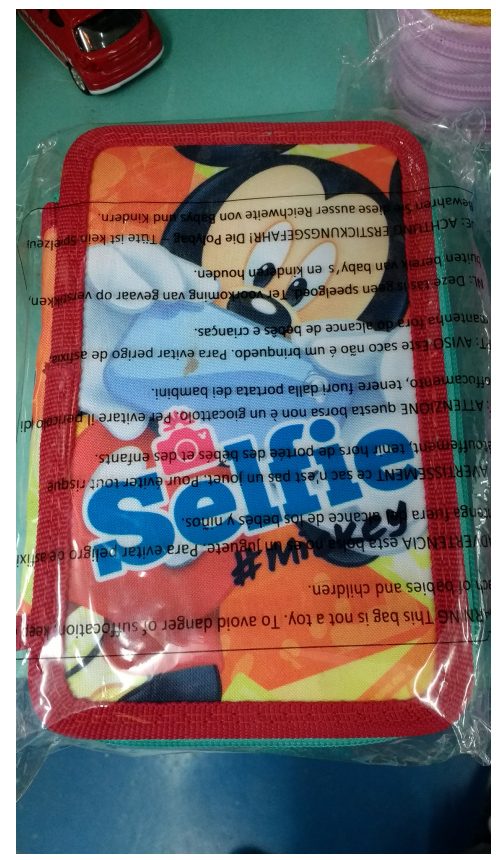

Imagen 9.104: Cartera infantil.

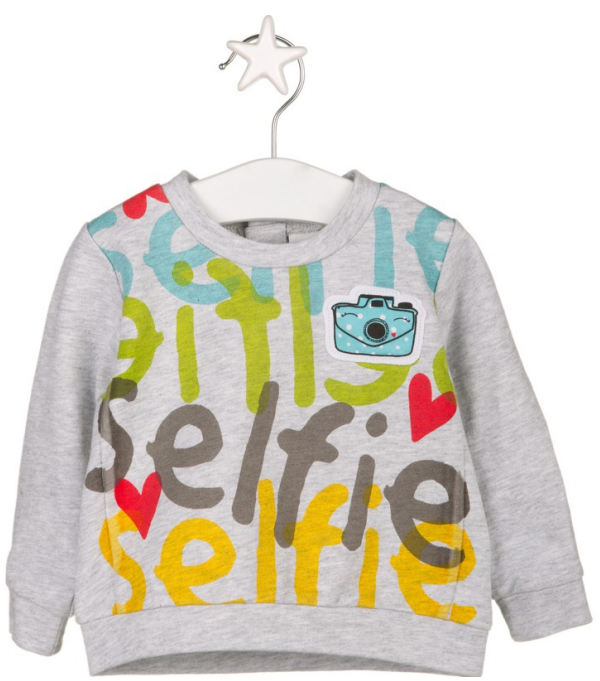

Imagen 9.103: Prenda de ropa infantil vendida a través de Amazon que se sirve de la nomenclatura del selfie en su decoración.

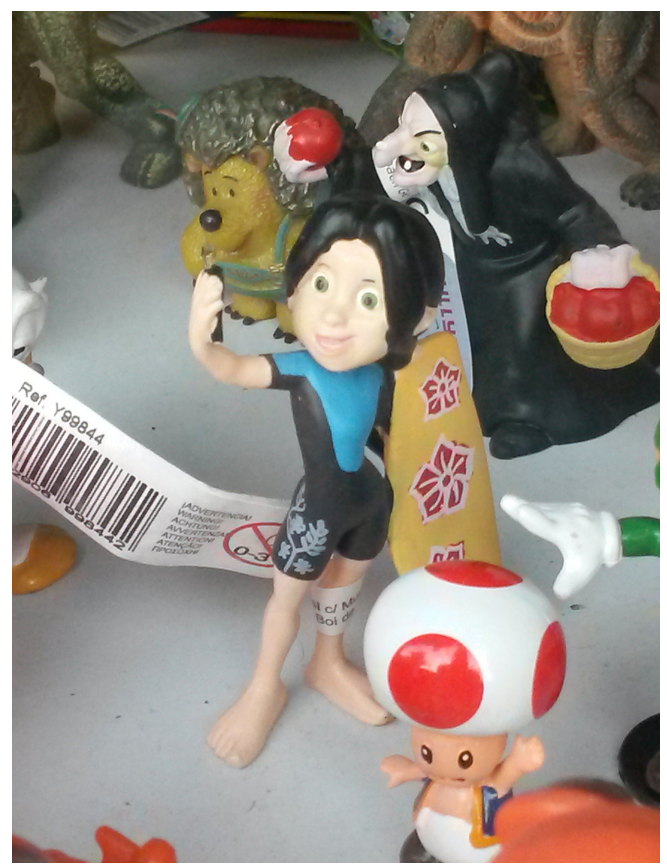

Imagen 9.105: Juguete infantil. 
Los orígenes adolescentes del selfie y su representación en el arte y en los medios de masas

$-560-$ 


\section{CONCLUSIONES}

Cada sociedad necesita una imagen a su semejanza. JOAN FONTCUBERTA, La cámara de Pandora, 2010.

Hemos intentado poner de relieve el hecho de que el self shot y sus derivados (entre ellos el actualmente más extendido selfie) ha sido y es un fenómeno expansivo, en auge y en constante crecimiento. Así pues, podemos considerar al autorretrato fotográfico-digital publicado en la red como una práctica contemporánea que, casi con total certeza, será tenida en consideración como uno de los frutos culturales y populares de nuestra época.

Aunque $a$ priori estas prácticas y sus representaciones pueden parecernos banales y arbitrarias, el selfie es un ejercicio especialmente creativo y, en la mayoría de ocasiones, completamente libre. Un ejercicio que genera productos fotográficos que podemos entender como objetos de investigación e interés estético, formal y conceptual, y que si bien actualmente son aceptados (tras un auge de popularidad experimentado durante esta última década) y practicados 
por la mayoría de los grupos de población mundial que tienen acceso a este tipo de tecnologías, en su origen fueron creaciones fotográficas exclusivas de un colectivo adolescente, emancipado como creador de imágenes, que supo combinar el uso de los entonces novedosos dispositivos de captura fotográfica digital con los espacios cobijados en la red de publicación y encuentro cibernético-social que comenzaban a operar a mediados de la década pasada (la primera del siglo XXI). Los adolescentes, en su mayoría mujeres, acuñaron este tipo de modelo o de iconografía propia, generada de manera colectiva mediante su experimentación, divertimento, exhibición y erotismo, un modelo que aproximó la esfera privada a la pública superponiendo ambas. Entendemos que fueron ellas las pioneras de un modelo (formal en la imagen y metódico en el acto) que terminaría por contagiar al resto de población en todas sus latitudes de edad y condición.

En todo caso, y con la perspectiva que nos haya podido otorgar el bagaje en torno a casi una década de investigación sobre el fenómeno que es nuestro objeto de estudio, podemos afirmar que las variantes del self shot o del autorretrato digital publicado en la red han adquirido suficientes méritos para convertirse actualmente en una de las principales prácticas específicas de la fotografía digital.

En cuanto a sus formas predecesoras anteriores a la llegada de esta tecnología fotográfico-digital a finales del siglo XX y que le es propia y exclusiva, también hemos repasado algunos conceptos en torno al autorretrato realizado a lo largo de la historia del arte y más especificamente durante el desarrollo de la fotografía química o argéntica durante los siglos XIX y XX. Hemos partido del hecho de que el selfie es fundamentalmente un autorretrato con una nueva serie de actualizaciones que si, por un lado, le aportan distinción respecto a sus formas predecesoras (como sus modos de construcción y difusión), por otro, le aproximan a esas mismas formas (puesto que refleja la manera en la que su autor quiere ser visto por el mundo). Precisamente, este breve repaso a través del 
autorretrato fotográfico nos ha parecido pertinente por su relación, ya no tanto con la fotografía artística, sino con la fotografía popular realizada por las masas una vez la fotografía amateur comienza a democratizarse a principios del siglo XX con la llegada de las cámaras Kodak, hecho que permitió reducir las complejidades técnicas a un simple clic, aliviando los anhelos populares por poseer (y producir) sus propias imágenes. Debemos atribuir, pues, cierta conexión entre estos hechos y los del movimiento aparentemente espontáneo que a principios del siglo XXI quedaría constatado tras la comunión de los ejes: fotografía digital, adolescente emancipado fotográficamente y red global como herramienta de difusión, generando así ese self shot o autorretrato digital que ha vertebrado como objeto principal de estudio esta Tesis Doctoral.

Efectivamente, y como hemos visto en multitud de ejemplos a lo largo de estas páginas, la práctica del autorretrato digital publicado de manera voluntaria o involuntaria en la red, junto con todas sus variantes formales, comenzará a institucionalizarse a mediados de la década pasada (primera del siglo XXI). Dicha institucionalización será llevada a cabo mediante una producción masiva realizada principalmente por el colectivo adolescente que, poseedor de una cierta emancipación fotográfica, de unos espacios privados e íntimos ganados en el hogar y de una adopción temprana de las nuevas tecnologías de interconexión global a través de las recientemente inauguradas redes sociales, será el principal artífice (tanto en contenido como en forma) de estas nuevas formas fotográficas.

Así, el desarrollo experimental, masivo, global y hasta cierto punto ritual de los adolescentes, habría concebido unas nuevas formas de autorretrato, generalmente íntimo, pero paradójicamente extendido hacia esferas más públicas que, de unos años a esta parte, habría sido puesto en práctica por la mayoría de usuarios y usuarias de la fotografía digital y de Internet. En poco más de diez años las derivas en torno a estos objetos fotográficos los han empujado desde una posición de novedosos autorretratos compartidos a través de las 
telarañas más profundas del ciberespacio adolescente, hasta las prácticas del actual selfie, fuertemente arraigado en la cultura popular.

Nos ha parecido oportuno aportar una serie de definiciones conceptuales, modos de ejecución y acotaciones temporales o históricas no solo como contribución o guía para el futuro, sino también como estructura útil para manejar y entender terminológicamente nuestro objeto de estudio a lo largo de toda esta investigación. Así, y basándonos parcialmente en multitud de fuentes de diversa índole, hemos definido el self shot como un autorretrato fotográficodigital publicado en la red de manera voluntaria o involuntaria y, tras matizar (y demostrar con capturas de buscadores de imagen realizadas durante toda esta década) que actualmente es un término en desuso dentro de la jerga de Internet, nos ha sido también de utilidad para englobar con su nomenclatura una serie de subproductos también definidos: el mirrorpic, el selfie primitivo, el selfie y otros tipos de self shots.

Respecto a las terminologías empleadas, hemos advertido cómo durante estos últimos años, el término selfie (el cual no hemos dejado de tratar como una tipología formal concreta de autorretrato digital publicado en la red) se ha popularizado en demasía, mientras que el término self shot ha quedado poco a poco en desuso. Dicho acontecimiento se refleja en la jerga propia de la red y en los textos académicos, además de en el lenguaje popular, que tan pronto olvida lo viejo como adopta lo nuevo. Por tanto, hemos concluido que nos encontramos ante una colonización e invasión por parte de un objeto (subtipo) anidado dentro del estado-conjunto general (tipo) que lo acoge, dicho con otras palabras: hoy en día se empieza a utilizar el término selfie para definir casi cualquier tipo de autorretrato fotográfico, cuando en realidad, y como hemos postulado a lo largo de nuestro estudio, atiende a un tipo muy concreto de autorretrato digital publicado en la red que viene determinado principalmente por el tipo de pantalla-espejo del smartphone que lo hace posible. 
En cuanto a los modos de ejecución o tipos de visión, también nos han acompañado y consideramos igualmente útiles las nomenclaturas que hemos expuesto: la visión directa por visor, la visión directa por pantalla, la visión indirecta y la visión directa por pantalla-espejo; a la vez que las consideramos estrechamente relacionadas con los distintos subtipos de autorretratos digitales publicados en la red que invitan (u obligan) a practicar.

En relación a la acotación histórica, nos ha parecido pertinente dividir el recorrido temporal de nuestro objeto de estudio en tres fases que contemplan su completo desarrollo desde sus orígenes hasta nuestros días. Una primera fase que hemos llamado fase de desarrollo del self shot y que comprende desde los primeros autorretratos digitales publicados por parte del colectivo adolescente en las primeras redes sociales como MySpace, Fotolog o Metroflog (años 2004, 2005 y 2006), hasta la llegada de los primeros smartphones con cámara frontal, hecho que se conecta con la popularización de la red social fotográfica Instagram (año 2010). Otra segunda fase que hemos denominado fase de consolidación formal del self shot y de expansión del selfie, que abarca desde el final de la primera fase en torno a 2010, hasta la viralización tanto del término como de su metología práctica gracias al nombramiento como palabra del año por parte de The Oxford English Dictionary (finales de 2013) y al impacto mediático del selfie de la 86a ceremonia de los Premios Oscar, imagen conocida como el "Selfie de los Oscar" (principios de 2014). Por último, hemos establecido una tercera etapa que hemos calificado de fase de popularización del self shot y que comprende desde el final de la fase anterior, con los dos acontecimientos citados, hasta el día de hoy (julio de 2018), momento en el que nuestro objeto de estudio no ha vuelto a sufrir ningún tipo de cambio salvo este fuerte arraigo en nuestra cultura popular.

Respecto a la legitimidad del self shot y sus variantes como imágenes y más concretamente como objetos fotográficos, hemos visto que su corporeidad se configura en torno a una selección de la realidad, que posee unos elementos configurantes y que ostenta también una sintaxis entendida como manifestación 
de orden. Nuestro objeto de estudio, pues, responde a una imagen técnica y fotográfica generada por un aparato electrónico-digital de captura y transcripción de la luz en imagen y parcialmente bajo el mando de una o un autor. Este objeto fotográfico clasificado como autorretrato ha realizado un recorrido íntimamente ligado al reflejo en un espejo o en una simulación de espejo. Así, de esta manera, hemos visto cómo mirarse en el espejo, al igual que ser visto por la sociedad, es el medio con el que la o el autorretratista construye e identifica su yo. Y también en relación al espejo entra en escena, como una maldición inevitable, el gran carácter narcisista que poseen las autoras y autores del self shot, cuestión que queda reflejada en la lectura simbólica del objeto fotográfico mediante la observación del sujeto autorrepresentado.

A nivel formal hemos encontrado algo característico en los mirrorpic (los autorretratos de espejo), un hecho que se ha convertido en una curiosa firma inconfundible de los mismos: la generalmente diagonalidad de la modelo y su contexto frente a la rectitud ideal de los cuatro lados del dispositivo reflejado, paralelo a los cuatro lados del cuadro de la imagen. Hemos visto cómo este hecho sucede solo en los casos en los que la autorretratista inclina unos pocos o muchos grados el smartphone o cámara fotográfica respecto al plano del suelo donde reposan sus pies, artificio que asumimos como una moda o como una necesidad en este tipo de autorretratos, dada su enorme proporcionalidad respecto a las formas correctamente erguidas. Este hecho de encontrar en las fotografías un mundo inclinado y un dispositivo como único elemento paralelo a los límites de la imagen, es algo que siempre ocurrirá, ya que el sensor electrónico de imagen que habita en el interior del aparato también se encuentra en paralelo a los lados de su dispositivo contenedor (la cámara o el smartphone); y es precisamente este sensor el que conformará una imagen digital de píxeles alineados en cuadrícula que construirán la imagen del dispositivo reflejado siempre con sus cuatro lados paralelos a los límites de la propia imagen creada. 
Hemos constatado esta peculiaridad técnica y formal en la construcción de la imagen en lo referente a los mirrorpics, pero también hemos detectado en relación al selfie y a su conformación mediante el uso de la pantalla-espejo, la peculiaridad mecánica que brinda la máquina en relación a la simulación de un supuesto espejo de mano en el que la o el autorretratista ve su rostro reflejado mediante un artificio electrónico de captura y muestra. Así, el procesador del dispositivo y su software integrado producirán la magia del volteo horizontal, la misma que hace el reflejo especular del espejo: la derecha será izquierda y la izquierda derecha, y ya tendremos nuestro reflejo ayudando a nuestro cerebro a encajar el selfie como si tratáramos de capturar lo que vemos en un espejo.

Concluimos también, partiendo de todas las imágenes encontradas y analizadas, lo mucho que han variado las estrategias compositivas, encuadres y puntos de vista a la hora de realizar estas autofotografías en relación a su etapa clásica: y es que la aparición de los nuevos dispositivos de captura digital ha generado una gran cantidad de nuevas formas y actitudes en cuanto a la realización de fotografías (y no solo de autorretratos). Hemos utilizado como ejemplo contrapuesto el hecho de que durante los registros de imagen clásicos (tanto en la fotografía como en el cine) la búsqueda del punto de vista de quien realiza la imagen, construida desde el eje ojo-visor-lente y desde una posición erguida, evidenciaba la presencia de este en algún lugar fuera de las paredes del plano o encuadre, y cómo, sin embargo, este tipo de encuadres y puntos de vista realizados siempre desde un supuesto ojo humano y que ponían de relieve la presencia del espectador humano en la escena, iban a dar paso con la llegada del dispositivo doméstico de grabación o, más recientemente, a través del dispositivo digital de captura, a la presencia ya no del humano, sino de la propia máquina captadora como protagonista de la escena desde su cuarta pared.

Así pues, el espectador que observa estas nuevas obras ya no será consciente de una presencia humana que mira la escena desde algún lugar fuera de esta, sino que asumirá la presencia de un dispositivo de captura de imagen 
que registra la escena, evidenciado mediante el acto del self por las manos del personaje presentado. Este versus entre las maneras de encuadrar la realidad que hacían los fotógrafos clásicos frente a los modos que tiene el autorretratista digital de encuadrar la realidad que rodea a su yo, es fruto también de la diferencia entre ambas actitudes. De este modo, el fotógrafo tradicional pone el punto de vista en el eje de cómo él ve el mundo y el selfshooter lo pone en el eje de cómo el mundo quiere que lo vea.

Por supuesto, todos estos condicionantes con los que incita a actuar la propia herramienta pueden en cierta manera acotar la voluntad de los autores que la manejan: la mirada del fotógrafo y su voluntad siguen presentes en este tipo de fotografías, no obstante, no son lo único que las conforma. La propia máquina decide mucho más de lo que parece en la construcción de estas imágenes: la herramienta también es coautora en el caso de los self shots, tal como ha ocurrido siempre entre los artistas, sus útiles y las huellas que estos útiles han dejado en sus obras durante la historia del arte. Las estrategias compositivas, las nuevas perspectivas y los encuadres en este tipo de fotografías son muchas veces fruto de los caprichos de la cámara y de los usos que esta invita a hacer de ella. Al mismo tiempo, las aplicaciones informáticas y sus normas también tienen mucho que ver aquí, al igual que las tecnologías de los nuevos dispositivos de captura digital, con la escisión que ha habido, por ejemplo, entre su visor y la visión del humano que la maneja, al crear nuevas estructuras formales en la construcción de las fotografías contemporáneas. Al respecto, las pantallas-espejo y la longitud del brazo que sujeta el dispositivo creador son, por ejemplo, dos elementos generalmente protagonistas en los self shots de los adolescentes.

Esta idea sobre a la dictadura del dispositivo en relación a nuestro objeto de estudio podría, sin embargo, no ser una tiranía totalitaria, aunque sí severa, pues estos dos conceptos contrapuestos conviven creando un equilibro que se 
retroalimenta en este tipo de creaciones, combinando una fuerte autoría por parte de la herramienta-máquina y una leve autoría por parte del autor o autora.

Ahora bien, no podemos olvidar que la aficionada o aficionado que se ha apropiado de la tecnología, exige estas mejoras aplicadas al sensor electrónico y a la máquina que lo contiene. Hoy las fotos producidas son más nítidas, pueden hacerse con menos luz, tienen más resolución y detalle. Y los aparatos son más portátiles, más fáciles de manejar a nivel técnico. Pero si las exigencias de los compradores han transformado el mercado, las competencias e innovaciones de este mismo mercado (en pos de la seducción de sus clientes) también han cambiado los hábitos y los usos de la fotografía al mismo tiempo que la construcción de las imágenes que la máquina produce.

Teniendo en consideración estos hechos, también hemos visto cómo, en tanto que el self shot y sus variantes son objetos exclusivamente fotográficodigitales (siendo no solo hijos de las doctrinas de esta nueva era electrónica de la fotografía, sino también uno de sus mayores abanderados), ello nos puede llevar a catalogar a la autofoto como un objeto postfotográfico con todas sus consecuencias: clonación automática, viralización, hipervisualidad, rizoma, inmaterialidad y huella de falsedad. También entendemos que realizar este tipo de fotografías (mirrorpics y selfies) es entendido como una manera de contribuir a construir nuestra realidad, ya que autorrepresentarnos y autopublicarnos genera una marca autoetnográfica de que estamos ahí cuando las cosas están sucediendo. Así, los dispositivos de captura fotográfico-digitales, que son a la vez máquinas publicadoras en red (los smartphones), se han convertido en herramientas de representación activas y masivas: son el vehículo para documentar las condiciones propias (de vida, trabajo y socialidad), para crear representaciones alternativas de uno mismo (de su sexo, clase, grupo de edad, raza, etc.) y para ganar poder sobre la imagen personal. 
$\mathrm{Al}$ margen de estas cuestiones que siempre debemos tener en cuenta cuando nos enfrentamos a este tipo de imágenes desde cualquiera de sus vertientes, los self shots se han convertido en objetos populares, icónicos y bellos. Y aunque existen ciertas autoras y autores que han alcanzado la fama a través de sus autorrepresentaciones, el fenómeno de estos autorretratos digitales (que todavía siguen siendo producidos mayoritariamente, aunque ya no exclusivamente, por colectivos adolescentes y jóvenes) son generalmente fruto del anonimato. De ahí que surjan espontáneamente desde el segmento de población joven. Como en muchos otros históricos ejemplos de la creatividad y evolución humana, nacen en la comunidad y no son obra de un único individuo, sino del grupo.

A su vez, hemos visto cómo, pese a que la fotografía argéntica siempre ha sido considerada como una memoria protésica exterior a nuestros pensamientos que dejaba constancia de un generalmente importante acontecimiento pasado y recordable en una futura visualización o consulta; este aluvión de nuevas instantáneas digitales creadas y publicadas casi a todas horas por los mayormente jóvenes, pero también adultos, hace que la memoria se torne volátil: frente a la fugacidad o al consumo de usar y tirar propio de la nueva era de la fotografía, esta quedaría desvinculada del hecho memorable y asumiría un decreto de directo consultable, convirtiendo la representación en presentación.

Por otro lado, ya hemos comentado al principio de estas conclusiones que el self shot o autorretrato digital publicado en la red y todos sus productos formales, entre ellos el selfie, fueron un nuevo producto generado a lo largo de la década pasada gracias al desarrollo de tres ejes: el adolescente emancipado fotográficamente, el surgimiento de los democratizados dispositivos fotográficodigitales y la posibilidad de visualización global y también democrática que ofrecía un relativamente maduro Internet en el que, sin embargo, empezaban a aflorar nuevas formas de comunicación online anidadas en las inauguradas plataformas sociales virtuales. Ahora bien, fue precisamente la emancipación 
fotográfica que protagonizan nuestros jóvenes (los principales autores de estas prácticas narcisistas), la que a nuestro entender puso de relieve el hecho de que el adolescente contemporáneo pudiera ejercer de una manera casual no solo como fotógrafo documentador de la vida joven, sino también como ejecutor de imágenes vinculadas a las pautas formales de la fotografía erótica, publicitaria y de moda (pautas que emanan del continuo asedio con el que los mass media bombardean la mirada de estos jóvenes a través de la imagen de lo corporal difundida por cada vez más canales y que, a su vez, fuerzan a imitar), obteniendo así en sus self shots los resultados de un experto autorretratista con, pese a lo que podía a priori suponerse, altas cotas de calidad en según qué ocasiones.

Debido a ello, hemos demostrado con una serie de ejemplos cómo, en relación a estas altas cotas de calidad de las que acabamos de hablar, los jóvenes (principalmente mujeres) tienen un alto grado de control de su propia belleza mientras realizan sus registros, en determinados momentos distanciándola de la propia realidad o compitiendo positivamente frente a segundos fotógrafos profesionales del sector. Escudándonos en nuestra propia observación y en ciertos conocimientos citados a lo largo de este estudio podemos deducir que, entre otros factores, este hecho se debería, por un lado, al control que ejerce la autoproducción solitaria en relación a la práctica perfeccionada mediante la prueba-error y, por otro, a la carencia de nerviosismo propia de la soledad. A ello, además, contribuiría otro factor puramente técnico: la deformación visual que ofrecen las lentes delanteras que producen los selfies en los smarthpones y que en principio fueron ideadas para el desarrollo de videollamadas. Estas deformaciones inherentes a la lente y al protocolo de captura de imagen agrandarían y desplazarían (no sin una interacción compositiva por parte de las y los autores) ciertos atributos faciales, aproximándolos al ideal de belleza que los mass media han configurado a lo largo de estos últimos años.

Cabe recordar, junto a ello, que la difusión de la propia imagen de cualquier autor o autora puede llegar a alcanzar cierta fama si se viraliza lo 
suficiente. Ese fue el caso de una cantidad de ejemplos que hemos analizado a lo largo de nuestro estudio en relación a ciertas autorretratistas cuya imagen se popularizó desde su anonimato, y sin pretenderlo, a lo largo de la década pasada, hasta alcanzar ciertas cotas de notoriedad global. Nos atrevemos a decir que una versión contemporánea de este protocolo, salvando algunas distancias, la podemos hallar en la figura del influencer.

Tal y como hemos desarrollado, la red es un elemento fundamental en la creación de estos objetos fotográficos tan practicados. Internet ejerce una doble vía: por un lado, actúa como ejemplificador y distribuidor de la cultura visual contemporánea a través de miles de imágenes contenidas y compartidas por medio de las redes sociales y de otros soportes de comunicación; pero, por otro lado, Internet también hace las veces de plataforma para la publicación y difusión de la imagen propia. El self shot se contempla en la red, pero también se exhibe y se comparte. De esta manera, voyeurs y narcisistas establecen su relación mediante impulsos electrónicos y código binario.

Aunque la red (y el uso que hacen de ella los adolescentes mediante la difusión de su propia imagen) ha aproximado y casi fundido las esferas pública y privada a la vez que ha establecido redes de socialización, experimentación sexual libre y escenarios para el desarrollo identitario, no siempre podemos entender esto como algo positivo, fomentador de divertimentos y/o generador de imágenes bellas. Hemos visto que existen malos usos y prácticas relacionadas con estas cuestiones que pueden poner en peligro al ya de por sí vulnerable colectivo adolescente (pensemos, por ejemplo, en el sexting y el ciberbullying). Aunque la mujer (protagonista en la mayoría de estas autorrepresentaciones) evidentemente es libre de usar su cuerpo y su imagen a su antojo, en demasiadas ocasiones se encuentra sometida a voluntades de terceros en la gestión de su imagen que, no debemos olvidar, siempre es de su propiedad. No obstante, no siempre es fácil evitar la propagación de una imagen no deseada: Internet es aún un territorio complejo y rápido al que nuestra realidad todavía no se ha 
adaptado, y estamos obligados como miembros de nuestra sociedad a estar en alerta permanente intentando detectar, combatir y depurar esa serie de peligros y atentados que tanto vulneran al ya de por si frágil colectivo adolescente.

Como hemos visto al repasar sus aproximadamente quince años de vida, el selfie goza ya de cierta codificación e imaginería (pese a su relativamente reciente origen), siendo capaz de influir (ser referente y referencia) en otros medios que no son el propio, como las artes plásticas (en donde puede ser utilizado como objeto artístico, como imagen representada, como proyecto, como simulación o como herramienta museística o literaria). Asimismo el selfie ha incidido en la publicidad, el marketing y el entretenimiento audiovisual. No obstante, su simulación fuera de su medio no deja de ser un artificio. El self shot y el selfie han estado y están íntimamente asociados con el ecosistema donde se alojan: el dispositivo fotográfico-electrónico y la red, lugar donde voyeurs y narcisistas establecen una relación asimétricamente recíproca y donde jóvenes y adultos realizan sus rituales de autorrepresentación publicada. Un espacio, por otro lado, en el que el acontecimiento y la fotografía-publicación de este propio acontecimiento se funden en un mismo hecho, y en donde también queda impuesta una fórmula (costumbrista y pactada socialmente) de creación de imágenes reconocibles, como hace décadas lo fueron las fotos grupales de turistas frente al monumento de la ciudad visitada.

Aunque, como hemos visto, el self shot y la iconicidad de sus variantes, (principalmente la del selfie) están ya relativamente asentados y pueden tratarse como un objeto tipo, estaremos expectantes a la hora de analizar hacia dónde se dirigirán estas prácticas durante los años venideros. Si cambian los jóvenes, cambiará el medio y también cambiará la herramienta, de ahí que estemos condenados a ver, también, mutaciones en este tipo de actuaciones y en las imágenes que se originarán. Seguro que así será. 
Al fin y al cabo, y como hemos citado, cada momento histórico presencia el nacimiento de unos particulares modos de expresión artística que corresponden al carácter político, a las maneras de pensar y a los gustos de la época que los cobija; gustos que se forman en función de unas condiciones de vida muy definidas y que caracterizan la estructura social. En este sentido, hemos intentado, durante todo este estudio, otorgar cierto valor y entidad propia a cualquier tipo de autorretrato digital publicado en la red, en tanto que objeto fotográfico fruto de nuestro tiempo.

Somos conscientes de que este trabajo de investigación puede contener algunas carencias en según qué lugares, bien sea debido al deseo de no exceder su extensión, bien por tratar temas novedosos que todavía no poseen un amplio y asentado marco conceptual (salvo el que nos ofrece la observación y la interpretación de los cacareos de la red). Asimismo, también asumimos la responsabilidad de que, pese a nuestro afán e intento de referenciar este análisis con los autores más relevantes que hemos encontrado para cada tema, nos hayan quedado muchos en el tintero, seguramente más pertinentes por su importancia. Esperamos en todo caso que, pese a todos nuestros errores, la presente Tesis Doctoral cumpla el cometido de resolver sus hipótesis y que todas estas páginas hagan las veces de guía para que futuros lectores recuerden o descubran cuáles fueron los orígenes, los desarrollos y las consecuencias de un objeto fotográfico o de una práctica fotográfica popular que indudablemente ya forma parte de la historia de la fotografía: el self shot en general y el selfie en particular.

Y también esperamos que, pese a su evidente institucionalización, estas prácticas que han sido nuestro principal objeto de estudio continúen, y que sus también hoy jóvenes creadoras y creadores no cesen en su afán por punzarnos (a la manera barthesiana) mediante su creatividad, imaginación, atrevimiento y erotismo. Al fin y al cabo han desarrollado unos autorretratos de gran interés que siguen manteniendo viva la fotografía. 


\title{
BIBLIOGRAFÍA
}

\section{Libros.}

\author{
ADAMS, Ansel \\ 2002 La cámara, Madrid, Omnicón.
}

ADAMS, Robert

1994 Why People Photograph, Nueva York, Aperture.

1996 Beauty in Photography, Nueva York, Aperture.

\section{ADATTO, Kiku}

2010 Imagen perfecta, Torrelavega, Quálea.

\section{ADORNO, Theodor W. y HORKHEIMER, Max}

2007 Dialéctica de la Ilustración, Madrid, Akal.

\section{AGUILERA, Emiliano}

1974 El desnudo en las artes, Madrid, Ediciones Giner.

\section{AGUIRRE, Patricia C. y CASCO, Javier}

2010 "El sexting, entre lo público y lo privado de Internet", en "Las audiencias activas, nuevas formas de participación pública. Consideraciones éticas y jurídicas", en VIII Congreso Internacional de Ética y Derecho de la Información, Guadalajara, Universidad Panamericana.

\section{ARBAÏZAR, Philippe y PICAUDÉ, Valérie (Eds.)}

2004 La confusión de los géneros en fotografía, Barcelona, Gustavo Gili. 
ALONSO, Francisco

2007 Documentalidad y artisticidad en el medio fotográfico, Barcelona, UOC.

AMSTRONG, Nancy

1991 Deseo y ficción doméstica, Madrid, Cátedra.

\section{ARDÈVOL, Elisenda y ENGUIX, Begonya}

2010 "Bodies in Action: Performing Identity in Dating Sites", en PIRANI, Bianca M. y VARGA, Ivan (Eds.), Acting Bodies and Social Networks: A Bridge Between Technology and Working Memory, Lanham, University Press of America.

\section{ARDÈVOL, Elisenda y VAYREDA, Agnès}

2003 “Identidades en línea, prácticas reflexivas", en Seminario sobre la identidad en la era digital. Canarias Mediafest, Las Palmas de Gran Canaria.

\section{ARNABAT, Ramón y DUCH, Montserrat (Coords.)}

2014 Historia de la sociabilidad contemporánea. Del asociacionismo a las redes sociales, Valencia, Universitat de València.

\section{ARNHEIM, Rudolf}

1992 Arte y percepción visual, Madrid, Alianza.

\section{AUMONT, Jacques}

1992 La imagen, Barcelona, Paidós.

\section{BAILI, Jean-Christophe}

2001 La llamada muda, Madrid, Akal.

\section{BALTRUSAITIS, Jurgis}

1988 El espejo. Ensayo sobre una leyenda científica, Madrid, Miraguano / Polifemo.

\section{BANKS, Michael A.}

2008 On the way to the Internet: the Secret History of the Internet and its Founders, California, Apress.

\section{BAÑUELOS, Jacob y MATA, Francisco}

2014 Fotografía y dispositivos móviles: escenarios de un nuevo paradigma visual, México D.F., Tecnológico de Monterrey-Porrúa Print. 


\section{BARCLAY, Carrie y CROFT, Malcolm}

2015 The Selfie Book, Londres, Carlton Books.

\section{BARTHES, Roland}

2003 Sistema de la moda, Barcelona, Paidós Ibérica.

2009 La cámara lúcida, Barcelona, Paidós Ibérica.

\section{BATAILLE, Georges}

2000 El erotismo, Barcelona, Tusquets.

\section{BATCHEN, Geoffrey}

2004a Arder en deseos. La concepción de la fotografía, Barcelona, Gustavo Gili.

2004b «Ectoplasma. La fotografía en la era digital», en RIBALTA, Jorge (Ed.), Efecto real. Debates posmodernos sobre fotografía, Barcelona, Gustavo Gili.

\section{BAUDELAIRE, Charles}

1997 Las flores del mal, Madrid, Cátedra.

\section{BAUDRILLARD, Jean}

1998 De la seducción, Madrid, Cátedra.

\section{BAUMAN, Zygmunt}

2007 Vida de consumo, Madrid, Paidós.

\section{BECEYRO, Raúl}

2003 Ensayos sobre fotografía, Buenos Aires, Paidós.

\section{BELTING, Hans}

2007 Antropología de la imagen, Buenos Aires, Katz Ediciones.

\section{BENJAMIN, Walter}

2004 Sobre la fotografía, Valencia, Pre-Textos.

\section{BERGER, John,}

1980 Mirar, Barcelona, Gustavo Gili, 2008.

1986 Y nuestros rostros, mi vida, breves como fotos, Madrid, Hermann Blume.

2007 Sobre las propiedades del retrato fotográfico, Barcelona, Gustavo Gili.

\section{BERGER, René}

1979 Arte y comunicación, Barcelona, Gustavo Gili. 


\section{BERLANGA, Inmaculada}

2013 El discurso en los medios digitales. Principios de retórica clásica en las redes sociales: el caso Facebook, Granada, Editorial Universidad de Granada.

\section{BERNERS-LEE, Tim}

2000 Tejiendo la red. El inventor del World Wide Web nos descubre su origen, Madrid, Siglo XXI.

\section{BORERO, Alejandra y LONDOÑO, Suanny}

2016 "Mujer selfie, construcción de un discurso femenino adolescente mediado por el consumo de la imagen”, en V Encuentro Internacional de Investigadores en Publicidad (RELAIP), Alicante.

\section{BORGES, Jorge Luis}

1997 Ficciones, Madrid, Alianza.

\section{BORNAY, Erika}

2005 Las hijas de Lilith, Madrid, Cátedra.

\section{BOURDIEU, Pierre}

1997 Sobre la televisión, Barcelona, Anagrama.

2003 Un arte medio, Barcelona, Gustavo Gili.

\section{BOURRIAUD, Nicolas}

2009 Radicante, Buenos Aires, Adriana Hidalgo.

\section{BRAIDOTTI, Rosi}

2005 Metamorfosis: hacia una teoría materialista del devenir, Madrid, Akal.

\section{BREA, José Luis}

2002 La era postmedia. Acción comunicativa, prácticas (post)artísticas y dispositivos neomediales, Salamanca, Centro de Arte de Salamanca.

2004 El tercer umbral: estatuto de las prácticas artísticas en la era del capitalismo cultural, Murcia, Cendeac.

2005 Estudios visuales: la epistemología de la visualidad en la era de la globalización, Madrid, Ediciones Akal.

2007 Cultura_RAM. Mutaciones de la cultura en la era de su distribución 
electrónica, Barcelona, Gedisa.

2010 Las tres eras de la imagen, Madrid, Akal.

\section{BRIGGS, Asa y BURKE, Peter}

2002 De Gutenberg a Internet: una historia social de los medios de comunicación, Madrid, Santillana.

\section{BROOKS, Susie}

2016 Selfie: The Changing Face of Self Portraits, Londres, Wayland.

\section{BURGIN, Victor}

2003 Ensayos, Barcelona, Gustavo Gili.

\section{CALVINO, Italo}

2012 "La aventura de un fotógrafo", en Los amores difíciles, Madrid, Siruela.

\section{CARRILLO, Jesús}

2004 Arte en la red, Madrid, Cátedra.

\section{CASARES, Nilo}

2009 Del net.art al web-art 2.o, Valencia, Institució Alfons el Magnànim / Diputació de València.

\section{CASTELLS, Manuel}

2000 La sociedad red, Madrid, Alianza.

2003 La galaxia Internet, Barcelona, Debolsillo.

\section{CASTRO, Fernando}

2016 Estética a golpe de like, Murcia, Newcastle Ediciones.

\section{CHÉROUX, Clément}

2009 Breve historia del error fotográfico, México D.F., Ediciones Ve.

\section{CHEVRIER, Jean-François}

2007 La fotografía entre las Bellas Artes y los medios de comunicación, Barcelona, Gustavo Gili.

\section{CHILVERS, Ian}

2003 Artist Revealed: Artists and Their Self-portraits (History of Self Portraits), Berkeley, Thunder Bay Press. 


\section{CLARK, Kenneth}

2008 El desnudo: un estudio de la forma ideal, Madrid, Alianza.

\section{COLÁs, Ana María}

2015 Acoso y ciberacoso escolar. La doble responsabilidad civil y penal, Barcelona, Bosch.

\section{COLORADO, Arturo}

1997 Hipercultura visual. El reto hipermedia en el arte y la educación, Madrid, Editorial Universidad Complutense.

\section{CONTRERAS, Fernando R.}

$2009 \operatorname{Re}(d) u n i d o s:$ cultura, innovación y comunicación, Barcelona, Anthropos.

\section{CONTRERAS, Salvador}

2012 La protección del honor, la intimidad y la propia imagen en Internet, Madrid, Aranzadi.

\section{CORELLA, Miguel y GARCÍA, Wenceslao (Eds.)}

2015 Metáforas de la multitud, en III Congreso Internacional Estética y Política, Valencia.

\section{COZINESS, Robert V.}

2010 Netnography: Doing Ethnographic Research Online, Thousand Oaks, SAGE Publications.

\section{CUCó, Josepa}

2008 Antropología urbana, Barcelona, Ariel.

\section{DE HARO, María V.; GRANDÍO, María M. y HERNÁNDEZ, Manuel} (Coords.)

2012 Historias en red. Impacto de las redes sociales en los procesos de comunicación, Murcia, Universidad de Murcia.

\section{DE LA PUENTE-HERRERA, Inmaculada}

2011 El imperio de la moda, Madrid, Arcopress.

\section{DE LAURENTIS, Teresa}

1992 Alicia ya no, Madrid, Cátedra. 


\section{DEBORD, Guy}

2002 La sociedad del espectáculo, Valencia, Pre-Textos.

\section{DEBRAY, Régis}

1998 Vida y muerte de la imagen. Historia de la mirada en occidente, Barcelona, Paidós Ibérica.

2001 Introducción a la mediología, Barcelona, Paidós Ibérica.

\section{DECHERT, Charles R.}

1996 The Social Impact of Cybernetics, Nueva York, Simon \& Schuster.

\section{DELEUZE, Gilles y GUATTARI, Félix}

2005 Rizoma (Introducción), Valencia, Pre-Textos.

\section{DIJKSTRA, Bram}

1994 Ídolos de perversidad, Madrid, Debate.

\section{DUBAR, Claude}

2002 La crisis de las identidades. La interpretación de una mutación, Barcelona, Bellaterra.

\section{DUBOIS, Philippe}

1986 El acto fotográfico. De la representación a la recepción, Barcelona, Paidós.

\section{DURAND, Régis}

1998 El tiempo de la imagen. Ensayo sobre las condiciones de una historia de las formas fotográficas, Salamanca, Universidad de Salamanca.

\section{DYER, Geoff}

2010 El momento interminable de la fotografia, Oaxaca, Ediciones Ve.

\section{ECO, Umberto}

1968 Apocalípticos e integrados ante la cultura de masas, Barcelona, Lumen.

1983 La definición del arte, Barcelona, Martínez Roca.

2000 De los espejos y otros ensayos, Barcelona, Lumen.

2004 Historia de la belleza, Barcelona, Lumen.

\section{EGUIZÁBAL, Raúl}

2006 Fotografía publicitaria, Madrid, Cátedra, 2006. 


\section{EUGENIDES, Jeffrey}

2001 Las vírgenes suicidas, Barcelona, Anagrama.

EVANS, Jessica y HALL, Stuart (Eds.)

2002 Visual Culture: the Reader, Londres, Sage and Open University.

\section{FAERMAN, Juan}

2010 Faceboom: el nuevo fenómeno de masas Facebook, Barcelona, Alienta.

\section{FISCHER, Ernst}

1985 La necesidad del arte, Barcelona, Nexos.

\section{FLICHY, Patrice}

2003 Lo imaginario de Internet, Madrid, Tecnos.

\section{FLUSSER, Vilém}

2001 Una filosofía de la fotografía, Madrid, Síntesis.

\section{FONTCUBERTA, Joan}

2002 Fotografía. Crisis de historia, Barcelona, Actar.

2003 Estética fotográfica: una selección de textos, Barcelona, Gustavo Gili.

2009 El beso de Judas. Fotografía y verdad, Barcelona, Gustavo Gili.

2010 La cámara de Pandora. La fotografi@ después de la fotografía, Barcelona, Gustavo Gili.

\section{FORLANI, Alessandro}

2016 To Self or Not To Self, Milan, Delos Digital.

\section{FRANCASTEL, Pierre}

1990 Pintura y sociedad, Madrid, Cátedra.

\section{FREELAND, Cynthia}

2004 Pero ciesto es arte? Una introducción a la teoría del arte, Madrid, Cátedra.

\section{FREUD, Sigmund}

1987 Introducción al narcisismo. Obras Completas VI, Madrid, Biblioteca Nueva.

1987 Psicología de las masas y análisis del yo. Obras Completas VII, Madrid, Biblioteca Nueva. 


\section{FREUND, Gisèle}

2008 La fotografía como documento social, Barcelona, Gustavo Gili.

\section{GATES, Bill}

1997 Camino al futuro, Madrid, McGraw-Hill.

\section{GERNSHEIM, Alison y GERNSHEIM Helmut}

1967 Historia gráfica de la fotografía, Barcelona, Omega.

\section{GIL, Ana M.}

2012 El derecho a la propia imagen del menor en Internet, Madrid, Dykinson.

\section{GIMÉNEZ, Ana M. y HERNÁNDEZ, María A.}

2015 “Ciberbullying. Revisión conceptual y efectos colaterales”, en Congreso

Internacional Infancia en Contextos de Riesgo, Cádiz, Universidad de Cádiz.

\section{GOFFMAN, Erving}

1997 La presentación de la persona en la vida cotidiana, Buenos Aires, Amorrortu.

\section{GOMBRICH, Ernst $H$.}

2003 Historia del arte, Madrid, Debate.

\section{GÓMEZ-CRUZ, Edgar}

2003 Cibersexo. ¿La última frontera del Eros? Un estudio etnográfico, Colima, Universidad de Colima.

2008 "Imagen pública-privada y ética: Reflexiones desde una investigación etnográfica sobre las prácticas de fotografía digital”, en ARDÈVOL, Elisenda; DOMÍNGUEZ, Daniel y ESTALELLA, Adolfo (Eds), La mediación tecnológica en la práctica etnogràfica, en XI Congreso de Antropología, San Sebastián, FAAEE.

2012 De la cultura Kodak a la imagen en red: una etnografía sobre fotografía digital, Barcelona, UOC.

\section{GONZÁLEZ-ANLEO, Juan M.}

2015 Generación selfie, México D.F., PPC Editorial.

\section{GONZÁLEZ REQUENA, Jesús}

1992 El discurso televisivo. Espectáculo de la postmodernidad, Madrid, Cátedra. 


\section{GRAHAM, Gordon}

2001 Internet: una indagación filosófica, Madrid, Cátedra.

\section{GREEN, David (Ed.)}

2007 ¿Qué ha sido de la fotografía?, Barcelona, Gustavo Gili.

\section{GREY, Sasha}

2013 La sociedad Juliette, Barcelona, Grijalbo.

\section{GRIMAL, Pierre}

1981 Diccionario de mitología griega y romana, Barcelona, Paidós.

\section{GUASCH, Anna M.}

2009 Autobiografías visuales, Madrid, Siruela.

\section{GUBERN, Román}

1988 Mensajes icónicos en la cultura de masas, Barcelona, Lumen.

2004 La imagen pornográfica y otras perversiones ópticas, Barcelona, Anagrama.

\section{HAGEMANN, Stephan y VOSSEN, Gottfried}

2007 Unleashing Web 2.o: From Concepts to Creativity, Boston, Morgan Kaufmann.

\section{HALL, James}

2014 The Self-Portrait: A Cultural History, Nueva York, Thames \& Hudson.

\section{HERNÁIZ, Juan Ignacio}

2007 Historia de la comunicación: del tintero a Internet, Madrid, Universitas.

\section{HERRERA, Ángel M. y VILLABONA, Jorge}

200815 años de Internet, Madrid, Grupo Búho.

\section{HESS, Thomas B. y NOCHLIN, Linda (Eds.)}

1973 Woman as Sex Object. Studies in Erotic Art. 1730-1970, Nueva York, Newsweek Inc.

\section{IGLESIAS, David}

2008 La fotografía digital en los archivos. Qué es y cómo se trata, Gijón, Trea. 


\section{JOLY, Martine}

2003 La interpretación de la imagen: entre memoria, estereotipo y seducción. Barcelona, Paidós.

\section{JULLIER, Laurent}

2004 La imagen digital. De la tecnología a la estética, Buenos Aires, La Marca.

\section{KAUFMANN, Jean-Claude}

2013 Sex@mor, Madrid, Pasos Perdidos.

\section{KAUFFMAN, Linda $\mathbf{S}$.}

2000 Malas y perversos. Fantasías en la cultura y el arte contemporáneos, Madrid, Cátedra.

\section{KEEN, Andrew}

2007 The Cult of the Amateur: How Today's Internet is Killing Our Culture. Nueva York, Doubleday.

\section{LACAN, Jacques}

2009 "El estadio del espejo como formador de la función del yo [je] tal como se nos revela en la experiencia psicoanalítica”, en Escritos (Vol. I), México D.F., Siglo XXI.

\section{LANDOW, George P. (Ed.)}

1997 Teoría del hipertexto, Barcelona, Paidós.

\section{LASÉN, Amparo}

2009 "Tecnologías afectivas: de cómo los teléfonos móviles participan en la constitución de subjetividades e identidades”, en GATTI, Gabriel; MARTÍNEZ, Iñaki y TEJERINA, Benjamín (Eds.), Tecnología, cultura experta e identidad en la sociedad del conocimiento, Bilbao, Servicio de Publicaciones Universidad del País Vasco.

2012 “Autofotos. Subjetividades y medios sociales", en GARCÍA-CANCLINI, Néstor y CRUCES, Francisco (Eds.), Jóvenes, culturas urbanas y redes digitales. Prácticas emergentes en las artes, el campo editorial y la música, Madrid, Ariel.

\section{LE BRETON, David}

2002 Antropología del cuerpo y modernidad, Madrid, Nueva Visión. 


\section{LÉVY, Pierre}

1995 Qu'est-ce que le virtuel?, París, La Découverte.

\section{LINASCHKE, Joseph}

2011 Getting the Most from Instagram, San Francisco, Peachpit Press.

\section{LISTER, Martin (Comp.)}

1997 La imagen fotográfica en la cultura digital, Barcelona, Paidós Ibérica.

\section{MANOVICH, Lev}

2005 El lenguaje de los nuevos medios de comunicación. La imagen en la era digital, Barcelona, Paidós.

\section{MARCHÁN, Simón (Comp.)}

2006 Real/Virtual en la estética y la teoría de las artes, Barcelona, Paidós.

\section{MARÍN, Enric y TRESSERAS, Joan M.}

1994 Cultura de masses i postmodernitat, Valencia, Tres i Quatre.

MARQUÉS, María P. y MUÑ̃Z, M.

2014 “Análisis de redes sociales. Definición y conceptos básicos”, en GARCÍA, Miguel

F. (Coord.), Conectados por redes sociales: introducción al análisis de redes sociales y casos prácticos, Barcelona, UOC.

\section{MARTÍNEZ-ARTERO, Rosa}

2004 El retrato: del sujeto en el retrato, Barcelona, Montesinos.

MARZAL, Javier

2007 Cómo se lee una fotografía, Madrid, Cátedra.

\section{McGREGOR, Richard}

1996 Japan Swings: Politics, Culture and Sex in the New Japan, Sydney, Allen \& Unwin.

\section{McLUHAN, Marshall y JEROME, Agel}

1988 El medio es el masaje, Barcelona, Paidós.

\section{McQUAIL, Denis}

1985 Introducción a la teoría de la comunicación de masas, Barcelona, Paidós. 


\section{MELCHIOR-BONNET, Sabine}

2014 Historia del espejo, Buenos Aires, Edhasa.

\section{MELENDO, Laura}

2013 "De las pinturas rupestres al smartphone: la historia del ser humano en busca de una comunicación móvil, instantánea y accesible”, en RÖMER, Max (Coord.), Miradas a las pantallas en el bolsillo, Madrid, Universidad Camilo José Cela.

\section{MELOT, Michel}

2010 Breve historia de la imagen, Madrid, Siruela.

\section{MERLEAU-PONTY, Maurice}

2010 Lo visible y lo invisible, Buenos Aires, Nueva Visión.

\section{MIRZOEFF, Nicholas}

2003 Una introducción a la cultura visual, Barcelona, Paidós.

\section{MITCHELL, William J.}

1998 The Reconfigured Eye Visual Truth in the Post-photographic Era, Cambridge, MIT Press.

\section{MONSORIU, Mar}

2010 Diccionario Web 2.o. Todos los términos que se necesita conocer sobre las redes sociales y los medios sociales, Madrid, Creaciones Copyright.

\section{MONTANARI, Paola}

2015 Selfie tra le righe, Viareggio, Giovane Holden Edizioni.

\section{MONTERO, Yolanda}

2006 Televisión, valores y adolescencia, Barcelona, Gedisa.

\section{MORDUCHOWICZ, Roxana}

2012 Los adolescentes y las redes sociales. La construcción de la identidad juvenil en Internet, Buenos Aires, Fondo de Cultura Económica.

\section{MUÑ̃̃, Elisa}

2012 La seguridad jurídica de los menores en el uso de las redes sociales, Madrid, Editorial Académica Española. 


\section{NEAD, Lynda}

1998 El desnudo femenino. Arte, obscenidad y sexualidad, Madrid, Tecnos.

\section{NEBREDA, David}

1998 David Nebreda. Autorretratos, Madrid, Doce Notas.

\section{NEGROPONTE, Nicholas}

1995 El mundo digital, Barcelona, Ediciones B.

\section{NEWHALL, Beaumont}

1983 Historia de la fotografía. Desde sus orígenes hasta nuestros días, Barcelona, Gustavo Gili.

\section{NISSENBAUM, Helsen}

2010 Privacy in Context: Technology, Policy and Integrity of Social Life.

Stanford, Stanford University Press.

\section{PALAO, José Antonio}

2004 La profecía de la imagen-mundo: para una genealogía del paradigma informativo, Valencia, Ediciones de la Filmoteca / Instituto Valenciano de Cinematografía Ricardo Muñoz Suay.

\section{PALMGREN, Ann-Charlotte}

2009 «Today's Outfit in Swedish Fashion Weblogs: An Ethnographical Study of the Online Body», en V European Symposium on Gender \& ICT. Digital Cultures: Participation-Empowerment-Diversity, Bremen, University of Bremen.

\section{PANOFSKY, Erwin}

1999 La perspectiva como forma simbólica, Barcelona, Tusquets.

1979 El significado en las artes visuales, Madrid, Alianza.

\section{PERALBO, Ángel}

2013 De niñas a malotas, Madrid, La Esfera de los Libros.

\section{PÉREZ, Antonio E.}

2004 ¿Ciberciudadanía o ciudadanía.com?, Barcelona, Gedisa. 


\section{PÉREZ, David (Ed.)}

2004 La certeza vulnerable. Cuerpo y fotografía en el siglo XXI, Barcelona, Gustavo Gili.

\section{PÉREZ, Francisca}

1988 Los placeres del parecido: icono y representación, Madrid, Visor.

\section{PÉREZ, Helena y SOUGEZ, Marie-Loup}

2003 Diccionario de la historia de la fotografía, Madrid, Cátedra.

\section{PÉREZ, Juan C.}

2000 El cuerpo en venta. Relación entre arte y publicidad, Madrid, Cátedra.

\section{PISANI, Francis y PIOTET, Dominique}

2008 La alquimia de las multitudes. Cómo la Web está cambiando el mundo, Barcelona, Paidós.

\section{POPELIER, Willem}

2015 The Do-It-Yourselfie Guide: The Ultimate Selfie Guide to Capture the Best Version of Yourself, Amsterdam, Bis Publishers.

\section{PULTZ, John}

2003 La fotografía y el cuerpo, Madrid, Akal.

\section{QUEMADA, Juan}

2004 Hacia una Internet de nueva generación, Madrid, Cátedra Telefónica UPM.

\section{RAMÍrEZ, José Antonio}

1976 Medios de masas e historia del arte, Madrid, Cátedra.

\section{RANCIÈRE, Jacques}

2003 El maestro ignorante. Cinco lecciones sobre la emancipación intelectual, Barcelona, Laertes.

\section{RIBALTA, Jorge (Ed.)}

2004 Efecto real: debates posmodernos sobre fotografía, Barcelona, Gustavo Gili.

\section{RITCHIN, Fred}

2008 After Photography, Nueva York, Norton \& Company. 


\section{ROBERTS, Pamela}

2008 Cien años de fotografía en color, Barcelona, Electa.

\section{RODRÍGUEZ, Daniel}

2011 Ceros y unos: la increíble historia de la informática, Internet y los videojuegos, Madrid, Ciudadela.

\section{RODRÍGUEZ, Leti}

2016 Com sobreviure a les xarxes socials, Barcelona, Ara Llibres.

\section{SABORIT, José}

1992 La imagen publicitaria en televisión, Madrid, Cátedra.

\section{SÁNCHEZ-VIGIL, Juan Miguel}

2006 El documento fotográfico. Historia, usos, aplicaciones, Gijón, Trea.

\section{SANCHIS, María T.}

2004 Derechos de autor, digitalización e Internet, Madrid, Universitas.

\section{SCHAEFFER, Jean-Marie}

1990 La imagen precaria. Del dispositivo fotográfico, Madrid, Cátedra.

\section{SCHARF, Aaron}

1994 Arte y fotografía, Madrid, Alianza.

\section{SCOLARI, Carlos}

2004 Hacer clic. Hacia una sociodemiótica de las interacciones digitales, Barcelona, Gedisa.

\section{SIBILIA, Paula}

2008 La intimidad como espectáculo, Buenos Aires, Fondo de Cultura Económica.

\section{SOLER, María}

2007 Las empresas de fotografía ante la era digital. El caso de la Comunidad Valenciana, Madrid, Ediciones de las Ciencias Sociales.

\section{SONTAG, Susan}

2008 Sobre la fotografía, Barcelona, Debolsillo. 


\section{SOUGEZ, Marie-Loup}

2006 Historia de la fotografía, Madrid, Cátedra.

\section{TAUSK, Petr}

1978 Historia de la fotografía en el siglo XX. De la fotografía artística al periodismo gráfico, Barcelona, Gustavo Gili.

\section{THOMPSON, John B.}

1998 Los media y la modernidad: una teoría de los medios de comunicación, Barcelona, Paidós.

\section{TISSERON, Serge}

2000 El misterio de la cámara lúcida. Fotografía e inconsciente, Salamanca, Ediciones Universidad de Salamanca.

\section{TOURIÑO, Alejandro}

2014 El derecho al olvido y a la intimidad en Internet, Madrid, Los Libros de la Catarata.

\section{TOWNSEND, Chris}

1998 Vile Bodies. Photography and the Crisis of Looking, Múnich-Nueva York, Prestel-Verlang.

\section{TURKLE, Sherry}

1997 La vida en la pantalla: la construcción de la identidad en la era de Internet, Barcelona, Paidós.

\section{VENTURA, Lourdes}

2000 La tiranía de la belleza. Las mujeres ante los modelos estéticos, Barcelona, Plaza \& Janés.

\section{VILLAFAÑ}

1988 Introducción a la teoría de la imagen, Madrid, Pirámide.

VV. AA.

1993 Historia de la vida privada. De la Primera Guerra Mundial a nuestros días. Vol. V, Barcelona, Círculo de Lectores.

1996 Photography after Photography. Memory and Representation in the Digital Age, Ámsterdam-Múnich, G+B Arts. 
2007 History of the Internet: A Chronology, 1843 to the Present, Santa Barbara, ABCCLIO Incorporated.

2016 La sociedad de la información en España 2016, Madrid, Fundación Telefónica.

\section{WALL, Jeff}

2007 Fotografía e inteligencia líquida, Barcelona, Gustavo Gili.

\section{WATTS, Duncan J.}

2003 Six Degrees: The Science of a Connected Age, Nueva York, W. W. Norton \& Company.

\section{WEIERMAIR, Peter (Ed.)}

1999 Erotic Art. From the $17^{\text {th }}$ Century to the $2 O^{\text {th }}$ Century, Zúrich-Nueva York, Edition Stemmler.

\section{WOOLF, Virginia}

2008 Una habitación propia, Barcelona, Seix Barral.

\section{ZAFRA, Remedios}

2010 Un cuarto propio conectado. (Ciber)espacio y (auto)gestión del yo, Madrid, Fórcola Ediciones.

2013 (H)adas. Mujeres que crean, programan, prosumen, teclean, Madrid, Páginas de Espuma.

\section{ZEVIN, Dan}

2015 Mr. Selfie, Nueva York, USA Penguin Press.

\section{ZUNZUNEGUI, Santos}

2010 Pensar la imagen, Madrid, Cátedra. 


\section{Tesis doctorales y trabajos de investigación.}

\section{CANET, Fernando}

2002 Nuevas formas de comunicación multimedia en la red: análisis y producción de espacios de entretenimiento online, Valencia, Universitat Politècnica de València.

\section{CEREIJO, María}

2015 El yo frente a la cámara. Construcción de la imagen mediante el selfie y el retrato fotográfico, Valencia, Universitat Politècnica de València.

\section{CUETO, José L.}

2001 El hecho pictórico. El acto fotográfico: la mirada y la memoria como material de la práctica artística, Valencia, Universitat Politècnica de València.

\section{ESCOHOTADO, Sandra}

2005 Autorretrato, arte y mujer, Madrid, Universidad Complutense de Madrid.

\section{FERNÁNDEZ, Lilia C.}

2009 Accesibilidad y usabilidad de contenidos digitales. Por una sociedad de la información y el conocimiento no excluyente, Valencia, Universitat Politècnica de València.

\section{GALLIS, María I.}

2011 Autorretrato y autorrepresentación: territorio de experimentación y cambio de paradigma en el siglo $X X$, Valencia, Universitat Politècnica de València.

\section{GENARO, Noemí}

2013 El autorretrato fotográfico como herramienta educativa, Granada, Universidad de Granada.

\section{GÓMEZ-CRUZ, Edgar}

2011 De la cultura Kodak a la cultura Flickr. Prácticas de fotografía digital en la vida cotidiana, Barcelona, UOC. 


\section{GORRIS, Gisela}

2016 La imagen del perfil en Facebook: la metamorfosis del autorretrato y el yo publicitado, Valencia, Universitat Politècnica de València.

\section{GUERREIRO, Regina N.}

2016 Competencias socioemocionales y bullying en adolescentes, Cáceres, Universidad de Extremadura.

\section{LÓPEZ, Mónica}

2013 Nuevas formas de hacer, nuevas formas de ser. Las tecnologías digitales como agentes dinamizadores del aprendizaje informal, Cádiz, Universidad de Cádiz.

\section{MARTÍNEZ, Diego}

2016 Miniaturización y democratización de las cámaras cinematográficas y de vídeo digital, Gandía, Universitat Politècnica de València.

\section{RIERA SOLER, Begoña}

2015 La certeza de uno mismo, Valencia, Universitat Politècnica de València.

\section{ROBLES, Elena}

2014 Tumblr: estudios estéticos sobre la plataforma web Tumblr. Construcción de la identidad a través de la creación colectiva, Valencia, Universitat Politècnica de València.

\section{ROJO, Leticia}

2014 Análisis del marketing viral. Estudio de casos, Valencia, Universitat Politècnica de València.

\section{RUIZ, Sonia}

2009 Del blog al microblog. El devenir del receptor en generador y emisor de contenidos en la Web 2.o, Málaga, Universidad de Málaga.

\section{SÁNCHEZ, Nieves}

2004 Evolución de la fotografía a través de la obra de Lewis Carroll: Alicia en el país de las maravillas y a través del espejo, Madrid, Universidad Complutense de Madrid. 


\section{SILVESTRE , María}

2007 La imagen de la preadolescente y su representación en el arte, Valencia, Universitat Politècnica de València.

\section{SOCUÉLLAMOS, Anna}

2015 Análisis de posicionamiento de las marcas en el sector tecnológico de los smartphones, Valencia, Universitat Politècnica de València.

\section{VÁZQUEZ, María F.}

2015 La cultura visual en la adolescencia, Sevilla, Universidad de Sevilla.

\section{WANG, Yin-Han}

2012 Taiwanese Girls' Self-portraiture on a Social Networking Site, Londres, The London School of Economics and Political Science.

\section{Artículos en revistas y prensa periódica.}

\section{ALCÁZAR, Pilar}

2008 "Una imagen y pocas palabras. Las ideas que han convertido a Fotolog, la primera red social basada en compartir fotos, en una de las páginas con más tráfico en Internet”, en Emprendedores. Las claves de la economía y el éxito profesional, no 130 , págs. 40-42.

\section{ALONSO, Patricia; MAgALHÃES, Maria José; PÉREZ, Carmen y RODRÍGUEZ, Yolanda}

2015 "Estudio cualitativo en un grupo de estudiantes ourensanos/as sobre el fenómeno del sexting”, en Revista de estudios e investigación en psicología y educación, $\mathrm{n}^{0} 13$, págs. 58-62.

\section{ARAUNA, Núria; MARTÍNEZ, Inmaculada J. y TORTAJADA, \\ Iolanda}

2013 "Estereotipos publicitarios y representaciones de género en las redes sociales", en Comunicar. Revista científica iberoamericana de comunicación y educación, $\mathrm{n}^{\mathrm{o}}$ 41, págs. 177-186. 


\section{AVGITIDOU, Angeliki}

2003 "Performances of the Self", Digital Creativity, nº 14, págs. 131-138.

BALAKRISHNAN, Janarthanan y GRIFFITHS, Mark D.

2017 “An Exploratory Study of «Selfitis» and the Development of the Selfitis Behavior Scale”, en International Journal of Mental Health and Addiction, págs. 1-15.

\section{BASILE, Diego y LINNE, Joaquín}

2014 "Performances de autopresentación a través de fotografías digitales. El caso de los adolescentes de sectores populares en Facebook", en Cuadernos.Info, $\mathrm{n}^{\mathrm{0}} 35$ (Ejemplar dedicado a: Comunicación y educación), págs. 209-217.

\section{BERJANO, Pablo G.}

2015 “El valor de lo efímero. SnapChat”, en Cambio 16, nº2222, págs. 96-97.

\section{BERNERS-LEE, Tim}

1999 "Realising the Full Potential of the Web", en Technical Communication, $\mathrm{n}^{0}{ }_{1}$, pág. 79 .

\section{BEN-ZE'EV, Aaron}

2003 "Privacy, Emotional Closeness and Opennes in Cyberspace", en Computers in Human Behaviour, nº 19, págs. 451-467.

\section{BIANCIOTTI, María C.}

2011 “Cuerpo y género: apuntes para pensar prácticas eróticas de mujeres jóvenes. Aportes de Judith Butler y Pierre Bourdieu”, en Revista latinoamericana de estudios sobre cuerpo, emociones y sociedad, vol. 6, nº 3 , págs. 70-82.

\section{BONAVITTA, Paola; CAMACHO, Jeli E. y DE GARAY, Jimena}

2015 "Mujeres, feminismos y redes sociales. Acceso, censura y potencialización”, en Question, vol. 1, nº 48, págs. 33-44.

\section{BREA, José Luis}

2003 "Yo y los otros. Fábricas de identidad (retóricas del autorretrato)", en Exit. Imagen y cultura, $\mathrm{n}^{\circ} 10$ (Ejemplar dedicado a: Autorretratos), pág. 81.

2007 “Cambio de régimen escópico: del inconsciente óptico a la e-image", en Estudios visuales, $\mathrm{n}^{\circ} 4$, págs. 145-163. 


\section{BRINGUÉ, Xavier ; DEL RÍO, Jorge y SÁDABA, Charo}

2010 "Menores y redes ¿̇sociales? De la amistad al cyberbullying”, en Revista de estudios de juventud, no 88, págs. 115-129.

\section{BROULLÓN-LOZANO, Manuel A.}

2015 "Por una semiótica del selfie en la cultura visual digital", en Fotocinema. Revista científica de cine y fotografía, $\mathrm{n}^{0}$ 11, págs. 215-234.

\section{BUSHEY, Jessica}

2014 “La fotografía en las redes sociales carchivos personales o materiales efímeros?”, en Tabula. Revista de archivos de Castilla y León, $\mathrm{n}^{\mathrm{0}} 17$ (Ejemplar dedicado a: Ego archivo. Memorias personales en un mundo digital), págs. 107-122.

\section{CAEROLS, Raquel; CARRETERO, Andrés y TAPIA, Alejandro}

2013 "Instagram, la imagen como soporte de discurso comunicativo participado", en Vivat academia, no ${ }^{0}$ 124, págs. 68-78.

\section{CALABRESE, Natalia}

2016 “¿Por qué llamarlo fotografía?”, en Question, vol. 1, nº 51, págs. 347-359.

\section{CALDEVILLA, David}

2010 "Las redes sociales. Tipología, uso y consumo de las redes 2.o en la sociedad digital actual”, en Documentación de las ciencias de la información, $\mathrm{n}^{\circ} 33$, págs. 45-68.

\section{CANGA, Manuel}

2015 "Introducción al fenómeno del selfie: valoración y perspectivas de análisis", en Fotocinema. Revista científica de cine y fotografía, nº 10, págs. 383-405.

\section{CARO, Lucía}

2015 "WhatsApp y la búsqueda de control de la situación informacional por parte de los jóvenes”, en Sphera publica. Revista de ciencias sociales y de la comunicación, vol. 1-2, no 15 (Ejemplar dedicado a: Tensiones y desafíos contemporáneos de la comunicación), págs. 76-96.

\section{CASADO, Miguel A.; GARITAONANDIA, Carmelo; GARMENDIA, Maialen S. y MARTÍNEZ, Gemma}

2012 "Els menors a Internet. Usos i seguretat des d'una perspectiva europea”, en 
Quaderns del $C A C, \mathrm{n}^{\mathrm{o}} 38$ (Ejemplar dedicado a: Reptes de l'audiovisual europeu), págs. 33-44.

\section{CASTILLO POMEDA, José M.}

2015 "La composición en los tiempos del selfie", en Espéculo. Revista de estudios literarios, $\mathrm{n}^{0} 54$ (Ejemplar dedicado a: Narrar en la era digital), págs. 126-140.

\section{CATALINA, Beatriz; GARCíA, Antonio y LÓPEZ DE AYALA, María C.}

2014 "Los riesgos de los adolescentes en Internet", en Revista latina de comunicación social, nº 69 , págs. 462-485.

\section{CHAUTEMPS, Jaques}

2005 “Sensores de imagen CMOS y CCD. Comparación”, en Mundo electrónico, $\mathrm{n}^{\circ}$ 361, págs. 31-35.

\section{CID, Carlos}

1985 “Algunas reflexiones sobre el autorretrato", en Liño. Revista anual de historia del arte, $\mathrm{n}^{0} 5$, págs. 177-204.

\section{COBLEY, Paul y HAEFFNER, Nick}

2009 "Digital Cameras and Domestic Photography: Communication, Agency and Structure”, en Visual Commnunication, vol. 8, nº 2, págs. 123-146.

\section{COLADONATO, Valerio}

2014 "Power, Gender, and the Selfie. The Cases of Hillary Clinton, Barack Obama, Pope Francis”, en Comunicazioni sociali, vol. 36, $\mathrm{n}^{\circ} 3$ (Ejemplar dedicado a: (En)Gendered Creativity Actors Agencies Artifacts), págs. 394-405.

\section{COLEMAN, Rebecca}

2008 “The Becoming of Bodies. Girls, Media Effects, and Body Image», en Feminist Media Studies, vol. 8, nº 2, págs. 163-179.

\section{COLLE, Raymond}

2013 "La revolución de la fonofotografía. Teléfonos con cámara y redes sociales”, en Revista mediterránea de comunicación, nº 4, págs. 6-12.

\section{CRESCEBZI, Lanna y TORTAJADA, Iolanda}

2013 "Privacy, Self-disclosure and Self-image of Spanish Teenagers on Social 
Networking Sites. The Case of Fotolog", en Communication \& Society, vol. 26, $\mathrm{n}^{0} 2$, págs. 65-78.

\section{CUBITT, Clayton y KEHE, Jadon}

2015 "Too Hot for Instagram. The Erotic Pictures that Got People Kicked off the Photo-sharing Service”, en Wired 8, vol. 23, $\mathrm{n}^{\circ}$ 3, págs. 8o-89.

\section{CUESTA, Ubaldo y GASPAR, Sandra}

2013 "Análisis motivacional del uso del smartphone entre jóvenes: una investigación cualitativa”, en Historia y comunicación social, vol. 18, nº 2, págs. 435-447.

\section{DALTON, Jennifer; LEE, Nikki S.; GOICOLEA, Anthony y BROWN Jr,} David H.

2000 "Look at Me: Self-Portrait Photography after Cindy Sherman", en PAJ: A Journal of Performance and Art, vol. 22, $\mathrm{n}^{0}$ 3, págs. 47-56.

\section{DAVARA, Miguel Ángel}

2014 "Intercambio de mensajes por Internet. El caso WhatsApp", en Consultor de los ayuntamientos y de los juzgados. Revista técnica especializada en administración local y justicia municipal, $\mathrm{n}^{0}$ 7, págs. 832-837.

\section{DE PIERO, José L. y NARVAJA, María E.}

2016 "Prácticas juveniles éxtimas: sexting y vlogging", en Aposta. Revista de ciencias sociales, $\mathrm{n}^{\mathrm{0}} 69$ (Ejemplar dedicado a: El análisis del discurso digital en las ciencias sociales), págs. 239-270.

\section{PRÓSPERO, Carolina E.}

2011 “Autopresentación en Facebook: un yo para el público", en Revista latinoamericana de estudios sobre cuerpo, emociones y sociedad, vol. $6, \mathrm{n}^{0} 3$, págs. 44-52.

\section{DÍEZ, Emeterio; PERELLó, María M. y RÖMER, Max}

2012 "Análisis semiótico de la fotografía de perfil de jóvenes en Tuenti", en Estudios sobre el mensaje periodístico, $\mathrm{n}^{0}$ 18, págs. 811-818.

\section{DOMíNGUEZ, Sandra}

2011 "La publicación en las redes sociales de fotografías realizadas en ámbitos 
personales o domésticos”, en Datospersonales.org. La revista de la Agencia de protección de datos de la Comunidad de Madrid, nº 52, págs. 26-27.

\section{DOS SANTOS, Gesualda}

2016 “A prática do(a) selfie e modos de subjetivação na contemporaneidade”, en Linguagem em (Dis)curso, vol. 16, nº 1, págs 122-143.

\section{DUARTE, Pablo}

2014 “Medios. Autorretrato sobre la pantalla digital”, en Letras libres, n 187, págs. 76-77.

\section{FEATHERSTONE, Mike}

2010 “Body, Image and Affect in Consumer Culture», en Body \& Society, vol. 16, nº 1, págs. 193-221.

\section{FERREDAY, Debra}

2014 "The Feminine Art of Failure: Queering Feminist Spectatorship", en Quaderns de Psicologia, vol. 16, nº 1, págs. 141-152.

\section{FROSH, Paul}

2001 "The Public Eye and the Citizen-Voyeur: Photography as a Performance of Power”, en Social Semiotics, vol. 11, nº 1, págs. 43-59.

\section{GALÁN, Mercè}

2016 "El posicionamiento subjetivo del \#selfie", en Asparkia. Investigació feminista, $\mathrm{n}^{0}$ 27, págs. 31-49.

\section{GENARO, Noemí}

2012 “Autorretrato fotográfico como memoria”, en Revista digital de comunicación, vol. $1, \mathrm{n}^{0} 2$, págs. 271-278.

\section{GIMÉNEZ, Ana M. y MAQUILÓN, Javier J.}

2015 "Usos problemáticos y agresivos de las TIC por parte de adolescentes implicados en cyberbullying”, en Revista de investigación educativa, vol. 33, nº 2, págs. 335-351.

\section{GIRALDO, Diana y RUEDA, Rocío}

2016 "La imagen de perfil en Facebook. Identidad y representación en esta red social”, en Folios. Revista de la facultad de humanidades, nº 43, págs. 119-135. 


\section{GÓMEZ-CRUZ, Edgar y ARDÈVOL, Elisenda}

2011 "Imágenes revueltas: los contextos de la fotografía digital”, en Quaderns-e, vol. $16, \mathrm{n}^{0} 1$, págs. 89-102.

2012 "Cuerpo privado, imagen pública: el autorretrato en la práctica de la fotografía digital”, en Revista de dialectología y tradiciones populares, vol. 67, $\mathrm{n}^{0}$ 1, págs. 181-208.

\section{HERNÁNDEZ, Leanna M.; PAYTON, Ashley A. y SHERMAN,}

\section{Lauren E.}

2016 "The Power of the Like in Adolescence: Effects of Peer Influence on Neural and Behavioral Responses to Social Media”, en Psychological Science, vol. 27, $\mathrm{n}^{0}$ 7, págs. 1027-1035.

\section{HJORTH, Larissa}

2007 "Snapshots of Almost Contact: the Rise of Camera Phone Practices and a Case Study in Seoul, Korea”, en Continuum. Journal of Media \& Cultural Studies, vol. 21, $\mathrm{n}^{\mathrm{o}} 2$, págs. 227-238.

\section{LEE, Dong-Hoo}

2005 “Women’s Creation of Camera Phone Culture”, en Fibreculture Journal 6.

\section{LEIBRANDT, Isabella}

2015 "Narrarse a uno mismo, auto-tematización y la cultura de la confesión”, en Espéculo. Revista de estudios literarios, $\mathrm{n}^{0} 54$ (Ejemplar dedicado a: Narrar en la era digital), págs. 141-154.

\section{LEONARDO, Norberto}

2015 "Del mito del Narciso a la selfie. Una arqueología de los cuerpos codificados", en Palabra clave, vol. 18, nº 3 , págs. 676-700.

\section{LISTER, Martin}

2011 “Demasiadas fotografías? La fotografía como contenido generado por el usuario", en adComunica. Revista científica de estrategias, tendencias e innovación en comunicación, $\mathrm{n}^{\mathrm{O}} 2$ (Ejemplar dedicado a: Nuevas tendencias e hibridaciones de los discursos audiovisuales en la cultura digital contemporánea), págs. 25-41. 


\section{LIVINGSTONE, Sonia}

2008. “Taking Risky Opportunities in Youthful Content Creation: Teenagers' Use of Social Networking Sites for Intimacy, Privacy and Self-expression”, en New Media \& Society, nº 3, pág. 393.

\section{LÓPEZ, Alfonso}

2010 "Los adolescentes y las redes sociales en Internet”, en Diálogo: familia colegio, $\mathrm{n}^{\mathrm{o}} 281$, págs. 3-10.

\section{LORENTE, María}

2015 "El selfie perfecto. Todos los gadgets para conseguir la mejor autofoto", en Personal Computer \& Internet, nº 149, págs. 126-129.

\section{MARCELINO, Georgina V.}

2015 "Migración de los jóvenes españoles en redes sociales, de Tuenti a Facebook y de Facebook a Instagram. La segunda migración”, en Icono14, vol. 13, nº 2 (Ejemplar dedicado a: Comunicación y redes sociales), págs 48-72.

\section{MARTÍN, Marta}

2002 "La tiranía de la apariencia en la sociedad de las representaciones", en Revista latina de comunicación social, nº 50, págs 35-39.

\section{MARTÍN, Lucía}

2014 “¿Facebook o Fuckbook?”, en Tiempo, no 1648, págs. 74-76.

\section{MARTÍNEZ, Juan M.}

2013 "La difusión de sexting sin consentimiento del protagonista: un análisis jurídico”, en Derecom, $\mathrm{n}^{0}$ 12, págs 1-16.

\section{MARTÍNEZ, Silvia}

2011 "Fotografiarse, retratarse, expresarse. Fotografía y expresión de lo personal en adolescentes”, en Arteterapia. Papeles de arteterapia y educación artística para la inclusión social, nº 6, págs. 269-288.

\section{MARWICK, Alice E.}

2015 "Instafame: Luxury Selfies in the Attention Economy", en Public Culture, vol. 27, $\mathrm{n}^{0}$ 1, págs. 137-16o. 


\section{MARZAL, Javier}

2008 "La muerte de la fotografía: la revolución digital y la crisis de identidad del medio fotográfico", en Revista de Occidente, $\mathrm{n}^{0}$ 328, págs. 67-83.

\section{MATTEI, Maria M.}

2015 "El divismo en tiempos de \#Instagram", en CIC. Cuadernos de información y comunicación, $\mathrm{n}^{0} 20$ (Ejemplar dedicado a: Ídolos e iconos en la semiosfera mediática), págs. 95-107.

\section{MESENES, María E. J.}

2010 "La red es el mensaje. Redes sociales virtuales en la esfera pública”, en Revista mexicana de comunicación, vol. 23, nº 123 (Ejemplar dedicado a: Facebook: la reina de las redes sociales), págs. 19-23.

\section{MINCHINELA, Raúl}

2014 "Selfies. Un autorretrato", en Leer, nº 249 (Ejemplar dedicado a: iCultura digital! Gozos y sombras de una revolución en marcha), págs. 26-27.

\section{MIRA, Enric}

2014 "Tras la crisis de la cultura Kodak. Un análisis de la funcionalidad de la fotografía personal en la Web 2.0", en Historia y comunicación social, vol. 19, nº 2 (Ejemplar dedicado a: La comunicación en la profesión y en la universidad de hoy), págs. 747-758.

\section{MONROY, Rebeca}

2015 "Nuevos retos para los fotohistoriadores de la fotografía analógica a la digital”, en Iztapalapa. Revista de ciencias sociales y humanidades, $\mathrm{n}^{0} 78$ (Ejemplar dedicado a: Imágenes y cultura digital), págs. 15-44.

\section{MORENO, Adriana Marcela}

2016 "Fotografía amateur: la construcción cultural de un rol”, en Comunicación, no 34 , págs. 23-38.

\section{MORENO, Dana}

2014 "Selfies, breve historia del autorretrato", en ArtyHum. Revista digital de artes y humanidades, $\mathrm{n}^{0} 3$, págs. 143-150. 


\section{NAVARIDAS, Fermín y SANTIAGO, Raúl}

2012 "La Web 2.0 en escena”, en Pixel-Bit. Revista de medios y educación, n 41, págs. 19-30.

\section{NÚÑEZ, Cristina}

2009 "The Self -Portrait, a Powerful Tool for Self-Therapy", en European Journal of Psychotherapy \& Counselling, vol. 11, $\mathrm{n}^{0}$ 1, págs. 51-61.

\section{OKABE, Daisuke y MIZUKO, Ito}

2003 "Camera Phones Changing the Definition of Picture-Worthy", en Japan Media Review, no 29, págs. 1-2.

\section{PÉREZ, Javier}

2016 "SnapChat. Luces y sombras en el arcoiris", en Interactiva. Revista de la comunicación y el marketing digital, $\mathrm{n}^{\circ} 177$ (Ejemplar dedicado a: Agencias digitales. ¿Dónde está la magia?), págs. 56-61.

\section{PÉREZ, Johanna}

2015 "Fotografía en tiempos de darwinismo tecnológico", en Aularia. Revista digital de comunicación, vol. 4, $\mathrm{n}^{0} 1$, págs. 9-14.

\section{PÉREZ, Pilar}

1998 "El autorretrato del adulto como revelador de valores culturales", en Arte, individuo y sociedad, $\mathrm{n}^{\circ}$ 10, págs. 147-180.

\section{PERL, Jonathan}

2016 "United States: No Copyright Protection for a «Monkey Selfie»", en Legal Observations of the European Audiovisual Observatory, nº 4, págs. 54-58.

\section{RABADÁN, Ángel V.}

2016 "Selfie y la impronta visual: el autorretrato 3.0. Representación, presentación, corporealización”, en Icono14, , vol. 14, nº 2 (Ejemplar dedicado a: Digital Economy and its Impact in the Media), págs 25-47.

\section{RAMÍREZ, Juan A.}

2003 "Yo mismo. Automodelo e identidad quebrada", en Exit. Imagen y cultura, n ${ }^{\circ} 10$ (Ejemplar dedicado a: Autorretratos), pág. 17. 


\section{RAVENTÓS-PONS, Esther}

2005 “Ouka Lele y sus autorretratos. La ficcionalización del ego", en Confluencia.

Revista hispánica de cultura y literatura, vol. 21, nº 1, págs. 195-209.

\section{RIEGO, Bernardo}

2015 "La historia de la fotografía ante un nuevo tiempo cultural. Reflexiones para un encuentro interdisciplinar", en Fotocinema. Revista científica de cine y fotografía, $\mathrm{n}^{0} 10$ (Ejemplar dedicado a: Miradas convergentes: la fotografía y sus interpretaciones en humanidades y ciencias sociales.), págs. 9-25.

\section{RÓDENAS, Gabriel}

2013 “Capturar es compartir. Filosofía, redes sociales y fotografía 2.0", en Enrahonar. An International Journal of Theoretical and Practical Reason, $\mathrm{n}^{\mathrm{o}} 5 \mathrm{O}$ (Ejemplar dedicado a: Estética de las imágenes), págs. 59-72.

\section{ROMERO, Irene}

2012 "Autorretratos. El cuerpo como campo de batalla en la fotografía femenina del s. XX”, en HUM 736. Papeles de cultura contemporánea, $\mathrm{n}^{0}$ 15, págs. 39-45.

\section{SÁEZ, Maite}

2014 "Autorretrato en Twitter", en Anuncios. Semanario de publicidad y marketing, $n^{0} 1485$, pág. 33.

\section{SÁNCHEZ, Sara}

2010 "Peligros ocultos tras la red. Análisis jurídico de las redes sociales", en Lex nova, no 61, págs. 24-28.

\section{SAURA, Ángeles}

2013 “Avatares. Exposición en clave 2.0”, en Tercio creciente, $\mathrm{n}^{0}$ 4, págs. 79-80.

\section{SCHWARZ, Ori}

2010 "On Friendship, Boobs and the Logic of the Catalogue: Online Self-Portraits as a Means for the Exchange of Capital», en Convergence, vol. 16, nº 2, pág. 163.

\section{SEVICK-BORTREE, Denise}

2005 "Presentation of Self on the Web: An Ethnographic Study of Teenage Girls' Weblogs", en Education, Communication and Information, vol 5, $\mathrm{n}^{\mathrm{0}}$ 1, págs. 2539. 


\section{SOLA-MARTÍNEZ, María José}

2009 "Redes sociales. Más allá de la privacidad», en El profesional de la información, vol. 18, no 4 , págs. 470-474.

\section{SPADARO, Antonio}

2009 "El fenómeno Facebook", en Razón y fe. Revista hispanoamericana de cultura, vol. 259, no 1325, págs. 179-192.

\section{SUHR, Hiesun C.}

2010 "Comprendiendo la aparición de los protocolos sociales en MySpace. Impacto y ramificaciones”, en Comunicar. Revista científica iberoamericana de comunicación y educación, $\mathrm{n}^{\mathrm{o}} 34$ (Ejemplar dedicado a: Música y pantallas: mediaciones en el nuevo escenario digital), págs. 45-53.

\section{THOMPSON, John B.}

2011 "Los límites cambiantes de la vida pública y la privada”, en Comunicación y sociedad, no 15 , págs. 11-42.

\section{TINKLER, Penny}

2008 "A Fragmented Picture: Reflections on the Photographic Practices of Young People”, en Visual Studies, vol. 23, nº 3, págs. 255-266.

\section{TRUEBA, Fernando}

1978 "Howard Hawks o la escritura invisible, en El País [edición impresa del jueves 5 de enero de 1978].

\section{TUCKER, Sharon}

2016 “The Vital Signs Selfie Campaign”, en American Journal of Nursing: The Leading Voice of Nursing Since 19oo, vol. 116, nº 5, págs. 11-12.

\section{URIBARRI, Fátima}

2009 “Adolescentes e Internet”, en Época, no 1261, págs. 56-59.

\section{VAN DIJCK, José}

2008 “Digital Photography: Communication, Identity, Memory”, en Visual Communication, $\mathrm{n}^{0} 7$, págs. 57-76.

VV. AA.

2001 Exit. Imagen y cultura, $\mathrm{n}^{\circ} 4$ (Ejemplar dedicado a: Un mundo adolescente). 


\section{WEISS, Marie-Andrée}

2016 "Comment prendre des selfies en toute légalité", en I2D. Information, données \& documents, $\mathrm{n}^{\mathrm{O}} 2$, págs. 23-24.

\section{Catálogos y fotolibros.}

\section{AOKI, Shoichi}

2005 Fresh Fruit, Tokio, Phaidon Press.

\section{BILLETER, Erika}

1985 Self-Portrait in the Age of Photography. Photographers Reflecting Their own Image, Zúrich, Museé Cantonal des Beux-Arts.

\section{BRIGHT, Susan}

2010 Autofocus. The Self-Portrait in Contemporary Photography, Londres, Thames Hudson Ltd.

\section{ELLIS, Charlie}

2016 Animal Selfies, Londres, Summersdale Publishers.

\section{FONTCUBERTA, Joan}

2011 A través del espejo, Barcelona, Galeria dels Àngels.

\section{GREY, Sasha}

2011 Neü Sex, Nueva York, Vice Books.

\section{KARDASHIAN, Kim}

2015 Selfish, Nueva York, Universe Publishing.

\section{MERRITT, Natacha}

2000 Digital Diaries, Colonia, Taschen.

\section{OMMER, Uwe}

2007 Do it Yourself, Colonia, Taschen. 


\section{SANDERS, Brock}

2015 My Selfie Journal: A \#Nofilter Look at Your Life, Fort Collins, Adams Media Corporation.

\section{THUN-HOHENSTEIN, Felicitas (Ed.)}

2015 Self-Timer Stories, Viena, Austrian Federal Chancellery. VV. AA.

2005 The New Erotic Photography, Colonia, Taschen.

\section{Filmografía.}

2008 ARONSON, Letty; ROURES, Jaume; TENENBAUM, Stephen y WILEY, Gareth (Productores), ALLEN, Woody (Director), Vicky, Cristina, Barcelona (Vicky, Cristina, Barcelona) [Cinta cinematográfica], Estados Unidos / España, The Weinstein Company / Gravier Productions / Mediapro.

2017 AYER, David; NEWMAN, Eric; SARANDOS, Ted y UNKELESS, Bryan (Productores), AYER, David (Director), Bright (Bright) [Cinta cinematográfica], Estados Unidos, Netflix / Overbrook Entertainment / Clubhouse Pictures.

2014 BELKEDDAR, Mourad, et al. (Productores), FROST, Matthew (Director), Aspirational (Aspirational) [Cinta cinematográfica], Estados Unidos, Iconoclast.

2016 BORG, Laurie; BROOKER, Charlie; HOGAN, Ian; JONES, Annabel y PHILIPS, Angela (Productores), WRIGHT, Joe (Director), Nosedive (Caída en picado) [Episodio de la serie televisiva Black Mirror], Reino Unido, Netflix UK / House Of Tomorrow.

2014 BREZINER, Salomé, et al. (Productores), BREZINER, Salomé (Directora), Helicopter Mom (Mi madre contra todos) [Cinta cinematográfica], Estados Unidos, American Film Productions.

1998 BRYCE, Ian; GORDON, Mark; LEVINSOHN, Gary y SPIELBERG, Steven (Productores), SPIELBERG, Steven (Director), Saving Private Ryan (Salvar al 
soldado Ryan) [Cinta cinematográfica], Estados Unidos, DreamWorks SKG / Paramount Pictures / Amblin Entertainment.

2017 CARMONA, José; FIGUEROA, Ana; TUSELL, Félix y VALLS, Arturo (Productores), MONTERO, Pepón (Director), Los del túnel [Cinta cinematográfica], España, Estela Films / Pipa Film / Pólvora Films.

2014 CONLI, Roy y REED, Kristina (Productores), HALL, Don y WILLIAM, Chris (Directores), Big Hero 6 (Big Hero 6) [Cinta cinematográfica], Estados Unidos, Walt Disney Animation Studios / Marvel Studios.

1999 COWIE, Robin y HALE, Gregg (Productores), MYRICK, Daniel y SÁNCHEZ, Eduardo (Directores), The Blair Witch Project (El proyecto de la bruja de Blair) [Cinta cinematográfica], Estados Unidos, Artisan Entertainment / Haxan Films.

2014 DAVIS, John y SCHROEDER, Adam (Productores), TRANK, Josh (Director), Chronicle (Chronicle) [Cinta cinematográfica], Estados Unidos, 2oth Century Fox.

1992 EVERETT, Gimel (Productor), LEONARD, Brett (Director), The Lawnmower Man (El cortador de césped) [Cinta cinematográfica], Estados Unidos, Alliance Atlantis Communications / Allied Vision Lane Pringle Productions.

2017 ÉVOLE, Jordi y LARA, Ramón (Productores), ÉVOLE, Jordi (Director), Salvados: Conectados [Programa de televisión], España, Producciones del Barrio.

1998 FELDMAN, Edward S.; NICCOL, Andrew; RUDIN, Scott y SCHROEDER, Adam (Productores), WEIR, Peter (Director), The Truman Show (El show de Truman) [Cinta cinematográfica], Estados Unidos, Paramount Pictures / Scott Rudin Productions.

2017 GARCÍA, Víctor; GONA, Jaime y LÓPEZ, Enrique (Productores), GARCÍA, Víctor (Director), Selfie [Cinta cinematográfica], España, Gonita / II Acto / Apache Films.

2014 GROSSMAN, Nora; OSTROWSKY, Ido y SCHWARZMAN, Teddy (Productores), TYLDUM, Morten (Director), The Imitation Game (Descifrando Enigma) [Cinta cinematográfica], Estados Unidos, Black Bear Pictures. 
2013 HOBACK, Cullen; KHANNA, Nitin y RAMOS, John (Productores), HOBACK, Cullen (Director), Terms and Conditions May Apply (Terms and Conditions May Apply) [Cinta cinematográfica], Estados Unidos, Variance Films.

2015 IACOFANO, Tom (Productor), RYMER, Michael, et al. (Directores), Jessica Jones (Jessica Jones) [Serie de televisión], Estados Unidos, American Broadcasting Company [USA] / Marvel Studios / Netflix.

2017 INCAPRERA, Joseph (Productor), YORKEY, Brian, et al. (Directores), 13 Reasons Why (Por trece razones) [Serie de televisión], Estados Unidos, Netflix / Kicked to the Curb Productions / Anonymous Content / July Moon Productions / Paramount Network Television Productions.

2014 KAPNEK, Emily y ROBINSON, Julie A. (Productores), KAPNEK, Emily (Directora), Selfie (Selfie) [Serie de televisión], Estados Unidos, Piece of Pie Productions / Warner Bros.

2015 KUPFER, Jerry; MEANS Sam y SCHNAPPER, Schnapper (Productores), SHAPEERO, Tristram, et al. (Directores), Unbreakable Kimmy Schmidt (Unbreakable Kimmy Schmidt) [Serie de televisión], Estados Unidos, Little Stranger / Universal TV / Netflix.

2014 PIZZOLATTO, Nic, et al. (Productores), PIZZOLATTO, Nic, et al. (Directores), True Detective (True Detective) [Serie de televisión], Estados Unidos, Home Box Office (HBO) / Anonymous Content.

2015 SAVAGE Christopher y VARGAS Kevin (Productores), LAHAIE, Michael (Director), Donny! (Donny!) [Serie de televisión], Estados Unidos, Left / Right.

2015 SILVA, Johanna, et al. (Productores), RUFFIN, François (Director), Merci Patron! (iGracias jefe!) [Cinta cinematográfica], Francia, Fakir / Mille et Une Productions.

2016 SPENCER, Clarck (Productor), HOWARD, Byron y MOORE, Rich (Directores), Zootopia (Zootrópolis) [Cinta cinematográfica], Estados Unidos, Walt Disney Animation Studios.

2014 TISDALE, Ashley, et al. (Productores), CADIFF, Andy; LEWIS, Phil y SANFORD, Arlene (Directores), Young \& Hungry (Una chef en casa) [Serie de televisión], 
Estados Unidos, Emitida por ABC family; Blondie Girl Productions / The Tannenbaum Company.

2015 WILKSEN, Carrie (Productora), CHONG, Daniel y HERNÁNDEZ, Manny (Directores), We Bare Bears (Somos osos) [Serie de televisión], Estados Unidos, Cartoon Network Studios.

\section{Artículos online.}

\section{ACEBES, Belén y MONTANERA, Ramón}

2017 "Estudio anual de redes sociales 2017 (IABS)", disponible en: <http://iabspain.es/wp-content/uploads/iab_estudioredessociales_2017_ vreducida.pdf?ct=t(Texturas_Express_110_copy_01_2_19_2017)\&mc_cid= cf5502273a\&mc_eid=42cf8a663d > [Fecha de consulta: 20 de julio de 2017].

\section{ALPAÑ́́S, Enrique}

2016 "Muerte por selfie: la realidad que esconden los números", disponible en: <https://elpais.com/elpais/2016/o2/o4/tentaciones/1454589530_250716. html> [Fecha de consulta: 20 de abril de 2017].

\section{ALPUENTE, Enrique}

2017 "El 70\% de los escolares ha sufrido, presenciado o realizado ciberacoso", <http://www.elmundo.es/sociedad/2016/04/16/571129ff468aebb6748b4650. html $>$ [Fecha de consulta: 20 de julio de 2017].

\section{ÁLVAREZ, Pilar}

2009 “Así se portan los ciberjóvenes”, disponible en: <http://elpais.com/diario/ 2009/05/04/madrid/1241436261_850215.html> [Fecha de consulta: 20 de julio de 2016].

\section{APARICIO, Daniel G.}

2017 "El Día de Internet y las impresionantes cifras del invento que nos ha cambiado la vida", disponible en: <https://www.20minutos.es/noticia/3038210/o/ diainternet-cifras/> [Fecha de consulta: 20 de julio de 2017]. 


\section{BERENGUERAS, Josep M.}

2017 “Cuánto cobra un influencer?”, disponible en:

<https://www.elperiodico.com/es/economia/20170508/influencer-cuantocobra-gana-6024716> [Fecha de consulta: 25 de julio de 2017].

\section{BOZA, Pepe}

2016 “Exconectados: ¿algo más que una moda?”, disponible en: <http:// www.medioambientesimbolico.asumearagon.es/exconectados-algo-mas-queuna-moda/> [Fecha de consulta: 20 de noviembre de 2016].

\section{CABRIA, Elsa}

2014 "Anatomía del selfie", disponible en: <http://www.yorokobu.es/anatomia-delselfie/> [Fecha de consulta: 22 de abril de 2015].

\section{CANTÓN, Eva}

2014 "Beyoncé, selfie VIP con La Gioconda”, disponible en: <https://www.elperiodico.com/es/gente/20141014/beyonce-selfie-vip-con-lagioconda-3601638> [Fecha de consulta: 8 de enero de 2017].

\section{CEBALlOS, Noel}

2014 "Breve historia cultural del selfie", disponible en: <http://www.revistagq.com/ noticias/tecnologia/articulos/breve-historia-cultural-del-selfie/19701> [Fecha de consulta: 22 de julio de 2017].

\section{CERUZZI, Paul E.}

2015 “Tim Berners-Lee y el origen de la Web”, disponible en: <https:// www.bbvaopenmind.com/tim-berners-lee-y-el-origen-de-la-web/> [Fecha de consulta: 2 de julio de 2016].

\section{CHAYKA, Kyle}

2014 "National Geographic's New Ad Campaign Features Animals Taking Selfies", disponible en: <http://time.com/97561/national-geographics-new-ad-campaignfeatures-animals-taking-selfies/> [Fecha de consulta: 10 de julio de 2017].

\section{COLLADO, Christian}

2017 “Así funciona la cámara de fotos de tu smartphone", disponible en: <https://andro4all.com/2017/o5/camara-smartphone-como-funciona> [Fecha de consulta: 10 de agosto de 2017]. 


\section{COLORADO, Óscar}

2013 "Autorretrato y fotografía”, disponible en:

<https://oscarenfotos.com/2013/o8/11/autorretrato-y-fotografia/> [Fecha de consulta: 25 de julio de 2017].

\section{CRESPO, Gloria}

2017 "Rineke Dijkstra: «Un selfie es una imagen idealizada, un cliché»”, disponible en: <https://elpais.com/cultura/2017/10/19/babelia/1508412110_560353.html? por $=$ mosaico $>$ [Fecha de consulta: 19 de diciembre de 2017].

\section{CRISÓSTOMO, Mamen}

2011 “Interfaces. Retratos de El Fayum”, disponible en: <http://egiptologia.com/ interfaces-retratos-de-el-fayum/> [Fecha de consulta: 10 de julio de 2017].

\section{DE LA CAL, Lucas}

2016 "Olvida tu smartphone, este móvil vuelve a estar de moda”, disponible en: <http://www.elmundo.es/papel/todologia/2016/o4/04/ 56fe4a8a22601d52618b4678. html> [Fecha de consulta: 20 de julio de 2017].

\section{DELCLós, Tomàs}

2013 "Francia alucina con la moda de los dedipix", disponible en: <http:// tecnologia.elpais.com/tecnologia/2009/10/13/actualidad/1255424465_ 850215.html> [Fecha de consulta: 20 de julio de 2016].

\section{DÍAZ, Carlos Alberto}

2011 “JenniCam y el cibervoyeurismo cumplen 15 años”, disponible en: <http:// www.enter.co/vida-digital/jennicam-y-el-cibervoyeurismo-cumplen-15-anos/> [Fecha de consulta: 20 de julio de 2016].

\section{DOMínguEZ, Chus y SOLÁ, Belén}

2012 "El trabajo sobre autobiografía de Cristina Núñez", disponible en: <http://raraweb.org/el-trabajo-sobre-autobiografia-de-cristina-nunez.html> [Fecha de consulta: 16 de julio de 2016].

\section{EBOLA, Joseba}

2017 "El smartphone, ese arma de distracción masiva", disponible en: <https:// elpais.com/elpais/2017/o6/23/ciencia/1498217993_075316.html> [Fecha de consulta: 1 de julio de 2017]. 


\section{FANJUL, Sergio C.}

2016 “¿Por qué estas muchachas sexys quieren ser mis amigas en Facebook?”, disponible en: <https://verne.elpais.com/verne/2016/07/o9/articulo/ 1468087028_159176.html> [Fecha de consulta: 20 de julio de 2017].

\section{GARCÍA, Atenea}

2015 "Kim Kardashian presenta su libro Selfish con trucos para autofotos", disponible en: <https://computerhoy.com/noticias/life/kim-kardashian-presenta-su-libroselfish-trucos-autofotos-28011> [Fecha de consulta: 1 de marzo de 2018].

\section{GARCÍA, David}

2015 "Evolución de los sensores digitales en fotografía, de CCD a CMOS", disponible en: <http://dgpfotografia.com/2015/o6/24/evolucion-de-los-sensores-digitalesen-fotografia-de-ccd-a-cmos/> [Fecha de consulta: 29 de enero de 2018].

\section{GARCÍA, Óscar}

2014 "Selfies para Juan Francisco Casas", disponible en:

<http://www.plataformadeartecontemporaneo.com/pac/selfies-para-juanfrancisco-casas/> [Fecha de consulta: 21 de abril de 2015].

\section{GAURAV, Adip}

2016 “Android Smartphone Me Selfie Lene Ke Liye Top Best Apps”, disponible en: <https://www.futuretricks.in/top-best-selfie-expert-apps-for-android> [Fecha de consulta: 10 de agosto de 2017].

\section{GÓMEZ, Sergio}

2016 "El cyberbullying afecta a ocho de cada diez casos de acoso escolar", disponible en: <http://www.publico.es/sociedad/cyberbullying-afecta-ocho-diezcasos.html $>$ [Fecha de consulta: 12 de noviembre de 2017].

\section{GUEK}

2013 "A Relic from Back Before Instagram Turned the Self-shot Portrait into Kitschy Garbage”, disponible en: <https://imgur.com/gallery/33TIoB1> [Fecha de consulta: 3 de marzo de 2018].

\section{IVY, Jeanne}

2011 "The Exploration of Self: What Artists Find when They Search in the Mirror. The 
Self-Portrait as a Signature", disponible en: <http://userpages.umbc.edu/ ivy/selfportrait/signat.html > [Fecha de consulta: 1 de julio de 2017].

\section{JUAN SANZ, Miriam}

2008 "El caso de Tiffy Toodlepoo", disponible en: <http://publimarketingviral.blogspot.com.es/2008/o4/el-caso-de-tiffy-toodlepoo.html $>$ [Fecha de consulta: 15 de julio de 2016].

\section{KNIGHT, Tara}

2014 “I Love You Guys Infinitely - Leda Muir's (Hailedabear) Goodbye Video”, disponible en: <https://www.youtube.com/watch?v=oUS9FsP_GpY> [Fecha de consulta: 4 de marzo de 2017].

\section{LANTIGUA, Isabel F.}

2017 “iMamá, papá! Dejad de contar mi vida en vuestras redes sociales”, disponible en: <http://www.elmundo.es/sociedad/2017/05/20/59159abc468aeb4c678b 462c.html> [Fecha de consulta: 22 de mayo de 2017].

\section{LEE, Jenny (jennlee)}

2011 "I <3 my New Anthro Sweater", disponible en: <https://www.instagram.com/ p/BDas2/> [Fecha de consulta: 20 de abril de 2018].

\section{LIRA, Francisco}

2015 "Estos son los 88 personajes del año de la revista TIME desde su inicio", disponible en: <http://www.upsocl.com/comunidad/estos-son-los-88personajes-del-ano-de-la-revista-time-desde-su-inicio/> [Fecha de consulta: 12 de julio de 2017].

\section{LIZANA, José Alberto}

2017 “Apple reconoce en qué fotos sales en sujetador desde iOS 10", disponible en: <https://apple5x1.com/ios-10-sujetador/> [Fecha de consulta: 1 de noviembre de 2017].

\section{LÓPEZ, Nina}

2016 “Consejos para hacer sexting seguro", disponible en: <https://elpais.com/elpais/ 2016/o8/12/videos/1471022240_891226.html> [Fecha de consulta: 20 de julio de 2017]. 


\section{LOVYT, Brynn}

2016 "Death by Selfie: 11 Disturbing Stories of Social Media Pics Gone Wrong”, disponible en: <https://www.rollingstone.com/culture/pictures/death-by-selfie10-disturbing-stories-of-social-media-pics-gone-wrong-20160714/selfie-sticklightning-rod-20160714> [Fecha de consulta: 30 de mayo de 2017].

\section{MAISON, Kadiee}

2013 "Nude Self Shot, Exotics", disponible en: <http://exoticsbykm.blogspot.com.es/ 2013/o9/nude-self-shot.html?zx=dbeecocf5a1038c3> [Fecha de consulta: 10 de agosto de 2017].

\section{MATT, Samantha}

2013 "Flashback Friday: MySpace", disponible en: <http://forevertwentysomethings. com/2013/01/04/flashback-friday-myspace/> [Fecha de consulta: 4 de agosto de 2017].

\section{McGUIRE, Patrick}

2012 "El pervertido que destruyó la vida de Amanda Todd", disponible en: <http:// www.vice.com/es/read/el-pervertido-que-destruyo-la-vida-de-amanda-todd > [Fecha de consulta: 20 de julio de 2016].

\section{MORALEDA, Alba}

2017 "Cuando el museo quiere que te saques un selfi con el cuadro", disponible en: <https://retina.elpais.com/retina/2017/12/12/tendencias/1513094758_374018. html> [Fecha de consulta: 20 de diciembre de 2017].

\section{MUIR, Leda}

2015 "Hi I'm Back Babies ; .;”, disponible en: <https://www.youtube.com/watch? $\mathrm{v}=$ nh9rsvP9Gvk\&t=7S $>$ [Fecha de consulta: 4 de marzo de 2017].

\section{NEAL, Leon}

2018 "Selfieccino, la nueva moda gastro que arrasará en 2018”, disponible en: <http://www.lavanguardia.com/comer/tendencias/20180109/434168994051/ selfieccino-la-nueva-moda-gastro-que-arrasara-en-2018.html $>$ [Fecha de consulta: 20 de marzo de 2018].

\section{NORMAN, Jeremy}

2014 "Willard Boyle \& George Smith Develop the CCD, a Sensor for Recording 
Images", disponible en: <http://www.historyofinformation.com/expanded.php? id=1103> [Fecha de consulta: 12 de enero de 2018].

\section{O'REILLY, Tim}

2005 "What Is Web 2.0. Design Patterns and Business Models for the Next Generation of Software”, disponible en: <http://www.oreilly.com/pub/a/web2/archive/ what-is-web-20.html> [Fecha de consulta: 17 de julio de 2017].

\section{PAÑoS, José V.}

2017 "Un menor, grave tras caer al vacío en la fábrica de El Turia cuando se hacía un selfi”, disponible en: <http://www.historyofinformation.com/expanded.php? id=1103> [Fecha de consulta: 12 de enero de 2018].

\section{PAYO, Alberto}

2017 "Las víctimas de la Torre Grenfell piden que paren los selfies: «Es una tragedia, no una atracción turística»", disponible en: <http://www.elmundo.es/f5/ comparte/2017/o6/23/594cdoc5468aeb1a248b45fd.html > [Fecha de consulta: 24 de julio de 2017].

\section{PÉREZ, Mario}

2018 "Tipos y características de los sensores de cámaras de fotos”, disponible en: <https://www.blogdelfotografo.com/tipos-caracteristicas-ventajas-sensorescamaras-fotos/> [Fecha de consulta: 29 de enero de 2018].

\section{PONCE, Isabel}

2012 "Monográfico: redes sociales", disponible en: <http://recursostic.educacion.es/ observatorio/web/es/internet/web-20/1043-redes-sociales?start=1> [Fecha de consulta: 5 de julio de 2017].

\section{RECIO, Enrique}

2017 "Un instituto de Lleida prohíbe usar el móvil a los alumnos para que hablen en el patio entre ellos", disponible en: <http://www.elmundo.es/sociedad/2017/o1/ 17/587e1a94268e3ea95b8b4661.html> [Fecha de consulta: 20 de julio de 2017].

\section{Redacción 20 Minutos}

2007 "La chica rubia que perdió su cámara", disponible en: <http:// www.20minutos.es/noticia/271106/o/camara/rubia/marketing/> [Fecha de consulta: 15 de julio de 2016]. 


\section{Redacción BBC Mundo}

2016 "El selfie que unió a Corea del Norte y Corea del Sur en las Olimpiadas de Río 2016", disponible en: <http://www.bbc.com/mundo/noticias-america-latina37014947> [Fecha de consulta: 10 de agosto de 2016].

\section{RODRÍGUEZ DE LUIS, Eva}

2017 “Quieres saber qué red social es la que tiene más usuarios?”, disponible en: <https://www.ipadizate.es/2017/04/10/facebook-whatsapp-red-socialranking/> [Fecha de consulta: 20 de julio de 2017].

\section{ROS, Eva}

2011 “4 años después, Eva se desnuda”, disponible en: <http://evasedesnuda. blogspot.com.es/> [Fecha de consulta: 11 de agosto de 2017].

\section{ROSSIGNOL, Joe}

2015 "iPhone Remains Flickr's Most Popular Camera in 2015 Ahead of Canon, Nikon and Samsung”, disponible en: <https://www.macrumors.com/2015/12/03/ flickr-iphone-most-popular-camera-2015/> [Fecha de consulta: 3 de enero de 2017].

\section{RUIZ, David}

2015 "Selfies extremos que llevan a la muerte", disponible en: <http:// www. lavanguardia.com/sucesos/20150705/54433730328/selfies-muerte.html> [Fecha de consulta: 30 de mayo de 2017].

\section{SABÁN, Antonio}

2017 "El modo retrato después de la doble cámara", disponible en: < https:// hipertextual.com/2017/10/doble-camara-modo-retrato $>$ [Fecha de consulta: 2 de diciembre de 2017].

\section{SÁEZ, Alberto B.}

2015 "Deconstruyendo el selfie, la historia completa", disponible en: <http:// www.huffingtonpost.es/2015/o1/21/historia-selfie_n_6517496.html $>$ [Fecha de consulta: 22 de julio de 2017].

\section{SALAS, Javier}

2017 "Esta notificación te está robando un pedazo de vida", disponible en: < https:// 
elpais.com/elpais/2017/o5/o4/ciencia/1493890150_694485.html> [Fecha de consulta: 1 de julio de 2017].

\section{SÁNCHEZ-MELLADO, Luz}

2013 "Retrato del eterno adolescente", disponible en: <http://elpais.com/diario/2011/ 10/o9/eps/1318141616_850215.html> [Fecha de consulta: 20 de julio de 2013].

\section{SARTORIO, Guillem}

2016 "Pegados al móvil: así es la vida de tu hijo adolescente", disponible en: <http://www.elmundo.es/papel/historias/2016/11/27/ 58381e3622601db6198b4678.html > [Fecha de consulta: 2 de julio de 2017].

\section{SCHLEICHER, Andreas}

2015 "El bienestar de los estudiantes: resultados de PISA 2015 (OECD)", disponible en: <http://www.oecd.org/pisa/PISA2015-Students-Well-being-Country-noteSpain-Spanish.pdf $>$ [Fecha de consulta: 20 de julio de 2017].

\section{SCOLARI, Carlos}

2016 "De Picasso a Pikachu”, disponible en: <https://elpais.com/cultura/2016/10/ 07/babelia/1475841791_221262.html> [Fecha de consulta: 20 de julio de 2017].

\section{SMITH, Josh}

2017 “13 Best Selfie Apps for 2018”, disponible en: <https://www.gottabemobile.com/ best-selfie-apps/?gbmsl=10 $>$ [Fecha de consulta: 2 de enero de 2018].

\section{SUANZES, Pablo R.}

2016 "Bélgica, contra Calvin Klein por «banalización de los selfies eróticos»", disponible en: <http://www.elmundo.es/television/2016/11/16/ 582c93a4e5fdeaofo28b466e.html> [Fecha de consulta: 20 de agosto de 2017].

\section{TIFENTALE, Alise}

2016 "Why Every Self-portrait is Not a Selfie, but Every Selfie is a Photograph", disponible en: <http://www.alisetifentale.net/research-blog-at/2016/3/9/whyevery-self-portrait-is-not-a-selfie-but-every-selfie-is-a-photograph $>$ [Fecha de consulta: 22 de julio de 2017].

\section{TJINTJELAAR, Joel}

2014 “Top 10 Self Portraits by Famous Artists - and Not Only Photographer", 
disponible en: <http://www.bwvision.com/top-10-self-portraits/> [Fecha de consulta: 20 de julio de 2017].

\section{VERA, Carlos y COLLAzOS, Carlos}

2011 “Joan Fontcuberta provoca en Sonimag”, disponible en: <http://videos. lavanguardia.com/20110325/54132752234/joan-fontcuberta-provoca-ensonimag.html> [Fecha de consulta: 16 de julio de 2013].

\section{VICIOSA, Mario}

2009 "Breve historia de Internet", disponible en: <http://equipoveinte.com/ garajebinario/breve-historia-de-internet/> [Fecha de consulta: 17 de julio de 2016].

VV. AA.

2011 “CCD, Coupled Charge Device”, disponible en: <http://wwwuser.cnb.csic.es/ $\sim$ fotonica/Photonic_en/Review/ccd1.htm> [Fecha de consulta: 29 de enero de 2018].

\section{VV. AA.}

2011 "Internet pesa lo mismo que un fresón”, disponible en: <http://www.telegraph. co.uk/technology/internet/8865093/Internet-weighs-the-same-as-astrawberry.html> [Fecha de consulta: 17 de julio de 2015].

VV. AA.

2011 "Sensor de imagen", disponible en: <https://es.wikipedia.org/wiki/ Sensor_de_imagen $>$ [Fecha de consulta: 29 de enero de 2018]. VV. AA.

2014 "Ahora que están de moda: breve historia de las fotos selfie", disponible en: <https://www.sopitas.com/301149-ahora-que-estan-de-moda-breve-historia-delas-fotos-selfie/> [Fecha de consulta: 20 de julio de 2017].

\section{VV. AA.}

2014 "Barack Obama compte sur le service secret pour impressionner les prétendants de ses filles", disponible en: <https://www.20minutes.fr/insolite/126632320131221-20131221-barack-obama-compte-service-secret-impressionnerpretendants-filles $>$ [Fecha de consulta: 10 de enero de 2017]. 


\section{VV. AA.}

2014 "Leda Monster Bunny Wiki”, disponible en: <http://ledamuir.wikia.com/wiki/ Leda_Monster_Bunny_Wiki> [Fecha de consulta: 4 de marzo de 2017].

\section{VV. AA.}

2014 "Michelle Obama llega a los 50 años. Razones para una celebración (Fotos)", disponible en: <https://www.huffingtonpost.com/2014/01/o6/michelle-obamacumpleanos-50_n_454996o.html?utm_hp_ref=voces $>$ [Fecha de consulta: 10 de enero de 2017].

\section{VV. AA.}

2014 "Selfi, adaptación al español de selfie", disponible en: <https://www.fundeu.es/ recomendacion/selfi-adaptacion-al-espanol-de-selfie/> [Fecha de consulta: 12 de julio de 2015].

\section{VV. AA.}

2015 "Boing estrena Selfie Show, programa que mostrará el talento de los más pequeños", disponible en <https://www.mediaset.es/Boing-Selfie-Showmostrara-pequenos_o_1968750175.html> [Fecha de consulta: 2 de julio de 2017].

\section{VV. AA.}

2015 "Kim Kardashian fracasa en la venta de su libro", disponible en: <https:// elpais.com/elpais/2015/o8/o5/estilo/1438794037_803613.html> [Fecha de consulta: 20 de marzo de 2018].

\section{VV. AA.}

2015 "Los millennials: un desafío para la banca", disponible en: <https://www.bbva. com/es/millennials-desafio-banca/> [Fecha de consulta: 2 de abril de 2018].

\section{VV. AA.}

2015 "Lugares a los que no podrás llevarte tu palo de selfies", disponible en: <https:// verne.elpais.com/verne/2015/o3/31/articulo/1427814695_994335.html> [Fecha de consulta: 1 de noviembre de 2017].

\section{VV. AA.}

2015 “Self-timer Stories", disponible en: <http://musac.es/\#exposiciones/expo/? $\mathrm{id}=6250 \&$ from $=$ futuras $>$ [Fecha de consulta: 20 de abril de 2018]. 


\section{VV. AA.}

2016 “Asesinada una conocida bloguera de fitness en un parque de EE.UU.", disponible en: <http://www.abc.es/recreo/abci-instagram-encuentran-violaday-asesinada-conocida-bloguera-fitness-parque-eeuu-201608051326_noticia. html> [Fecha de consulta: 20 de diciembre de 2016].

VV. AA.

2016 "Instagram deja de mostrar las imágenes en orden cronológico", disponible en: <http://www.lasprovincias.es/tecnologia/201606/o7/ instagram-deja-mostrarimagenes-20160607205410.html> [Fecha de consulta: 20 de julio de 2017].

\section{VV. AA.}

2016 "Llega el selfie-dron, la cámara voladora que te sigue a todas partes", disponible en: <http://www.expansion.com/directivos/estilo-vida/tendencias/2016/05/o1/ 57262fc546163f8c458b45c6.html> [Fecha de consulta: 20 de julio de 2017].

\section{VV. AA.}

2016 “Todo lo que los padres deben conocer sobre SnapChat", disponible en: <http://www.elmundo.es/sapos-y-princesas/2016/o8/30/ 57c54ba522601ddb3c8b45d3.html> [Fecha de consulta: 20 de julio de 2017].

\section{VV. AA.}

2016 "WhatsApp supera en uso a todas las llamadas de móvil y de fijo en España", disponible en: <hhttp://www.eleconomista.es/telecomunicacionestecnologia/noticias/8403828/o6/17/WhatsApp-supera-en-uso-a-todas-lasllamadas-de-movil-y-de-fijo-en-Espana.htmll> [Fecha de consulta: 2 de enero de 2018].

\section{VV. AA.}

2017 “2017 Digital Yearbook: Digital Data for Every Country in the World”, disponible en: <https://wearesocial.com/uk/special-reports/2017-digital-yearbook> [Fecha de consulta: 20 de julio de 2017].

\section{VV. AA.}

2017 "23 World Wide Web Consortium. About the World Wide Web Consortium (W3C)", disponible en: <http://www.w3c.es/Consorcio/> [Fecha de consulta: 9 de enero de 2017]. 


\section{VV. AA.}

2017 "El cambio que reflejan 8 años y medio de selfies", disponible en: <http:// videos.elmundo.es/v/o_ab7t4569-el-cambio-que-reflejan-8-anos-y-medio-deselfies?uetv_pl=virales\&count $=0>$ [Fecha de consulta: 20 de julio de 2017]. VV. AA.

2017 "Informe de salud de Internet", disponible en: < https://internethealthreport. org/v01/es/> [Fecha de consulta: 20 de julio de 2017].

\section{VV. AA.}

2017 "La batalla del vídeo vertical: 90 grados que están haciendo que nos perdamos una parte del mundo", disponible en: <https://lgmobile.xataka.com/la-batalladel-video-vertical-9o-grados-estan-nos-perdamos-una-parte-del-mundo/> [Fecha de consulta: 9 de octubre de 2017].

\section{VV. AA.}

2017 "Llegan a un acuerdo por los derechos de imagen de un selfie hecho por un mono", disponible en: <https://www.20minutos.es/noticia/3132849/o/acuerdoderechos-selfie-mono/> [Fecha de consulta: 20 de julio de 2017].

\section{VV. AA.}

2017 "Peligros del ciberpostureo en las redes sociales", disponible en: <http://www.levante-emv.com/vida-y-estilo/tecnologia/2017/o8/15/peligrosciberpostureo-redes-sociales/1604987.html> [Fecha de consulta: 12 de noviembre de 2017].

\section{VV. AA.}

2017 "Un estudio revela que Facebook o Twitter dañan la salud mental de los jóvenes", disponible en: <https://www.20minutos.es/noticia/3042029/o/estudio-revelaredes-sociales-populares-danan-salud-mental-jovenes/> [Fecha de consulta: 24 de diciembre de 2017].

\section{VV. AA.}

2017 "Usuarios extremos: un 22 \% de los adolescentes que pasa más de seis horas diarias en la red", disponible en: <https://www.20minutos.es/noticia/3038407/ o/usuarios-extremos-22-adolescentes-pasa-mas-seis-horas-diarias-internetred/> [Fecha de consulta: 20 de agosto de 2017]. 


\section{VV. AA.}

2018 “13 Reasons Why (serie de televisión)”, disponible en: <https://es.wikipedia.org/ wiki/13_Reasons_Why_(serie_de_televisión)> [Fecha de consulta: 12 de enero de 2018].

VV. AA.

2018 “Alan Turing”, disponible en: <https://es.wikipedia.org/wiki/Alan_Turing> [Fecha de consulta: 2 de enero de 2018].

VV. AA.

2018 “Aplicación móvil”, disponible en: <https://es.wikipedia.org/wiki/Aplicación_ móvil $>$ [Fecha de consulta: 12 de enero de 2018].

VV. AA.

2018 "Autofoto", disponible en: <https://es.wikipedia.org/wiki/Autofoto> [Fecha de consulta: 12 de enero de 2018].

VV. AA.

2018 "Ciberacoso", disponible en: <https://es.wikipedia.org/wiki/Ciberacoso> [Fecha de consulta: 18 de enero de 2018].

VV. AA.

2018 “Computación en la nube”, disponible en: <https:// es.wikipedia.org/wiki/ Computación_en_la_nube $>$ [Fecha de consulta: 2 de febrero de 2018].

VV. AA.

2018 "Filtración de fotografías de celebridades de 2014", disponible en: <https:// es.wikipedia.org/wiki/Filtración_de_fotografías_de_celebridades_de_2014>, [Fecha de consulta: 4 de enero de 2018].

VV. AA.

2018 "Hashtag", disponible en: <https://es.wikipedia.org/wiki/Hashtag> [Fecha de consulta: 4 de enero de 2018].

VV. AA.

2018 "Hazte un selfi", 2018, disponible en <https://es.wikipedia.org/wiki/ Hazte_un_selfi> [Fecha de consulta: 2 de julio de 2018]. 


\section{VV. AA.}

2018 "Hipertexto", disponible en: <https://es.wikipedia.org/wiki/Hipertexto> [Fecha de consulta: 4 de enero de 2018].

VV. AA.

2018 "Kim Kardashian", disponible en: <https://es.wikipedia.org/wiki/Kim_

Kardashian>, [Fecha de consulta: 12 de enero de 2018].

VV. AA.

2018 "Navegador web", disponible en: <https://es.wikipedia.org/wiki/

Navegador_web> [Fecha de consulta: 4 de enero de 2018].

\section{VV. AA.}

2018 "Píxel", disponible en: <https://es.wikipedia.org/wiki/Píxel> [Fecha de consulta: 3 de enero de 2018].

VV. AA.

2018 "Raw (formato)", disponible en: <https://es.wikipedia.org/wiki/Raw_ (formato) $>$ [Fecha de consulta: 3 de enero de 2018].

VV. AA.

2018 "Red social”, disponible en: <https://es.wikipedia.org/wiki/Red_social> [Fecha de consulta: 2 de enero de 2018].

VV. AA.

2018 "Selfie", disponible en: <en.m.wikipedia.org/wiki/Selfie> [Fecha de consulta: 12 de enero de 2018].

\section{YE, Susana}

2016 "One Finger Challenge: desafiar la censura del cuerpo desnudo en las redes sociales con un solo dedo", disponible en: <http://www.elmundo.es/f5/ comparte/2016/12/04/ 5841cee2468aeb61028b4614.html> [Fecha de consulta: 20 de julio de 2017].

\section{YOUNG, Katy}

2015 "Lady Gaga's Selfie Campaign for Shiseido", disponible en: <http://fashion. telegraph.co.uk/beauty/news-features/TMG11329722/Lady-Gagas-selfiecampaign-for-Shiseido.html > [Fecha de consulta: 21 de julio de 2017]. 


\section{Páginas web y recursos obtenidos en sitios de Internet.}

$<$ http://arteweb.ning.com > [Fecha de consulta: 25 de abril de 2015].

$<$ http://boards.4chan.org/s/> [Fecha de consulta: 30 de julio de 2017].

http://exoticsbykm.blogspot.com.es/2013/o9/ nude-self-shot.html?zx= dbeecocf5a1038c3> [Fecha de consulta: 10 de agosto de 2017].

<http://gs.statcounter.com/browser-market-share\#monthly-201706-201706-bar> [Fecha de consulta: 31 de enero de 2018].

$<$ http://imgur.com/a/Q2HCE\#g9ZfA> [Fecha de consulta: 15 de julio de 2016].

<http://jk-keller.com/daily-photo/> [Fecha de consulta: 25 de abril de 2015].

<http://metropoli.elmundo.es/b/exposiciones/21664/juan-francisco-casas-

autopic.html> [Fecha de consulta: 19 de abril de 2015].

$<$ http://mexico.cnn.com/salud/2013/11/19/selfie-se-convierte-en-la-palabra-en-inglesdel-ano-para-oxford $>$ [Fecha de consulta: 24 de julio de 2016].

$<$ http://russafaescenica.com/> [Fecha de consulta: 12 de enero de 2018].

$<$ http://selfiecity.net/> [Fecha de consulta: 24 de abril de 2015].

$<$ http://selfieradioshow.es/> [Fecha de consulta: 2 de julio de 2017].

<http://sociedad.elpais.com/sociedad/2009/12/02/actualidad/1259708416_850215.ht $\mathrm{ml}>$ [Fecha de consulta: 16 de julio de 2016].

$<$ http://thechive.com/category/sexy-girls/girls-in-mirror,/> [Fecha de consulta: 22 de julio de 2017].

$<$ http://time.com/97561/national-geographics-new-ad-campaign-features-animalstaking-selfies/> [Fecha de consulta: 10 de julio de 2017].

$<$ http://www.arttech.ab.ca/pbrown/jenni/jenni.html $>$ [Fecha de consulta: 20 de julio de 2016]. 
<http://www.bonjourtoutlemonde.com/168-bonjour-self-shot> [Fecha de consulta: 30 de julio de 2017].

<http://www.consorcimuseus.gva.es/aprende/del-autorretrato-al-selfie/?lang=es> [Fecha de consulta: 20 de septiembre de 2017].

<http://www.cruzroja.es/principal/web/donantes/canon> [Fecha de consulta: 8 de mayo de 2018].

<http://www.enter.co/vida-digital/jennicam-y-el-cibervoyeurismo-cumplen-15-anos/> [Fecha de consulta: 20 de julio de 2016].

<http://www.fotolog.com> [Fecha de consulta: 20 de julio de 2017].

<http://www.fotolog.com/estasflipanndo/62258212/> [Fecha de consulta: 20 de julio de 2017].

<http://www.fotolog.com/quieresungomet/14367439/\#profile_start> [Fecha de consulta: 20 de julio de 2017].

<http://www.fotolog.com/xksintinusoynada/44708732/> [Fecha de consulta: 12 de enero de 2018].

<http://www.girlfriendgalleries.net/user,Sweetescape9900,8617.html > [Fecha de consulta: 22 de julio de 2017].

<http://www.herselfpics.com/forums/f-in-the-mirror-self-shot-her-self-pics-77.html> [Fecha de consulta: 30 de julio de 2017].

<http://www.juanfranciscocasas.com/> [Fecha de consulta: 19 de abril de 2015].

<http://www.metroflog.com/MonicaPrinces > [Fecha de consulta: 30 de julio de 2017].

<http://www.pantallasamigas.net/> [Fecha de consulta: 20 de julio de 2016].

<http://www.self-portrait.eu/home/> [Fecha de consulta: 16 de julio de 2013].

<http://www.selfshotbabes.com/> [Fecha de consulta: 22 de julio de 2017].

<http://www.taschen.com/pages/es/catalogue/photography/all/45716/facts.uwe_omme r_do_it_yourself.htm > [Fecha de consulta: 16 de julio de 2016].

<http://www.tetedealencar.com/> [Fecha de consulta: 16 de julio de 2016]. 
<http://www.youtube.com/watch?v=jD_sqBAaZ_A> [Fecha de consulta: 16 de julio de 2015].

<http://www.youtube.com/watch?v=P9OG_WMVGws > [Fecha de consulta: 16 de julio de 2013].

<http://www.youtube.com/watch?v=Pc1sK1WX2LA $>$ [Fecha de consulta: 20 de julio de 2013].

<https://badoo.com/es/signin/> [Fecha de consulta: 29 de julio de 2017].

<https://www.cuantarazon.com> [Fecha de consulta: 20 de julio de 2017].

$<$ https://en.oxforddictionaries.com/definition/selfie $>$ [Fecha de consulta: 21 de enero de 2018].

<https://tinder.com/?lang=es-ES > [Fecha de consulta: 29 de julio de 2017].

<https://twitter.com/LedaBunnie> [Fecha de consulta: 20 de julio de 2013].

<https://twitter.com/theellenshow/status/440322224407314432> [Fecha de consulta: 20 de julio de 2016].

<https://www.20minutos.es/noticia/3038407/o/usuarios-extremos-22-adolescentespasa-mas-seis-horas-diarias-internet-red/> [Fecha de consulta: 20 de agosto de 2017].

<https://www.edarling.es/eDarling > [Fecha de consulta: 29 de julio de 2017].

<https://www.forocoches.com/foro/misc.php?do=page\&template=Info\&tid=1494507> [Fecha de consulta: 22 de marzo de 2018].

<https://www.instagram.com/jaimelaycock/?hl=es> [Fecha de consulta: 22 de marzo de 2018].

<https://www.instagram.com/monica_murillogo/?hl=es > [Fecha de consulta: 22 de marzo de 2018].

<https://www.instagram.com/p/Bbp2ucilgz6/?hl=es\&taken-by=theledabunny> [Fecha de consulta: 1 de enero de 2018].

<https://www.instagram.com/p/BI4yFX2DgTt/?taken-by=blankiblue > [Fecha de consulta: 23 de julio de 2017]. 
<https://www.meetic.es/> [Fecha de consulta: 29 de julio de 2017].

<https://www.sexyono.com/> [Fecha de consulta: 29 de julio de 2017].

$<$ https://www.urbandictionary.com/define.php?term=Self\%2oShooter $>$ [Fecha de consulta: 12 de enero de 2018].

$<$ https://www.urbandictionary.com/define.php?term=Selfshot $>$ [Fecha de consulta: 12 de enero de 2018].

$<$ https://www.votamicuerpo.com/> [Fecha de consulta: 29 de julio de 2017].

$<$ https://www.youtube.com/watch?v=CAzgzNw-V7w $>$ [Fecha de consulta: 25 de abril de 2015].

$<$ https://www.youtube.com/watch?v=pn7cyNr-qko $>$ [Fecha de consulta: 10 de febrero de 2015]. 
Los orígenes adolescentes del selfie y su representación en el arte y en los medios de masas 